DOE/ID-10516

July 1995

\title{
Air Emission Inventory for the Idaho National Engineering Laboratory- 1994 Emissions Report
}

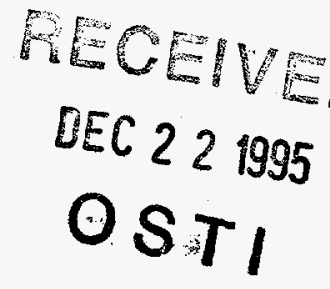

\section{Idaho National Engineering Laboratory}

U.S. Department of Energy $\cdot$ Idaho Operations Office
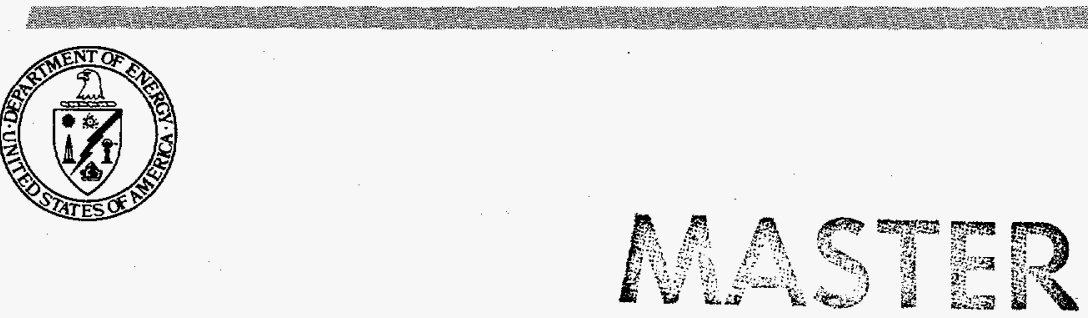


\section{DISCLAMMER}

Portions of this document may be illegible in electronic image products. Images are produced from the best available original document. 


\section{Air Emission Inventory for the Idaho National Engineering Laboratory- 1994 Emissions Report}

\section{DISCLAIMER}

This report was prepared as an account of work sponsored by an agency of the United States Government. Neither the United States Government nor any agency thereof, nor any of their employees, makes any warranty, express or implied, or assumes any legal liability or responsibility for the accuracy, completeness, or usefulness of any information, apparatus, product, or process disclosed, or represents that its use would not infringe privately owned rights. Reference herein to any specific commercial product, process, or service by trade name, trademark, manufacturer, or otherwise does not necessarily constitute or imply its endorsement, recommendation, or favoring by the United States Government or any agency thereof. The views and opinions of authors expressed herein do not necessarily state or reflect those of the United States Government or any agency thereof.

\section{Published July 1995}




\section{ABSTRACT}

This report presents the 1994 update of the Air Emission Inventory for the Idaho National Engineering Laboratory (INEL). The INEL Air Emission Inventory documents sources and emissions of non-radionuclide pollutants from operations at the INEL. The report describes the emission inventory process and all of the sources at the INEL, and provides non-radionuclide emissions estimates for stationary sources. 


\section{EXECUTIVE SUMMARY}

During the fall of 1989, the Air Emission Inventory was initiated at the Idaho National Engineering Laboratory (INEL) as a result of the Environmental Oversight and Monitoring Agreement between the State of Idaho and the Department of Energy Idaho Field Office, and a request from the Idaho Air Quality Bureau. The Air Emission Inventory documents sources and emissions of non-radionuclide pollutants at the INEL. Emissions of radionuclides are reported in the Idaho National Engineering Laboratory National Emission Standards for Hazardous Air Pollutants (NESHAP) - Annual Report. The INEL Air Emissions Inventory was used in the preparation of the INEL operating permit application, as required by Title $V$ regulations ( 40 CFR 70) of the Clean Air Act and State of Idaho regulations (IDAPA 16.01.01.300 et. seq.).

The Air Emission Inventory is updated annually to reflect the previous year's emissions, changes in operating sources, and inventory refinements. The current update of the Air Emission Inventory data reflects 1994 operations. The Air Emission Inventory System, an ORACLE-based database system, maintains the emissions inventory. The INEL contractors and their associated facilities provide information to the Air Emission Inventory System to reflect annual operations. The annual update of information is utilized to calculate air emissions for the INEL.

The inventory presently maintains approximately 10,500 vents, and of those vents, approximately 650 are possible emission sources. Emission source types range from conventional fuel combustion and storage sources to nuclear reactor and research facility exhausts. The Air Emission Inventory System uses the U.S. Environmental Protection Agency's (EPA) Compilation of Air Pollutant Emission Factors (AP-42) calculations to estimate emissions for many of the general sources. The air contaminants reported include nitrogen oxides, sulfur oxides, carbon monoxide, volatile organic compounds, particulates, and hazardous air pollutants (HAPs). Primary non-radionuclide emissions from sources at the INEL for 1994 are presented in the table below.

\begin{tabular}{|c|c|c|c|c|}
\hline Pollutant & $\begin{array}{l}\text { Actual } \\
\text { Hourly } \\
(\mathrm{lb} / \mathrm{hr}) \\
\end{array}$ & $\begin{array}{l}\text { Actual } \\
\text { Annual } \\
(\mathrm{tn} / \mathrm{yr}) \\
\end{array}$ & $\begin{array}{c}\text { Maximum } \\
\text { Hourly } \\
(\mathrm{lb} / \mathrm{hr})\end{array}$ & $\begin{array}{c}\text { Maximum } \\
\text { Annual } \\
(\mathrm{t} / \mathrm{yr})\end{array}$ \\
\hline Carbon monoxide & $3.6 \mathrm{E}+02$ & $4.4 \mathrm{E}+02$ & $1.1 \mathrm{E}+03$ & $3.9 \mathrm{E}+03$ \\
\hline Nitrogen oxides & $1.1 \mathrm{E}+04$ & $6.6 \mathrm{E}+02$ & $2.7 \mathrm{E}+03$ & $4.0 \mathrm{E}+03$ \\
\hline Particulates & $9.7 \mathrm{E}+01$ & $1.1 \mathrm{E}+02$ & $2.5 \mathrm{E}+02$ & $7.0 \mathrm{E}+02$ \\
\hline Sulfur oxides & $3.4 \mathrm{E}+02$ & $2.2 \mathrm{E}+02$ & $8.2 \mathrm{E}+02$ & $3.0 \mathrm{E}+03$ \\
\hline VOC - nonmethane & $5.3 \mathrm{E}+02$ & $2.7 \mathrm{E}+01$ & $6.4 \mathrm{E}+02$ & $3.0 \mathrm{E}+02$ \\
\hline
\end{tabular}

The INEL has recently completed preparation of their Title V permit to operate application under State of Idaho Regulations (IDAPA 16.01.01.300 et. seq.): the Application for a Title V Operating Permit for the Idaho National Engineering Laboratory (INEL-95/0155-I through IX). During preparation of the application, variations in data and operations from that indicated in the 1993 Air Emissions Inventory were identified, and source reporting was modified. These changes are noted in Section 3 of this report. In addition, the INEL anticipates revising aspects of the Air Emissions Inventory to better reflect source categories and report format of the INEL Title V Operating Permit Application and subsequent Operating Permit. Anticipated changes for the 1995 Air Emissions Inventory are discussed in this report as well. 


\section{ACKNOWLEDGMENTS}

This year, the Air Emission Inventory Report was the result of the cumulative effort of various people and the contractors at the Idaho National Engineering Laboratory: Argonne National Laboratory West; Lockheed Martin Idaho Technologies; and Westinghouse Electric Corporation. Special thanks are made to the Area Specific Coordinators for their diligence in supporting the inventory process and Title $V$ Operating Permit Application. 


\section{CONTENTS}

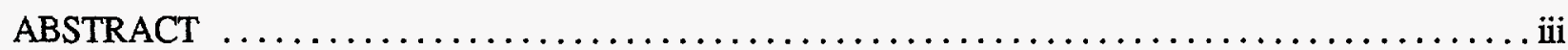

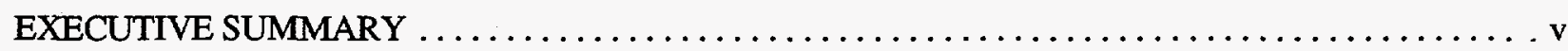

ACKNOWLEDGMENTS $\ldots \ldots \ldots \ldots \ldots \ldots \ldots \ldots \ldots \ldots \ldots \ldots \ldots \ldots \ldots \ldots \ldots \ldots \ldots \ldots \ldots \ldots \ldots$

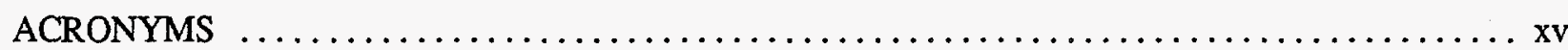

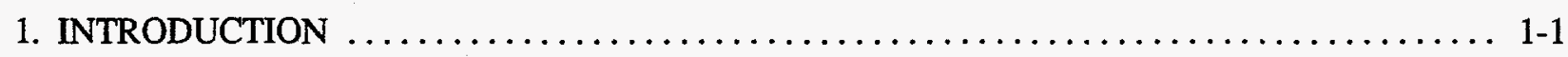

2. AIR EMISSION INVENTORY PROCESS $\ldots \ldots \ldots \ldots \ldots \ldots \ldots \ldots \ldots \ldots \ldots \ldots \ldots \ldots \ldots \ldots \ldots$

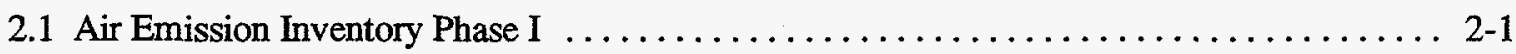

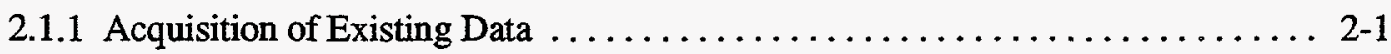

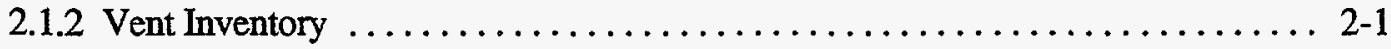

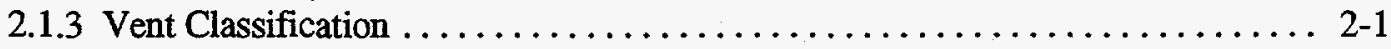

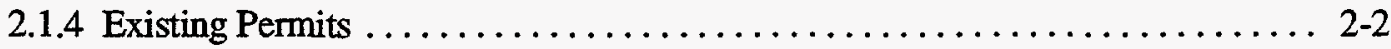

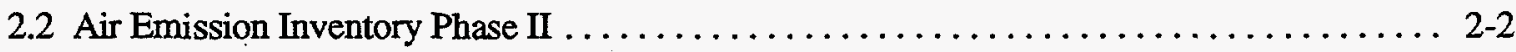

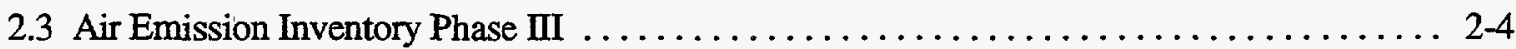

2.4 Air Emission Inventory Annual Update $\ldots \ldots \ldots \ldots \ldots \ldots \ldots \ldots \ldots \ldots \ldots \ldots \ldots \ldots \ldots$

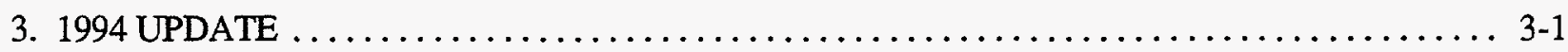

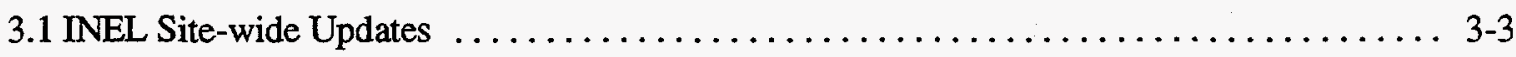

3.2 Argonne National Laboratory-West $\ldots \ldots \ldots \ldots \ldots \ldots \ldots \ldots \ldots \ldots \ldots \ldots \ldots \ldots \ldots \ldots \ldots \ldots \ldots \ldots$

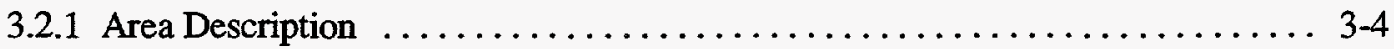

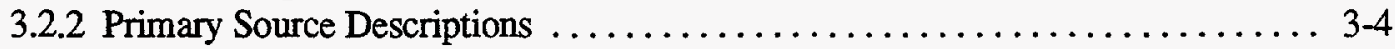

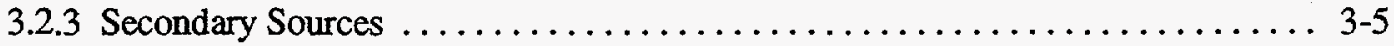

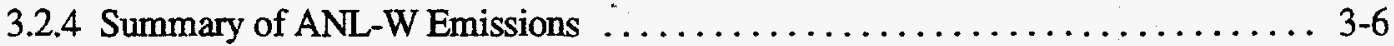

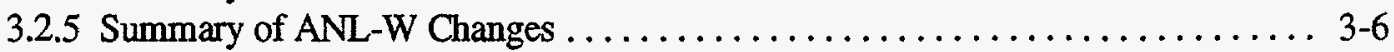

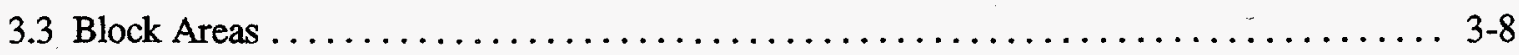

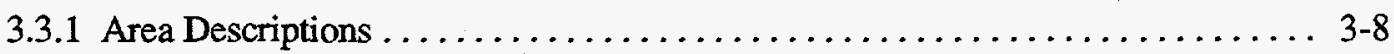

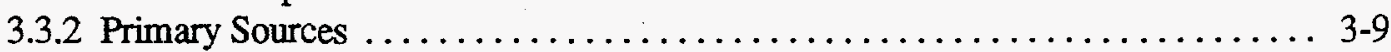

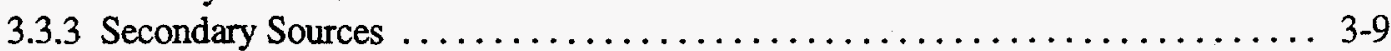

3.3.4 Summary of Block Area Emissions $\ldots \ldots \ldots \ldots \ldots \ldots \ldots \ldots \ldots \ldots \ldots \ldots . \ldots \ldots$

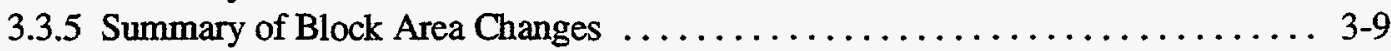




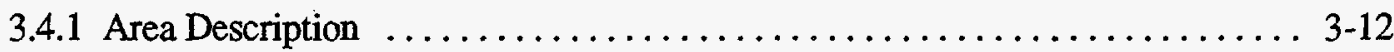

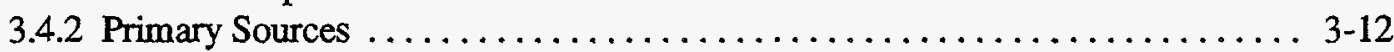

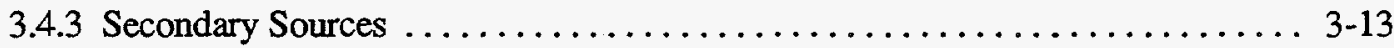

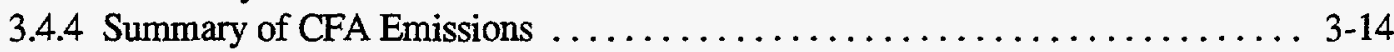

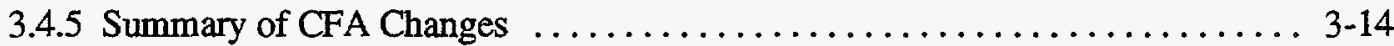

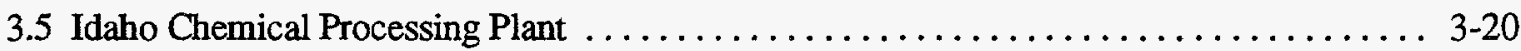

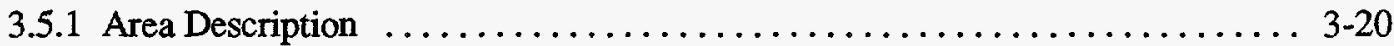

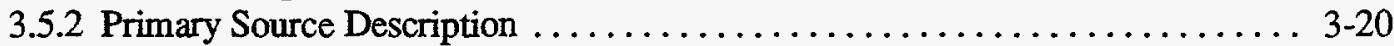

3.5.3 Secondary Sources ................................. 3-23

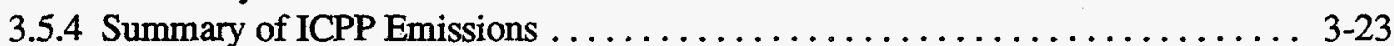

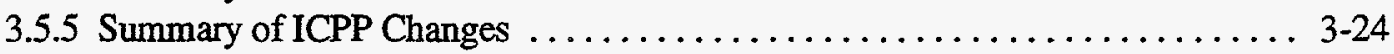

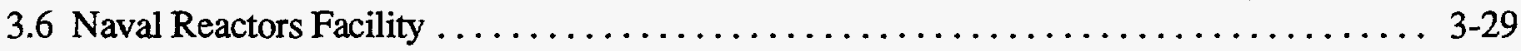

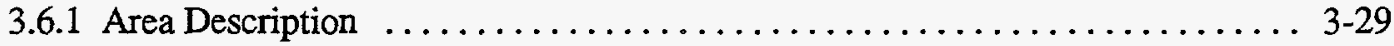

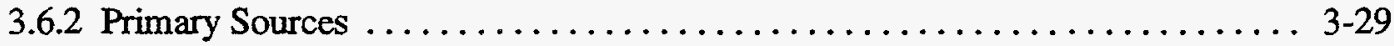

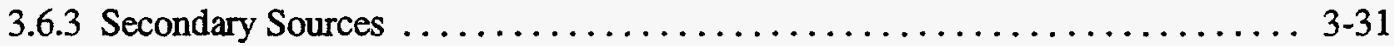

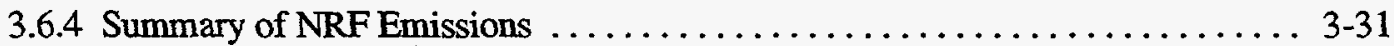

3.6.5 Summary of NRF Changes $\ldots \ldots \ldots \ldots \ldots \ldots \ldots \ldots \ldots \ldots \ldots \ldots \ldots \ldots \ldots \ldots \ldots \ldots \ldots \ldots, 32$

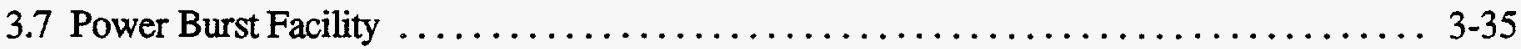

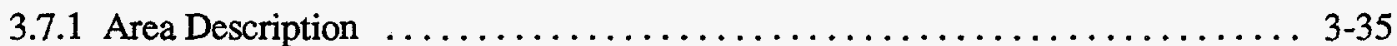

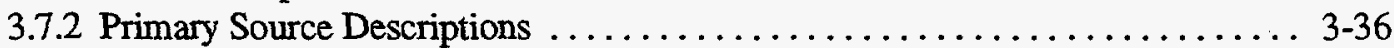

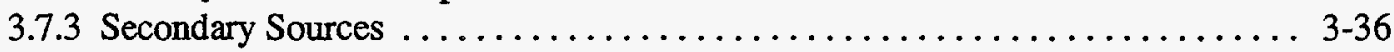

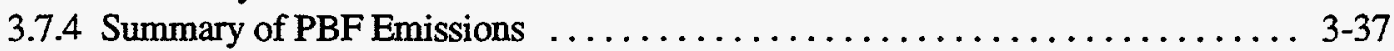

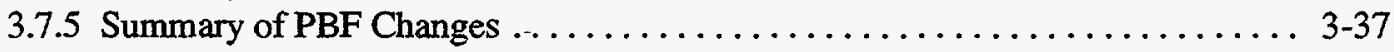

3.8 Radioactive Waste Management Complex ....................... 3-45

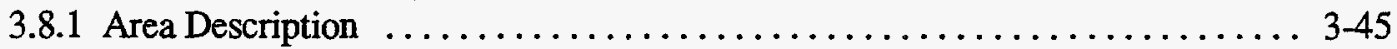

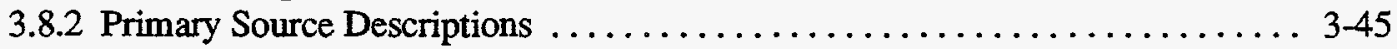

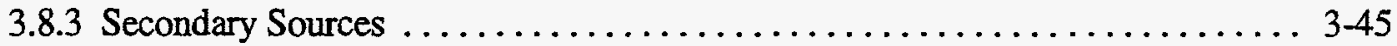

3.8.4 Summary of RWMC Emissions . . . . . . . . . . . . . . . . . . . 3-46

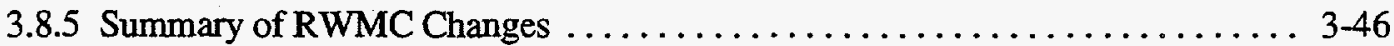

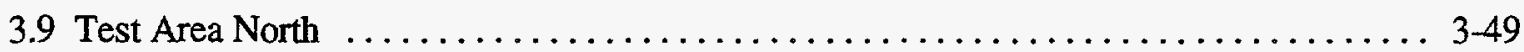

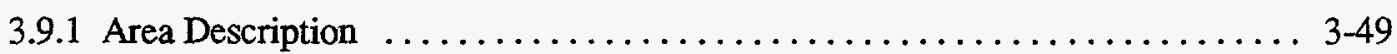

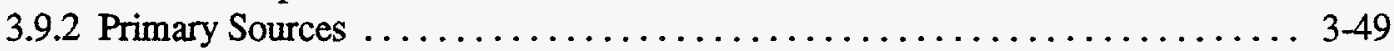

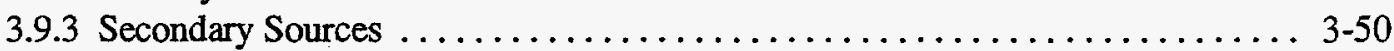

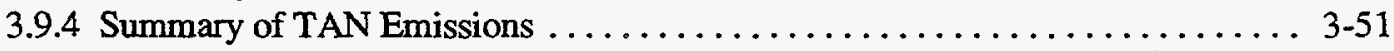

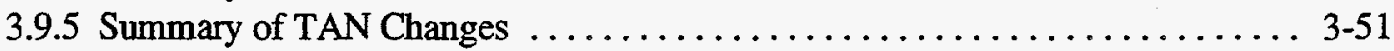




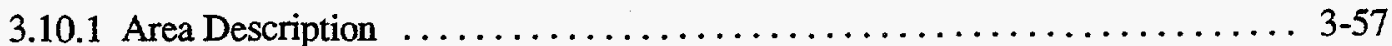

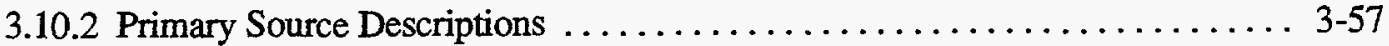

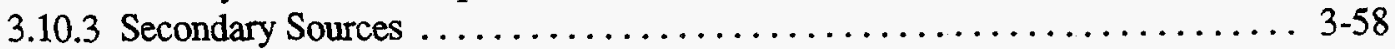

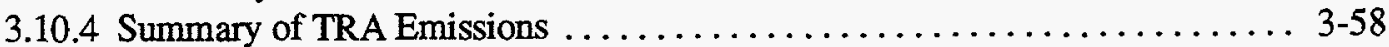

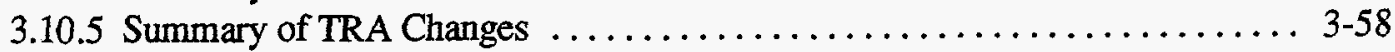

3.11 Summary of 1994 Emissions at the INEL $\ldots \ldots \ldots \ldots \ldots \ldots \ldots \ldots \ldots \ldots \ldots \ldots \ldots \ldots \ldots \ldots$

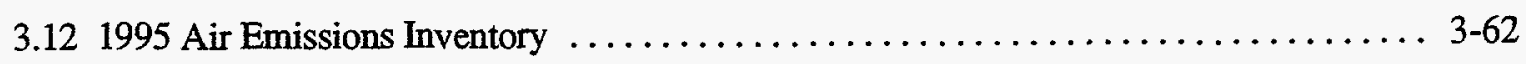

4 EMISSIONS ESTIMATES FOR STATIONARY SOURCES $\ldots \ldots \ldots \ldots \ldots \ldots \ldots \ldots \ldots \ldots$.

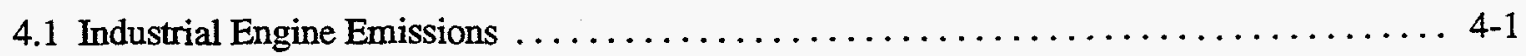

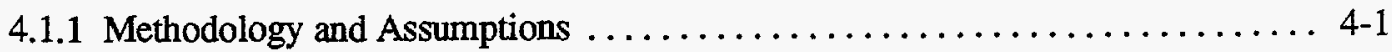

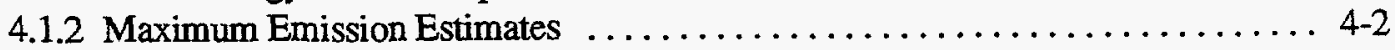

4.1.3 Calculations Performed by the Database $\ldots \ldots \ldots \ldots \ldots \ldots \ldots \ldots \ldots, 4$

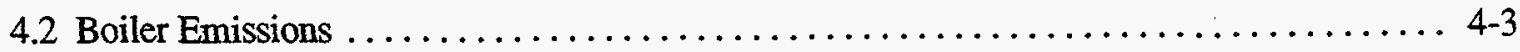

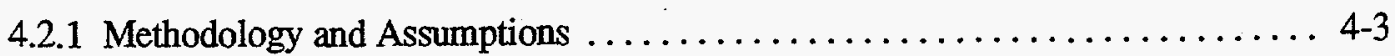

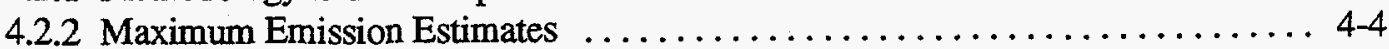

4.2.3 Calculations Performed by the Database $\ldots \ldots \ldots \ldots \ldots \ldots \ldots \ldots . \ldots \ldots$

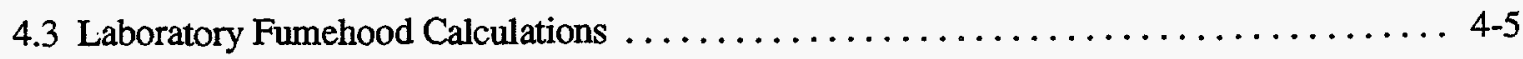

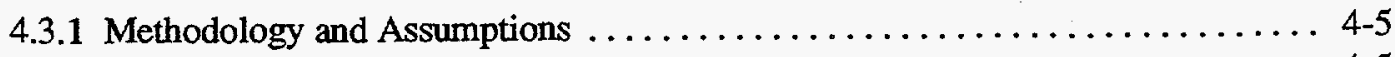

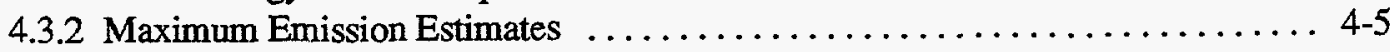

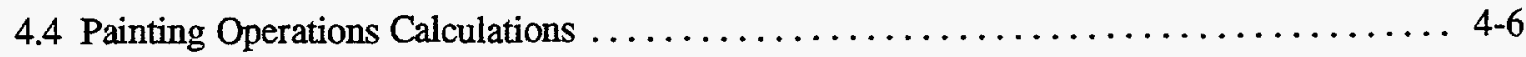

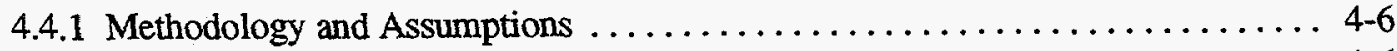

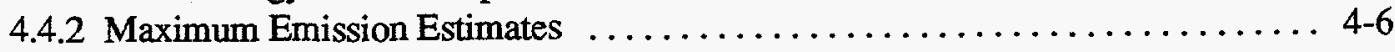

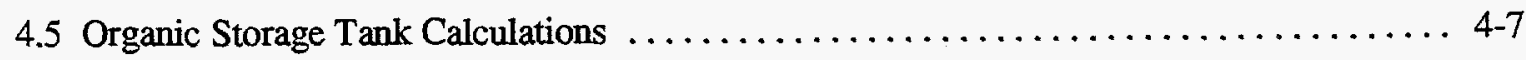

4.5.1 Methodology and Assumptions $\ldots \ldots \ldots \ldots \ldots \ldots \ldots \ldots \ldots \ldots \ldots \ldots \ldots \ldots$

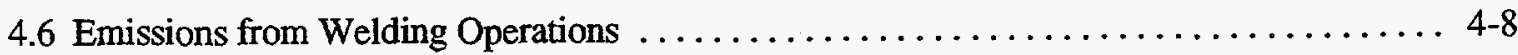

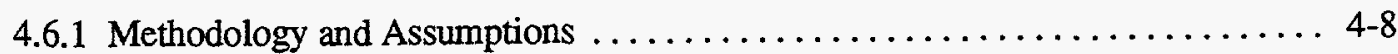

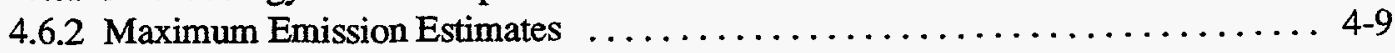

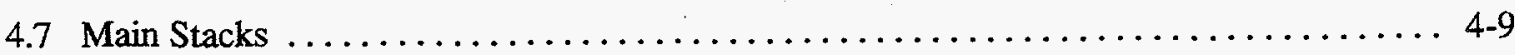

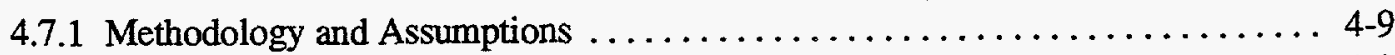

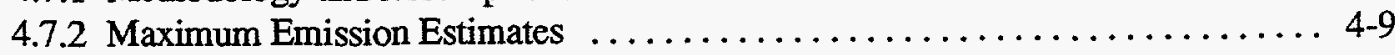


APPENDIX A-PHASE I \& II FORMS A-1

APPENDIX B-1993 AIR EMISSION INVENTORY EMISSIONS TABLES B-1 APPENDIX C-SUPPORTING DATA FOR THE 1993 AIR EMISSION INVENTORY FOR THE INEL 


\section{FIGURES}

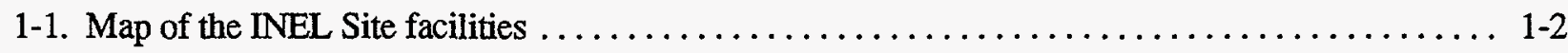

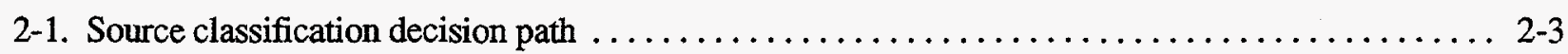

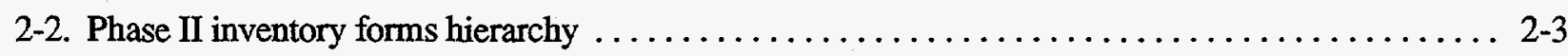

3-1. Area plot plan of Argonne National Laboratory-West $\ldots \ldots \ldots \ldots \ldots \ldots \ldots \ldots \ldots \ldots \ldots \ldots$

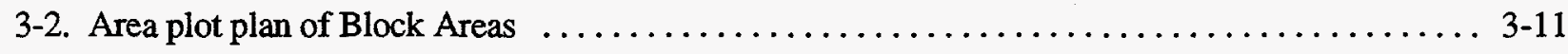

3-3. Area plot plan of the Central Facilities Area $\ldots \ldots \ldots \ldots \ldots \ldots \ldots \ldots \ldots \ldots \ldots \ldots \ldots \ldots$

3-4. Detail of Central Facilities Area plot plan $\ldots \ldots \ldots \ldots \ldots \ldots \ldots \ldots \ldots \ldots \ldots \ldots \ldots \ldots$

3-5. Area plot plan of the Idaho Chemical Processing Plant $\ldots \ldots \ldots \ldots \ldots \ldots \ldots \ldots \ldots \ldots \ldots$

3-6. Area plot plan of the Naval Reactors Facility $\ldots \ldots \ldots \ldots \ldots \ldots \ldots \ldots \ldots \ldots \ldots \ldots \ldots \ldots \ldots \ldots$

3-7. Area plot plan of the Power Burst Reactor area $\ldots \ldots \ldots \ldots \ldots \ldots \ldots \ldots \ldots \ldots \ldots \ldots \ldots \ldots$

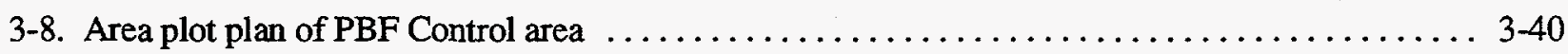

3-9. Area plot plan of PBF Reactor area $\ldots \ldots \ldots \ldots \ldots \ldots \ldots \ldots \ldots \ldots \ldots \ldots \ldots \ldots \ldots \ldots \ldots \ldots$

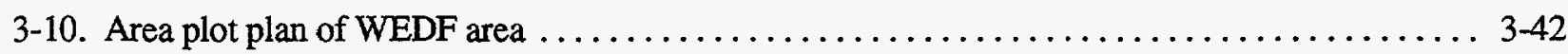

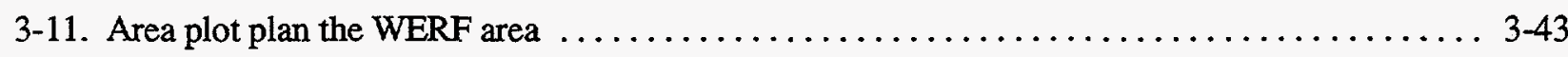

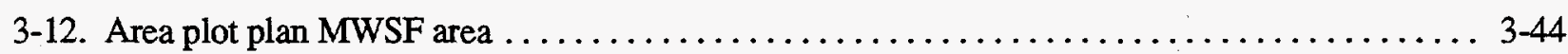

3-13. Area plot plan of the Radioactive Waste Management Complex $\ldots \ldots \ldots \ldots \ldots \ldots \ldots \ldots$

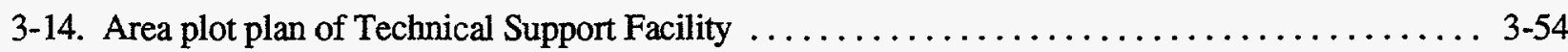

3-15. Area plot plan of Loss of Fluid Test and Specific Manufacturing Capability area ......... 3-55

3-16. Area plot plan of Water Reactor Research Test Facility. ................. 3-56

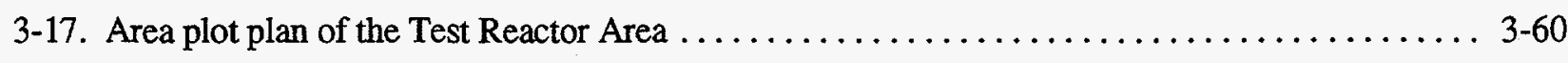




\section{TABLES}

3.2-1. Summary of non-radionuclide principal pollutants at ANL-W $\ldots \ldots \ldots \ldots \ldots \ldots \ldots \ldots \ldots$

3.3-1. Summary of non-radionuclide principal pollutants at Block Areas $\ldots \ldots \ldots \ldots \ldots \ldots \ldots . . .6$

3.3-2. Summary of source changes at Block Areas - 1993 to 1994 Inventory . . . . . . . . . . . 3-10

3.4-1. Summary of the totals for each of the non-radionuclide principal pollutants at CFA ...... 3-14

3.4-2. Summary of source changes at CFA - 1993 to 1994 Inventory . . . . . . . . . . . 3-14

3.5-1. Summary of the totals for each of the non-radionuclide principal pollutants at ICPP ...... 3-23

3.5-2. Summary of source changes at ICPP - 1993 to 1994 Inventory . . . . . . . . . . . . 3-24

3.6-1. Summary of non-radionuclide principal pollutants at NRF $\ldots \ldots \ldots \ldots \ldots \ldots \ldots \ldots \ldots$ 3-31

3.6-2. Summary of source changes at NRF - 1993 to 1994 Inventory $\ldots \ldots \ldots \ldots \ldots \ldots \ldots \ldots$.

3.6-3. Summary of source changes at NRF - 1994 Inventory to INEL Tier I Operating Permit

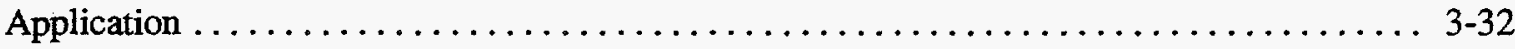

3.7-1. Summary of non-radionuclide principal pollutants at PBF $\ldots \ldots \ldots \ldots \ldots \ldots \ldots \ldots \ldots$

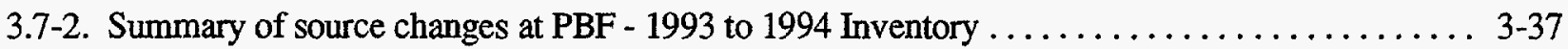

3.8-1. Summary of the totals for each of the non-radionuclide principal pollutants at the RWMC . . . 3-46

3.8-2. Summary of source changes at RWMC - 1993 to 1994 Inventory . . . . . . . . . . . . 3-46

3.9-1. Summary of the totals for each of the non-radionuclide principal pollutants at TAN ...... 3-51

3.9-2. Summary of source changes at TAN - 1993 to 1994 Inventory ................ 3-51

3.10-1. Summary of non-radionuclide principal pollutants at TRA $\ldots \ldots \ldots \ldots \ldots \ldots \ldots \ldots \ldots$

3.10-2. Summary of source changes at TRA - 1993 to 1994 Inventory . . . . . . . . . . . 3-58

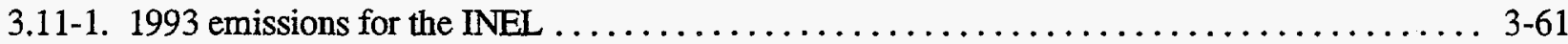




\section{ACRONYMS}

\begin{tabular}{|c|c|}
\hline A1W & NRF Large Ship Reactor \\
\hline AFSR & Argonne Fast Source Reactor \\
\hline ANL-W & Argonne National Laboratory - West \\
\hline $\mathrm{AP}-42$ & EPA Compilation of Air Pollutant Emission Factors \\
\hline ARA & Auxiliary Reactor Area \\
\hline BER & basic emission rate \\
\hline BORAX & Boiling Water Reactor Experiment \\
\hline Btu & British thermal unit \\
\hline CFA & Central Facilities Area \\
\hline $\operatorname{cfm}$ & cubic feet per minute \\
\hline CFR & Code of Federal Regulations \\
\hline CFSGF & Coal-Fired Steam-Generating Facility \\
\hline $\mathrm{Ci}$ & Curie \\
\hline DOE & Department of Energy \\
\hline DOE-ID & Department of Energy Idaho Field Office \\
\hline $\mathrm{EB}$ & East Butte \\
\hline EBR-I & Experimental Breeder Reactor I \\
\hline EBR-II & Experimental Breeder Reactor II \\
\hline ECF & NRF Expended Core Facility \\
\hline EPA & Environmental Protection Agency \\
\hline ER & emission rate \\
\hline FAST & Fluorinel Dissolution Process and Fuel Storage \\
\hline FCF & Fuel Cycle Facility \\
\hline FMF & Fuel Manufacturing Facility \\
\hline HEPA & high-efficiency particulate air \\
\hline HFEF & Hot Fuel Examination Facility \\
\hline HPTF & Howe Peak Transformer Facility \\
\hline ICPP & Idaho Chemical Processing Plant \\
\hline IET & Initial Engine Test \\
\hline IFR & Integral Fast Reactor \\
\hline INEL & Idaho National Engineering Laboratory \\
\hline $\mathrm{kW}$ & kilowatt \\
\hline LOFT & Loss of Fluid Test \\
\hline MDF & Material Development Facility \\
\hline $\mathrm{mph}$ & miles per hour \\
\hline MW & megawatt \\
\hline MWSF & Mixed Waste Storage Facility \\
\hline NESHAPs & National Emission Standards for Hazardous Air Pollutants \\
\hline NOAA & National Oceanic and Atmospheric Administration \\
\hline NRF & Naval Reactor Facility \\
\hline NWCF & New Waste Calcining Facility \\
\hline PBF & Power Burst Facility \\
\hline PCB & polychlorinated biphenyl \\
\hline PER & Power Excursion Reactor \\
\hline PSD & prevention of significant deterioration (State of Idaho air quality permit) \\
\hline RCRA & Resource Conservation and Recovery Act \\
\hline RESL & Radiological and Environmental Sciences Laboratory \\
\hline RWMC & Radioactive Waste Management Complex \\
\hline
\end{tabular}


S1W NRF Submarine Thermal Reactor

S5G NRF Natural Circulation Reactor

SCF speed correction factor

SDA Subsurface Disposal Area

SMC Specific Manufacturing Capability

SPERT Special Power Excursion Reactor Test

STF Security Training Facility

TAN Test Area North

TRA Test Reactor Area

TREAT Transient Reactor Test Facility

TSA Transuranic Storage Area

TSF Technical Support Facility

VOC volatile organic compound

WEDF Waste Engineering Development Facility

WERF Waste Experimental Reduction Facility

WMF Waste Management Facility

WMO Waste Management Office

WRRTF Water Reactor Research Test Facility

ZPPR Zero Power Physics Reactor 


\section{INTRODUCTION}

This report presents 1994 source and emissions data for non-radionuclide pollutants from operations at the Idaho National Engineering Laboratory (INEL). Data compiled in the Air Emission Inventory was used for preparation of the INEL Tier I operating permit application required under Title $V$ regulations ( 40 CFR 70) of the Clean Air Act and State of Idaho regulations (IDAPA 16.01.01.300 et. seq.). This report describes the emission inventory process used at the INEL, sources other than insignificant sources, and provides emissions estimates for stationary sources.

The INEL is an 890 square mile research facility managed by the U.S. Department of Energy (DOE) and contains approximately 600 buildings and 500 other structures. The size and complexity of the INEL required the development of the Air Emission Inventory System, an ORACLE-based database system, that maintains the emissions inventory. The Air Emission Inventory System utilizes the United States Environmental Protection Agency's (EPA's) Compilation of Air Pollutant Emission Factors (AP-42) calculations to estimate emissions for many of the general sources.

The 1994 Air Emission Inventory Report includes the following areas at the INEL (see Figure 1-1).

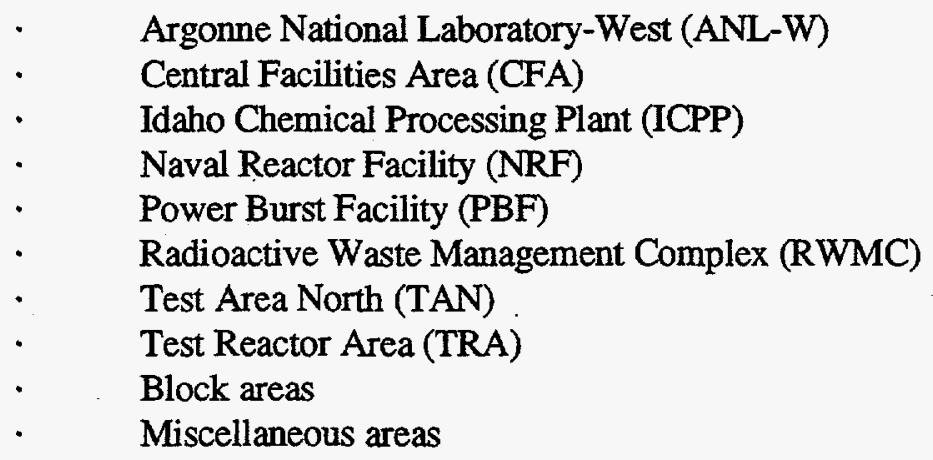

The inventory presently maintains approximately 10,500 vents, and of those vents, approximately 650 are possible emission sources. Emission sources range from conventional fuel combustion and storage sources to nuclear reactor and research facility exhausts. Air contaminants reported in this inventory include nitrogen oxides, sulfur oxides, carbon monoxide, volatile organic compounds (VOCs), hazardous air pollutants (HAPs), and particulates. Emissions of radionuclides are reported in the Idaho National Engineering Laboratory National Emission Standards for Hazardous Air Pollutants (NESHAP) - Annual Report. 


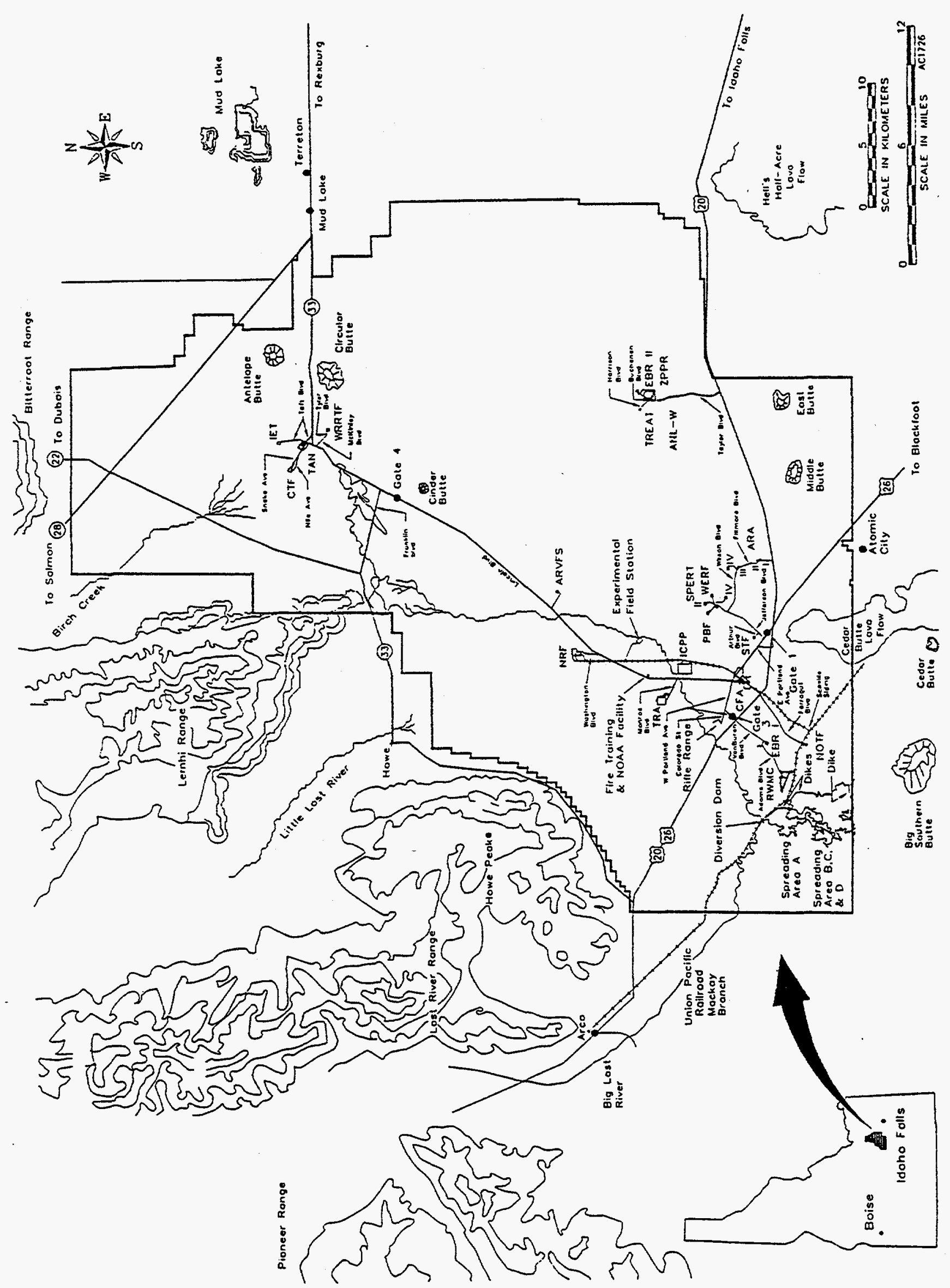

Figure 1-1. Map of the INEL Site facilities. 


\section{AIR EMISSION INVENTORY PROCESS}

The Air Emission Inventory process was initiated at the INEL in 1989. In order to evaluate all of the potential sources of air contamination at the INEL, every vent was inventoried. The process was implemented in three phase(i.e., Phases I, II and III) to ensure comprehensive and accurate data. Data collected from each phase of the inventory process were compiled and managed on an ORACLE-based data management system. Since the initial 1989 inventory process, the Air Emission Inventory System has been redesigned to reflect a production database system. The new Air Emission Inventory System has been incorporated into an INEL-wide effluent inventory: the INEL Effluent Inventory System.

The INEL maintains a current inventory of emission sources which reflects any new or upgraded structures, vents, and sources.

\subsection{Air Emission Inventory Phase I}

Phase I of the INEL Air Emissions Inventory included four activities: identification of potential emission points from existing inventories, surveys of buildings and potential sources, a preliminary classification to eliminate vents that were not potential air pollution sources, and an evaluation of existing air permits and permit applications.

\subsubsection{Acquisition of Existing Data}

Previous air emission inventories were evaluated to determine the usefulness of the compiled data for the initial Air Emission Inventory. Data used from an existing inventory were checked for accuracy by comparing the data collected during the Phase I inventory.

\subsubsection{Vent Inventory}

Standardized forms were developed to collect and organize data (see Phase I Forms, Appendix A). Building Source Form (Form 1) were developed to record the survey team members' names, building contact's name, source number, description and location, and any other information available for the source. Any vent considered a potential air pollution source was recorded on Form 1. Building Summary Forms (Form 2) were developed to list and briefly describe all vents on a building, including those not listed as potential sources of air pollution.

\subsubsection{Vent Classification}

Vents were considered a source if the vent had the potential to emit any criteria pollutants (carbon monoxide, sulfur oxides, nitrogen oxides, particulates, lead, and volatile organic compounds), non-criteria pollutants (asbestos, beryllium, mercury, vinyl chloride, radionuclides, fluorides, sulfuric acid mist, hydrogen sulfide, and reduced sulfur compounds), or toxic air pollutants listed in Tables V-A, V-B, and V-C of the draft State of Idaho Guidance Manual for Obtaining a Permit to Construct, Modify or Operate an Air Pollution Source.

Vents that were considered sources included those associated with combustion processes; radiological processes (or vents on radiologically contaminated equipment); chemical process exhausts; storage tank vents; fume hood exhausts; and area sources such as waste piles, evaporation ponds, and lagoons. If a vent was considered a potential source of air pollutants, it became part of the Phase II inventory. 


\subsubsection{Existing Permits}

The Phase I inventory gathered all existing Idaho Air Quality Bureau permits and permit applications. Data from the existing permits were incorporated into the Phase II portion of the inventory.

\subsection{Air Emission Inventory Phase II}

Phase II of the inventory included the collection of detailed data for vents identified as potential sources of air contamination in Phase I. Phase II data included operating and engineering parameters necessary for emission calculations, physical location, process descriptions with flow diagrams if necessary and available, and any previously permitted or otherwise documented information concerning potential emissions.

The initial aspects of the Phase II inventory organized the preliminary information for a given area and their corresponding structures. The material included available drawings, data forms, permit applications, and other existing data. Any additional information required to estimate emissions was also collected and included engineering drawings and safety analysis reports, contacting equipment manufacturers, and interviewing shift supervisors, operators, and area landlords.

On completion of data collection, the status of any unknown and out-of-service vents was determined. Unknown vents were changed to either a vent with no emissions, or a potential source of emissions. Many potential sources were not emitting at the time of the 1994 inventory. Many of these inactive vents were permanently out of service while others were only temporarily inactive. A summary of the decision process used to determine the status of unknown vents and whether any estimates need to be made concerning their emissions or potential emissions is provided in Figure 2-1.

The data were compiled on a set of inventory forms (see Phase II Forms, Appendix A). The Phase II inventory comprised 16 different data forms, but not all were needed for each source. The Phase II forms were organized into several levels, where each level was divided into increasingly more detailed degrees of data to be collected. Figure 2-2 is a flow chart diagraming the use of Phase II forms.

Level 1 forms were prepared for every potential source. These forms described the process stack and provided a gross evaluation of the source type. The source type section of the form identifies the appropriate Level 2 form. A Level 2 form is completed depending on the source type. Level 2 forms are supplied for chemical sources, fuel burning equipment, volatile organic liquid storage, and inorganic chemical storage. The Level 2 forms are used to gather source-specific information required for emission estimates. A check box is provided to indicate which Level 3 forms are required.

Level 3 forms compiled information on the chemicals, fuel, and materials used in specific sources. Level 4 is the final tier in the Phase II inventory form classification. This level was used to record information on pollution control equipment, pollution monitoring equipment, and additional information applicable to fume or laboratory hoods and paint booths.

Not all sources could be standardized on these forms and were handled on a case-by-case basis using generic data forms. The generic forms recorded sources whose emissions had to be calculated by hand or were of such an unusual nature that the standardized forms are not applicable. 


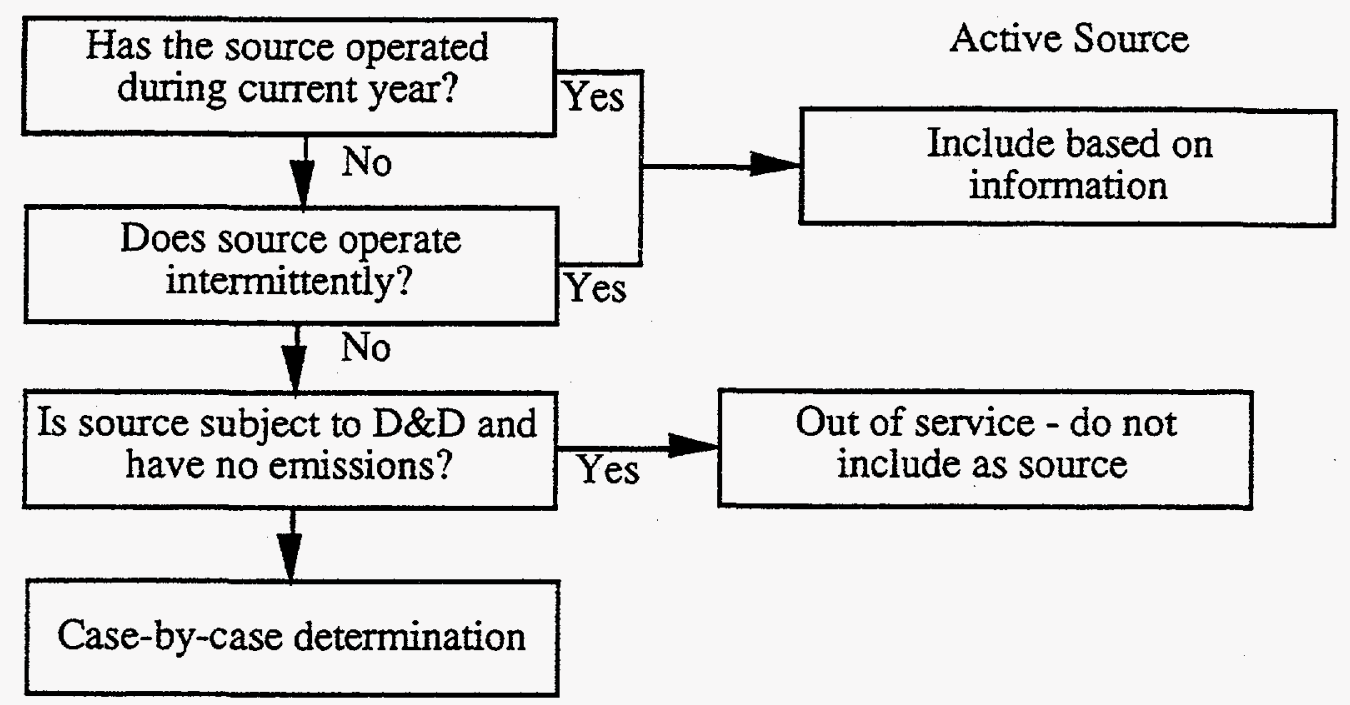

Figure 2-1. Source classification decision path.

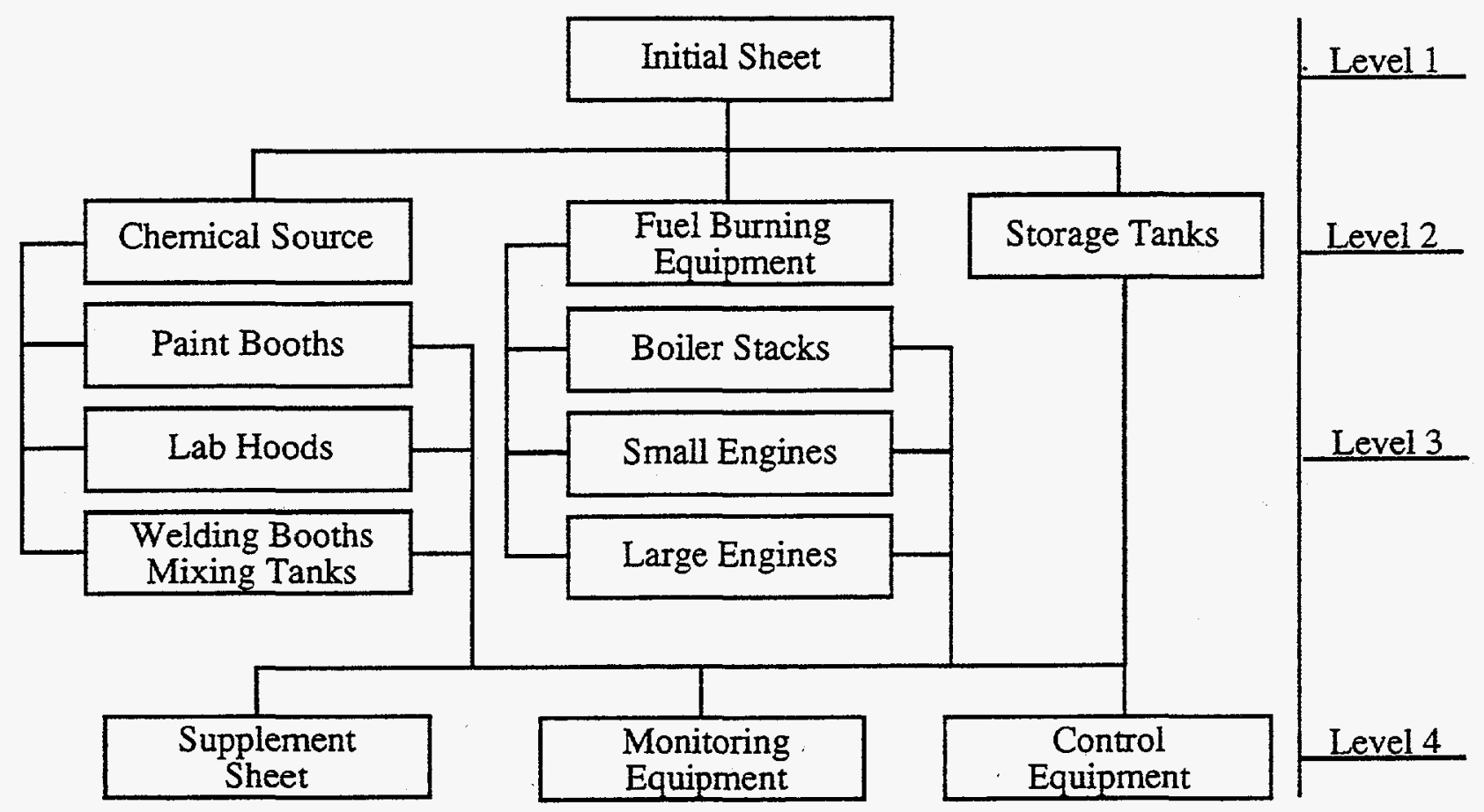

Figure 2-2. Phase II inventory forms hierarchy. 


\subsection{Air Emission Inventory Phase III}

Phase III utilized the data gathered during Phases I and II to estimate the emissions of air pollutants from sources at the INEL. The development of Phase III included calculating emissions from the following sources:

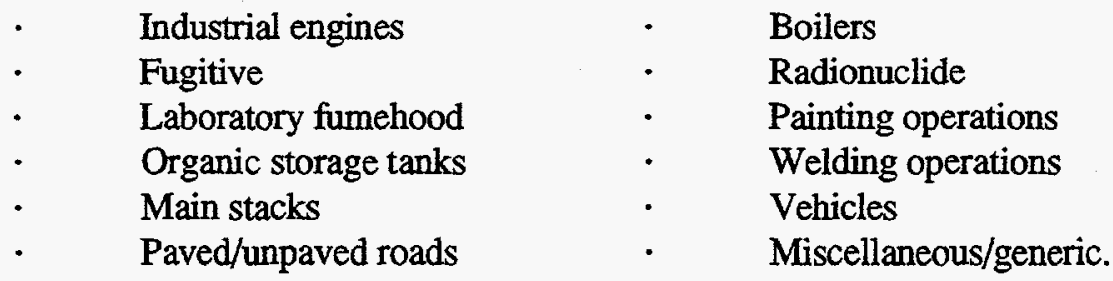

The calculations for the above sources involve EPA acceptable methods per Volumes I and II of AP42 and used several assumptions for each source. Descriptions of the various calculations used to estimate the emissions from the INEL sources are provided in Section 4 of this report.

\subsection{Air Emission Inventory Annual Update}

The INEL contractors and their associated facilities are required to provide information into the Air Emission Inventory System to reflect annual operations. The purpose of the annual update is to estimate the emissions for the previous calender year, reflect current source status, and update information to reflect current operations and area descriptions. INEL contractors are encouraged to verify approximately $10 \%$ of the Air Emission Inventory data on an annual basis. For the 1994 update, extensive data verification was conducted to ensure completeness and accuracy of the Application for a Title V Operating Permit for the Idaho National Engineering Laboratory.

Each INEL contractor provides a coordinator for each operating area. The data to be updated is provided to each responsible area-specific coordinator which in turn is provided to the Air Emissions Inventory Coordinator. The Air Emission Inventory Coordinator compiles and reviews all data and provides the updates to the Air Emission Inventory System Administrator for data entry. The data are provided via update forms that are generated by the database. Each form details all the information pertinent to each source.

After the updated information is inputted, the applicable emission calculations are performed. All calculations performed during the update process follow the guidelines and assumptions as presented in the initial Air Emission Inventory report (DOE-ID 1991). Additional assumptions or guidelines are provided where applicable.

The data update process includes deleting sources, adding sources, process changes for sources, recalculating emissions, and adding data to reflect current operations. If a new vent, stack, source, or building has been added since the last survey, Phase I and Phase II forms are used to report the information. 


\section{1994 AREA UPDATE}

The 1994 update incorporates into the 1994 Air Emission Inventory operational changes reflecting the removal of sources, the addition of sources, updating source information, and the estimate of annual emissions. The 1994 updates reflect site-wide changes to reporting (section 3.1), as well as updates for each of the eight principal INEL functional areas where the majority of activities occur (sections 3.2 through 3.10). The eight functional areas correspond to the Area-Specific Volumes of the INEL Title V Operating Permit Application and include:

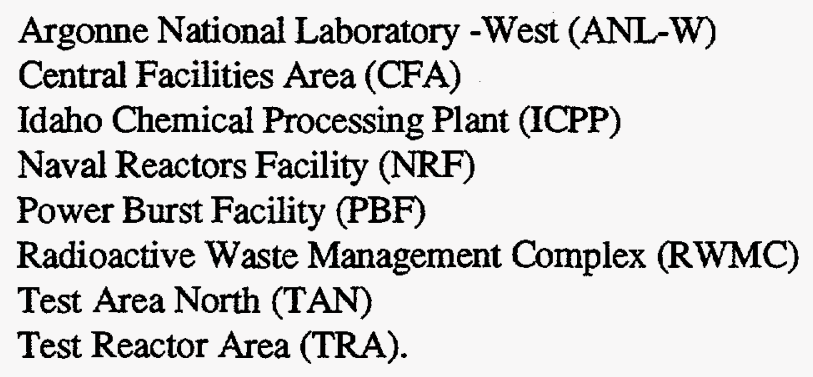

In addition, various secondary emission sources are distributed around and near the INEL site. These areas are identified in the inventory as the block areas.

Area-specific sections (3.2 through 3.10) include the following:

- Area description: A brief description of the role and function of the area, discussion of major programs, and an area plot plan.

- Primary sources: Primary sources of emissions (i.e., those generally corresponding to significant emission sources) including main stacks, operational reactors, and large boilers, where applicable, are discussed for each area. The information presents a functional description of each source and a brief qualitative description of emission types.

- Secondary sources: Secondary sources of emissions (i.e., those generally corresponding to not-significant emission sources) including fumehoods, small fuel burning equipment, and miscellaneous sources not considered primary sources are discussed.

- Summary of area-wide emissions: Total principal non-radionuclide pollutant emissions for each individual area are tabulated. The information includes the area, the pollutant, the actual hourly rates, and the actual annual quantities with their respective units.

- Summary of area changes: A table of source information changes reflecting added and removed sources, and other information changed from the 1993 Air Emissions Inventory is provided. In instances of new emission sources, not all data may be entered into the inventory.

Summaries of emissions for each area, organized by pollutant, are provided in Appendix B. Information provided includes the area, calculational method, and the emissions for each source. Notsignificant sources are identified with an asterix in the inventory emissions data. If a source was inactive during 1994, the emissions appear as zero, or the source is not shown. 
The INEL anticipates significant reformatting of their Air Emissions Inventory during the next several years. A summary of potential changes are discussed in section 3.12 of this report. 


\subsection{INEL Site-wide Changes}

The 1994 Air Emissions Inventory for the INEL reflects changes from the 1993 Air Emissions Inventory in reporting and source information updated during preparation of the INEL Title V Operating Permit Application. These changes often occur at sources located in many, or all of the eight functional areas, and are categorically applied to sources where appropriate. Therefore, these categorical changes are summarized herein to eliminate redundancy in the area-specific updates (sections 3.2 through 3.10).

Categorical changes include the following:

- The emissions associated with sources emitting only radionuclides are not reported in the 1994 Air Emissions Inventory. Emissions of radionuclides are and will continue to be reported in the Annual NESHAPs Report. Radionuclide emissions will not be included in future versions of this Air Inventory. Sources that have non-radionuclide emissions in addition to radionuclide emissions will continue to report the non-radionuclide emissions in this report.

- "Insignificant" activities, as defined in the Application for a Title V Operating Permit for the INEL, are not reported in the 1994 Air Emission Inventory and will not be included in future versions of this Air Emissions Inventory.

- Not-significant sources of emissions, as described in the INEL Title V Operating Permit Application, will continue to be reported in this inventory unless notified otherwise by the State of Idaho.

- Emissions of Hazardous Air Pollutants (HAPs) are provided for the first time in the 1994 Air Emissions Inventory (Appendix B). Lead emissions are provided only in Appendix B under HAPs, and are no longer summarized in the principal pollutant tables in the text.

- Stack parameters, including, but not limited to stack height, diameter and flow were corrected as necessary. Stack flow rates were changed to reflect maximum flow rates where nominal flow rates had been previously reported.

- Maximum calculated emission rates changed in certain instances due to correction of errors in prior reporting, or changes to original assumptions, hours of operation and other factors. To the extent practicable, significant changes are identified in the area-specific updates. A complete review of notsignificant sources was not conducted.

- Improved calculation methodology for organic storage tanks was used in 1994 reflecting more accurate emissions.

- In certain instances, multiple sources from a facility are combined for emission reporting purposes under a single vent number.

- Emissions from mobile sources, paved and unpaved roads, and the Auxiliary Reactor Area, Boiling Water Reactor Experiment, Experimental Breeder Reactor I, and Initial Engine Test areas are no longer reported in the INEL Air Emissions Inventory. 


\subsection{Argonne National Laboratory-West}

\subsubsection{Area Description}

ANL-W is a laboratory facility associated with the INEL and operated by the University of Chicago for the DOE Chicago Field Office. ANL-W is located near the south east corner of the INEL, approximately three miles north of U.S. Highway 20. ANL-W is presently involved in a broad range of research activities including fuel recycling and nuclear waste remediation.

The present primary experimental facilities are

$\begin{array}{ll}\text {. } & \text { Experimental Breeder Reactor II (EBR-II) } \\ \text { - } & \text { Transient Reactor Test Facility (TREAT) } \\ \text { - } & \text { Horo Power Physics Reactor (ZPPR) } \\ \text {. } & \text { Fuel Conditioning Facility (FCF) (formerly HFEF South) } \\ \text {. } & \text { Fuel Manufacturing Facility (FMF) } \\ \text { - } & \text { Laboratory and Office Building }\end{array}$

These facilities are well maintained and are projected to have useful lives of at least fifteen more years. Figure 3-1 presents an area plot plan of ANL-W.

\subsubsection{Primary Source Descriptions}

3.2.2.1 EBR-II. The EBR-II complex consists primarily of the EBR-II reactor building (ANL-767) and the power plant (ANL-768). EBR-II consists of an unmoderated, sodium-cooled reactor with a thermal power rating of 62.5-megawatt (MW), an intermediate closed loop of secondary sodium, and a steam plant capable of producing $19 \mathrm{MW}$ of electrical power through a conventional turbine generator. The reactor was shut down in October 1994. Measurements are presently made for gross alpha and gross beta gamma.

The power plant involves a number of support operations for the reactor, but the primary emission sources are the four industrial boilers. Boiler 1 is the primary boiler, and Boiler 2 is online approximately $20 \%$ of the time. Boilers 3 and 4 are $100 \%$ backup to Boilers 1 and 2 and run less than $1 \%$ of the time. Other sources include emergency diesel generators, fuel tanks, mix tanks for water treatment, and health physics lab hoods for decontamination of small items such as hand tools.

3.2.2.2 TREAT. The TREAT reactor (ANL-720) is a uranium-oxide-fueled, graphite-moderated, and air-cooled reactor designed to produce short, intense bursts of nuclear energy for the purpose of simulating accident conditions on test specimens in the reactor core. TREAT vents through the main stack, identified in the inventory as ANL-720-007. The offgas is HEPA filtered and continuously monitored. Present monitors are for gamma radiation only. Principal emissions include noble gases and Ba-La-140. Two diesel generators and associated fuel tanks are also located at ANL-720. The TREAT reactor is presently inactive.

3.2.2.3 HFEF. HFEF, formerly HFEF North (ANL-785), is designed for examination of irradiated fuel and waste specimens and houses a semi-automated hot-cell facility with an argon-atmosphere cell designed to handle and examine large experiments containing sodium and plutonium. HFEF also houses a neutron-radiography facility, a diesel generator, and an associated fuel tank. 
HFEF vents all the labs and the hot cells through a single stack: ANL-785-018. The gas stream from the lab area is HEPA filtered independently of the hot-cell gas stream, which also has a set of HEPA filters, and both streams combine at the stack. The emissions are continuously monitored for radionuclides, which are primarily noble gases. Some acids and some organics are also vented from the labs at this stack.

3.2.2.4 FCF. FCF was recently modified and equipped to demonstrate fuel cycle technology. The facility will now be used to apply this technology to high-level nuclear waste remediation.

FCF is vented out of the main stack (ANL-764) along with the EBR-II reactor building. Gas streams are HEPA filtered and continuously monitored. Emissions include noble gases and tritium. FCF also houses an emergency diesel generator and associated fuel tank.

3.2.2.5 ZPPR. The ZPPR reactor (presently inactive) complex includes the ZPPR reactor building (ANL-776), the ZPPR Support Wing (ANL-774), which houses the Argonne Fast Source Reactor (AFSR), the ZPPR Equipment Room (ANL-777), the ZPPR Vault/Workroom Equipment Room (ANL-775), the ZPPR Materials Control Building (ANL-784), and the ZPPR Mockup Building (ANL-792). The ZPPR reactor is designed for experiments that are most easily performed and studied under low-power conditions. AFSR is a small reactor that serves as a neutron source for calibrating nuclear instruments and developing experimental equipment, primarily for ZPPR. AFSR is air cooled and has a maximum power level of $1 \mathrm{~kW}$. The Materials Control Building is for storage of nonfissile material plates for reactor mockups. The ZPPR equipment room houses the filters, ventilation, and air conditioning equipment for the ZPPR mound area. The ZPPR Mockup building is used for storage and mockup and testing of experimental equipment.

The primary point of emissions from the ZPPR reactor complex is the main stack, identified in the inventory as ANL-777-002. The air from the inactive reactor cell enters ANL-775, where it is HEPA filtered along with the ventilation air from ANL-775. This gas stream then vents to the main stack. This stack is continuously monitored, and emissions include noble gases and unidentified beta-gamma emitters.

The AFSR cooling air vents at source ANL-774-025 (which is presently inactive), and the AFSR room vents at ANL-774-008. ANL-774-025 is HEPA filtered and monitored for gamma radiation when operating. Under normal operations, these sources produce no emissions.

ANL-W maintains diesel generators, fuel tanks, and a few miscellaneous fumehoods associated with the ZPPR complex.

3.2.2.6 FMF. FMF (ANL-704) is located near the ZPPR complex. It is a high-security facility that fabricated fuel assemblies for the EBR-II reactor. EBR-II driver and experimental fuel pins, elements, and subassemblies were also manufactured, inspected, and stored at FMF. The building is also equipped for the receipt and storage of fuel feedstock.

All parts of the building are maintained at negative pressure, and air flows from areas of least likelihood of contamination to areas of the greatest likelihood. Hoods, gloveboxes, and room vents all discharge to a single stack, identified as ANL-704-008. Emissions include alpha, beta, and gamma radiation, as well as small amounts of ethanol and acetone. An emergency diesel generator and small fuel tank are also located at FMF.

\subsubsection{Secondary Sources}

Secondary sources comprise sources that are not considered primary sources and include potential sources with little or no emissions; sources with relatively insignificant emissions; and sources with emissions 
that may be comparable to some sources associated with primary sources/programs but function only in support of the primary activities at this facility (such as the main cooling tower for EBR-II). Secondary sources at ANL-W include lab fumehoods, paint spray booths, welding booths, cooling towers, a blueprint machine, several multi-source large stacks, miscellaneous small radioactive sources, diesel engines, small furnaces and heaters, inorganic storage tanks, and organic storage tanks.

The large stacks typically operate 24 hours per day, 7 days per week, 52 weeks per year. Fumehood blowers may only operate while hoods are in use. Furnaces and heaters generally only operate eight months out of the year. Diesel engines typically operate on a routine preventative maintenance schedule of 0.5 hours per week, 52 weeks per year.

\subsubsection{Summary of ANL-W Emissions}

Totals of each of the non-radionuclide principal pollutant emissions from sources at ANL-W during 1994 are summarized in Table 3.2-1.

Table 3.2- 1. Summary of non-radionuclide principal pollutants at ANL-W.

\begin{tabular}{lcccc}
\hline \multicolumn{1}{c}{ Pollutant } & $\begin{array}{c}\text { Actual } \\
\text { Hourly } \\
(\mathrm{lb} / \mathrm{hr})\end{array}$ & $\begin{array}{c}\text { Actual } \\
\text { Annual } \\
(\mathrm{m} / \mathrm{yr})\end{array}$ & $\begin{array}{c}\text { Maximum } \\
\text { Hourly } \\
(\mathrm{lb} / \mathrm{hr})\end{array}$ & $\begin{array}{c}\text { Maximum } \\
\text { Annual } \\
(\mathrm{t} / \mathrm{yr})\end{array}$ \\
\hline Carbon monoxide & $1.579 \mathrm{E}+01$ & $2.766 \mathrm{E}+00$ & $3.358 \mathrm{E}+01$ & $8.022 \mathrm{E}+01$ \\
Nitrogen oxides & $6.993 \mathrm{E}+01$ & $1.116 \mathrm{E}+01$ & $1.505 \mathrm{E}+02$ & $3.486 \mathrm{E}+02$ \\
Particulate & $4.864 \mathrm{E}+00$ & $1.091 \mathrm{E}+00$ & $1.226 \mathrm{E}+01$ & $2.350 \mathrm{E}+01$ \\
Sulfur oxides & $4.382 \mathrm{E}+01$ & $3.750 \mathrm{E}+01$ & $5.050 \mathrm{E}+01$ & $2.446 \mathrm{E}+02$ \\
VOC - nonmethane & $5.454 \mathrm{E}+01$ & $6.053 \mathrm{E}-01$ & $6.486 \mathrm{E}+01$ & $5.807 \mathrm{E}+00$ \\
\hline
\end{tabular}

\subsubsection{Summary of ANL-W Changes}

Changes to specific sources located at ANL-W will be identified in the 1995 Air Emissions Inventory. In certain instances, differences between information presented in the 1994 Air Emissions Inventory and the INEL Tier I Operating Permit Application may occur. Discrepancies noted will be corrected in the 1995 inventory. 


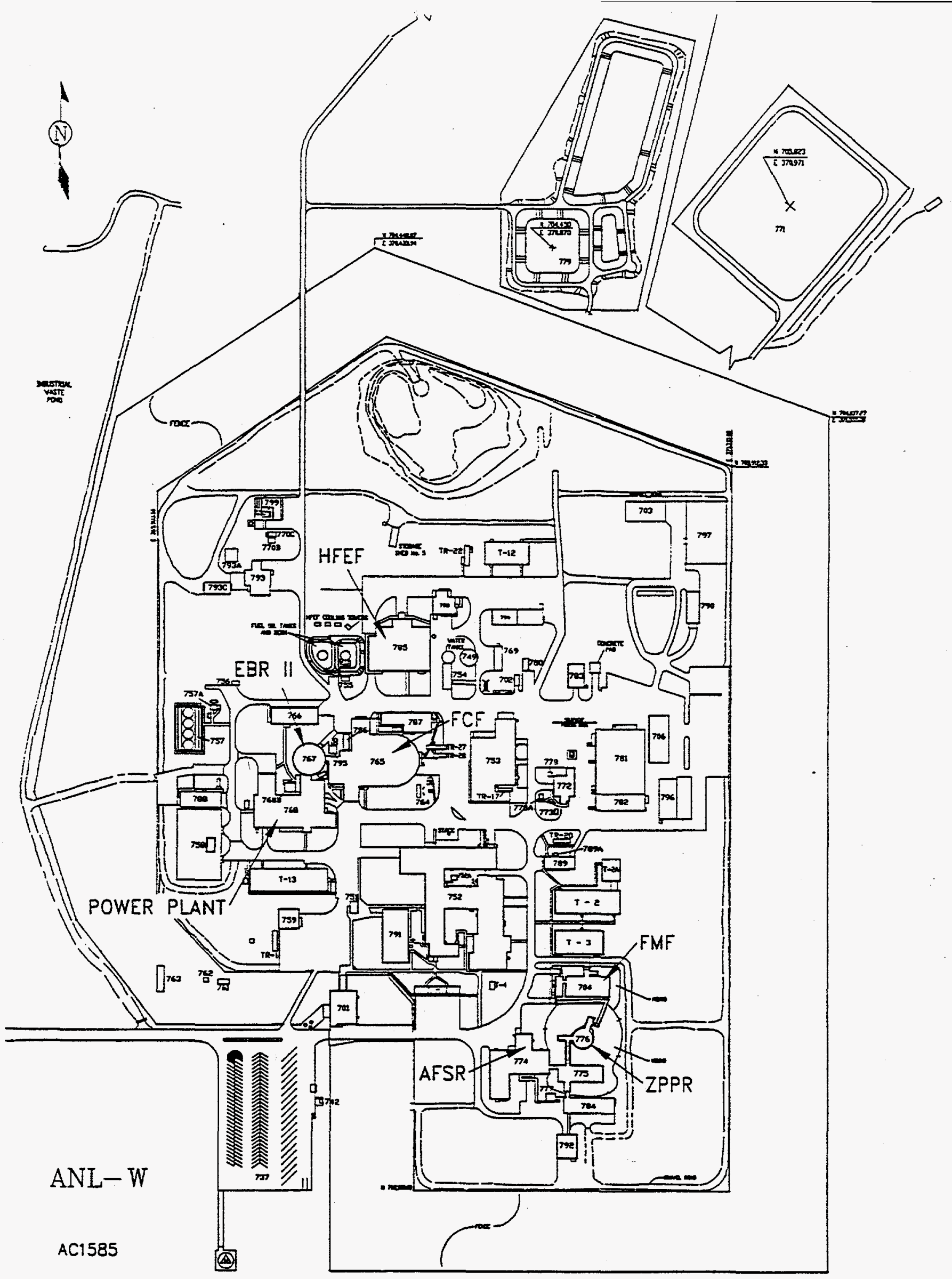

Figure 3-1. Area plot plan of Argonne National Laboratory-West. 


\subsection{Block Areas}

\subsubsection{Area Descriptions}

For administrative purposes, the INEL has been divided into a grid system, and each area is identified as a block and assigned a unique number. Many of these block areas have within them buildings or facilities that are not specifically assigned to one of the main INEL areas. These include the following:

Howe Peak Transformer Station (HPTF)

Security Firing Range, Block 21 (B21)

Fire Station 2 and the Experimental Dairy Farm, Block 16 (B16)

Main Guard Gate, Block 27 (B27)

Security Training Facility (STF)

North Guard Gate, Block 8 (B08)

East Butte (EB)

Figure 3-2 presents a map of the INEL and surrounding area showing the location of the above facilities.

HPTF is part of the INEL radio network and is located near the summit of Howe Peak, due west of the INEL. The facility consists of a few small buildings, radio antennas, and an emergency propane generator. This generator is the only source of emissions. The facility is unoccupied, though maintenance personnel make regular trips for preventative maintenance.

The Security Firing Range consists of an outdoor firing range, an indoor firing range, and administrative and support buildings. Emission points include the exhaust system for the indoor range, and an exhaust hood over three solvent sinks used for cleaning guns. This facility is occupied regularly.

Fire Station 2 consists of a few buildings and an outdoor fire training facility, including a tower and several fire pits. The buildings are presently occupied on a part-time basis by the National Oceanic and Atmospheric Administration (NOAA). The only sources in the buildings are the two oil burning furnaces that vent from a single stack and the fuel oil tank that supplies these furnaces. The fire training facilities consist of several concrete pits where oil is poured in and ignited. After training activities, the water and residual oil drains to a small evaporation pond. Emission estimates for these facilities consider all of the fire training components as a single source. The dairy farm is presently unoccupied, and there are no known emissions from those buildings.

The Main Guard Gate is located on E. Portland Avenue between CFA and U.S. Highways 20 and 26. The only source is the emergency diesel generator that resides in the generator building. This facility is always occupied, and the generator runs primarily on a preventive maintenance schedule.

The STF, formerly Experimental Organic Cooled Reactor and Organic Moderated Reactor Experiment, is located west of Jefferson Avenue, which runs northeast from E. Portland Avenue just north of the main guard gate, to the PBF area. This area was a reactor facility at one time and has been turned over for security training and mock procedures. The only source at STF is a solvent sink used for gun cleaning purposes. STF is no longer occupied and is presently slated for decontamination and decomissioning.

The North Guard Gate is on Lincoln Boulevard, just before it turns into U.S. Highway 33, between CFA and TAN. This is a small facility that consists of a single guard station in the middle of the road and a 
small emergency generator building, which houses the only source. This guard gate is typically only occupied by one or two security personnel.

East Butte is one of two natural volcanic buttes that are present in the southeast corner of the INEL, south of U.S. Highway 20. The top of the butte has been subdivided into several lots, most with a transmitter station. These stations include transmitters for local television and radio stations, Idaho State University, the Bureau of Land Management, Utah Power and Light, the State of Idaho, and others. The NEL has a small transmitter as well, consisting of a small trailer and a single tower. Many of the buildings house emergency diesel generators for their respective transmission towers, but the INEL transistor area does not. Consequently, these sources are not included in the inventory since they are not INEL property nor property of any INEL contractor. The only fully occupied operation on East Butte belongs to KIDK television station, based in Idaho Falls, who takes much of the responsibility for the maintenance of the East Butte facilities.

\subsubsection{Primary Sources}

All primary sources in any of the block areas are associated with one of the main areas and are discussed in the appropriate area discussion.

\subsubsection{Secondary Sources}

All sources in the block areas are considered to be secondary sources. Most are fuel burning equipment with associated fuel tanks, but there are a few chemical sources as well. There are no sources of radiation in any of the block areas. The secondary sources include two solvent sinks, lead and particulate from the firing range, a furnace/heater, an emergency generator, organic storage tanks, and an evaporation/fire pit.

\subsubsection{Summary of Block Area Emissions}

Totals of each of the non-radionuclide principal pollutant emissions from sources in the Block Areas during 1994 are summarized in Table 3.3-1.

Table 3.3-1. Summary of non-radionuclide principal pollutants at block areas.

\begin{tabular}{lcccc}
\hline \multicolumn{1}{c}{ Pollutant } & $\begin{array}{c}\text { Actual } \\
\text { Hourly } \\
(\mathrm{lb} / \mathrm{hr})\end{array}$ & $\begin{array}{c}\text { Actual } \\
\text { Annual } \\
(\mathrm{tn} / \mathrm{yr})\end{array}$ & $\begin{array}{c}\text { Maximum } \\
\text { Hourly } \\
(\mathrm{lb} / \mathrm{hr})\end{array}$ & $\begin{array}{c}\text { Maximum } \\
\text { Annual } \\
(\mathrm{m} / \mathrm{yr})\end{array}$ \\
\hline Carbon monoxide & $3.405 \mathrm{E}+01$ & $4.240 \mathrm{E}-01$ & $1.194 \mathrm{E}+01$ & $5.221 \mathrm{E}+01$ \\
Nitrogen oxides & $1.000 \mathrm{E}+04$ & $1.330 \mathrm{E}-00$ & $1.616 \mathrm{E}+01$ & $7.079 \mathrm{E}+01$ \\
Particulate & $8.003 \mathrm{E}+00$ & $1.010 \mathrm{E}-01$ & $1.584 \mathrm{E}+00$ & $6.921 \mathrm{E}+00$ \\
Sulfur oxides & $4.769 \mathrm{E}+00$ & $5.300 \mathrm{E}-02$ & $3.801 \mathrm{E}+00$ & $1.666 \mathrm{E}+01$ \\
VOC - nonmethane & $9.447 \mathrm{E}+00$ & $1.112 \mathrm{E}+00$ & $2.494 \mathrm{E}+00$ & $6.239 \mathrm{E}+00$ \\
\hline
\end{tabular}

\subsubsection{Summary of Block Area Changes}

Changes to specific sources located within the Block Areas between the 1993 and 1994 Air Emissions Inventories are summarized in Table 3.3-2. Justification to changes are provided to clarify the status of the source. 
Table 3.3-2. Summary of source changes at Block Areas - 1993 to 1994 Inventory.

\begin{tabular}{|c|c|c|}
\hline 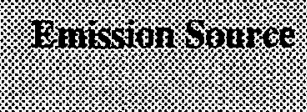 & 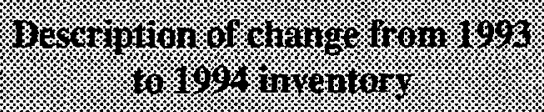 & 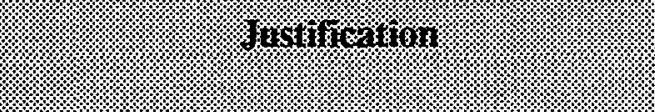 \\
\hline B16-601-007 & Vent \# deleted & $\begin{array}{l}\text { Source removed. Fire station \#2 fuel-oil } \\
\text { furnaces. (For } 1994 \text { update) }\end{array}$ \\
\hline $\begin{array}{l}\text { B16-704-001 } \\
\text { B16-704-002 }\end{array}$ & Vent \# added & $\begin{array}{l}\text { Newly identified source. Vehicle fuel tanks } \\
\text { located at NRF parking lot. }\end{array}$ \\
\hline
\end{tabular}




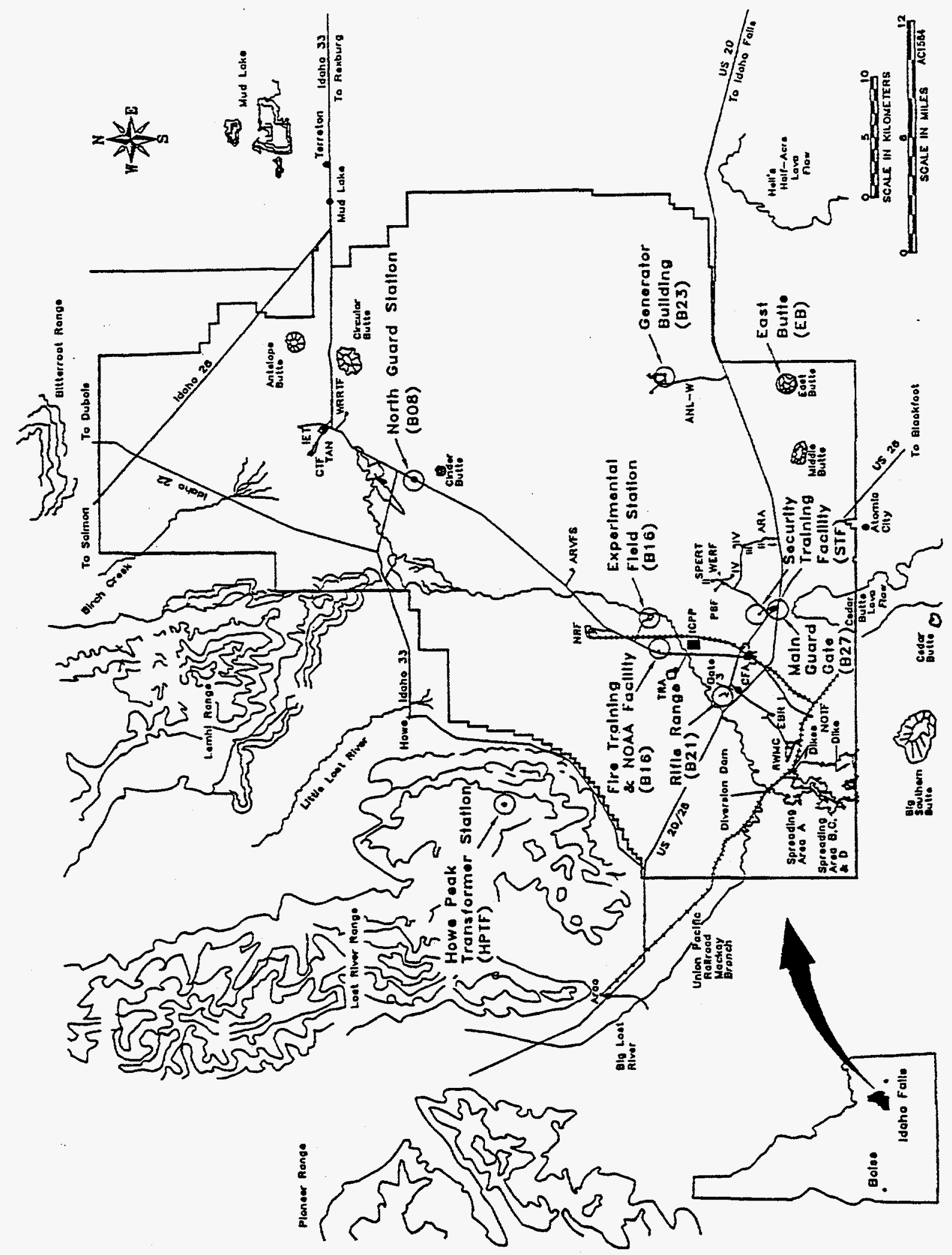

Figure 3-2. Area plot plan of Block Areas. 


\subsection{Central Facilities Area}

\subsubsection{Area Description}

CFA is located in the southern part of the INEL, roughly 2.5 miles north of U.S. Highways 20 and 26. The original facilities at CFA were constructed during 1940 through 1950 and were used to house Naval Gunnery Range personnel and later National Reactor Testing Station personnel. The facilities have since been modified to fit the changing needs of the INEL and now provide four primary types of functional space: craft, office, service, and laboratory.

The craft areas consist primarily of the four new multicraft shops as well as warehouses for craft materials storage. Activities include painting, welding, carpentry, machining, and other related crafts needed to support INEL operations.

Office space is provided for administrative, scientific, and engineering personnel, particularly those associated with the many labs and service groups. Services at CFA are provided for the support of the INEL and include bus and vehicle maintenance, equipment mechanics, equipment operation, radio and alarm shops, telecommunication facilities, cafeterias, service stations, fuel distribution, facility maintenance, instrument calibration, and training. Laundry and respirator decontamination activities were discontinued in June 1993.

Laboratories are located in CFA-612, the Environmental Chemistry Laboratories in CFA-625 and -633, the Radiological and Environmental Sciences Laboratories (RESL) in CFA-690, and the Technical Center and High Bay at CFA-686, -688 , and -689 . These laboratories are chemistry and engineering laboratories used for both research and analysis.

Figure 3-3 presents an area plot plan of CFA, highlighting a few of the primary facilities. Figure 3-4 presents a detail of the shaded area in Figure 3-3.

\subsubsection{Primary Sources}

Because of the administrative and support nature of the work performed at CFA, few sources of emissions of the same order of magnitude are found elsewhere at the site. The more significant emission sources at CFA are the many large boilers used to produce steam for most of the buildings. Large boilers are located in the following buildings:

\footnotetext{
- CFA-650 - one boiler

- CFA-662 - one full-time boiler, and one backup

- $\quad$ CFA-665 - one large full-time boiler

- CFA-671 - two large boilers

- CFA-688 - two large boiler.
}

Smaller boilers/furnaces are located in the following areas:
CFA-608 - one boiler
CFA-609 - one boiler
CFA-613 - one furnace
CFA-668 - one furnace. 
All boilers at CFA burn No. 2 fuel oil, and most have a propane ignition. Most boilers provide space heating only and typically do not operate during the summer months ${ }^{\mathrm{a}}$.

The Environmental Chemistry Labs at CFA-625 are divided into two areas, each with a different function. One area is responsible for all radiologically contaminated samples, and the hoods on that half of the building vent to a single stack with a HEPA filter.

The RESL is a DOE facility that provides several support functions. There are several analytical laboratories and a few environmental laboratories. The laboratories perform the radioisotope analysis of soil and organic samples. These labs have two or three hoods per room that vent to large stainless steel stacks on the roof. The primary emissions from RESL are acids that are used to digest the samples and then are boiled away as part of the analytical procedure. All radiological releases are below normal background levels.

Numerous fuel storage tanks contribute to the VOC emissions, but the biggest sources are the tanks at the tank farm (CFA-754) and the large fuel oil tank behind the Technical Center (CFA-708). The tank farm tanks contained No. 2 fuel oil, diesel and diesel blends, and gasoline. These became inactive during 1994 due to electrical pump problems. All are very large, aboveground, vertical tanks that dispense fuel to various tanks around the site.

The CFA landfill is estimated to be a primary source of particulate. The CFA landfill services all of the INEL, disposing only industrial and commercial wastes and asbestos in proper containers. During 1993, the INEL Landfill Complex relocated disposal activities from the CFA Landfill III Extension to the area associated with the bulky waste pit. Dirt moving activities, soil piles, and vehicle travel at the landfill are estimated to contribute a significant quantity of particulate to the atmosphere.

\subsubsection{Secondary Sources}

The secondary sources at CFA constitute the bulk of all sources at the facility. Some of the fumehoods at CFA-690 (RESL) would individually be considered as secondary sources, but since the RESL facility is considered to be a primary source, the primary and secondary sources are not differentiated in this discussion. A single health physics hood in the Health Physics Instrument laboratory at CFA-633, and CFA625 are the only secondary potential sources of radiation.

Secondary sources at CFA include several fumehoods, two paint booths, several welding booths, emergency engines, heaters/furnaces, and numerous organic storage tanks. Most of the tanks, all the engines, most of the fumehoods, and all of the small heaters and furnaces have been considered as secondary sources.

a Note: CFA - 617 process steam currently inactive - propane boiler for laundry facility.

Note: All boilers must undergo off-season preventative maintenance and associated operational periods of time. 


\subsubsection{Summary of CFA Emissions}

Totals of each of the non-radionuclide principal pollutant emissions from sources at CFA during 1994 are summarized in Table 3.4-1.

Table 3.4-1. Summary of the totals for each of the non-radionuclide principal pollutants at CFA.

\begin{tabular}{lcccc}
\hline \multicolumn{1}{c}{ Pollutant } & $\begin{array}{c}\text { Actual } \\
\text { Hourly } \\
(\mathrm{lb} / \mathrm{hr})\end{array}$ & $\begin{array}{c}\text { Actual } \\
\text { Annual } \\
(\mathrm{tm} / \mathrm{yr})\end{array}$ & $\begin{array}{c}\text { Maximum } \\
\text { Hourly } \\
(\mathrm{lb} / \mathrm{hr})\end{array}$ & $\begin{array}{c}\text { Maximum } \\
\text { Annual } \\
(\mathrm{m} / \mathrm{yr})\end{array}$ \\
\hline Carbon monoxide & $9.112 \mathrm{E}+00$ & $8.197 \mathrm{E}-01$ & $1.265 \mathrm{E}+01$ & $3.653 \mathrm{E}+01$ \\
Nitrogen oxides & $3.809 \mathrm{E}+01$ & $3.366 \mathrm{E}+00$ & $5.771 \mathrm{E}+01$ & $1.659 \mathrm{E}+02$ \\
Particulate & $4.598 \mathrm{E}+01$ & $4.762 \mathrm{E}+01$ & $5.514 \mathrm{E}+01$ & $6.461 \mathrm{E}+01$ \\
Sulfur oxides & $6.215 \mathrm{E}+00$ & $1.075 \mathrm{E}+01$ & $2.997 \mathrm{E}+01$ & $9.205 \mathrm{E}+01$ \\
VOC - nonmethane & $1.364 \mathrm{E}+02$ & $9.232 \mathrm{E}+00$ & $1.387 \mathrm{E}+02$ & $8.414 \mathrm{E}+01$ \\
\hline
\end{tabular}

\subsubsection{Summary of CFA Changes}

Changes to specific sources located at CFA between the 1993 and 1994 Air Emissions Inventories are summarized in Table 3.4-2. Justification to changes are provided to clarify the status of the source.

Table 3.4-2. Summary of source changes at CFA - 1993 to 1994 Inventory.

\begin{tabular}{|l|l|l|}
\hline CFA-100-001 & $\begin{array}{l}\text { Change in emissions due to } \\
\text { improved and current data. }\end{array}$ & $\begin{array}{l}\text { Landfill operations include 3 operational } \\
\text { areas. Fugitive emissions from the asbestos } \\
\text { pit recalculated based on current operational } \\
\text { data. }\end{array}$ \\
\hline CFA-104-001 & Vent \# added & $\begin{array}{l}\text { New source designation. Landfill operations } \\
\text { are 3 separate operational areas. } \\
\text { Commercial/industrial landfill operations. }\end{array}$ \\
\hline CFA-105-001 & Vent \# added & $\begin{array}{l}\text { New source designation. Landfill operations } \\
\text { are 3 separate operational areas. Petroleum- } \\
\text { contaminated soil landfarming area. }\end{array}$ \\
\hline CFA-609-018 & Vent \# deleted & $\begin{array}{l}\text { Source removed from service. Weapons } \\
\text { cleaning hood. (1993 for 1994 update) }\end{array}$ \\
\hline CFA-609-019 & Vent added & $\begin{array}{l}\text { Currently inactive/unused fume hood at } \\
\text { helicopter parts cleaning bench. Source } \\
\text { added based on Tiger Team request to } \\
\text { install fume hood. No expected emissions } \\
\text { from this source. }\end{array}$ \\
\hline
\end{tabular}


Table 3.4-2 - Continued. Summary of source changes at CFA - 1993 to 1994 Inventory.

\begin{tabular}{|c|c|c|}
\hline 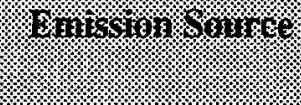 & I. & 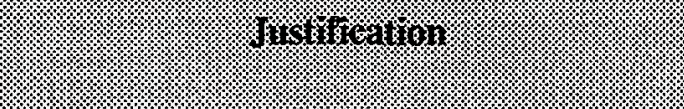 \\
\hline CFA-609-020 & Vent \# added & $\begin{array}{l}\text { New source. Soldering area vent trunk. } \\
\text { Source added based on Tiger Team request } \\
\text { to install vent trunk. }\end{array}$ \\
\hline CFA-622-006 & Vent \# deleted & $\begin{array}{l}\text { Source designation removed. No regulated } \\
\text { emissions from this welding shop blower } \\
\text { exhaust vent (zero emission vent). }\end{array}$ \\
\hline CFA-624-009 & Vent \# deleted & $\begin{array}{l}\text { Source removed from service. Blueprint } \\
\text { Machine. (1993) }\end{array}$ \\
\hline $\begin{array}{l}\text { CFA-633-001 } \\
\text { CFA-633-003 } \\
\text { CFA-633-008 } \\
\text { CFA-633-009 } \\
\text { CFA-633-011 } \\
\text { CFA-633-015 } \\
\text { CFA-633-020 } \\
\text { CFA-633-021 } \\
\text { CFA-633-028 } \\
\text { CFA-633-040 }\end{array}$ & Vent \# deleted & $\begin{array}{l}\text { Source inactive, locked and tagged out } \\
\text { fume hoods. There are no plans to reactivate } \\
\text { these sources. }\end{array}$ \\
\hline CFA-640-029 & Vent \# added & $\begin{array}{l}\text { New source. Power operations magnetic } \\
\text { particle trough. (1994) }\end{array}$ \\
\hline CFA-668-001 & Vent \# deleted & $\begin{array}{l}\text { Source removed. (Tank replaced by CFA- } \\
\text { 1701-001) Continued emission source. }\end{array}$ \\
\hline CFA-668-010 & Vent \# deleted & $\begin{array}{l}\text { Source removed from service. } \\
\text { Communications building emergency } \\
\text { generator fuel tank. }\end{array}$ \\
\hline CFA-682-002 & Vent \# deleted & $\begin{array}{l}\text { Source removed from service. Firewater } \\
\text { pump. }\end{array}$ \\
\hline CFA-688-048 & Vent \# deleted & $\begin{array}{l}\text { Source removed from inventory. Improper } \\
\text { source designation. Engineering Technical } \\
\text { Center fuel tank/vent line. (1994) }\end{array}$ \\
\hline CFA-689-030 & Vent \# deleted & $\begin{array}{l}\text { Source removed from service. Fume hood. } \\
\text { (1994) }\end{array}$ \\
\hline $\begin{array}{l}\text { CFA-690-045 } \\
\text { CFA-690-059 }\end{array}$ & Vent \# Added & $\begin{array}{l}\text { Vent \# reactivated to support new lab } \\
\text { activity within lab area. No emissions to } \\
\text { report for } 1994 \text {. }\end{array}$ \\
\hline
\end{tabular}


Table 3.4-2 - Continued. Summary of source changes at CFA - 1993 to 1994 Inventory.

\begin{tabular}{|c|c|c|}
\hline 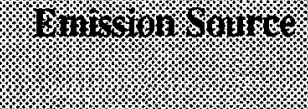 & 3) & molumating \\
\hline $\begin{array}{l}\text { CFA-696-001 } \\
\text { CFA-696-002 } \\
\text { CFA-696-003 } \\
\text { CFA-696-006 } \\
\text { CFA-696-007 } \\
\text { CFA-696-008 } \\
\text { CFA-696-009 } \\
\text { CFA-696-010 } \\
\text { CFA-696-011 } \\
\text { CFA-696-012 } \\
\text { CFA-696-021 } \\
\text { CFA-696-022 } \\
\text { CFA-696-023 } \\
\text { CFA-696-024 } \\
\text { CFA-696-025 } \\
\text { CFA-696-026 } \\
\text { CFA-696-027 } \\
\text { CFA-696-040 }\end{array}$ & Vent \# added & $\begin{array}{l}\text { New sources. Transportation Complex. (No } \\
\text { emissions during 1994.) }\end{array}$ \\
\hline CFA-748-001 & Vent \# deleted & $\begin{array}{l}\text { Source removed from service. Fuel tank. } \\
\text { (1994) }\end{array}$ \\
\hline CFA-751-004 & Vent \# deleted & $\begin{array}{l}\text { Improper source designation. Propane } \\
\text { vaporizer not considered an emission } \\
\text { source. }\end{array}$ \\
\hline CFA-1603-001 & Vent \# added & $\begin{array}{l}\text { New source. Emergency firewater pump } \\
\text { engine. (1994) }\end{array}$ \\
\hline CFA-1603-002 & Vent \# added & $\begin{array}{l}\text { New source. Emergency firewater pump } \\
\text { engine. (1994) }\end{array}$ \\
\hline CFA-1603-003 & Vent \# added & New source. Fuel tank. (1994) \\
\hline CFA-1603-004 & Vent \# added & New source. Fuel tank. (1994) \\
\hline CFA-1701-001 & Vent \# added & New source. Replacement fuel tank. \\
\hline CFA-1702-001 & Vent \# added & New source. Replacement fuel tank. \\
\hline CFA-1703-001 & Vent \# added & New source. Replacement fuel tank. \\
\hline CFA-1708-001 & Vent \# added & New source. Replacement fuel tank. \\
\hline
\end{tabular}


Table 3.4-2 - Continued. Summary of source changes at CFA - 1993 to 1994 Inventory.

\begin{tabular}{|c|c|c|}
\hline 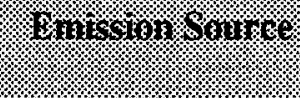 & 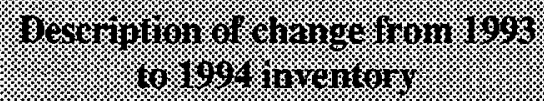 & 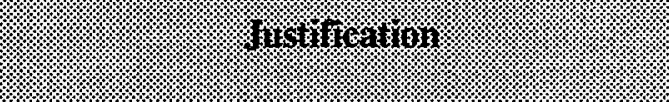 \\
\hline $\begin{array}{l}\text { CFA-1709-001 } \\
\text { CFA-1709-002 } \\
\text { CFA-1709-003 } \\
\text { CFA-1709-004 } \\
\text { CFA-1709-005 } \\
\text { CFA-1709-006 } \\
\text { CFA-1709-007 }\end{array}$ & Vent \# added & $\begin{array}{l}\text { New Source. (Fuel and new used oil tanks - } \\
\text { No emissions will be reported until 1995). }\end{array}$ \\
\hline
\end{tabular}




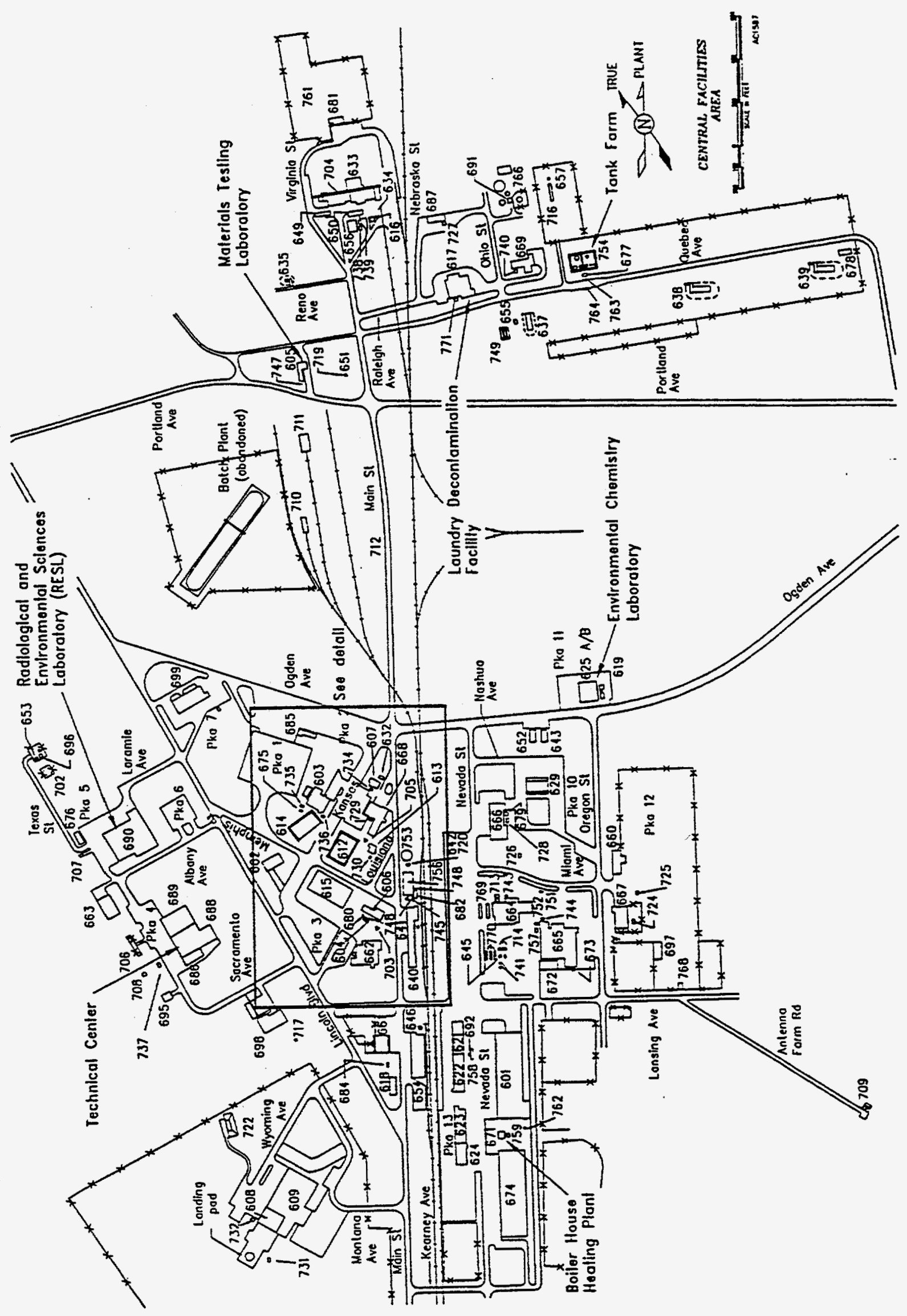

Figure 3-3. Area plot plan of the Central Facilities Area. 


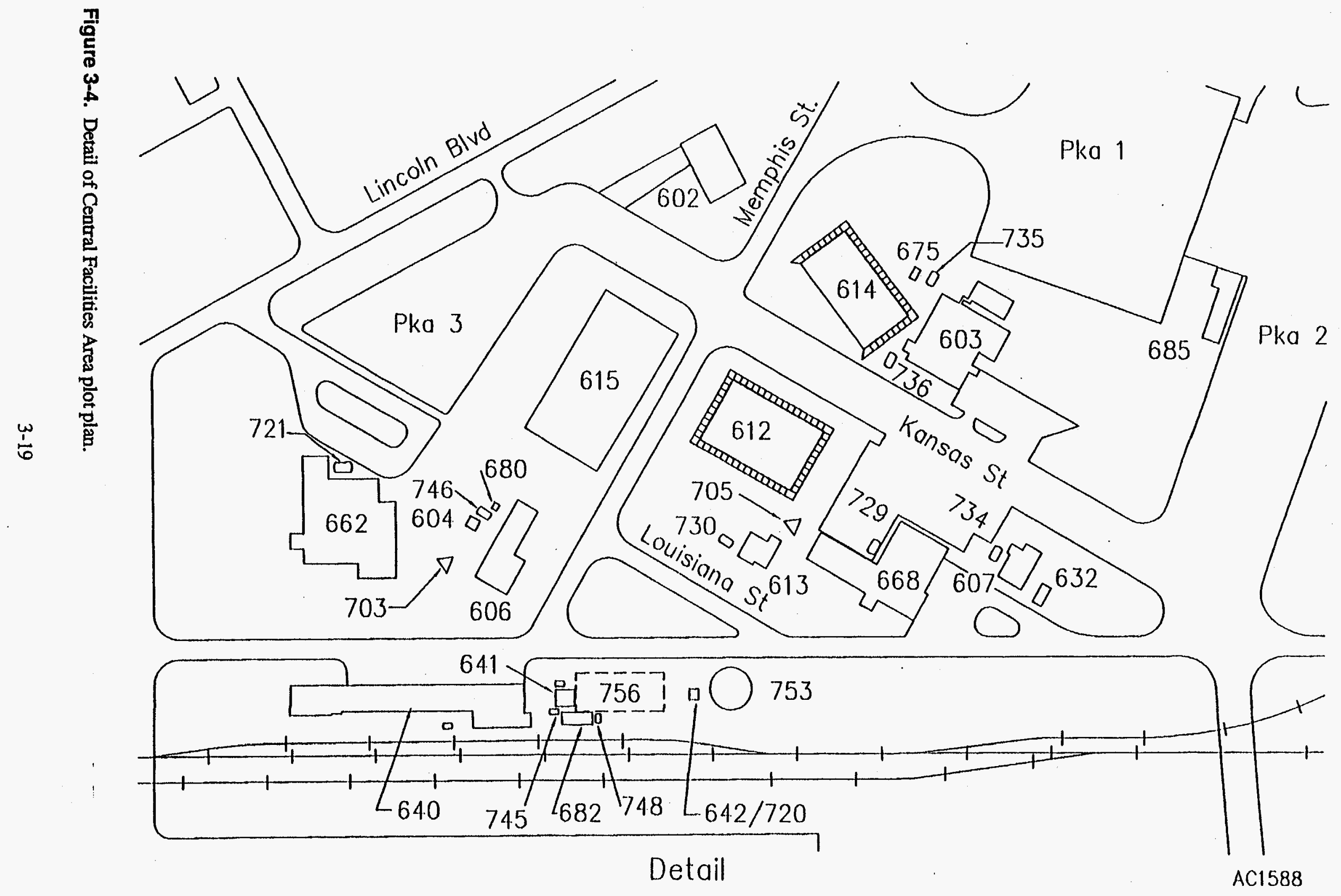




\subsection{Idaho Chemical Processing Plant}

\subsubsection{Area Description}

ICPP was originally constructed in 1953 as an engineering-scale demonstration facility to process highly enriched spent reactor fuel. The plant became the INEL's principal facility for receiving, storing, reprocessing, and managing nuclear materials from test, defense, and research reactors in the United States and other countries. Since 1963, the ICPP has converted more than six million gallons of radioactive liquid waste to granular solid form. In 1992 reprocessing of spent nuclear fuel was stopped. Currently, ICPP has several primary functions, including fuel storage, waste management, technical support, and utilities. Figure 3-5 shows a plot plan of ICPP.

Fuel receipt and storage areas include the Fuel Receiving and Storage Building (CPP-603), the Fluorinel Dissolution Process and Fuel Storage (FAST) facility (CPP-666), and the Peach Bottom Fuel Storage Facility (CPP-749). CPP-666 stores fuels in water pools, and CPP-749 stores the fuel rods in underground dry containment. CPP-603 houses fuels in both dry and underwater storage.

Waste management facilities manage liquid, solid, and gaseous radioactive wastes. Waste management facilities include the tank farm, CPP-604, CPP-605/649, CPP-659, and the calcine storage bin sets. The tank farm area consists of large storage tanks that store liquid radioactive waste before it is sent to CPP-659. CPP-659, the New Waste Calcining Facility (NWCF), is a process building used to calcine liquid radioactive waste into a more stable solid radioactive waste (calcine). The calcine is then temporarily stored in storage bins until final treatment and disposal of the waste. CPP-604 houses the process equipment waste evaporators that concentrate dilute low-level radioactively contaminated liquid waste. The atmospheric protection system filters process offgas and process ventilation through banks of HEPA filters.

Technical facilities provide for chemical, radiochemical, and spectroscopic analysis and process development. Those facilities include the remote analytical facility (CPP-627), the Remote Analytical Laboratory (CPP-684), the process improvement facility (CPP-637), the process building (CPP-601), the laboratory and office building (CPP-602), and the safety and spectrometry building (CPP-630).

CPP-601 houses the alpha handling laboratory. CPP-602 contains radiochemistry, wet chemistry, quality control and accountability, spectrochemical, instrument, and methods research and development laboratories. CPP-627 incorporates remote analytical facilities and the production support analysis laboratory. CPP-637 houses technical laboratories, offices, and pilot plant facilities. CPP-630 houses the mass spectrometry laboratory.

Utility support buildings primarily include CPP-606, service building powerhouse, and CPP-687, the Coal-Fired Steam-Generating Facility (CFSGF). CPP- 606 houses four boilers that are used as backup for the CFSGF (one of the boilers is not presently operable but will be used again). CFSGF houses two boilers and is the main source of steam for ICPP. CFSGF has an EPA air quality prevention of significant deterioration (PSD) permit.

\subsubsection{Primary Source Description}

The Remote Analytical Laboratory (CPP-684) is used for chemical analysis of samples generated at various areas throughout ICPP. Some of those areas include the FAST facility (CPP-666), the process building (CPP-601), the service waste system, various pilot plants, the decontamination facility, and NWCF. The building consists of radioactive and nonradioactive laboratories, offices, and other support space. The facility was designed to segregate work areas. 
The warm (slightly radioactive) laboratory area receives filtered air from the heating, ventilating, and air conditioning air supply room as four separate streams. These streams flow to the following areas (some of which may be slightly radioactive): offices, change rooms, operating gallery, and maintenance corridor, valve room and operating gallery; and the warm (radioactive) laboratory. Total flow through these areas is about $16,000 \mathrm{cfm}$, and the flow goes from the least contaminated to the most contaminated areas. These streams are combined and exhausted through a double HEPA filter to the warm laboratory exhaust stack. The warm exhaust stream is continuously sampled and monitored for radioactive material.

The cold (nonradioactive) laboratory system is supplied by two filtered streams. One stream supplies the vestibule, offices, sample data room, and toilets. The other stream supplies the cold laboratories. The laboratory stream, with a flow of about $4680 \mathrm{cfm}$, discharges unfiltered through the cold laboratory exhaust stack. The other stream, with a volume of $530 \mathrm{cfm}$, exhausts through the office area exhaust blower. As a chemical laboratory, a large variety of chemicals are used in the facility. Most of these are liquid and are used in small quantities. Organic chemicals that are sometimes used in the area include propane used as a laboratory fuel supply, isopropanol used for cleaning equipment, and methyl isobutyl ketone used as an extractant. Inorganic materials that could be present include boron, cadmium, mercury, chromium, hydrofluoric acid, and nitric acid.

ICPP, like other industrial plants, uses steam for a variety of purposes, including heating and other process needs. CFSGF is the primary facility at ICPP for generating this steam, with other oil-fired boilers used as backup. This facility had a PSD permit before construction began.

CFSGF has two fluidized bed boilers that burn coal to provide the heat to generate steam. This burning process generates unburned organics, particulates, sulfur oxides, nitrogen oxides, and other materials that are, after appropriate cleanup, discharged to the atmosphere. The facility consists of the two boilers and associated equipment such as coal unloading and handling facilities, an ash pit, and other items necessary to operate the facility. Particulates are removed by passing the offgas through bag filters, and a limestone injection system is used to remove most of the sulfur that is generated during the burning of the coal.

CFSGF has a design heat generation rate of $165 \mathrm{MBtu}$ per $\mathrm{hr}$. The design coal consumption rate is $16,500 \mathrm{lb} / \mathrm{hr}$. At this rate, $135,000 \mathrm{lbs}$ of steam are generated per hour. Offgases from the coal combustion discharge through a dedicated stack that is $150 \mathrm{ft}$ high and about $5.8 \mathrm{ft}$ in diameter. The effluent discharges at a temperature of $350^{\circ} \mathrm{F}$ and at a flow rate of $75,000 \mathrm{cfm}$, resulting in a velocity of approximately $47 \mathrm{ft} / \mathrm{sec}$.

CPP-606, the Service Building Power House, houses four oil fired boilers used as backup for the CFSGF. The boilers in CPP- 606 are considered primary sources even though they are standby boilers. The four boilers consist of two Babcock \& Wilcox Company boilers, one Murray boiler, and one Cleaver Brooks boiler. These boilers have been included in the PSD permit for the ICPP NO ${ }_{x}$ sources. There are only three stacks for all four boilers because the two Babcock \& Wilcox Company boilers share a common stack. One of those boilers is presently not used but plans are being developed to bring that boiler back online.

The FAST facility (CPP-666) is a primary facility at ICPP for storing nuclear fuel. Fuel received from other locations is brought to the FAST facility in large, shielded casks, where it is unloaded and stored in large water-filled basins.

The Fuel Storage Area consists of a truck receiving area, a cask receiving area, decontamination rooms, a fuel unloading area, and a water treatment area in addition to the fuel storage area. The decontamination area is used to remove any surface contamination that may be present on the cask. The flourinel dissolution process area contains the cells where the fuel dissolution occurs, as well as change rooms, offices and the control room, a chemical makeup area, and other support areas. Both areas share one 
overall ventilation system that discharges to a special, dedicated FAST stack located north of the building. This stack is approximately $160 \mathrm{ft}$ high. A bypass is available if the stack or the line leading to it becomes inoperable. The bypass is located on the roof of the CPP- 666 near the northwest corner. Total flow through the ventilation system is about 90,700 actual cubic feet per minute.

All gaseous effluents at FAST, both radiological and nonradiological, are routed through HEPA filters before discharging to the environment. In general, the offgas from each area is filtered through roughing and HEPA filters before it leaves the area. These streams are then combined with the general ventilation air, which is again filtered before releasing to the environment. The individual treatment of an offgas stream before it leaves an area is based on the knowledge of the process and potential contents of the stream, which determines the number of filter stages needed or if other cleanup equipment is appropriate. The final cleanup system that treats the stream leaving the facility consists of four pairs of prefilters followed by HEPA filters. (The stream is split into four parts as it leaves the building.) Heat recovery coils are present to help conserve and recover heat from the exiting stream. The air stream then flows through a common duct to one of three blowers, each of which is sized to handle half of the total flow. The exhaust then flows through an underground duct to the FAST stack.

The ICPP main stack is the primary emission point at ICPP because of the volume of gas discharged and the contaminants released. The main stack is $250 \mathrm{ft}$ tall and has a diameter of about $6.5 \mathrm{ft}$. Air flow through the stack is about 100,000 to $150,000 \mathrm{cfm}$, resulting in a velocity up the stack of about $61 \mathrm{ft} / \mathrm{sec}$. Offgas release points from throughout the ICPP area are collected and lead to the main stack where the emissions are monitored, sampled, and released to the environment. The streams leading to the main stack can be classified according to their origin as well as the activities from which they come. The effluent from the main stack is constantly monitored for the primary emissions, specifically nitrogen oxides and radionuclides. Releases of nitrogen oxides and radionuclides from the main stack are regulated by the ICPP $\mathrm{NO}_{\mathrm{x}}$ sources Permit to Construct issued by the State of Idaho.

Although a large number of activities are conducted at ICPP, the primary sources that generate emissions are classified as a) nuclear fuel storage, $b$ ) treatment of the waste generated during dissolution by converting it from a liquid to a solid in a process called calcination, c) treatment of other waste streams by evaporation, d) sampling of many of the liquid streams, and e) various support activities involving chemical analysis, process development, steam generation, and other activities associated with operation of the plant.

These activities are reflected in the design of the system that collects offgases for transport to and release from the main stack. This system collects offgases from the following areas: a) general ventilation air from buildings CPP-601, CPP-602, CPP-604, CPP-633, CPP-627, and CPP-640; b) dissolver offgas lines that collect the offgases that are generated during the actual fuel dissolution process; $c$ ) sample offgas lines that collect emissions generated when samples are obtained by using air or steam jets to obtain samples from various tanks or lines; d) vessel offgas lines that are connected to many vessels in all parts of the plant and generate offgases as they are filled or breathe; and e) and process offgas lines from the calcination process that are high in nitrogen oxides because of the destruction of the nitrate present in the wastes, which occurs during the calcination process.

The general ventilation air typically contains only minor quantities of pollutants which come from areas that under normal circumstances do not contain hazardous materials and that are normally occupied, so the concentration of any potentially dangerous material is minimal. Air from hoods, normally radioactive areas, and similar areas is not included in the normal ventilation air. This air, like all releases to the ICPP main stack, is processed through the Atmospheric Protection System before being released to the environment. 
Releases to the main stack are highly dependent on the individual activities that are in operation at the time, and these can vary greatly over the years or throughout any given year. Operation of NWCF results in large quantities of nitrogen oxides being released; nitrogen oxide releases are minimal if NWCF is not operating.

Certain materials considered toxic by the State of Idaho could be present in the gas exhausted from the main stack. Because of the extensive cleanup system present on the offgas stream, most or all of these substances would be present in concentrations significantly below the levels considered as toxic by the State of Idaho. Laboratory ventilation air discharges to this system, and this air could contain minute quantities of the many chemicals typically used in a laboratory, although these chemicals would normally be used only in a hood with a separate discharge point. Some of the toxic materials that could be present in the exhaust in small quantities include acetic acid, cadmium compounds, sulfuric acid, various solvents, tributyl phosphate, aluminum nitrate, ammonia, barium compounds, borates, chromium compounds, fluorides, formic acid, hydrochloric acid, nitric acid, oxalic acid, sodium hydroxide, mercury, chlorine and uranium and zirconium compounds.

\subsubsection{Secondary Sources}

ICPP contains the most secondary sources of any area at the INEL. Secondary sources at ICPP include organic and inorganic storage tanks, several propane burners, large engines, small engines, and chemical sources. Chemical sources encompass numerous fumehoods, chemical processes, blueprint machines, and painting operations.

There are also several miscellaneous sources such as chemical pumps and lines and potential sources of radionuclides (i.e., the ICPP percolation ponds). Most of these sources contribute very small quantities of air pollutants and have little impact on air quality.

\subsubsection{Summary of ICPP Emissions}

Totals of each of the non-radionuclide principal pollutant emissions from sources at ICPP during 1994 are summarized in Table 3.5-1.

Table 3.5-1. Summary of the totals for each of the non-radionuclide principal pollutants at ICPP.

\begin{tabular}{lcccc}
\multicolumn{1}{c}{ Pollutant } & $\begin{array}{c}\text { Actual } \\
\text { Hourly } \\
(\mathrm{lb} / \mathrm{hr})\end{array}$ & $\begin{array}{c}\text { Actual } \\
\text { Annual } \\
(\mathrm{m} / \mathrm{yr})\end{array}$ & $\begin{array}{c}\text { Maximum } \\
\text { Hourly } \\
(\mathrm{lb} / \mathrm{hr})\end{array}$ & $\begin{array}{c}\text { Maximum } \\
\text { Annual } \\
(\mathrm{m} / \mathrm{yr})\end{array}$ \\
\hline Carbon monoxide & $2.082 \mathrm{E}+02$ & $4.029 \mathrm{E}+02$ & $8.589 \mathrm{E}+02$ & $3.552 \mathrm{E}+03$ \\
Nitrogen oxides & $3.365 \mathrm{E}+02$ & $5.181 \mathrm{E}+02$ & $1.868 \mathrm{E}+03$ & $2.513 \mathrm{E}+03$ \\
Particulate & $1.075 \mathrm{E}+01$ & $3.658 \mathrm{E}+01$ & $7.843 \mathrm{E}+01$ & $7.133 \mathrm{E}+01$ \\
Sulfur oxides & $5.031 \mathrm{E}+01$ & $4.689 \mathrm{E}+01$ & $2.258 \mathrm{E}+02$ & $8.309 \mathrm{E}+02$ \\
VOC - nonmethane & $2.769 \mathrm{E}+02$ & $1.064 \mathrm{E}+01$ & $3.531 \mathrm{E}+02$ & $1.369 \mathrm{E}+02$ \\
& & & & \\
\hline
\end{tabular}




\subsubsection{Summary of ICPP changes}

Changes to specific sources located at ICPP between the 1993 and 1994 Air Emissions Inventories are summarized in Table 3.5-2. Justification to changes are provided to clarify the status of the source.

Table 3.5-2. Summary of source changes at ICPP - 1993 to 1994 Inventory.

\begin{tabular}{|c|c|c|}
\hline 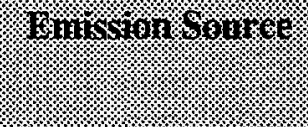 & 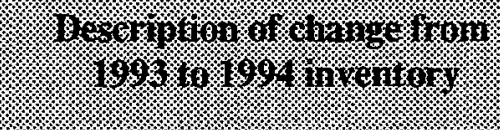 & 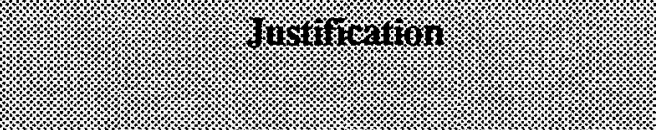 \\
\hline CPP-601-014 & Vent \# added & New source. \\
\hline CPP-603-008 & Maximum hours decreased. & $\begin{array}{l}\text { Correction of data based on maximum } \\
\text { operations for a not-significant source. }\end{array}$ \\
\hline $\begin{array}{l}\text { CPP-606-004 } \\
\text { CPP-606-005 } \\
\text { CPP-606-019 }\end{array}$ & Increase $\mathrm{gal} / \mathrm{hr}$ to 402 . & $\begin{array}{l}\text { Correction of data based on improved } \\
\text { calculations from rated boiler capacity. }\end{array}$ \\
\hline CPP-606-019 & Maximum emission increase. & $\begin{array}{l}1993 \text { Inventory accounted from one boiler. } \\
\text { Two boilers are present. Corrected } \\
\text { emissions reflect both boilers operating } \\
\text { concurrently. }\end{array}$ \\
\hline CPP-615-005 & Vent \# deleted & Insignificant emission source. \\
\hline $\begin{array}{l}\text { CPP-620-001 } \\
\text { CPP-620-002 } \\
\text { CPP-620-004 } \\
\text { CPP-620-005 } \\
\text { CPP-620-006 } \\
\text { CPP-620-009 }\end{array}$ & Vent \# deleted & $\begin{array}{l}\text { Source location previously incorrect. } \\
\text { Changed to CPP-637-xxx. }\end{array}$ \\
\hline CPP-633-021 & Vent \# deleted & Source removed from service (WCF). \\
\hline CPP-637-034 & Vent \# deleted & Source removed. \\
\hline CPP-637-037 & Vent \# deleted & $\begin{array}{l}\text { Emergency release point not requiring } \\
\text { source designation. }\end{array}$ \\
\hline CPP-637-044 & Vent \# deleted & Source removed. \\
\hline $\begin{array}{l}\text { CPP-637-052 } \\
\text { CPP-637-053 } \\
\text { CPP-637-056 } \\
\text { CPP-637-058 }\end{array}$ & Vent \# added & $\begin{array}{l}\text { Sources previously listed under CPP-620- } \\
\text { xxx. }\end{array}$ \\
\hline CPP-637-057 & Vent \# added & Newly identified source. Tank. \\
\hline
\end{tabular}


Table 3.5-2 - Continued. Summary of source changes at ICPP - 1993 to 1994 Inventory.

\begin{tabular}{|c|c|c|}
\hline 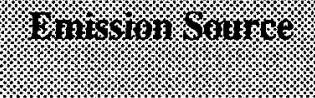 & 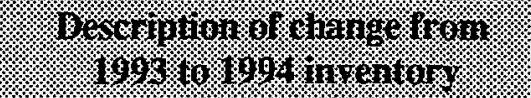 & How \\
\hline $\begin{array}{l}\text { CPP-640-001 } \\
\text { CPP-640-002 } \\
\text { CPP-640-003 } \\
\text { CPP-640-004 } \\
\text { CPP-640-005 } \\
\text { CPP-640-006 } \\
\text { CPP-640-007 } \\
\text { CPP-640-008 } \\
\text { CPP-640-023 } \\
\text { CPP-640-024 }\end{array}$ & Vent \# deleted & Source removed. \\
\hline CPP-644-005 & $\begin{array}{l}\text { Change fuel from diesel to } \\
\text { gasoline. }\end{array}$ & Correction of data. \\
\hline $\begin{array}{l}\text { CPP-644-002 } \\
\text { CPP-644-005 }\end{array}$ & Maximum hours decreased. & $\begin{array}{l}\text { Correction of data based on maximum } \\
\text { operations for a not-significant source. }\end{array}$ \\
\hline CPP-655-023 & Vent \# added & Newly identified source. \\
\hline $\begin{array}{l}\text { CPP-655-019 } \\
\text { CPP-655-026 } \\
\text { CPP-655-028 } \\
\text { CPP-655-030 } \\
\text { CPP-655-031 }\end{array}$ & Change propane burner to heater. & Correction of data. \\
\hline CPP-659-006 & Change Small to Large. & Correction of data. \\
\hline CPP-659-007 & Change $25 \mathrm{hp}$ to $8 \mathrm{hp}$. & Correction of data. \\
\hline $\begin{array}{l}\text { CPP-659-006 } \\
\text { CPP-659-007 } \\
\text { CPP-659-008 }\end{array}$ & Maximum hours decreased. & $\begin{array}{l}\text { Correction of data based on maximum } \\
\text { operations for a not-significant source. }\end{array}$ \\
\hline CPP-659-033 & VOCs added & Not previously reported. \\
\hline CPP-662-004 & Vent \# deleted & Source removed from service. \\
\hline $\begin{array}{l}\text { CPP-663-055 } \\
\text { CPP-663-063 } \\
\text { CPP-663-065 }\end{array}$ & Vent \# deleted & Source removed. \\
\hline $\begin{array}{l}\text { CPP-665-001 } \\
\text { CPP-665-002 } \\
\text { CPP-665-010 }\end{array}$ & Vent \# deleted & Source removed. \\
\hline
\end{tabular}


Table 3.5-2 - Continued. Summary of source changes at ICPP - 1993 to 1994 Inventory.

\begin{tabular}{|c|c|c|}
\hline 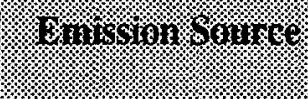 & ") & (1) \\
\hline $\begin{array}{l}\text { CPP-666-003 } \\
\text { CPP-666-004 } \\
\text { CPP-666-039 } \\
\text { CPP-666-048 } \\
\end{array}$ & Vent \# deleted & Source removed. \\
\hline $\begin{array}{l}\text { CPP-679-002 } \\
\text { CPP-679-003 }\end{array}$ & Change propane burner to heater. & Correction of data. \\
\hline CPP-687-010 & $\begin{array}{l}\text { Maximum emissions increase per } \\
\text { hour. }\end{array}$ & Typographical error correction. \\
\hline CPP-687-012 & Vent \# added & Newly identified source. \\
\hline $\begin{array}{l}\text { CPP-687-026 } \\
\text { CPP-687-049 }\end{array}$ & Maximum hours decreased. & $\begin{array}{l}\text { Correction of data based on maximum } \\
\text { operations for a not-significant source. }\end{array}$ \\
\hline CPP-687-049 & Changed $150 \mathrm{hp}$ to $14 \mathrm{hp}$. & Correction of data. \\
\hline $\begin{array}{l}\text { CPP-698-009 } \\
\text { CPP-698-010 } \\
\text { CPP-698-016 } \\
\text { CPP-698-017 } \\
\text { CPP-698-018 }\end{array}$ & Change propane burner to heater. & Correction of data. \\
\hline CPP-708-001 & Change in maximum emissions. & $\begin{array}{l}\text { Corrected values due to improved } \\
\text { calculation method. }\end{array}$ \\
\hline $\begin{array}{l}\text { CPP-727-002 } \\
\text { CPP-727-003 }\end{array}$ & Vent \# deleted & Source removed. \\
\hline CPP-732-001 & Vent \# deleted & $\begin{array}{l}\text { Incorrect previous designation. Bins vent to } \\
\text { CPP-708. }\end{array}$ \\
\hline CPP-742-001 & Vent \# deleted & $\begin{array}{l}\text { Incorrect previous designation. Bins vent to } \\
\text { CPP-708. }\end{array}$ \\
\hline CPP-746-001 & Vent \# deleted & $\begin{array}{l}\text { Incorrect previous designation. Bins vent to } \\
\text { CPP-708. }\end{array}$ \\
\hline $\begin{array}{l}\text { CPP-749-001 } \\
\text { CPP-749-005 } \\
\end{array}$ & Vent \# deleted & $\begin{array}{l}\text { Incorrect previous designation. Not a } \\
\text { source. }\end{array}$ \\
\hline CPP-757-001 & Vent \# deleted & Source removed from service. \\
\hline $\begin{array}{l}\text { CPP-791-005 } \\
\text { CPP-791-006 }\end{array}$ & Vent \# deleted & $\begin{array}{l}\text { Emergency release points not requiring } \\
\text { source designation. }\end{array}$ \\
\hline $\begin{array}{l}\text { CPP-795-005 } \\
\text { CPP-795-006 }\end{array}$ & Vent \# deleted & $\begin{array}{l}\text { Emergency release points not requiring } \\
\text { source designation. }\end{array}$ \\
\hline
\end{tabular}


Table 3.5-2 - Continued. Summary of source changes at ICPP - 1993 to 1994 Inventory.

\begin{tabular}{|c|c|c|}
\hline 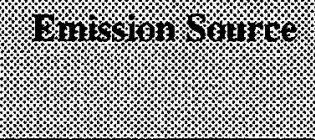 & B. & Hosmeatron: \\
\hline CPP-1605-004 & Vent \# deleted & Source removed from service. \\
\hline $\begin{array}{l}\text { CPP-1605-008 } \\
\text { CPP-1605-018 } \\
\text { CPP-1605-064 } \\
\end{array}$ & Vent \# deleted & Insignificant emission source. \\
\hline CPP-1619-001 & Toxic pollutants deleted. & $\begin{array}{l}\text { Source is a radioactive emission source. } \\
\text { Toxic pollutants under vent \# 1619-005 } \\
\text { previously reported under this vent. }\end{array}$ \\
\hline CPP-1619-005 & Toxic pollutants added. & $\begin{array}{l}\text { Toxic pollutants are emitted from the } \\
\text { source. Previously reported under CPP- } \\
\text { 1619-001 }\end{array}$ \\
\hline $\begin{array}{l}\text { CPP-1619-004 } \\
\text { CPP-1619-006 } \\
\end{array}$ & Vent \# deleted & No emissions from source. \\
\hline CPP-1642-007 & Added $370 \mathrm{hp}$. & Addition of data. \\
\hline CPP-1642-007 & Maximum hours changed. & $\begin{array}{l}\text { Correction of data based on maximum } \\
\text { operations for a not-significant source. }\end{array}$ \\
\hline CPP-1643-007 & Added $370 \mathrm{hp}$. & Addition of data. \\
\hline CPP-1643-007 & Maximum hours decreased. & $\begin{array}{l}\text { Correction of data based on maximum } \\
\text { operations for a not-significant source. }\end{array}$ \\
\hline CPP-1749-004 & Maximum hours decreased. & $\begin{array}{l}\text { Correction of data based on maximum } \\
\text { operations for a not-significant source. }\end{array}$ \\
\hline $\begin{array}{l}\text { CPP-T-1-001 } \\
\text { CPP-T-1-007 } \\
\end{array}$ & Vent \# deleted & Source converted to electric. \\
\hline $\begin{array}{l}\text { CPP-T-5-001 } \\
\text { CPP-T-5-003 }\end{array}$ & Vent \# deleted & Source converted to electric. \\
\hline $\begin{array}{l}\text { CPP-TR27-002 } \\
\text { CPP-TR27-003 }\end{array}$ & Vent \# deleted & Trailers and source removed from service. \\
\hline
\end{tabular}




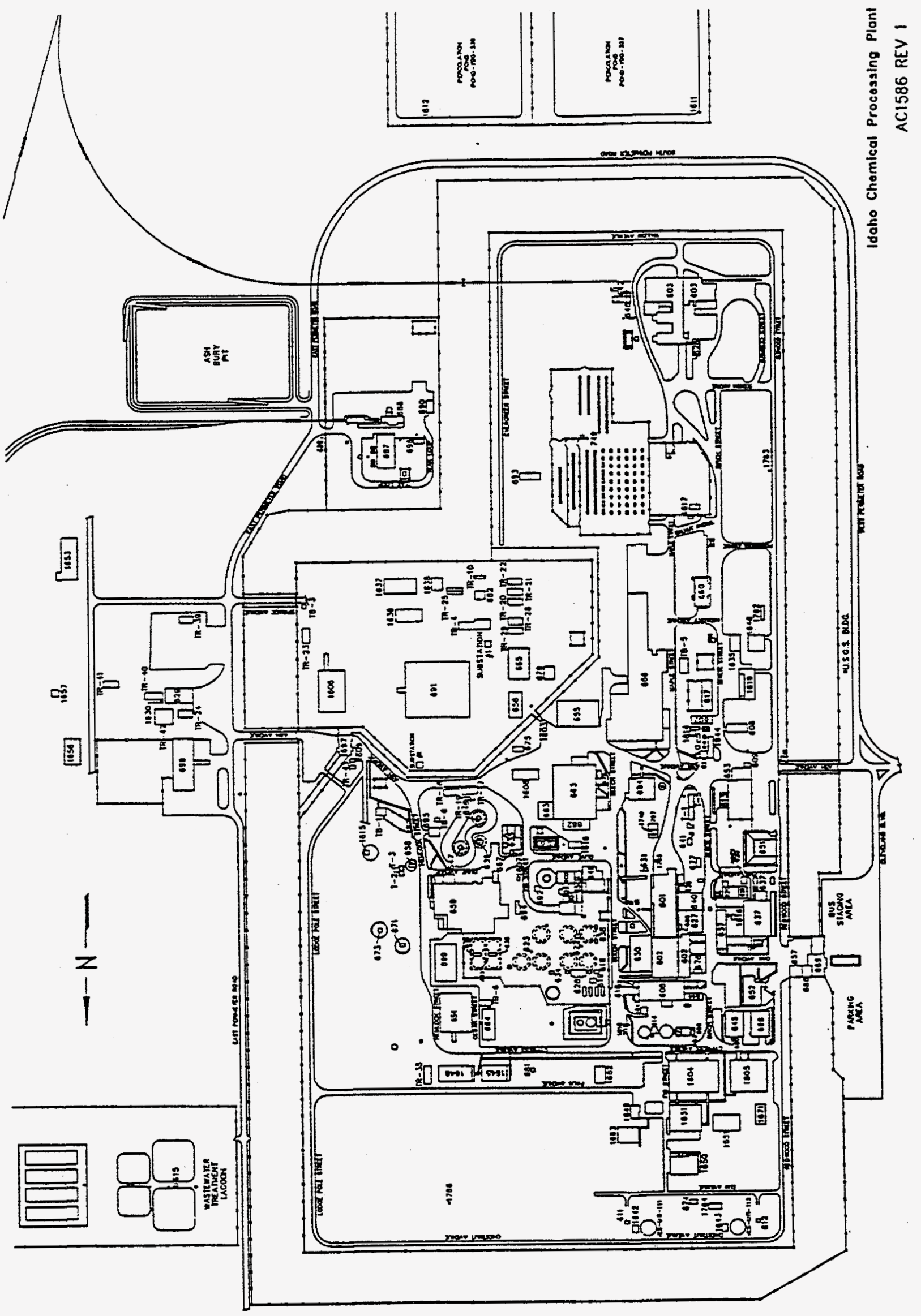

Figure 3-5. Area plot plan of the Idaho Chemical Processing Plant. 


\subsection{Naval Reactors Facility}

\subsubsection{Area Description}

NRF is located in the southwestem part of the INEL site. One of the oldest areas on the INEL, NRF has operated more than 35 consecutive years and trained thousands of naval officer and enlisted personnel. NRF has provided several reactor prototypes for the U.S. Navy. There are five main operational areas at NRF: the Natural Circulation Reactor (S5G) prototype plant, the Large Ship Reactor (A1W) prototype plant, the Expended Core Facility (ECF), the Submarine Thermal Reactor (S1W) prototype plant, and NRF Production. An area plot plan of NRF is shown in Figure 3-6.

In 1994, the S5G prototype plant operated as a training platform for U.S. Navy personnel who operate nuclear powered submarines. The S5G operational area includes the Test Plant Building, the S5G Cooling Tower, and several smaller buildings. S5G is scheduled to be inactivated in 1995, which will involve stopping all training, performing end-of-life testing, and shutting down, defueling and inactivating the reactor plant prior to being placed in systems layup.

The A1W prototype plant underwent final shutdown in January 1994. The A1W operations area includes the A1W Hull Structure Building, the A1W Operations Building, the Radioactive Waste Disposal Equipment Building, the A1W Cooling Tower, the Circulating Water Facility building, and numerous other support buildings and shops. Most of the work in the A1W operations area will consist of defueling and inactivating the $\mathrm{A} 1 \mathrm{~W}$ prototype plant.

The ECF houses hot cell facilities, shipping container loading and unloading bays, and water pits to examine and process spent nuclear fuel, prior to being transferred to ICPP. The ECF examines and evaluates performance of core components removed from submarines, surface ships, and land-based naval reactor prototypes; conducts a materials testing program involving preparing, examining, and testing material specimens that have been irradiated in the Advanced Test Reactor, located at the INEL's Test Reactor Area; unloads spent reactor core components from shipping casks; prepare spent core components for shipment to ICPP for storage; and maintains shielded shipping casks.

The S1W prototype plant was placed in systems layup in 1989. The S1W operational area includes the S1W Main Building, which houses the inactivated S1W prototype plant, the Site Chemistry Laboratory, and various office buildings. The only regular activity occurring in the S1W area is analytical testing performed in the chemistry labs.

NRF Production is centrally located on the NRF site. The area includes machine, welding, paint, and fabrication shops, the site boilerhouse, and office spaces. Most of NRFs nonradiological maintenance and repair in support of the NRF site is conducted by Production personnel in this area. All of NRF's steam for space heating is produced in the boilerhouse.

\subsubsection{Primary Sources}

The boilers account for most of the criteria pollutant emissions from NRF. The three NRF boilers are located in the boilerhouse (NRF-620), which is centrally located at the NRF site and under control of NRF Production. They provide steam for space heating in most NRF buildings.

The NRF boilers burn primarily No. 5 fuel oil and relatively small amounts of No. 2 fuel oil during startup evolutions. The heating season at NRF typically runs from October until May, depending on demand for space heating. Normally, only one of the three boilers is operating, with a second boiler in hot standby 
and the third boiler in a cold layup condition. Since the inactivation of the prototypes, NRF has an excess of boiler capacity. This makes it extremely unlikely that NRF would ever need to operate more than one of the three boilers at a time.

No emission controls or monitors are installed on the NRF boilers. Primary emissions are sulfur oxides, nitrogen oxides, carbon monoxide, and particulate.

NRF Production also has cognizance of the Power System Upgrade emergency diesel power system. In 1991, the Power System Upgrade consolidated most of NRF's emergency power generating capability into one system. Four identical 1400-horsepower engines are housed in NRF-686. Normally, each of these engines is operated about 60 hours per year for training and preventive maintenance. Primary pollutants include carbon monoxide and nitrogen oxides. Actual emissions are small because of the limited operating schedule.

The Production Services Paint Shop Spray Booth (NRF-602-006) accounts for a large percentage of NRF's VOC emissions. The booth has a water curtain that controls emissions of particulate at or near $100 \%$ efficiency. Many items are painted just outside of the paint shop, resulting in fugitive emissions of air toxics and VOCs. For purposes of this inventory, all of the emissions due to painting performed outside the paint shop have been assigned to the booth exhaust. Emissions were calculated based on the estimated total of paints and thinners used.

In the S5G operational area, there are two primary sources of emissions. The S5G Test Plant Building Radioactive Area Ventilation system ventilates the S5G prototype plant and the plant water discharge facilities and discharges the HEPA-filtered and monitored air through the stack (NRF-633A-057). The primary emissions consist of small amounts of radionuclides.

The S5G Cooling Tower (NRF-716-001) cools secondary water from operation of the S5G plant. It is a seven-cell, induced draft tower with 22 -foot diameter venturi exhaust stacks and drift eliminators. Maximum design circulating water capacity is 37,000 gallons per minute. The operating level and schedule of the tower is extremely variable, depending on training schedules, plant power level, and ambient weather conditions. The primary emission of the cooling tower is particulate.

The primary sources of the A1W operational area include the A1W Reactor Compartment 3A exhaust (NRF-617-013), the A1W Cooling Tower (NRF-708-001), the A1W Nucleonics Room Ventilation stack (NRF-616-039), the A1W RWPS Tank Ventilation (NRF-628A-006), and the emergency diesel generators \#3 and \#4 exhausts (NRF-617C-001, -002). The A1W Cooling Tower and the two A1W emergency diesel engines no longer operate. The A1W prototype has been shutdown and has begun the inactivation process. Monitoring of ventilation systems for A1W will continue during inactivation.

The ECF building has three primary sources of air emissions: Stack No. 1 (NRF-618-099), Stack No. 2 (NRF-618-103), and the High Bay roof vents (NRF-618-024 through -043). Stack No. 1 is a HEPA filtered exhaust system that ventilates hot cells, a chemistry laboratory, a decontamination shop, and various other areas of the building. The main operations which produce emissions from this source are: preparation of specimens for examination and evaporation of chemical descale solutions in the hot cells; waste reduction in the two evaporators used to reduce the volume of liquid waste at ECF; and decontamination of large pieces of equipment in Decontamination Shop No. 1. Most of the nonradiological machining work at ECF is performed in the Operations Support machine shop. The ventilation system is monitored for radioactive particulate, and iodine-131. The primary emissions are VOCs and radionuclides. 
ECF Stack No. 2 is a HEPA filtered exhaust system that ventilates hot cells, shipping cask unloading area (the Receiving Station), and various other areas in the building. The main operations that produce emissions from this source are: radiological examination work in the hot cells and the unloading, decontamination, and maintenance of spent fuel shipping containers in the Receiving Station. The ventilation system is monitored for radioactive particulate and iodine-131. The primary emissions are VOCs and radionuclides.

Eighteen roof vents are located along the length of the ECF High Bay. They operate intermittently to provide temperature and radon control and to remove diesel exhaust fumes from trucks. Radiological work in the High Bay is performed underwater, in HEPA filtered containments, and in designated work areas.

Welding and painting operations are also performed routinely in the high bay. The roof vents are not filtered. Three of the vents are monitored for radioactive particulate and tritium. The primary emissions are VOCs from painting and metal fabricating operations, and radionuclides.

The only primary source of emissions in the S1W operational area is the S1W Building main stack (NRF-601-019), which ventilates the NRF Site Chemistry Laboratory. The stack is actually seven exhaust systems that are collocated and appear as one from the exterior; four of these seven exhaust systems are still operational and are identified as A, B, C, and F in the Air Emission Inventory. NRF-601A-019 is the emissions point for the Site Chemistry Laboratory Ventilation System. Most of NRF's analytical chemistry is performed in this area, including radiological counting of environmental monitoring samples, isotopic analysis, and water chemistry analysis. The chemistry laboratory exhaust is monitored for radioactive particulate. The primary emissions are VOCs, chlorofluorocarbons, and radionuclides.

\subsubsection{Secondary Sources}

NRF has a variety of secondary sources, including organic and inorganic liquid storage tanks, fuel burning equipment, and chemical sources. The secondary fuel burning equipment is made up of stationary diesel engines used for emergency power production and emergency water pumping systems. The chemical sources include laboratory fumehoods, a paint shop, welding exhausts, a reproduction center, and miscellaneous sources.

\subsubsection{Summary of NRF Emissions}

Totals of each of the non-radionuclide principal pollutant emissions from sources at NRF during 1994 are summarized in Table 3.6-1.

Table 3.6-1. Summary of non-radionuclide principal pollutants at NRF.

\begin{tabular}{lcccc}
\hline \multicolumn{1}{c}{ Pollutant } & $\begin{array}{c}\text { Actual } \\
\text { Hourly } \\
(\mathrm{lb} / \mathrm{hr})\end{array}$ & $\begin{array}{c}\text { Actual } \\
\text { Annual } \\
(\mathrm{tn} / \mathrm{yr})\end{array}$ & $\begin{array}{c}\text { Maximum } \\
\text { Hourly } \\
(\mathrm{lb} / \mathrm{hr})\end{array}$ & $\begin{array}{c}\text { Maximum } \\
\text { Annual } \\
(\mathrm{m} / \mathrm{yr})\end{array}$ \\
\hline Carbon monoxide & $4.286 \mathrm{E}+01$ & $3.011 \mathrm{E}+00$ & $5.781 \mathrm{E}+01$ & $4.263 \mathrm{E}+01$ \\
Nitrogen oxides & $1.855 \mathrm{E}+02$ & $2.348 \mathrm{E}+01$ & $2.750 \mathrm{E}+02$ & $3.823 \mathrm{E}+02$ \\
Particulate & $1.250 \mathrm{E}+01$ & $1.642 \mathrm{E}+01$ & $6.162 \mathrm{E}+01$ & $2.525 \mathrm{E}+02$ \\
Sulfur oxides & $1.381 \mathrm{E}+02$ & $7.951 \mathrm{E}+01$ & $3.518 \mathrm{E}+02$ & $1.416 \mathrm{E}+03$ \\
VOC - nonmethane & $5.899 \mathrm{E}+00$ & $3.913 \mathrm{E}-01$ & $7.690 \mathrm{E}+00$ & $5.035 \mathrm{E}+00$ \\
\hline
\end{tabular}




\subsubsection{Summary of NRF Changes}

Changes to specific sources located at NRF from the 1993 Air Emission Inventory and the 1994 Air Emissions Inventory are summarized in Table 3.6-2. Source information in the 1994 Inventory which deviates from that noted in the INEL Tier I Operating Permit Application is summarized in Table 3.6-3. Corrections to these latter discrepancies will be made during preparation of the 1995 Air Emissions Inventory. Justification to changes are provided to clarify the status of the source.

Table 3.6-2. Summary of source changes at NRF - 1993 to 1994 Inventory.

\begin{tabular}{|c|c|c|}
\hline Hininsion Stringred & 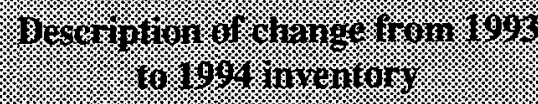 & 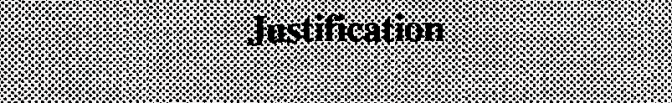 \\
\hline NRF-619-018 & Reporting change. & $\begin{array}{l}\text { Emissions for sources indicated as } \\
\text { "chemical sources" combined into one total } \\
\text { release under } 619-018 \text {. }\end{array}$ \\
\hline
\end{tabular}

Table 3.6-3. Summary of source changes at NRF - 1994 Inventory to INEL Tier I Operating Permit Application.

\begin{tabular}{|c|c|c|}
\hline 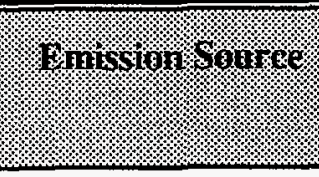 & 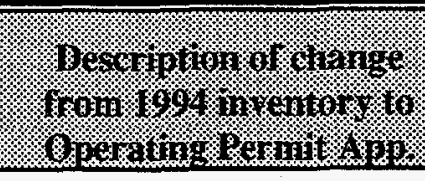 & (1) \\
\hline NRF-602-037 & $\begin{array}{l}\text { Not indicated in Operating } \\
\text { Permit Application. }\end{array}$ & $\begin{array}{l}\text { Insignificant emission source: Office activity, } \\
\text { Photolab machine vent. }\end{array}$ \\
\hline NRF-603-039 & $\begin{array}{l}\text { Not indicated in Operating } \\
\text { Permit Application. }\end{array}$ & $\begin{array}{l}\text { Insignificant emission source: Office activity, } \\
\text { Quick Copy room vent. }\end{array}$ \\
\hline NRF-617C-001 & $\begin{array}{l}\text { Not indicated in Operating } \\
\text { Permit Application. }\end{array}$ & $\begin{array}{l}\text { Source removed from service. (retired-in- } \\
\text { place/deactivated). A1W \#4 emergency diesel } \\
\text { generator exhaust. }\end{array}$ \\
\hline NRF-617C-002 & $\begin{array}{l}\text { Not indicated in Operating } \\
\text { Permit Application. }\end{array}$ & $\begin{array}{l}\text { Source removed from service. (retired-in- } \\
\text { place/deactivated). A1W \#3 emergency diesel } \\
\text { generator exhaust. }\end{array}$ \\
\hline NRF-617C-003 & $\begin{array}{l}\text { Not indicated in Operating } \\
\text { Permit Application. }\end{array}$ & $\begin{array}{l}\text { Source removed from service. (retired-in- } \\
\text { place/deactivated). A1W emergency diesel } \\
\text { generator room exhaust (day tanks). }\end{array}$ \\
\hline NRF-618-200 & $\begin{array}{l}\text { Not indicated in Operating } \\
\text { Permit Application. }\end{array}$ & $\begin{array}{l}\text { Source removed from service. (retired-in- } \\
\text { place/deactivated). ECF emergency diesel day } \\
\text { tank vent. }\end{array}$ \\
\hline NRF-633A-024 & $\begin{array}{l}\text { Not indicated in Operating } \\
\text { Permit Application. }\end{array}$ & $\begin{array}{l}\text { Source removed from service. (retired-in- } \\
\text { place/deactivated). Acid tank flame arrestor. }\end{array}$ \\
\hline
\end{tabular}


Table 3.6-3 - Continued. Summary of source changes at NRF - 1994 Inventory to INEL Tier I Operating Permit Application.

\begin{tabular}{|c|c|c|}
\hline 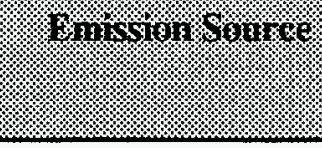 & \% & 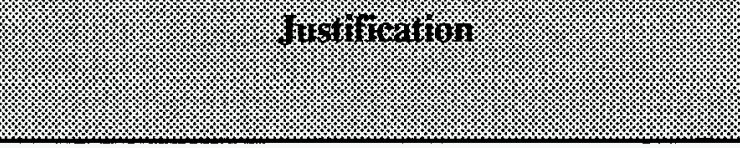 \\
\hline NRF-633A-038 & $\begin{array}{l}\text { Not indicated in Operating } \\
\text { Permit Application. }\end{array}$ & $\begin{array}{l}\text { Source removed from service. (retired-in- } \\
\text { place/deactivated). S5G emergency diesel } \\
\text { generator exhaust. }\end{array}$ \\
\hline NRF-633A-088 & $\begin{array}{l}\text { Not indicated in Operating } \\
\text { Permit Application. }\end{array}$ & $\begin{array}{l}\text { Source removed from service. Plastisol oven } \\
\text { vent. }\end{array}$ \\
\hline NRF-663-022 & $\begin{array}{l}\text { Not indicated in Operating } \\
\text { Permit Application. }\end{array}$ & $\begin{array}{l}\text { Source removed from service. Weapons } \\
\text { cleaning tank exhaust. }\end{array}$ \\
\hline NRF-708-001 & $\begin{array}{l}\text { Not indicated in Operating } \\
\text { Permit Application. }\end{array}$ & $\begin{array}{l}\text { Source removed from service. (retired-in- } \\
\text { place/deactivated). A1W cooling tower north } \\
\text { intake. }\end{array}$ \\
\hline NRF-709-001 & $\begin{array}{l}\text { Not indicated in Operating } \\
\text { Permit Application. }\end{array}$ & $\begin{array}{l}\text { Source removed from service. (retired-in- } \\
\text { place/deactivated). Diesel oil storage tank vent. }\end{array}$ \\
\hline NRF-716-001 & $\begin{array}{l}\text { Not indicated in Operating } \\
\text { Permit Application. }\end{array}$ & $\begin{array}{l}\text { Source removed from service. (retired-in- } \\
\text { place/deactivated). S5G cooling tower top vent } \\
\# 7 \text {. }\end{array}$ \\
\hline NRF-730C-031 & $\begin{array}{l}\text { Not indicated in Operating } \\
\text { Permit Application. }\end{array}$ & $\begin{array}{l}\text { Source removed from service. Muse diesel fuel } \\
\text { tank vent. (retired-in-place/ deactivated). }\end{array}$ \\
\hline NRF-739-008 & $\begin{array}{l}\text { Not indicated in Operating } \\
\text { Permit Application. }\end{array}$ & $\begin{array}{l}\text { Source removed from service. LDHR diesel fuel } \\
\text { tank vent. (retired-in-place/ deactivated). }\end{array}$ \\
\hline NRF-739-009 & $\begin{array}{l}\text { Not indicated in Operating } \\
\text { Permit Application. }\end{array}$ & $\begin{array}{l}\text { Source removed from service. LDHR diesel fuel } \\
\text { tank vent. (retired-in-place/ deactivated). }\end{array}$ \\
\hline NRF-743-001 & $\begin{array}{l}\text { Not indicated in Operating } \\
\text { Permit Application. }\end{array}$ & $\begin{array}{l}\text { Source removed from service. A1W sulfuric } \\
\text { acid tank vent. (retired-in-place/ deactivated). }\end{array}$ \\
\hline NRF-747-001 & $\begin{array}{l}\text { Not indicated in Operating } \\
\text { Permit Application. }\end{array}$ & $\begin{array}{l}\text { Source removed from service. Bunker oil } \\
\text { storage tank A. (retired-in-place/ deactivated). }\end{array}$ \\
\hline NRF-747-002 & $\begin{array}{l}\text { Not indicated in Operating } \\
\text { Permit Application. }\end{array}$ & $\begin{array}{l}\text { Source removed from service. Bunker oil } \\
\text { storage tank B. (retired-in-place/ deactivated). }\end{array}$ \\
\hline
\end{tabular}




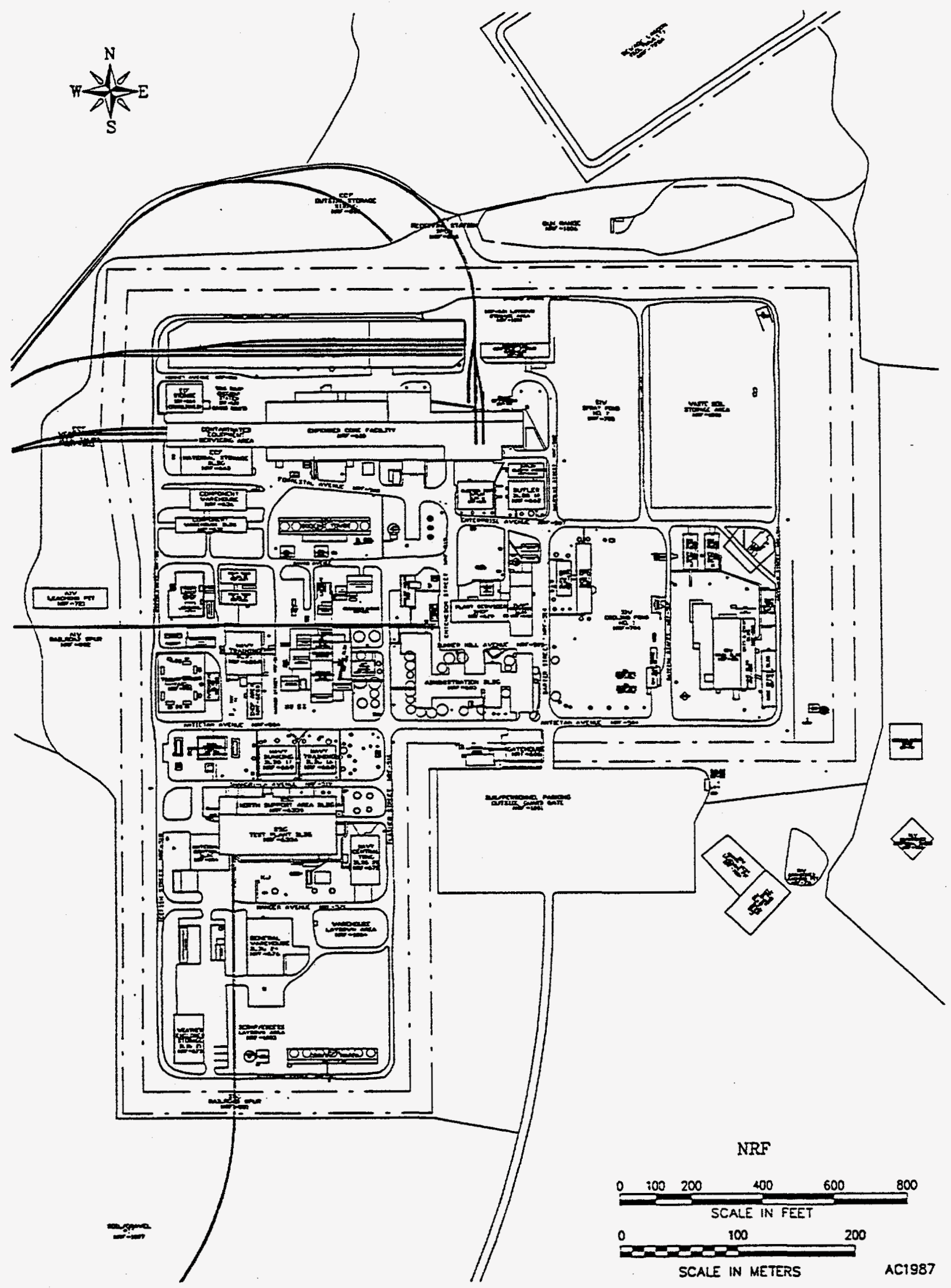

Figure 3-6. Area plot plan of the Naval Reactors Facility. 


\subsection{Power Burst Facility}

\subsubsection{Area Description}

The PBF area is located approximately 6 miles northeast of CFA and is shown in Figure 3-7. Originally, the PBF was used to test reactor transient behavior and for safety studies on light-watermoderated enriched-fuel systems. These tests were called Special Power Excursion Reactor Test (SPERT) and commenced in the late 1950s. At that time, the PBF area consisted of the Control Area and the Reactor Area, the latter including SPERT I (now decontaminated, dismantled, and returned to its natural state), SPERT II, SPERT III, and SPERT IV reactors. The PBF Control Area served as the control center for all SPERT and PBF operations.

The PBF Control Area (Figure 3-8) now is the central administrative area for the PBF operations. The buildings at the control area house the PBF reactor controls, offices, maintenance and instrumentation areas.

The PBF Reactor Area (Figure 3-9) consists of the PBF reactor, which was constructed north of the site of the SPERT I reactor site. The SPERT I reactor was decommissioned in 1964 and the area has been revegetated. The PBF reactor has been used for reactor research on fuel behavior during normal and offnormal operating conditions but has been shut down pending inactivation.

The SPERT II area (Figure 3-10) consists mainly of the SPERT II reactor, which was constructed to study kinetic behavior for information on reactor safety. The reactor has been decommissioned, and most of the equipment (i.e., reactor vessel and primary coolant loop) has been removed. The building now houses the Waste Engineering Development Facility (WEDF), which is used for lead receiving, storing, and shipping and for developing waste treatment processes for hazardous and mixed wastes.

The SPERT III area (Figure 3-11) consisted of SPERT III Reactor Building (PER-609), the second SPERT reactor in operation and built in the late 1950 s. The reactor was designed to conduct studies on highpower, high-temperature, heterogeneous, light water reactors. Its primary function was to determine the effect of water flow, pressure, and temperature on the transient characteristics of the reactor. The reactor was placed in standby in 1968 and was decontaminated and decommissioned in 1980. All system components were removed and the remaining areas were decontaminated. The area was converted to the Waste Experimental Reduction Facility (WERF). Facilities at WERF include a 4.8-million BTU/hr incinerator, a $524-\mathrm{kW}$ induction melting furnace, a 200 -ton compactor, and a $960-\mathrm{ft}^{2}$ sizing shop where metallic waste is cut up using plasma arc torches. Also included are an offgas/ash solidification room, indoor mixed waste storage, and a 4,600- $\mathrm{ft}^{2}$ outdoor radioactive waste storage area. The induction furnace was used for melting metal objects and pouring them into ingot molds. The compactor is used to process all materials that cannot be processed through the incinerator (such as PVC). The solidification process is used to stabilize the incinerator ash by solidifying the ash with cement/water. The WERF incinerator was inactive in 1994 .

The SPERT IV reactor (Figure 3-12) was constructed to extend the range and type of controlled test parameters and to provide a facility for the kinetic testing of advanced-design reactor cores. The reactor has been removed, and the area is being used to store mixed waste at the Mixed Waste Storage Facility (MWSF). MWSF is now a Resource Conservation and Recovery Act (RCRA) Storage Facility under RCRA interim status for the storage of mixed waste, which is both hazardous [defined by Code of Federal Regulations (CFR) 40 CFR 261] and radioactive. MWSF has segregated areas to accommodate storage of polychlorinated biphenyls (PCBs), corrosives, and flammables in compliance with RCRA requirements. Special provisions for these waste forms include special isolation diking and ventilation systems. 


\subsubsection{Primary Source Descriptions}

WERF.

The primary sources at the PBF consists of two boilers used for heating in the winter; WEDF; and

The two boilers are located in PER-613 and PER-620. Both of the boilers have been identified in the Fuel Processing Restoration PSD permit as CFA/PER-613 B-501 (Powermaster boiler) and CFA/PEF-620 M-31 (Cyclotherm boiler). The boilers are designed to run automatically from September to May of each year and have essentially the same allowable emission level in the permit.

The WEDF facility is located in PER-612. The facility is used for receiving, storing, and shipping clean lead and the development of waste treatment processes for hazardous and mixed wastes. Currently, no continuous operations are associated with WEDF.

WERF is dedicated to the development of volume reduction processes for low-level radioactive and mixed waste. WERF consists of PER-609, PER-622, PER-623, and a storage area located northwest of PER-622. Two processes take place in PER-609: a) incineration of combustible solid and liquid low-level radioactive and mixed waste, and b) solidification, by grouting, of mixed waste. PER-622 houses sizing, compaction, and waste-sorting operations, which emit through a . Sizing reduces the volume of low-level radioactively contaminated metal for further processing or more efficient disposal at the RWMC. PER-623, the WERF Waste Storage Building (WWSB), provides interim storage of hazardous and mixed waste until the waste is treated at an INEL treatment unit or is shipped offsite for treatment and/or disposal. Compaction reduces the volume of materials that cannot be incinerated or exceed contamination limits for incineration. An open air asphalt and concrete pad is used to store low-level beta-gamma contaminated waste destined for processing. The waste can be in the form of actual structures or assemblies with the contaminated portions covered, or cargo containers containing incinerable waste.

\subsubsection{Secondary Sources}

The majority of the secondary sources are fuel burning equipment and VOC storage tanks. There are also two inorganic storage tanks (sulfuric acid) and a fumehood used for removing caustic and acid vapors from the demineralizer mixing tanks. The VOC storage tanks contain materials that include No. 2 diesel or gasoline. 


\subsubsection{Summary of PBF Emissions}

Totals of each of the non-radionuclide principal pollutant emissions from sources at PBF during 1994 are summarized in Table 3.7-1.

Table 3.7-1. Summary of non-radionuclide principal pollutants at PBF.

\begin{tabular}{lcccc}
\hline \multicolumn{1}{c}{ Pollutant } & $\begin{array}{c}\text { Actual } \\
\text { Hourly } \\
(\mathrm{b} / \mathrm{hr})\end{array}$ & $\begin{array}{c}\text { Actual } \\
\text { Annual } \\
(\mathrm{tn} / \mathrm{yr})\end{array}$ & $\begin{array}{c}\text { Maximum } \\
\text { Hourly } \\
(\mathrm{lb} / \mathrm{hr})\end{array}$ & $\begin{array}{c}\text { Maximum } \\
\text { Annual } \\
(\mathrm{m} / \mathrm{yr})\end{array}$ \\
\hline Carbon monoxide & $3.088 \mathrm{E}+00$ & $1.436 \mathrm{E}-01$ & $1.478 \mathrm{E}+01$ & $1.439 \mathrm{E}+01$ \\
Nitrogen oxides & $1.423 \mathrm{E}+01$ & $5.937 \mathrm{E}-01$ & $2.762 \mathrm{E}+01$ & $6.510 \mathrm{E}+01$ \\
Particulate & $1.023 \mathrm{E}+00$ & $5.522 \mathrm{E}-02$ & $9.002 \mathrm{E}+00$ & $6.005 \mathrm{E}+00$ \\
Sulfur oxides & $3.353 \mathrm{E}+00$ & $1.639 \mathrm{E}+00$ & $7.144 \mathrm{E}+00$ & $1.924 \mathrm{E}+01$ \\
VOC-nonmethane & $7.093 \mathrm{E}-01$ & $1.170 \mathrm{E}-02$ & $1.046 \mathrm{E}+00$ & $2.051 \mathrm{E}+00$ \\
\hline
\end{tabular}

\subsubsection{Summary of PBF Changes}

Changes to specific sources located at PBF between the 1993 and 1994 Air Emissions Inventories are summarized in Table 3.7-2. Justification to changes are provided to clarify the status of the source.

Table 3.7-2. Summary of source changes at PBF - 1993 to 1994 Inventory.

\begin{tabular}{|c|c|c|}
\hline$\frac{1}{42}$ & 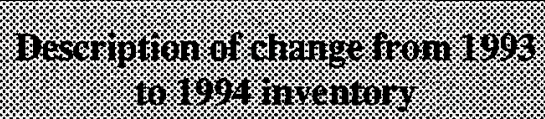 & 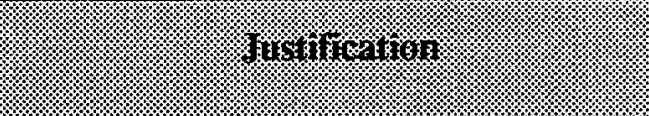 \\
\hline PER-620-023 & Hours of operation added. & Addition of data. \\
\hline PER-620-023 & Stack parameters added. & Addition of data. \\
\hline PER-622-003 & Vent \# deleted & Source removed. \\
\hline PER-625-001 & Vent \# added & Potential new source. \\
\hline PER-626-004 & Vent \# deleted & $\begin{array}{l}\text { Pump replaced. (New pump \# PER-638- } \\
004)\end{array}$ \\
\hline PER-638-004 & Vent \# Added & New Source. \\
\hline PER-638-005 & Vent \# Added & New Source. \\
\hline PER-755-001 & $\begin{array}{l}\text { Delete "permit rates" for carbon } \\
\text { monoxide, sulfur oxides, and } \\
\text { nitrogen oxides. }\end{array}$ & $\begin{array}{l}\text { Incorrect previous data entry. There are no } \\
\text { permit limits for these parameters at this } \\
\text { source. }\end{array}$ \\
\hline PER-755-001 & $\begin{array}{l}\text { Changed max particulate } \\
\text { emissions rates to } 7.3 \mathrm{E}-01 \mathrm{lb} / \mathrm{hr} \\
\text { and } 2.1 \mathrm{E}+00 \text { ton/yr. }\end{array}$ & $\begin{array}{l}\text { Information corrected to reflect maximum } \\
\text { operating parameters. }\end{array}$ \\
\hline
\end{tabular}


Table 3.7-2 - Continued. Summary of source changes at PBF - 1993 to 1994 Inventory.

\begin{tabular}{|l|l|l|l|}
\hline PER-755-001 & $\begin{array}{l}\text { Changed carbon monoxide } \\
\text { maximums to 9.7E-1 lb/hr and } \\
2.8 \mathrm{E}+00 \text { tons/yr. }\end{array}$ & $\begin{array}{l}\text { Information corrected to reflect maximum } \\
\text { operating parameters. }\end{array}$ \\
\hline PER-755-001 & Hours of operation added. & Addition of data. \\
\hline PER-756-001 & Deleted NOx emissions. & $\begin{array}{l}\text { Incorrect previous data entry. Source has } \\
\text { only radionuclide emissions. }\end{array}$ \\
\hline PER-756-001 & Hours of operation added. & Addition of data. \\
\hline PER-765-001 & Change baghouse to HEPA Filter. & Change in filtration system. \\
\hline PER-765-001 & Hours of operation added. & Addition of data. \\
\hline PER-765-001 & Particulate emissions added. & Addition of data. \\
\hline
\end{tabular}




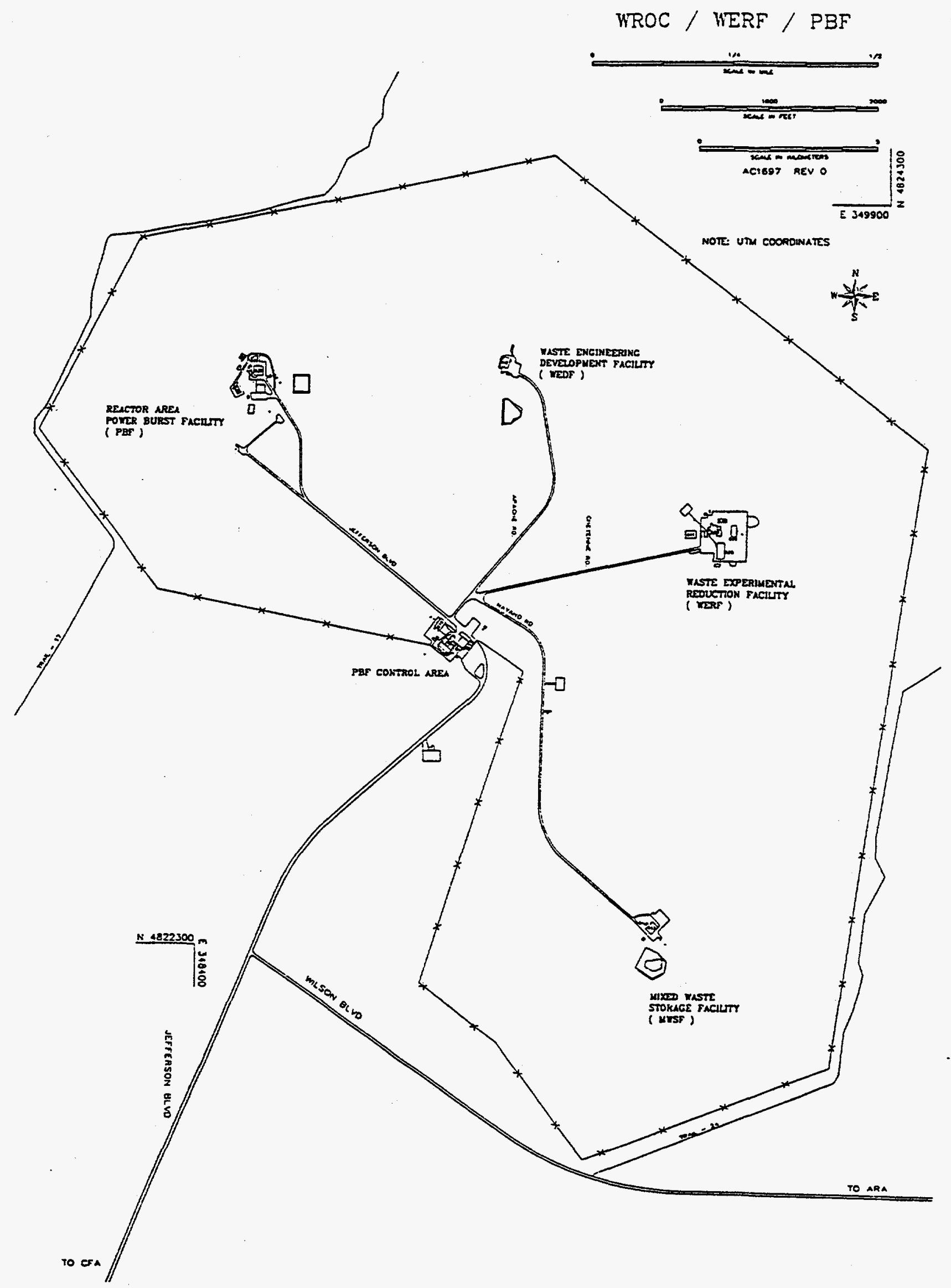

Figure 3-7. Area plot plan of the Power Burst Facility area. 


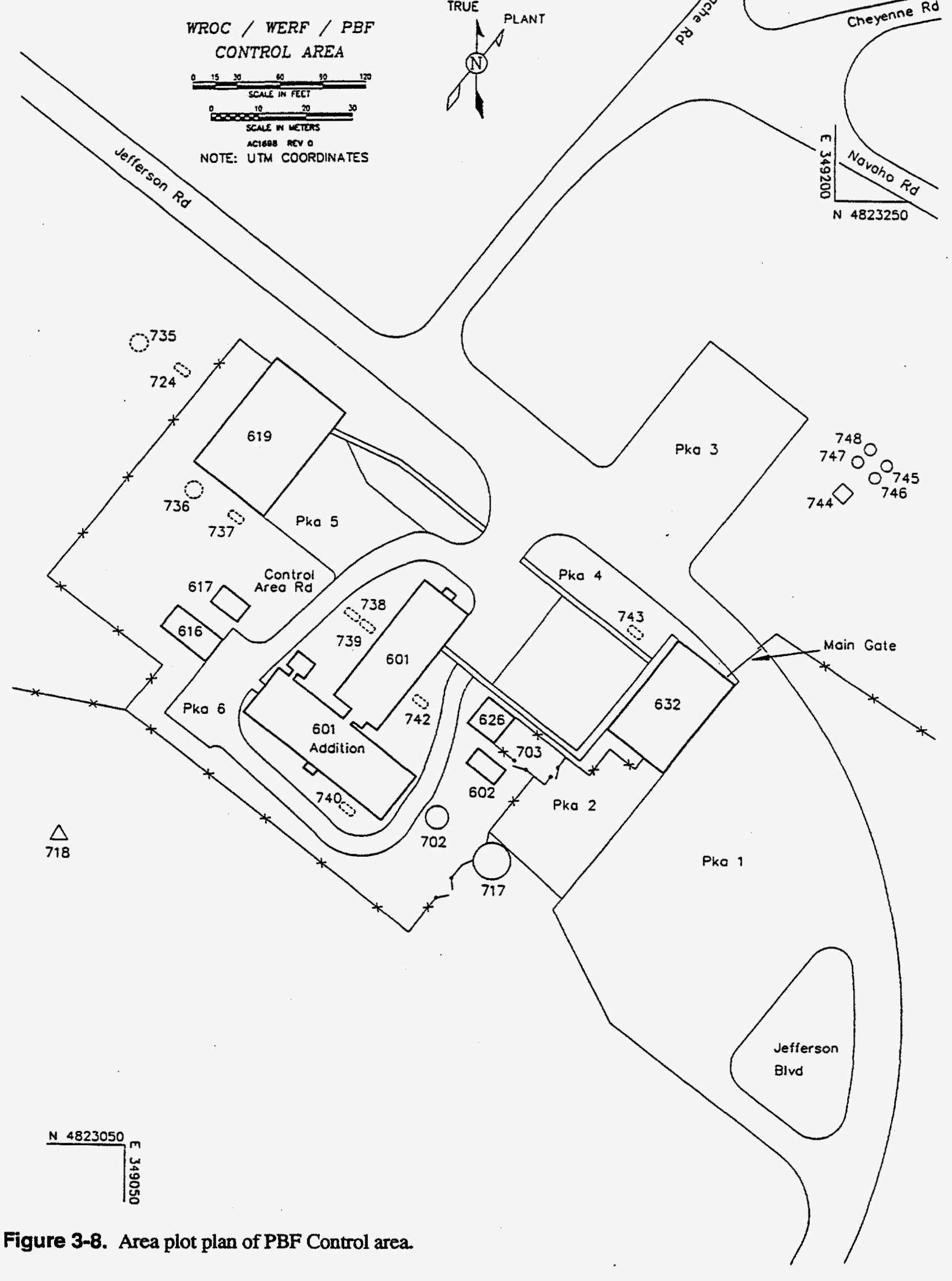




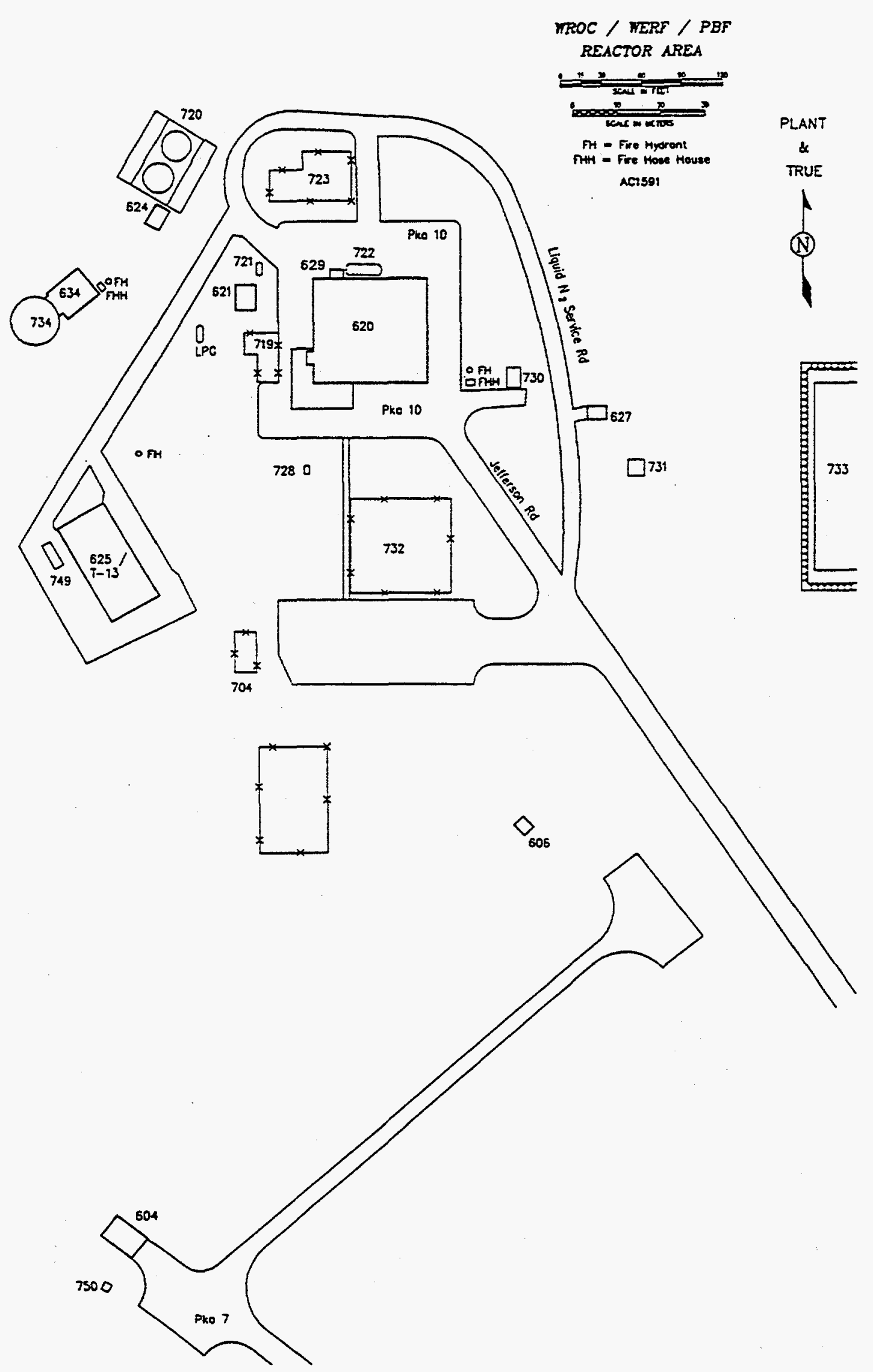

Figure 3-9. Area plot plan of PBF Reactor area. 
WROC / WERF / PBF

WEDF

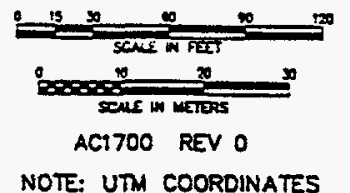

NOTE: UTM COORDINATES

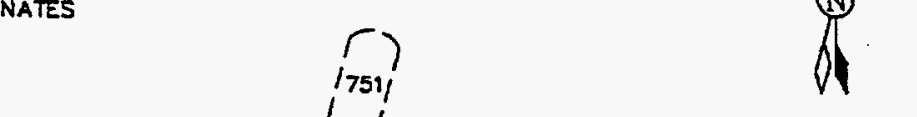

TRUE PLANT
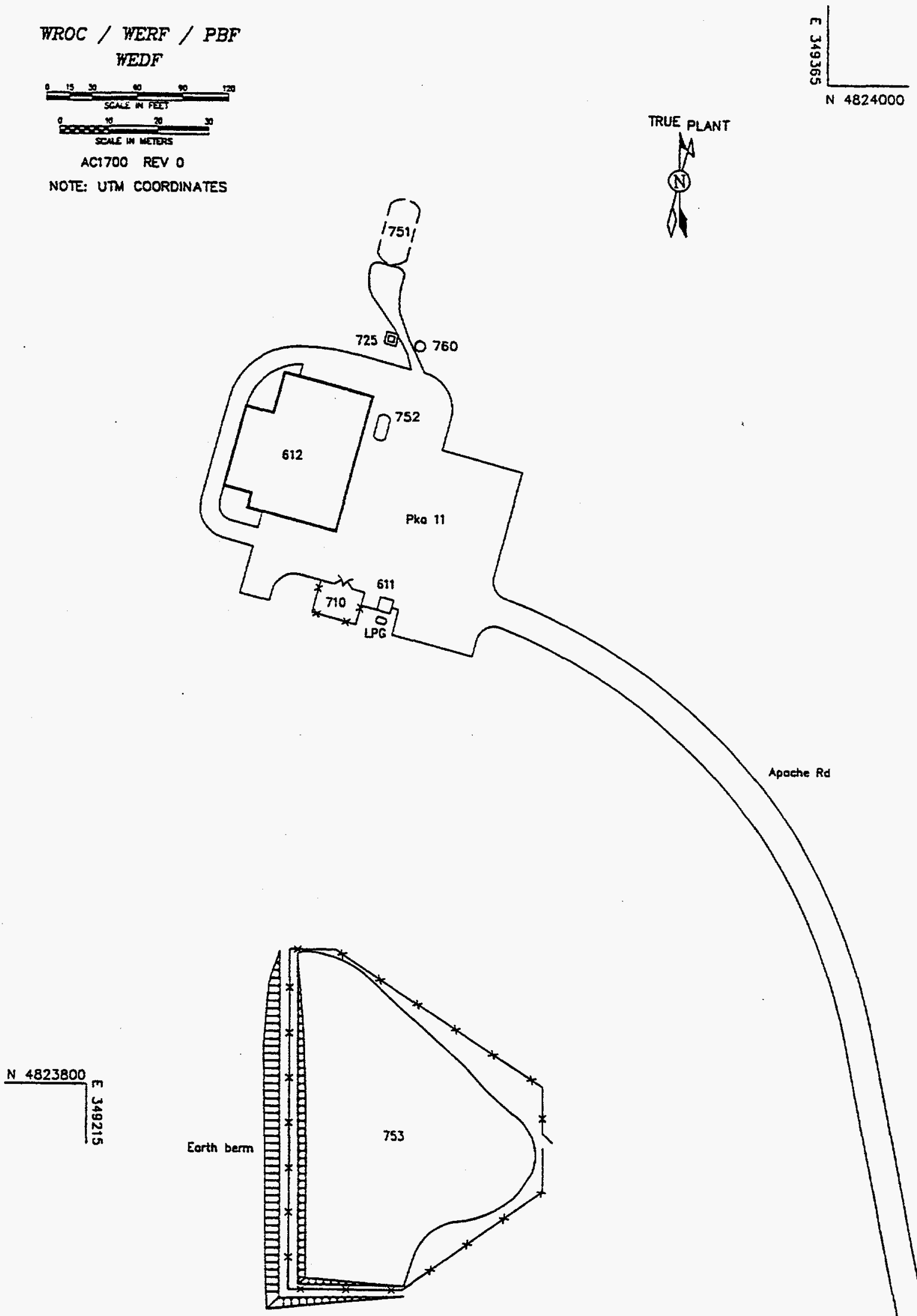

Figure 3-10. Area plot plan of WEDF area.

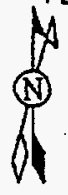




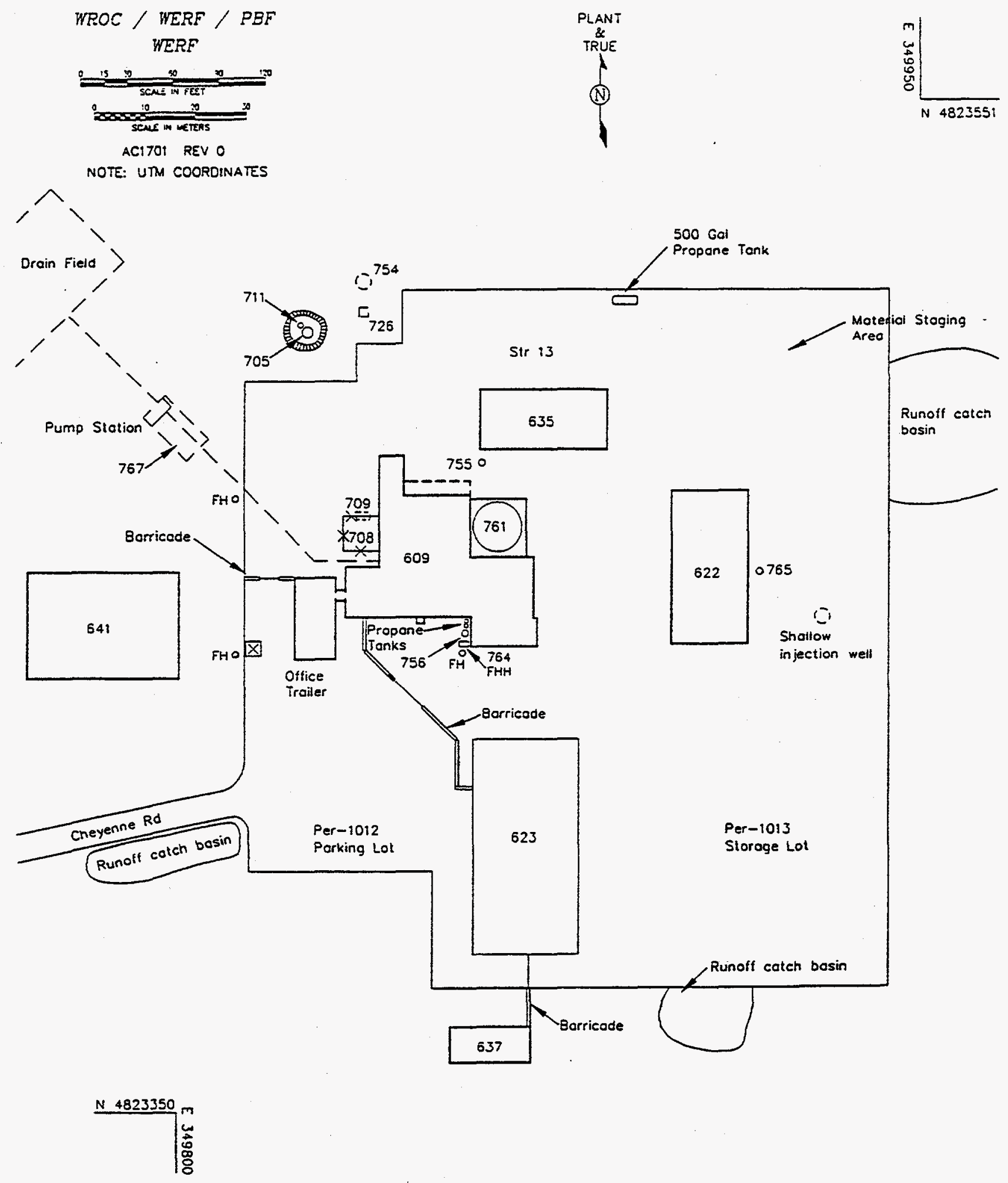

Figure 3-11. Area plot plan the WERF area. 


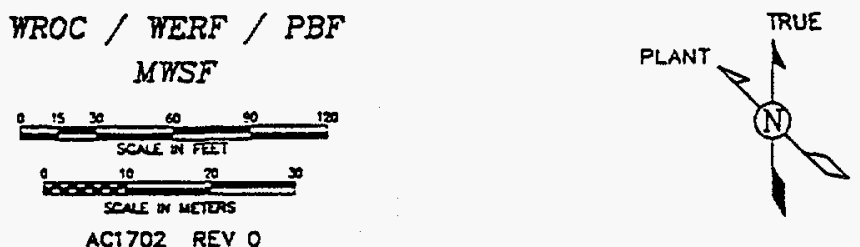

NOTE: UTM COORDINATES
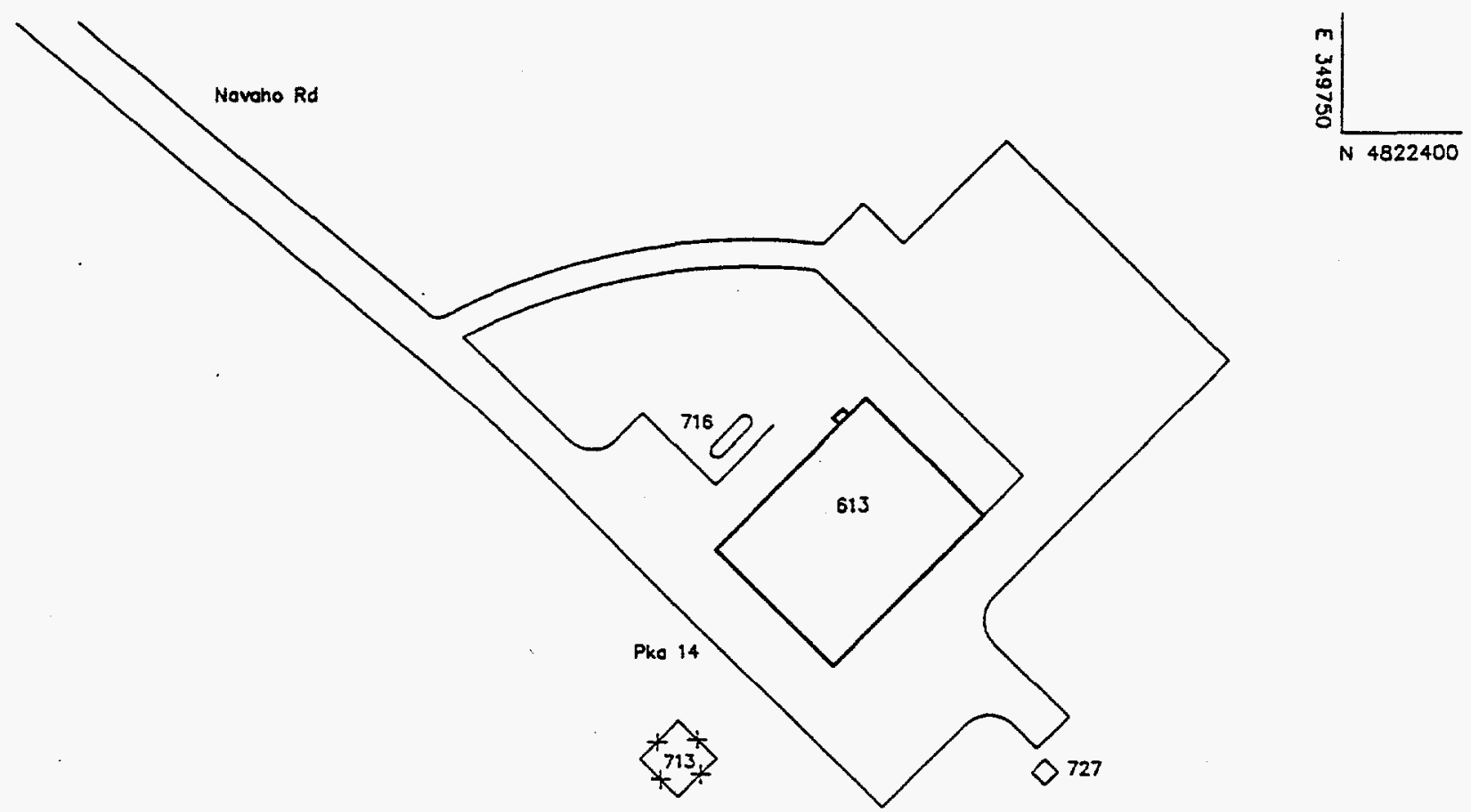

0757

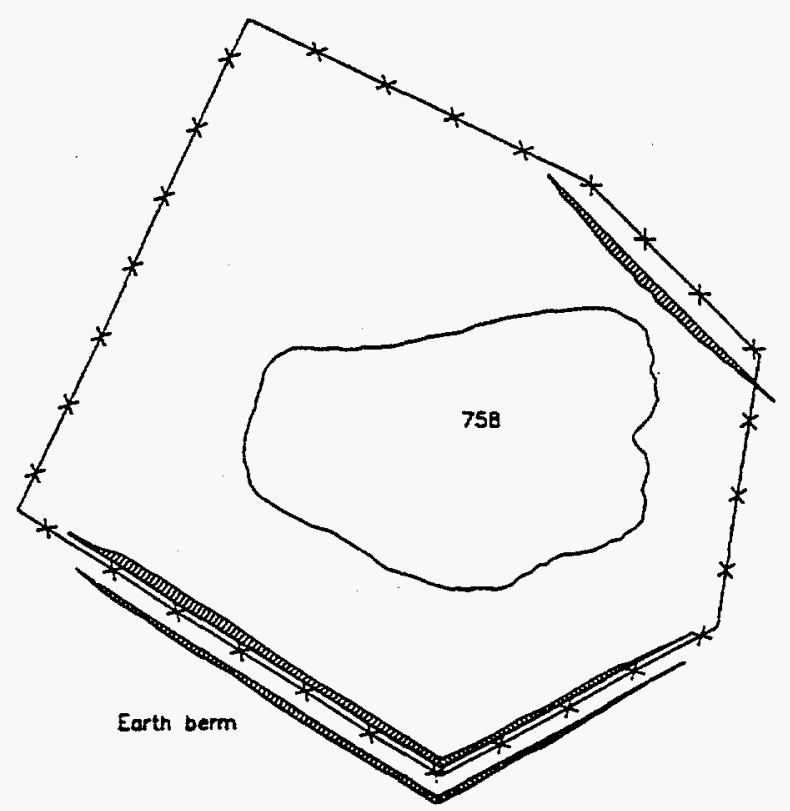

Figure 3-12. Area plot plan MWSF area. 


\subsection{Radioactive Waste Management Complex}

\subsubsection{Area Description}

RWMC was established in 1952 and is located 7 miles southwest of CFA. RWMC, a restricted area, provides waste management for solid low-level radioactive and transuranic wastes. Waste management includes retrieval, examination, and certification of transuranic waste for ultimate disposal at the DOE Waste Isolation Pilot Plant in New Mexico. The facility also supports research and development activities for shallow land burial technology. Figure 3-13 presents a plot plan of RWMC.

RWMC is divided into four zones: the Administrative Area, the Operational Support Zone, the Subsurface Disposal Area (SDA), and the Transuranic Storage Area (TSA).

The Administrative Area is located in the northeast section of the RWMC and consists of office support buildings.

The Operational Support Zone is located west of the Administrative zone and consists of maintenance shops, change facilities, storage facilities, the guardhouse, support trailers, and the raw water supply system.

SDA occupies approximately 88 acres and is used for the permanent disposal of solid low-level betagamma waste. Before 1970, RWMC received and buried transuranic waste at SDA from both offsite and onsite facilities. Since 1970, only low-level waste has been buried at SDA. Most of the low-level waste is buried in pits, trenches, and soil vaults; however, low-level radioactively contaminated nitrate salts are stored separately on an asphalt pad, Pad A, and covered with a layer of soil. The SDA also receives radioactively contaminated asbestos waste for disposal.

TSA consists of several facilities and asphalt pads and occupies approximately 56 acres. TSA was established in 1970 to provide temporary storage of transuranic waste until a federal repository could be available for permanent disposal. Transuranic waste is stacked on asphalt pads and then covered with plywood, plastic sheeting, and three feet of soil. Since 1975, a movable, inflatable fabric dome known as the Air Support Weather Shield has protected the waste containers from the weather. The Stored Waste Examination Pilot Plant provides nondestructive examination and segregated storage of waste containers prior to shipment to the Waste Isolation Pilot Plant. The Stored Waste Examination Pilot Plant also vents waste containers to prevent the buildup of potentially explosive gases.

\subsubsection{Primary Source Descriptions}

There are no primary sources of air emissions at the RWMC.

\subsubsection{Secondary Sources}

There are several secondary sources of air emissions at the RWMC. These sources include primarily emergency generators or furnaces that burn propane and one diesel emergency generator and its associated fuel tank are located at WMF-603. The fumehood located at WMF-601 vents emissions from decontamination of health physics equipment. The Drum Venting Facility (WMF-615) houses the Drum Venting System. The Drum Venting System installs carbon composite fibers in the lids of stored waste drums to prevent hydrogen buildup inside the drums. All exhaust air from the Drum Venting System is filtered by two HEPA filters before discharging to the atmosphere. Currently the Drum Venting Facility operates on a limited basis. 


\subsubsection{Summary of RWMC Emissions}

Totals of each of the non-radionuclide principal pollutant emissions from sources at RWMC during 1994 are summarized in Table 3.8-1.

Table 3.8-1. Summary of the totals for each of the non-radionuclide principal pollutants at the RWMC.

\begin{tabular}{lcccc}
\hline \multicolumn{1}{c}{ Pollutant } & $\begin{array}{c}\text { Actual } \\
\text { Hourly } \\
(\mathrm{lb} / \mathrm{hr})\end{array}$ & $\begin{array}{c}\text { Actual } \\
\text { Annual } \\
(\mathrm{t} / \mathrm{yr})\end{array}$ & $\begin{array}{c}\text { Maximum } \\
\text { Hourly } \\
(\mathrm{lb} / \mathrm{hr})\end{array}$ & $\begin{array}{c}\text { Maximum } \\
\text { Annual } \\
(\mathrm{m} / \mathrm{yr})\end{array}$ \\
\hline Carbon monoxide & $2.016 \mathrm{E}-02$ & $3.871 \mathrm{E}-02$ & $2.574 \mathrm{E}-02$ & $1.270 \mathrm{E}-01$ \\
Nitrogen oxides & $9.976 \mathrm{E}-02$ & $1.899 \mathrm{E}-01$ & $1.260 \mathrm{E}-01$ & $6.203 \mathrm{E}-01$ \\
Particulate & $4.928 \mathrm{E}-03$ & $9.509 \mathrm{E}-03$ & $6.298 \mathrm{E}-03$ & $3.101 \mathrm{E}-02$ \\
Sulfur oxides & $1.008 \mathrm{E}-03$ & $1.942 \mathrm{E}-03$ & $1.287 \mathrm{E}-03$ & $6.330 \mathrm{E}-03$ \\
VOC - nonmethane & $3.422 \mathrm{E}-01$ & $9.157 \mathrm{E}-03$ & $3.437 \mathrm{E}-01$ & $3.317 \mathrm{E}-02$ \\
\hline
\end{tabular}

\subsubsection{Summary of RWMC Changes}

Changes to specific sources located at RWMC between the 1993 and 1994 Air Emissions Inventories are summarized in Table 3.8-2. Justification to changes are provided to clarify the status of the source.

Table 3.8-2. Summary of source changes at RWMC - 1993 to 1994 Inventory.

\begin{tabular}{|c|c|c|}
\hline 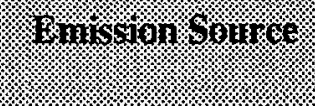 & B. & 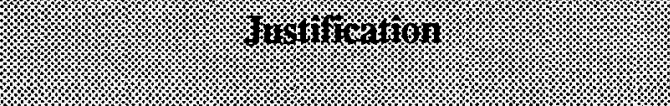 \\
\hline WMF-603-001 & Vent \# deleted & $\begin{array}{l}\text { Source number change due to relocation of } \\
\text { firewater pump to building } 639 \text { (vent 001). }\end{array}$ \\
\hline WMF-603-002 & Vent \# deleted & $\begin{array}{l}\text { Source number change due to relocation of } \\
\text { fuel tank for firewater pump to building } 639 \\
\text { (vent 002). }\end{array}$ \\
\hline WMF-603-008 & Vent \# deleted & $\begin{array}{l}\text { Improper source designation. Propane } \\
\text { vaporizer not considered an emission } \\
\text { source. }\end{array}$ \\
\hline WMF-614-001 & Vent \# deleted & $\begin{array}{l}\text { Improper source designation. Propane tank } \\
\text { and vaporizer not considered an emission } \\
\text { source. }\end{array}$ \\
\hline WMF-628-001 & Vent\# added & New source. \\
\hline WMF-629-001 & Vent \# added & New source. \\
\hline WMF-639-001 & Vent \# added & $\begin{array}{l}\text { Relocated firewater pump. (formerly WMF } \\
603-001 \text { ). }\end{array}$ \\
\hline
\end{tabular}


Table 3.8-2 - Continued. Summary of source changes at RWMC - 1993 to 1994 Inventory.

\begin{tabular}{|c|c|c|}
\hline 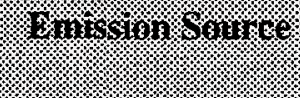 & 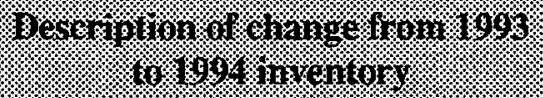 & 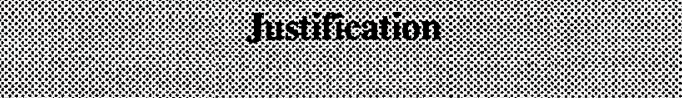 \\
\hline WMF-639-002 & Vent \# added & $\begin{array}{l}\text { Tank supporting furewater pump. (formerly } \\
\text { WMF 603-002). }\end{array}$ \\
\hline WMF-637-001 & Vent \# added & $\begin{array}{l}\text { New source. Categorically exempt } 1.2 \\
\mathrm{MMBtu} / \mathrm{hr} \text { propane boiler. }\end{array}$ \\
\hline WMF-637-002 & Vent \# added & $\begin{array}{l}\text { New source. } 1.2 \mathrm{MMBTU} / \mathrm{hr} \text { propane water } \\
\text { heater. }\end{array}$ \\
\hline WMF-656-001 & Vent \# added & Newly identified source. \\
\hline WMF-700-005 & Vent \# added & Newly identified source. (SDA) \\
\hline
\end{tabular}




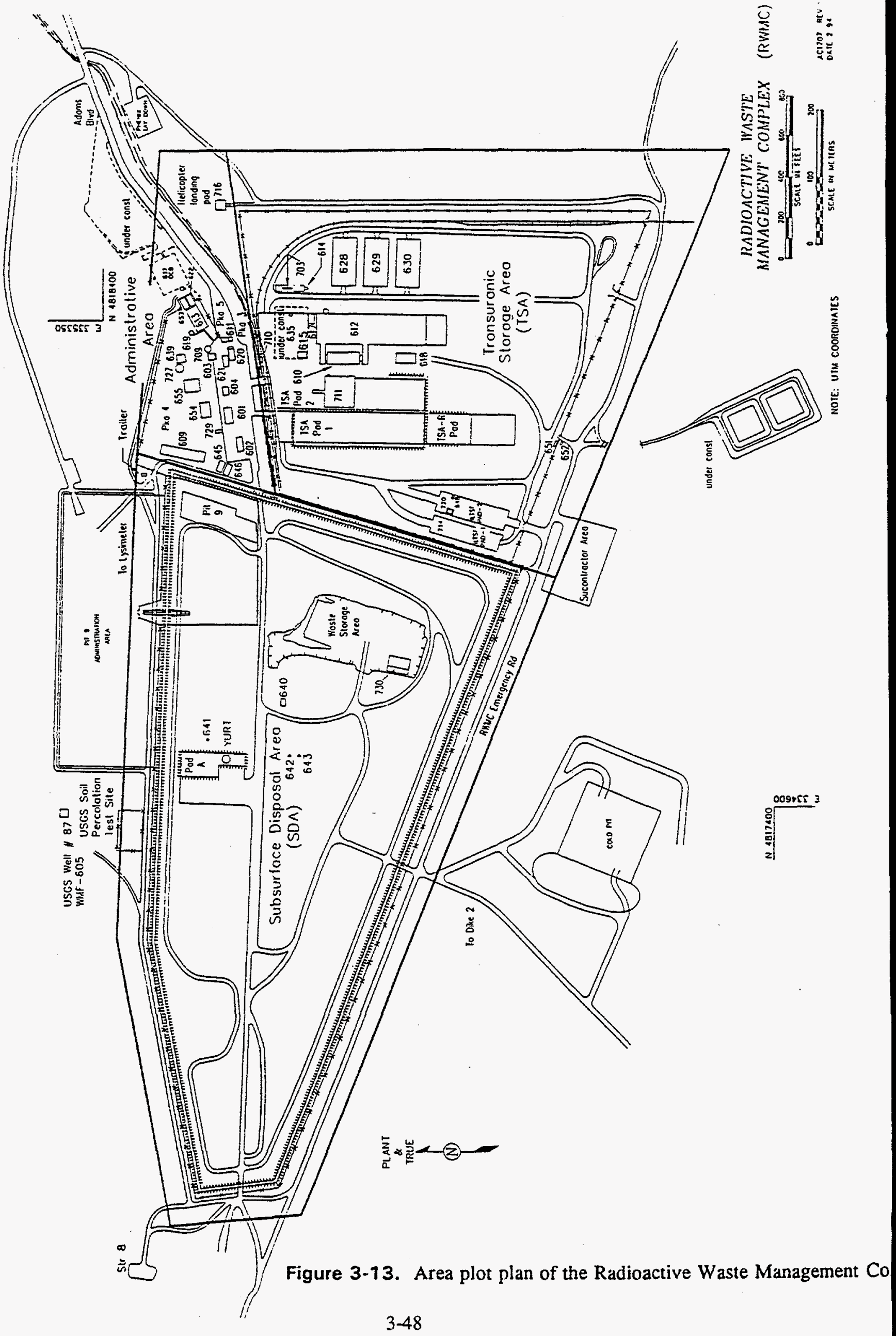




\title{
3.9 Test Area North
}

\subsubsection{Area Description}

TAN is located in the northern part of the INEL site and presently comprises three operational areas: the Technical Support Facility (TSF); the Containment Test Facility (CTF); the Loss Of Fluid Test (LOFT) area, which includes the Specific Manufacturing Capability (SMC) Project; and the Water Reactor Research Test Facility (WRRTF).

The TSF area functions as the administrative and support hub for all areas of TAN except the SMC Project. TAN supports many important programs, including Three Mile Island Unit 2 Core Offsite Examination; the Process Experimental Pilot Plant; and the Spent Fuel Program. Maintenance for TSF \& WRRTF is located at TSF. Figure 3-14 is an area plot plan of the TSF area.

The LOFT area is approximately 1.5 miles West of the TSF area. This area includes the LOFT containment vessel and service building, the LOFT reactor control and equipment building, and numerous support facilities. The SMC Project is housed in a large concrete aircraft hangar and other associated buildings that has been converted to support the manufacturing process, and numerous buildings for the various phases of the manufacturing and production process. SMC provides most of the activity at LOFT. Figure $3-15$ is an area plot plan of LOFT/SMC.

The WRRTF area (see Figure 3-16) includes the Semiscale Project, the Blowdown Project, and the Two-Phase-Flow Loop Project, all of which are now decommissioned. Very little activity now exists at WRRTF, with the exception of some engineering-scale tests.

\subsubsection{Primary Sources}

The boilers at TAN constitute some of the largest sources of emissions and are present in all three of the functional TAN areas. These boilers all provide steam for space heating and are located in the following buildings:

\author{
TAN-603 (TSF) - Two backup boilers, one main boiler \\ TAN-630 (LOFT, TAN-716) - One boiler \\ TAN-641 (WRRTF) - One main boiler, one backup boiler \\ TAN-675 (LOFT/SMC) - Two backup boilers \\ TAN-679 (LOFT/SMC) - One main boiler, one backup boiler.
}

The TAN boilers burn No. 2 grade fuel oil. Since these boilers mostly provide steam for space heating, they typically do not run during the summer months. All of the SMC boilers have an oxygen trim to reduce the nitrogen oxide emissions by $11 \%$, and the values reported here reflect that reduction.

Other than the boilers, other significant emission sources at TSF are at TAN-607, the TAN Hot Shop Building (TAN-734) and the SMC Material Development Facility (MDF). The Hot Shop is one of the world's largest, measuring $51 \times 165 \times 55 \mathrm{ft}$ and is used exclusively as part of DOE's Nuclear Spent Fuel Cask Testing program. All ventilation air exhausts to the main stack, TAN-734-001, on the northeast end of the building. There is a warm shop adjacent to the hot shop, where low to medium contaminated parts and equipment are fabricated and modified. This air also vents to the main stack. A smaller hot cell is at the south end of the Hot Shop and is used for study, observation, and analysis of small radioactive objects as well as disassembly and examination of research and commercial fuel rods. This room also vents to the main stack. 
Other programs that are supported at TAN-607 include the Three-Mile Island Unit 2 Core Examination Project, where analytical data necessary to understand the Three-Mile Island accident sequence can be collected. Also, the Spent Fuel Program is housed in TAN-607, which includes testing fuel storage casks with intact or consolidated fuel and developing a dry rod consolidation technology and prototypical equipment. The SMC Project also occupies the south end of TAN 607 [the Material Development Facility (MDF)] where research and development work is performed in support of the SMC Manufacturing Process.

Significant sources at LOFT, aside from the boilers, would include several sources at SMC, in buildings TAN-629 (the hangar), TAN-679, and TAN-681. Emissions from these stacks are primarily radionuclides from depleted uranium, particulate, nitrogen oxides, and some organics. Since the SMC Project is responsible for most of the activity at the LOFT Area, a thorough description of SMC is provided here.

The SMC Project assembly is a multi-phased classified project that includes fabrication, process reclamation, research and development analytical lab facilities, and maintenance/utility support facilities. The SMC Project builds armor assemblies from various materials, including depleted uranium. The SMC Project produces emissions from chemical and manufacturing process, boilers, storage tanks, emergency generators, and miscellaneous building vents.

The SMC Project consists of MDF, TAN-679 Fabrication, TAN-629 Assembly, and support facilities. The project life of the facility is approximately 20 years. Thereafter, it will be decontaminated and decommissioned in accordance with DOE requirements.

MDF is located in TAN-607A at the TSF area of TAN, which is approximately one mile southeast from the main SMC facilities. A portion of TAN-607 was designated for use as the MDF facility. The MDF is primarily a research and development facility and involves fabrication and assembly operations to produce test size armor assemblies. The process utilizes standard metal working equipment such as punches, shears, brakes, and lasers. About 31,000 square feet is available and includes research and development processes, an analytical laboratory, and a maintenance and machine shop.

Two double-wide trailers on the east side of TAN-607 house Health Physics and locker rooms and provide controlled access to the facility. Other facilities at TSF that support SMC operations include the TAN-602 office building, the TAN-606 carpenter shop, and the TAN-628 hazardous waste storage facility/warehouse.

SMC Assembly facilities, located within TAN-629, contain manufacturing processes and space for offices, support functions (e.g., Health Physics, field laboratory), and service areas. Manufacturing processes are semi-automated systems that manufacture products similar to those manufactured in the MDF facility on an automated basis to produce full-scale armor assemblies at a higher throughput. Total square footage in TAN-629 for SMC use is about 80,000 square feet. TAN-675 is located on the north side of TAN-629 and houses utilities; TAN-677 is located on the south side for truck receiving and loading.

SMC TAN-679 Fabrication facilities consist of a manufacturing area, assembly processes, and a Process Reclamation Facility. Fabrication production is a rolling process and produces depleted uranium metal sheets that are subsequently used as feedstock for TAN-629. TAN-679 operations cover an area of 64,000 square feet and include a production line; an area for shipping and receiving; a Health Physics field office; maintenance area; boiler/utilities area; computer room; administrative offices; and change room facilities. In addition, space is provided for other support requirements such as a toolroom, rest rooms, and a lunchroom. 
The Process Reclamation Facility, adjoining the northwest portion of TAN-679, contains approximately 12,000 square feet for collection and recycling of liquid wastes generated in TAN-679 fabrication processes. Liquid wastes, generated in the North process area are transferred to the PRF facility for processing as required for recycling and calcination. All liquid wastes are collected in storage tanks for treatment. Nitrogen oxide gas streams from the acid bath are piped to the Process Reclamation Facility for processing through a wet scrubber and filters before release to the atmosphere.

There are no significant emission sources at the WRRTF other than the boilers.

\subsubsection{Secondary Sources}

TAN has a wide variety of secondary sources, including chemical sources, fuel burning equipment, organic and inorganic storage tanks, and fugitive sources. Chemical sources include fumehoods, paint booths, welding booths, a blue print machine, two chemical mixing tanks, and several miscellaneous sources. Secondary fuel burning equipment includes emergency generators and a heater/furnace.

\subsubsection{Summary of TAN Emissions}

Totals of each of the non-radionuclide principal pollutant emissions from sources at TAN during 1994 are summarized in Table 3.9-1.

Table 3.9-1. Summary of the totals for each of the non-radionuclide principal pollutants at TAN.

\begin{tabular}{lcccc}
\hline \multicolumn{1}{c}{ Pollutant } & $\begin{array}{c}\text { Actual } \\
\text { Hourly } \\
(\mathrm{lb} / \mathrm{hr})\end{array}$ & $\begin{array}{c}\text { Actual } \\
\text { Annual } \\
(\mathrm{m} / \mathrm{yr})\end{array}$ & $\begin{array}{c}\text { Maximum } \\
\text { Hourly } \\
(\mathrm{lb} / \mathrm{hr})\end{array}$ & $\begin{array}{c}\text { Maximum } \\
\text { Annual } \\
(\mathrm{m} / \mathrm{yr})\end{array}$ \\
\hline Carbon monoxide & $2.028 \mathrm{E}+01$ & $2.317 \mathrm{E}+00$ & $3.579 \mathrm{E}+01$ & $4.786 \mathrm{E}+01$ \\
Nitrogen oxides & $8.955 \mathrm{E}+01$ & $9.474 \mathrm{E}+00$ & $1.801 \mathrm{E}+02$ & $2.121 \mathrm{E}+02$ \\
Particulate & $8.061 \mathrm{E}+00$ & $1.073 \mathrm{E}+00$ & $1.819 \mathrm{E}+01$ & $2.883 \mathrm{E}+01$ \\
Sulfur oxides & $8.058 \mathrm{E}+01$ & $2.889 \mathrm{E}+01$ & $1.310 \mathrm{E}+02$ & $3.646 \mathrm{E}+02$ \\
VOC - nonmethane & $3.865 \mathrm{E}+01$ & $2.128 \mathrm{E}+00$ & $6.420 \mathrm{E}+01$ & $4.955 \mathrm{E}+01$ \\
\hline
\end{tabular}

\subsubsection{Summary of TAN Changes}

Changes to specific sources located at TAN between the 1993 and 1994 Air Emissions Inventories are summarized in Table 3.9-2. Justification to changes are provided to clarify the status of the source.

Table 3.9-2. Summary of source changes at TAN - 1993 to 1994 Inventory.

\begin{tabular}{|c|c|c|}
\hline 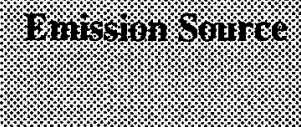 & 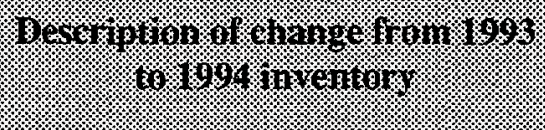 & 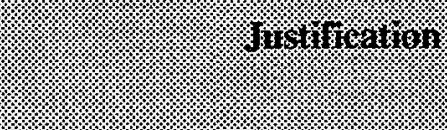 \\
\hline $\begin{array}{l}\text { TAN-602-034 } \\
\text { TAN-602-066 }\end{array}$ & Vent \# deleted & Source removed. \\
\hline TAN-603-022 & Change fuel oil \#5 to \#2. & Change in fuel. \\
\hline
\end{tabular}


Table 3.9-2 - Continued. Summary of source changes at TAN - 1993 to 1994 Inventory.

\begin{tabular}{|c|c|c|}
\hline (6) & 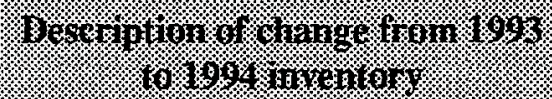 & 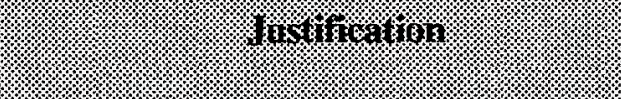 \\
\hline TAN-604-035 & Vent \# deleted & $\begin{array}{l}\text { Improper designation as a source. Not a } \\
\text { valid source. }\end{array}$ \\
\hline $\begin{array}{l}\text { TAN-606-026 } \\
\text { TAN-606-027 }\end{array}$ & Vent \# added & Newly identified source. \\
\hline TAN-607-021 & Vent \# deleted & Source intended for $D \& D$. \\
\hline TAN-607-049 & Vent \# deleted & Source intended for $D \& D$. \\
\hline TAN-607-059 & Vent \# deleted & Source intended for $D \& D$. \\
\hline TAN-607-066 & Vent \# deleted & Source intended for D\&D. \\
\hline TAN-607-136 & Vent \# deleted & Source intended for D\&D. \\
\hline $\begin{array}{l}\text { TAN-629-012 } \\
\text { TAN-629-014 }\end{array}$ & $\begin{array}{l}\text { Maximum flow rates changed to } \\
6.0 \mathrm{E}+03 \text {. }\end{array}$ & Nominal flow rates previously provided. \\
\hline TAN-640-001 & Vent \# deleted & Source intended for D\&D. \\
\hline TAN-641-022 & Vent \# deleted & Source intended for D\&D. \\
\hline $\begin{array}{l}\text { TAN-650-007 } \\
\text { TAN-650-010 }\end{array}$ & Vent \# deleted & Source removed. \\
\hline $\begin{array}{l}\text { TAN-675-011 } \\
\text { TAN-675-012 } \\
\text { TAN-675-013 }\end{array}$ & Vent \# deleted & Source removed. \\
\hline TAN-675-035 & $\begin{array}{l}\text { Exit gas temperature changed to } \\
\text { reflect maximum }(3.65 \mathrm{E}+02) \text {. }\end{array}$ & Nominal flow rates previously provided. \\
\hline TAN-677-030 & Vent \# added & Newly identified source. \\
\hline TAN-687-020 & Change $50 \mathrm{hp}$ to $99 \mathrm{hp}$. & Corrections of data. \\
\hline TAN-716-004 & Vent \# deleted & Source intended for D\&D. \\
\hline TAN-724-001 & Vent \# deleted & Source intended for D\&D. \\
\hline TAN-726-001 & Vent \# deleted & Source removed. \\
\hline TAN-738-001 & Vent \# deleted & Source intended for D\&D. \\
\hline TAN-753-001 & Vent \# deleted & Source intended for D\&D. \\
\hline TAN-766-002 & Vent \# deleted & Source intended for D\&D. \\
\hline TAN-771-001 & Vent \# deleted & Source intended for D\&D. \\
\hline
\end{tabular}


Table 3.9-2 - Continued. Summary of source changes at TAN - 1993 to 1994 Inventory.

\begin{tabular}{|c|c|c|}
\hline 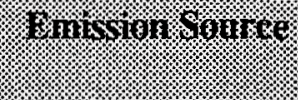 & 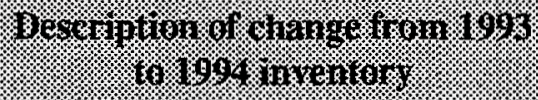 & 81186 iffer \\
\hline TAN-787-001 & Vent \# deleted & Source intended for D\&D. \\
\hline
\end{tabular}




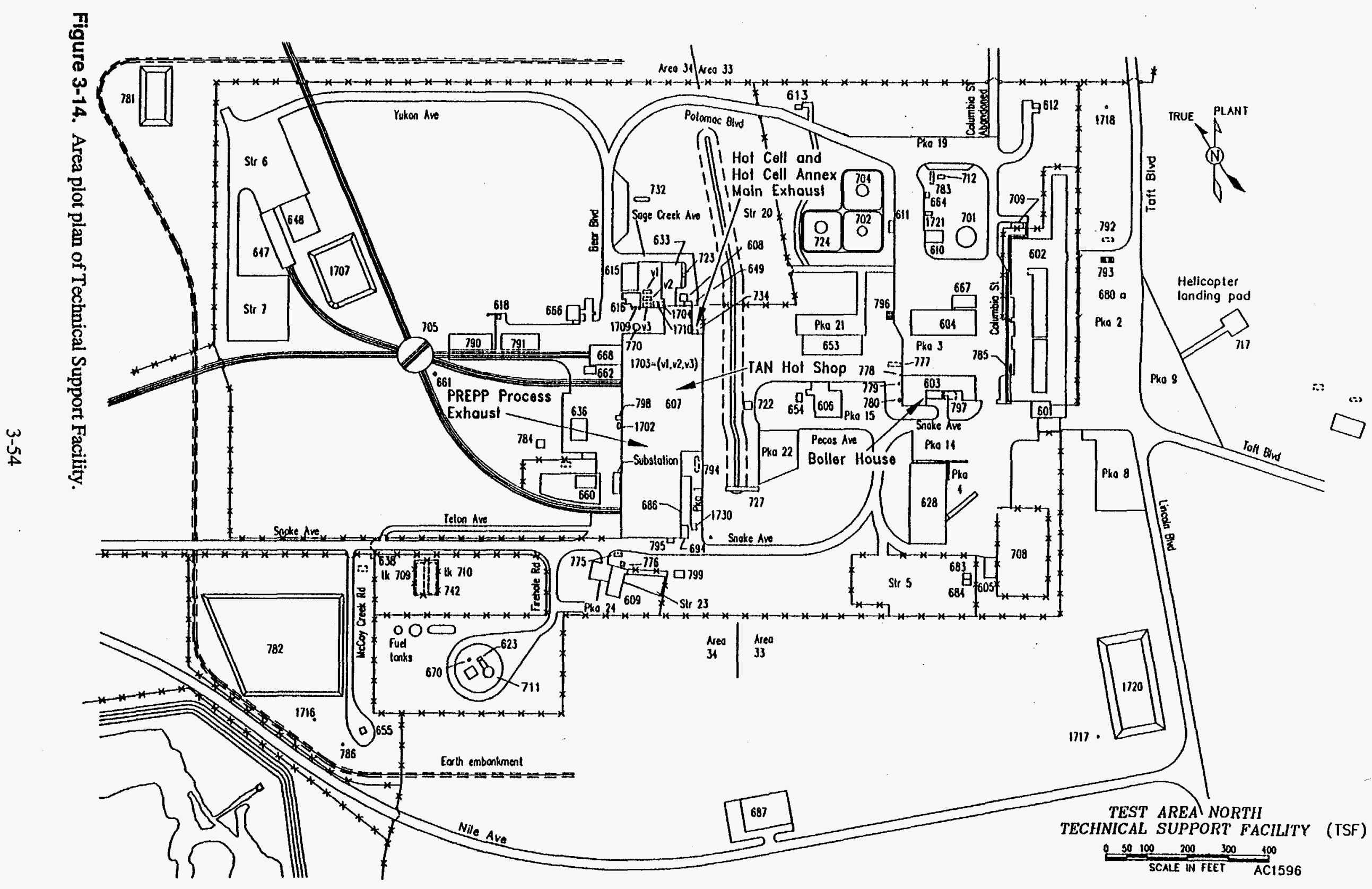




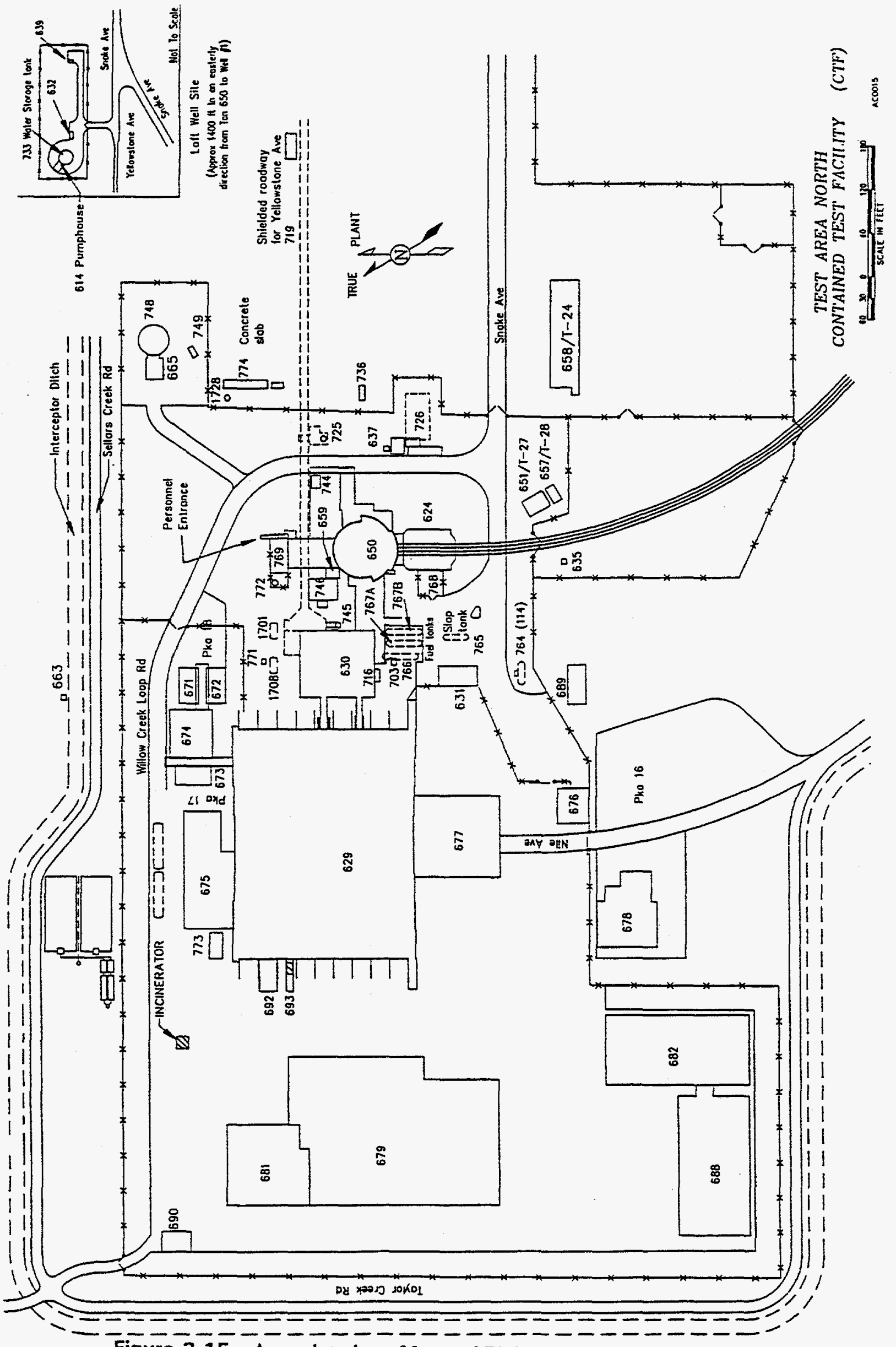

一采员

Figure 3-15. Area plot plan of Loss of Fluid Test and Specific Manufacturing Capability area. 


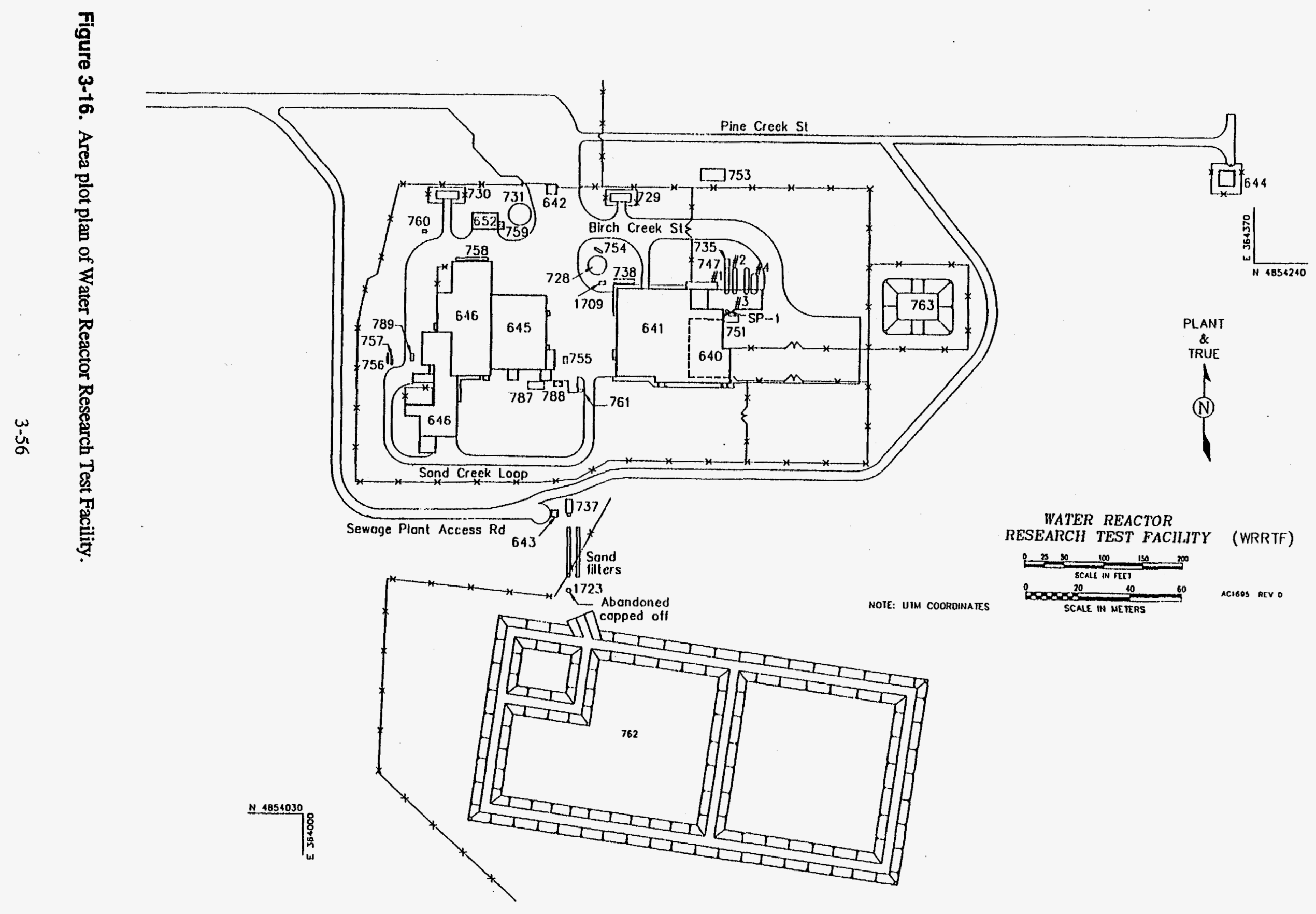




\subsection{Test Reactor Area}

\subsubsection{Area Description}

TRA contains nuclear reactors used for testing fuel, materials, and reactor components in the highneutron environment that can be obtained in the reactors. Three primary test reactors have operated in this area: The Materials Testing Reactor, the Engineering Test Reactor, and the Advanced Test Reactor. Of these reactors, only the Advanced Test Reactor is presently operating or planned to be operated. In addition to the three test reactors, this area contains support facilities for the work routinely conducted in this area, including chemistry laboratories, hot shops for the examination of highly radioactive samples, maintenance shops, water purification facilities, waste management facilities, and other facilities, some of which are currently being decommissioned.

Each reactor has a main stack from which air emissions from that reactor are discharged. This effluent consists of air from the reactor ventilation systems, sampling stations, reactor access areas, fuel storage areas (underwater), and reactor coolant water degassing areas. Since both the Materials Testing Reactor and the Engineering Test Reactor are no longer operating, effluent from these sources are minimal and negligible, respectively. Most of the emissions are radioactive materials that discharge the ventilating or degassing air. Some of the activity is formed when air or other gases become irradiated by the neutron flux in the Advanced Test Reactor. Figure 3-17 shows a plot plan of the TRA.

\subsubsection{Primary Source Descriptions}

The Advanced Test Reactor stack vents air from the main reactor building (TRA-670) including the main reactor floor and its basements. About 65,000 cubic feet per minute of air circulates through this system, flowing progressively from cleaner areas to the areas where more contamination may be present. The main source of radioactivity is the degassing tanks, where gases in the reactor coolant water are released. About 150 cubic feet per minute of gas comes from this source. Other sources of gas include vents from radioactive waste holding tanks, the experimental cubicle vents, and the reactor cooling air system.

The exhaust to the stack is monitored closely for temperature, flow rate, pressure, and radioactivity. The majority of the activity released is due to noble gas fission products such as krypton and xenon or activation products such as argon. Only about two percent of the activity is due to particulates.

The Engineering Test Reactor ventilating air discharges through the 250-ft high Engineering Test Reactor stack. Since the reactor is no longer operating, the ventilating air contains essentially no activity.

The Materials Testing Reactor offgas system serves the Materials Testing Reactor area including radioactive laboratories. Most laboratory streams are HEPA filtered before the gas is released. The stack offgas is sampled and monitored, but little activity has been detected since the Materials Testing Reactor was shut down.

The ventilation systems for most TRA-604 laboratory fumehoods and several TRA-661 laboratory fumehoods exhaust out a stack that is attached to the west side of the Materials Testing Reactor building (TRA-603). The vent emits a small quantity of VOCs and radioactivity. The exhaust stream goes through a HEPA filtering system, is monitored for radioactivity, and then is emitted out the stack.

The Hot Cell building, TRA-632, contains three hot cells for handling radioactive materials; the hot cell, the light cell, and the heavy cell. The cells are used for the assembly, disassembly, or destruction of radioactive materials. The light cell is also used for metallography. All three exhaust stacks are monitored 
for radioactivity by a common constant air monitor. All exhaust streams pass through a HEPA filtration system and an iodine removal system, either activated charcoal or silver-zeolite. A very small amount of decontamination work is also performed in the cells.

\subsubsection{Secondary Sources}

TRA has numerous secondary radiological sources, including radiological fumehoods used for research and analysis. Other secondary sources of emissions include a fumehood where only organic material is prepared for analysis, one welding hood, and two out-of-service radiological sources. The fumehoods are mainly used for either research or analysis. Some of the "radiological only" fumehoods are strictly used for sample preparation. Some of the chemicals emitted from various fumehood stacks are VOCs, nitric acid, and perchloric acid.

VOCs in the storage tanks include diesel fuel and unleaded gasoline. The fuel burning equipment includes two large bore diesel generators at the Advanced Test Reactor facility, two standby diesel generators, and two standby diesel water pumps, and one standby diesel compressor. The two water pumps both have dual exhausts, one for each side of the engine. The inorganic storage tanks contain sulfuric acid and sodium hydroxide. These materials are used in the demineralization system and for the cooling tower system.

\subsubsection{Summary of TRA Emissions}

Totals of each of the non-radionuclide principal pollutant emissions from sources at TRA during 1994 are summarized in Table 3.10-1.

Table 3.10-1. Summary of non-radionuclide principal pollutants at TRA.

\begin{tabular}{lcccc}
\hline \multicolumn{1}{c}{ Pollutant } & $\begin{array}{c}\text { Actual } \\
\text { Hourly } \\
(\mathrm{lb} / \mathrm{hr})\end{array}$ & $\begin{array}{c}\text { Actual } \\
\text { Annual } \\
(\mathrm{tm} / \mathrm{yr})\end{array}$ & $\begin{array}{c}\text { Maximum } \\
\text { Hourly } \\
(\mathrm{lb} / \mathrm{hr})\end{array}$ & $\begin{array}{c}\text { Maximum } \\
\text { Annual } \\
(\mathrm{t} / \mathrm{yr})\end{array}$ \\
\hline Carbon monoxide & $2.288 \mathrm{E}+01$ & $2.344 \mathrm{E}+01$ & $3.257 \mathrm{E}+01$ & $6.876 \mathrm{E}+01$ \\
Nitrogen oxides & $9.758 \mathrm{E}+01$ & $8.995 \mathrm{E}+01$ & $1.405 \mathrm{E}+02$ & $2.718 \mathrm{E}+02$ \\
Particulate & $6.022 \mathrm{E}+00$ & $6.992 \mathrm{E}+00$ & $9.000 \mathrm{E}+00$ & $2.467 \mathrm{E}+01$ \\
Sulfur oxides & $1.038 \mathrm{E}+01$ & $1.454 \mathrm{E}+01$ & $1.418 \mathrm{E}+01$ & $3.955 \mathrm{E}+01$ \\
VOC - nonmethane & $2.782 \mathrm{E}+00$ & $3.163 \mathrm{E}+00$ & $3.378 \mathrm{E}+00$ & $7.885 \mathrm{E}+00$ \\
\hline
\end{tabular}

\subsubsection{Summary of TRA Changes}

Changes to specific sources located at TRA between the 1993 and 1994 Air Emissions Inventories are summarized in Table 3.10-2. Justification to changes are provided to clarify the status of the source.

Table 3.10-2. Summary of source changes at TRA - 1993 to 1994 Inventory.

\begin{tabular}{|c|c|c|}
\hline 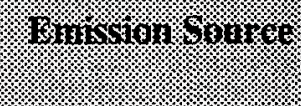 & 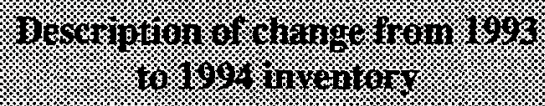 & I. \\
\hline TRA-604-027 & Vent \# deleted & Insignificant source. \\
\hline TRA-607-010 & Vent \# added & Newly identified source. \\
\hline TRA-609A-001 & Vent \# added & Newly identified source. \\
\hline
\end{tabular}


Table 3.10-2 - Continued. Summary of source changes at TRA - 1993 to 1994 Inventory.

\begin{tabular}{|c|c|c|}
\hline 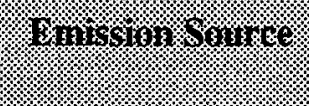 & 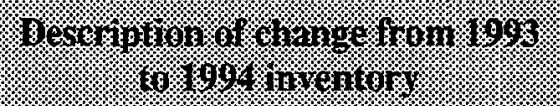 & (1) \\
\hline TRA-625-015 & Vent \# added & Newly identified source. \\
\hline $\begin{array}{l}\text { TRA-635-030 } \\
\text { TRA-635-031 }\end{array}$ & Vent \# deleted & Source removed from service. \\
\hline TRA-640-004 & Vent \# deleted & Insignificant source. \\
\hline TRA-653-041 & Vent \# deleted & Source removed (prior to '94). \\
\hline TRA-665-001 & Vent \# deleted & Source removed. \\
\hline TRA-670-044 & Vent \# deleted & $\begin{array}{l}\text { Source previously identified as } 670-044 \text { and } \\
776-001 \text {. Only } 776-001 \text { is appropriate. }\end{array}$ \\
\hline $\begin{array}{l}\text { TRA-670-047 } \\
\text { TRA-670-054 } \\
\end{array}$ & Vent \# deleted & Insignificant source. \\
\hline TRA-670A-001 & Vent \# added & New source. \\
\hline $\begin{array}{l}\text { TRA-675-001 } \\
\text { TRA-675-002 } \\
\end{array}$ & Vent \# deleted & Insignificant source. \\
\hline TRA-680-002 & Vent \# added & Newly identified source. \\
\hline TRA-707-001 & Vent \# deleted & Source removed. \\
\hline TRA-771-001 & $\begin{array}{l}\text { Changed maximum particulate } \\
\text { emissions from } 6.6 \text { ton/year to } 238 \\
\text { ton/year. }\end{array}$ & Maximum drift fraction of $0.3 \%$ used. \\
\hline TRA-776-001 & Vent \# added & $\begin{array}{l}\text { Source originally identified as TRA- } 670 \text { - } \\
044 \text {. Designated now as a separate source. }\end{array}$ \\
\hline TRA-777B-001 & Vent \# added & $\begin{array}{l}\text { Newly identified source. (Replaces TRA- } \\
707-001 \text { ). }\end{array}$ \\
\hline TRA-777C-001 & Vent \# added & $\begin{array}{l}\text { Newly identified source. (Replaces TRA- } \\
707-001 \text { ). }\end{array}$ \\
\hline
\end{tabular}



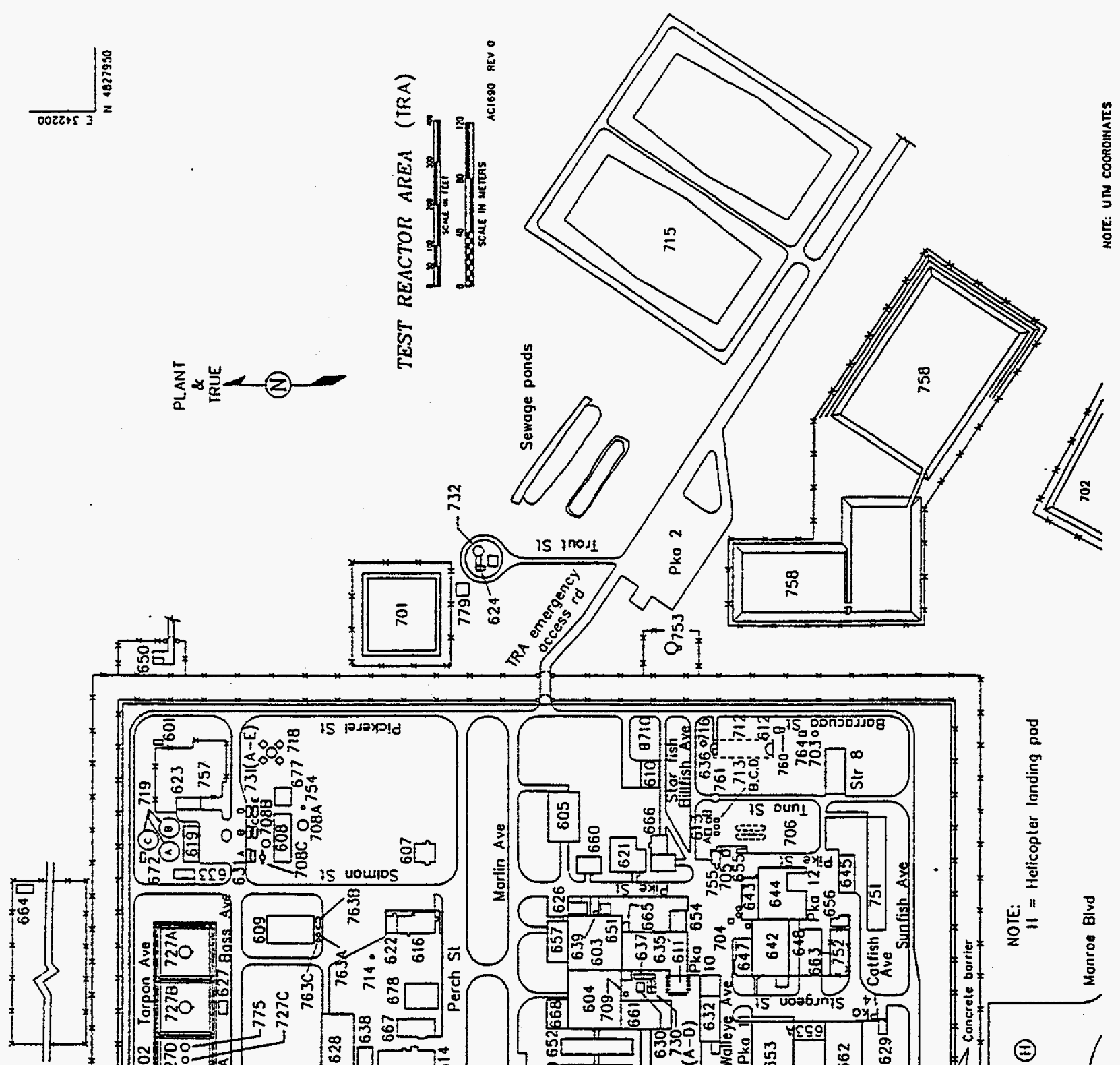

量?
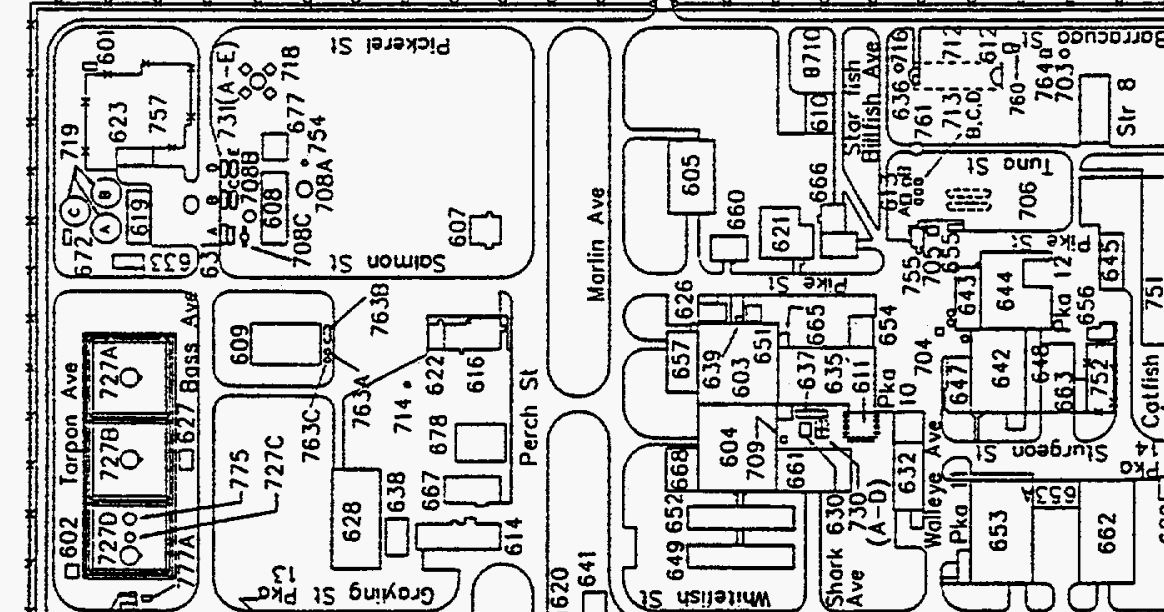


\subsection{Summary of 1994 Emissions at the INEL}

For the purpose of the Air Emission Inventory, the INEL is considered a single contiguous facility, even though the emission points are divided among distinct areas within the site. Table 3.11-1 summarizes the total emissions of the principal non-radionuclide pollutant emissions from the entire INEL. Results are given as an emission rate $(\mathrm{lb} / \mathrm{hr})$ and as annual release $(\mathrm{m} / \mathrm{yr})$ for stationary sources.

Table 3.11-1. 1994 emissions for the INEL.

\begin{tabular}{lcccc}
\hline \multicolumn{1}{c}{ Pollutant } & $\begin{array}{r}\text { Actual } \\
\text { Hourly } \\
(\mathrm{lb} / \mathrm{hr})\end{array}$ & $\begin{array}{c}\text { Actual } \\
\text { Annual } \\
(\mathrm{m} / \mathrm{yr})\end{array}$ & $\begin{array}{c}\text { Maximum } \\
\text { Hourly } \\
(\mathrm{lb} / \mathrm{hr})\end{array}$ & $\begin{array}{c}\text { Maximum } \\
\text { Annual } \\
(\mathrm{m} / \mathrm{yr})\end{array}$ \\
\hline Carbon monoxide & $3.6 \mathrm{E}+02$ & $4.4 \mathrm{E}+02$ & $1.1 \mathrm{E}+03$ & $3.9 \mathrm{E}+03$ \\
Nitrogen oxides & $1.1 \mathrm{E}+04$ & $6.6 \mathrm{E}+02$ & $2.7 \mathrm{E}+03$ & $4.0 \mathrm{E}+03$ \\
Particulates & $9.7 \mathrm{E}+01$ & $1.1 \mathrm{E}+02$ & $2.5 \mathrm{E}+02$ & $7.0 \mathrm{E}+02$ \\
Sulfur oxides & $3.4 \mathrm{E}+02$ & $2.2 \mathrm{E}+02$ & $8.2 \mathrm{E}+02$ & $3.0 \mathrm{E}+03$ \\
VOC - nonmethane & $5.3 \mathrm{E}+02$ & $2.7 \mathrm{E}+01$ & $6.4 \mathrm{E}+02$ & $3.0 \mathrm{E}+02$ \\
\hline
\end{tabular}




\subsection{Air Emissions Inventory}

The INEL initiated the Air Emissions Inventory process in 1989 to obtain baseline information required for preparation of an operating permit application in accordance with Title V of the Clean Air Act. Information obtained has been utilized and a State of Idaho Tier I Operating Permit Application has been prepared for submittal to the State of Idaho (INEL-95/0155-I through IX).

Areas of the INEL Air Emissions Inventory were identified for improvement. These areas typically include nomenclature changes and formatting. Many of these changes will be reflected in the 1995 Air Emissions Inventory such as:.

- Revision to background information concerning initial and continuing inventory data collection.

- Revisions to sections describing Primary and Secondary sources to reflect Significant, NotSignificant and Insignificant activities.

- The addition of UTM Coordinates where absent, or correction to coordinates where errors are identified.

- The updating of area plot plans in the Air Emissions Inventory.

- The accurate portrayal of maximum emissions for certain permitted sources. These are not currently clear in Appendix C of the Air Emissions Inventory. These sources share a maximum permitted emission limit, but operate on various schedules ranging from standby status to full time operation. This issue will be clarified during preparation of the 1995 Air Emissions Inventory.

- The prorating of fuel consumption in instances where multiple sources feed from a single tank requires clarification. This issue will be clarified during preparation of the 1995 Air Emissions Inventory. 


\section{EMISSIONS ESTIMATES FOR STATIONARY SOURCES}

The following sections describe the various calculations used to estimate the emissions from sources based on the data collected in the initial Phase II of the inventory and successive annual updates. Each section includes a list of assumptions made and calculational methods as applicable. Appendix $\mathrm{C}$ presents the data used to calculate the 1994 Air Emission Inventory.

An important consideration for regulatory purposes is an understanding of maximum emissions. Currently, the inventory requires the estimation of maximum emissions for each source. Maximum emission estimates represent emissions associated with the maximum operation of the given source. Sources with permits have already had maximum values attributed to them. These have been included in the inventory as they appear in the permit or application. Other maximum values were estimated as outlined in the following sections. If a maximum emission estimate could not be determined, the actual emission estimates were used as the maximum emissions estimates.

The database performs several calculations. The types of sources that the database produced calculations for are diesel and gas engines; boilers, furnaces, and heaters; and volatile organic compound storage tanks. AP-42 equations and tables were used in the calculations.

\subsection{Industrial Engine Emissions}

\subsubsection{Methodology and Assumptions}

Industrial stationary engines are commonly used throughout the INEL for emergency electrical power generation and water pumping. These sources generally operate on a routine schedule of 0.5 hours per week. This routine operation and maintenance are required to ensure that the systems are ready when needed. The operation schedule during an emergency is dependent on the nature of the problem. Based on discussions with the maintenance personnel around the facility, the usual power outage lasts from 1 to 4 hours. Power outages occur infrequently and at any time, so a specific schedule is impossible to predict.

These calculations cover two basic categories of engines with two fuel types. These categories generally include gasoline and diesel industrial engines with power ratings up to $600 \mathrm{hp}$, and large bore diesel engines with displacements greater than $560 \mathrm{in} .{ }^{3} /$ cylinder or power ratings greater than $600 \mathrm{hp}$. Emissions from these sources include carbon monoxide, hydrocarbons, nitrogen oxides, sulfur oxides, volatile organic compounds (VOCs), hazardous air pollutants (HAPs), and particulates. The emissions for these sources are estimated based on published emission factors found in EPA's AP-42 Volume I.

A few industrial engines at the INEL have horsepower ratings in excess of $600 \mathrm{hp}$ but are not classifiable as large bore engines. A consultant from Radian reviewed this issue, and after talking with respective manufacturers of these engines, determined that the AP-42 factors for engines less than $600 \mathrm{hp}$ were appropriate in each case.

Assumptions:

- Operation schedule was based on routine operation according to information supplied by maintenance personnel.

The primary method for estimating emissions was based on fuel consumption. Generally, fuel figures were available for most engines and were a better estimate than estimating an operating schedule. 
If fuel consumption figures were not available, estimates were based on engine power and operating schedule.

Where several engines are operated from a common fuel tank, the fuel consumption for each engine was based on the ratio of each engine's power rating to the total for all the engines.

The following steps are required to estimate the emissions from industrial engines.

1. Determine engine size (horsepower, cubic inch displacement).

2. Look up emission factors in AP-42 (4/93), Volume 1;

100-600 hp engines:

Fuel input data - Table 3.3-1,

Fuel input data for speciated PM - EPA SPECIATE Data Base, profile 32104

$>600$ hp engines:

$\mathrm{NO}_{\mathrm{x}}, \mathrm{SO}_{\mathrm{x}}, \mathrm{CO}$, Non-methane TOC - Table 3.4-1

VOCs - Tables 3.4-3 and 3.4-4,

PM - Table 3.4-5,

Speciated PM compounds - EPA SPECLATE Data Base, profile 32206

3. Apply factor to either the fuel consumed or the operating schedule, and convert the units to pounds per hour and tons per year.

In the event that the data were limited, maximum and actual fuel consumption rates were sometimes obtained by one of the following methods. Since most of the engines at the INEL are for emergency purposes, they typically run only during preventive maintenance checks. Mechanics at several areas indicated that the engines are checked at $50 \%$ load. A large quantity of data was collected to determine on the average what percentage of the maximum fuel throughput is burned at $50 \%$ load, and it was determined to be roughly $50 \%$. Therefore, if the maximum throughput was known, but not the actual, the actual was assumed to be $50 \%$ of the maximum, assuming that virtually all run time is at 50\% load. Likewise, if the actual was known but not the maximum, the same relationship was assumed to be true. In rare cases, no information was available, and throughputs were determined to be the same as for similar engines with the same horsepower rating.

It was also determined to be necessary to check the validity of some throughput data since it appeared that the assumed throughput compared to the horsepower was indicating engine efficiency well in excess of the $35 \%$ average. To do this, a spreadsheet was developed with all the engines and their respective throughputs and horsepowers included. The efficiency was calculated and those with suspiciously high values were rechecked and corrected.

\subsubsection{Maximum Emission Estimates}

The method for determining maximum emissions from all standard sources of fuel burning equipment was identical to the AP-42 method used to calculate actual emissions. The only difference is that the maximum rate of fuel consumption for 8,760 hours of operation is applied to the emission factors; except in cases where permit limits restrict the hours of operation, or classification as a not-significant source in the operating permit application restricts the hours of operation. A maximum fuel consumption rate was generally available from information either directly on the piece of equipment or from data provided by vendors. In a few instances, assumptions were made based on a knowledge of operation schedules. For 
example, most emergency generators are operated for a known period each week for preventive maintenance purposes. When they do run, they typically run at 50\% load. Vendor data indicates that on the average, when an industrial engine runs at 50\% load, the fuel consumption rate is roughly $50 \%$ of the maximum. Therefore, if normal consumption rates are known from fuel tank loading information, then a good approximation of the maximum fuel consumption rate can be made knowing this $50 \%$ relationship. Sometimes working this relationship the other way was useful, estimating the normal rate of consumption when only the maximum was known.

In some cases, maximum emissions were calculated based on the maximum horsepower of the engine and the appropriate emissions factor in $\mathrm{g} / \mathrm{ph}-\mathrm{hr}$.

horsepower $\times \mathrm{AP}-42$ factor $\times$ maximum allowed hours $=$ yearly maximum emissions

\subsubsection{Calculations Performed by the Database}

The emission calculations for internal combustion engines (diesel and gas) used the following equation:

Gal/year $\times \mathrm{AP}-42$ factor $(\mathrm{lb} / 1,000 \mathrm{gal}) / 2,000(\mathrm{lb} / \mathrm{ton})=$ yearly emission $($ ton/year $)$.

Using the operation schedule provided on the data sheets, the hourly emissions were calculated as follows:

$\mathrm{Gal} / \mathrm{hr} \times \mathrm{AP}-42$ factor $(\mathrm{lb} / 1,000 \mathrm{gal})=$ hourly emission $(\mathrm{lb} / \mathrm{hr})$.

\subsection{Boiler Emissions}

\subsubsection{Methodology and Assumptions}

Boilers are used throughout the INEL primarily to provide space heating and process steam. Their fuels range from natural gas to coal. Boiler sizes range from residential sized heaters (less than $0.5 \mathrm{MBtu} / \mathrm{hr}$ ) to the large coal fired steam generation facility at ICPP $(165 \mathrm{MBtu} / \mathrm{hr})$. Boiler operation schedules vary depending on operations, weather, and reactor schedules. Because of the critical need for boilers in several areas, many boiler installations include up to $100 \%$ backup capacity for emergency purposes. These backup boilers are generally only operated for maintenance purposes. The best way to determine boiler use is to measure boiler fuel consumption. Fuel consumption automatically takes into account both hours of operation and boiler load. Fuel consumption figures are typically well documented and reliable.

Boiler emissions include carbon monoxide, nitrogen oxides, sulfur oxides, volatile organics, HAPs, and particulates. These emissions are estimated using published emission factors found in AP-42 (4/93).

Assumptions:

Operation schedule is based on best estimates of boiler operators or maintenance staff.

Emission estimates are primarily based on the annual fuel consumption. 
When several boilers have the same fuel source, the emissions for each boiler are based on the ratio of the individual capacity to the total capacity.

During the initial inventory process, the sulfur content for No. 2 fuel oil was considered to be 0.24 weight percent, and 0.9 weight percent for No. 5 fuel oil. However, per the present vendor contracts, the current emissions estimates use the sulfur content of No. 2 fuel oil as 0.5 weight percent and the sulfur content of No. 5 fuel oil as 1.5 weight percent.

In several instances, a boiler may burn a mixture of No. 1 fuel oil and No. 2 fuel oil; in such cases, the emissions estimates assumed all fuel burned was represented by No. 2 fuel oil.

The following steps are required to determine the emissions from boilers.

1. Determine fuel type (coal, oil, natural gas).

2. Determine boiler capacity (utility, industrial, commercial, residential).

3. Look up emission factor in AP-42 (4/93), Volume 1;

$\mathrm{NO}_{\mathrm{x}}, \mathrm{SO}_{\mathrm{x}}, \mathrm{CO}$, - Table 1.3-1,

Non-methane VOC - Table 1.3-4

PM - Table 1.3-8

Trace metals - Table 1.3-11

Hexane and formaldehyde - EPA SPECIATE Data Base, profile 0001

4. Multiply emission factor by fuel consumed and correct units to $\mathrm{lb} / \mathrm{hr}$ or ton/year.

\subsubsection{Maximum Emission Estimates}

The method for determining maximum emissions from all standard sources of boilers was identical to the AP-42 method used to calculate actual emissions. The only difference is that the maximum rate of fuel consumption for 8,760 hours of operation is applied to the emission factors. The maximum fuel consumption rate was generally available from information either directly on the piece of equipment or from data provided by vendors. In a few instances, assumptions were made based on a knowledge of operation schedules and permit limits.

$$
\begin{aligned}
& \text { Gallyr }=8760 \mathrm{hr} / \mathrm{yr} \times(\max \mathrm{lb} / \mathrm{hr} / 7.21 \mathrm{lb} / \mathrm{gal}) \\
& \text { Max lb/hr }=(\text { MCR of steam })(1,000 \mathrm{Btu} / \mathrm{lb}) /(0.8)(19,400 \mathrm{Btu} / \mathrm{lb})
\end{aligned}
$$

where:

$$
\begin{aligned}
& \text { Maximum continuous rating (MCR of steam) }=\text { steam lb/hr } \\
& \text { Heat content of No. } 2 \text { fuel oil }=19,400 \mathrm{Btu} / \mathrm{lb} \\
& \text { Boiler efficiency (assumed) }=80 \text { percent } \\
& \text { Density of No. } 2 \text { fuel oil }=7.21 \mathrm{lb} / \mathrm{gal}
\end{aligned}
$$




\subsubsection{Calculations Performed by the Database}

The emission calculations for boilers, heaters, and furnaces used the following equation:

$\mathrm{Gal} / \mathrm{yr} \times \mathrm{AP}-42$ factor(lb/1,000 gal)/2,000 (lb/ton) $=$ yearly emission (ton/yr)

Using the operation schedule provided on the data sheets, the hourly emissions were calculated as follows:

$\mathrm{Gal} / \mathrm{hr} \times \mathrm{AP}-42$ factor $(\mathrm{lb} / 1,000 \mathrm{gal})=$ hourly emission $(\mathrm{lb} / \mathrm{hr})$

\subsection{Laboratory Fumehood Calculations}

\subsubsection{Methodology and Assumptions}

Many buildings at the INEL have laboratories with fumehoods. These hoods are used for chemical analysis, radiological analysis, chemical storage, and research and development. The types of pollutants that may be involved include acids, bases, volatile organics, particulates, and a variety of other chemicals and gases that may or may not be of regulatory concern. The majority of hoods are used mostly for precautionary measures or infrequent experimental work, but some are used routinely for both research and analysis.

In general, process knowledge provides the emissions estimates for laboratory fumehoods. Process knowledge included laboratory fumehood chemical inventories and associated uses. Because of the wide variety of materials that could be used in a laboratory hood, the laboratory custodians and technicians were relied upon to provide information about potential emissions based on knowledge of hood use and present programs. Whenever question arose about quantities that were actually emitted, the most conservative estimate was used. The most conservative estimate is to assume $100 \%$ of the chemical inventories are emitted. Whenever possible, log books were referred to for the numbers and types of analysis/experiments performed in specific hoods over a period of several months.

Assumptions:

Acids and bases are not emitted unless they are heated or boiled off, in which case $100 \%$ is assumed emitted.

$100 \%$ of the volatile organic compounds are vented unless knowledge of disposal procedures can account for a known percentage of volatile organic compounds used in the hoods.

- Solid chemicals mixed in solution remain in solution and are not otherwise emitted to the atmosphere.

- Laboratories with more than one hood are assumed to emit an equal distribution of the identified quantities of pollutants from that lab, unless the custodians specifically indicate otherwise.

\subsubsection{Maximum Emission Estimates}

Quantifying the maximum amount of material that could be emitted from a laboratory fumehood is very difficult. The only reasonable means for doing so in the context of this inventory was to assume that the 
actual emission rate was reasonably representative of the maximum and multiply that value by 8,760 hours to obtain the maximum yearly emissions.

\subsection{Painting Operations Calculations}

\subsubsection{Methodology and Assumptions}

A variety of painting operations occur at the INEL, including spray booths, brush applications inside craft shops, spraying and brushing on location, paint mixing, and brush/equipment cleaning. The paint booths are typically the only sources with a designated blower specific to that source. Any painting that occurs elsewhere in the shop is considered to be vented either from a nearby room exhaust, or through the paint booth, whichever is most appropriate.

For convenience, all painting that occurs on location around the INEL is attributed to the paint shop that supplied the paint, and all emissions are assumed to vent with the paint booth. Shop managers and material safety data sheets provided information about the materials used in the paint booths.

Emissions estimates associated with painting operations were hand calculated and based on process knowledge of the given operation. The database does not provide calculations for these types of operations.

Assumptions:

- $100 \%$ of VOCs from paint is emitted

- $15 \%$ of paint solids are emitted from spraying activities

- $0 \%$ of solids are emitted from brush application activities

- $40 \%$ of lacquer thinner and other thinners are evaporated to the atmosphere (60\% is disposed of in satellite accumulation areas)

- $10 \%$ of mineral spirits solvent is evaporated to the atmosphere $(90 \%$ is disposed of in satellite accumulation area)

All painting operations are associated with a vent

$90 \%$ filter efficiency for particulate in a spray booth

$0 \%$ filter efficiency for all volatile organic compounds, and for particulate from activities outside the spray booth

Typical operating schedule (if not provided by operator) is 4 hours/day, 5 days/week, 52 weeks/year, or 1,040 hours per year.

\subsubsection{Maximum Emission Estimates}

Maximum emission estimates from paint booths are based on the assumption that the average spray gun can spray 2.5 gallons of paint per hour and that $100 \%$ of the solvents purchased for paint thinning and brush cleaning are emitted. An emission rate can then be determined in the same manner as for the actual emissions, assuming 8,760 hours of operation. 


\subsection{Organic Tank Emissions Calculations Methodology}

\subsubsection{Methodology and Assumptions}

INEL storage tanks may be vertical or horizontal, above ground or underground, and inside or outside buildings. The majority of the organic liquid storage tanks are vertical with a fixed roof. This type of tank consists of a cylindrical steel shell with a permanently affixed roof, which may vary in design from coneor dome-shaped to flat. Fixed roof tanks at the INEL are typically freely vented.

The INEL methodology for estimating emissions for organic storage tanks is derived from EPA's AP-42, Compilation of Air Emission Factors-Stationary Sources, Section 4.3, "Storage of Organic Liquids." Emissions from tanks occur when the vapor space is either pressurized by a change in temperature or pressure, relieving the pressure by "breathing" out of the vent (breathing loss), or when the tank is filled, displacing the vapor out of the tank (working loss). Aboveground tanks are much more susceptible to daily temperature changes, and tank color and paint condition are therefore considered in calculating their emissions.

The INEL uses AP-42, Volume I, Section 4.3 (September 1985) to calculate the emissions from the storage of organic liquids. The INEL Emissions Inventory System is programmed to perform these calculations. However, the EPA recently reissued the organic storage tank calculations in AP-42 Chapter 12. At the request of industry, the EPA redeveloped the complicated calculations to provide for easier calculations and to support the development of an EPA program to calculate storage tank emissions. Although the original calculations are more complex, the INEL inventory system is programmed with and uses the more complex calculations for the 1994 Air Emissions Inventory.

The two types of emissions from fixed-roof, organic storage tanks are breathing loss and working loss. Breathing loss is the expulsion of vapor from a tank through vapor expansion and contraction because of changes in temperature and barometric pressure. Breathing loss does not change the liquid level in the tank. Working loss is the combined loss from filling and emptying tank contents. Filling loss comes with an increase of the liquid level in the tank, when the pressure inside the tank exceeds the relief pressure, or atmospheric pressure, and vapors are expelled from the tank. Emptying loss occurs when air drawn into the tank during liquid removal becomes saturated with organic vapor and expands, thus exceeding the capacity of the vapor space.

Above ground, horizontal organic storage tanks pose a unique problem from an AP-42 standpoint, since the empirical equation is specifically for vertical tanks. The equation considers the tank diameter as a function of the liquid surface area, but the diameter on a horizontal tank will have a much different effect on the surface area than will the diameter of a vertical tank. To correct for this, an average surface area is computed for horizontal tanks, and then an equivalent diameter factor is calculated based on that area. This diameter is then inserted into the AP- 42 equation directly as though it was for a vertical tank.

The following assumptions standardize the storage tank calculations.

Daily temperature change of underground tanks and inside tanks is approximately zero, and therefore the breathing loss is also approximately zero.

Average atmospheric pressure is 12.3 psi. 
- Working loss emissions are equal to volume of vapor displaced by fuel during tank filling. The number of times the tank is filled is assumed to be equal to the annual throughput divided by the volume of the tank.

The vapor space height for horizontal cylindrical tanks is approximated as though the tank were of square cross section. This greatly simplifies the calculation.

The maximum fill rates of the tanks were provided by the INEL Idaho Traffic Division as follows:

Aboveground tanks: trucks pump at $200 \mathrm{gal} / \mathrm{min}$

Underground tanks: gravity fed at $100 \mathrm{gal} / \mathrm{min}$

CFA-754 and TAN-724: self pumping at $90 \mathrm{gal} / \mathrm{min}$.

\subsection{Emissions from Welding Operations}

\subsubsection{Methodology and Assumptions}

Welding operations are located at ANL-W, CFA, ICPP, NRF, and TAN. During welding, a percentage of the welding rod is deposited and the balance goes to fume. The fumes are then removed by the ventilation system and released to the atmosphere. To calculate the amount and composition of the fume released to the atmosphere, the type and amount of welding rod used per year at each welding operation, the percentage of welding rod used that goes to fume for each rod type, the composition of the fumes from each rod type, and the stack parameters of the ventilation systems information was collected.

Assumptions:

- All fumes produced during welding are vented through the stack on the associated ventilation system.

- Fumes produced during tungsten inert gas welding are negligible (Barnes, Tak) and thus are not considered.

The percent fume generated and fume constituents will be the same for welding rods of the same type but different manufacturers.

For modeling purposes, all welding fumes generated in a building will be vented to the atmosphere through one stack.

Formula:

Amount of rod used $\times \frac{\text { weight } \% \text { of fumes }}{100}=$ fumes generated $(\mathrm{lb})$

Fumes generated $(\mathrm{lb}) \times \frac{\text { weight } \% \text { of constituent }}{100}=$ constituent generated $(\mathrm{lb})$. 


\subsubsection{Maximum Emission Estimates}

The maximum emissions from welding booths are based on welders' estimates that each welder in any given booth can burn a maximum of ten pounds of weld rod per hour. Multiplying the particulate factors for ten pounds per hour provides the emission rate, and multiplying the rate by 8,760 hours per year gives the annual maximum quantity.

\subsection{Main Stacks}

\subsubsection{Methodology and Assumptions}

Main stacks are large emission points that consist of several effluent streams culminating in a single, typically very large stack, such as the ICPP main stack. Each main stack is unique: processes that it exhausts are peculiar to that stack alone. The general method used for determining the emissions from these sources is to track each individual effluent stream to its source and estimate the emissions. The main stack's emissions then are the sum of each contributing source. Main stack emission estimates were determined using stack monitoring results, process knowledge, existing permits, permit applications, engineering drawings, interviews with cognizant engineers, and calculations.

\subsubsection{Maximum Emission Estimates}

The maximum emissions for main stacks were typically determined from either permit values or cognitive engineers. Some National Environmental Policy Act documents, including environmental assessments, were also used.

\subsection{Miscellaneous Sources}

\subsubsection{Methodology and Assumptions}

Occasionally during the inventory, a source was encountered that did not fit into any of the above categories. Each of these had to be handled on a case-by-case basis. Calculations were typically based on a set of assumptions that allowed these sources to be characterized in a fashion similar to other more familiar sources. These assumptions and calculations were documented and attached to the field data sheets.

\subsubsection{Maximum Emission Estimates}

Unusual or unique source types that did not fit the above source types had maximum emissions calculated on a case by case basis. The most common method was to assume that the hourly emission rate was the maximum and multiply by 8,760 hours for the annual quantity. If a maximum emission estimate could not be assigned, the actual emissions estimates were utilized as the maximums. 



\section{REFERENCES}

DOE-ID, 1993, Idaho National Engineering Laboratory Technical Site Information, DOE/ID-10401, May 1993.

DOE-ID, 1992, Air Emission Inventory for the Idaho National Engineering Laboratory-1990\& 1991 Emissions Report, U.S. Department of Energy, Field Office, Idaho, DOE/ID-10433(92), June 1992.

DOE-ID, 1991, Air Emission Inventory for the Idaho National Engineering Laboratory, DOE/ID10432(91), March 1991.

DOE 1990, NESHAPs 40 CRF 61.93 Monitoring Requirements for Radiological Emission Sources at INEL, DOE/ID-10310, November 1990.

EPA, Compilation of Air Pollutant Emission Factors, U.S. Environmental Protection Agency, AP-42, current revision.

INEL 1995, Application for a Title V Operating Permit for the Idaho National Engineering Laboratory, INEL-95/0155-I through IX, July 1995. 

Appendix A

Phase I \& II Forms 

DOE-ID ECO Air Emission Inventory - 1989

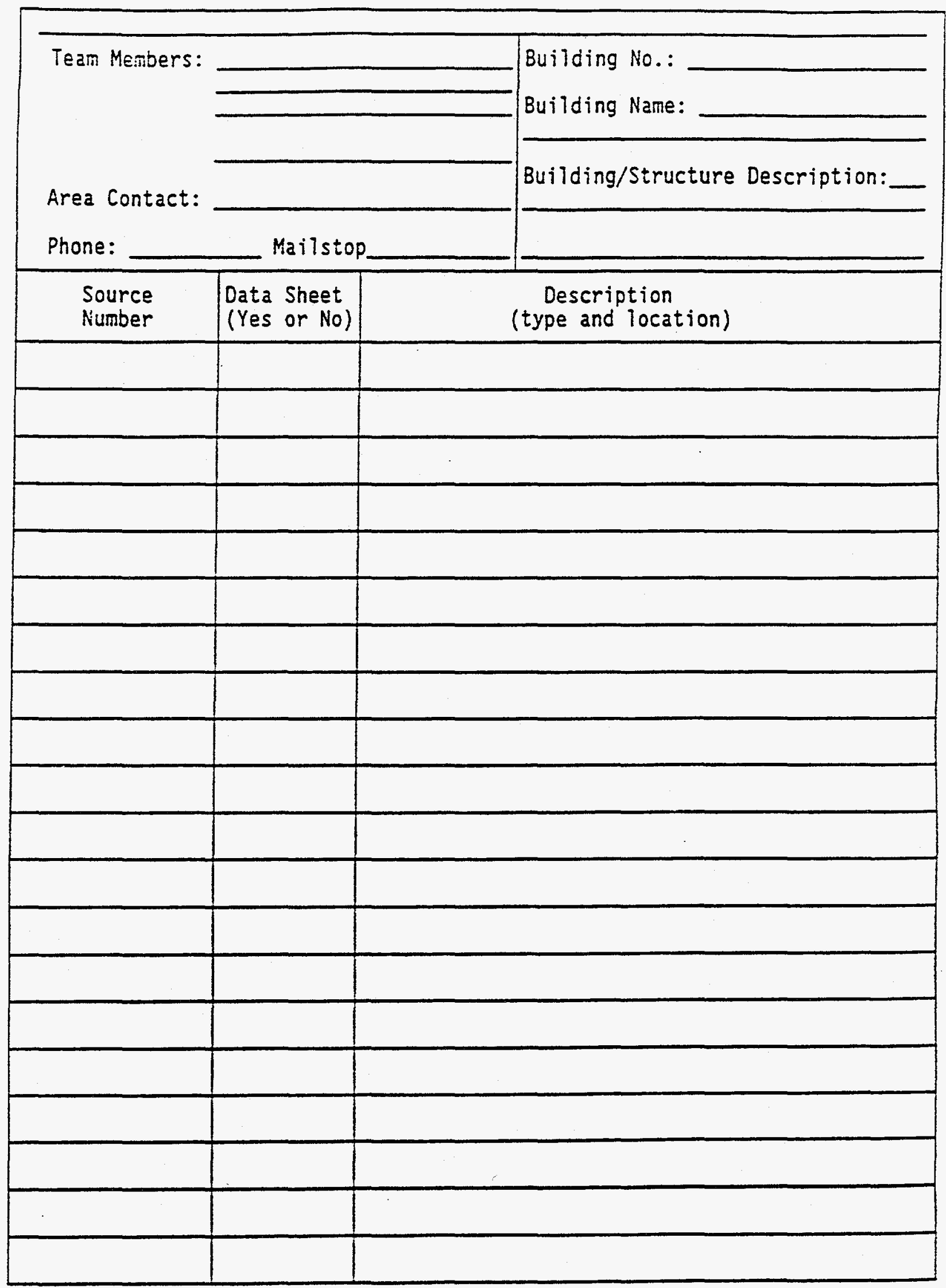


COE-IC ECO Air Emission Inventory - 1989

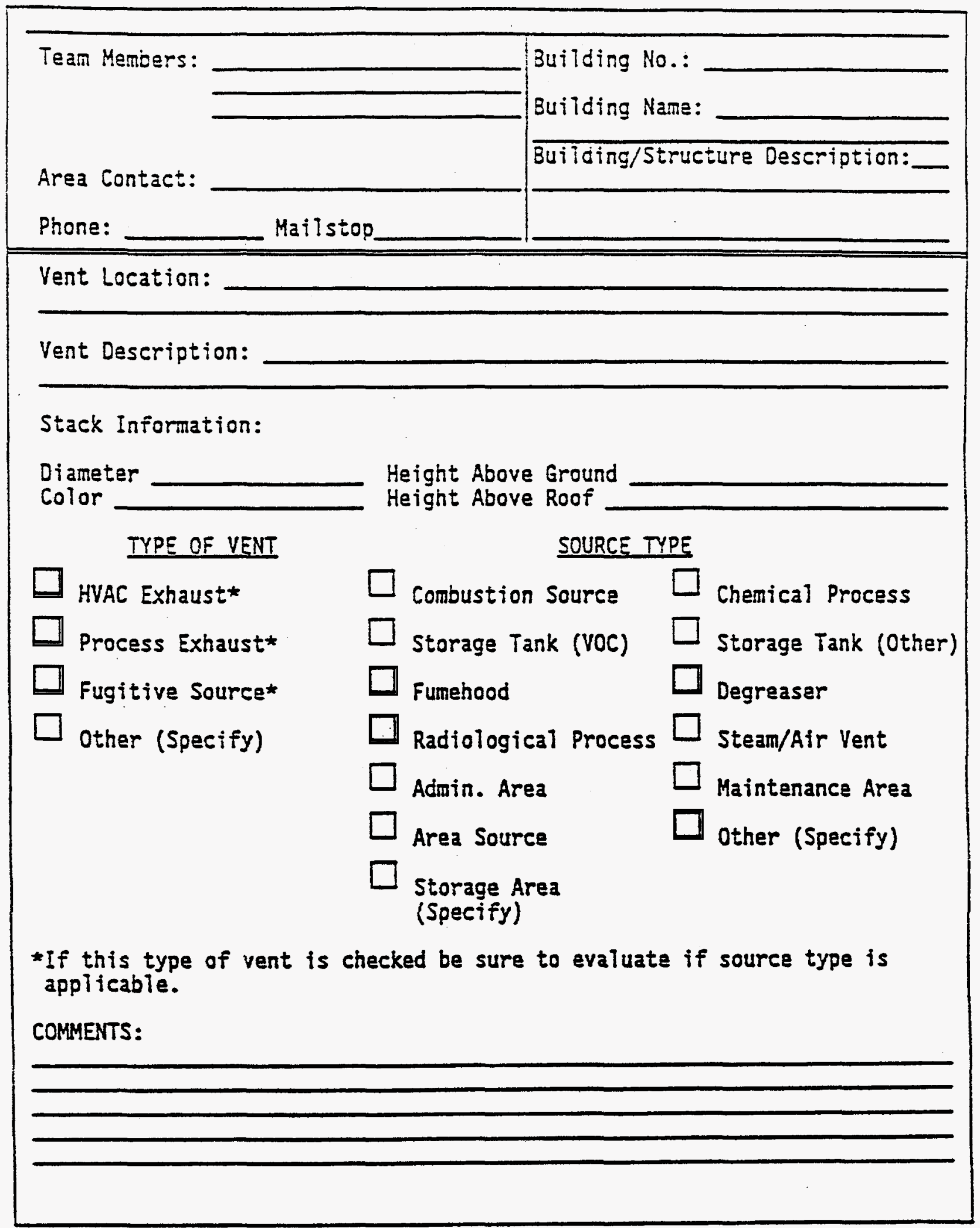

DOE/ECS RAY. I 
OCE-10 ECO Air Emission Inventory Phasa II, 1990

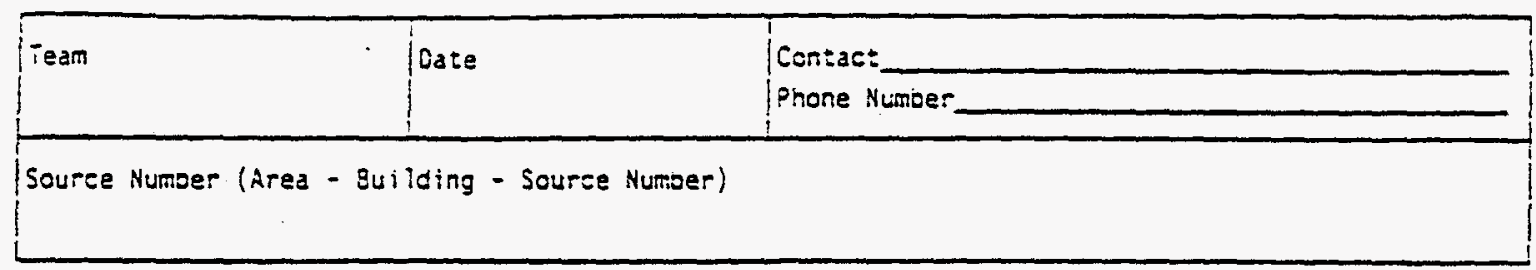

PROCESS DATA

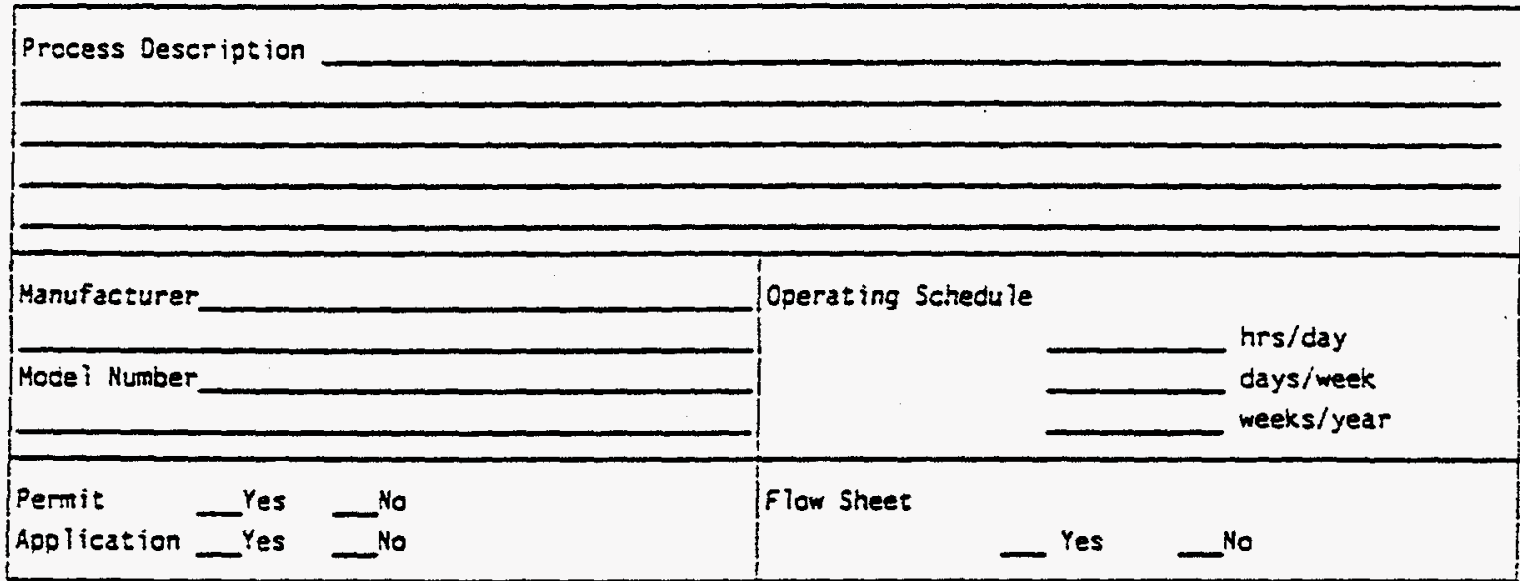

\section{STACK DATA}

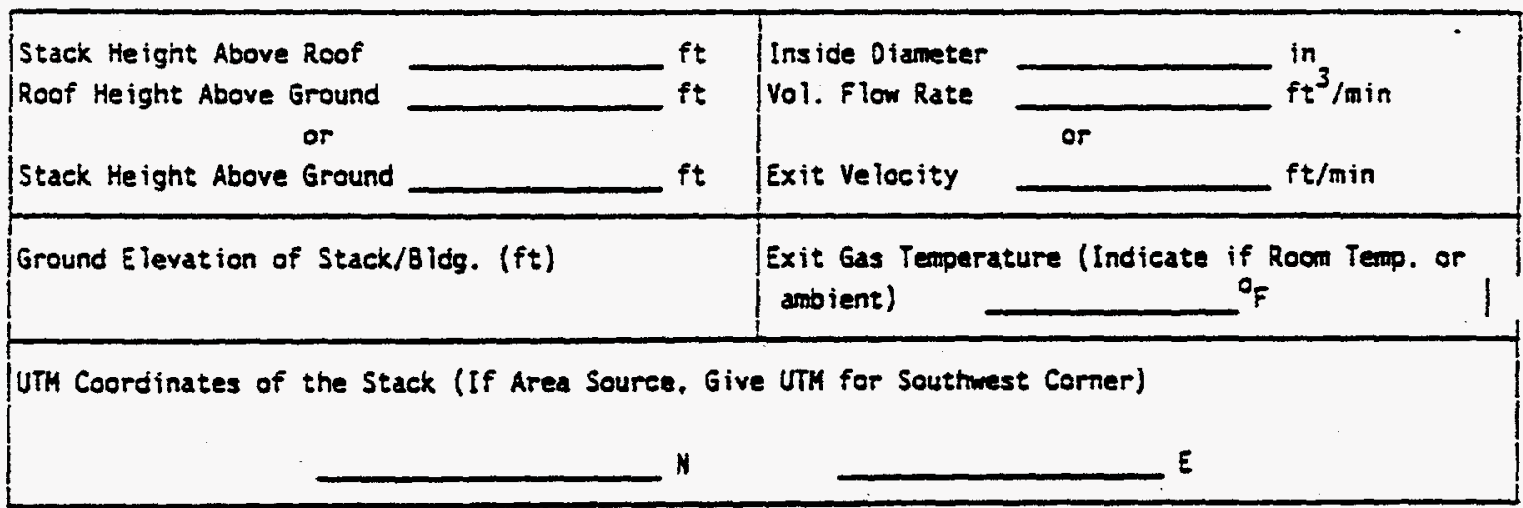

\section{DATA CATEGORY}

Chenical Sourses

Fuel Burning Equipment

Storage Tariks for liguid

Fuels. Solvents, and

Other Volatile Organies
Storage Tanks for

Inorganic Liquids

other 


\section{III}

Source Number

Comments:

References (People or documents):

Prints or photos:

A-6 


\section{DOE-IO ECO Air Emission Inventory Phase II-1990 Chemical Sources}

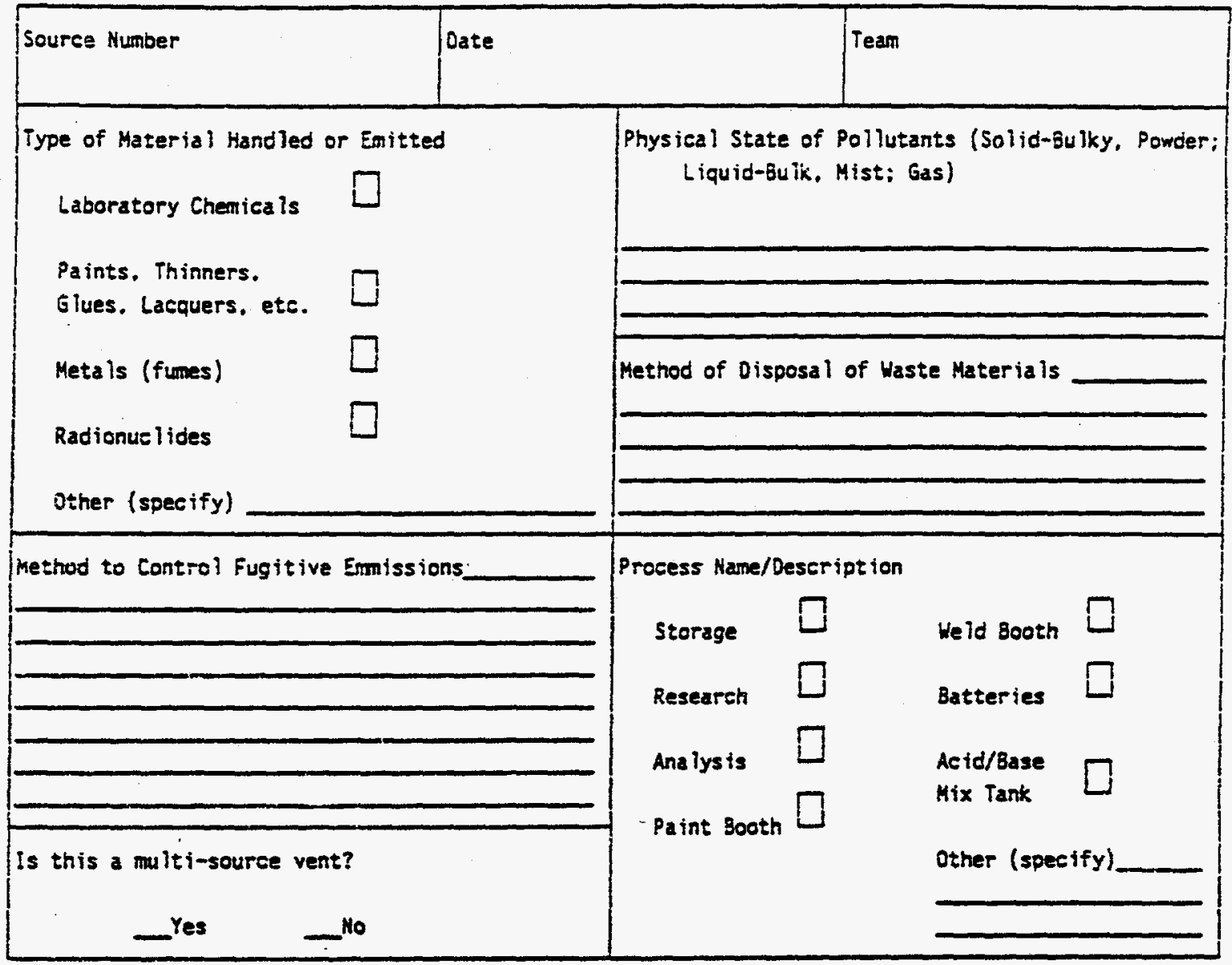


DOE-ID ECO Air Emission Inventory Phase II-1990

Fuel Burning Equipment

\begin{tabular}{|c|c|c|c|}
\hline Source Number & Date & Tean & \\
\hline $\begin{array}{l}\text { Fuel Type } \\
\text { Primary } \\
\text { Secondary }\end{array}$ & & \multicolumn{2}{|c|}{$\begin{array}{l}\text { Fue } 1 \text { Consumption Per Quarter as } \% \text { of Annua } \\
\text { January - Mareh } \\
\text { April - June } \\
\text { July - August } \\
\text { Septenber - December }\end{array}$} \\
\hline $\begin{array}{l}\text { Hourly Fue l Consumption } \\
\text { Maximum anount } \\
\text { burned/hour } \\
\text { Normal amount } \\
\text { burned/hour } \\
\text { or } \\
\text { Normal amount } \\
\text { burned/year }\end{array}$ & Secondary & 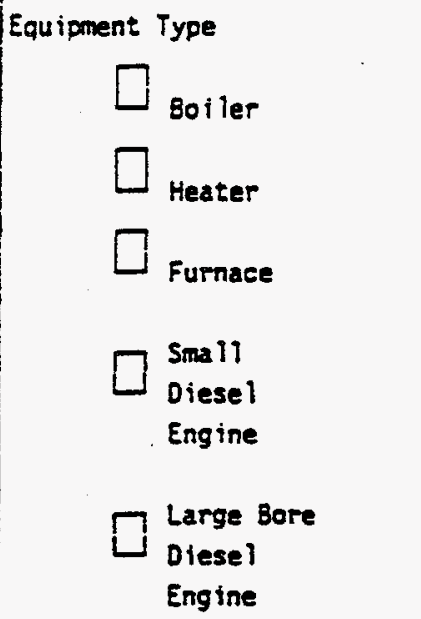 & $\square_{\text {Burners }}^{\text {Propane/Butane }}$ \\
\hline
\end{tabular}




\section{DOE-ID ECO Air Emission Inventory Phase II-1990 \\ Storage Tanks for Liquid Fuels, Solvents, and Other Volatile Organic Compounds}

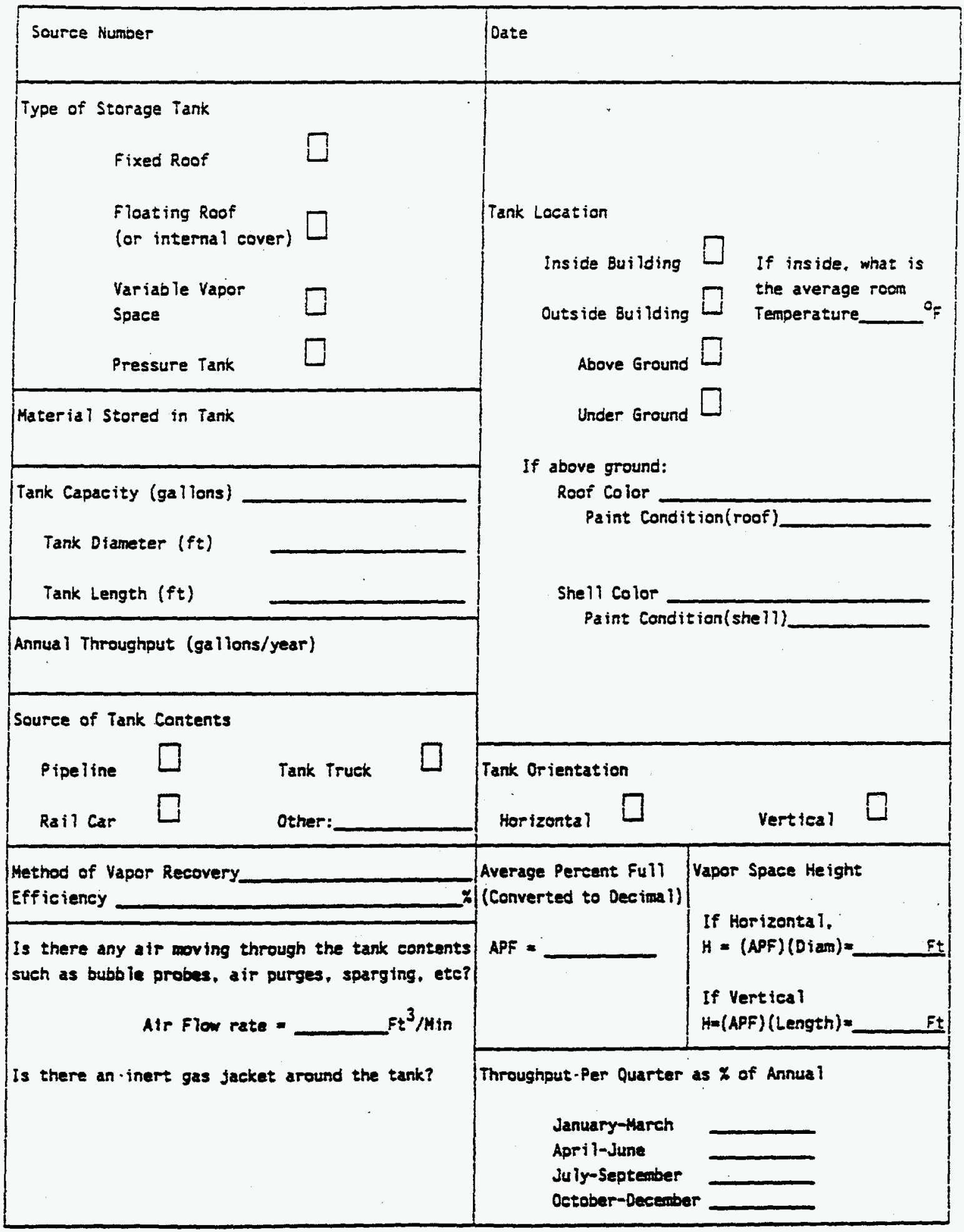




\section{DOE-ID ECO Air Emission Inventory Phase II-1990 \\ Inorganic Storage Tanks}

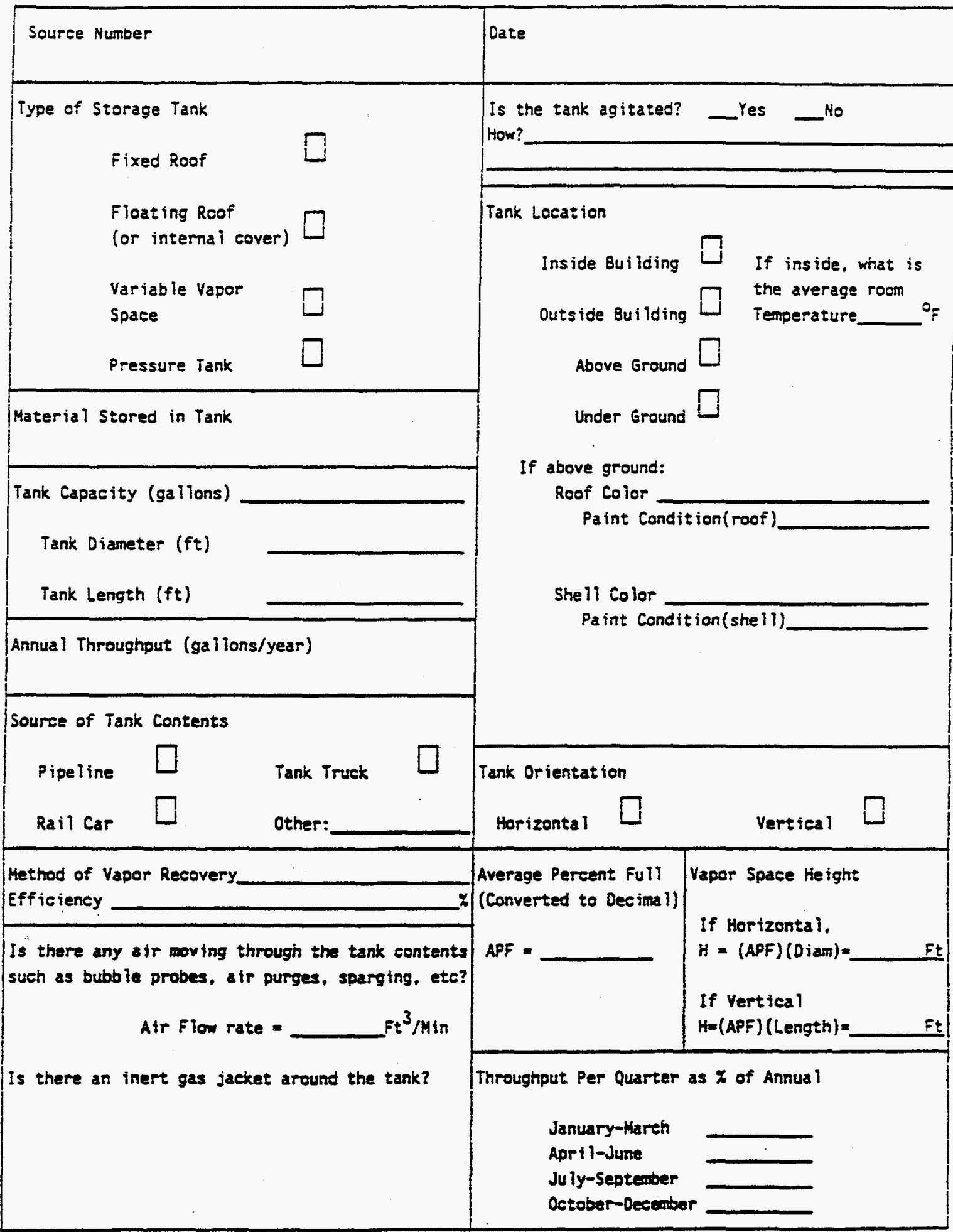


DOE-ID ECO Air Emission Inventory Phase II-1990

Laboratory Fumehood Inventory

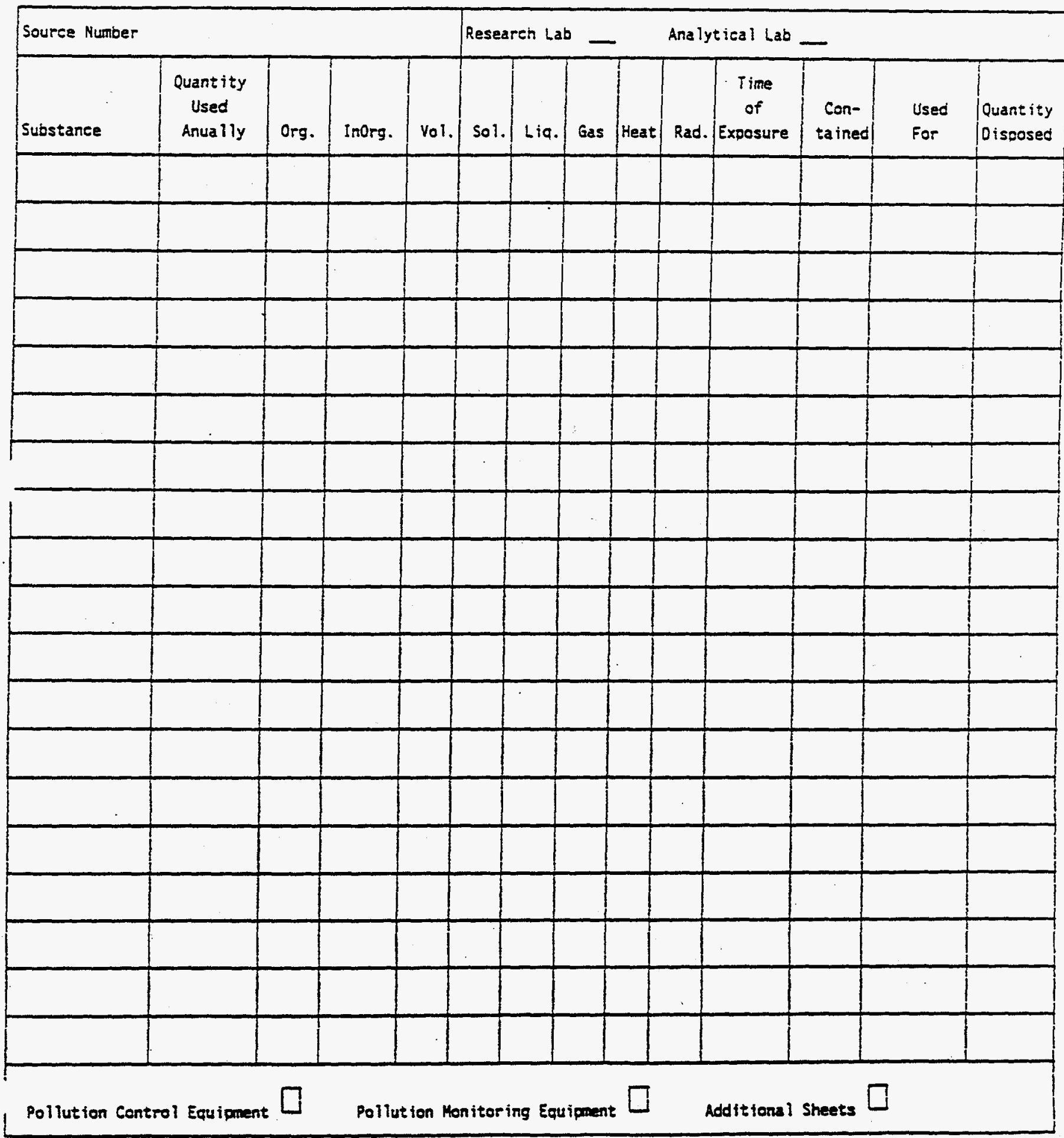


Field Data Form for Surface Coating Operations (Paint Booths)

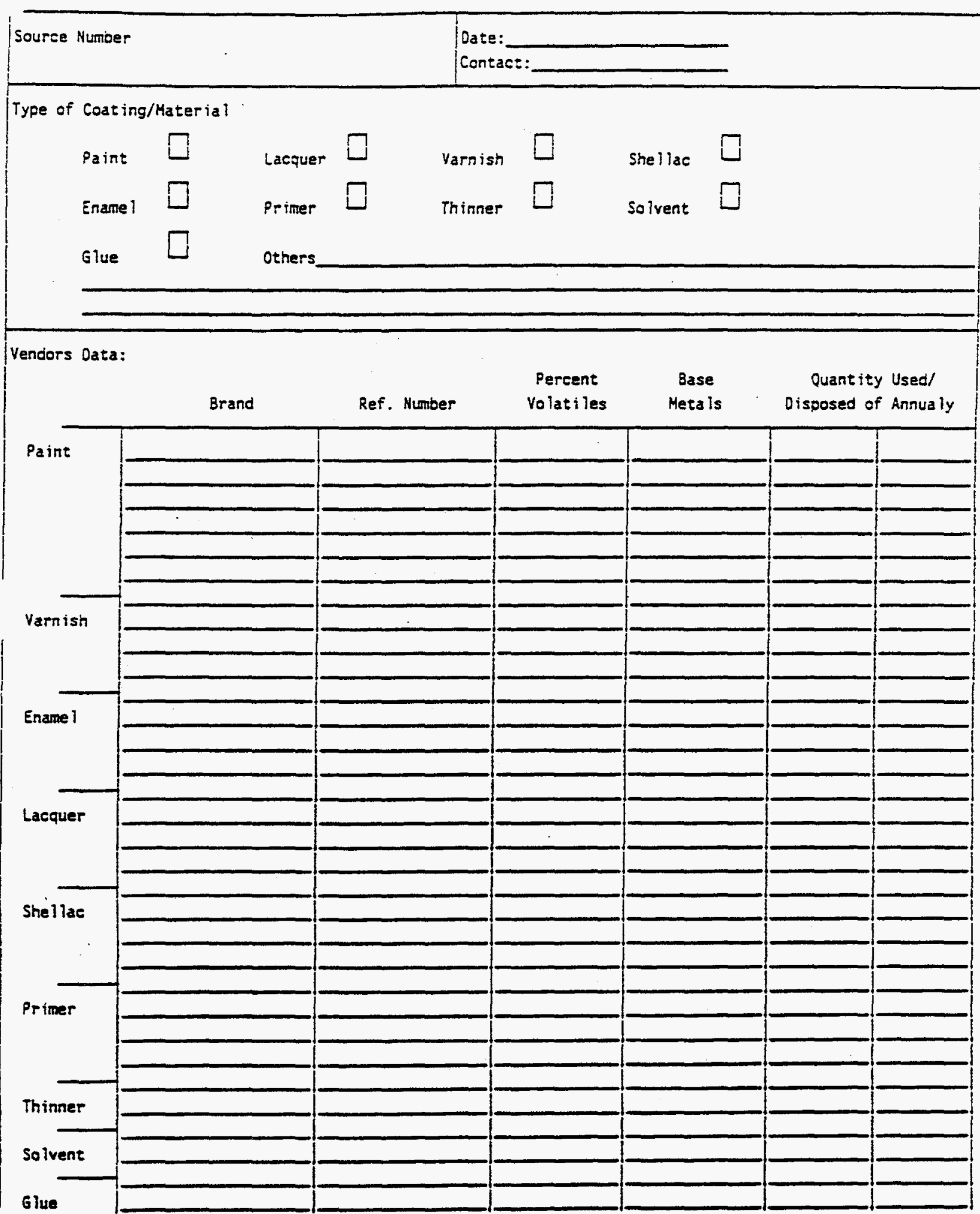

Pollution Control Equtpment 
WELD BOOTH

Welding

BATTERIES

\begin{tabular}{|l|l|l|}
\hline Number of Batteries & Condition of Batteries & Is exhaust powered? \\
\hline
\end{tabular}

\section{ACID/BASE MIX TANKS}

\begin{tabular}{|c|c|c|}
\hline Volume of Tanik (ga Tlons) & Is tank covered by sonething other than hood? & Is tank agitated? \\
\hline
\end{tabular}

Pollution Control Equipment

Pollution Monitoring Equipnent

Comments: 
Source Number

\section{BOILERS}

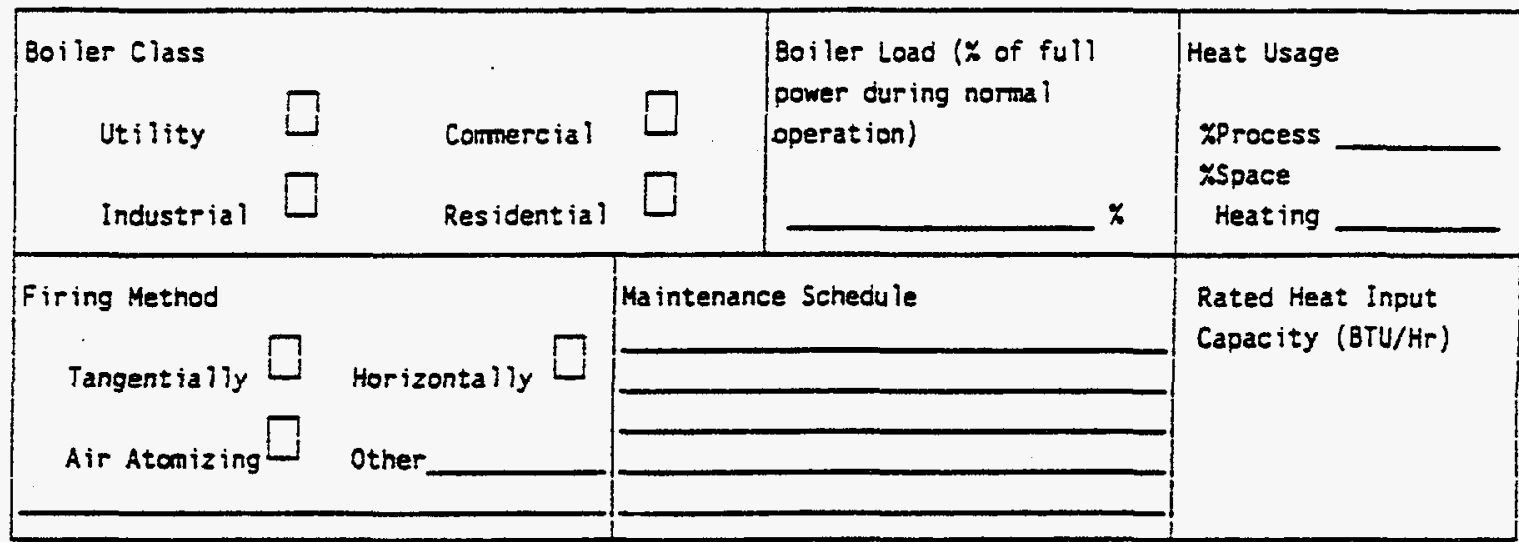

\section{GAS/DIESEL INDUSTRIAL ENGINES}

\begin{tabular}{|l|l|}
\hline Engine Horsepower & $\begin{array}{l}\text { If engine burns gasoline, is there a day tank that feeds the } \\
\text { engine? }\end{array}$ \\
\hline Energency Use Oniy? & If Yes, how many hours per day is the day tank full? \\
\hline Any relevant manufacturers data on releases: \\
\hline
\end{tabular}

LARGE BORE DIESEL ENGINES (560 Cubie Ineh Displaeenent or Larger)

\begin{tabular}{|c|c|c|}
\hline Engine Horsepowar & Emergency On Iy? & Cubic Inch Oisplacenent \\
\hline Manufacturer guaranteed releases:_Hes & Ho \\
\hline Pollutant Control Equipment $\square$ & Pollutant Mon itoring Equipment \\
\hline
\end{tabular}


DOE-ID ECO Emmision Inventory Phase II-1990

Field Data Form for Liquid Propane Combustion Sources

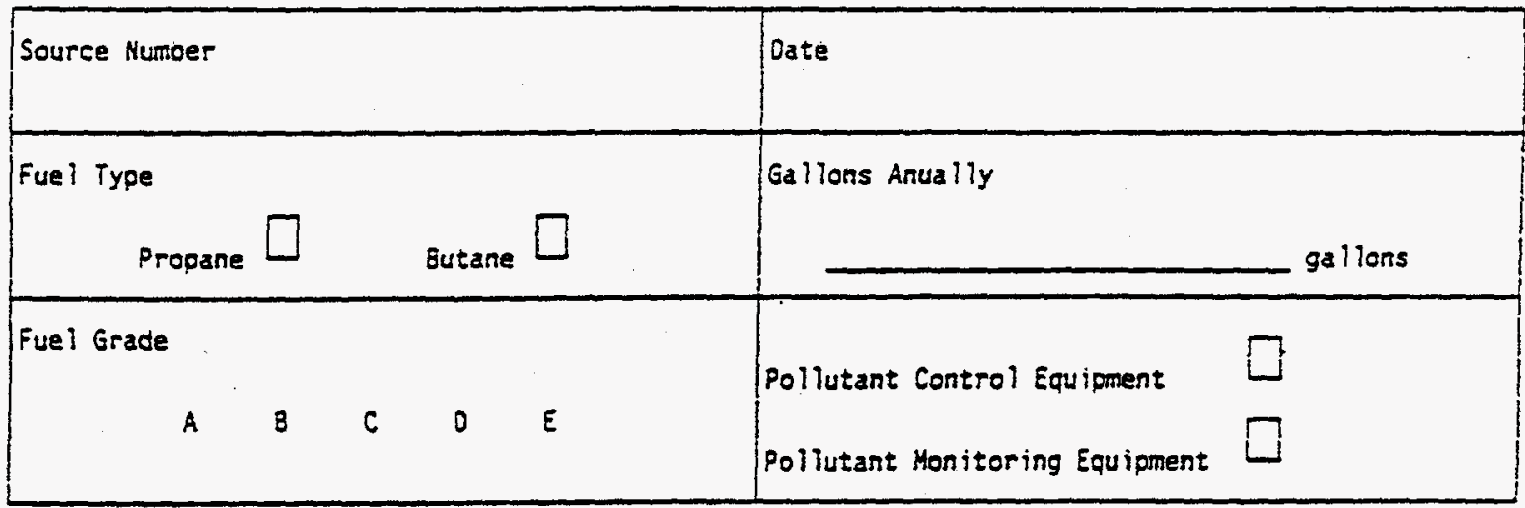




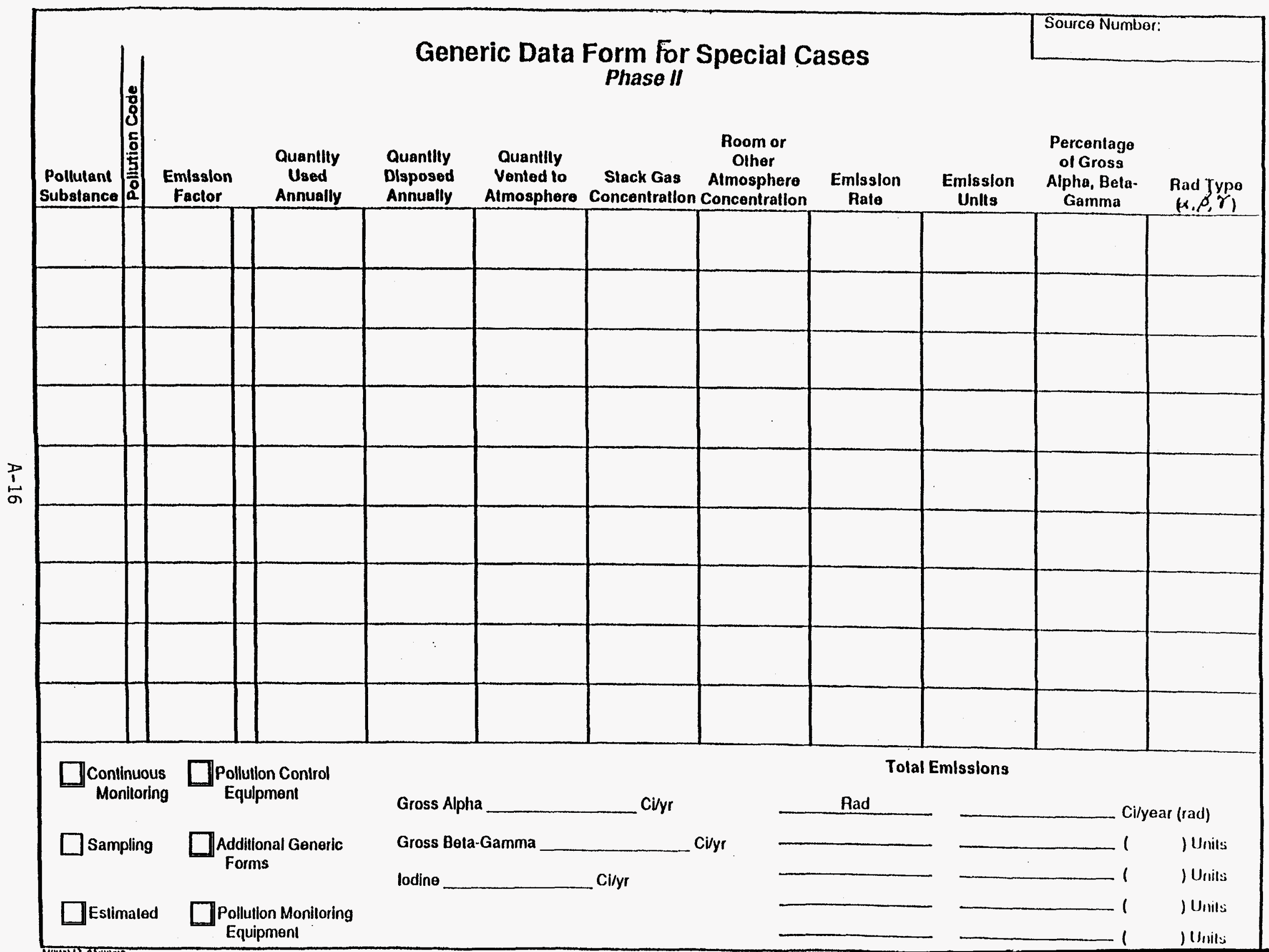


DOE-ID ECO Air Emission Inventory Phase II-1990

Pollution Control Equipment Suppliment
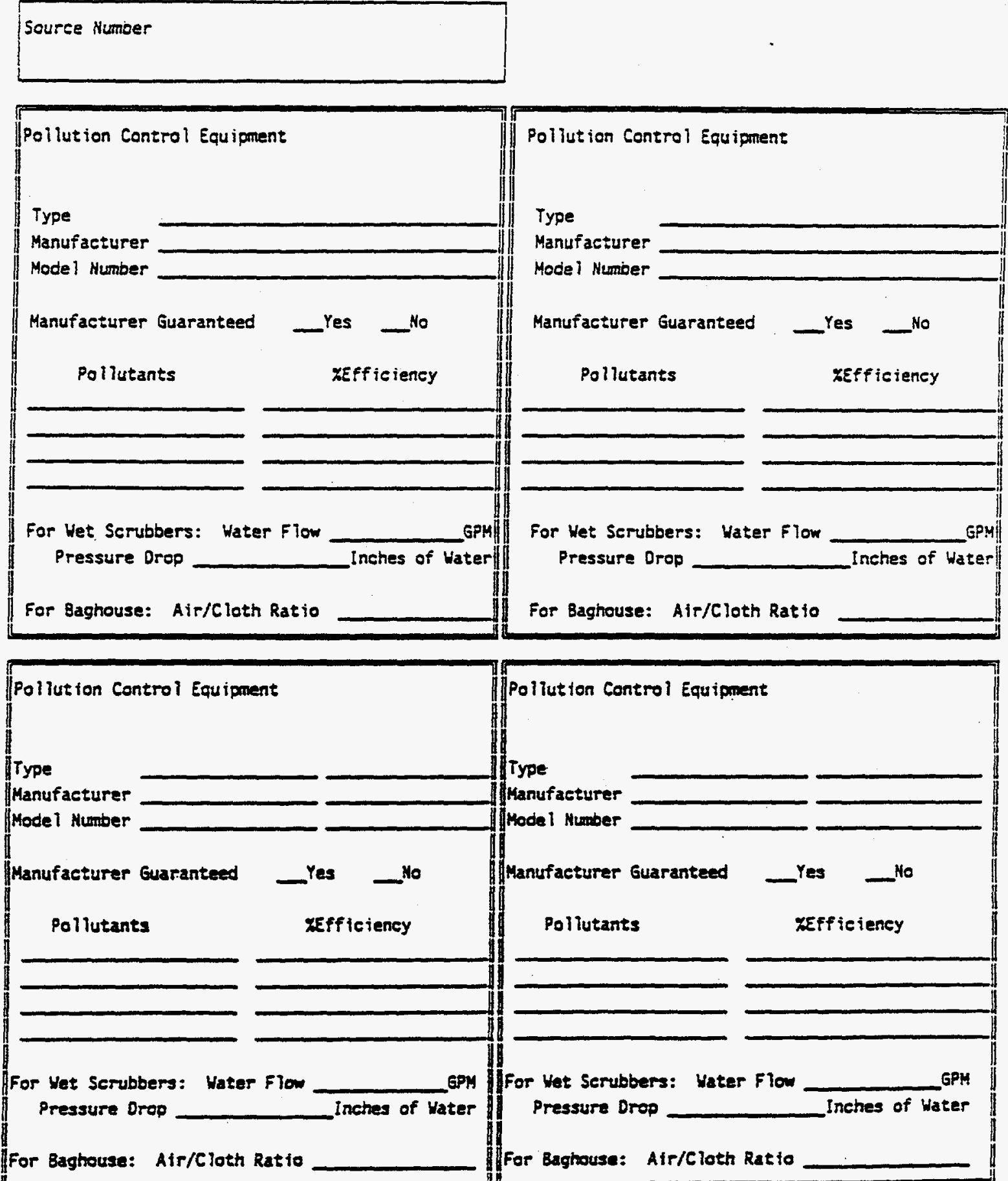

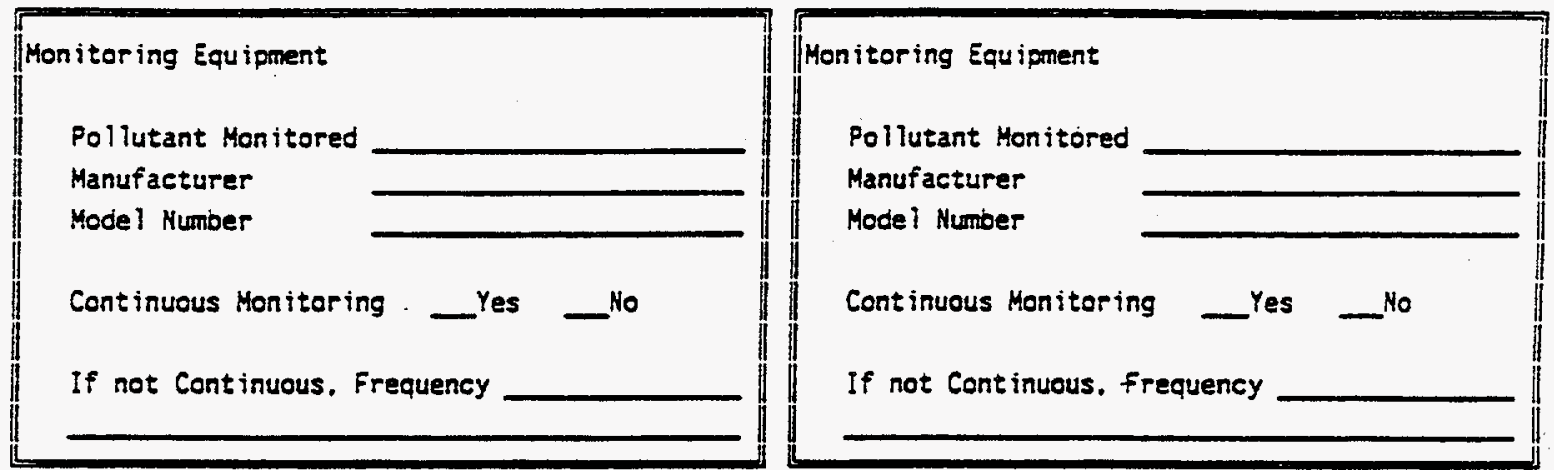

\section{Monitoring Equipment}

Pollutant Monitored

Manuf acturer

Hodei Number

Continuous Monitoring

Yes

No

If not Continuous. Frequency

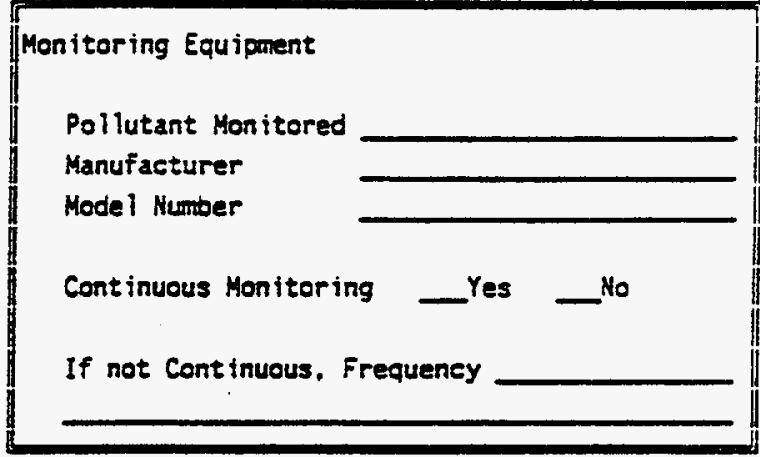

Monitoring Equipment

Pollutant Monitored

Manufacturer

Model Number

Cont inuous Mositoring

Yes _Mo

If not Continuous, Frequency

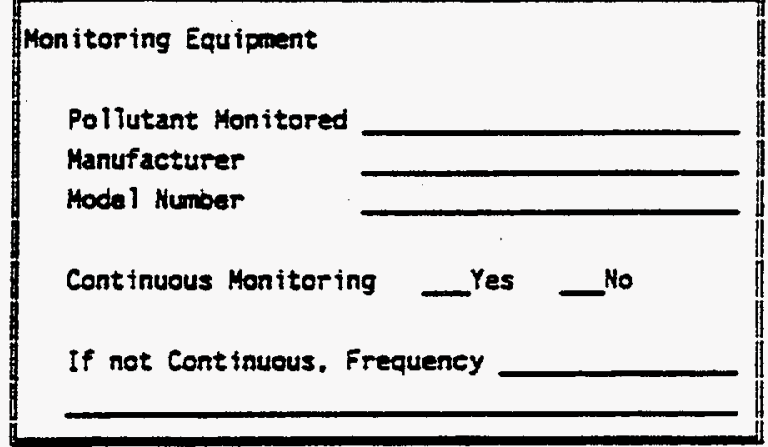




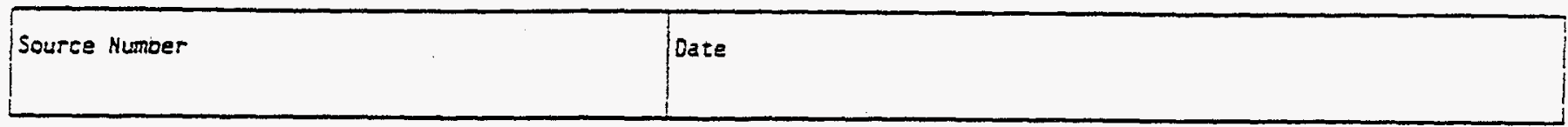

Side 2

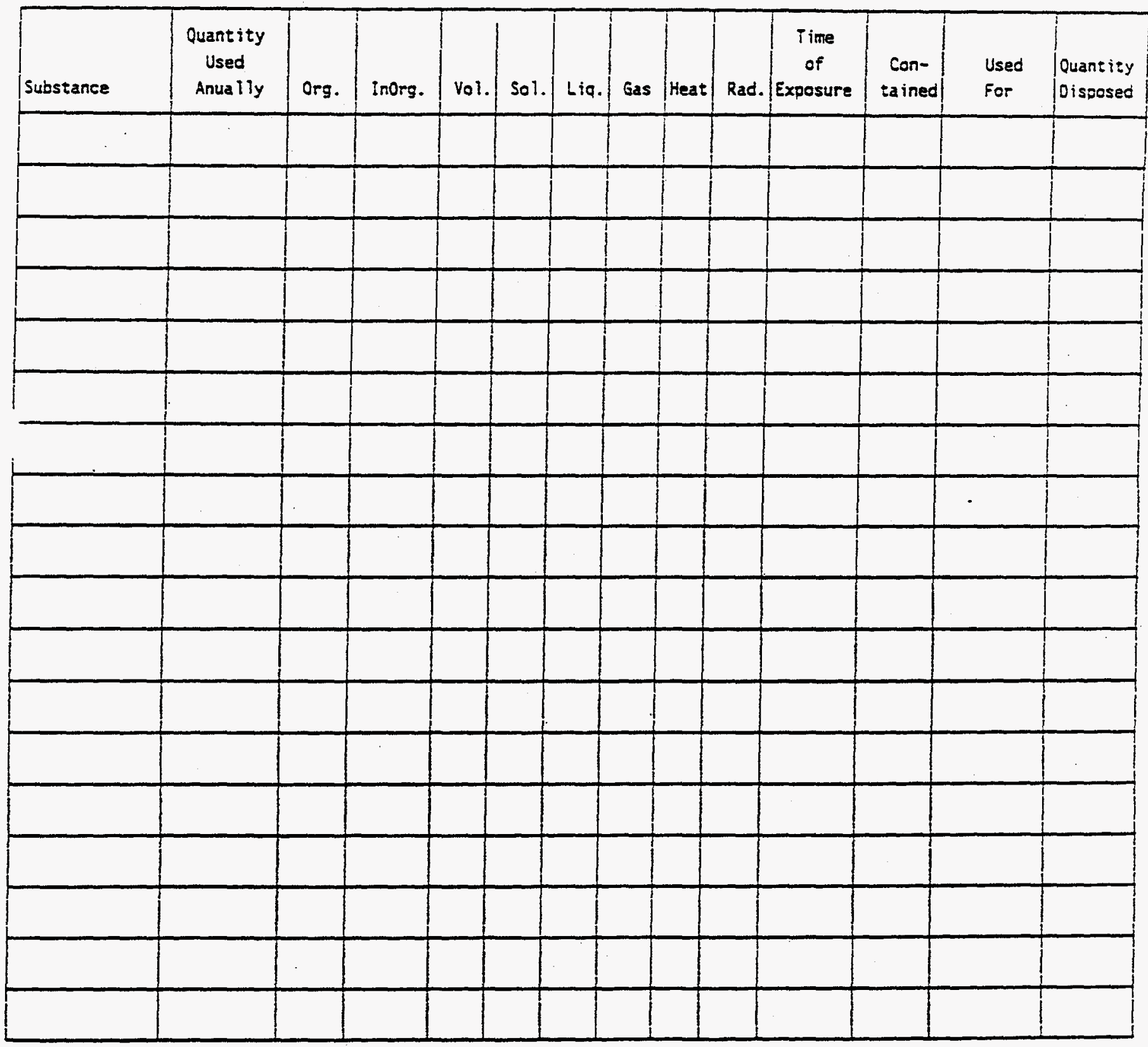

Additional Sheets $\square$ 


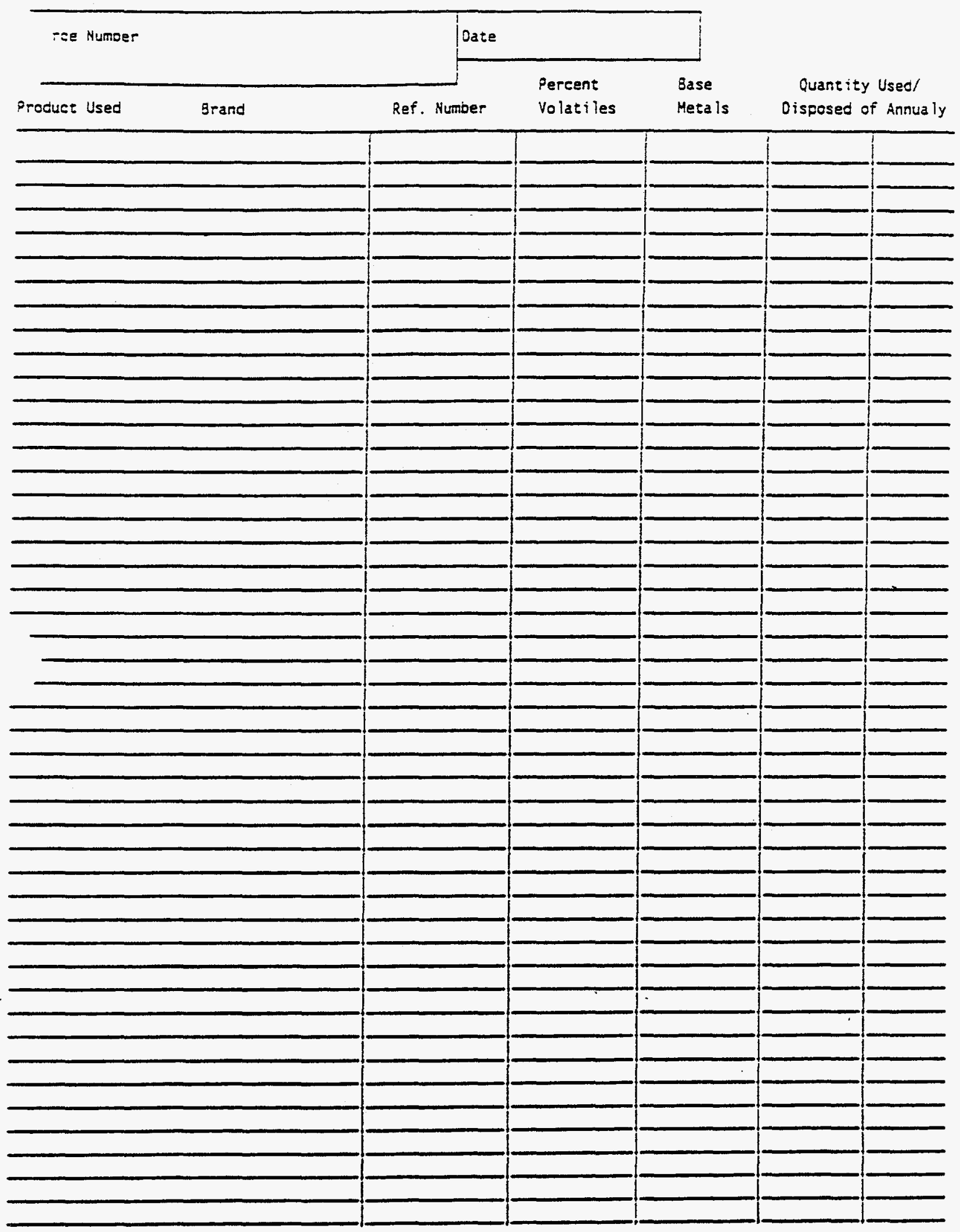




\section{Appendix B}

1994 Air Emission Inventory Emissions Tables 
B-2 


\section{Appendix B}

\section{Air Emission Inventory Emissions Tables}

This appendix presents the breakdown of emissions estimates as presented in the summary tables within the document text. The first set of tables present the summary of emissions for each pollutant for each area. The second set of tables present the ranking of the more significant sources for each pollutant. The third set of tables present the complete breakdown of the emissions for each source and area. The final set of tables includes hazardous air pollutants (HAPs) emitted from INEL sources.

Maximum emissions listed in the inventory do not reflect the cited not-significant maximums in the INEL Operating Permit Application (e.g. not-significant levels for laboratory sources of 1 ton/yr of any HAP). 
SUMMARY OF TOTALS FOR EACH PRINCIPAL POLLUTANTS AT ANL FOR 1994

\begin{tabular}{lcccl} 
POLLUTANT & $\begin{array}{c}\text { HOURLY } \\
\text { RATES } \\
\text { LBS/HR }\end{array}$ & $\begin{array}{c}\text { YEARLY } \\
\text { RATES } \\
\text { TNS/YR }\end{array}$ & $\begin{array}{c}\text { HOURLY } \\
\text { RATES } \\
\text { LBS/HR }\end{array}$ & $\begin{array}{c}\text { YEARLY } \\
\text { RATES } \\
\text { TNS/YR }\end{array}$ \\
\hline CARBON MONOXIDE & $1.579 E+01$ & $2.766 E+00$ & $3.358 E+01$ & $8.022 E+01$ \\
NITROGEN OXIDES & $6.993 E+01$ & $1.116 E+01$ & $1.505 E+02$ & $3.486 E+02$ \\
PARTICULATE & $4.864 E+00$ & $1.091 E+00$ & $1.226 E+01$ & $2.350 E+01$ \\
SULFUR OXIDES & $4.382 E+01$ & $3.750 E+01$ & $6.050 E+01$ & $2.446 E+02$ \\
VOC-NONMETHANE & $5.454 E+01$ & $6.053 E-01$ & $6.486 E+01$ & $5.807 E+00$
\end{tabular}

\section{SUMMARY OF TOTALS FOR EACH PRINCIPAL POLLUTANTS AT B08 FOR 1994}

\begin{tabular}{lcccc} 
POLLUTANT & $\begin{array}{c}\text { HOURLY } \\
\text { RATES } \\
\text { LBS/HR }\end{array}$ & $\begin{array}{c}\text { YEARLY } \\
\text { RATES } \\
\text { TNS/YR }\end{array}$ & $\begin{array}{c}\text { HOURLY } \\
\text { RATES } \\
\text { LBS/HR }\end{array}$ & $\begin{array}{c}\text { YEARLY } \\
\text { RATES } \\
\text { TNS/YR }\end{array}$ \\
\hline CARBON MONOXIDE & $3.250 E-01$ & $4.225 E-03$ & $6.500 E-01$ & $2.847 E+00$ \\
NITROGEN OXIDES & $1.510 E+00$ & $1.963 E-02$ & $3.020 E+00$ & $1.323 E+01$ \\
PARTICULATE & $1.063 E-01$ & $1.381 E-03$ & $2.125 E-01$ & $9.308 E-01$ \\
SULFUR OXIDES & $9.925 E-02$ & $1.290 E-03$ & $1.985 E-01$ & $8.694 E-01$ \\
VOC-NONMETHANE & $3.493 E-01$ & $1.611 E-04$ & $3.616 E-01$ & $1.080 E-01$
\end{tabular}

\section{SUMMARY OF TOTALS FOR EACH PRINCIPAL POLLUTANTS AT B16 FOR 1994}

\begin{tabular}{lllll} 
POLLUTANT & $\begin{array}{c}\text { HOURLY } \\
\text { RATES } \\
\text { LBS/HR }\end{array}$ & $\begin{array}{c}\text { YEARLY } \\
\text { RATES } \\
\text { TNSTR }\end{array}$ & $\begin{array}{c}\text { HOURLY } \\
\text { RATES } \\
\text { LBS/HR }\end{array}$ & $\begin{array}{c}\text { YEARLY } \\
\text { RATES } \\
\text { TNS } / Y R\end{array}$ \\
\hline CARBON MONOXIDE & $2.800 E+00$ & $1.700 E-02$ & $1.060 E+01$ & $4.650 E+01$ \\
NITROGEN OXIDES & $1.300 E+00$ & $8.100 E-03$ & $1.000 E+01$ & $4.380 E+01$ \\
PARTICULATE & $3.100 E-01$ & $1.900 E-03$ & $1.150 E+00$ & $5.020 E+00$ \\
SULFUR OXIDES & $1.000 E+00$ & $5.500 E-03$ & $3.400 E+00$ & $1.490 E+01$ \\
VOC-NONMETHANE & $4.080 E-01$ & $9.500 E-01$ & $1.358 E+00$ & $5.690 E+00$
\end{tabular}




\begin{tabular}{lcccc} 
HOURLY & $\begin{array}{c}\text { YEARLY } \\
\text { RATES } \\
\text { LBS/HR }\end{array}$ & $\begin{array}{c}\text { HOURLY } \\
\text { RATES } \\
\text { TNS/YR }\end{array}$ & $\begin{array}{c}\text { RATES } \\
\text { LBS/HR }\end{array}$ & $\begin{array}{c}\text { YEARLY } \\
\text { RATES } \\
\text { TNS/YR }\end{array}$ \\
\hline CARBON MONT & $3.000 E-03$ & $4.000 E-03$ & $3.000 E-03$ & $1.400 E-02$ \\
PARTICULATE & $2.400 E-06$ & $3.190 E-06$ & $2.400 E-06$ & $1.100 E-05$ \\
VOC-NONMETHANE & $1.300 E-02$ & $5.800 E-02$ & $6.600 E-02$ & $2.910 E-01$
\end{tabular}

\section{SUMMARY OF TOTALS FOR EACH PRINCIPAL POLLUTANTS AT B23 FOR 1994}

\begin{tabular}{|c|c|c|c|c|}
\hline POLLUTANT & $\begin{array}{l}\text { HOURLY } \\
\text { RATES } \\
\text { LBS/HR }\end{array}$ & $\begin{array}{l}\text { YEARLY } \\
\text { RATES } \\
\text { TNSNR }\end{array}$ & $\begin{array}{l}\text { HOURLY } \\
\text { RATES } \\
\text { LBS/HR }\end{array}$ & $\begin{array}{l}\text { YEARLY } \\
\text { RATES } \\
\text { TNS/YR }\end{array}$ \\
\hline VOC-NONMETHANE & $3.370 \mathrm{E}-01$ & $9.126 \mathrm{E}-07$ & $3.370 \mathrm{E}-01$ & $9.126 \mathrm{E}-07$ \\
\hline
\end{tabular}

\section{SUMMARY OF TOTALS FOR EACH PRINCIPAL POLLUTANTS AT B27 FOR 1994}

\begin{tabular}{lcccc}
\hline & $\begin{array}{c}\text { HOURLY } \\
\text { RATES } \\
\text { LBS/HR }\end{array}$ & $\begin{array}{c}\text { YEARLY } \\
\text { RATES } \\
\text { TNS } / \text { R }\end{array}$ & $\begin{array}{c}\text { HOURLY } \\
\text { RATES } \\
\text { LBS/HR }\end{array}$ & $\begin{array}{c}\text { YEARLY } \\
\text { RATES } \\
\text { TNS } / Y R\end{array}$ \\
\hline CALLUTANT & $3.250 E-01$ & $4.225 E-04$ & $6.500 E-01$ & $2.847 E+00$ \\
NITROGEN OXIDES & $1.510 E+00$ & $1.963 E-03$ & $3.020 E+00$ & $1.323 E+01$ \\
PARTICULATE & $1.063 E-01$ & $1.381 E-04$ & $2.125 E-01$ & $9.308 E-01$ \\
SULFUR OXIDES & $9.925 E-02$ & $1.290 E-04$ & $1.985 E-01$ & $8.694 E-01$ \\
VOC-NONMETHANE & $3.493 E-01$ & $1.694 E-05$ & $3.616 E-01$ & $1.080 E-01$
\end{tabular}


SUMMARY OF TOTALS FOR EACH PRINCIPAL POLLUTANTS AT CFA FOR 1994

\begin{tabular}{lcccc} 
POLLUTANT & $\begin{array}{c}\text { HOURLY } \\
\text { RATES } \\
\text { LBS/HR }\end{array}$ & $\begin{array}{c}\text { YEARLY } \\
\text { RATES } \\
\text { TNS/YR }\end{array}$ & $\begin{array}{c}\text { HOURLY } \\
\text { RATES } \\
\text { LBS/HR }\end{array}$ & $\begin{array}{c}\text { YEARLY } \\
\text { RATES } \\
\text { TNS/YR }\end{array}$ \\
\hline CARBON MONOXIDE & $9.112 E+00$ & $\mathbf{8 . 1 9 7 E - 0 1}$ & $1.265 E+01$ & $3.653 E+01$ \\
NITROGEN OXIDES & $3.809 E+01$ & $3.366 E+00$ & $5.771 E+01$ & $1.659 E+02$ \\
PARTICULATE & $4.598 E+01$ & $4.762 E+01$ & $5.514 E+01$ & $6.461 E+01$ \\
SULFUR OXIDES & $6.215 E+00$ & $1.075 E+01$ & $2.997 E+01$ & $9.205 E+01$ \\
VOC-NONMETHANE & $1.364 E+02$ & $9.232 E+00$ & $1.387 E+02$ & $8.414 E+01$
\end{tabular}

\section{SUMMARY OF TOTALS FOR EACH PRINCIPAL POLLUTANTS AT CPP FOR 1994}

\begin{tabular}{lllll} 
POLLUTANT & $\begin{array}{c}\text { HOURLY } \\
\text { RATES } \\
\text { LBS } / \mathrm{HR}\end{array}$ & $\begin{array}{c}\text { YEARLY } \\
\text { RATES } \\
\text { TNS } N R\end{array}$ & $\begin{array}{c}\text { HOURLY } \\
\text { RATES } \\
\text { LBS/HR }\end{array}$ & $\begin{array}{c}\text { YEARLY } \\
\text { RATES } \\
\text { TNS } / \text { RR }\end{array}$ \\
\hline CARBON MONOXIDE & $2.082 E+02$ & $4.029 E+02$ & $8.589 E+02$ & $3.552 E+03$ \\
NITROGEN OXIDES & $3.365 E+02$ & $5.181 E+02$ & $1.868 E+03$ & $2.513 E+03$ \\
PARTICULATE & $1.075 E+01$ & $3.658 E+01$ & $7.843 E+01$ & $7.133 E+01$ \\
SULFUR OXIDES & $5.031 E+01$ & $4.689 E+01$ & $2.258 E+02$ & $8.309 E+02$ \\
VOC-NONMETHANE & $2.769 E+02$ & $1.064 E+01$ & $3.531 E+02$ & $1.369 E+02$
\end{tabular}

SUMMARY OF TOTALS FOR EACH PRINCIPAL POLLUTANTS AT HPTF FOR 1994

\begin{tabular}{lcccc}
\hline & $\begin{array}{c}\text { HOURLY } \\
\text { RATES } \\
\text { LBS/HR }\end{array}$ & $\begin{array}{c}\text { YEARLY } \\
\text { RATES } \\
\text { TNS } / \text { RR }\end{array}$ & $\begin{array}{c}\text { HOURLY } \\
\text { RATES } \\
\text { LBS/HR }\end{array}$ & $\begin{array}{c}\text { YEARLY } \\
\text { RATES } \\
\text { TNS/YR }\end{array}$ \\
\hline POLLUTANT & $3.060 E+01$ & $3.980 E-01$ & $3.710 E-02$ & $1.620 E-01$ \\
\hline CARBON MONOXIDE & $1.000 E+04$ & $1.300 E+00$ & $1.220 E-01$ & $5.320 E-01$ \\
NITROGEN OXIDES & $7.480 E+00$ & $9.720 E-02$ & $9.060 E-03$ & $3.970 E-02$ \\
PARTICULATE & $3.570 E+00$ & $4.640 E-02$ & $4.330 E-03$ & $1.890 E-02$ \\
SULFUR OXIDES & $7.990 E+00$ & $1.040 E-01$ & $9.680 E-03$ & $4.240 E-02$
\end{tabular}




\begin{tabular}{lllll} 
POLLUTANT & $\begin{array}{c}\text { HOURLY } \\
\text { RATES } \\
\text { LBS/HR }\end{array}$ & $\begin{array}{c}\text { YEARLY } \\
\text { RATES } \\
\text { TNS/YR }\end{array}$ & $\begin{array}{c}\text { HOURLY } \\
\text { RATES } \\
\text { LBS/HR }\end{array}$ & $\begin{array}{c}\text { YEARLY } \\
\text { RATES } \\
\text { TNS/YR }\end{array}$ \\
\hline CARBON MONOXIDE & $4.286 E+01$ & $3.011 E+00$ & $5.781 E+01$ & $4.263 E+01$ \\
NITROGEN OXIDES & $1.855 E+02$ & $2.348 E+01$ & $2.750 E+02$ & $3.823 E+02$ \\
PARTICULATE & $1.250 E+01$ & $1.642 E+01$ & $6.162 E+01$ & $2.525 E+02$ \\
SULFUR OXIDES & $1.381 E+02$ & $7.951 E+01$ & $3.518 E+02$ & $1.416 E+03$ \\
VOC-NONMETHANE & $5.899 E+00$ & $3.913 E-01$ & $7.690 E+00$ & $5.035 E+00$
\end{tabular}

\section{SUMMARY OF TOTALS FOR EACH PRINCIPAL POLLUTANTS AT PER FOR 1994}

\begin{tabular}{lllll}
\hline & $\begin{array}{c}\text { HOURLY } \\
\text { RATES } \\
\text { LBS/HR }\end{array}$ & $\begin{array}{c}\text { YEARLY } \\
\text { RATES } \\
\text { TNS/YR }\end{array}$ & $\begin{array}{c}\text { HOURLY } \\
\text { RATES } \\
\text { LBS/HR }\end{array}$ & $\begin{array}{c}\text { YEARLY } \\
\text { RATES } \\
\text { TNSTR }\end{array}$ \\
\hline CALLUTANT & $3.088 E+00$ & $1.436 E-01$ & $1.478 E+01$ & $1.432 E+01$ \\
NITROGEN OXIDES & $1.423 E+01$ & $5.937 E-01$ & $2.762 E+01$ & $6.510 E+01$ \\
PARTICULATE & $1.023 E+00$ & $5.522 E-02$ & $9.002 E+00$ & $6.005 E+00$ \\
SULFUR OXIDES & $3.353 E+00$ & $1.639 E+00$ & $7.144 E+00$ & $1.924 E+01$ \\
VOC-NONMETHANE & $7.093 E-01$ & $1.170 E-02$ & $1.046 E+00$ & $2.051 E+00$
\end{tabular}

\section{SUMMARY OF TOTALS FOR EACH PRINCIPAL POLLUTANTS AT TAN FOR 1994}

\begin{tabular}{lllll} 
POURLY & $\begin{array}{c}\text { YEARLY } \\
\text { RATES } \\
\text { LBS/HR }\end{array}$ & $\begin{array}{c}\text { HOURLY } \\
\text { RATES } \\
\text { TNS/YR }\end{array}$ & $\begin{array}{c}\text { RATES } \\
\text { LBS/HR }\end{array}$ & $\begin{array}{c}\text { YEARLY } \\
\text { RATES } \\
\text { TNS/YR }\end{array}$ \\
\hline CARBON MONOXIDE & $2.028 E+01$ & $2.317 E+00$ & $3.579 E+01$ & $4.786 E+01$ \\
NITROGEN OXIDES & $8.955 E+01$ & $9.474 E+00$ & $1.801 E+02$ & $2.121 E+02$ \\
PARTICULATE & $8.061 E+00$ & $1.073 E+00$ & $1.819 E+01$ & $2.883 E+01$ \\
SULFUR OXIDES & $8.058 E+01$ & $2.889 E+01$ & $1.310 E+02$ & $3.646 E+02$ \\
VOC-NONMETHANE & $3.865 E+01$ & $2.128 E+00$ & $6.420 E+01$ & $4.955 E+01$
\end{tabular}


SUMMARY OF TOTALS FOR EACH PRINCIPAL POLLUTANTS AT TRA FOR 1994

\begin{tabular}{lllll} 
POLLUTANT & $\begin{array}{c}\text { HOURLY } \\
\text { RATES } \\
\text { LBS } / H R\end{array}$ & $\begin{array}{c}\text { YEARLY } \\
\text { RATES } \\
\text { TNS } / Y R\end{array}$ & $\begin{array}{c}\text { HOURLY } \\
\text { RATES } \\
\text { LBS/HR }\end{array}$ & $\begin{array}{c}\text { YEARLY } \\
\text { RATES } \\
\text { TNS/YR }\end{array}$ \\
\hline CARBON MONOXIDE & $2.288 E+01$ & $2.344 E+01$ & $3.257 E+01$ & $6.876 E+01$ \\
NITROGEN OXIDES & $9.758 E+01$ & $8.995 E+01$ & $1.405 E+02$ & $2.718 E+02$ \\
PARTICULATE & $6.022 E+00$ & $6.992 E+00$ & $9.000 E+00$ & $2.467 E+02$ \\
SULFUR OXIDES & $1.038 E+01$ & $1.454 E+01$ & $1.418 E+01$ & $3.955 E+01$ \\
VOC-NONMETHANE & $2.782 E+00$ & $3.163 E+00$ & $3.378 E+00$ & $7.885 E+00$
\end{tabular}

\section{SUMMARY OF TOTALS FOR EACH PRINCIPAL POLLUTANTS AT WMF FOR 1994}

\begin{tabular}{lcccc} 
POLLUTANT & $\begin{array}{c}\text { HOULY } \\
\text { RATES } \\
\text { LBS/HR }\end{array}$ & $\begin{array}{c}\text { YEARLY } \\
\text { RATES } \\
\text { TNSTR }\end{array}$ & $\begin{array}{c}\text { HOURLY } \\
\text { RATES } \\
\text { LBS/HR }\end{array}$ & $\begin{array}{c}\text { YEARLY } \\
\text { RATES } \\
\text { TNS } / \text { RR }\end{array}$ \\
\hline CARBON MONOXIDE & $2.016 E-02$ & $3.871 E-02$ & $2.574 E-02$ & $1.270 E-01$ \\
NITROGEN OXIDES & $9.976 E-02$ & $1.899 E-01$ & $1.260 E-01$ & $6.203 E-01$ \\
PARTICULATE & $4.928 E-03$ & $9.509 E-03$ & $6.298 E-03$ & $3.101 E-02$ \\
SULFUR OXIDES & $1.008 E-03$ & $1.942 E-03$ & $1.287 E-03$ & $6.330 E-03$ \\
VOC-NONMETHANE & $3.422 E-01$ & $9.157 E-03$ & $3.437 E-01$ & $3.317 E-02$
\end{tabular}




\section{EMISSIONS FOR THE INEL}

\begin{tabular}{lcccc}
\multicolumn{1}{c}{ Pollutant } & $\begin{array}{c}\text { Actual } \\
\text { Hourly } \\
(\mathrm{lb} / \mathrm{hr})\end{array}$ & $\begin{array}{c}\text { Actual } \\
\text { Annual } \\
(\mathrm{tn} / \mathrm{yr})\end{array}$ & $\begin{array}{c}\text { Maximum } \\
\text { Hourly } \\
(\mathrm{lb} / \mathrm{hr})\end{array}$ & $\begin{array}{c}\text { Maximum } \\
\text { Annual } \\
\text { (tn/yr) }\end{array}$ \\
\hline CARBON MONOXIDE & $3.6 E+02$ & $4.4 E+02$ & $1.1 E+03$ & $3.9 E+03$ \\
NITROGEN OXIDES & $1.1 E+04$ & $6.6 E+02$ & $2.7 E+03$ & $4.0 E+03$ \\
PARTICULATE & $9.7 E+01$ & $1.1 E+02$ & $2.5 E+02$ & $7.0 E+02$ \\
SULFUR OXIDES & $3.4 E+02$ & $2.2 E+02$ & $8.2 E+02$ & $3.0 E+03$ \\
VOC-NONMETHANE & $5.3 E+02$ & $2.7 E+01$ & $6.4 E+02$ & $3.0 E+02$
\end{tabular}


SUMMARY OF CARBON MONOXIDE EMISSIONS AT THE INEL 1994

\begin{tabular}{|c|c|c|c|c|}
\hline AREA & $\begin{array}{l}\text { ACTUAL } \\
\text { TNSYR }\end{array}$ & $\begin{array}{l}\text { ACTUAL } \\
\text { LBS/HR }\end{array}$ & $\begin{array}{r}\text { MAX } \\
\text { TNSNR }\end{array}$ & $\begin{array}{r}\text { MAX } \\
\text { LBS } / H R\end{array}$ \\
\hline ANL & $2.766 E+00$ & 1.579E+01 & 8.022E+01 & $3.358 E+01$ \\
\hline BO8 & $4.225 E-03$ & $3.250 E-01$ & $2.847 E+00$ & 6.500E-01 \\
\hline B16 & $1.700 E-02$ & $2.800 E+00$ & $4.650 E+01$ & $1.060 E+01$ \\
\hline B21 & 4.000E-03 & 3.000E-03 & $1.400 \mathrm{E}-02$ & 3.000 E-03 \\
\hline $\mathrm{B} 27$ & $4.225 E-04$ & 3.250E-01 & $2.847 E+00$ & $6.500 \mathrm{E}-01$ \\
\hline CFA & 8.197E-01 & $9.112 E+00$ & $3.653 E+01$ & $1.265 E+01$ \\
\hline CPP & $4.029 E+02$ & 2.082E+02 & $3.552 E+03$ & $8.589 E+02$ \\
\hline HPTF & 3.980E-01 & 3.060E+01 & 1.620E-01 & $3.710 E-02$ \\
\hline NRF & $3.011 E+00$ & 4.286E+01 & $4.263 E+01$ & $5.781 E+01$ \\
\hline PER & 1.436E-01 & $3.088 E+00$ & $1.432 \mathrm{E}+01$ & $1.478 E+01$ \\
\hline TAN & 2.317E+00 & 2.028E+01 & 4.786E+01 & $3.579 E+01$ \\
\hline TRA & 2.344E+01 & 2.288E+01 & $6.876 E+01$ & $3.257 \mathrm{E}+01$ \\
\hline WMF & 3.871E-02 & $2.016 E-02$ & 1.270 E-01 & 2.574E-02 \\
\hline
\end{tabular}

\section{SUMMARY OF NITROGEN OXIDES EMISSIONS AT THE INEL 1994}

\begin{tabular}{lrrrr}
\hline AREA & $\begin{array}{r}\text { ACTUAL } \\
\text { TNS } / \text { R }\end{array}$ & $\begin{array}{r}\text { ACTUAL } \\
\text { LBS/HR }\end{array}$ & $\begin{array}{r}\text { MAX } \\
\text { TNS } / Y R\end{array}$ & $\begin{array}{r}\text { MAX } \\
\text { LBS/HR }\end{array}$ \\
\hline ANL & $1.116 E+01$ & $6.993 E+01$ & $3.486 E+02$ & $1.505 E+02$ \\
B08 & $1.963 E-02$ & $1.510 E+00$ & $1.323 E+01$ & $3.020 E+00$ \\
B16 & $8.100 E-03$ & $1.300 E+00$ & $4.380 E+01$ & $1.000 E+01$ \\
B27 & $1.963 E-03$ & $1.510 E+00$ & $1.323 E+01$ & $3.020 E+00$ \\
CFA & $3.366 E+00$ & $3.809 E+01$ & $1.659 E+02$ & $5.771 E+01$ \\
CPP & $5.181 E+02$ & $3.365 E+02$ & $2.513 E+03$ & $1.868 E+03$ \\
HPTF & $1.300 E+00$ & $1.000 E+04$ & $5.320 E-01$ & $1.220 E-01$ \\
NRF & $2.348 E+01$ & $1.855 E+02$ & $3.823 E+02$ & $2.750 E+02$ \\
PER & $5.937 E-01$ & $1.423 E+01$ & $6.510 E+01$ & $2.762 E+01$ \\
TAN & $9.474 E+00$ & $8.955 E+01$ & $2.121 E+02$ & $1.801 E+02$ \\
TRA & $8.995 E+01$ & $9.758 E+01$ & $2.718 E+02$ & $1.405 E+02$ \\
WMF & $1.899 E-01$ & $9.976 E-02$ & $6.203 E-01$ & $1.260 E-01$
\end{tabular}


SUMMARY OF PARTICULATE EMISSIONS AT THE INEL 1994

\begin{tabular}{lrrrr}
\hline AREA & $\begin{array}{r}\text { ACTUAL } \\
\text { TNSTR }\end{array}$ & $\begin{array}{r}\text { ACTUAL } \\
\text { LBS/HR }\end{array}$ & $\begin{array}{r}\text { MAX } \\
\text { TNS/YR }\end{array}$ & $\begin{array}{r}\text { MAX } \\
\text { LBS/HR }\end{array}$ \\
\hline ANL & $1.091 E+00$ & $4.864 E+00$ & $2.350 E+01$ & $1.226 E+01$ \\
B08 & $1.381 E-03$ & $1.063 E-01$ & $9.308 E-01$ & $2.125 E-01$ \\
B16 & $1.900 E-03$ & $3.100 E-01$ & $5.020 E+00$ & $1.150 E+00$ \\
B21 & $3.190 E-06$ & $2.400 E-06$ & $1.100 E-05$ & $2.400 E-06$ \\
B27 & $1.381 E-04$ & $1.063 E-01$ & $9.308 E-01$ & $2.125 E-01$ \\
CFA & $4.762 E+01$ & $4.598 E+01$ & $6.461 E+01$ & $5.514 E+01$ \\
CPP & $3.658 E+01$ & $1.075 E+01$ & $7.133 E+01$ & $7.843 E+01$ \\
HPTF & $9.720 E-02$ & $7.480 E+00$ & $3.970 E-02$ & $9.060 E-03$ \\
NRF & $1.642 E+01$ & $1.250 E+01$ & $2.525 E+02$ & $6.162 E+01$ \\
PER & $5.522 E-02$ & $1.023 E+00$ & $6.005 E+00$ & $9.002 E+00$ \\
TAN & $1.073 E+00$ & $8.061 E+00$ & $2.883 E+01$ & $1.819 E+01$ \\
TRA & $6.992 E+00$ & $6.022 E+00$ & $2.467 E+02$ & $9.000 E+00$ \\
WMF & $9.509 E-03$ & $4.928 E-03$ & $3.101 E-02$ & $6.298 E-03$
\end{tabular}

\section{SUMMARY OF SULFUR OXIDES EMISSIONS AT THE INEL 1994}

\begin{tabular}{lrrrr}
\hline AREA & $\begin{array}{r}\text { ACTUAL } \\
\text { TNSTR }\end{array}$ & $\begin{array}{r}\text { ACTUAL } \\
\text { LBS/HR }\end{array}$ & $\begin{array}{r}\text { MAX } \\
\text { TNS } N R\end{array}$ & $\begin{array}{r}\text { MAX } \\
\text { LBS/HR }\end{array}$ \\
\hline ANL & $3.750 E+01$ & $4.382 E+01$ & $2.446 E+02$ & $6.050 E+01$ \\
B08 & $1.290 E-03$ & $9.925 E-02$ & $8.694 E-01$ & $1.985 E-01$ \\
B16 & $5.500 E-03$ & $1.000 E+00$ & $1.490 E+01$ & $3.400 E+00$ \\
B27 & $1.290 E-04$ & $9.925 E-02$ & $8.694 E-01$ & $1.985 E-01$ \\
CFA & $1.075 E+01$ & $6.215 E+00$ & $9.205 E+01$ & $2.997 E+01$ \\
CPP & $4.689 E+01$ & $5.031 E+01$ & $8.309 E+02$ & $2.258 E+02$ \\
HPTF & $4.640 E-02$ & $3.570 E+00$ & $1.890 E-02$ & $4.330 E-03$ \\
NRF & $7.951 E+01$ & $1.381 E+02$ & $1.416 E+03$ & $3.518 E+02$ \\
PER & $1.639 E+00$ & $3.353 E+00$ & $1.924 E+01$ & $7.144 E+00$ \\
TAN & $2.889 E+01$ & $8.058 E+01$ & $3.646 E+02$ & $1.310 E+02$ \\
TRA & $1.454 E+01$ & $1.038 E+01$ & $3.955 E+01$ & $1.418 E+01$ \\
WMF & $1.942 E-03$ & $1.008 E-03$ & $6.330 E-03$ & $1.287 E-03$
\end{tabular}




\section{SUMMARY OF VOC-NONMETHANE EMISSIONS AT THE INEL 1994}

\begin{tabular}{lrrrr}
\hline AREA & $\begin{array}{r}\text { ACTUAL } \\
\text { TNS } / Y R\end{array}$ & $\begin{array}{r}\text { ACTUAL } \\
\text { LBS/HR }\end{array}$ & $\begin{array}{r}\text { MAX } \\
\text { TNS } / Y R\end{array}$ & $\begin{array}{r}\text { MAX } \\
\text { LBS/HR }\end{array}$ \\
\hline ANL & $6.053 E-01$ & $5.454 E+01$ & $5.807 E+00$ & $6.486 E+01$ \\
B08 & $1.611 E-04$ & $3.493 E-01$ & $1.080 E-01$ & $3.616 E-01$ \\
B16 & $9.500 E-01$ & $4.080 E-01$ & $5.690 E+00$ & $1.358 E+00$ \\
B21 & $5.800 E-02$ & $1.300 E-02$ & $2.910 E-01$ & $6.600 E-02$ \\
B23 & $9.126 E-07$ & $3.370 E-01$ & $9.126 E-07$ & $3.370 E-01$ \\
B27 & $1.694 E-05$ & $3.493 E-01$ & $1.080 E-01$ & $3.616 E-01$ \\
CFA & $9.232 E+00$ & $1.364 E+02$ & $8.414 E+01$ & $1.387 E+02$ \\
CPP & $1.064 E+01$ & $2.769 E+02$ & $1.369 E+02$ & $3.531 E+02$ \\
HPTF & $1.040 E-01$ & $7.990 E+00$ & $4.240 E-02$ & $9.680 E-03$ \\
NRF & $3.913 E-01$ & $5.899 E+00$ & $5.035 E+00$ & $7.690 E+00$ \\
PER & $1.170 E-02$ & $7.093 E-01$ & $2.051 E+00$ & $1.046 E+00$ \\
TAN & $2.128 E+00$ & $3.865 E+01$ & $4.955 E+01$ & $6.420 E+01$ \\
TRA & $3.163 E+00$ & $2.782 E+00$ & $7.885 E+00$ & $3.378 E+00$ \\
WMF & $9.157 E-03$ & $3.422 E-01$ & $3.317 E-02$ & $3.437 E-01$
\end{tabular}




\section{EMISSION SUMMARY - 1994}

\begin{tabular}{lllll} 
* AREA & BLDG & VENT & POLLUTANT & SOURCE TYPE \\
\hline ANL & 701 & 009 & CARBON MONOXIDE & FUEL BURNING EQUIPMENT \\
& 707 & 002 & \\
& 709 & 008 & FUEL BURNING EQUIPMENT \\
& 016 & FUEL BURNING EQUIPMENT \\
$*$ & 720 & 017 & FUEL BURNING EQUIPMENT \\
& $752 A$ & 001 & FUEL BURNING EQUIPMENT \\
$*$ & 754 & 003 & FUEL BURNING EQUIPMENT \\
& 768 & 003 & FUEL BURNING EQUIPMENT \\
& & 022 & FUEL BURNING EQUIPMENT \\
& & 024 & FUEL BURNING EQUIPMENT \\
& & 027 & FUEL BURNING EQUIPMENT \\
& & 028 & FUEL BURNING EQUIPMENT \\
& & 034 & FUEL BURNING EQUIPMENT \\
& 774 & 001 & FUEL BURNING EQUIPMENT \\
& 785 & 017 & FUEL BURNING EQUIPMENT \\
& & & FUEL BURNING EQUIPMENT
\end{tabular}

$\begin{array}{llll}\text { * ANL } & 701 & 009 & \text { NITROGEN OXIDES } \\ & 707 & 002 & \\ & 709 & 008 & \\ & & 016 & \\ * & 720 & 017 & \\ & 752 A & 001 & \\ * & 754 & 003 & \\ * & 768 & 003 & \\ & & 022 \\ & & 024 & \\ & & 027 \\ & & 028 \\ & & 034 \\ * & 774 & 001 \\ * & 785 & 017\end{array}$

SUM

$\begin{array}{llll}\text { * ANL } & 701 & 009 & \text { PARTICULATE } \\ & 707 & 002 \\ & 709 & 008 \\ & & 016 \\ * & 720 & 017 \\ & 752 A & 001 \\ & 753 & 029 & \\ * & 754 & 003 \\ * & 768 & 003 \\ & & 022 \\ & & 024 \\ & & 027 \\ & & 028 \\ & & 034 \\ * & 774 & 001\end{array}$

FUEL BURNING EQUIPMENT FUEL BURNING EQUIPMENT FUEL BURNING EQUIPMENT FUEL BURNING EQUIPMENT FUEL BURNING EQUIPMENT FUEL BURNING EQUIPMENT FUEL BURNING EQUIPMENT FUEL BURNING EQUIPMENT FUEL BURNING EQUIPMENT FUEL BURNING EQUIPMENT FUEL BURNING EQUIPMENT FUEL BURNING EQUIPMENT FUEL BURNING EQUIPMENT FUEL BURNING EQUIPMENT FUEL BURNING EQUIPMENT

FUEL BURNING EQUIPMENT FUEL BURNING EQUIPMENT FUEL BURNING EQUIPMENT FUEL BURNING EQUIPMENT FUEL BURNING EQUIPMENT FUEL BURNING EQUIPMENT CHEMICAL SOURCE FUEL BURNING EQUIPMENT FUEL BURNING EQUIPMENT FUEL BURNING EQUIPMENT FUEL BURNING EQUIPMENT FUEL BURNING EQUIPMENT FUEL BURNING EQUIPMENT FUEL BURNING EQUIPMENT FUEL BURNING EQUIPMENT

\section{C}

$\begin{array}{lllll}\text { A ACTUAL } & \text { ACTUAL } & \text { MAX } & \text { MAX } \\ \text { L } & \text { HOURLY } & \text { YEARLY } & \text { HOURLY YEARLY } \\ & \text { HOBSHR } & \text { TNSYR } & \text { LBSTR } & \text { TNSTR }\end{array}$ C LBS/HR TNSTR LBS/HR TNS/YR

$\begin{array}{lllll}\mathrm{N} & 6.5 \mathrm{E}-01 & 7.8 \mathrm{E}-03 & 9.9 \mathrm{E}+00 & 2.7 \mathrm{E}+01\end{array}$

$\begin{array}{lllll}N & 2.6 E+00 & 3.9 E-02 & 3.0 E+00 & 2.7 E+00\end{array}$

$\begin{array}{lllll}\mathrm{N} & 9.7 \mathrm{E}-01 & 6.7 \mathrm{E}-03 & 1.8 \mathrm{E}+00 & 7.8 \mathrm{E}+00\end{array}$

$\begin{array}{lllll}N & 1.1 E+00 & 8.9 E-03 & 2.2 E+00 & 9.7 E+00\end{array}$

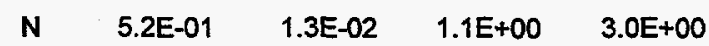

N $\quad 2.2 E+00 \quad 2.2 E-02 \quad 3.3 E+00 \quad 4.5 E+00$

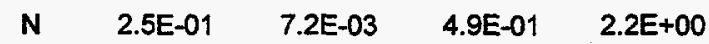

$N \quad 2.3 E+00 \quad 3.3 E-02 \quad 4.7 E+00 \quad 4.7 E-01$

N $\quad 6.5 E-01 \quad 6.3 E-01 \quad 8.5 E-01 \quad 3.7 E+00$

$\mathrm{N} \quad 6.5 \mathrm{E}-01 \quad 6.3 \mathrm{E}-01 \quad 8.5 \mathrm{E}-01 \quad 3.7 \mathrm{E}+00$

N $\quad 6.7 E-01 \quad 6.3 E-01 \quad 8.4 E-01 \quad 3.7 E+00$

$N \quad 1.2 E+00 \quad 9.8 E-03 \quad 1.2 E+00 \quad 3.2 E+00$

N $\quad 7.5 \mathrm{E}-01 \quad 7.3 \mathrm{E}-01 \quad 9.4 \mathrm{E}-01 \quad 4.1 \mathrm{E}+00$

$N \quad 5.7 E-01 \quad 7.4 \mathrm{E}-03,1.1 \mathrm{E}+00 \quad 3.1 \mathrm{E}+00$

$\begin{array}{lllll}\mathrm{N} & 6.9 \mathrm{E}-01 & 1.2 \mathrm{E}-02 & 1.4 \mathrm{E}+00 & 1.9 \mathrm{E}+00\end{array}$

\begin{tabular}{llll}
$1.9 E-01$ & $1.2 E-02$ & $1.4 E+00$ & $1.9 E+00$ \\
\hline $1.6 E+01$ & $2.8 E+00$ & $3.4 E+01$ & $8.0 E+01$
\end{tabular}

$\mathrm{N} \quad 3.0 \mathrm{E}+00 \quad 3.6 \mathrm{E}-02 \quad 4.6 \mathrm{E}+01 \quad 1.2 \mathrm{E}+02$

N $1.2 \mathrm{E}+01 \quad 1.8 \mathrm{E}-01 \quad 1.4 \mathrm{E}+01 \quad 1.2 \mathrm{E}+01$

$N \quad 3.7 \mathrm{E}+00 \quad 2.6 \mathrm{E}-02 \quad 6.8 \mathrm{E}+00 \quad 3.0 \mathrm{E}+01$

N $\quad 4.3 E+00 \quad 3.4 E-02 \quad 8.5 E+00 \quad 3.7 E+01$

$\mathrm{N} \quad 2.4 \mathrm{E}+00 \quad 6.0 \mathrm{E}-02 \quad 5.1 \mathrm{E}+00 \quad 1.4 \mathrm{E}+01$

$\begin{array}{lllll}N & 1.0 E+01 & 1.0 E-01 & 1.5 E+01 & 2.1 E+01\end{array}$

N $\quad 1.1 E+00 \quad 3.3 E-02 \quad 2.3 E+00 \quad 1.0 E+01$

$N \quad 1.1 E+01 \quad 1.5 E-01 \quad 2.2 E+01 \quad 2.2 E+00$

$\begin{array}{lllll}N & 2.6 E+00 & 2.5 E+00 & 3.4 E+00 & 1.5 E+01\end{array}$

N $\quad 2.6 \mathrm{E}+00 \quad 2.5 \mathrm{E}+00 \quad 3.4 \mathrm{E}+00 \quad 1.5 \mathrm{E}+01$

N $\quad 2.7 \mathrm{E}+00 \quad 2.5 \mathrm{E}+00 \quad 3.4 \mathrm{E}+00 \quad 1.5 \mathrm{E}+01$

N $\quad 5.4 \mathrm{E}+00 \quad 4.5 \mathrm{E}-02 \quad 5.4 \mathrm{E}+00 \quad 1.5 \mathrm{E}+01$

N $\quad 3.0 \mathrm{E}+00 \quad 2.9 \mathrm{E}+00 \quad 3.7 \mathrm{E}+00 \quad 1.6 \mathrm{E}+01$

N $\quad 2.7 \mathrm{E}+00 \quad 3.4 \mathrm{E}-02 \quad 5.3 \mathrm{E}+00 \quad 1.4 \mathrm{E}+01$

$\begin{array}{lllll}N & 3.2 E+00 & 5.7 E-02 & 6.4 E+00 & 8.6 E+00\end{array}$

$\begin{array}{llll}7.0 E+01 & 1.1 E+01 & 1.5 E+02 & 3.5 E+02\end{array}$

$\begin{array}{lllll}\mathrm{N} & 2.1 \mathrm{E}-01 & 2.6 \mathrm{E}-03 & 3.2 \mathrm{E}+00 & 8.7 \mathrm{E}+00 \\ \mathrm{~N} & 8.5 \mathrm{E}-01 & 1.3 \mathrm{E}-02 & 9.6 \mathrm{E}-01 & 8.7 \mathrm{E}-01 \\ \mathrm{~N} & 8.2 \mathrm{E}-02 & 5.6 \mathrm{E}-04 & 1.5 \mathrm{E}-01 & 6.6 \mathrm{E}-01 \\ \mathrm{~N} & 9.4 \mathrm{E}-02 & 7.5 \mathrm{E}-04 & 1.9 \mathrm{E}-01 & 8.2 \mathrm{E}-01 \\ \mathrm{~N} & 1.7 \mathrm{E}-01 & 4.3 \mathrm{E}-03 & 3.6 \mathrm{E}-01 & 9.8 \mathrm{E}-01 \\ \mathrm{~N} & 7.2 \mathrm{E}-01 & 7.1 \mathrm{E}-03 & 1.1 \mathrm{E}+00 & 1.5 \mathrm{E}+00 \\ \mathrm{Y} & 4.4 \mathrm{E}-03 & 1.3 \mathrm{E}-04 & 2.0 \mathrm{E}+00 & 4.0 \mathrm{E}-01 \\ \mathrm{~N} & 8.1 \mathrm{E}-02 & 2.3 \mathrm{E}-03 & 1.6 \mathrm{E}-01 & 7.1 \mathrm{E}-01 \\ \mathrm{~N} & 7.7 \mathrm{E}-01 & 1.1 \mathrm{E}-02 & 1.5 \mathrm{E}+00 & 1.5 \mathrm{E}-01 \\ \mathrm{~N} & 2.6 \mathrm{E}-01 & 2.5 \mathrm{E}-01 & 3.4 \mathrm{E}-01 & 1.5 \mathrm{E}+00 \\ \mathrm{~N} & 2.6 \mathrm{E}-01 & 2.5 \mathrm{E}-01 & 3.4 \mathrm{E}-01 & 1.5 \mathrm{E}+00 \\ \mathrm{~N} & 2.7 \mathrm{E}-01 & 2.5 \mathrm{E}-01 & 3.4 \mathrm{E}-01 & 1.5 \mathrm{E}+00 \\ \mathrm{~N} & 3.8 \mathrm{E}-01 & 3.2 \mathrm{E}-03 & 3.8 \mathrm{E}-01 & 1.0 \mathrm{E}+00 \\ \mathrm{~N} & 3.0 \mathrm{E}-01 & 2.9 \mathrm{E}-01 & 3.7 \mathrm{E}-01 & 1.6 \mathrm{E}+00 \\ \mathrm{~N} & 1.9 \mathrm{E}-01 & 2.4 \mathrm{E}-03 & 3.7 \mathrm{E}-01 & 1.0 \mathrm{E}+00\end{array}$

\footnotetext{
* Not Significant Source
} 


\section{EMISSION SUMMARY - 1994}

\begin{tabular}{ccccc} 
AREA & BLDG & VENT & POLLUTANT & SOURCE TYPE \\
\hline ANL & 785 & 017 & PARTICULATE & FUEL BURNING EQUIPMENT \\
& & & SUM
\end{tabular}

\begin{tabular}{|c|c|c|}
\hline \multirow[t]{4}{*}{ * ANL } & 701 & 009 \\
\hline & 707 & 002 \\
\hline & 709 & 008 \\
\hline & & 016 \\
\hline \multirow[t]{2}{*}{ * } & 720 & 017 \\
\hline & $752 \mathrm{~A}$ & 001 \\
\hline * & 754 & 003 \\
\hline \multirow[t]{6}{*}{ * } & 768 & 003 \\
\hline & & 022 \\
\hline & & 024 \\
\hline & & 027 \\
\hline & & 028 \\
\hline & & 034 \\
\hline * & 774 & 001 \\
\hline * & 785 & 017 \\
\hline
\end{tabular}

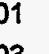

.

24

\begin{tabular}{|c|c|c|}
\hline * ANL & 701 & 009 \\
\hline * & & 012 \\
\hline & 704 & 008 \\
\hline * & 707 & 001 \\
\hline & & 002 \\
\hline * & 709 & 001 \\
\hline & & 008 \\
\hline * & & 009 \\
\hline & & 016 \\
\hline * & 720 & 017 \\
\hline * & & 025 \\
\hline * & 721 & 003 \\
\hline * & 742 & 002 \\
\hline * & & 005 \\
\hline * & & 006 \\
\hline & 752 & 004 \\
\hline & & 005 \\
\hline & $752 \mathrm{~A}$ & 001 \\
\hline * & & 005 \\
\hline & 753 & 029 \\
\hline * & 754 & 001 \\
\hline * & & 003 \\
\hline * & $755 \mathrm{~A}$ & 001 \\
\hline * & $755 B$ & 002 \\
\hline$\star$ & 768 & 003 \\
\hline * & & 004 \\
\hline * & & 005 \\
\hline & & 022 \\
\hline & & 024 \\
\hline
\end{tabular}

SULFUR OXIDES 16 sum

FUEL BURNING EQUIPMENT FUEL BURNING EQUIPMENT FUEL BURNING EQUIPMENT FUEL BURNING EQUIPMENT FUEL BURNING EQUIPMENT FUEL BURNING EQUIPMENT FUEL BURNING EQUIPMENT FUEL BURNING EQUIPMENT FUEL BURNING EQUIPMENT FUEL BURNING EQUIPMENT FUEL BURNING EQUIPMENT FUEL BURNING EQUIPMENT FUEL BURNING EQUIPMENT FUEL BURNING EQUIPMENT FUEL BURNING EQUIPMENT

\section{VOC-NONMETHANE}

CH STORAGE TANK - VOC FUEL BURNING EQUIPMENT STORAGE TANK - VOC FUEL BURNING EQUIPMENT STORAGE TANK - VOC FUEL BURNING EQUIPMENT FUEL BURNING EQUIPMENT STORAGE TANK - VOC STORAGE TANK - VOC STORAGE TANK - VOC STORAGE TANK - VOC STORAGE TANK - VOC CHEMICAL SOURCE CHEMICAL SOURCE FUEL BURNING EQUIPMENT STORAGE TANK - VOC CHEMICAL SOURCE STORAGE TANK - VOC FUEL BURNING EQUIPMENT STORAGE TANK - VOC STORAGE TANK - VOC FUEL BURNING EQUIPMENT STORAGE TANK - VOC STORAGE TANK - VOC FUEL BURNING EQUIPMENT FUEL BURNING EQUIPMENT
C

A ACTUAL ACTUAL MAX MAX

L HOURLY YEARLY HOURLY YEARLY

C LBS/HR TNS/YR LBS/HR TNS $M R$

\begin{tabular}{lllll}
$N$ & $2.3 \mathrm{E}-01$ & $4.0 \mathrm{E}-03$ & $4.5 \mathrm{E}-01$ & $6.1 \mathrm{E}-01$ \\
\hline
\end{tabular}

$\begin{array}{llll}4.9 E+00 & 1.1 E+00 & 1.2 E+01 & 2.3 E+01\end{array}$

N 2.0E-01 2.4E-03 3.0E+00 8.1E+00

$N \quad 7.9 E-01 \quad 1.2 E-02 \quad 9.0 E-01 \quad 8.1 E-01$

$N \quad 6.0 E-01 \quad 4.2 E-03 \quad 1.1 E+00 \quad 4.8 E+00$

$N \quad 6.9 E-01 \quad 5.5 E-03 \quad 1.4 E+00 \quad 6.1 E+00$

$N \quad 1.6 E-01 \quad 4.0 E-03 \quad 3.4 E-01 \quad 9.1 E-01$

$N \quad 6.7 E-01 \quad 6.6 E-03 \quad 1.0 E+00 \quad 1.4 E+00$

$N \quad 7.5 E-02 \quad 2.2 E-03 \quad 1.5 E-01 \quad 6.6 E-01$

$N \quad 7.1 E-01 \quad 9.9 E-03 \quad 1.4 E+00 \quad 1.4 E-01$

$N \quad 9.4 E+00 \quad 9.0 E+00 \quad 1.2 E+01 \quad 5.4 E+01$

$N \quad 9.4 E+00 \quad 9.0 E+00 \quad 1.2 E+01 \quad 5.4 E+01$

$N \quad 9.6 E+00 \quad 9.0 E+00 \quad 1.2 E+01 \quad 5.3 E+01$

$N \quad 3.6 E-01 \quad 3.0 E-03 \quad 3.6 E-01 \quad 9.6 E-01$

$N \quad 1.1 E+01 \quad 1.0 E+01 \quad 1.3 E+01 \quad 5.9 E+01$

$N \quad 1.7 E-01 \quad 2.3 E-03 \quad 3.5 E-01 \quad 9.3 E-01$

$N \quad 2.1 E-01 \quad 3.8 E-03 \quad 4.2 E-01 \quad 5.7 E-01$

$\begin{array}{llll}4.4 E+01 & 3.7 E+01 & 6.1 E+01 & 2.4 E+02\end{array}$

$N \quad 2.5 E-02 \quad 3.0 E-04 \quad 3.7 E-01 \quad 1.0 \mathrm{E}+00$

N $\quad 0.0 E+00 \quad 0.0 E+00 \quad 0.0 E+00 \quad 0.0 E+00$

$Y \quad 5.7 E-03 \quad 2.5 E-02 \quad 5.7 E-03 \quad 2.5 E-02$

$N \quad 3.4 E-02 \quad 8.4 E-06 \quad 3.4 E-02 \quad 8.4 E-06$

$N \quad 9.9 E-02 \quad 1.5 E-03 \quad 1.1 E-01 \quad 1.0 E-01$

$N \quad 1.7 E-01 \quad 1.7 E-05 \quad 1.7 E-01 \quad 1.7 E-05$

$N \quad 1.2 E-01 \quad 8.2 E-04 \quad 2.2 E-01 \quad 9.6 E-01$

$N \quad 1.7 E-01 \quad 1.7 E-05 \quad 1.7 E-01 \quad 1.7 E-05$

$N \quad 1.4 E-01 \quad 1.1 E-03 \quad 2.7 E-01 \quad 1.2 E+00$

$N \quad 2.0 E-02 \quad 4.9 E-04 \quad 4.2 E-02 \quad 1.1 E-01$

$\mathrm{N} \quad 5.8 \mathrm{E}-02 \quad 8.0 \mathrm{E}-07 \quad 5.8 \mathrm{E}-02 \quad 8.0 \mathrm{E}-07$

$\mathrm{N} \quad 0.0 \mathrm{E}+00 \quad 5.8 \mathrm{E}-06 \quad 0.0 \mathrm{E}+00 \quad 5.8 \mathrm{E}-06$

$\mathrm{N} \quad 3.2 \mathrm{E}+01 \quad 1.2 \mathrm{E}-02 \quad 3.2 \mathrm{E}+01 \quad 1.2 \mathrm{E}-02$

$N \quad 5.8 \mathrm{E}-02 \quad 1.9 \mathrm{E}-05 \quad 5.8 \mathrm{E}-02 \quad 1.9 \mathrm{E}-05$

$\mathrm{N} \quad 2.0 \mathrm{E}+01 \quad 2.5 \mathrm{E}-02 \quad 2.0 \mathrm{E}+01 \quad 2.5 \mathrm{E}-02$

$Y \quad 1.4 \mathrm{E}-02 \quad 6.3 \mathrm{E}-02 \quad 1.4 \mathrm{E}-02 \quad 6.3 \mathrm{E}-02$

$Y \quad 1.4 \mathrm{E}-02 \quad 6.3 \mathrm{E}-02 \quad 1.4 \mathrm{E}-02 \quad 6.3 \mathrm{E}-02$

$N \quad 8.4 E-02 \quad 8.3 E-04 \quad 1.3 E-01 \quad 1.7 E-01$

$N \quad 5.8 E-02 \quad 1.6 E-06 \quad 5.8 E-02 \quad 1.6 E-06$

$Y \quad 1.3 E-02 \quad 5.7 E-02 \quad 9.5 E+00 \quad 8.0 E-01$

$N \quad 1.7 E-01 \quad 8.4 E-07 \quad 1.7 E-01 \quad 8.4 E-07$

$N \quad 9.4 E-03 \quad 2.7 E-04 \quad 1.9 E-02 \quad 8.2 E-02$

N 1.3E-01 $5.0 E-02 \quad 1.3 E-01 \quad 5.0 E-02$

N $\quad 1.2 \mathrm{E}-01 \quad 2.2 \mathrm{E}-02 \quad 1.2 \mathrm{E}-01 \quad 2.2 \mathrm{E}-02$

$\mathrm{N} \quad 8.9 \mathrm{E}-02 \quad 1.2 \mathrm{E}-03 \quad 1.8 \mathrm{E}-01 \quad 1.8 \mathrm{E}-02$

$N \quad 5.8 E-02 \quad 9.7 E-06 \quad 5.8 E-02 \quad 9.7 E-06$

$N \quad 2.7 E-02 \quad 2.3 E-03 \quad 2.7 E-02 \quad 2.3 E-03$

$N \quad 2.6 E-02 \quad 2.5 E-02 \quad 3.4 E-02 \quad 1.5 E-01$

$\mathrm{N} \quad 2.6 \mathrm{E}-02 \quad 2.5 \mathrm{E}-02 \quad 3.4 \mathrm{E}-02 \quad 1.5 \mathrm{E}-01$ 


\begin{tabular}{|c|c|c|c|c|c|c|c|c|c|}
\hline \multicolumn{5}{|c|}{ EMISSION SUMMARY - 1994} & \multirow{2}{*}{$\begin{array}{l}\text { C } \\
\text { A } \\
\text { L } \\
C\end{array}$} & \multirow{2}{*}{$\begin{array}{l}\text { ACTUAL } \\
\text { HOURLY } \\
\text { LBS/HR }\end{array}$} & \multirow{2}{*}{$\begin{array}{l}\text { ACTUAL } \\
\text { YEARLY } \\
\text { TNS/YR }\end{array}$} & \multirow{2}{*}{$\begin{array}{c}\text { MAX } \\
\text { HOURLY } \\
\text { LBS/HR }\end{array}$} & \multirow{2}{*}{$\begin{array}{c}\text { MAX } \\
\text { YEARLY } \\
\text { TNS/YR }\end{array}$} \\
\hline AREA & BLDG & VENT & POLLUTANT & SOURCE TYPE & & & & & \\
\hline \multirow{6}{*}{$\overline{A N L}$} & \multirow{3}{*}{768} & 027 & VOC-NONMETHANE & FUEL BURNING EQUIPMENT & $\mathbf{N}$ & $2.7 \mathrm{E}-02$ & $2.5 \mathrm{E}-02$ & $3.4 E-02$ & $1.5 \mathrm{E}-01$ \\
\hline & & 028 & & FUEL BURNING EQUIPMENT & $\mathbf{N}$ & 4.4E-02 & 3.7E-04 & 4.4E-02 & $1.2 \mathrm{E}-01$ \\
\hline & & 034 & & FUEL BURNING EQUIPMENT & $\mathbf{N}$ & $3.0 \mathrm{E}-02$ & $2.9 E-02$ & 3.7E-02 & $1.6 \mathrm{E}-01$ \\
\hline & \multirow[t]{2}{*}{774} & 001 & & FUEL BURNING EQUIPMENT & $\mathbf{N}$ & $2.2 \mathrm{E}-02$ & $2.8 E-04$ & 4.3E-02 & $1.2 \mathrm{E}-01$ \\
\hline & & 003 & & STORAGE TANK - VOC & $\mathbf{N}$ & $5.8 \mathrm{E}-02$ & $9.7 E-07$ & $5.8 E-02$ & $9.7 E-07$ \\
\hline & \multirow[t]{2}{*}{785} & 017 & & FUEL BURNING EQUIPMENT & $\mathbf{N}$ & $2.6 \mathrm{E}-02$ & 4.7E-04 & $5.2 E-02$ & 7.1E-02 \\
\hline & & 018 & & CHEMICAL SOURCE & $\mathbf{Y}$ & $1.0 \mathrm{E}-02$ & $4.5 E-02$ & $1.0 \mathrm{E}-02$ & 4.5E-02 \\
\hline & 787 & 001 & & CHEMICAL SOURCE & $\mathbf{Y}$ & $1.4 \mathrm{E}-02$ & $6.3 E-02$ & $1.4 \mathrm{E}-02$ & $6.3 E-02$ \\
\hline & \multirow[t]{3}{*}{793} & 001 & & CHEMICAL SOURCE & $\mathrm{Y}$ & 4.1E-03 & $1.8 E-02$ & 4.1E-03 & $1.8 \mathrm{E}-02$ \\
\hline & & 012 & & STORAGE TANK - VOC & $\mathbf{Y}$ & $6.7 E-03$ & $2.7 E-02$ & $6.7 \mathrm{E}-03$ & $2.7 E-02$ \\
\hline & & 014 & & STORAGE TANK - VOC & $\mathbf{Y}$ & $1.0 \mathrm{E}-03$ & $4.5 \mathrm{E}-03$ & $1.0 \mathrm{E}-03$ & 4.5E-03 \\
\hline & \multirow[t]{7}{*}{$793 \mathrm{~A}$} & 025 & & STORAGE TANK - VOC & $\mathbf{Y}$ & $6.8 \mathrm{E}-04$ & $3.0 \mathrm{E}-03$ & $6.8 E-04$ & 3.0E-03 \\
\hline & & 027 & & STORAGE TANK - VOC & $Y$ & $1.0 \mathrm{E}-03$ & $4.5 E-03$ & $1.0 E-03$ & $4.5 \mathrm{E}-03$ \\
\hline & & 029 & & STORAGE TANK - VOC & $Y$ & $5.7 \mathrm{E}-04$ & $2.5 \mathrm{E}-03$ & 5.7E-04 & $2.5 E-03$ \\
\hline & & 031 & & STORAGE TANK - VOC & $Y$ & 4.5E-04 & $2.0 E-03$ & 4.5E-04 & $2.0 E-03$ \\
\hline & & 033 & & STORAGE TANK - VOC & $Y$ & $1.0 \mathrm{E}-03$ & $4.5 E-03$ & $1.0 E-03$ & $4.5 E-03$ \\
\hline & & 035 & & STORAGE TANK - VOC & Y & 2.3E-04 & $1.0 \mathrm{E}-03$ & 2.3E-04 & $1.0 \mathrm{E}-03$ \\
\hline & & & sum & & & $5.5 E+01$ & $6.1 E-01$ & $6.5 E+01$ & $5.8 \mathrm{E}+00$ \\
\hline
\end{tabular}

* Not Significant Source 


\begin{tabular}{|c|c|c|c|c|c|c|c|c|c|}
\hline AREA & IISSI & ON & SUMMARY - 1 & SOURCE TYPE & $\begin{array}{l}C \\
A \\
L \\
C \\
\end{array}$ & $\begin{array}{l}\text { ACTUAL } \\
\text { HOURLY } \\
\text { LBS/HR }\end{array}$ & $\begin{array}{l}\text { ACTUAL } \\
\text { YEARLY } \\
\text { TNS/YR } \\
\end{array}$ & $\begin{array}{c}\text { MAX } \\
\text { HOURLY } \\
\text { LBS/HR } \\
\end{array}$ & $\begin{array}{c}\text { MAX } \\
\text { YEARLY } \\
\text { TNSNRR } \\
\end{array}$ \\
\hline \multirow[t]{2}{*}{ * B08 } & 601 & 003 & CARBON MONOXIDE & FUEL BURNING EQUIPMENT & $\mathbf{N}$ & 3.3E-01 & $4.2 \mathrm{E}-03$ & $6.5 \mathrm{E}-01$ & $2.8 E+00$ \\
\hline & & & sum & & & $3.3 \mathrm{E}-01$ & $4.2 E-03$ & $6.5 \mathrm{E}-01$ & $2.8 E+00$ \\
\hline \multirow[t]{2}{*}{ * B08 } & 601 & 003 & NITROGEN OXIDES & FUEL BURNING EQUIPMENT & $\mathbf{N}$ & $1.5 \mathrm{E}+00$ & $2.0 \mathrm{E}-02$ & $3.0 \mathrm{E}+00$ & $1.3 E+01$ \\
\hline & & & sum & & & $1.5 \mathrm{E}+00$ & $2.0 E-02$ & $3.0 \mathrm{E}+00$ & $1.3 E+01$ \\
\hline \multirow[t]{2}{*}{ * B08 } & 601 & 003 & PARTICULATE & FUEL BURNING EQUIPMENT & $\mathbf{N}$ & 1.1E-01 & $1.4 \mathrm{E}-03$ & 2.1E-01 & 9.3E-01 \\
\hline & & & sum & & & $1.1 \mathrm{E}-01$ & $1.4 \mathrm{E}-03$ & $2.1 E-01$ & 9.3E-01 \\
\hline \multirow[t]{2}{*}{ * B08 } & 601 & 003 & SULFUR OXIDES & FUEL BURNING EQUIPMENT & $\mathbf{N}$ & $9.9 \mathrm{E}-02$ & $1.3 E-03$ & 2.0E-01 & 8.7E-01 \\
\hline & & & sum & & & $9.9 \mathrm{E}-02$ & $1.3 E-03$ & $2.0 E-01$ & $8.7 E-01$ \\
\hline \multirow{3}{*}{$\begin{array}{l}\text { * B08 } \\
*\end{array}$} & 601 & 001 & VOC-NONMETHANE & STORAGE TANK - VOC & $\mathbf{N}$ & $3.4 \mathrm{E}-01$ & $9.1 E-07$ & 3.4E-01 & $9.1 E-07$ \\
\hline & & 003 & & FUEL BURNING EQUIPMENT & $\mathbf{N}$ & $1.2 E-02$ & $1.6 \mathrm{E}-04$ & 2.5E-02 & $1.1 \mathrm{E}-01$ \\
\hline & & & sum & & & 3.5E-01 & 1.6E-04 & 3.6E-01 & $1.1 \mathrm{E}-01$ \\
\hline
\end{tabular}

* Not Significant Source 


\section{EMISSION SUMMARY - 1994}

AREA BLDG VENT POLLUTANT

SOURCE TYPE

\section{C}

A ACTUAL ACTUAL MAX MAX

L HOURLY YEARLY HOURLY YEARLY

* B16 708001 CARBON MONOXIDE CHEMICAL SOURCE

SUM

\begin{tabular}{ccccc} 
C & LBS/HR & TNS/YR & LBS/HR & TNS/YR \\
\hline$Y$ & $2.8 E+00$ & $1.7 E-02$ & $1.1 E+01$ & $4.7 E+01$
\end{tabular}

\begin{tabular}{|c|c|c|c|c|}
\hline \multicolumn{5}{|c|}{ SUM } \\
\hline * B16 & 708 & 001 & $\begin{array}{l}\text { NITROGEN OXIDES } \\
\text { SUM }\end{array}$ & CHEMICAL SOURCE \\
\hline * B16 & 708 & 001 & $\begin{array}{l}\text { PARTICULATE } \\
\text { SUM }\end{array}$ & CHEMICAL SOURCE \\
\hline * B16 & 708 & 001 & $\begin{array}{l}\text { SULFUR OXIDES } \\
\text { SUM }\end{array}$ & CHEMICAL SOURCE \\
\hline * B16 & 601 & 008 & VOC-NONMETHANE & ȘTORAGE TANK - VOC \\
\hline 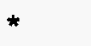 & 703 & 001 & & STORAGE TANK - VOC \\
\hline & 704 & 001 & & STORAGE TANK - VOC \\
\hline & & 002 & & STORAGE TANK - VOC \\
\hline & 708 & 001 & & CHEMICAL SOURCE \\
\hline
\end{tabular}

SUM

\begin{tabular}{lllll} 
& $2.8 E+00$ & $1.7 E-02$ & $1.1 E+01$ & $4.7 E+01$ \\
$Y$ & $1.3 E+00$ & $8.1 E-03$ & $1.0 E+01$ & $4.4 E+01$ \\
\hline & $1.3 E+00$ & $8.1 E-03$ & $1.0 E+01$ & $4.4 E+01$ \\
$Y$ & $3.1 E-01$ & $1.9 E-03$ & $1.2 E+00$ & $5.0 E+00$ \\
\hline & $3.1 E-01$ & $1.9 E-03$ & $1.2 E+00$ & $5.0 E+00$ \\
$Y$ & $1.0 E+00$ & $5.5 E-03$ & $3.4 E+00$ & $1.5 E+01$ \\
\hline & $1.0 E+00$ & $5.5 E-03$ & $3.4 E+00$ & $1.5 E+01$ \\
& & & & \\
$N$ & $5.8 E-02$ & $2.7 E-06$ & $5.8 E-02$ & $2.7 E-06$ \\
$N$ & $0.0 E+00$ & $0.0 E+00$ & $0.0 E+00$ & $0.0 E+00$ \\
$N$ & $0.0 E+00$ & $0.0 E+00$ & $0.0 E+00$ & $0.0 E+00$ \\
$N$ & $0.0 E+00$ & $0.0 E+00$ & $0.0 E+00$ & $0.0 E+00$ \\
$Y$ & $3.5 E-01$ & $9.5 E-01$ & $1.3 E+00$ & $5.7 E+00$ \\
\hline & $4.1 E-01$ & $9.5 E-01$ & $1.4 E+00$ & $5.7 E+00$
\end{tabular}




\begin{tabular}{|c|c|c|c|c|c|c|c|c|c|}
\hline EN & $|S S|$ & ON & SUMMARY - 1 & SOURCE TYPE & $\begin{array}{l}C \\
A \\
L \\
C\end{array}$ & $\begin{array}{l}\text { ACTUAL } \\
\text { HOURLY } \\
\text { LBS/HR }\end{array}$ & $\begin{array}{l}\text { ACTUAL } \\
\text { YEARLY } \\
\text { TNS/YR }\end{array}$ & $\begin{array}{c}\text { MAX } \\
\text { HOURLY } \\
\text { LBS/HR }\end{array}$ & $\begin{array}{c}\text { MAX } \\
\text { YEARLY } \\
\text { TNS/YR }\end{array}$ \\
\hline \multirow[t]{2}{*}{ * B21 } & 608 & 012 & CARBON MONOXIDE & CHEMICAL SOURCE & $\mathrm{Y}$ & $3.0 \mathrm{E}-03$ & 4.0E-03 & $3.0 \mathrm{E}-03$ & $1.4 E-02$ \\
\hline & & & SUM & & & $3.0 \mathrm{E}-03$ & $4.0 \mathrm{E}-03$ & $3.0 \mathrm{E}-03$ & $1.4 \mathrm{E}-02$ \\
\hline \multirow[t]{2}{*}{ * B21 } & 608 & 012 & PARTICULATE & CHEMICAL SOURCE & $\mathrm{Y}$ & $2.4 \mathrm{E}-06$ & $3.2 \mathrm{E}-06$ & 2.4E-06 & $1.1 \mathrm{E}-05$ \\
\hline & & & sum & & & $2.4 \mathrm{E}-06$ & $3.2 E-06$ & 2.4E-06 & $1.1 \mathrm{E}-05$ \\
\hline \multirow[t]{2}{*}{ * B21 } & 608 & 008 & VOC-NONMETHANE & CHEMICAL SOURCE & $Y$ & $1.3 \mathrm{E}-02$ & $5.8 \mathrm{E}-02$ & $6.6 \mathrm{E}-02$ & 2.9E-01 \\
\hline & & & sum & & & $1.3 E-02$ & $5.8 \mathrm{E}-02$ & $6.6 E-02$ & 2.9E-01 \\
\hline
\end{tabular}




\begin{tabular}{|c|c|c|c|c|c|c|c|c|c|}
\hline EM & BLDG & ON & SUMMARY - & SOURCE TYPE & $\begin{array}{l}C \\
A \\
L \\
C\end{array}$ & $\begin{array}{l}\text { ACTUAL } \\
\text { HOURLY } \\
\text { LBS/HR }\end{array}$ & $\begin{array}{l}\text { ACTUAL } \\
\text { YEARLY } \\
\text { TNSNRR }\end{array}$ & $\begin{array}{c}\text { MAX } \\
\text { HOURLY } \\
\text { LBS/HR }\end{array}$ & $\begin{array}{c}\text { MAX } \\
\text { YEARLY } \\
\text { TNSTYR }\end{array}$ \\
\hline \multirow[t]{2}{*}{ B23 } & 602 & 002 & VOC-NONMETHANE & STORAGE TANK - VOC & $\mathbf{N}$ & 3.4E-01 & $9.1 \mathrm{E}-07$ & 3.4E-01 & $9.1 E-07$ \\
\hline & & & sum & & & $3.4 \mathrm{E}-01$ & $9.1 \mathrm{E}-07$ & 3.4E-01 & $9.1 E-07$ \\
\hline
\end{tabular}

* Not Significant Source 


\section{EMISSION SUMMARY - 1994}

\begin{tabular}{lllll} 
AREA & BLDG & VENT & POLLUTANT & SOURCE TYPE \\
\hline B27 & 601 & 001 & CARBON MONOXIDE & FUEL BURNING EQUIPMENT \\
& \multicolumn{4}{c}{ SUM }
\end{tabular}

* B27 $601 \quad 001 \quad$ NITROGEN OXIDES FUEL BURNING EQUIPMENT

SUM

* B27 $601 \quad 001 \quad$ PARTICULATE

SUM

* B27 $601 \quad 001 \quad$ SULFUR OXIDES

SUM

* B27 $601 \quad 001 \quad$ VOC-NONMETHANE FUEL BURNING EQUIPMENT

* 003
FUEL BURNING EQUIPMENT

FUEL BURNING EQUIPMENT STORAGE TANK - VOC

SUM

\begin{tabular}{ccccc} 
C & ACTUAL & ACTUAL & MAX & MAX \\
A & $\begin{array}{c}\text { HOURLY } \\
\text { YEARLY } \\
\text { C }\end{array}$ & $\begin{array}{c}\text { HOURLY } \\
\text { LBHR }\end{array}$ & $\begin{array}{c}\text { TNS } \text { TER } \\
\text { YBS/HR }\end{array}$ & $\begin{array}{c}\text { TERLY } \\
\text { TNSTR }\end{array}$ \\
\hline N & $3.3 E-01$ & $4.2 E-04$ & $6.5 E-01$ & $2.8 E+00$ \\
\hline & $3.3 E-01$ & $4.2 E-04$ & $6.5 E-01$ & $2.8 E+00$
\end{tabular}

$\mathbf{N}$

\begin{tabular}{llll}
$1.5 E+00$ & $2.0 E-03$ & $3.0 E+00$ & $1.3 E+01$ \\
\hline $1.5 E+00$ & $2.0 E-03$ & $3.0 E+00$ & $1.3 E+01$
\end{tabular}

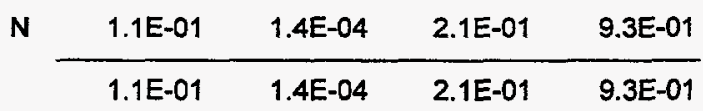

N

\begin{tabular}{cccc}
$9.9 E-02$ & $1.3 E-04$ & $2.0 E-01$ & $8.7 E-01$ \\
\hline $9.9 E-02$ & $1.3 E-04$ & $2.0 E-01$ & $8.7 E-01$
\end{tabular}

\begin{tabular}{lrrrr}
$N$ & $1.2 E-02$ & $1.6 E-05$ & $2.5 E-02$ & $1.1 E-01$ \\
$N$ & $3.4 E-01$ & $9.1 E-07$ & $3.4 E-01$ & $9.1 E-07$ \\
\hline & $3.5 E-01$ & $1.7 E-05$ & $3.6 E-01$ & $1.1 E-01$
\end{tabular}




\section{EMISSION SUMMARY - 1994}

\begin{tabular}{|c|c|c|c|c|}
\hline AREA & BLDG & VENT & POLLUTANT & SOURCE TYPE \\
\hline * CFA & 1603 & 001 & CARBON MONOXIDE & FUEL BURNING EQUIPMENT \\
\hline \multirow[t]{3}{*}{ * } & 604 & 001 & & FUEL BURNING EQUIPMENT \\
\hline & .607 & 004 & & FUEL BURNING EQUIPMENT \\
\hline & 608 & 001 & & FUEL BURNING EQUIPMENT \\
\hline \multirow[t]{6}{*}{ * } & 609 & 001 & & FUEL BURNING EQUIPMENT \\
\hline & & 005 & & FUEL BURNING EQUIPMENT \\
\hline & 613 & 003 & & FUEL BURNING EQUIPMENT \\
\hline & 650 & 007 & & FUEL BURNING EQUIPMENT \\
\hline & 662 & 011 & & FUEL BURNING EQUIPMENT \\
\hline & & 027 & & FUEL BURNING EQUIPMENT \\
\hline * & 664 & 034 & & FUEL BURNING EQUIPMENT \\
\hline \multirow[t]{2}{*}{ * } & & 035 & & FUEL BURNING EQUIPMENT \\
\hline & 665 & 029 & & FUEL BURNING EQUIPMENT \\
\hline \multirow[t]{4}{*}{ * } & 668 & 006 & & FUEL BURNING EQUIPMENT \\
\hline & & 023 & & FUEL BURNING EQUIPMENT \\
\hline & 671 & 007 & & FUEL BURNING EQUIPMENT \\
\hline & & 008 & & FUEL BURNING EQUIPMENT \\
\hline * & 675 & 002 & & FUEL BURNING EQUIPMENT \\
\hline \multirow{4}{*}{ 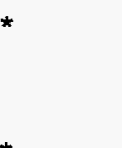 } & 679 & 007 & & FUEL BURNING EQUIPMENT \\
\hline & 688 & 043 & & FUEL BURNING EQUIPMENT \\
\hline & & 044 & & FUEL BURNING EQUIPMENT \\
\hline & & 047 & & FUEL BURNING EQUIPMENT \\
\hline
\end{tabular}

SuM

$\begin{array}{llll}* \text { CFA } & 104 & 001 & \text { NITROGEN OXIDES } \\ * & 1603 & 001 \\ * & 604 & 001 & \\ & 607 & 004 & \\ & 608 & 001 & \\ * & 609 & 001 & \\ & & 005 & \\ & 613 & 003 & \\ * & 625 & 009 \\ & 650 & 007 \\ & 662 & 011 \\ & & 027 \\ * & 664 & 034 \\ & & 035 \\ & 665 & 029 \\ & 668 & 006 \\ & & 023 \\ & 671 & 007 \\ & & 008 \\ * & 675 & 002 \\ * & 679 & 007 \\ & 688 & 043 \\ & & 044 \\ & & 047\end{array}$

FUEL BURNING EQUIPMENT FUEL BURNING EQUIPMENT FUEL BURNING EQUIPMENT FUEL BURNING EQUIPMENT FUEL BURNING EQUIPMENT FUEL BURNING EQUIPMENT FUEL BURNING EQUIPMENT CHEMICAL SOURCE FUEL BURNING EQUIPMENT FUEL BURNING EQUIPMENT FUEL BURNING EQUIPMENT FUEL BURNING EQUIPMENT FUEL BURNING EQUIPMENT FUEL BURNING EQUIPMENT FUEL BURNING EQUIPMENT FUEL BURNING EQUIPMENT FUEL BURNING EQUIPMENT FUEL BURNING EQUIPMENT FUEL BURNING EQUIPMENT FUEL BURNING EQUIPMENT FUEL BURNING EQUIPMENT FUEL BURNING EQUIPMENT FUEL BURNING EQUIPMENT

\begin{tabular}{|c|c|c|c|c|}
\hline L & $\begin{array}{l}\text { ACTUAL } \\
\text { HOURLY } \\
\text { LBS/HR }\end{array}$ & $\begin{array}{l}\text { ACTUAL } \\
\text { YEARLY } \\
\text { TNSNRR }\end{array}$ & $\begin{array}{c}\text { MAX } \\
\text { HOURLY } \\
\text { LBS/HR }\end{array}$ & $\begin{array}{c}\text { MAX } \\
\text { YEARLY } \\
\text { TNS/YR }\end{array}$ \\
\hline $\mathbf{N}$ & $1.4 E+00$ & $.8 E-02$ & $1.4 E+00$ & $3.7 E+C$ \\
\hline A & 2.6E-01 & $.9 E-03$ & $3 E+00$ & $5.7 \mathrm{E}+00$ \\
\hline Y & $4.5 \mathrm{E}-04$ & $.5 E-03$ & 7.2E-03 & $.5 \mathrm{E}-\mathrm{O}$ \\
\hline $\mathbf{N}$ & $5.7 \mathrm{E}-03$ & 3.2E-02 & $5.4 E-02$ & $2.3 \mathrm{E}-\mathrm{O}$ \\
\hline $\mathbf{N}$ & 7.3E-01 & $5.8 \mathrm{E}-03$ & $2.0 \mathrm{E}+00$ & $5.3 E+00$ \\
\hline$Y$ & $9.7 \mathrm{E}-03$ & $3.2 \mathrm{E}-02$ & 7.5E-02 & $6.3 \mathrm{E}-0$ \\
\hline$Y$ & $1.3 \mathrm{E}-03$ & 4.2E-03 & 1.3 & $.4 \mathrm{E}-0$ \\
\hline Y & $6.9 E-03$ & 2.3E-02 & 1.5 & $.8 \mathrm{E}-0$ \\
\hline Y & $1.7 \mathrm{E}-02$ & $E-02$ & 7.31 & $2.4 \mathrm{E}-0$ \\
\hline Y & 2.4E-02 & 02 & 1.7 & $.5 \mathrm{E}-0$ \\
\hline Y & $4.8 E-03$ & 04 & 4.8 & $1 E-0$ \\
\hline Y & $4.8 \mathrm{E}-03$ & 04 & 03 & $.1 E-0$ \\
\hline Y & $5.8 E-02$ & 01 & 01 & 1.1E+ +0 \\
\hline$N$ & $1.5 \mathrm{E}+00$ & BE-02 & $2.9 E+00$ & $3.9 \mathrm{E}+00$ \\
\hline Y & $.5 E-03$ & 02 & $1.3 \mathrm{E}-02$ & $4.2 \mathrm{E}-\mathrm{D}$ \\
\hline Y & $5.6 E-02$ & 22 & 01 & $.2 \mathrm{E}-0$ \\
\hline Y & $5.6 \mathrm{E}-02$ & 2 & 1.9 & 5.2E-0 \\
\hline $\mathbf{N}$ & 1 & 3 & $1.3 \mathrm{E}$ & $3.4 \mathrm{E}+0$ \\
\hline Y & $3.1 E+\infty 0$ & & 3. & $1.6 \mathrm{E}-0$ \\
\hline$Y$ & $2.2 E-02$ & 2 & 4.1 & $1.3 \mathrm{E}+00$ \\
\hline $\mathrm{N}$ & 2.2E-02 & 22 & $1.8 E-01$ & $5.4 E-C$ \\
\hline \multirow[t]{2}{*}{$\mathrm{N}$} & $9.8 E-01$ & $5.8 \mathrm{E}-03$ & $2.0 E+00$ & $5 E+c$ \\
\hline & $9.1 E+\infty 0$ & 8.2E-01 & $1.3 E+01$ & $37 \mathrm{~F}+$ \\
\hline$Y$ & $1.1 \mathrm{E}-01$ & $\mathrm{E}-02$ & 1.1 & $6 E-$ \\
\hline $\mathbf{N}$ & $6.3 E+00$ & 8.2E-02 & $6.3 E+00$ & $1.7 E+01$ \\
\hline $\mathbf{N}$ & $1.2 \mathrm{E}+00$ & $1.8 \mathrm{E}-02$ & $6.0 \mathrm{E}+00$ & $2.6 \mathrm{E}+0$ \\
\hline Y & $1.6 \mathrm{E}-03$ & 5.3E-03 & 2.6E-02 & $9.0 \mathrm{E}-\mathrm{C}$ \\
\hline $\mathbf{N}$ & 2.3E-02 & 1.3E-01 & $2.1 \mathrm{E}-01$ & $9.4 E-C$ \\
\hline $\mathbf{N}$ & $3.4 \mathrm{E}+00$ & 2.7E-02 & $9.1 \mathrm{E}+00$ & $2.4 \mathrm{E}+0$ \\
\hline Y & 3.9E-02 & $3 E-01$ & 3.0E-01 & $2.5 \mathrm{E}-$ \\
\hline Y & 4.6E-03 & $1.5 \mathrm{E}-02$ & $4.8 E-02$ & $.6 \mathrm{E}-$ \\
\hline$Y$ & $2.1 E-02$ & 2E-02 & $6.3 E-02$ & $6.5 E-$ \\
\hline$Y$ & $2.8 E-02$ & 1E-02 & $5.8 E-01$ & $1.9 E+1$ \\
\hline Y & $6.6 \mathrm{E}-02$ & 2.2E-01 & $2.9 \mathrm{E}-01$ & 9.5E-( \\
\hline Y & $9.6 E-02$ & $1 E-01$ & 6.7E-01 & $2.2 E+C$ \\
\hline Y & $3.5 \mathrm{E}-02$ & .4E-03 & $3.5 \mathrm{E}-02$ & $1.5 \mathrm{E}-\mathrm{C}$ \\
\hline$Y$ & 3.5E-02 & .4E-03 & $3.5 E-02$ & $.5 \mathrm{E}-$ \\
\hline Y & 3E-01 & $2 \mathrm{E}-01$ & $1.4 \mathrm{E}+00$ & $4.3 E+C$ \\
\hline $\mathbf{N}$ & $6.8 E+00$ & $1.8 \mathrm{E}-01$ & $1.4 E+01$ & $1.8 E+$ \\
\hline Y & $2.4 \mathrm{E}-02$ & 7E-02 & 4.6E-02 & $1.5 \mathrm{E}$ \\
\hline Y & 2.2E-01 & $6 E-01$ & 7.6E-01 & $2.5 E+C$ \\
\hline$Y$ & 2.2E-01 & $6 \mathrm{E}-01$ & 7.6E-01 & $2.5 E+C$ \\
\hline $\mathbf{N}$ & $4.5 E+00$ & 8E-02 & $5.9 \mathrm{E}+00$ & $1.6 \mathrm{E}+$ \\
\hline Y & $1.0 E+01$ & BE-03 & $1.2 \mathrm{E}-01$ & $.3 \mathrm{E}-$ \\
\hline $\mathrm{Y}$ & 8.7E-02 & 2.7E-01 & $1.6 E+00$ & \\
\hline $\mathbf{N}$ & $7 E-02$ & 7E-01 & 01 & \\
\hline iv & $4.5 E+00$ & 2.7E-02 & $9.1 E+\infty$ & \\
\hline
\end{tabular}

\footnotetext{
* Not Significant Source
} 


\section{EMISSION SUMMARY - 1994}

\begin{tabular}{|c|c|c|c|c|c|c|c|c|c|}
\hline AREA & BLDG & VENT & POLLUTANT & SOURCE TYPE & $\begin{array}{l}\mathrm{A} \\
\mathrm{L} \\
\mathbf{C}\end{array}$ & $\begin{array}{l}\text { ACTUAL } \\
\text { HOURLY } \\
\text { LBS/HR }\end{array}$ & $\begin{array}{l}\text { ACTUAL } \\
\text { YEARLY } \\
\text { TNS/YR }\end{array}$ & $\begin{array}{c}\text { MAX } \\
\text { HOURLY } \\
\text { LBS/HR }\end{array}$ & $\begin{array}{c}\text { MAX } \\
\text { YEARLYY } \\
\text { TNSIYR } \\
\end{array}$ \\
\hline & & & SUM & & & $3.8 E+01$ & $3.4 E+00$ & $5.8 E+01$ & $1.7 E+02$ \\
\hline * CFA & 100 & 001 & PARTICULATE & CHEMICAL SOURCE & $\mathbf{Y}$ & $4.1 \mathrm{E}+00$ & $4.4 E+00$ & $4.0 E+00$ & $4.4 \mathrm{E}+00$ \\
\hline * & 101 & 001 & & CHEMICAL SOURCE & Y & $1.3 \mathrm{E}-01$ & 5.5E-01 & $2.8 \mathrm{E}+00$ & $6.3 E-01$ \\
\hline * & 104 & 001 & & & $\mathrm{Y}$ & $3.7 \mathrm{E}+01$ & $4.0 E+01$ & $3.7 E+01$ & $4.0 \mathrm{E}+01$ \\
\hline * & 1603 & 001 & & FUEL BURNING EQUIPMENT & $\mathbf{N}$ & 4.4E-01 & 5.7E-03 & 4.4E-01 & $1.2 E+00$ \\
\hline * & 602 & 016 & & CHEMICAL SOURCE & $\mathrm{Y}$ & 2.3E-04 & $9.9 E-04$ & 2.3E-04 & $2.9 \mathrm{E}-02$ \\
\hline \multirow[t]{3}{*}{ * } & 604 & 001 & & FUEL BURNING EQUIPMENT & $\mathbf{N}$ & $8.5 \mathrm{E}-02$ & $1.3 \mathrm{E}-03$ & 4.3E-01 & $1.9 E+00$ \\
\hline & 607 & 004 & & FUEL BURNING EQUIPMENT & $\mathbf{Y}$ & $2.2 \mathrm{E}-04$ & 7.3E-04 & $3.6 \mathrm{E}-03$ & $1.3 \mathrm{E}-02$ \\
\hline & 608 & 001 & & FUEL BURNING EQUIPMENT & $\mathrm{N}$ & $2.3 \mathrm{E}-03$ & 1.3E-02 & $2.1 \mathrm{E}-02$ & $9.4 \mathrm{E}-02$ \\
\hline \multirow[t]{3}{*}{ * } & 609 & 001 & & FUEL BURNING EQUIPMENT & $\mathbf{N}$ & 2.4E-01 & $1.9 \mathrm{E}-03$ & $6.4 E-01$ & $1.7 E+00$ \\
\hline & & 005 & & FUEL BURNING EQUIPMENT & $\mathbf{Y}$ & $3.9 \mathrm{E}-03$ & 1.3E-02 & $3.0 \mathrm{E}-02$ & $2.5 \mathrm{E}-02$ \\
\hline & 613 & 003 & & FUEL BURNING EQUIPMENT & $\mathbf{Y}$ & $6.4 \mathrm{E}-04$ & 2.1E-03 & $6.7 \mathrm{E}-03$ & $2.2 \mathrm{E}-02$ \\
\hline * & 622 & 009 & & CHEMICAL SOURCE & $\mathrm{Y}$ & $1.4 \mathrm{E}-03$ & $1.5 \mathrm{E}-03$ & $1.6 \mathrm{E}-02$ & $1.6 \mathrm{E}-02$ \\
\hline * & & 015 & & CHEMICAL SOURCE & $\mathbf{Y}$ & $1.4 \mathrm{E}-03$ & $1.0 \mathrm{E}-03$ & $1.6 \mathrm{E}-02$ & $1.6 \mathrm{E}-02$ \\
\hline * & & 019 & & CHEMICAL SOURCE & $\mathbf{Y}$ & 1.4E-03 & $1.5 \mathrm{E}-03$ & $1.6 \mathrm{E}-02$ & $1.6 \mathrm{E}-02$ \\
\hline * & & 020 & & CHEMICAL SOURCE & $\mathbf{Y}$ & $1.4 \mathrm{E}-01$ & $1.5 \mathrm{E}-03$ & $1.6 \mathrm{E}-02$ & $1.6 \mathrm{E}-02$ \\
\hline * & & 021 & & CHEMICAL SOURCE & $\mathbf{Y}$ & $1.4 \mathrm{E}-03$ & $1.5 \mathrm{E}-03$ & $1.6 \mathrm{E}-02$ & $1.6 \mathrm{E}-02$ \\
\hline & 623 & 007 & & CHEMICAL SOURCE & Y & $2.6 \mathrm{E}+00$ & $2.7 E+00$ & $7.0 \mathrm{E}+00$ & $7.3 \mathrm{E}+00$ \\
\hline \multirow[t]{4}{*}{ * } & & 017 & & CHEMICAL SOURCE & $\mathbf{Y}$ & $8.0 \mathrm{E}-02$ & 4.0E-02 & $9.0 E-02$ & $1.0 \mathrm{E}-01$ \\
\hline & 650 & 007 & & FUEL BURNING EQUIPMENT & $\mathbf{Y}$ & $2.8 \mathrm{E}-03$ & $9.1 E-03$ & $5.8 \mathrm{E}-02$ & $1.9 E-01$ \\
\hline & 662 & 011 & & FUEL BURNING EQUIPMENT & Y & $6.6 \mathrm{E}-03$ & 2.2E-02 & $2.9 \mathrm{E}-02$ & $9.5 E-02$ \\
\hline & & 027 & & FUEL BURNING EQUIPMENT & $\mathbf{Y}$ & $9.6 \mathrm{E}-03$ & $3.1 \mathrm{E}-02$ & $6.7 \mathrm{E}-02$ & 2.2E-01 \\
\hline * & 664 & 034 & & FUEL BURNING EQUIPMENT & $\mathbf{Y}$ & $1.0 \mathrm{E}-03$ & 4.0E-05 & $1.0 E-03$ & $4.4 \mathrm{E}-03$ \\
\hline \multirow[t]{2}{*}{ * } & & 035 & & FUEL BURNING EQUIPMENT & $\mathbf{Y}$ & $1.0 \mathrm{E}-03$ & 4.0E-05 & $1.0 E-03$ & 4.4E-03 \\
\hline & 665 & 029 & & FUEL BURNING EQUIPMENT & $\mathbf{Y}$ & 2.3E-02 & $7.2 \mathrm{E}-02$ & $1.4 \mathrm{E}-01$ & 4.3E-01 \\
\hline * & & 050 & & CHEMICAL SOURCE & $\mathrm{Y}$ & $8.5 \mathrm{E}-02$ & $6.6 \mathrm{E}-02$ & $1.3 E-01$ & 1.3E-01 \\
\hline \multirow[t]{4}{*}{ * } & 658 & 006 & & FUEL BURNING EQUIPMENT & $\mathbf{N}$ & $4.8 \mathrm{E}-01$ & $1.2 \mathrm{E}-02$ & $9.6 \mathrm{E}-01$ & $1.3 \mathrm{E}+00$ \\
\hline & & 023 & & FUEL BURNING EQUIPMENT & $\mathbf{Y}$ & 3.3E-03 & $1.1 \mathrm{E}-02$ & $6.4 \mathrm{E}-03$ & 2.1E-02 \\
\hline & 671 & 007 & & FUEL BURNING EQUIPMENT & Y & $2.2 \mathrm{E}-02$ & $3.6 \mathrm{E}-02$ & 7.6E-02 & $2.5 E-01$ \\
\hline & & 008 & & FUEL BURNING EQUIPMENT & $\mathbf{Y}$ & $2.2 \mathrm{E}-02$ & $3.6 \mathrm{E}-02$ & $7.6 \mathrm{E}-02$ & 2.5E-01 \\
\hline * & 675 & 002 & & FUEL BURNING EQUIPMENT & $\mathbf{N}$ & $3.2 \mathrm{E}-01$ & $1.3 \mathrm{E}-03$ & 4.2E-01 & $1.1 E+00$ \\
\hline \multirow[t]{4}{*}{ * } & 679 & 007 & & FUEL BURNING EQUIPMENT & $\mathbf{Y}$ & $7.5 \mathrm{E}-03$ & $9.7 \mathrm{E}-05$ & $9.1 E-03$ & 4.0E-02 \\
\hline & 688 & 002 & & CHEMICAL SOURCE & $\mathbf{Y}$ & $1.0 \mathrm{E}-03$ & 2.6E-04 & $1.0 \mathrm{E}-03$ & $2.6 \mathrm{E}-04$ \\
\hline & & 043 & & FUEL BURNING EQUIPMENT & $\mathrm{Y}$ & $8.7 E-03$ & 2.7E-02 & $1.6 \mathrm{E}-01$ & 5.0E-01 \\
\hline & & 044 & & FUEL BURNING EQUIPMENT & $\mathbf{N}$ & 8.7E-03 & $2.7 \mathrm{E}-02$ & $7.0 \mathrm{E}-02$ & $2.2 \mathrm{E}-01$ \\
\hline \multirow[t]{3}{*}{ * } & & 047 & & FUEL BURNING EQUIPMENT & $\mathbf{N}$ & $3.2 E-01$ & $1.9 \mathrm{E}-03$ & $6.4 E-01$ & $2.8 \mathrm{E}+00$ \\
\hline & 690 & 048 & & CHEMICAL SOURCE & Y & $0.0 E+00$ & $0.0 \mathrm{E}+00$ & $2.2 E-02$ & $9.6 \mathrm{E}-02$ \\
\hline & & & sum & & & $4.6 \mathrm{E}+01$ & 4.8E+01 & $5.5 \mathrm{E}+01$ & $6.5 E+01$ \\
\hline * CFA & 104 & 001 & SULFUR OXIDES & & $Y$ & $5.8 \mathrm{E}-03$ & $1.3 \mathrm{E}-03$ & $5.8 \mathrm{E}-03$ & $1.3 \mathrm{E}-03$ \\
\hline * & 1603 & 001 & & FUEL BURNING EQUIPMENT & $\mathbf{N}$ & 4.1E-01 & 5.4E-03 & 4.1E-01 & $1.1 E+00$ \\
\hline \multirow[t]{3}{*}{ * } & 604 & 001 & & FUEL BURNING EQUIPMENT & $\mathbf{N}$ & $7.9 \mathrm{E}-02$ & $1.2 \mathrm{E}-03$ & $4.0 \mathrm{E}-01$ & $1.7 E+00$ \\
\hline & 607 & 004 & & FUEL BURNING EQUIPMENT & $\mathbf{Y}$ & $6.4 \mathrm{E}-03$ & $2.1 E-02$ & $1.0 E-01$ & $3.6 \mathrm{E}-01$ \\
\hline & 608 & 001 & & FUEL BURNING EQUIPMENT & $\mathbf{N}$ & $8.2 \mathrm{E}-02$ & 4.6E-01 & $7.7 \mathrm{E}-01$ & $3.4 \mathrm{E}+00$ \\
\hline \multirow[t]{4}{*}{ * } & 609 & 001 & & FUEL BURNING EQUIPMENT & $\mathbf{N}$ & $2.2 \mathrm{E}-01$ & $1.8 \mathrm{E}-03$ & $6.0 \mathrm{E}-01$ & $1.6 \mathrm{E}+00$ \\
\hline & & 005 & & FUEL BURNING EQUIPMENT & $\mathrm{Y}$ & $1.4 \mathrm{E}-01$ & 4.6E-01 & $1.1 E+\infty 0$ & $9.0 E-01$ \\
\hline & 613 & 003 & & FUEL BURNING EQUIPMENT & $Y$ & $1.9 E-02$ & $6.1 E-02$ & $1.9 E-01$ & 6.4E-01 \\
\hline & 650 & 007 & & FUEL BURNING EQUIPMENT & $\mathbf{Y}$ & $1.0 \mathrm{E}-01$ & 3.3E-01 & $2.1 \mathrm{E}+00$ & $6.8 E+00$ \\
\hline
\end{tabular}

\footnotetext{
* Not Significant Source
} 


\section{EMISSION SUMMARY - 1994}

\begin{tabular}{|c|c|c|c|c|}
\hline AREA & BLDG & VENT & POLLUTANT & SOURCE TYPE \\
\hline \multirow{3}{*}{ CFA } & \multirow[t]{2}{*}{662} & 011 & \multirow{14}{*}{ SULFUR OXIDES } & FUEL BURNING EQUIPMENT \\
\hline & & 027 & & FUEL BURNING EQUIPMENT \\
\hline & \multirow[t]{2}{*}{664} & 034 & & FUEL BURNING EQUIPMENT \\
\hline & & 035 & & FUEL BURNING EQUIPMENT \\
\hline & 665 & 029 & & FUEL BURNING EQUIPMENT \\
\hline & \multirow{2}{*}{668} & 006 & & FUEL BURNING EQUIPMENT \\
\hline & & 023 & & FUEL BURNING EQUIPMENT \\
\hline & \multirow[t]{2}{*}{671} & 007 & & FUEL BURNING EQUIPMENT \\
\hline & & 008 & & FUEL BURNING EQUIPMENT \\
\hline & 675 & 002 & & FUEL BURNING EQUIPMENT \\
\hline & 679 & 007 & & FUEL BURNING EQUIPMENT \\
\hline & \multirow[t]{3}{*}{688} & 043 & & FUEL BURNING EQUIPMENT \\
\hline & & 044 & & FUEL BURNING EQUIPMENT \\
\hline & & 047 & & FUEL BURNING EQUIPMENT \\
\hline
\end{tabular}

\begin{tabular}{|c|c|c|c|}
\hline * CFA & 101 & 001 & VOC-NONMETHANE \\
\hline & 102 & 001 & \\
\hline * & 103 & 001 & \\
\hline * & 104 & 001 & \\
\hline * & 1603 & 001 & \\
\hline \multirow[t]{3}{*}{ * } & 604 & 001 & \\
\hline & 607 & 004 & \\
\hline & 608 & 001 & \\
\hline * & 609 & 001 & \\
\hline \multirow[t]{2}{*}{ * } & & 002 & \\
\hline & & 005 & \\
\hline * & & 017 & \\
\hline \multirow[t]{2}{*}{ * } & 612 & 010 & \\
\hline & 613 & 003 & \\
\hline * & 623 & 005 & \\
\hline * & & 017 & \\
\hline \multirow[t]{5}{*}{ * } & 625 & 009 & \\
\hline & & 010 & \\
\hline & 650 & 007 & \\
\hline & 662 & 011 & \\
\hline & & 027 & \\
\hline * & 664 & 034 & \\
\hline \multirow[t]{2}{*}{ * } & & 035 & \\
\hline & 665 & 029 & \\
\hline * & & 050 & \\
\hline \multirow[t]{4}{*}{ * } & 668 & 006 & \\
\hline & & 023 & . \\
\hline & 671 & 007 & \\
\hline & & 008 & \\
\hline * & 675 & 002 & \\
\hline * & 679 & 007 & \\
\hline \multirow[t]{3}{*}{ * } & 688 & 003 & \\
\hline & & 043 & \\
\hline & & 044 & \\
\hline
\end{tabular}

CHEMICAL SOURCE

CHEMICAL SOURCE

CHEMICAL SOURCE

FUEL BURNING EQUIPMENT

FUEL BURNING EQUIPMENT

FUEL BURNING EQUIPMENT

FUEL BURNING EQUIPMENT

FUEL BURNING EQUIPMENT

STORAGE TANK - VOC

FUEL BURNING EQUIPMENT

CHEMICAL SOURCE

CHEMICAL SOURCE

FUEL BURNING EQUIPMENT

CHEMICAL SOURCE

CHEMICAL SOURCE

CHEMICAL SOURCE

CHEMICAL SOURCE

FUEL BURNING EQUIPMENT

FUEL BURNING EQUIPMENT

FUEL BURNING EQUIPMENT

FUEL BURNING EQUIPMENT

FUEL BURNING EQUIPMENT

FUEL BURNING EQUIPMENT

CHEMICAL SOURCE

FUEL BURNING EQUIPMENT

FUEL BURNING EQUIPMENT

FUEL BURNING EQUIPMENT

FUEL BURNING EQUIPMENT

FUEL BURNING EQUIPMENT

FUEL BURNING EQUIPMENT

STORAGE TANK - VOC

FUEL BURNING EQUIPMENT

FUEL BURNING EQUIPMENT

C

A ACTUAL

ACTUAL

MAX

MAX

L HOURLY

YEARLY

HOURLY

YEARLY

C LBS/HR

TNSTYR

LBS/HR

TNS/YR

$\begin{array}{llll}2.4 \mathrm{E}-01 & 7.8 \mathrm{E}-01 & 1.0 \mathrm{E}+00 & 3.4 \mathrm{E}+00\end{array}$

$Y \quad 3.4 E-01 \quad 1.1 E+00 \quad 2.4 E+00 \quad 7.9 E+00$

$Y \quad 2.5 E-03 \quad 1.0 E-04 \quad 2.5 E-03 \quad 1.1 E-02$

$Y \quad 2.5 E-03 \quad 1.0 E-04 \quad 2.5 E-03 \quad 1.1 E-02$

$Y \quad 8.4 E-01 \quad 2.6 E+00 \quad 5.0 E+00 \quad 1.5 E+01$

$N \quad 4.5 E-01 \quad 1.2 E-02 \quad 8.9 E-01 \quad 1.2 E+00$

$Y \quad 9.4 \mathrm{E}-02 \quad 3.1 \mathrm{E}-01 \quad 1.8 \mathrm{E}-01 \quad 6.0 \mathrm{E}-11$

$Y \quad 8.0 E-01 \quad 1.3 E+00 \quad 2.7 E+00 \quad 9.0 E+00$

$Y \quad 8.0 E-01 \quad 1.3 E+00 \quad 2.7 E+00 \quad 9.0 E+00$

$\mathrm{N} \quad 3.0 \mathrm{E}-01 \quad 1.2 \mathrm{E}-03 \quad 3.9 \mathrm{E}-01 \quad 1.1 \mathrm{E}+00$

$Y \quad 3.6 E-01 \quad 4.6 E-05 \quad 4.3 E-03 \quad 1.9 E-02$

$Y \quad 3.1 E-01 \quad 9.8 E-01 \quad 5.8 E+00 \quad 1.8 E+01$

$\mathrm{N} \quad 3.1 \mathrm{E}-01 \quad 9.8 \mathrm{E}-01 \quad 2.5 \mathrm{E}+00 \quad 7.8 \mathrm{E}+00$

N $3.0 E-01 \quad 1.8 E-03 \quad 6.0 E-01 \quad 2.6 E+00$

$\begin{array}{llll}6.2 \mathrm{E}+00 & 1.1 \mathrm{E}+01 & 3.0 \mathrm{E}+01 & 9.2 \mathrm{E}+01\end{array}$

$\mathbf{Y}$

4.7E-01

2.1E+00

4.7E-01

$2.1 E+00$

3.1E-01

$1.4 E+00$

3.1E-01

$1.4 E+00$

1.9E-01

8.4E-01

1.9E-01

8.4E-01

$Y \quad 1.4 E-01$

3.3E-02

1.4E-01

3.3E-02

N.1E-02

6.7E-04

5.1E-02

1.4E-01

9.9E-03

1.5E-04

4.9E-02

2.2E-01

6.3E-05

2.1E-04

1.0E-03

3.6E-03

N 3.9E-04

2.2E-03

3.6E-03

1.6E-02

2.8E-02

2.2E-04

7.4E-02

2.0E-01

$N \quad 0.0 E+00$

$0.0 E+00$

$0.0 E+00$

$0.0 E+00$

6.6E-04

2.2E-03

5.1E-03

4.3E-03

5. OE-03

2.5E-06

1.3E-02

5.8E-02

6.7E-03

2.8E-03

1.8E-02

1.9E-02

1.8E-04

6.0E-04

1.9E-03

6.3E-03

8. OE-02

3.5E-01

2.9E-01

1.3E+00

5.4E-01

$2.4 E+00$

1.7E+00

$7.4 E+01$

1.1E-01

1.1E-01

3.1E-01

3.2E-01

5.8E-02

6.0E-02

1.8E-01

1.8E-01

$Y \quad 4.7 E-04$

1.5E-03

9.9E-03

3.2E-02

$Y$ 1.1E-03

3.7E-03

4.9E-03

1.6E-02

$Y$ 1.6E-03

5.3E-03

1.1E-02

3.7E-02

$Y$ 1.3E-03

5.0E-05

1.3E-03

$5.5 \mathrm{E}-03$

$Y$ 1.3E-03

5.0E-05

1.3E-03

5.5E-03

2.3E-03

7.2E-03

1.4E-02

4.3E-02

5.7E-01

4.4E-01

8.5E-01

8.8E-01

$N \quad 5.5 E-02$

1.4E-03

1.1E-01

1.5E-01

9.3E-04

3. OE-03

1.8E-03

6.OE-03

$Y$ 3.8E-03

6.2E-03

1.3E-02

4.2E-02

$Y \quad 3.8 E-03$

6.2E-03

1.3E-02

4.2E-02

$N \quad 3.7 E-02 \quad 1.5 E-04$

4.8E-02

1.3E-01

Y 8.0E-03

1.0E-04

9.7E-03

4.2E-02

N $\quad 5.8 E-02$

1.1E-05

5.8E-02

1.1E-05

$Y \quad 8.7 E-04$

2.7E-03

1.6E-02

5.0E-02

$N$

4.6E-03

1.2E-02

3.7E-02

* Not Significant Source 


\section{EMISSION SUMMARY - 1994}

\begin{tabular}{|c|c|c|c|c|c|c|c|c|c|}
\hline & & & \multirow{2}{*}{$\begin{array}{l}\text { POLLUTANT } \\
\text { VOC-NONMETHANE }\end{array}$} & & & \\
\hline \multirow[t]{2}{*}{$\overline{\text { CFA }}$} & 688 & 047 & & FUEL BURNING EQUIPMENT & $\mathbf{N}$ & 3.7E-02 & $2.2 \mathrm{E}-04$ & 7.4E-02 & $3.2 E-01$ \\
\hline & 690 & 015 & & CHEMICAL SOURCE & $\mathbf{Y}$ & $0.0 E+00$ & $0.0 E+00$ & $9.6 \mathrm{E}-04$ & $1.0 E-03$ \\
\hline & 698 & 007 & & CHEMICAL SOURCE & Y & $0.0 E+00$ & $0.0 E+00$ & $0.0 E+\infty 0$ & $0.0 E+00$ \\
\hline & 708 & 001 & & STORAGE TANK - VOC & $\mathbf{N}$ & $1.2 \mathrm{E}-01$ & $1.1 \mathrm{E}-02$ & $1.2 \mathrm{E}-01$ & $1.1 \mathrm{E}-02$ \\
\hline & 713 & 001 & & STORAGE TANK - VOC & $\mathbf{N}$ & $3.2 \mathrm{E}+01$ & $9.3 E-02$ & $3.2 \mathrm{E}+01$ & 9.3E-02 \\
\hline & & 002 & & STORAGE TANK - VOC & $\mathbf{N}$ & $3.2 E+01$ & $9.3 E-02$ & $3.2 E+01$ & $9.3 E-02$ \\
\hline & 721 & 001 & & STORAGE TANK - VOC & $\mathbf{N}$ & $5.8 \mathrm{E}-02$ & 2.6E-04 & $5.8 \mathrm{E}-02$ & 2.6E-04 \\
\hline & 729 & 001 & & STORAGE TANK - VOC & $\mathbf{N}$ & $5.8 \mathrm{E}-02$ & 4.1E-05 & $5.8 \mathrm{E}-02$ & 4.1E-05 \\
\hline & $730^{\circ}$ & 001 & & STORAGE TANK - VOC & $N$ & $5.8 E-02$ & 8.4E-06 & $5.8 E-02$ & 8.4E-06 \\
\hline & 731 & 001 & & STORAGE TANK - VOC & $\mathbf{N}$ & $9.2 \mathrm{E}+00$ & 7.6E-02 & $9.2 \mathrm{E}+00$ & $7.6 \mathrm{E}-02$ \\
\hline & 732 & 001 & & STORAGE TANK - VOC & $\mathbf{N}$ & $5.8 \mathrm{E}-02$ & $1.2 \mathrm{E}-04$ & $5.8 \mathrm{E}-02$ & $1.2 E-04$ \\
\hline & 734 & 001 & & STORAGE TANK - VOC & $\mathbf{N}$ & $5.8 \mathrm{E}-02$ & 3.0E-06 & $5.8 \mathrm{E}-02$ & $3.0 \mathrm{E}-06$ \\
\hline & 735 & 001 & & STORAGE TANK - VOC & $\mathbf{N}$ & $0.0 E+00$ & $0.0 E+00$ & $0.0 \mathrm{E}+00$ & $0.0 E+00$ \\
\hline & 738 & 001 & & STORAGE TANK - VOC & $\mathbf{N}$ & $5.8 \mathrm{E}-02$ & $2.5 \mathrm{E}-05$ & $5.8 \mathrm{E}-02$ & $2.5 \mathrm{E}-05$ \\
\hline & 739 & 001 & & STORAGE TANK - VOC & $\mathbf{N}$ & $5.8 \mathrm{E}-02$ & 2.5E-05 & $5.8 \mathrm{E}-02$ & $2.5 E-05$ \\
\hline & 741 & 001 & & STORAGE TANK - VOC & $\mathbf{N}$ & $5.8 \mathrm{E}-02$ & $8.4 \mathrm{E}-04$ & $5.8 \mathrm{E}-02$ & 8.4E-04 \\
\hline & & 002 & & STORAGE TANK - VOC & $\mathbf{N}$ & $5.8 \mathrm{E}-02$ & $8.4 \mathrm{E}-04$ & $5.8 \mathrm{E}-02$ & 8.4E-04 \\
\hline & 749 & 001 & & STORAGE TANK - VOC & $\mathbf{Y}$ & 3.4E-01 & 3.2E-04 & 3.4E-01 & $6.5 E-04$ \\
\hline & 754 & 001 & & STORAGE TANK - VOC & $\mathbf{N}$ & $5.6 \mathrm{E}-02$ & $1.6 \mathrm{E}-02$ & $5.6 \mathrm{E}-02$ & $1.6 \mathrm{E}-02$ \\
\hline & & 002 & & STORAGE TANK - VOC & $\mathbf{N}$ & $5.5 \mathrm{E}-02$ & $1.2 \mathrm{E}-02$ & $5.5 \mathrm{E}-02$ & $1.2 E-02$ \\
\hline & & 003 & & STORAGE TANK - VOC & $\mathbf{N}$ & $2.9 \mathrm{E}+01$ & $8.6 \mathrm{E}-01$ & $2.9 E+01$ & $8.6 E-01$ \\
\hline & & 004 & & STORAGE TANK - VOC & $\mathbf{N}$ & 5.3E-02 & $2.2 \mathrm{E}-03$ & 5.3E-02 & 2.2E-03 \\
\hline & & 005 & & STORAGE TANK - VOC & $\mathbf{N}$ & 5.3E-02 & $2.2 E-03$ & 5.3E-02 & $2.2 E-03$ \\
\hline & & 006 & & STORAGE TANK - VOC & $\mathbf{N}$ & $5.8 \mathrm{E}-02$ & 2.7E-02 & $5.8 E-02$ & 2.7E-02 \\
\hline & & 007 & & STORAGE TANK - VOC & $\mathbf{N}$ & $2.9 E+01$ & $3.5 \mathrm{E}-01$ & $2.9 \mathrm{E}+01$ & $3.5 E-01$ \\
\hline & 757 & 001 & & STORAGE TANK - VOC & $\mathbf{N}$ & $5.8 \mathrm{E}-02$ & 3.5E-04 & $5.8 \mathrm{E}-02$ & $3.5 \mathrm{E}-04$ \\
\hline & 759 & 001 & & STORAGE TANK - VOC & $\mathbf{N}$ & $5.8 E-02$ & $3.6 \mathrm{E}-04$ & $5.8 \mathrm{E}-02$ & $3.6 \mathrm{E}-04$ \\
\hline & & & sum & & & $1.4 E+02$ & $9.2 E+00$ & $1.4 \mathrm{E}+02$ & $8.4 E+01$ \\
\hline
\end{tabular}




\section{EMISSION SUMMARY - 1994}

\begin{tabular}{|c|c|c|c|c|c|c|c|c|c|}
\hline AREA & BLDG & VENT & POLLUTANT & SOURCE TYPE & $\begin{array}{l}\mathrm{A} \\
\mathrm{C}\end{array}$ & $\begin{array}{l}\text { HOURLY } \\
\text { LBS/HR }\end{array}$ & $\begin{array}{l}\text { YEARLY } \\
\text { TNSIYR }\end{array}$ & $\begin{array}{l}\text { HOURLY } \\
\text { LBS/HR }\end{array}$ & $\begin{array}{l}\text { YEARLY } \\
\text { TNS/YR }\end{array}$ \\
\hline * CPP & 1642 & 007 & CARBON MONOXIDE & FUEL BURNING EQUIPMENT & $\mathbf{N}$ & $2.6 \mathrm{E}+00$ & 3.4E-02 & $2.9 E+00$ & $3.9 E+00$ \\
\hline * & 1643 & 007 & & FUEL BURNING EQUIPMENT & $\mathbf{N}$ & $2.6 E+\infty 0$ & 3.4E-02 & $2.9 \mathrm{E}+00$ & $3.9 E+00$ \\
\hline * & 1749 & 004 & & FUEL BURNING EQUIPMENT & $\mathbf{N}$ & $3.9 E-01$ & 2.3E-03 & $5.9 E-01$ & 2. $6 \mathrm{E}+00$ \\
\hline \multirow[t]{4}{*}{ * } & 603 & 008 & & FUEL BURNING EQUIPMENT & $\mathbf{Y}$ & $2.2 \mathrm{E}-02$ & $2.0 E-04$ & 3.4E-01 & $9.1 E-02$ \\
\hline & 606 & 004 & & FUEL BURNING EQUIPMENT & $\mathbf{N}$ & 1.1 $1 E+00$ & $1.7 \mathrm{E}+00$ & $1.8 \mathrm{E}+00$ & $7.9 E+00$ \\
\hline & & 005 & & FUEL BURNING EQUIPMENT & $\mathbf{N}$ & $7.8 \mathrm{E}-01$ & $7.8 E-01$ & $2.0 E+00$ & $8.8 E+00$ \\
\hline & & 019 & & FUEL BURNING EQUIPMENT & $\mathbf{N}$ & 4.6E-01 & 3.7E-01 & $2.0 E+00$ & $8.8 E+00$ \\
\hline * & 614 & 002 & & FUEL BURNING EQUIPMENT & $\mathbf{N}$ & $1.8 E+00$ & $2.9 \mathrm{E}-02$ & $2.1 \mathrm{E}+00$ & $2.8 E+00$ \\
\hline * & 616 & 004 & & FUEL BURNING EQUIPMENT & $\mathbf{N}$ & $2.0 E+00$ & 3.0E-02 & $2.8 E+00$ & $3.8 E+00$ \\
\hline \multirow[t]{2}{*}{ * } & 637 & 021 & & CHEMICAL SOURCE & $\mathbf{Y}$ & 4.6E-05 & 4.7E-05 & 4.6E-05 & 4.7E-05 \\
\hline & & 032 & & CHEMICAL SOURCE & $\mathbf{Y}$ & $2.0 E+00$ & 4.5E-02 & $2.0 E+00$ & $1.0 E+00$ \\
\hline * & 644 & 002 & & FUEL BURNING EQUIPMENT & $\mathbf{N}$ & $5.6 \mathrm{E}+00$ & $2.9 \mathrm{E}-01$ & $1.1 \mathrm{E}+01$ & $1.1 E+00$ \\
\hline * & & 005 & & FUEL BURNING EQUIPMENT & $\mathbf{N}$ & 1.4E+01 & 7.2E-02 & $2.7 E+01$ & $1.2 E+02$ \\
\hline * & 654 & 007 & & FUEL BURNING EQUIPMENT & $y$ & $1.3 \mathrm{E}-03$ & 3.3E-03 & $1.5 \mathrm{E}-03$ & 5.7E-03 \\
\hline * & & 008 & & FUEL BURNING EQUIPMENT & $\mathbf{Y}$ & $1.3 E-03$ & 3.3E-03 & $1.5 \mathrm{E}-03$ & 5.7E-03 \\
\hline * & & 009 & & FUEL BURNING EQUIPMENT & $\mathbf{Y}$ & $1.3 E-03$ & 3.3E-03 & $1.5 \mathrm{E}-03$ & $5.7 \mathrm{E}-03$ \\
\hline * & & 010 & & FUEL BURNING EQUIPMENT & $\mathbf{Y}$ & $1.3 \mathrm{E}-03$ & 3.3E-03 & $1.5 \mathrm{E}-03$ & $5.7 \mathrm{E}-03$ \\
\hline * & & 011 & & FUEL BURNING EQUIPMENT & $Y$ & $1.3 E-04$ & 3.3E-03 & $1.5 \mathrm{E}-01$ & $5.7 E+01$ \\
\hline * & & 012 & & FUEL BURNING EQUIPMENT & $\mathbf{Y}$ & $1.3 E-03$ & 3.3E-03 & $1.5 \mathrm{E}-03$ & $5.7 \mathrm{E}-03$ \\
\hline * & 655 & 018 & & FUEL BURNING EQUIPMENT & $\mathrm{Y}$ & 4.6E-05 & 4.7E-05 & $1.5 \mathrm{E}-01$ & $6.6 \mathrm{E}-03$ \\
\hline * & & 019 & & FUEL BURNING EQUIPMENT & $\mathrm{Y}$ & 4.9E-03 & $1.2 E-02$ & 5.1E-03 & $2.2 \mathrm{E}-02$ \\
\hline * & & 026 & & FUEL BURNING EQUIPMENT & $Y$ & 3.9E-03 & $9.8 E-03$ & 4.0E-03 & $1.8 E-02$ \\
\hline * & & 028 & & FUEL BURNING EQUIPMENT & $y$ & 3.9E-03 & $9.8 \mathrm{E}-03$ & 4.0E-03 & $1.8 \mathrm{E}-02$ \\
\hline * & & 030 & & FUEL BURNING EQUIPMENT & $\mathrm{Y}$ & 4.9E-03 & $1.2 \mathrm{E}-02$ & $4.9 E-03$ & $2.1 E-02$ \\
\hline * & & 031 & & FUEL BURNING EQUIPMENT & $Y$ & 4.9E-03 & $1.2 \mathrm{E}-02$ & 4.9E-03 & 2.1E-02 \\
\hline * & 659 & 006 & & FUEL BURNING EQUIPMENT & $\mathbf{N}$ & $6.5 E+00$ & $5.9 E-02$ & $1.5 E+02$ & $1.5 \mathrm{E}+01$ \\
\hline * & & 007 & & FUEL BURNING EQUIPMENT & $\mathbf{N}$ & $1.6 E+00$ & 2.3E-02 & $3.6 E+02$ & $1.6 \mathrm{E}+03$ \\
\hline * & & 008 & & FUEL BURNING EQUIPMENT & $\mathbf{N}$ & $5.6 E+00$ & $5.0 E-02$ & $1.2 E+02$ & $1.2 E+01$ \\
\hline * & 679 & 002 & & FUEL BURNING EQUIPMENT & $Y$ & 2.9E-03 & 7.3E-03 & $3.8 \mathrm{E}-02$ & 1.7E-02 \\
\hline * & & 003 & & FUEL BURNING EQUIPMENT & $\mathbf{Y}$ & $2.9 \mathrm{E}-03$ & 7.3E-03 & $3.8 \mathrm{E}-03$ & 1.7E-02 \\
\hline * & 687 & 026 & & FUEL BURNING EQUIPMENT & $\mathbf{N}$ & $5.6 \mathrm{E}+00$ & 2.9E-01 & $1.1 E+01$ & 1.1E+00 \\
\hline * & & 049 & & FUEL BURNING EQUIPMENT & $\mathbf{N}$ & 2.0E-01 & $1.3 \mathrm{E}-03$ & $3.9 \mathrm{E}-01$ & 1.1E+00 \\
\hline * & 698 & 009 & & FUEL BURNING EQUIPMENT & $Y$ & $1.5 \mathrm{E}-03$ & $1.1 \mathrm{E}-03$ & $1.8 \mathrm{E}-03$ & 7.9E-03 \\
\hline * & & 010 & & FUEL BURNING EQUIPMENT & $Y$ & $1.5 \mathrm{E}-03$ & 1.1E-03 & $1.8 \mathrm{E}-01$ & $7.9 E-03$ \\
\hline * & & 016 & & FUEL BURNING EQUIPMENT & $Y$ & $1.5 \mathrm{E}-03$ & 1.1E-03 & $1.8 \mathrm{E}-03$ & 7.9E-03 \\
\hline * & & 017 & & FUEL BURNING EQUIPMENT & $Y$ & $1.5 \mathrm{E}-03$ & 1.1E-03 & $1.8 \mathrm{E}-03$ & 7.9E-03 \\
\hline * & & 018 & & FUEL BURNING EQUIPMENT & $Y$ & $1.5 \mathrm{E}-03$ & $1.1 \mathrm{E}-03$ & $1.8 \mathrm{E}-03$ & 7.9E-03 \\
\hline & 708 & 001 & & CHEMICAL SOURCE & $\mathbf{Y}$ & $1.2 \mathrm{E}+02$ & $3.2 \mathrm{E}+02$ & $1.2 E+02$ & $1.1 E+03$ \\
\hline & 787 & 001 & & FUEL BURNING EQUIPMENT & $Y$ & $3.6 \mathrm{E}+01$ & $7.9 \mathrm{E}+01$ & $3.6 \mathrm{E}+01$ & $6.5 E+02$ \\
\hline * & $T-6$ & 001 & & FUEL BURNING EQUIPMENT & $\mathrm{Y}$ & $1.5 E-03$ & $3.8 \mathrm{E}-03$ & $1.8 \mathrm{E}-03$ & $7.9 \mathrm{E}-03$ \\
\hline * & & 004 & & FUEL BURNING EQUIPMENT & $\mathbf{Y}$ & $1.5 \mathrm{E}-03$ & $3.8 \mathrm{E}-03$ & $1.8 \mathrm{E}-03$ & $7.9 \mathrm{E}-03$ \\
\hline * & TR19 & 002 & & FUEL BURNING EQUIPMENT & $\mathrm{Y}$ & $1.5 \mathrm{E}-03$ & 3.7E-03 & $1.8 \mathrm{E}+00$ & $7.9 E+00$ \\
\hline * & TR29 & 001 & & FUEL BURNING EQUIPMENT & $Y$ & $9.8 \mathrm{E}-04$ & $2.5 \mathrm{E}-03$ & $9.8 \mathrm{E}-02$ & $3.9 E-03$ \\
\hline \multirow[t]{2}{*}{ * } & & 008 & & FUEL BURNING EQUIPMENT & $\mathrm{Y}$ & $9.8 \mathrm{E}-04$ & $2.5 E-03$ & $1.8 \mathrm{E}-03$ & $7.9 E-03$ \\
\hline & & & SUM & & & $2.1 E+02$ & $4.0 E+02$ & $8.6 E+02$ & $3.6 \mathrm{E}+03$ \\
\hline * CPP & 1642 & 007 & NITROGEN OXIDES & FUEL BURNING EQUIPMENT & $\mathbf{N}$ & $1.2 \mathrm{E}+01$ & $1.6 \mathrm{E}-01$ & $1.3 \mathrm{E}+01$ & $1.8 \mathrm{E}+01$ \\
\hline * & 1643 & 007 & & FUEL BURNING EQUIPMENT & $N$ & $1.2 \mathrm{E}+01$ & $1.6 \mathrm{E}-01$ & $1.3 E+01$ & $1.8 \mathrm{E}+01$ \\
\hline * & 1749 & 004 & & FUEL BURNING EQUIPMENT & $\mathbf{N}$ & $1.8 \mathrm{E}+00$ & $1.1 \mathrm{E}-02$ & $2.7 \mathrm{E}+00$ & $1.2 \mathrm{E}+01$ \\
\hline
\end{tabular}

* Not Significant Source 


\section{EMISSION SUMMARY - 1994}

\begin{tabular}{|c|c|c|c|c|c|c|c|c|c|}
\hline AREA & BLDG & VENT & POLLUTANT & SOURCE TYPE & L & $\begin{array}{l}\text { ACTUAL } \\
\text { HOURLY } \\
\text { LBSIHR }\end{array}$ & $\begin{array}{l}\text { ACTUAL } \\
\text { YEARLY } \\
\text { TNSYYR }\end{array}$ & $\begin{array}{l}\text { MAXX } \\
\text { HOURLY } \\
\text { LBSHRR }\end{array}$ & $\begin{array}{l}\text { MAX } \\
\text { YEARLY } \\
\text { TNS/YR }\end{array}$ \\
\hline \multirow[t]{4}{*}{ * CPP } & 603 & 008 & NITROGEN OXIDES & FUEL BURNING EQUIPMENT & $\bar{Y}$ & $1.6 \mathrm{E}-01$ & $1.4 \mathrm{E}-03$ & $2.5 \mathrm{E}-01$ & $6.8 \mathrm{E}-01$ \\
\hline & 606 & 004 & & FUEL BURNING EQUIPMENT & $\mathbf{N}$ & $4.2 \mathrm{E}+00$ & $6.6 \mathrm{E}+00$ & $7.2 \mathrm{E}+00$ & $3.2 E+01$ \\
\hline & & 005 & & FUEL BURNING EQUIPMENT & $\mathbf{N}$ & $3.1 E+\infty 0$ & $3.1 E+00$ & $8.0 E+00$ & $3.5 E+01$ \\
\hline & & 019 & & FUEL BURNING EQUIPMENT & $\mathbf{N}$ & $1.8 \mathrm{E}+00$ & $1.5 E+00$ & $8.0 E+00$ & $3.5 E+01$ \\
\hline * & 614 & 002 & & FUEL BURNING EQUIPMENT & $\mathbf{N}$ & $8.5 \mathrm{E}+00$ & $1.3 \mathrm{E}-01$ & $9.7 E+00$ & $1.3 E+01$ \\
\hline * & 616 & 004 & & FUEL BURNING EQUIPMENT & $\mathbf{N}$ & $9.1 \mathrm{E}+00$ & $1.4 \mathrm{E}-01$ & $1.3 E+01$ & $1.8 E+01$ \\
\hline \multirow[t]{3}{*}{ * } & 637 & 021 & & CHEMICAL SOURCE & $\mathbf{Y}$ & $3.4 E-04$ & $3.5 \mathrm{E}-04$ & $3.4 \mathrm{E}-04$ & 3.5E-04 \\
\hline & & 032 & & CHEMICAL SOURCE & $\mathbf{Y}$ & $2.0 E+00$ & $2,9 \mathrm{E}-02$ & $2.3 E+00$ & $1.1 E+00$ \\
\hline & & 056 & & CHEMICAL SOURCE & $\mathbf{Y}$ & & & $5.2 E+01$ & $3.1 E+\infty$ \\
\hline * & 644 & 002 & & FUEL BURNING EQUIPMENT & $\mathbf{N}$ & $2.1 \mathrm{E}+01$ & $1.1 E+00$ & 4.3E+01 & $4.3 \mathrm{E}+00$ \\
\hline * & & 005 & & FUEL BURNING EQUIPMENT & $\mathbf{N}$ & $3.5 \mathrm{E}-01$ & $1.9 \mathrm{E}-03$ & 7.1E-01 & $3.1 E+00$ \\
\hline * & 654 & 007 & & FUEL BURNING EQUIPMENT & $\mathbf{y}$ & $9.6 \mathrm{E}-03$ & $2.4 \mathrm{E}-02$ & 1.1E-01 & 4.2E-02 \\
\hline * & & 008 & & FUEL BURNING EQUIPMENT & $Y$ & $9.6 \mathrm{E}-03$ & $2.4 \mathrm{E}-02$ & $1.0 \mathrm{E}-01$ & 4.2E-02 \\
\hline * & & 009 & & FUEL BURNING EQUIPMENT & $\mathbf{Y}$ & $9.6 E-03$ & 2.4E-02 & $1.1 \mathrm{E}-02$ & 4.2E-02 \\
\hline * & & 010 & & FUEL BURNING EQUIPMENT & $\mathbf{Y}$ & $9.6 \mathrm{E}-03$ & $2.4 E-02$ & $1.1 \mathrm{E}-01$ & 4.2E-02 \\
\hline * & & 011 & & FUEL BURNING EQUIPMENT & $\mathbf{Y}$ & $9.6 E-03$ & $2.4 E-02$ & $1.1 \mathrm{E}-02$ & 4.0E-02 \\
\hline * & & 012 & & FUEL BURNING EQUIPMENT & $Y$ & $9.6 \mathrm{E}-03$ & $2.4 E-02$ & 1.1E-01 & 4.2E-02 \\
\hline * & 655 & 018 & & FUEL BURNING EQUIPMENT & $\mathbf{Y}$ & 3.4E-04 & $3.5 E-04$ & $1.1 \mathrm{E}-01$ & 4.8E-02 \\
\hline * & & 019 & & FUEL BURNING EQUIPMENT & $\mathbf{Y}$ & 3.6E-02 & $9.1 E-02$ & $3.8 \mathrm{E}-02$ & 1.7E-01 \\
\hline * & & 026 & & FUEL BURNING EQUIPMENT & $\mathrm{Y}$ & $2.9 \mathrm{E}-02$ & 7.3E-02 & $2.9 \mathrm{E}-02$ & 1.3E-01 \\
\hline * & & 028 & & FUEL BURNING EQUIPMENT & $y$ & $2.9 \mathrm{E}-02$ & 7.3E-02 & $2.9 \mathrm{E}-02$ & $1.3 E-01$ \\
\hline * & & 030 & & FUEL BURNING EQUIPMENT & $\mathrm{Y}$ & 3.6E-02 & $9.1 E-02$ & $3.8 E-01$ & $1.6 \mathrm{E}-01$ \\
\hline * & & 031 & & FUEL BURNING EQUIPMENT & $\mathrm{Y}$ & 3.6E-02 & $9.1 E-02$ & $3.6 \mathrm{E}-02$ & $1.6 \mathrm{E}-01$ \\
\hline * & 659 & 006 & & FUEL BURNING EQUIPMENT & $\mathbf{N}$ & $3.0 E+01$ & $2.7 \mathrm{E}-01$ & $6.8 E+02$ & $6.8 E+01$ \\
\hline * & & 007 & & FUEL BURNING EQUIPMENT & $\mathbf{N}$ & $4.2 \mathrm{E}-02$ & $5.9 E-04$ & $9.4 E+\infty 0$ & 4.1E+01 \\
\hline * & & 008 & & FUEL BURNING EQUIPMENT & $\mathbf{N}$ & $2.1 E+01$ & $1.9 E-01$ & $4.8 \mathrm{E}+02$ & $4.8 \mathrm{E}+01$ \\
\hline * & 679 & 002 & & FUEL BURNING EQUIPMENT & $\mathrm{Y}$ & 2.1E-02 & $5.3 E-02$ & $2.8 \mathrm{E}-02$ & $1.2 E-01$ \\
\hline * & & 003 & & FUEL BURNING EQUIPMENT & $\mathrm{Y}$ & 2.1E-02 & 5.3E-02 & $2.8 \mathrm{E}-02$ & $1.2 E-01$ \\
\hline * & 687 & 026 & & FUEL BURNING EQUIPMENT & $\mathbf{N}$ & $2.1 E+01$ & $1.1 E+\infty$ & $4.3 E+01$ & $4.3 E+\infty 0$ \\
\hline * & & 049 & & FUEL BURNING EQUIPMENT & $\mathbf{N}$ & 9.1E-01 & $5.9 E-03$ & $1.8 \mathrm{E}+00$ & $4.9 E+\infty 0$ \\
\hline * & 698 & 009 & & FUEL BURNING EQUIPMENT & $\mathrm{Y}$ & 1.1E-02 & $8.0 \mathrm{E}-03$ & $1.3 \mathrm{E}-02$ & 5.7E-02 \\
\hline * & & 010 & & FUEL BURNING EQUIPMENT & Y & $1.1 \mathrm{E}-02$ & $8.0 E-04$ & $1.3 \mathrm{E}-02$ & $5.7 \mathrm{E}-02$ \\
\hline * & & 016 & & FUEL BURNING EQUIPMENT & Y & 1.1E-02 & $8.0 \mathrm{E}-03$ & $1.3 \mathrm{E}-02$ & 5.7E-02 \\
\hline * & & 017 & & FUEL BURNING EQUIPMENT & $Y$ & $1.1 \mathrm{E}-02$ & $8.0 \mathrm{E}-03$ & $1.3 \mathrm{E}-02$ & 5.7E-02 \\
\hline * & & 018 & & FUEL BURNING EQUIPMENT & $\mathbf{Y}$ & $1.1 \mathrm{E}-02$ & $8.0 E-03$ & $1.3 \mathrm{E}-02$ & 5.7E-02 \\
\hline & 708 & 001 & & CHEMICAL SOURCE & $\mathbf{Y}$ & $1.7 E+02$ & 4.6E+02 & $4.7 \mathrm{E}+02$ & $1.7 E+03$ \\
\hline & 787 & 001 & & FUEL BURNING EQUIPMENT & $Y$ & $1.6 \mathrm{E}+01$ & $4.5 E+01$ & $1.6 E+01$ & $4.5 \mathrm{E}+02$ \\
\hline * & $T-6$ & 001 & & FUEL BURNING EQUIPMENT & $\mathrm{Y}$ & $1.1 \mathrm{E}-02$ & $2.8 \mathrm{E}-02$ & $1.3 \mathrm{E}-02$ & $5.7 \mathrm{E}-02$ \\
\hline$*$ & & 004 & & FUEL BURNING EQUIPMENT & $\mathbf{Y}$ & 1.1E-02 & $2.8 \mathrm{E}-02$ & $1.3 \mathrm{E}-02$ & 5.7E-02 \\
\hline * & TR19 & 002 & & FUEL BURNING EQUIPMENT & $\mathbf{Y}$ & $1.1 \mathrm{E}-02$ & $2.8 \mathrm{E}-02$ & 1.3E-02 & $5.7 \mathrm{E}-02$ \\
\hline * & TR29 & 001 & & FUEL BURNING EQUIPMENT & $\mathbf{Y}$ & 7.2E-03 & $1.8 \mathrm{E}-02$ & $1.3 \mathrm{E}-02$ & 5.7E-02 \\
\hline \multirow[t]{2}{*}{ * } & & 008 & & FUEL BURNING EQUIPMENT & $\mathbf{Y}$ & $7.2 E-03$ & $1.8 \mathrm{E}-02$ & 1.3E-02 & 5.7E-02 \\
\hline & & & SUM & & & $3.4 E+02$ & $5.2 E+02$ & $1.9 E+03$ & $2.5 \mathrm{E}+03$ \\
\hline CPP & 025 & 001 & PARTICULATE & CHEMICAL SOURCE & $Y$ & $2.0 \mathrm{E}-01$ & $7.9 E-03$ & 7.1E-01 & $3.1 E+00$ \\
\hline * & 1642 & 007 & & FUEL BURNING EQUIPMENT & $\mathbf{N}$ & $8.5 E-01$ & $1.1 \mathrm{E}-02$ & $9.5 \mathrm{E}-01$ & $1.3 E+00$ \\
\hline 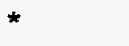 & 1643 & 007 & & FUEL BURNING EQUIPMENT & $\mathbf{N}$ & $8.5 \mathrm{E}-01$ & $1.1 \mathrm{E}-02$ & $9.5 \mathrm{E}-01$ & $1.3 E+00$ \\
\hline * & 1749 & 004 & & FUEL BURNING EQUIPMENT & $\mathbf{N}$ & $1.3 E-01$ & 7.6E-04 & $1.9 \mathrm{E}-01$ & $8.4 E-01$ \\
\hline \multirow[t]{2}{*}{ 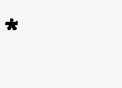 } & 603 & 008 & & FUEL BURNING EQUIPMENT & $\mathbf{Y}$ & 4.6E-03 & 4.1E-05 & $7.1 \mathrm{E}+00$ & $1.9 E-02$ \\
\hline & 606 & 004 & & FUEL BURNING EQUIPMENT & $\mathbf{N}$ & $4.2 \mathrm{E}-01$ & $6.6 \mathrm{E}-01$ & 7.2E-01 & $3.2 \mathrm{E}+00$ \\
\hline
\end{tabular}




\section{EMISSION SUMMARY - 1994}

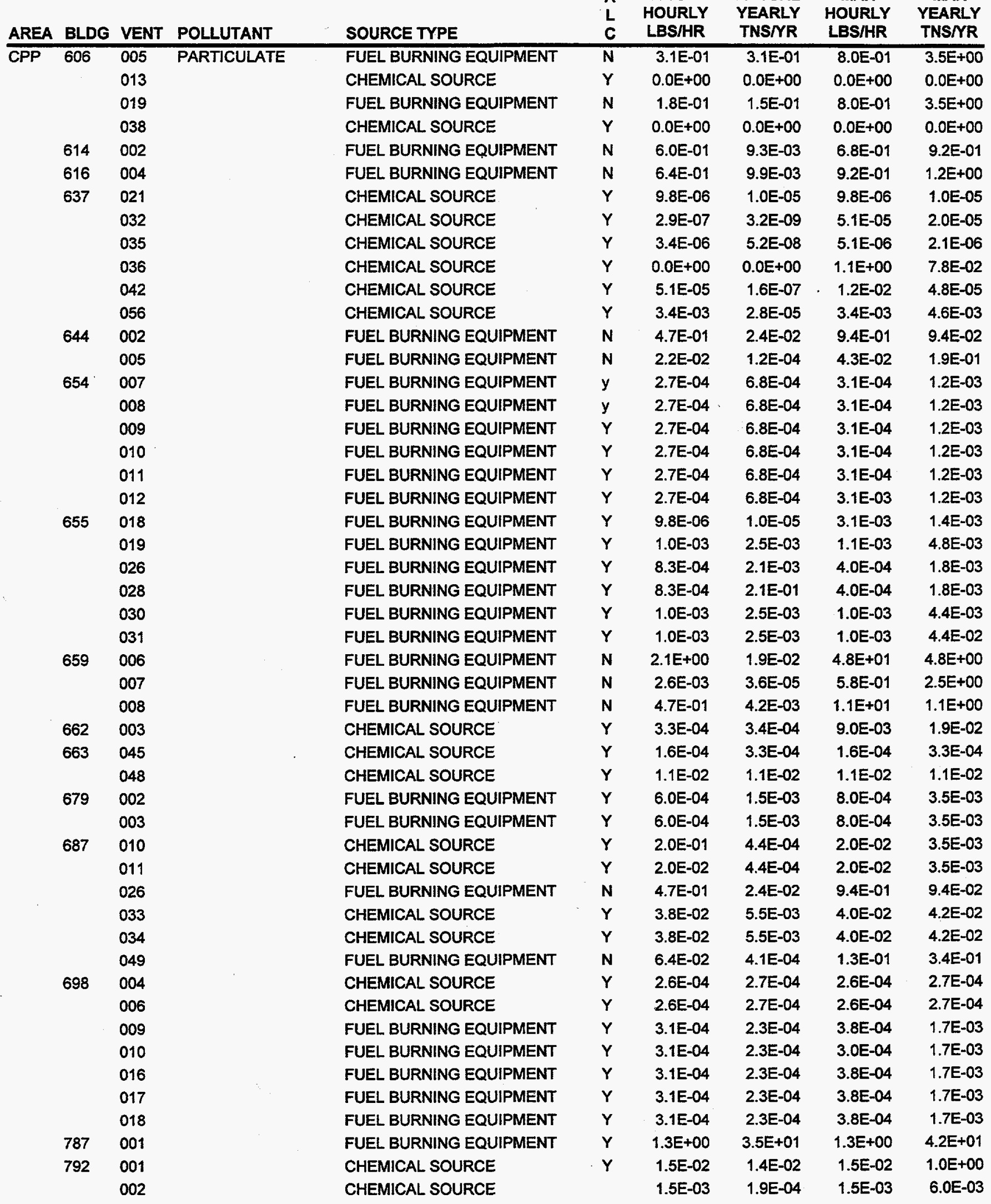

* Not Significant Source 


\section{EMISSION SUMMARY - 1994}

\begin{tabular}{|c|c|c|c|}
\hline AREA & BLDG & VENT & POLLUTANT \\
\hline \multirow[t]{3}{*}{ CPP } & 792 & 003 & PARTICULATE \\
\hline & 793 & 002 & \\
\hline & 794 & 001 & \\
\hline * & $T-6$ & 001 & \\
\hline * & & 004 & \\
\hline * & TR19 & 002 & \\
\hline * & TR29 & 001 & \\
\hline * & & 008 & \\
\hline
\end{tabular}

SUM

\begin{tabular}{|c|c|c|c|}
\hline * CPP & 1642 & 007 & SULFUR OXIDES \\
\hline * & 1643 & 007 & \\
\hline * & 1749 & 004 & \\
\hline \multirow[t]{4}{*}{ * } & 603 & 008 & \\
\hline & 606 & 004 & \\
\hline & & 005 & \\
\hline & & 019 & \\
\hline * & 614 & 002 & \\
\hline * & 616 & 004 & \\
\hline \multirow[t]{2}{*}{ * } & 637 & 021 & \\
\hline & & 032 & \\
\hline * & 644 & 002 & \\
\hline * & & 005 & \\
\hline * & 654 & 007 & \\
\hline * & & 008 & \\
\hline * & & 009 & \\
\hline * & & 010 & \\
\hline * & & 011 & \\
\hline * & & 012 & \\
\hline * & 655 & 018 & \\
\hline * & & 019 & \\
\hline * & & 026 & \\
\hline * & & 028 & \\
\hline * & & 030 & \\
\hline * & & 031 & \\
\hline $\begin{array}{l}\star \\
\star\end{array}$ & 659 & $\begin{array}{l}006 \\
007\end{array}$ & \\
\hline * & & 008 & \\
\hline * & 679 & 002 & \\
\hline * & & 003 & \\
\hline * & 687 & 026 & \\
\hline * & & 049 & \\
\hline * & 698 & 009 & \\
\hline * & & 010 & \\
\hline * & & 016 & \\
\hline * & & 017 & \\
\hline * & & 018 & \\
\hline & 708 & 001 & \\
\hline & 787 & 001 & \\
\hline * & $T-6$ & 001 & \\
\hline
\end{tabular}

SOURCE TYPE

CHEMICAL SOURCE

CHEMICAL SOURCE

CHEMICAL SOURCE

FUEL BURNING EQUIPMENT

FUEL BURNING EQUIPMENT

FUEL BURNING EQUIPMENT

FUEL BURNING EQUIPMENT

FUEL BURNING EQUIPMENT

FUEL BURNING EQUIPMENT FUEL BURNING EQUIPMENT FUEL BURNING EQUIPMENT FUEL BURNING EQUIPMENT FUEL BURNING EQUIPMENT FUEL BURNING EQUIPMENT FUEL BURNING EQUIPMENT FUEL BURNING EQUIPMENT FUEL BURNING EQUIPMENT CHEMICAL SOURCE

CHEMICAL SOURCE

FUEL BURNING EQUIPMENT FUEL BURNING EQUIPMENT FUEL BURNING EQUIPMENT FUEL BURNING EQUIPMENT FUEL BURNING EQUIPMENT FUEL BURNING EQUIPMENT FUEL BURNING EQUIPMENT FUEL BURNING EQUIPMENT FUEL BURNING EQUIPMENT FUEL BURNING EQUIPMENT FUEL BURNING EQUIPMENT FUEL BURNING EQUIPMENT FUEL BURNING EQUIPMENT FUEL BURNING EQUIPMENT FUEL BURNING EQUIPMENT FUEL BURNING EQUIPMENT FUEL BURNING EQUIPMENT FUEL BURNING EQUIPMENT FUEL BURNING EQUIPMENT FUEL BURNING EQUIPMENT FUEL BURNING EQUIPMENT FUEL BURNING EQUIPMENT FUEL BURNING EQUIPMENT FUEL BURNING EQUIPMENT FUEL BURNING EQUIPMENT FUEL BURNING EQUIPMENT CHEMICAL SOURCE

FUEL BURNING EQUIPMENT FUEL BURNING EQUIPMENT
ACTUAL ACTUAL

HOURLY YEARLY LBS/HR

TNSTR

MAX
HOURLY
LBS/HR

MAX

C

1.5E-03

1.1E-02

2.1E-01

4.9E-02

2.1E-01

1.1E+00

3.1E-04

7.8E-04

7.8E-04

3.1E-04

3.1E-04

7.8E-04

2.1E-04

5.3E-04

5.3E-04

2.1E-04

3.7E+0

$7.8 E+01$

1.0E-02

1.OE-02

7.1E-04

4.5E-05

2.4E+01

1.1E+01

$5.3 E+00$

8.7E-03

9.3E-03

1.1E-05

3.1E-05

1.8E-01

9.7E-05

7.6E-04

7.6E-04

7.6E-04

7.6E-04

7.6E-04

7.6E-04

1.1E-05

2.8E-03

2.3E-03

2.3E-03

2.8E-03

2.8E-03

1.8E-02

3.0E-05

3.1E-02

1.7E-03

1.7E-03

1.8E-01

3.9E-04

2.5E-04

2.5E-04

2.5E-04

2.5E-04

2.5E-04

5.9E-01

$5.4 \mathrm{E}+00$

8.6E-04
8.9E-01

8.9E-01

1.8E-01

7.8E-03

2.6E+01

$2.9 E+01$

2.9E+01

6.4E-01

8.6E-01

1.1E-05

7.6E-03

$6.9 \mathrm{E}+00$

3.6E-02

3.4E-04

3.4E-04

3.4E-04

3.4E-04

3.4E-04

3.4E-04

3.4E-04

1.2E-03

9.2E-04

9.2E-04

1.1E-03

1.1E-03

4. $4 E+01$

4.8E-01

7.7E+01

8.8E-04

8.8E-04

$6.9 \mathrm{E}+00$

1.2E-01

4.7E-04

4.7E-04

4.7E-04

4.7E-04

4.7E-04

2.2E-01

1. $9 \mathrm{E}+00$

4.1E-04
YEARLY 6.0E-03

8.0E-02

4. $0 \mathrm{E}-01$

1.7E-03

1.7E-03

1.7E-03

1.7E-02

1.7E-03

7.1E+01

1.2E +00 1.2E+00

7.8E-01

2.1E-02

$1.1 E+02$

1.3E+02

1.3E+02

8.6E-01

1.2E $\div 00$

1.1E-05

3.6E-03

6.9E-01

1.6E-01

1.3E-03

1.3E-03

1.3E-03

1.3E-03

1.3E-03

1.3E-03

1.5E-03

5.3E-03

4. $0 \mathrm{E}-03$

4.0E-03

4.8E-03

4.8E-03

4. $4 \mathrm{E}+00$

$2.1 E+00$

7.7E+00

3.9E-03

3.9E-03

6.9E-01

3.2E-01

1.8E-03

1.8E-03

1.8E-03

1.8E-03

1.8E-03

$7.9 \mathrm{E}+00$

4.3E+02

1.8E-03

* Not Significant Source 


\section{EMISSION SUMMARY - 1994}

\begin{tabular}{llll} 
AREA & BLDG & VENT & POLLUTANT \\
\hline CPP & T-6 & 004 & SULFUR OXIDES \\
& TR19 & 002 & \\
& TR29 & 001 & \\
& & 008 &
\end{tabular}

SUM

\begin{tabular}{|c|c|c|c|}
\hline * CPP & 1611 & 001 & VOC-NONMETHANE \\
\hline * & 1612 & 001 & \\
\hline * & 1642 & 003 & \\
\hline * & & 007 & \\
\hline$\star$ & 1643 & 003 & \\
\hline * & & 007 & \\
\hline * & 1749 & 004 & \\
\hline * & 601 & 024 & \\
\hline * & 602 & 012 & \\
\hline * & & 014 & \\
\hline * & & 031 & \\
\hline \multirow[t]{4}{*}{ * } & 603 & 008 & \\
\hline & 606 & 004 & \\
\hline & & 005 & \\
\hline & & 019 & \\
\hline * & 614 & 001 & \\
\hline * & & 002 & \\
\hline * & 616 & 004 & \\
\hline * & & 007 & \\
\hline * & 627 & 007 & \\
\hline * & & 008 & \\
\hline$\star$ & & 013 & \\
\hline * & 630 & 012 & \\
\hline * & 637 & 010 & \\
\hline \multirow[t]{2}{*}{ * } & & 021 & \\
\hline & & 032 & \\
\hline * & 644 & 002 & \\
\hline * & & 004 & \\
\hline * & & 005 & \\
\hline * & & 006 & \\
\hline * & & 013 & \\
\hline * & 654 & 007 & \\
\hline * & & 008 & \\
\hline * & & 009 & \\
\hline * & & 010 & \\
\hline * & & 011 & \\
\hline * & & 012 & \\
\hline * & 655 & 018 & \\
\hline * & & 019 & \\
\hline * & & 026 & \\
\hline * & & 028 & \\
\hline * & & 030 & \\
\hline * & & 031 & \\
\hline * & 659 & 006 & \\
\hline
\end{tabular}

SOURCE TYPE

FUEL BURNING EQUIPMENT FUEL BURNING EQUIPMENT FUEL BURNING EQUIPMENT FUEL BURNING EQUIPMENT

CHEMICAL SOURCE CHEMICAL SOURCE STORAGE TANK - VOC FUEL BURNING EQUIPMENT STORAGE TANK - VOC FUEL BURNING EQUIPMENT FUEL BURNING EQUIPMENT STORAGE TANK - VOC CHEMICAL SOURCE CHEMICAL SOURCE CHEMICAL SOURCE FUEL BURNING EQUIPMENT FUEL BURNING EQUIPMENT FUEL BURNING EQUIPMENT FUEL BURNING EQUIPMENT STORAGE TANK - VOC FUEL BURNING EQUIPMENT FUEL BURNING EQUIPMENT STORAGE TANK - VOC CHEMICAL SOURCE CHEMICAL SOURCE CHEMICAL SOURCE CHEMICAL SOURCE CHEMICAL SOURCE CHEMICAL SOURCE CHEMICAL SOURCE FUEL BURNING EQUIPMENT STORAGE TANK - VOC FUEL BURNING EQUIPMENT STORAGE TANK - VOC STORAGE TANK - VOC FUEL BURNING EQUIPMENT FUEL BURNING EQUIPMENT FUEL BURNING EQUIPMENT FUEL BURNING EQUIPMENT FUEL BURNING EQUIPMENT FUEL BURNING EQUIPMENT FUEL BURNING EQUIPMENT FUEL BURNING EQUIPMENT FUEL BURNING EQUIPMENT FUEL BURNING EQUIPMENT FUEL BURNING EQUIPMENT FUEL BURNING EQUIPMENT FUEL BURNING EQUIPMENT

\section{c}

\begin{tabular}{|c|c|c|c|c|}
\hline A & $\begin{array}{l}\text { ACTUAL } \\
\text { HOURLY } \\
\text { LBS/HR }\end{array}$ & $\begin{array}{l}\text { ACTUAL } \\
\text { YEARLY } \\
\text { TNS/YR }\end{array}$ & $\begin{array}{c}\text { MAX } \\
\text { HOURLY } \\
\text { LBS/HR }\end{array}$ & $\begin{array}{c}\text { MAX } \\
\text { YEARLY } \\
\text { TNSIYR }\end{array}$ \\
\hline$Y$ & 3.4E-04 & 8.6E-04 & 4.1E-04 & $1.8 \mathrm{E}-03$ \\
\hline$Y$ & $3.4 \mathrm{E}-04$ & 8.6E-04 & 4.1E-04 & $1.8 E-03$ \\
\hline Y & 2.3E-04 & $5.8 \mathrm{E}-04$ & 4.1E-04 & $1.8 \mathrm{E}-03$ \\
\hline \multirow[t]{2}{*}{$Y$} & 2.3E-04 & 5.8E-04 & 4.1E-04 & 1.8E-03 \\
\hline & & 7..1 & 2.ULT & \\
\hline
\end{tabular}$$
Y
$$$$
\text { N }
$$$$
\text { N }
$$$$
\text { n }
$$$$
\mathrm{N}
$$$$
\begin{aligned}
& \mathrm{N} \\
& \mathrm{Y}
\end{aligned}
$$$$
\begin{aligned}
& Y \\
& Y
\end{aligned}
$$$$
\begin{aligned}
& Y \\
& Y
\end{aligned}
$$

$Y$
$Y$

$Y$
$Y$
$Y$

$Y$
$N$
$N$

$\mathrm{N}$

$\mathrm{N}$

N

$\mathrm{N}$

$\mathrm{N}$

N

$Y$

$Y$

Y

$Y$

$Y$

$Y$

$Y$

$\mathrm{N}$

$\mathrm{N}$

$\mathrm{N}$

$\mathrm{N}$

$\mathrm{N}$

$N$

y

$Y$

$Y$

$Y$

$Y$

$\begin{array}{ll}Y & 3.4 E-04 \\ Y & 3.4 E-04\end{array}$

$\begin{array}{ll}Y & 3.4 E-04 \\ Y & 1.05\end{array}$

$\begin{array}{ll}Y & 1.2 E-05 \\ Y & 1.3 E-03\end{array}$

$Y \quad 1.0 E-03$

$1.0 \mathrm{E}-03$

$Y \quad 1.3 E-03$

$Y$ 1.3E-03

$N \quad 2.5 E-01$

\begin{tabular}{|c|c|c|}
\hline $0.0 E+00$ & $0.0 E+00$ & $0.0 E+00$ \\
\hline $0.0 E+00$ & $0.0 E+00$ & $0.0 E+00$ \\
\hline $3.5 \mathrm{E}-06$ & 1.7E-01 & 3.5E-06 \\
\hline $1.3 E-03$ & 1.1E-01 & $1.5 \mathrm{E}-01$ \\
\hline $3.6 \mathrm{E}-06$ & 1.7E-01 & 3.6E-06 \\
\hline 1.3E-03 & 1.1E-01 & $1.5 \mathrm{E}-01$ \\
\hline 8.9E-05 & 2.2E-02 & 9.7E-02 \\
\hline 4.0E-03 & 9.1E-04 & 4.0E-03 \\
\hline 7.6E-02 & $0.0 \mathrm{E}+00$ & $2.0 E+00$ \\
\hline $0.0 \mathrm{E}+00$ & $0.0 E+00$ & $0.0 \mathrm{E}+00$ \\
\hline $0.0 \mathrm{E}+00$ & $0.0 E+00$ & $0.0 \mathrm{E}+00$ \\
\hline 5.1E-05 & 8.9E-03 & 2.4E-02 \\
\hline $6.6 \mathrm{E}-02$ & 7.2E-02 & 3.2E-01 \\
\hline $3.1 E-02$ & 8.0E-02 & 3.5E-01 \\
\hline 1.5E-02 & $8.0 E-02$ & $3.5 E-01$ \\
\hline $6.6 \mathrm{E}-07$ & $3.4 E-01$ & 6.6E-07 \\
\hline 1.1E-03 & $7.9 E-02$ & 1.1E-01 \\
\hline 1.2E-03 & 1.1E-01 & 1.4E-01 \\
\hline 3.1E-06 & 3.4E-01 & 3.1E-06 \\
\hline $0.0 E+00$ & $0.0 E+00$ & $0.0 E+00$ \\
\hline 1.3E-03 & 1.3E-03 & $2.0 E+00$ \\
\hline $0.0 E+00$ & $0.0 E+00$ & $0.0 E+00$ \\
\hline 6.7E-04 & $6.4 \mathrm{E}-04$ & $2.0 E+00$ \\
\hline $3.8 \mathrm{E}-03$ & $1.8 \mathrm{E}-03$ & $2.0 \mathrm{E}+00$ \\
\hline 1.2E-05 & 1.2E-05 & 1.2E-05 \\
\hline 1.1E-05 & $3.2 \mathrm{E}-03$ & 4.6E-03 \\
\hline $3.6 \mathrm{E}-02$ & $1.4 E+00$ & $1.4 \mathrm{E}-01$ \\
\hline 7.9E-05 & $1.2 E+02$ & 7.9E-05 \\
\hline 3.5E-03 & $1.3 E+00$ & $5.7 \mathrm{E}+00$ \\
\hline 7.3E-05 & 1.7E-02 & 7.3E-05 \\
\hline 7.4E-04 & $1.2 E-01$ & 7.4E-04 \\
\hline 8.6E-04 & $3.9 E-04$ & $1.5 \mathrm{E}-03$ \\
\hline 8.6E-04 & $3.9 E-04$ & 1.5E-03 \\
\hline 8.6E-04 & $3.9 E-04$ & 1.5E-03 \\
\hline 8.6E-04 & $3.9 E-04$ & 1.5E-03 \\
\hline 8.6E-04 & $3.9 E-04$ & $1.5 E-03$ \\
\hline 8.6E-04 & $3.9 \mathrm{E}-04$ & $1.5 E-03$ \\
\hline 1.2E-05 & 3.9E-03 & 1.7E-03 \\
\hline 3.3E-03 & 1.4E-03 & $6.1 E-03$ \\
\hline 2.6E-03 & 1.1E-03 & 4.8E-03 \\
\hline 2.6E-03 & $1.3 \mathrm{E}-03$ & 5.7E-03 \\
\hline 3.3E-03 & 1.3E-03 & 3.3E-03 \\
\hline 3.3E-03 & 1.3E-03 & 5.7E-03 \\
\hline 2.2E-03 & $5.5 E+00$ & 5.5E-01 \\
\hline
\end{tabular}

* Not Significant Source 


\section{EMISSION SUMMARY - 1994}

\begin{tabular}{|c|c|c|c|c|c|c|c|c|c|}
\hline AREA & BLDG & VENT & POLLUTANT & SOURCE TYPE & L & $\begin{array}{l}\text { HOURLY } \\
\text { LBS/HR }\end{array}$ & $\begin{array}{l}\text { YEARLY } \\
\text { TNS/YR }\end{array}$ & $\begin{array}{l}\text { HOURLY } \\
\text { LBS/HR }\end{array}$ & $\begin{array}{l}\text { YEARLY } \\
\text { TNS/YR }\end{array}$ \\
\hline * $\overline{\mathrm{CPP}}$ & 659 & 007 & VOC-NONMETHANE & FUEL BURNING EQUIPMENT & $\mathbf{N}$ & $7.9 \mathrm{E}-02$ & $1.1 \mathrm{E}-03$ & $1.7 \mathrm{E}+01$ & $7.7 \mathrm{E}+01$ \\
\hline * & & 008 & & FUEL BURNING EQUIPMENT & $\mathbf{N}$ & $6.9 \mathrm{E}-01$ & $6.2 E-03$ & $1.5 E+01$ & $1.5 \mathrm{E}+00$ \\
\hline * & & 010 & & STORAGE TANK - VOC & $\mathbf{N}$ & $0.0 \mathrm{E}+00$ & $0.0 E+00$ & $0.0 E+00$ & $0.0 \mathrm{E}+00$ \\
\hline * & & 011 & & STORAGE TANK - VOC & $\mathbf{N}$ & $0.0 E+\infty$ & $0.0 \mathrm{E}+00$ & $0.0 E+00$ & $0.0 E+00$ \\
\hline * & & 033 & & CHEMICAL SOURCE & & $3.0 \mathrm{E}-02$ & $5.6 \mathrm{E}-02$ & $3.0 \mathrm{E}-02$ & $5.6 \mathrm{E}-02$ \\
\hline * & & 035 & & STORAGE TANK - VOC & $\mathbf{N}$ & $1.2 \mathrm{E}+02$ & $2.0 E-05$ & $1.2 E+02$ & $2.0 \mathrm{E}-05$ \\
\hline * & 663 & 054 & & CHEMICAL SOURCE & $\mathbf{Y}$ & $1.7 \mathrm{E}-02$ & $3.6 E-02$ & 1.7E-02 & $3.6 \mathrm{E}-02$ \\
\hline * & 679 & 002 & & FUEL BURNING EQUIPMENT & $\mathbf{Y}$ & $7.5 E-04$ & $1.9 E-03$ & $1.0 E-03$ & $4.4 \mathrm{E}-03$ \\
\hline * & & 003 & & FUEL BURNING EQUIPMENT & $\mathbf{Y}$ & $7.5 \mathrm{E}-04$ & $1.9 E-03$ & $1.0 \mathrm{E}-03$ & 4.4E-03 \\
\hline * & 687 & 026 & & FUEL BURNING EQUIPMENT & $\mathbf{N}$ & $6.9 \mathrm{E}-01$ & 3.6E-02 & $1.4 E+\infty 0$ & $1.4 \mathrm{E}-01$ \\
\hline * & & 049 & & FUEL BURNING EQUIPMENT & $\mathbf{N}$ & $7.4 E-03$ & $4.8 \mathrm{E}-05$ & $1.5 \mathrm{E}-02$ & $4.0 \mathrm{E}-02$ \\
\hline * & 694 & 007 & & CHEMICAL SOURCE & $\mathbf{Y}$ & $0.0 \mathrm{E}+00$ & $0.0 \mathrm{E}+00$ & $0.0 E+00$ & $0.0 \mathrm{E}+00$ \\
\hline * & & 008 & & CHEMICAL SOURCE & $\mathbf{Y}$ & $0.0 E+00$ & $0.0 E+00$ & $0.0 E+00$ & $0.0 E+00$ \\
\hline * & & 010 & & CHEMICAL SOURCE & $\mathbf{Y}$ & $0.0 E+\infty 0$ & $0.0 \mathrm{E}+00$ & $0.0 E+00$ & $0.0 \mathrm{E}+00$ \\
\hline * & 698 & 009 & & FUEL BURNING EQUIPMENT & $\mathrm{Y}$ & $3.9 E-04$ & 2.8E-04 & 4.7E-04 & 2.1E-03 \\
\hline * & & 010 & & FUEL BURNING EQUIPMENT & $\mathbf{Y}$ & $3.9 E-04$ & $2.8 \mathrm{E}-04$ & 4.7E-04 & $2.1 E-03$ \\
\hline * & & 016 & & FUEL BURNING EQUIPMENT & $\mathbf{Y}$ & $3.9 \mathrm{E}-04$ & $2.8 \mathrm{E}-04$ & 4.7E-04 & $2.1 E-03$ \\
\hline * & & 017 & & FUEL BURNING EQUIPMENT & $\mathbf{Y}$ & $3.9 E-04$ & $2.8 \mathrm{E}-04$ & 4.7E-04 & $2.1 \mathrm{E}-03$ \\
\hline * & & 018 & & FUEL BURNING EQUIPMENT & $\mathbf{Y}$ & $3.9 E-04$ & $2.8 \mathrm{E}-04$ & 4.7E-04 & $2.1 \mathrm{E}-03$ \\
\hline * & $701 \mathrm{~A}$ & 001 & & STORAGE TANK - VOC & $\mathbf{N}$ & $1.3 E-01$ & $6.3 \mathrm{E}-02$ & $1.3 E-01$ & 6.3E-02 \\
\hline * & $701 B$ & 001 & & STORAGE TANK - VOC & $\mathbf{N}$ & 3.7E-03 & $1.6 E-02$ & 3.7E-03 & $1.6 \mathrm{E}-02$ \\
\hline * & $702 \mathrm{~A}$ & 001 & & STORAGE TANK - VOC & $\mathbf{N}$ & $1.1 E-03$ & 4.8E-03 & 1.1E-03 & $4.8 \mathrm{E}-03$ \\
\hline * & $702 \mathrm{~B}$ & 001 & & STORAGE TANK - VOC & $\mathbf{N}$ & $1.1 \mathrm{E}-03$ & 4.8E-03 & 1.1E-03 & $4.8 \mathrm{E}-03$ \\
\hline * & 703 & 001 & & STORAGE TANK - VOC & $\mathbf{N}$ & $5.8 \mathrm{E}-02$ & $1.3 E-05$ & $5.8 E-02$ & $1.3 \mathrm{E}-05$ \\
\hline \multirow[t]{2}{*}{ * } & & 002 & & STORAGE TANK - VOC & $\mathbf{N}$ & $3.2 E+01$ & $1.7 \mathrm{E}-02$ & $3.2 E+01$ & $1.7 \mathrm{E}-02$ \\
\hline & 708 & 001 & & CHEMICAL SOURCE & $\mathbf{Y}$ & $3.7 E+00$ & $9.9 E+00$ & $4.0 E+01$ & $4.0 \mathrm{E}+01$ \\
\hline \multirow[t]{2}{*}{ * } & 775 & 005 & & STORAGE TANK - VOC & $\mathbf{N}$ & $1.2 \mathrm{E}-01$ & $1.1 E-03$ & $1.2 E-01$ & $1.1 \mathrm{E}-03$ \\
\hline & 787 & 001 & & FUEL BURNING EQUIPMENT & $Y$ & $7.9 \mathrm{E}-02$ & $2.2 \mathrm{E}-01$ & 7.9E-02 & $1.8 E+\infty$ \\
\hline * & $T-6$ & 001 & & FUEL BURNING EQUIPMENT & $\mathbf{Y}$ & $3.9 E-04$ & $9.8 \mathrm{E}-04$ & 4.7E-04 & 2.1E-03 \\
\hline * & & 004 & & FUEL BURNING EQUIPMENT & $Y$ & $3.9 \mathrm{E}-04$ & $9.8 \mathrm{E}-04$ & 4.7E-04 & 2.1E-03 \\
\hline * & TR19 & 002 & & FUEL BURNING EQUIPMENT & $\mathrm{Y}$ & $3.9 E-04$ & $9.8 E-04$ & 4.7E-04 & $2.1 \mathrm{E}-03$ \\
\hline * & TR29 & 001 & & FUEL BURNING EQUIPMENT & $\mathbf{Y}$ & 2.6E-04 & $6.6 \mathrm{E}-04$ & 4.7E-04 & $2.1 E-03$ \\
\hline \multirow[t]{2}{*}{ 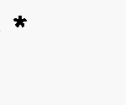 } & & 008 & & FUEL BURNING EQUIPMENT & $Y$ & 2.6E-04 & $6.6 \mathrm{E}-04$ & 4.7E-04 & 2.1E-03 \\
\hline & & & SUM & & & $2.8 E+02$ & $1.1 \mathrm{E}+01$ & $3.5 E+02$ & $1.4 E+02$ \\
\hline
\end{tabular}




\begin{tabular}{|c|c|c|c|c|c|c|c|c|c|}
\hline EN & IISSI & ON & SUMMARY - & SOURCE TYPE & $\begin{array}{l}\mathbf{C} \\
\mathbf{A} \\
\mathbf{L} \\
\mathbf{C}\end{array}$ & $\begin{array}{l}\text { ACTUAL } \\
\text { HOURLY } \\
\text { LBS/HR }\end{array}$ & $\begin{array}{l}\text { ACTUAL } \\
\text { YEARLY } \\
\text { TNS } Y R\end{array}$ & $\begin{array}{c}\text { MAX } \\
\text { HOURLY } \\
\text { LBSIHR }\end{array}$ & $\begin{array}{c}\text { MAX } \\
\text { YEARLY } \\
\text { TNSIYR }\end{array}$ \\
\hline \multirow[t]{2}{*}{ * HPTF } & 601 & 001 & CARBON MONOXIDE & FUEL BURNING EQUIPMENT & $Y$ & $3.1 E+01$ & 4.0E-01 & 3.7E-02 & $1.6 E-01$ \\
\hline & & & sum & & & $3.1 E+01$ & $4.0 \mathrm{E}-0.1$ & $3.7 E-02$ & $1.6 \mathrm{E}-01$ \\
\hline \multirow[t]{2}{*}{ * HPTF } & 601 & 001 & NITROGEN OXIDES & FUEL BURNING EQUIPMENT & $Y$ & $1.0 \mathrm{E}+04$ & $1.3 E+00$ & $1.2 \mathrm{E}-01$ & 5.3E-01 \\
\hline & & & SUM & & & $1.0 \mathrm{E}+04$ & $1.3 E+00$ & $1.2 E-01$ & 5.3E-01 \\
\hline \multirow[t]{2}{*}{ * HPTF } & 601 & 001 & PARTICULATE & FUEL BURNING EQUIPMENT & $\mathbf{Y}$ & $7.5 E+\infty 0$ & $9.7 E-02$ & $9.1 E-03$ & 4.0E-02 \\
\hline & & & sum & & & $7.5 \mathrm{E}+00$ & $9.7 \mathrm{E}-02$ & $9.1 \mathrm{E}-03$ & 4.0E-02 \\
\hline \multirow[t]{2}{*}{ * HPTF } & 601 & 001 & SULFUR OXIDES & FUEL BURNING EQUIPMENT & $Y$ & $3.6 \mathrm{E}+\infty 0$ & 4.6E-02 & 4.3E-03 & $1.9 E-02$ \\
\hline & & & sum & & & $3.6 \mathrm{E}+00$ & $4.6 \mathrm{E}-02$ & 4.3E-03 & $1.9 \mathrm{E}-02$ \\
\hline \multirow[t]{2}{*}{ * HPTF } & 601 & 001 & VOC-NONMETHANE & FUEL BURNING EQUIPMENT & $\mathbf{Y}$ & $8.0 E+00$ & $1.0 \mathrm{E}-01$ & $9.7 \mathrm{E}-03$ & 4.2E- 02 \\
\hline & & & sum & & & $8.0 E+00$ & $1.0 \mathrm{E}-01$ & $9.7 \mathrm{E}-03$ & 4.2E-02 \\
\hline
\end{tabular}




\section{EMISSION SUMMARY - 1994}

\begin{tabular}{|c|c|c|c|}
\hline AREA & BLDG & VENT & POLLUTANT \\
\hline \multirow[t]{4}{*}{ * NRF } & 602 & 005 & CARBON MONOXIDE \\
\hline & 620 & 012 & \\
\hline & & 013 & \\
\hline & & 014 & \\
\hline * & 622 & 001 & \\
\hline * & $633 A$ & 038 & \\
\hline * & 635 & 006 & \\
\hline * & & 007 & \\
\hline * & 686 & 016 & \\
\hline * & & 017 & \\
\hline * & & 018 & \\
\hline \multirow[t]{2}{*}{ * } & & 019 & \\
\hline & & & SUM \\
\hline NRF & 601 & $19 \mathrm{~A}$ & NITROGEN OXIDES \\
\hline \multirow[t]{4}{*}{ * } & 602 & 005 & \\
\hline & 620 & 012 & \\
\hline & & 013 & \\
\hline & & 014 & \\
\hline * & 622 & 001 & \\
\hline * & $633 A$ & 038 & \\
\hline * & 635 & 006 & \\
\hline * & & 007 & \\
\hline * & 686 & 016 & \\
\hline * & & 017 & \\
\hline * & & 018 & \\
\hline * & & 019 & \\
\hline
\end{tabular}

SUM

$\begin{array}{llll}\text { * NRF } & 602 & 005 & \text { PARTICULATE } \\ * & & 008 \\ * & & 023 \\ * & 618 & \text { HBR } \\ * & 619 & 004 \\ * & & 016 \\ * & & 017 \\ * & & 018 \\ & & 620 & 012 \\ & & 013 \\ & & 014 \\ * & 622 & 001 \\ * & 633 A & 038 \\ * & 635 & 006 \\ * & & 007 \\ * & 686 & 016 \\ * & & 017 \\ * & & 018 \\ * & & 019 \\ * & 716 & 001\end{array}$

SOURCE TYPE FUEL BURNING EQUIPMENT FUEL. BURNING EQUIPMENT FUEL BURNING EQUIPMENT FUEL BURNING EQUIPMENT FUEL BURNING EQUIPMENT FUEL BURNING EQUIPMENT FUEL BURNING EQUIPMENT FUEL BURNING EQUIPMENT FUEL BURNING EQUIPMENT FUEL BURNING EQUIPMENT FUEL BURNING EQUIPMENT

CHEMICAL SOURCE

FUEL BURNING EQUIPMENT FUEL BURNING EQUIPMENT FUEL BURNING EQUIPMENT FUEL BURNING EQUIPMENT FUEL BURNING EQUIPMENT FUEL BURNING EQUIPMENT FUEL BURNING EQUIPMENT FUEL BURNING EQUIPMENT FUEL BURNING EQUIPMENT FUEL BURNING EQUIPMENT FUEL BURNING EQUIPMENT FUEL BURNING EQUIPMENT

FUEL BURNING EQUIPMENT CHEMICAL SOURCE CHEMICAL SOURCE CHEMICAL SOURCE CHEMICAL SOURCE CHEMICAL SOURCE CHEMICAL SOURCE CHEMICAL SOURCE FUEL BURNING EQUIPMENT FUEL BURNING EQUIPMENT FUEL BURNING EQUIPMENT FUEL BURNING EQUIPMENT FUEL BURNING EQUIPMENT FUEL BURNING EQUIPMENT FUEL BURNING EQUIPMENT FUEL BURNING EQUIPMENT FUEL BURNING EQUIPMENT FUEL BURNING EQUIPMENT FUEL BURNING EQUIPMENT CHEMICAL SOURCE
FUEL BURNING EQUIPMENT

\section{C}

A ACTUAL ACTUAL MAX MAX

L HOURLY YEARLY HOURLY YEARLY C LBS/HR TNS/YR LBS/HR TNSTR

\begin{tabular}{lllll}
$\mathrm{N}$ & $1.6 \mathrm{E}+00$ & $7.8 \mathrm{E}-02$ & $1.6 \mathrm{E}+00$ & $2.1 \mathrm{E}+00$ \\
$\mathrm{~N}$ & $8.0 \mathrm{E}-01$ & $5.5 \mathrm{E}-01$ & $2.3 \mathrm{E}+00$ & $9.9 \mathrm{E}+00$ \\
$\mathrm{~N}$ & $8.0 \mathrm{E}-01$ & $5.5 \mathrm{E}-01$ & $2.3 \mathrm{E}+00$ & $9.9 \mathrm{E}+00$ \\
$\mathrm{~N}$ & $8.0 \mathrm{E}-01$ & $5.5 \mathrm{E}-01$ & $2.3 \mathrm{E}+00$ & $9.9 \mathrm{E}+00$ \\
$\mathrm{~N}$ & $1.6 \mathrm{E}+00$ & $1.2 \mathrm{E}-02$ & $1.6 \mathrm{E}+00$ & $2.1 \mathrm{E}+00$ \\
$\mathrm{~N}$ & $4.3 \mathrm{E}+00$ & $2.6 \mathrm{E}-01$ & $4.7 \mathrm{E}+00$ & $4.7 \mathrm{E}-01$ \\
$\mathrm{~N}$ & $1.0 \mathrm{E}+00$ & $2.6 \mathrm{E}-02$ & $1.6 \mathrm{E}+00$ & $2.2 \mathrm{E}+00$ \\
$\mathrm{~N}$ & $1.0 \mathrm{E}+00$ & $2.6 \mathrm{E}-02$ & $1.6 \mathrm{E}+00$ & $2.2 \mathrm{E}+00$ \\
$\mathrm{~N}$ & $7.8 \mathrm{E}+00$ & $2.4 \mathrm{E}-01$ & $1.0 \mathrm{E}+01$ & $1.0 \mathrm{E}+00$ \\
$\mathrm{~N}$ & $7.8 \mathrm{E}+00$ & $2.4 \mathrm{E}-01$ & $1.0 \mathrm{E}+01$ & $1.0 \mathrm{E}+00$ \\
$\mathrm{~N}$ & $7.8 \mathrm{E}+00$ & $2.4 \mathrm{E}-01$ & $1.0 \mathrm{E}+01$ & $1.0 \mathrm{E}+00$ \\
$\mathrm{~N}$ & $7.8 \mathrm{E}+00$ & $2.4 \mathrm{E}-01$ & $1.0 \mathrm{E}+01$ & $1.0 \mathrm{E}+00$ \\
\cline { 2 - 5 } & $4.3 \mathrm{E}+01$ & $3.0 \mathrm{E}+00$ & $5.8 \mathrm{E}+01$ & $4.3 \mathrm{E}+01$
\end{tabular}

\begin{tabular}{lllll}
$\mathrm{Y}$ & $0.0 \mathrm{E}+00$ & $0.0 \mathrm{E}+00$ & $0.0 \mathrm{E}+00$ & $0.0 \mathrm{E}+00$ \\
$\mathrm{~N}$ & $7.2 \mathrm{E}+00$ & $3.6 \mathrm{E}-01$ & $7.2 \mathrm{E}+00$ & $9.8 \mathrm{E}+00$ \\
$\mathrm{~N}$ & $8.8 \mathrm{E}+00$ & $6.1 \mathrm{E}+00$ & $2.5 \mathrm{E}+01$ & $1.1 \mathrm{E}+02$ \\
$\mathrm{~N}$ & $8.8 \mathrm{E}+00$ & $6.1 \mathrm{E}+00$ & $2.5 \mathrm{E}+01$ & $1.1 \mathrm{E}+02$ \\
$\mathrm{~N}$ & $8.8 \mathrm{E}+00$ & $6.1 \mathrm{E}+00$ & $2.5 \mathrm{E}+01$ & $1.1 \mathrm{E}+02$ \\
$\mathrm{~N}$ & $7.2 \mathrm{E}+00$ & $5.8 \mathrm{E}-02$ & $7.2 \mathrm{E}+00$ & $9.8 \mathrm{E}+00$ \\
$\mathrm{~N}$ & $1.6 \mathrm{E}+01$ & $9.8 \mathrm{E}-01$ & $1.8 \mathrm{E}+01$ & $1.8 \mathrm{E}+00$ \\
$\mathrm{~N}$ & $4.7 \mathrm{E}+00$ & $1.2 \mathrm{E}-01$ & $7.6 \mathrm{E}+00$ & $1.0 \mathrm{E}+01$ \\
$\mathrm{~N}$ & $4.7 \mathrm{E}+00$ & $1.2 \mathrm{E}-01$ & $7.6 \mathrm{E}+00$ & $1.0 \mathrm{E}+01$ \\
$\mathrm{~N}$ & $3.0 \mathrm{E}+01$ & $9.2 \mathrm{E}-01$ & $3.8 \mathrm{E}+01$ & $3.8 \mathrm{E}+00$ \\
$\mathrm{~N}$ & $3.0 \mathrm{E}+01$ & $9.2 \mathrm{E}-01$ & $3.8 \mathrm{E}+01$ & $3.8 \mathrm{E}+00$ \\
$\mathrm{~N}$ & $3.0 \mathrm{E}+01$ & $9.2 \mathrm{E}-01$ & $3.8 \mathrm{E}+01$ & $3.8 \mathrm{E}+00$ \\
$\mathrm{~N}$ & $3.0 \mathrm{E}+01$ & $9.2 \mathrm{E}-01$ & $3.8 \mathrm{E}+01$ & $3.8 \mathrm{E}+00$ \\
\cline { 2 - 5 } & $1.9 \mathrm{E}+02$ & $2.3 \mathrm{E}+01$ & $2.7 \mathrm{E}+02$ & $3.8 \mathrm{E}+02$
\end{tabular}

$\begin{array}{lllll}N & 5.1 E-01 & 2.6 E-02 & 5.1 E-01 & 6.9 E-01 \\ Y & 0.0 E+00 & 0.0 E+00 & 0.0 E+00 & 0.0 E+00 \\ Y & 0.0 E+00 & 0.0 E+00 & 0.0 E+00 & 0.0 E+00 \\ Y & 0.0 E+00 & 0.0 E+00 & 0.0 E+00 & 0.0 E+00 \\ Y & 0.0 E+00 & 0.0 E+00 & 0.0 E+00 & 0.0 E+00 \\ Y & 0.0 E+00 & 0.0 E+00 & 0.0 E+00 & 0.0 E+00 \\ Y & 0.0 E+00 & 0.0 E+00 & 0.0 E+00 & 0.0 E+00 \\ Y & 8.7 E-02 & 6.6 E-02 & 2.5 E-01 & 2.0 E-01 \\ N & 1.6 E+00 & 1.1 E+00 & 4.5 E+00 & 2.0 E+01 \\ N & 1.6 E+00 & 1.1 E+00 & 4.5 E+00 & 2.0 E+01 \\ N & 1.6 E+00 & 1.1 E+00 & 4.5 E+00 & 2.0 E+01 \\ N & 5.1 E-01 & 4.1 E-03 & 5.1 E-01 & 6.9 E-01 \\ N & 3.6 E-01 & 2.2 E-02 & 4.0 E-01 & 4.0 E-02 \\ N & 3.3 E-01 & 8.5 E-03 & 5.3 E-01 & 7.2 E-01 \\ N & 3.3 E-01 & 8.5 E-03 & 5.3 E-01 & 7.2 E-01 \\ N & 6.6 E-01 & 2.0 E-02 & 8.5 E-01 & 8.5 E-02 \\ N & 6.6 E-01 & 2.0 E-02 & 8.5 E-01 & 8.5 E-02 \\ N & 6.6 E-01 & 2.0 E-02 & 8.5 E-01 & 8.5 E-02 \\ N & 6.6 E-01 & 2.0 E-02 & 8.5 E-01 & 8.5 E-02 \\ Y & 3.0 E+00 & 1.3 E+01 & 4.2 E+01 & 1.9 E+02\end{array}$

* Not Significant Source 


\section{EMISSION SUMMARY - 1994}

AREA BLDG VENT POLLUTANT

SUM

\begin{tabular}{|c|c|c|c|}
\hline \multirow[t]{2}{*}{ NRF } & 601 & $19 A$ & SULFUR OXIDES \\
\hline & 602 & 005 & \\
\hline & 620 & 012 & \\
\hline & & 013 & \\
\hline & & 014 & \\
\hline & 622 & 001 & \\
\hline & 633A & 038 & \\
\hline & \multirow[t]{2}{*}{635} & 006 & \\
\hline & & 007 & \\
\hline & \multirow[t]{4}{*}{686} & 016 & \\
\hline & & 017 & \\
\hline & & 018 & \\
\hline & & 019 & \\
\hline
\end{tabular}

suM

\begin{tabular}{|c|c|c|c|c|}
\hline \multirow{3}{*}{\multicolumn{2}{|c|}{ NRF }} & $19 \mathrm{~A}$ & \multirow[t]{2}{*}{ VOC-NONMETHANE } & \multirow{2}{*}{$\begin{array}{l}\text { CHEMICAL SOURCE } \\
\text { FUEL BURNING EQUIPMENT }\end{array}$} \\
\hline & & 005 & & \\
\hline & & 006 & & CHEMICAL SOURCE \\
\hline & 603 & 039 & & CHEMICAL SOURCE \\
\hline & 616 & 012 & & CHEMICAL SOURCE \\
\hline & $617 \mathrm{C}$ & 003 & & STORAGE TANK - VOC \\
\hline & \multirow[t]{2}{*}{618} & 099 & & CHEMICAL SOURCE \\
\hline & & 103 & & CHEMICAL SOURCE \\
\hline & 619 & 018 & & CHEMICAL SOURCE \\
\hline & \multirow[t]{3}{*}{620} & 012 & & FUEL BURNING EQUIPMENT \\
\hline & & 013 & & FUEL BURNING EQUIPMENT \\
\hline & & 014 & & FUEL. BURNING EQUIPMENT \\
\hline & 622 & 001 & & FUEL BURNING EQUIPMENT \\
\hline & 633A & 038 & & FUEL BURNING EQUIPMENT \\
\hline & \multirow[t]{2}{*}{635} & 006 & & FUEL BURNING EQUIPMENT \\
\hline & & 007 & & FUEL BURNING EQUIPMENT \\
\hline & 663 & 022 & & CHEMICAL SOURCE \\
\hline & \multirow[t]{8}{*}{686} & 001 & & STORAGE TANK - VOC \\
\hline & & 002 & & STORAGE TANK - VOC \\
\hline & & 003 & & STORAGE TANK - VOC \\
\hline & & 004 & & STORAGE TANK - VOC \\
\hline & & 016 & & FUEL BURNING EQUIPMENT \\
\hline & & 017 & & FUEL BURNING EQUIPMENT \\
\hline & & 018 & & FUEL BURNING EQUIPMENT \\
\hline & & 019 & & FUEL BURNING EQUIPMENT \\
\hline & $711 \mathrm{~A}$ & 001 & & STORAGE TANK - VOC \\
\hline & $711 B$ & 001 & & STORAGE TANK - VOC \\
\hline & $711 C$ & 001 & & STORAGE TANK - VOC \\
\hline & \multirow[t]{2}{*}{747} & 001 & & STORAGE TANK - VOC \\
\hline & & 002 & & STORAGE TANK - VOC \\
\hline
\end{tabular}

SUM

SOURCE TYPE

CHEMICAL SOURCE

FUEL BURNING EQUIPMENT

FUEL BURNING EQUIPMENT

FUEL BURNING EQUIPMENT

FUEL BURNING EQUIPMENT

FUEL BURNING EQUIPMENT

FUEL BURNING EQUIPMENT

FUEL BURNING EQUIPMENT

FUEL BURNING EQUIPMENT

FUEL BURNING EQUIPMENT

FUEL BURNING EQUIPMENT

FUEL BURNING EQUIPMENT

FUEL BURNING EQUIPMENT

$A$
$C$
$Y$
$N$
$N$
$N$
$N$
$N$
$N$
$N$
$N$
$N$
$N$
$N$
$N$

\begin{tabular}{l} 
C \\
A \\
L \\
C \\
\hline
\end{tabular}

ACTUAL ACTUAL

LBS/HR

TNSMR

LBS/HR

$1.3 E+01$

$1.6 \mathrm{E}+01$

$6.2 E+01$

$2.5 \mathrm{E}+02$

$\begin{array}{lllll}Y & 0.0 E+00 & 0.0 E+00 & 0.0 E+00 & 0.0 E+00\end{array}$

$\mathrm{N} \quad 4.8 \mathrm{E}-01 \quad 2.4 \mathrm{E}-02 \quad 4.8 \mathrm{E}-01 \quad 6.4 \mathrm{E}-01$

$N \quad 3.8 E+01 \quad 2.6 E+01 \quad 1.1 E+02 \quad 4.7 E+02$

$N \quad 3.8 E+01 \quad 2.6 E+01 \quad 1.1 E+02 \quad 4.7 E+02$

$\mathrm{N} \quad 3.8 \mathrm{E}+01 \quad 2.6 \mathrm{E}+01 \quad 1.1 \mathrm{E}+02 \quad 4.7 \mathrm{E}+02$

$N \quad 4.8 E-01 \quad 3.8 E-03 \quad 4.8 E-01 \quad 6.4 E-01$

$N \quad 2.7 E+00 \quad 1.6 E-01 \quad 2.9 E+00 \quad 2.9 E-01$

$N \quad 3.1 E-01 \quad 7.9 E-03 \quad 5.0 E-01 \quad 6.7 E-01$

$N \quad 3.1 E-01 \quad 7.9 E-03 \quad 5.0 E-01 \quad 6.7 E-01$

$N \quad 4.8 E+00 \quad 1.5 E-01 \quad 6.2 E+00 \quad 6.2 E-01$

$N \quad 4.8 E+00 \quad 1.5 E-01 \quad 6.2 E+00 \quad 6.2 E-01$

$N \quad 4.8 E+00 \quad 1.5 E-01 \quad 6.2 E+00 \quad 6.2 E-01$

$\mathrm{N} \quad 4.8 \mathrm{E}+00 \quad 1.5 \mathrm{E}-01 \quad 6.2 \mathrm{E}+00 \quad 6.2 \mathrm{E}-01$

\begin{tabular}{llll}
\hline $1.4 E+02$ & $8.0 E+01$ & $3.5 E+02$ & $1.4 E+03$
\end{tabular}

$\begin{array}{lllll}Y & 0.0 E+00 & 0.0 E+00 & 0.0 E+00 & 0.0 E+00\end{array}$

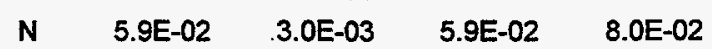

$\begin{array}{lllll}Y & 0.0 E+00 & 0.0 E+00 & 0.0 E+00 & 0.0 E+00\end{array}$

$\begin{array}{lllll}Y & 0.0 E+00 & 0.0 E+00 & 0.0 E+00 & 0.0 E+00\end{array}$

$\begin{array}{lllll}Y & 0.0 E+00 & 0.0 E+00 & 0.0 E+00 & 0.0 E+00\end{array}$

$\begin{array}{lllll}\mathrm{N} & 0.0 \mathrm{E}+00 & 0.0 \mathrm{E}+00 & 0.0 \mathrm{E}+00 & 0.0 \mathrm{E}+00\end{array}$

$\begin{array}{lllll}Y & 0.0 E+00 & 0.0 E+00 & 0.0 E+00 & 0.0 E+00\end{array}$

$\begin{array}{lllll}Y & 0.0 E+00 & 0.0 E+00 & 0.0 E+00 & 0.0 E+00\end{array}$

y $\quad 7.3 \mathrm{E}-02$ 1.4E-01 4.2E-01 2.5E+00

$N \quad 4.5 E-02 \quad 3.1 E-02 \quad 1.3 E-01 \quad 5.5 E-01$

$N \quad 4.5 E-02 \quad 3.1 E-02 \quad 1.3 E-01 \quad 5.5 E-01$

$\mathrm{N} \quad 4.5 \mathrm{E}-02 \quad 3.1 \mathrm{E}-02 \quad 1.3 \mathrm{E}-01 \quad 5.5 \mathrm{E}-01$

$\mathrm{N} \quad 5.9 \mathrm{E}-02 \quad 4.7 \mathrm{E}-04 \quad 5.9 \mathrm{E}-02 \quad 8.0 \mathrm{E}-02$

$\mathrm{N} \quad 5.3 \mathrm{E}-01 \quad 3.2 \mathrm{E}-02 \quad 5.8 \mathrm{E}-01 \quad 5.8 \mathrm{E}-02$

$\mathrm{N} \quad 3.8 \mathrm{E}-02 \quad 9.9 \mathrm{E}-04 \quad 6.2 \mathrm{E}-02 \quad 8.3 \mathrm{E}-02$

$\mathrm{N} \quad 3.8 \mathrm{E}-02 \quad 9.9 \mathrm{E}-04 \quad 6.2 \mathrm{E}-02 \quad 8.3 \mathrm{E}-02$

$\begin{array}{lllll}Y & 0.0 E+00 & 0.0 E+00 & 0.0 E+00 & 0.0 E+00\end{array}$

$N \quad 3.4 E-01 \quad 6.0 E-05 \quad 3.4 E-01 \quad 6.0 E-05$

$N \quad 1.2 E-01 \quad 1.7 E-04 \quad 1.2 E-01 \quad 1.7 E-04$

$N \quad 3.4 E-01 \quad 6.0 E-05 \quad 3.4 E-01 \quad 6.0 \mathrm{E}-05$

$N \quad 3.4 E-01 \quad 6.0 E-05 \quad 3.4 E-01 \quad 6.0 E-05$

$\mathrm{N} \quad 9.6 \mathrm{E}-01 \quad 3.0 \mathrm{E}-02 \quad 1.2 \mathrm{E}+00 \quad 1.2 \mathrm{E}-01$

$N \quad 9.6 E-01 \quad 3.0 E-02 \quad 1.2 E+00 \quad 1.2 E-01$

$\mathrm{N} \quad 9.6 \mathrm{E}-01 \quad 3.0 \mathrm{E}-02 \quad 1.2 \mathrm{E}+00 \quad 1.2 \mathrm{E}-01$

$\mathrm{N} \quad 9.6 \mathrm{E}-01 \quad 3.0 \mathrm{E}-02 \quad 1.2 \mathrm{E}+00 \quad 1.2 \mathrm{E}-01$

$N \quad 1.2 E-03 \quad 4.8 E-04 \quad 1.2 E-03 \quad 4.8 E-04$

$\mathrm{N} \quad 1.2 \mathrm{E}-03 \quad 4.8 \mathrm{E}-04 \quad 1.2 \mathrm{E}-03 \quad 4.8 \mathrm{E}-04$

$N \quad 1.2 E-03 \quad 4.8 E-04 \quad 1.2 E-03 \quad 4.8 E-04$

$N \quad 3.8 E-05 \quad 1.7 E-04 \quad 3.8 E-05 \quad 1.7 E-04$

N $\quad 3.8 E-05 \quad 1.7 E-04 \quad 3.8 E-05 \quad 1.7 E-04$

$5.9 E+00 \quad 3.9 E-01 \quad 7.7 E+00 \quad 5.0 E+00$

* Not Significant Source 


\section{EMISSION SUMMARY - 1994}

\begin{tabular}{|c|c|c|c|c|c|c|c|c|c|}
\hline AREA & BLDG & VENT & POLLUTANT & SOURCE TYPE & $\mathrm{L}$ & $\begin{array}{c}\text { HOURLY } \\
\text { LBS/HR } \\
\end{array}$ & $\begin{array}{l}\text { YEARLY } \\
\text { TNSTYR }\end{array}$ & $\begin{array}{l}\text { HOURLY } \\
\text { LBS/HR }\end{array}$ & $\begin{array}{l}\text { YEARLY } \\
\text { TNS } Y \text { R } \\
\end{array}$ \\
\hline \multirow[t]{2}{*}{ PER } & 601 & 010 & CARBON MONOXIDE & FUEL BURNING EQUIPMENT & $\mathbf{N}$ & $6.5 E-02$ & $2.3 \mathrm{E}-02$ & $6.5 \mathrm{E}-02$ & $2.8 \mathrm{E}-02$ \\
\hline & $601 \mathrm{~A}$ & 010 & & FUEL BURNING EQUIPMENT & $\mathbf{N}$ & $6.5 \mathrm{E}-03$ & 2.3E-02 & $6.5 \mathrm{E}-03$ & $2.8 \mathrm{E}-02$ \\
\hline \multirow[t]{5}{*}{ k } & 609 & 006 & & FUEL BURNING EQUIPMENT & $\mathbf{N}$ & $1.3 \mathrm{E}+00$ & 7.8E-03 & $2.6 E+00$ & $3.5 E+00$ \\
\hline & 612 & 006 & & FUEL BURNING EQUIPMENT & $\mathbf{N}$ & $6.5 \mathrm{E}-03$ & 2.3E-02 & $6.5 \mathrm{E}-03$ & $2.8 \mathrm{E}-02$ \\
\hline & 613 & 009 & & FUEL BURNING EQUIPMENT & $\mathbf{N}$ & $2.2 \mathrm{E}-02$ & $6.8 \mathrm{E}-04$ & $6.0 \mathrm{E}-02$ & $1.9 \mathrm{E}-01$ \\
\hline & 632 & 007 & & FUEL BURNING EQUIPMENT & $\mathbf{N}$ & $6.5 \mathrm{E}-03$ & 2.3E-02 & $6.5 \mathrm{E}-03$ & $2.8 \mathrm{E}-02$ \\
\hline & & 008 & & FUEL BURNING EQUIPMENT & $\mathbf{N}$ & $6.5 \mathrm{E}-02$ & 2.3E-02 & $6.5 \mathrm{E}-02$ & $2.8 \mathrm{E}-02$ \\
\hline * & 638 & 004 & & FUEL BURNING EQUIPMENT & $\mathbf{N}$ & $1.4 \mathrm{E}+00$ & $1.8 E-02$ & $1.4 E+00$ & $3.7 E+00$ \\
\hline & & 005 & & STORAGE TANK - VOC & $\mathbf{N}$ & 2.7E-01 & $5.0 \mathrm{E}-03$ & $9.2 \mathrm{E}-01$ & $4.0 E+\infty 0$ \\
\hline & 755 & 001 & & CHEMICAL SOURCE & Y & $0.0 \mathrm{E}+00$ & $0.0 E+00$ & $9.7 \mathrm{E}+00$ & $2.8 \mathrm{E}+00$ \\
\hline & & & sum & & & $3.1 \mathrm{E}+00$ & $1.4 \mathrm{E}-01$ & $1.5 \mathrm{E}+01$ & $1.4 \mathrm{E}+01$ \\
\hline \multirow[t]{2}{*}{ PER } & 601 & 010 & NITROGEN OXIDES & FUEL BURNING EQUIPMENT & $\mathbf{N}$ & 2.6E-01 & $9.0 \mathrm{E}-02$ & 2.6E-01 & 1.1E-01 \\
\hline & $601 \mathrm{~A}$ & 010 & & FUEL BURNING EQUIPMENT & $\mathbf{N}$ & $2.6 \mathrm{E}-02$ & $9.0 \mathrm{E}-02$ & $2.6 \mathrm{E}-02$ & 1.1E-01 \\
\hline \multirow[t]{5}{*}{ * } & 609 & 006 & & FUEL BURNING EQUIPMENT & $\mathbf{N}$ & $6.0 E+00$ & 3.6E-02 & $1.2 E+01$ & $1.6 \mathrm{E}+01$ \\
\hline & 612 & 006 & & FUEL BURNING EQUIPMENT & $\mathbf{N}$ & 2.6E-02 & $9.0 \mathrm{E}-02$ & $2.6 \mathrm{E}-02$ & 1.1E-01 \\
\hline & 613 & 009 & & FUEL BURNING EQUIPMENT & $\mathbf{N}$ & 8.6E-02 & 2.7E-03 & $2.4 \mathrm{E}-01$ & 7.7E-01 \\
\hline & 632 & 007 & & FUEL BURNING EQUIPMENT & $\mathbf{N}$ & 2.6E-02 & $9.0 \mathrm{E}-02$ & $2.6 \mathrm{E}-02$ & 1.1E-01 \\
\hline & & 008 & & FUEL BURNING EQUIPMENT & $\mathbf{N}$ & $2.6 \mathrm{E}-01$ & $9.0 \mathrm{E}-02$ & $2.6 \mathrm{E}-01$ & $1.1 \mathrm{E}-01$ \\
\hline * & 638 & 004 & & FUEL BURNING EQUIPMENT & $\mathbf{N}$ & $6.3 E+00$ & 8.2E-02 & $6.3 E+00$ & $1.7 E+01$ \\
\hline \multirow[t]{3}{*}{ * } & & 005 & & STORAGE TANK - VOC & $\mathbf{N}$ & $1.2 E+00$ & 2.3E-02 & $4.2 \mathrm{E}+00$ & $1.8 E+01$ \\
\hline & 755 & 001 & & CHEMICAL SOURCE & Y & $0.0 E+00$ & $0.0 E+00$ & $4.2 E+00$ & $1.2 \mathrm{E}+01$ \\
\hline & & & sum & & & $1.4 \mathrm{E}+01$ & $5.9 \mathrm{E}-01$ & $2.8 E+01$ & $6.5 \mathrm{E}+01$ \\
\hline \multirow[t]{2}{*}{ PER } & 601 & 010 & PARTICULATE & FUEL BURNING EQUIPMENT & $\mathbf{N}$ & 2.6E-02 & $9.0 \mathrm{E}-03$ & $2.6 E-02$ & $1.1 \mathrm{E}-02$ \\
\hline & $601 \mathrm{~A}$ & 010 & & FUEL BURNING EQUIPMENT & $\mathbf{N}$ & 2.6E-03 & $9.0 \mathrm{E}-03$ & 2.6E-03 & 1.1E-02 \\
\hline \multirow[t]{5}{*}{ * } & 609 & 006 & & FUEL BURNING EQUIPMENT & $\mathbf{N}$ & 4.3E-01 & $2.6 \mathrm{E}-03$ & $8.5 \mathrm{E}-01$ & $1.1 E+\infty 0$ \\
\hline & 612 & 006 & & FUEL BURNING EQUIPMENT & $\mathbf{N}$ & $2.6 \mathrm{E}-03$ & $9.0 \mathrm{E}-03$ & $2.6 \mathrm{E}-03$ & $1.1 \mathrm{E}-02$ \\
\hline & 613 & 009 & & FUEL BURNING EQUIPMENT & $\mathbf{N}$ & 8.6E-03 & 2.7E-04 & $2.4 \mathrm{E}-02$ & 7.7E-02 \\
\hline & 632 & 007 & & FUEL BURNING EQUIPMENT & $\mathbf{N}$ & 2.6E-03 & $9.0 \mathrm{E}-03$ & $2.6 \mathrm{E}-03$ & $1.1 \mathrm{E}-02$ \\
\hline & & 008 & & FUEL BURNING EQUIPMENT & $\mathbf{N}$ & 2.6E-02 & $9.0 \mathrm{E}-03$ & $2.6 \mathrm{E}-02$ & 1.1E-02 \\
\hline * & 638 & 004 & & FUEL BURNING EQUIPMENT & $\mathbf{N}$ & 4.4E-01 & $5.7 \mathrm{E}-03$ & $4.4 \mathrm{E}-01$ & $1.2 \mathrm{E}+00$ \\
\hline \multirow[t]{2}{*}{ * } & & 005 & & STORAGE TANK - VOC & $\mathbf{N}$ & 8.7E-02 & $1.7 \mathrm{E}-03$ & $3.0 \mathrm{E}-01$ & $1.3 \mathrm{E}+00$ \\
\hline & 755 & 001 & & CHEMICAL SOURCE & $\mathbf{Y}$ & $0.0 E+00$ & $0.0 \mathrm{E}+00$ & $7.3 E+\infty 0$ & 2.1E+00 \\
\hline \multirow[t]{2}{*}{ * } & 765 & 001 & & CHEMICAL SOURCE & & & & $2.5 \mathrm{E}-02$ & $1.1 \mathrm{E}-01$ \\
\hline & & & sum & & & $1.0 E+00$ & $5.5 \mathrm{E}-02$ & $9.0 E+\infty 0$ & $6.0 \mathrm{E}+00$ \\
\hline \multirow[t]{2}{*}{ PER } & 601 & 010 & SULFUR OXIDES & FUEL BURNING EQUIPMENT & $\mathbf{N}$ & 9.4E-01 & $3.2 \mathrm{E}-01$ & $9.4 \mathrm{E}-01$ & 4.1E-01 \\
\hline & 601A & 010 & & FUEL BURNING EQUIPMENT & $\mathbf{N}$ & $9.4 \mathrm{E}-02$ & 3.2E-01 & $9.4 \mathrm{E}-02$ & 4.1E-01 \\
\hline \multirow[t]{5}{*}{ * } & 609 & 006 & & FUEL BURNING EQUIPMENT & N & 4.0E-01 & 2.4E-03 & 7.9E-01 & $1.1 \mathrm{E}+00$ \\
\hline & 612 & 006 & & FUEL BURNING EQUIPMENT & $\mathbf{N}$ & $9.4 \mathrm{E}-02$ & 3.2E-01 & 9.4E-02 & 4.1E-01 \\
\hline & 613 & 009 & & FUEL BURNING EQUIPMENT & $\mathbf{N}$ & 3.1E-01 & $9.7 E-03$ & 8.6E-01 & $2.8 \mathrm{E}+\infty 0$ \\
\hline & 632 & 007 & & FUEL BURNING EQUIPMENT & $\mathbf{N}$ & $9.4 \mathrm{E}-02$ & 3.2E-01 & $9.4 \mathrm{E}-02$ & 4.1E-01 \\
\hline & & 008 & & FUEL BURNING EQUIPMENT & $\mathbf{N}$ & 9.4E-01 & 3.2E-01 & $9.4 \mathrm{E}-01$ & 4.1E-01 \\
\hline * & 638 & 004 & & FUEL BURNING EQUIPMENT & $\mathbf{N}$ & 4.1E-01 & $5.4 E-03$ & 4.1E-01 & $1.1 E+00$ \\
\hline & & 005 & & STORAGE TANK - VOC & $\mathbf{N}$ & 8.1E-02 & $1.5 E-03$ & 2.8E-01 & $1.2 E+00$ \\
\hline & 755 & 001 & & CHEMICAL SOURCE & $Y$ & $0.0 E+00$ & $0.0 E+00$ & $2.6 E+00$ & $1.1 \mathrm{E}+01$ \\
\hline & & & SUM & & & $3.4 E+00$ & $1.6 E+00$ & $7.1 E+\infty 0$ & $1.9 \mathrm{E}+01$ \\
\hline
\end{tabular}

\footnotetext{
* Not Significant Source
} 


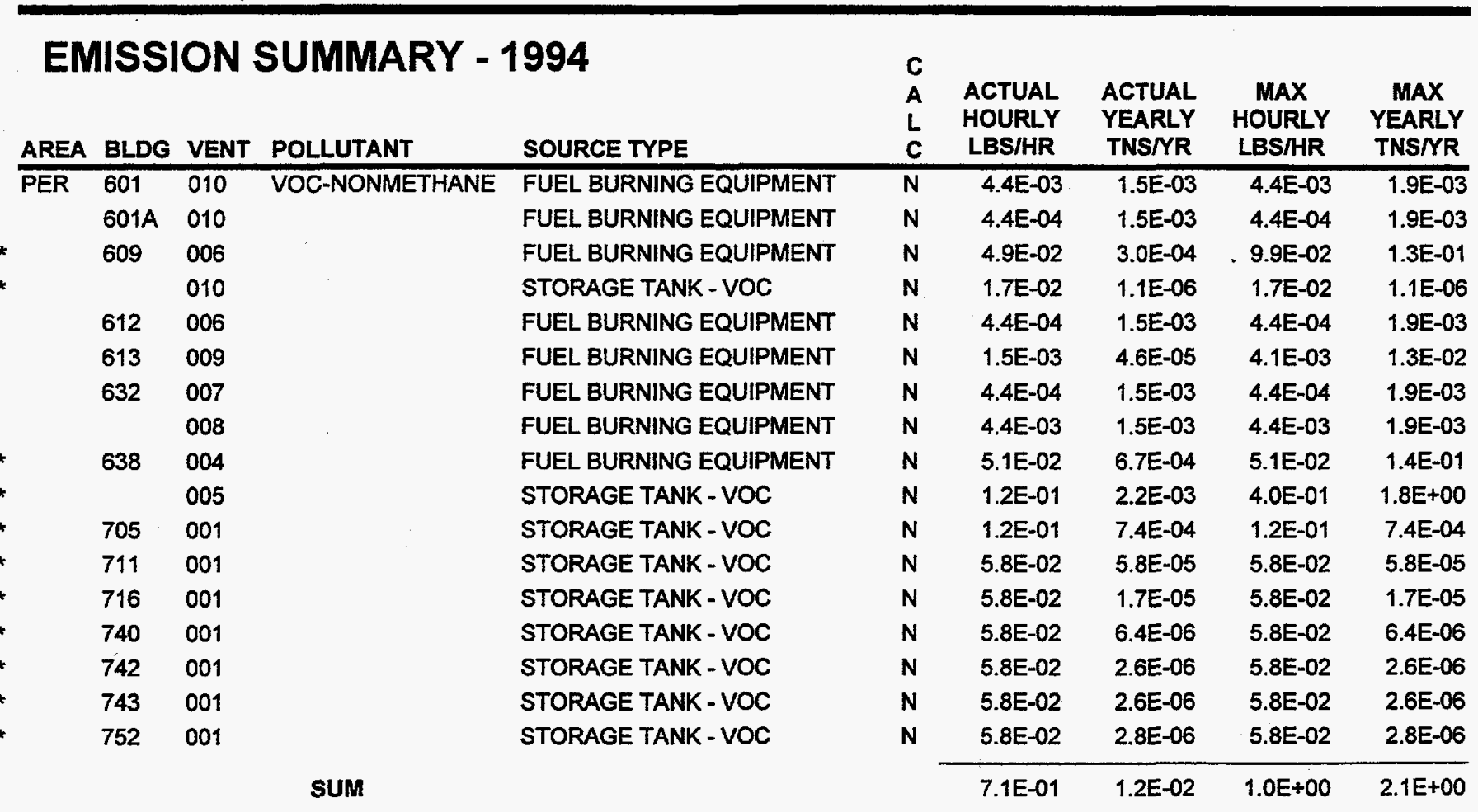




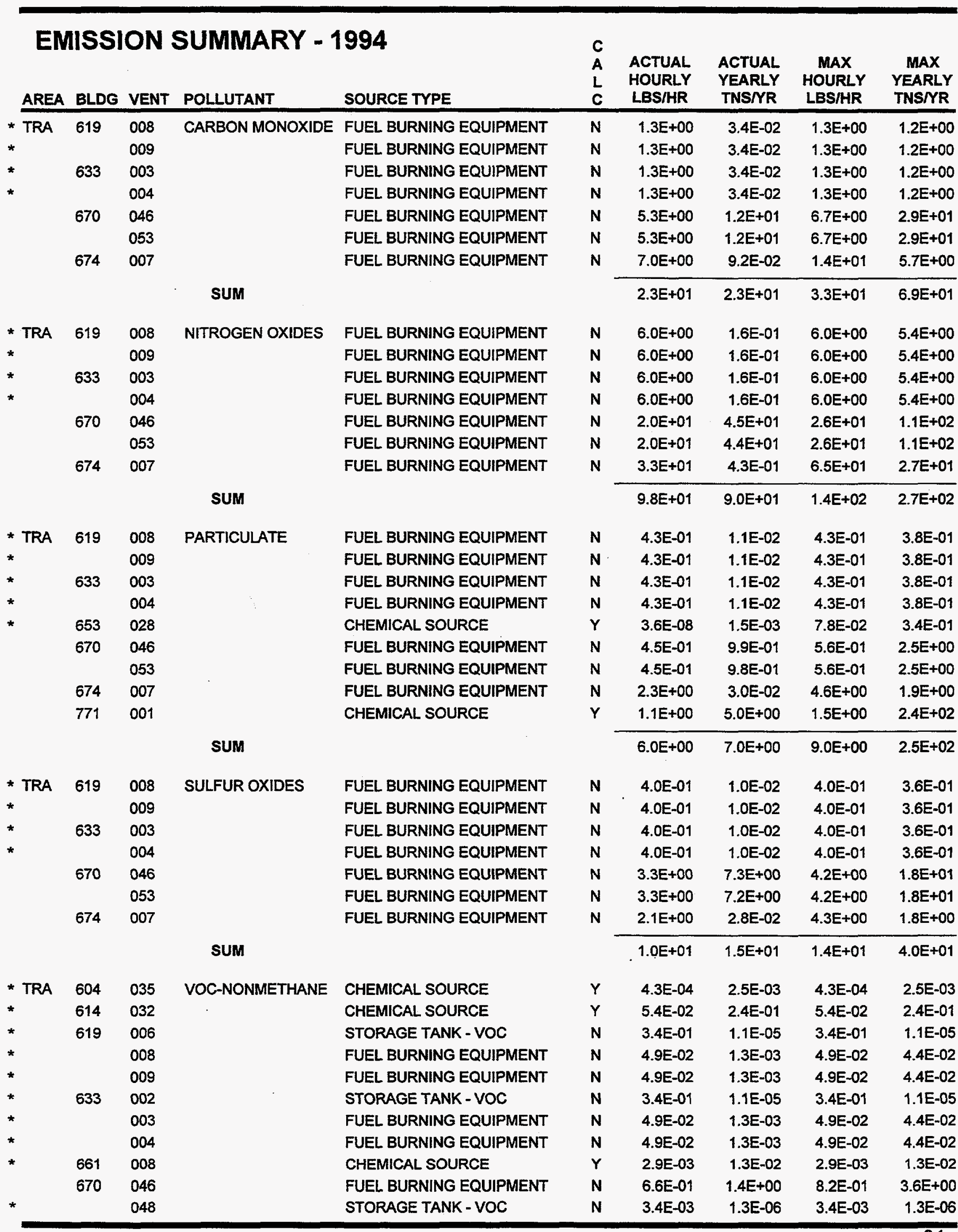

* Not Significant Source 


\begin{tabular}{|c|c|c|c|c|c|c|c|c|c|}
\hline \multicolumn{5}{|c|}{ EMISSION SUMMARY - 1994} & \multirow{2}{*}{$\begin{array}{l}\mathbf{C} \\
\mathbf{A} \\
\mathbf{L} \\
\mathbf{C}\end{array}$} & \multirow{2}{*}{$\begin{array}{l}\text { ACTUAL } \\
\text { HOURLY } \\
\text { LBS/HR }\end{array}$} & \multirow{2}{*}{$\begin{array}{l}\text { ACTUAL } \\
\text { YEARLY } \\
\text { TNS } / Y R\end{array}$} & \multirow{2}{*}{$\begin{array}{c}\text { MAX } \\
\text { HOURLY } \\
\text { LBS/HR }\end{array}$} & \multirow{2}{*}{$\begin{array}{c}\text { MAX } \\
\text { YEARLY } \\
\text { TNS/YR }\end{array}$} \\
\hline AREA & BLDG & VENT & POLLUTANT & SOURCE TYPE & & & & & \\
\hline \multirow[t]{2}{*}{$\overline{T R A}$} & 670 & 053 & VOC-NONMETHANE & FUEL BURNING EQUIPMENT & $\mathbf{N}$ & $6.6 \mathrm{E}-01$ & $1.4 \mathrm{E}+00$ & $8.2 E-01$ & $3.6 \mathrm{E}+00$ \\
\hline & 674 & 007 & & FUEL BURNING EQUIPMENT & $\mathbf{N}$ & 2.7E-01 & $3.5 \mathrm{E}-03$ & 5.3E-01 & 2.2E-01 \\
\hline \multirow[t]{4}{*}{ 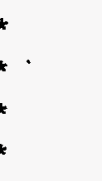 } & 727 & 001 & & STORAGE TANK - VOC & $Y$ & $0.0 E+00$ & $0.0 \mathrm{E}+00$ & $0.0 \mathrm{E}+00$ & $0.0 \mathrm{E}+00$ \\
\hline & & 002 & & STORAGE TANK - VOC & $\mathrm{Y}$ & $0.0 \mathrm{E}+00$ & $0.0 \mathrm{E}+00$ & $0.0 E+00$ & $0.0 E+\infty 0$ \\
\hline & & 003 & & STORAGE TANK - VOC & $\mathbf{N}$ & $8.9 E-02$ & $9.3 E-03$ & $8.9 E-02$ & 9.3E-03 \\
\hline & & 004 & & STORAGE TANK - VOC & $\mathbf{N}$ & $9.0 \mathrm{E}-02$ & $1.5 \mathrm{E}-02$ & $9.0 \mathrm{E}-02$ & $1.5 \mathrm{E}-02$ \\
\hline & 775 & 001 & & STORAGE TANK - VOC & $\mathbf{N}$ & $9.0 \mathrm{E}-02$ & $1.2 E-02$ & $9.0 \mathrm{E}-02$ & 1.2E-02 \\
\hline & & & sum & & & $2.8 E+00$ & $3.2 E+\infty 0$ & $3.4 E+00$ & $7.9 \mathrm{E}+00$ \\
\hline
\end{tabular}




\begin{tabular}{|c|c|c|c|c|}
\hline AREA & BLDG & VENT & POLLUTANT & SOURCE TYPE \\
\hline * WMF & 603 & 005 & CARBON MONOXIDE & FUEL BURNING EQUIPMENT \\
\hline * & 610 & 003 & & FUEL BURNING EQUIPMENT \\
\hline * & & 004 & & FUEL BURNING EQUIPMENT \\
\hline * & 612 & 001 & & FUEL BURNING EQUIPMENT \\
\hline * & & 004 & & FUEL BURNING EQUIPMENT \\
\hline * & 711 & 001 & & FUEL BURNING EQUIPMENT \\
\hline . & & 004 & & FUEL BURNING EQUIPMENT \\
\hline
\end{tabular}

\begin{tabular}{|c|c|c|}
\hline * WMF & 603 & 005 \\
\hline$*$ & 610 & 003 \\
\hline * & & 004 \\
\hline & 612 & 001 \\
\hline & & 004 \\
\hline & 711 & 001 \\
\hline & & 004 \\
\hline
\end{tabular}

SUM

NITROGEN OXIDES FUEL BURNING EQUIPMENT FUEL BURNING EQUIPMENT FUEL BURNING EQUIPMENT FUEL BURNING EQUIPMENT FUEL BURNING EQUIPMENT FUEL BURNING EQUIPMENT FUEL BURNING EQUIPMENT

SUM

$\begin{array}{llll}\text { * WMF } & 603 & 005 & \text { PARTICULATE } \\ \text { * } & 610 & 003 & \\ * & & 004 \\ \text { * } & 612 & 001 \\ \text { * } & & 004 \\ \text { * } & & 711 & 001 \\ \text { * } & & 004\end{array}$

SUM

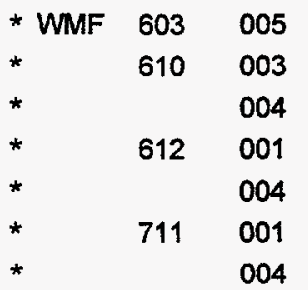

$\begin{array}{lll}\text { * WMF } & 603 & 005 \\ * & 610 & 003 \\ * & & 004 \\ * & 612 & 001 \\ * & & 004 \\ * & 639 & 002 \\ * & 711 & 001 \\ * & & 004\end{array}$

\section{SULFUR OXIDES}

FUEL BURNING EQUIPMENT FUEL BURNING EQUIPMENT FUEL BURNING EQUIPMENT FUEL BURNING EQUIPMENT FUEL BURNING EQUIPMENT FUEL BURNING EQUIPMENT FUEL BURNING EQUIPMENT

SuM

VOC-NONMETHANE FUEL BURNING EQUIPMENT FUEL BURNING EQUIPMENT FUEL BURNING EQUIPMENT FUEL BURNING EQUIPMENT FUEL BURNING EQUIPMENT STORAGE TANK - VOC FUEL BURNING EQUIPMENT FUEL BURNING EQUIPMENT

\section{C}

\begin{tabular}{|c|c|c|c|c|}
\hline $\begin{array}{l}\text { A } \\
\text { L } \\
\text { C }\end{array}$ & $\begin{array}{c}\text { ACTUAL } \\
\text { HOURLY } \\
\text { LBS/HR }\end{array}$ & $\begin{array}{l}\text { ACTUAL } \\
\text { YEARLY } \\
\text { TNSIYR }\end{array}$ & $\begin{array}{c}\text { MAX } \\
\text { HOURLY } \\
\text { LBS/HR }\end{array}$ & $\begin{array}{c}\text { MAX } \\
\text { YEARLY } \\
\text { TNSNR }\end{array}$ \\
\hline$Y$ & 3.6E-03 & 2.6E-04 & 4.9E-03 & 2.1E-02 \\
\hline Y & $3.6 E-03$ & 1.2E-04 & 4.9E-03 & 2.1E-02 \\
\hline $\mathbf{Y}$ & 3.6E-04 & 1.3E-02 & 3.6E-04 & 1.6E-02 \\
\hline $\mathbf{Y}$ & $3.6 \mathrm{E}-03$ & 1.2E-04 & 4.9E-03 & 2.1E-02 \\
\hline $\mathbf{Y}$ & $3.6 \mathrm{E}-03$ & 1.3E-02 & 3.6E-03 & 1.6E-02 \\
\hline Y & $1.8 \mathrm{E}-03$ & 1.2E-04 & 2.3E-03 & $1.0 \mathrm{E}-02$ \\
\hline \multirow[t]{2}{*}{$Y$} & $3.6 \mathrm{E}-03$ & 1.3E-02 & 4.9E-03 & 2.1E-02 \\
\hline & 2.0E-02 & 3.9E-02 & 2.6E-02 & 1.3E-01 \\
\hline
\end{tabular}

\begin{tabular}{lllll}
$\mathrm{Y}$ & $1.8 \mathrm{E}-02$ & $1.3 \mathrm{E}-03$ & $2.4 \mathrm{E}-02$ & $1.0 \mathrm{E}-01$ \\
$\mathrm{Y}$ & $1.8 \mathrm{E}-02$ & $5.7 \mathrm{E}-04$ & $2.4 \mathrm{E}-02$ & $1.0 \mathrm{E}-01$ \\
$\mathrm{Y}$ & $1.8 \mathrm{E}-03$ & $6.2 \mathrm{E}-02$ & $1.8 \mathrm{E}-03$ & $7.7 \mathrm{E}-02$ \\
$\mathrm{Y}$ & $1.8 \mathrm{E}-02$ & $5.7 \mathrm{E}-04$ & $2.4 \mathrm{E}-02$ & $1.0 \mathrm{E}-01$ \\
$\mathrm{Y}$ & $1.8 \mathrm{E}-02$ & $6.2 \mathrm{E}-02$ & $1.8 \mathrm{E}-02$ & $7.7 \mathrm{E}-02$ \\
$\mathrm{Y}$ & $8.8 \mathrm{E}-03$ & $5.7 \mathrm{E}-04$ & $1.1 \mathrm{E}-02$ & $5.0 \mathrm{E}-02$ \\
$\mathrm{Y}$ & $1.8 \mathrm{E}-02$ & $6.2 \mathrm{E}-02$ & $2.4 \mathrm{E}-02$ & $1.0 \mathrm{E}-01$ \\
\hline & $1.0 \mathrm{E}-01$ & $1.9 \mathrm{E}-01$ & $1.3 \mathrm{E}-01$ & $6.2 \mathrm{E}-01$
\end{tabular}

$\begin{array}{lllll}Y & 8.8 E-04 & 6.4 E-05 & 1.2 E-03 & 5.2 E-03\end{array}$

$Y \quad 8.8 \mathrm{E}-04 \quad 2.8 \mathrm{E}-05 \quad 1.2 \mathrm{E}-03 \quad 5.2 \mathrm{E}-03$

$Y \quad 8.8 E-05 \quad 3.1 E-03 \quad 8.8 E-05 \quad 3.9 E-03$

$Y \quad 8.8 E-04 \quad 2.8 E-05 \quad 1.2 \mathrm{E}-03 \quad 5.2 \mathrm{E}-03$

$Y \quad 8.8 E-04 \quad 3.1 E-03 \quad 8.8 E-04 \quad 3.9 E-03$

$Y$ 4.4E-04 2.8E-05 5.7E-04 2.5E-03

$Y \quad 8.8 E-04 \quad 3.1 E-03 \quad 1.2 E-03 \quad 5.2 E-03$

$\begin{array}{llll}4.9 E-03 & 9.5 E-03 & 6.3 E-03 & 3.1 E-02\end{array}$

$\begin{array}{lllll}Y & 1.8 E-04 & 1.3 E-05 & 2.4 E-04 & 1.1 E-03\end{array}$

$Y \quad 1.8 E-04 \quad 6.0 E-06 \quad 2.4 E-04 \quad 1.1 E-03$

$\begin{array}{lllll}Y & 1.8 E-05 & 6.4 E-04 & 1.8 E-05 & 7.9 E-04\end{array}$

$Y \quad 1.8 E-04 \quad 6.0 E-06 \quad 2.4 E-04 \quad 1.1 E-03$

$Y \quad 1.8 \mathrm{E}-04 \quad 6.4 \mathrm{E}-04 \quad 1.8 \mathrm{E}-04 \quad 7.9 \mathrm{E}-04$

$Y \quad 9.0 E-05 \quad 6.0 E-06 \quad 1.2 E-04 \quad 5.1 E-04$

$Y \quad 1.8 E-04 \quad 6.4 E-04 \quad 2.4 E-04 \quad 1.1 E-03$

$\begin{array}{llll}1.0 \mathrm{E}-03 & 1.9 \mathrm{E}-03 & 1.3 \mathrm{E}-03 & 6.3 \mathrm{E}-03\end{array}$

\begin{tabular}{lllll}
$Y$ & $9.4 E-04$ & $6.8 E-05$ & $1.3 E-03$ & $5.6 E-03$ \\
$Y$ & $9.4 E-04$ & $3.0 E-05$ & $1.3 E-03$ & $5.6 E-03$ \\
$Y$ & $9.4 E-05$ & $2.3 E-03$ & $9.4 E-05$ & $4.1 E-03$ \\
$Y$ & $9.4 E-04$ & $3.0 E-05$ & $1.3 E-03$ & $5.6 E-03$ \\
$Y$ & $9.4 E-04$ & $3.3 E-03$ & $9.4 E-04$ & $4.1 E-03$ \\
$N$ & $3.4 E-01$ & $7.9 E-06$ & $3.4 E-01$ & $7.9 E-06$ \\
$Y$ & $4.7 E-04$ & $3.0 E-05$ & $6.1 E-04$ & $2.7 E-03$ \\
$Y$ & $9.4 E-04$ & $3.3 E-03$ & $1.3 E-03$ & $5.6 E-03$ \\
\cline { 2 - 5 } & $3.4 E-01$ & $9.2 E-03$ & $3.4 E-01$ & $3.3 E-02$
\end{tabular}




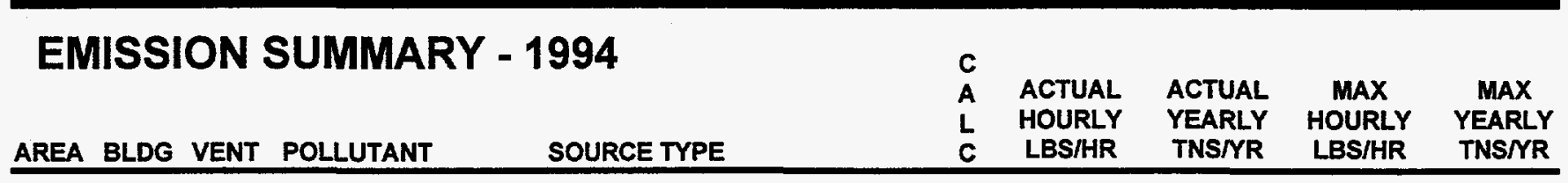

* Not Significant Source 



\section{EMISSION SUMMARY - 1994 - TAN}

AREA BLDG VENT POLLUTANT

\begin{tabular}{|c|c|c|c|}
\hline \multirow[t]{4}{*}{ * TAN } & 603 & 011 & CARBON MONOXIDE \\
\hline & & 022 & \\
\hline & & 027 & \\
\hline & & 028 & \\
\hline * & 607 & 046 & \\
\hline \multirow[t]{3}{*}{ * } & 610 & 002 & \\
\hline & 641 & 034 & \\
\hline & & 035 & \\
\hline * & 652 & 003 & \\
\hline * & 665 & 002 & \\
\hline \multirow[t]{2}{*}{ * } & 687 & 020 & \\
\hline & & & SUM \\
\hline \multirow[t]{4}{*}{ * TAN } & 603 & 011 & NITROGEN OXIDES \\
\hline & & 022 & \\
\hline & & 027 & \\
\hline & & 028 & \\
\hline * & 607 & 046 & \\
\hline \multirow[t]{3}{*}{ * } & 610 & 002 & \\
\hline & 641 & 034 & \\
\hline & & 035 & \\
\hline * & 652 & 003 & \\
\hline * & 665 & 002 & \\
\hline * & 687 & 020 & \\
\hline
\end{tabular}

SOURCE TYPE

FUEL BURNING EQUIPMENT FUEL BURNING EQUIPMENT FUEL BURNING EQUIPMENT FUEL BURNING EQUIPMENT FUEL BURNING EQUIPMENT FUEL BURNING EQUIPMENT FUEL. BURNING EQUIPMENT FUEL BURNING EQUIPMENT FUEL BURNING EQUIPMENT FUEL BURNING EQUIPMENT FUEL BURNING EQUIPMENT

SUM

$\begin{array}{ccc}* \text { TAN } & 603 & 011 \\ & & 022 \\ & & 027 \\ & & 028 \\ * & 604 & 022 \\ & 606 & 005 \\ & & 026 \\ & & 027 \\ * & 607 & 046 \\ * & 610 & 002 \\ * & 636 & 002 \\ & 641 & 034 \\ & & 035 \\ * & 652 & 003 \\ * & 665 & 002 \\ * & 687 & 020\end{array}$

PARTICULATE 22 027 028 022 026 027 046 002 002 35 003 002

$-687-020$
-10

$\begin{array}{cccc}\text { * TAN } & 603 & 011 & \text { SULFUR OXIDES } \\ & & 022 & \\ & & 027 \\ & & 028 & \\ & & 028\end{array}$

FUEL BURNING EQUIPMENT FUEL BURNING EQUIPMENT FUEL BURNING EQUIPMENT FUEL BURNING EQUIPMENT FUEL BURNING EQUIPMENT FUEL BURNING EQUIPMENT FUEL BURNING EQUIPMENT FUEL BURNING EQUIPMENT FUEL BURNING EQUIPMENT FUEL BURNING EQUIPMENT FUEL BURNING EQUIPMENT

FUEL BURNING EQUIPMENT FUEL BURNING EQUIPMENT FUEL BURNING EQUIPMENT FUEL BURNING EQUIPMENT CHEMICAL SOURCE CHEMICAL SOURCE CHEMICAL SOURCE CHEMICAL SOURCE FUEL BURNING EQUIPMENT FUEL BURNING EQUIPMENT CHEMICAL SOURCE

FUEL BURNING EQUIPMENT FUEL BURNING EQUIPMENT FUEL BURNING EQUIPMENT FUEL BURNING EQUIPMENT FUEL BURNING EQUIPMENT

FUEL BURNING EQUIPMENT FUEL BURNING EQUIPMENT FUEL BURNING EQUIPMENT FUEL BURNING EQUIPMENT FUEL BURNING EQUIPMENT

\begin{tabular}{|c|c|c|c|c|}
\hline $\begin{array}{l}\mathrm{C} \\
\mathrm{A} \\
\mathrm{C}\end{array}$ & $\begin{array}{l}\text { ACTUAL } \\
\text { HOURLY } \\
\text { LBS/HR }\end{array}$ & $\begin{array}{l}\text { ACTUAL } \\
\text { YEARLY } \\
\text { TNS YR }\end{array}$ & $\begin{array}{c}\text { MAX } \\
\text { HOURLY } \\
\text { LBS/HR }\end{array}$ & $\begin{array}{c}\text { MAX } \\
\text { YEARLY } \\
\text { TNSNR }\end{array}$ \\
\hline$N$ & $3.3 E+00$ & $4.2 E-02$ & $5.6 E+00$ & 5.6E-01 \\
\hline $\mathbf{N}$ & $3.3 E+00$ & $3.9 E-01$ & $3.3 E+00$ & $2.1 E+00$ \\
\hline$N$ & $3.9 \mathrm{E}-01$ & 2.5E-01 & 6.9E-01 & $3.0 \mathrm{E}+00$ \\
\hline$N$ & $3.9 E-01$ & 2.2E-01 & 7.0E-01 & $3.1 E+\infty 0$ \\
\hline $\mathbf{N}$ & $4.4 E+\infty 0$ & 1.1E-01 & $5.8 E+00$ & $7.9 E+00$ \\
\hline $\mathbf{N}$ & $1.4 \mathrm{E}+\infty 0$ & 2.0E-02 & $2.7 E \div 00$ & $3.6 E+00$ \\
\hline$N$ & 2.2E-02 & & 2.3E-01 & 9.9E-01 \\
\hline$N$ & $2.2 E-02$ & & 2.3E-01 & 9.9E-01 \\
\hline$N$ & 4.9E-01 & $6.5 E-03$ & $9.9 E-01$ & $1.3 E+00$ \\
\hline$N$ & $1.3 E+\infty$ & 1.7E-02 & 2.6E $\div 00$ & $3.5 \mathrm{E}+00$ \\
\hline \multirow[t]{2}{*}{$\mathbf{N}$} & 2.3E-01 & 1.4E-03 & 4.7E-01 & $2.0 \mathrm{E}+00$ \\
\hline & $1.5 E+01$ & $1.1 E+00$ & $2.3 E+01$ & $2.9 E+01$ \\
\hline $\mathbf{N}$ & $1.5 E+01$ & 2.0E-01 & $2.6 E+01$ & $2.6 E+00$ \\
\hline $\mathbf{N}$ & $1.3 E+01$ & $1.5 E+00$ & $1.3 E+01$ & $8.5 E+00$ \\
\hline $\mathbf{N}$ & $1.6 E+00$ & $1.0 E+00$ & $2.8 E+00$ & $1.2 E+01$ \\
\hline $\mathbf{N}$ & $1.6 E+00$ & 8.8E-01 & $2.8 E+00$ & $1.2 E+01$ \\
\hline $\mathbf{N}$ & $2.0 \mathrm{E}+01$ & 5.3E-01 & 2.7E+01 & $3.7 E+01$ \\
\hline$N$ & $6.6 E+00$ & $9.1 \mathrm{E}-02$ & $1.2 E+01$ & 1.7E+01 \\
\hline $\mathbf{N}$ & 8.9E-02 & & 9.0E-01 & $3.9 E+00$ \\
\hline$N$ & 8.9E-02 & & $9.0 \mathrm{E}-01$ & $3.9 E+00$ \\
\hline $\mathbf{N}$ & $2.3 E+00$ & 3.0E-02 & $4.6 E+00$ & $6.2 \mathrm{E}+00$ \\
\hline$N$ & $6.0 E+00$ & $7.9 E-02$ & $1.2 E+01$ & $1.6 E+01$ \\
\hline \multirow[t]{2}{*}{$\mathbf{N}$} & 1.1E+00 & $6.3 E-03$ & $2.2 E+\infty 0$ & $9.5 E+00$ \\
\hline & $6.8 E+01$ & $4.4 E+00$ & $1.0 \mathrm{E}+02$ & $1.3 E+02$ \\
\hline$N$ & $1.1 E+00$ & 1.4E-02 & $1.8 E+00$ & $1.8 \mathrm{E}-01$ \\
\hline $\mathbf{N}$ & $1.3 E+00$ & $1.5 \mathrm{E}-01$ & $1.3 E+00$ & 8.5E-01 \\
\hline$N$ & 1.6E-01 & 1.0E-01 & $2.8 E-01$ & $1.2 \mathrm{E}+00$ \\
\hline$N$ & 1.6E-01 & 8.8E-02 & 2.8E-01 & $1.2 E+00$ \\
\hline$Y$ & 5.2E-02 & 2.7E-02 & 1.1E-01 & 5.1E-01 \\
\hline$Y$ & 8.4E-01 & $3.8 \mathrm{E}-02$ & 2.1E+00 & 8.1E-01 \\
\hline$Y$ & $6.4 E-03$ & 1.7E-03 & 1.5E-01 & 7.8E-02 \\
\hline$Y$ & $6.3 E-03$ & 1.7E-03 & 1.5E-01 & 7.8E-02 \\
\hline $\mathbf{N}$ & 1. $4 \mathrm{E}+00$ & 3.7E-02 & $1.9 E+0 D$ & $2.6 E+00$ \\
\hline $\mathbf{N}$ & 4.7E-01 & $6.4 E-03$ & 8.7E-01 & $1.2 \mathrm{E}+00$ \\
\hline$Y$ & 2.3E-02 & $9.8 E-02$ & 2.1E+00 & $9.0 \mathrm{E}+00$ \\
\hline $\mathbf{N}$ & $8.9 E-03$ & & $9.0 \mathrm{E}-02$ & $3.9 E-01$ \\
\hline $\mathbf{N}$ & $8.9 E-03$ & & $9.0 E-02$ & 3.9E-01 \\
\hline $\mathbf{N}$ & 1.6E-01 & 2.1E-03 & $3.2 E-01$ & 4.4E-01 \\
\hline $\mathbf{N}$ & 4.3E-01 & 5.5E-03 & 8.5E-01 & $1.1 E+00$ \\
\hline \multirow[t]{2}{*}{$N$} & 7.7E-02 & 4.5E-04 & $1.5 E-01$ & $6.7 E-01$ \\
\hline & $6.2 E+00$ & $5.8 E-01$ & $1.3 \mathrm{E}+01$ & 2.1E+01 \\
\hline $\mathbf{N}$ & $9.9 E-01$ & 1.3E-02 & 1.7E+00 & 1.7E-01 \\
\hline $\mathbf{N}$ & $4.8 E+01$ & $5.6 E+00$ & $4.8 E+01$ & 3.1E+01 \\
\hline $\mathbf{N}$ & $5.7 E+00$ & $3.6 \mathrm{E}+00$ & $9.9 E+00$ & $4.3 E+01$ \\
\hline $\mathbf{N}$ & $5.7 E+00$ & $3.2 E+00$ & $1.0 E+01$ & $4.4 E+01$ \\
\hline $\mathbf{N}$ & $1.3 E+00$ & 3.5E-02 & $1.8 E+00$ & $2.4 E+00$ \\
\hline
\end{tabular}

" Not Significant Source 


\section{EMISSION SUMMARY - 1994 - TAN}

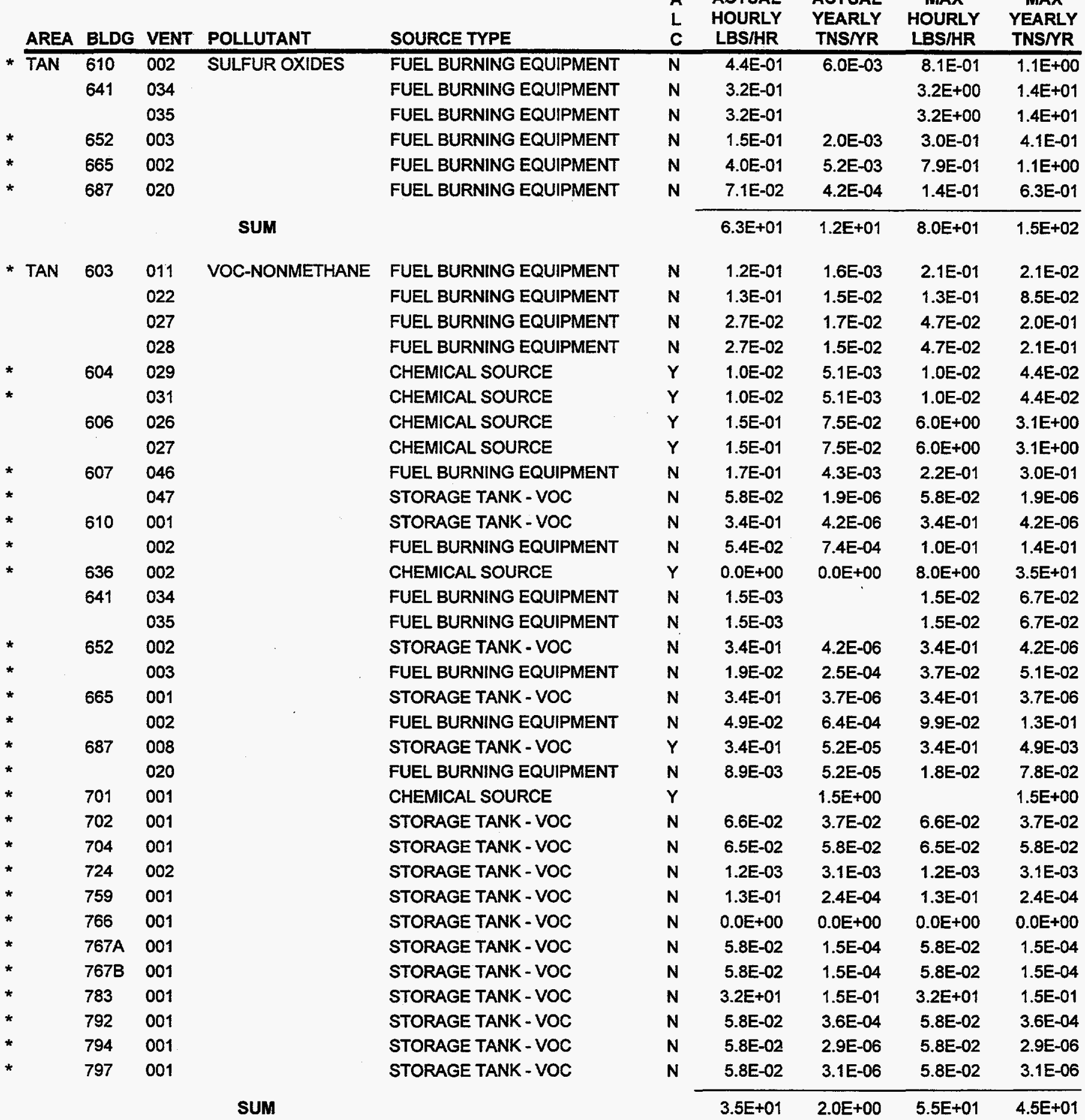

* Not Significant Source 


\section{EMISSION SUMMARY - 1994 - SMC}

\begin{tabular}{cccll} 
* AREA & BLDG & VENT & POLLUTANT & SOURCE TYPE \\
\hline TAN 675 & 010 & CARBON MONOXIDE & FUEL BURNING EQUIPMENT \\
& & 035 & & FUEL BURNING EQUIPMENT \\
& & 037 & FUEL BURNING EQUIPMENT \\
& 679 & 012 & FUEL BURNING EQUIPMENT \\
& 067 & FUEL BURNING EQUIPMENT \\
& 068 & FUEL BURNING EQUIPMENT \\
& 681 & 023 & CHEMICAL SOURCE
\end{tabular}

sum

$\begin{array}{rrrr}\text { TAN } & 607 & 119 & \text { NITROGEN OXIDES } \\ * & 675 & 010 \\ & & 035 \\ & & 037 \\ & 679 & 012 \\ & & 067 \\ & & 068 \\ & 681 & 012 \\ & 023\end{array}$

CHEMICAL SOURCE

FUEL BURNING EQUIPMENT FUEL BURNING EQUIPMENT FUEL BURNING EQUIPMENT FUEL BURNING EQUIPMENT FUEL BURNING EQUIPMENT FUEL. BURNING EQUIPMENT CHEMICAL SOURCE CHEMICAL SOURCE

SUM

$\begin{array}{cccc}\text { TAN } & 607 & 039 & \text { PARTICULATE } \\ \text { * } & 041 & \\ & 629 & 002 & \\ & 012 & \\ & & 014 & \\ * & 675 & 010 \\ & & 035 \\ & & 037 \\ & & 012 \\ & 679 & 067 \\ & & 068 \\ & 681 & 023\end{array}$

sum

$\begin{array}{cccc}\text { * TAN } & 675 & 010 & \text { SULFUR OXIDES } \\ & & 035 & \\ & & 037 & \\ * & 679 & 012 & \\ & & 067 & \\ & & 068 & \\ & 681 & 023 & \end{array}$

FUEL BURNING EQUIPMENT
FUEL BURNING EQUIPMENT
FUEL BURNING EQUIPMENT
FUEL BURNING EQUIPMENT
FUEL BURNING EQUIPMENT
FUEL BURNING EQUIPMENT
CHEMICAL SOURCE

SUM

$\begin{array}{cccc}\text { TAN } & 607 & 039 & \text { VOC-NONMETHANE } \\ & 119 & \\ 629 & 002 & \\ & 012 & \\ & 014 & \\ & 675 & 010 & \\ & 675 & \end{array}$

CHEMICAL SOURCE

CHEMICAL SOURCE

CHEMICAL SOURCE

CHEMICAL SOURCE

CHEMICAL SOURCE

FUEL BURNING EQUIPMENT

FUEL BURNING EQUIPMENT

FUEL BURNING EQUIPMENT

FUEL BURNING EQUIPMENT

FUEL BURNING EQUIPMENT

FUEL BURNING EQUIPMENT

CHEMICAL SOURCE

C

\begin{tabular}{|c|c|c|c|c|}
\hline 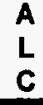 & $\begin{array}{l}\text { ACTUAL } \\
\text { HOURLY } \\
\text { LBS/HR }\end{array}$ & $\begin{array}{l}\text { ACTUAL } \\
\text { YEARLY } \\
\text { TNS/YR }\end{array}$ & $\begin{array}{c}\text { MAX } \\
\text { HOURLY } \\
\text { LBS/HR }\end{array}$ & $\begin{array}{c}\text { MAX } \\
\text { YEARLY } \\
\text { TNSYYR }\end{array}$ \\
\hline $\mathbf{N}$ & $1.6 \mathrm{E}+00$ & $4.6 \mathrm{E}-02$ & $4.0 \mathrm{E}+00$ & $3.6 \mathrm{E}+00$ \\
\hline & $1.3 E-01$ & $5.5 \mathrm{E}-02$ & $8.4 E-01$ & 3.7E +00 \\
\hline & 4.7E-01 & $3.5 E-02$ & 8.4E-01 & $3.7 E+O C$ \\
\hline & $2.0 E+00$ & $6.4 E-02$ & $4.8 E+00$ & $4.8 E-01$ \\
\hline & $3.1 \mathrm{E}-01$ & $6.2 E-01$ & $8.4 \mathrm{E}-01$ & $3.7 E+O C$ \\
\hline & 2.1E-01 & 4.3E-01 & $8.4 E-01$ & 3.7E +00 \\
\hline & 3.1E-01 & 7.5E-03 & 3.1E-01 & $2.0 \mathrm{E}-02$ \\
\hline & & & & 01 \\
\hline
\end{tabular}

\begin{tabular}{lrrrr}
$\mathrm{Y}$ & $3.1 \mathrm{E}-02$ & $3.0 \mathrm{E}-02$ & $3.1 \mathrm{E}-02$ & $3.0 \mathrm{E}-02$ \\
$\mathrm{~N}$ & $7.6 \mathrm{E}+00$ & $2.1 \mathrm{E}-01$ & $1.9 \mathrm{E}+01$ & $1.7 \mathrm{E}+01$ \\
$\mathrm{~N}$ & $5.4 \mathrm{E}-01$ & $2.2 \mathrm{E}-01$ & $3.4 \mathrm{E}+00$ & $1.5 \mathrm{E}+01$ \\
$\mathrm{~N}$ & $1.9 \mathrm{E}+00$ & $1.4 \mathrm{E}-01$ & $3.4 \mathrm{E}+00$ & $1.5 \mathrm{E}+01$ \\
$\mathrm{~N}$ & $9.2 \mathrm{E}+00$ & $3.0 \mathrm{E}-01$ & $2.2 \mathrm{E}+01$ & $2.2 \mathrm{E}+00$ \\
$\mathrm{~N}$ & $1.2 \mathrm{E}+00$ & $2.5 \mathrm{E}+00$ & $3.4 \mathrm{E}+00$ & $1.5 \mathrm{E}+01$ \\
$\mathrm{~N}$ & $8.2 \mathrm{E}-01$ & $1.7 \mathrm{E}+00$ & $3.4 \mathrm{E}+00$ & $1.5 \mathrm{E}+01$ \\
$\mathrm{Y}$ & $5.2 \mathrm{E}-02$ & $4.8 \mathrm{E}-03$ & $2.1 \mathrm{E}+01$ & $5.7 \mathrm{E}+00$ \\
$\mathrm{Y}$ & $9.4 \mathrm{E}-02$ & $2.3 \mathrm{E}-03$ & $9.4 \mathrm{E}-02$ & $9.6 \mathrm{E}-02$ \\
\hline & $2.1 \mathrm{E}+01$ & $5.1 \mathrm{E}+00$ & $7.5 \mathrm{E}+01$ & $8.4 \mathrm{E}+01$
\end{tabular}

$\begin{array}{lllll}Y & 3.0 E-05 & 1.3 E-07 & 8.0 E-03 & 6.3 E-03\end{array}$

$Y \quad 5.1 E-04 \quad 3.1 E-04 \quad 5.6 E-03 \quad 5.9 E-03$

$Y \quad 3.5 E-05 \quad 1.7 E-07 \quad 1.9 E-01 \quad 1.1 E-01$

$\begin{array}{lllll}Y & 2.2 E-04 & 7.8 E-06 & 5.0 E-01 & 2.5 E-01\end{array}$

$Y \quad 2.2 E-04 \quad 7.8 E-06 \quad 5.0 E-01 \quad 2.5 E-01$

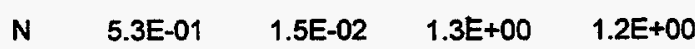

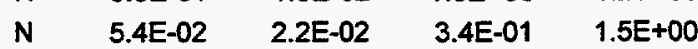

$\begin{array}{lllll}N & 1.9 E-01 & 1.4 \mathrm{E}-02 & 3.4 \mathrm{E}-01 & 1.5 \mathrm{E}+00\end{array}$

$\begin{array}{lllll}\mathrm{N} & 6.5 \mathrm{E}-01 & 2.1 \mathrm{E}-02 & 1.6 \mathrm{E}+00 & 1.6 \mathrm{E}-01\end{array}$

$\mathrm{N} \quad 1.2 \mathrm{E}-01 \quad 2.5 \mathrm{E}-01 \quad 3.4 \mathrm{E}-01 \quad 1.5 \mathrm{E}+00$

$\mathrm{N} \quad 8.2 \mathrm{E}-02 \quad 1.7 \mathrm{E}-01 \quad 3.4 \mathrm{E}-01 \quad 1.5 \mathrm{E}+00$

\begin{tabular}{lllll}
$Y$ & $2.2 \mathrm{E}-01$ & $5.3 \mathrm{E}-03$ & $2.2 \mathrm{E}-01$ & $2.5 \mathrm{E}-01$ \\
\hline
\end{tabular}

$\begin{array}{llll}1.8 E+00 & 5.0 E-01 & 5.7 E+00 & 8.1 E+00\end{array}$

\begin{tabular}{crrrr}
$N$ & $5.0 E-01$ & $1.4 E-02$ & $1.2 E+00$ & $1.1 E+00$ \\
$N$ & $1.9 E+00$ & $8.0 E-01$ & $1.2 E+01$ & $5.3 E+01$ \\
$N$ & $6.7 E+00$ & $5.0 E-01$ & $1.2 E+01$ & $5.3 E+01$ \\
$N$ & $6.1 E-01$ & $1.9 E-02$ & $1.5 E+00$ & $1.5 E-01$ \\
$N$ & $4.4 E+00$ & $8.9 E+00$ & $1.2 E+01$ & $5.3 E+01$ \\
$N$ & $3.0 E+00$ & $6.2 E+00$ & $1.2 E+01$ & $5.3 E+01$ \\
$Y$ & $7.8 E-02$ & $1.9 E-03$ & $7.8 E-02$ & $1.9 E-03$ \\
\hline & $1.7 E+01$ & $1.6 E+01$ & $5.1 E+01$ & $2.1 E+02$ \\
& & & & \\
$Y$ & $3.9 E-02$ & $1.6 E-04$ & $5.0 E-02$ & $6.0 E-03$ \\
$Y$ & $8.9 E-04$ & $8.7 E-04$ & $8.2 E-02$ & $4.0 E-03$ \\
$Y$ & $4.6 E-02$ & $2.2 E-04$ & $7.3 E-02$ & $4.0 E-02$ \\
$Y$ & $1.5 E+00$ & $5.2 E-02$ & $4.0 E+00$ & $2.1 E+00$ \\
$Y$ & $1.5 E+00$ & $5.2 E-02$ & $4.0 E+00$ & $2.1 E+00$ \\
$N$ & $6.2 E-02$ & $1.7 E-03$ & $1.5 E-01$ & $1.4 E-01$ \\
\hline
\end{tabular}

* Not Significant Source

CHEMICAL SOURCE

CHEMICAL SOURCE

CHEMICAL SOURCE

CHEMICAL SOURCE

CHEMICAL SOURCE

FUEL BURNING EQUIPMENT 


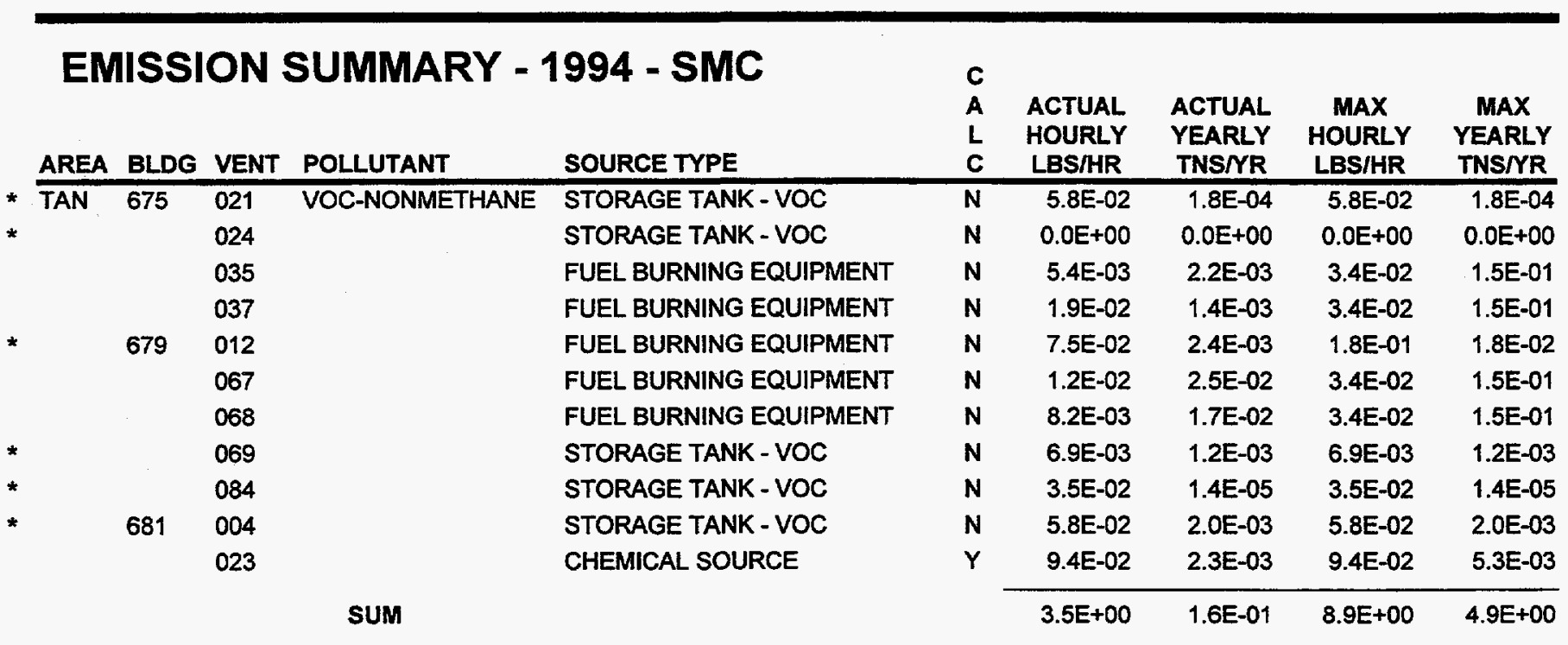

* Not Significant Source 


\begin{tabular}{|c|c|c|c|c|c|c|c|}
\hline AREA & BLDG & VENT & Toxic & $\begin{array}{l}\text { Actual } \\
\text { Hourly } \\
\text { Rates } \\
\text { Lbs/Hr } \\
\text { or } \\
\text { Ci/Mo }\end{array}$ & $\begin{array}{c}\text { Actual } \\
\text { Yearly } \\
\text { Rates } \\
\text { Tns } / Y r \\
\text { or } \\
\mathrm{Ci} / \mathrm{Yr}_{\mathrm{r}}\end{array}$ & $\begin{array}{c}\text { Max. } \\
\text { Hourly } \\
\text { Rates } \\
\text { Lbs/Hr } \\
\text { or } \\
\text { Ci/Mo }\end{array}$ & $\begin{array}{c}\text { Max. } \\
\text { Yearly } \\
\text { Rates } \\
\text { Tns } / Y r \\
\text { or } \\
\text { Ci } / \text { r }\end{array}$ \\
\hline \multirow[t]{41}{*}{ ANL } & 701 & 009 & 1,3-Butadiene & $1.73 E-03$ & $2.07 E-05$ & 2.62E-02 & $7.08 E-02$ \\
\hline & & & Arsenic & 8.50E-06 & $1.02 E-07$ & $1.29 E-04$ & 3.49E-04 \\
\hline & & & Benzene & 1.95E-03 & 2.34E-05 & $2.96 E-02$ & 7.99E-02 \\
\hline & & & Chromium Compounds & 1.49E-05 & 1.79E-07 & 2.26E-04 & $6.10 E-04$ \\
\hline & & & Lead Compounds & 1.17E-04 & 1.40E-06 & $1.78 \mathrm{E}-03$ & 4.80E-03 \\
\hline & & & Manganese & 1.49E-05 & 1.79E-07 & $2.26 \mathrm{E}-04$ & $6.10 \mathrm{E}-04$ \\
\hline & & & Mercury Compounds & 4.25E-06 & 5.10E-08 & $6.46 \mathrm{E}-05$ & 1.74E-04 \\
\hline & & & Nickel & 6.38E-06 & 7.65E-08 & $9.69 \mathrm{E}-05$ & 2.62E-04 \\
\hline & & & Selenium Compounds & 4.25E-06 & 5.10E-08 & 6.46E-05 & $1.74 E-04$ \\
\hline & 707 & 002 & 1,3-Butadiene & $6.90 \mathrm{E}-03$ & 1.04E-04 & 7.83E-03 & 7.05E-03 \\
\hline & & & Arsenic & 3.40E-05 & 5.10E-07 & 3.86E-05 & 3.47E-05 \\
\hline & & & Benzene & 7.79E-03 & 1.17E-04 & $8.84 \mathrm{E}-03$ & 7.96E-03 \\
\hline & & & Chromium Compounds & 5.95E-05 & 8.92E-07 & $6.75 \mathrm{E}-05$ & $6.08 E-05$ \\
\hline & & & Lead Compounds & 4.68E-04 & 7.01E-06 & $5.31 E-04$ & 4.78E-04 \\
\hline & & & Manganese & 5.95E-05 & 8.92E-07 & 6.75E-05 & $6.08 E-05$ \\
\hline & & & Mercury Compounds & 1.70E-05 & 2.55E-07 & 1.93E-05 & 1.74E-05 \\
\hline & & & Nickel & 2.55E-05 & $3.83 E-07$ & 2.89E-05 & 2.60E-05 \\
\hline & & & Selenium Compounds & 1.70E-05 & 2.55E-07 & 1.93E-05 & 1.74E-05 \\
\hline & 709 & 008 & 1,3-Butadiene & 8.34E-03 & $5.75 E-05$ & 1.53E-02 & $6.72 E-02$ \\
\hline & & & Arsenic & 3.27E-06 & $2.26 E-08$ & $6.02 E-06$ & 2.64E-05 \\
\hline & & & Benzene & 9.42E-03 & $6.49 E-05$ & 1.73E-02 & 7.58E-02 \\
\hline & & & Chromium Compounds & 5.72E-06 & $3.95 E-08$ & 1.05E-05 & 4.61E-05 \\
\hline & & & Lead Compounds & 4.50E-05 & $3.10 \mathrm{E}-07$ & $8.27 E-05$ & $3.62 E-04$ \\
\hline & & & Manganese & 5.72E-06 & 3.95E-08 & $1.05 \mathrm{E}-0.05$ & 4.61E-05 \\
\hline & & & Mercury Compounds & $1.64 \mathrm{E}-06$ & 1.13E-08 & 3.01E-06 & 1.32E-05 \\
\hline & & & Nickel & 2.45E-06 & 1.69E-08 & 4.51E-06 & 1.98E-05 \\
\hline & & & Selenium Compounds & 1.64E-06 & 1.13E-08 & 3.01E-06 & 1.32E-05 \\
\hline & & 016 & 1,3-Butadiene & $9.59 E-03$ & 7.67E-05 & 1.92E-02 & $8.40 \mathrm{E}-02$ \\
\hline & & & Arsenic & 3.76E-06 & 3.01E-08 & 7.52E-06 & 3.29E-05 \\
\hline & & & Benzene & $1.08 \mathrm{E}-02$ & 8.66E-05 & $2.16 \mathrm{E}-02$ & $9.48 E-02$ \\
\hline & & & Chromium Compounds & $6.58 \mathrm{E}-06$ & 5.26E-08 & 1.32E-05 & 5.76E-05 \\
\hline & & & Lead Compounds & 5.17E-05 & 4.14E-07 & $1.03 E-04$ & 4.53E-04 \\
\hline & & & Manganese & $6.58 \mathrm{E}-06$ & $5.26 E-08$ & 1.32E-05 & 5.76E-05 \\
\hline & & & Mercury Compounds & $1.88 \mathrm{E}-06$ & $1.50 E-08$ & $3.76 \mathrm{E}-06$ & 1.65E-05 \\
\hline & & & Nickel & 2.82E-06 & 2.26E-08 & 5.64E-06 & 2.47E-05 \\
\hline & & & Selenium Compounds & 1.88E-06 & $1.50 E-08$ & $3.76 \mathrm{E}-06$ & 1.65E-05 \\
\hline & 720 & 007 & Cadmium & 1.14E-09 & 5.00E-09 & 1.14E-09 & 5.00E-09 \\
\hline & & 017 & 1,3-Butadiene & 1.38E-03 & 3.45E-05 & 2.93E-03 & 7.92E-03 \\
\hline & & & Arsenic & $6.80 \mathrm{E}-06$ & 1.70E-07 & 1.45E-05 & 3.90E-05 \\
\hline & & & Benzene & 1.56E-03 & 3.89E-05 & $3.31 E-03$ & 8.94E-03 \\
\hline & & & Chromium Compounds & 1.19E-05 & 2.98E-07 & $2.53 E-05$ & $6.83 E-05$ \\
\hline
\end{tabular}

* Not Significant Source 


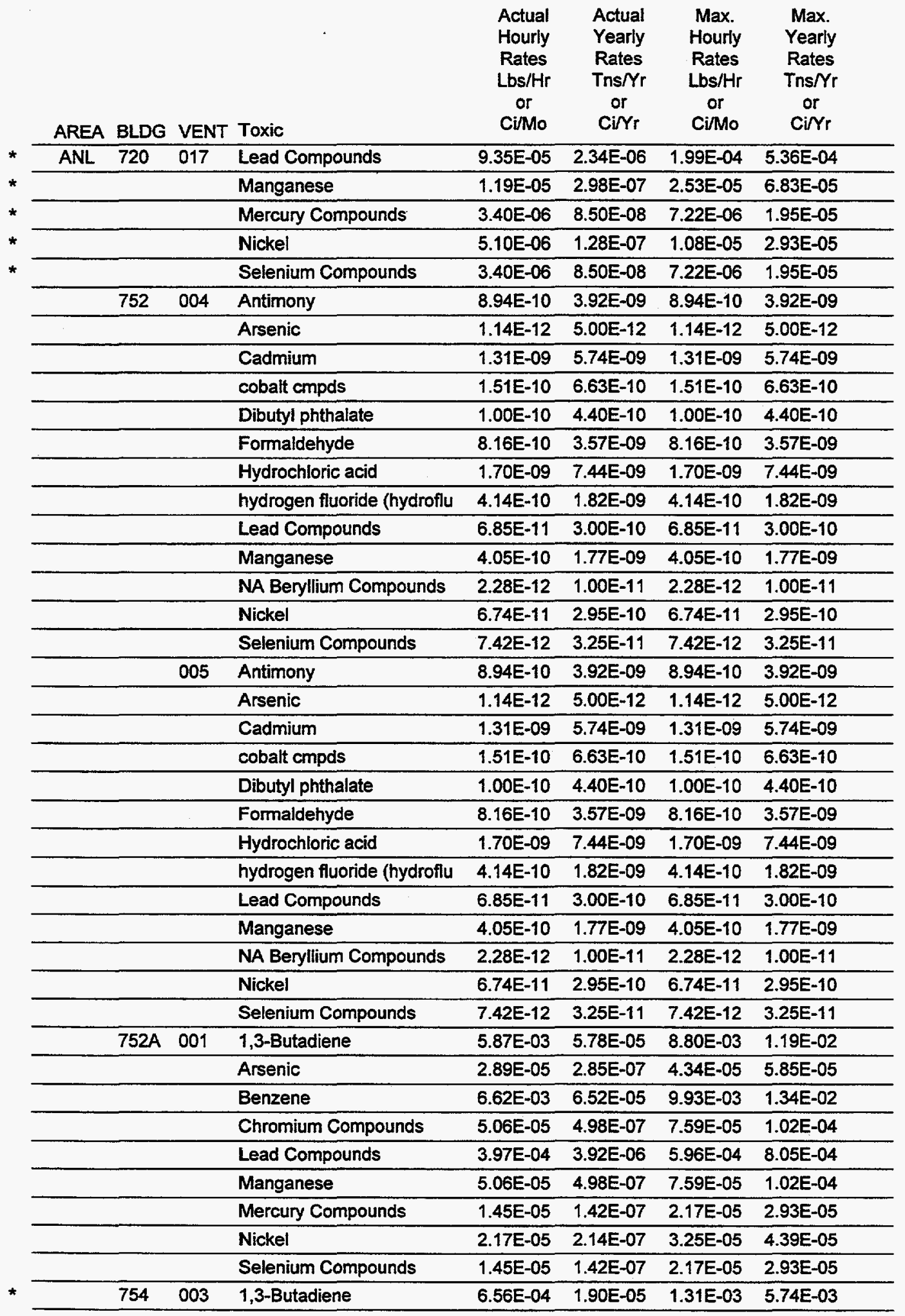

* Not Significant Source 


\begin{tabular}{|c|c|c|c|c|c|c|c|}
\hline AREA & BLDG & VENT & Toxic & $\begin{array}{c}\text { Actual } \\
\text { Hourly } \\
\text { Rates } \\
\text { Lbs/Hr } \\
\text { or } \\
\text { Ci/Mo }\end{array}$ & $\begin{array}{c}\text { Actual } \\
\text { Yearly } \\
\text { Rates } \\
\text { Tns } / Y r \\
\text { or } \\
\text { Ci/Yr }\end{array}$ & $\begin{array}{c}\text { Max. } \\
\text { Hourly } \\
\text { Rates } \\
\text { Lbs/Hr } \\
\text { or } \\
\text { Ci/Mo }\end{array}$ & $\begin{array}{c}\text { Max. } \\
\text { Yearly } \\
\text { Rates } \\
\text { Tns } / Y r \\
\text { or } \\
\text { CirYr }\end{array}$ \\
\hline \multirow[t]{41}{*}{ ANL 7} & 754 & 003 & Arsenic & 3.23E-06 & 9.35E-08 & $6.46 \mathrm{E}-06$ & 2.83E-05 \\
\hline & & & Benzene & 7.40E-04 & 2.14E-05 & $1.48 \mathrm{E}-03$ & $6.48 E-03$ \\
\hline & & & Chromium Compounds & 5.65E-06 & $1.64 \mathrm{E}-07$ & 1.13E-05 & 4.95E-05 \\
\hline & & & Lead Compounds & 4.44E-05 & 1.29E-06 & 8.88E-05 & 3.89E-04 \\
\hline & & & Manganese & $5.65 \mathrm{E}-06$ & $1.64 \mathrm{E}-07$ & 1.13E-05 & 4.95E-05 \\
\hline & & & Mercury Compounds & 1.62E-06 & 4.68E-08 & 3.23E-06 & 1.41E-05 \\
\hline & & & Nickel & 2.42E-06 & 7.01E-08 & 4.85E-06 & 2.12E-05 \\
\hline & & & Selenium Compounds & $1.62 \mathrm{E}-06$ & $4.68 \mathrm{E}-08$ & 3.23E-06 & $1.41 E-05$ \\
\hline & 768 & 003 & 1,3-Butadiene & $6.21 E-03$ & 8.63E-05 & $1.24 \mathrm{E}-02$ & $1.24 \mathrm{E}-03$ \\
\hline & & & Arsenic & 3.06E-05 & 4.25E-07 & $6.12 \mathrm{E}-05$ & 6.12E-06 \\
\hline & & & Benzene & 7.01E-03 & $9.74 \mathrm{E}-05$ & $1.40 \mathrm{E}-02$ & $1.40 \mathrm{E}-03$ \\
\hline & & & Chromium Compounds & 5.35E-05 & 7.44E-07 & 1.07E-04 & 1.07E-05 \\
\hline & & & Lead Compounds & $4.21 \mathrm{E}-04$ & $5.84 \mathrm{E}-06$ & $8.41 E-04$ & 8.42E-05 \\
\hline & & & Manganese & 5.35E-05 & 7.44E-07 & 1.07E-04 & 1.07E-05 \\
\hline & & & Mercury Compounds & 1.53E-05 & 2.13E-07 & $3.06 \mathrm{E}-05$ & 3.06E-06 \\
\hline & & & Nickel & 2.30E-05 & 3.19E-07 & 4.59E-0.5 & 4.59E-06 \\
\hline & & & Selenium Compounds & 1.53E-05 & $2.13 E-07$ & $3.06 E-05$ & 3.06E-06 \\
\hline & & 022 & Antimony & $1.50 E-04$ & 1.44E-04 & $1.96 \mathrm{E}-04$ & $8.58 E-04$ \\
\hline & & & Arsenic & 6.71E-05 & 6.45E-05 & 8.77E-05 & $3.84 \mathrm{E}-04$ \\
\hline & & & Cadmium & 5.14E-05 & 4.95E-05 & $6.73 E-05$ & 2.95E-04 \\
\hline & & & Chromium Compounds & $1.25 \mathrm{E}-04$ & $1.20 E-04$ & $1.64 \mathrm{E}-04$ & 7.17E-04 \\
\hline & & & Formaldehyde & 1.27E-02 & $1.22 \mathrm{E}-02$ & $1.66 \mathrm{E}-02$ & 7.25E-02 \\
\hline & & & Hexane (n-Hexane) & 2.81E-03 & $2.70 \mathrm{E}-03$ & $3.67 E-03$ & 1.61E-02 \\
\hline & & & Lead Compounds & 2.71E-04 & 2.60E-04 & 3.54E-04 & $1.55 \mathrm{E}-03$ \\
\hline & & & Manganese & 1.21E-04 & $1.16 \mathrm{E}-04$ & $1.58 \mathrm{E}-04$ & $6.92 E-04$ \\
\hline & & & Mercury Compounds & 1.34E-05 & 1.29E-05 & $1.75 \mathrm{E}-05$ & $7.68 \mathrm{E}-05$ \\
\hline & & & Nickel & 1.37E-02 & $1.31 E-02$ & 1.79E-02 & $7.82 \mathrm{E}-02$ \\
\hline & & & Selenium Compounds & 1.34E-05 & 1.29E-05 & 1.75E-05 & $7.68 \mathrm{E}-05$ \\
\hline & & 024 & Antimony & $1.50 \mathrm{E}-04$ & $1.44 \mathrm{E}-04$ & 1.96E-04 & 8.58E-04 \\
\hline & & & Arsenic & 6.71E-05 & 6.45E-05 & 8.77E-05 & 3.84E-04 \\
\hline & & & Cadmium & 5.14E-05 & 4.95E-05 & $6.73 E-05$ & 2.95E-04 \\
\hline & & & Chromium Compounds & 1.25E-04 & $1.20 \mathrm{E}-04$ & $1.64 \mathrm{E}-04$ & 7.17E-04 \\
\hline & & & Formaldehyde & 1.27E-02 & $1.22 \mathrm{E}-02$ & $1.66 \mathrm{E}-02$ & 7.25E-02 \\
\hline & & & Hexane (n-Hexane) & 2.81E-03 & 2.70E-03 & 3.67E-03 & $1.61 \mathrm{E}-02$ \\
\hline & & & Lead Compounds & 2.71E-04 & $2.60 \mathrm{E}-04$ & 3.54E-04 & 1.55E-03 \\
\hline & & & Manganese & 1.21E-04 & 1.16E-04 & 1.58E-04 & 6.92E-04 \\
\hline & & & Mercury Compounds & 1.34E-05 & 1.29E-05 & 1.75E-05 & 7.68E-05 \\
\hline & & & Nickel & 1.37E-02 & 1.31E-02 & $1.79 E-02$ & $7.82 \mathrm{E}-02$ \\
\hline & & & Selenium Compounds & $1.34 \mathrm{E}-05$ & $1.29 \mathrm{E}-05$ & $1.75 \mathrm{E}-05$ & 7.68E-05 \\
\hline & & 027 & Antimony & $1.54 E-04$ & $1.44 \mathrm{E}-04$ & $1.94 E-04$ & 8.48E-04 \\
\hline & & & Arsenic & 6.91E-05 & 6.45E-05 & 8.67E-05 & 3.80E-04 \\
\hline
\end{tabular}

- Not Significant Source 


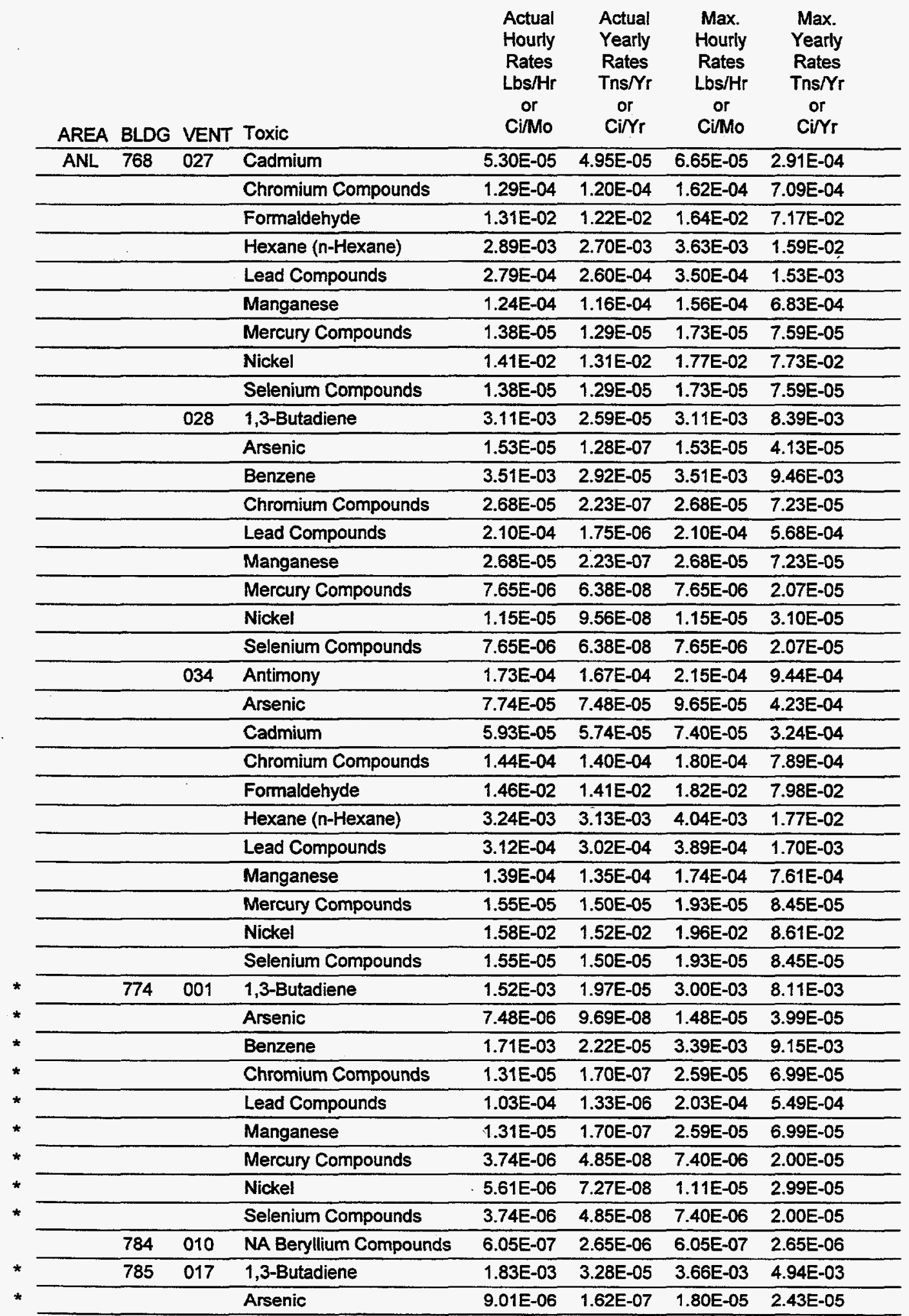

- Not Significant Source 


\begin{tabular}{|c|c|c|c|c|c|c|c|}
\hline AREA & BLDG & VENT & Toxic & CVIMo & CuYr & Ci/Mo & $\mathrm{Ci} / \mathrm{Yr}$ \\
\hline ANL & 785 & 017 & Benzene & 2.06E-03 & 3.70E-05 & 4.13E-03 & 5.57E-03 \\
\hline & & & Chromium Compounds & $1.58 \mathrm{E}-05$ & 2.83E-07 & 3.15E-05 & 4.26E-05 \\
\hline & & & Lead Compounds & 1.24E-04 & 2.22E-06 & $2.48 E-04$ & 3.34E-04 \\
\hline & & & Manganese & $1.58 \mathrm{E}-05$ & 2.83E-07 & 3.15E-05 & 4.26E-05 \\
\hline & & & Mercury Compounds & 4.51E-06 & 8.07E-08 & 9.01E-06 & $1.22 \mathrm{E}-05$ \\
\hline & & & Nickel & 6.76E-06 & 1.21E-07 & $1.35 \mathrm{E}-05$ & $1.82 \mathrm{E}-05$ \\
\hline & & & Selenium Compounds & 4.51E-06 & 8.07E-08 & 9.01E-06 & $1.22 E-05$ \\
\hline
\end{tabular}


AREA BLDG VENT Toxic

\begin{tabular}{cccc}
$\begin{array}{c}\text { Actual } \\
\text { Hourly } \\
\text { Rates } \\
\text { Lbs/Hr } \\
\text { or } \\
\text { Ci/Mo }\end{array}$ & $\begin{array}{c}\text { Actual } \\
\text { Yearly } \\
\text { Rates } \\
\text { Tns } / Y r \\
\text { or } \\
\text { Ci/Yr }\end{array}$ & $\begin{array}{c}\text { Max. } \\
\text { Hourly } \\
\text { Rates } \\
\text { Lbs/Hr } \\
\text { or } \\
\text { Ci/Mo }\end{array}$ & $\begin{array}{c}\text { Max. } \\
\text { Yearly } \\
\text { Rates } \\
\text { Tns } / Y r \\
\text { or } \\
\text { Ci/Yr }\end{array}$ \\
\hline $8.63 E-04$ & $1.12 E-05$ & $1.73 E-03$ & $7.56 E-03$ \\
\hline $4.25 E-06$ & $5.53 E-08$ & $8.50 E-06$ & $3.72 E-05$ \\
\hline $9.74 E-04$ & $1.27 E-05$ & $1.95 E-03$ & $8.53 E-03$ \\
\hline $7.44 E-06$ & $9.67 E-08$ & $1.49 E-05$ & $6.52 E-05$ \\
\hline $5.84 E-05$ & $7.60 E-07$ & $1.17 E-04$ & $5.12 E-04$ \\
\hline $7.44 E-06$ & $9.67 E-08$ & $1.49 E-05$ & $6.52 E-05$ \\
\hline $2.13 E-06$ & $2.76 E-08$ & $4.25 E-06$ & $1.86 E-05$ \\
\hline $3.19 E-06$ & $4.14 E-08$ & $6.38 E-06$ & $2.79 E-05$ \\
\hline $2.13 E-06$ & $2.76 E-08$ & $4.25 E-06$ & $1.86 E-05$ \\
\hline
\end{tabular}

* Not Significant Source 


\begin{tabular}{|c|c|c|c|c|c|c|c|}
\hline AREA & BLDG & VENT & Toxic & $\begin{array}{c}\text { Actual } \\
\text { Hourly } \\
\text { Rates } \\
\text { Lbs/Hr } \\
\text { or } \\
\text { Ci/Mo }\end{array}$ & $\begin{array}{c}\text { Actual } \\
\text { Yearly } \\
\text { Rates } \\
\text { Tns } / Y r \\
\text { or } \\
\text { Ci } / Y r\end{array}$ & $\begin{array}{c}\text { Max. } \\
\text { Hourly } \\
\text { Rates } \\
\text { Lbs/Hr } \\
\text { or } \\
\text { CiMo }\end{array}$ & $\begin{array}{c}\text { Max. } \\
\text { Yearly } \\
\text { Rates } \\
\text { Tns } / \text { rr } \\
\text { or } \\
\text { Ci } / Y r\end{array}$ \\
\hline $\mathbf{B 2 1}$ & 608 & 012 & Lead Compounds & $2.00 \mathrm{E}-06$ & $3.00 \mathrm{E}-06$ & $2.00 E-06$ & 1.10E-05 \\
\hline
\end{tabular}

- Not Significant Source 


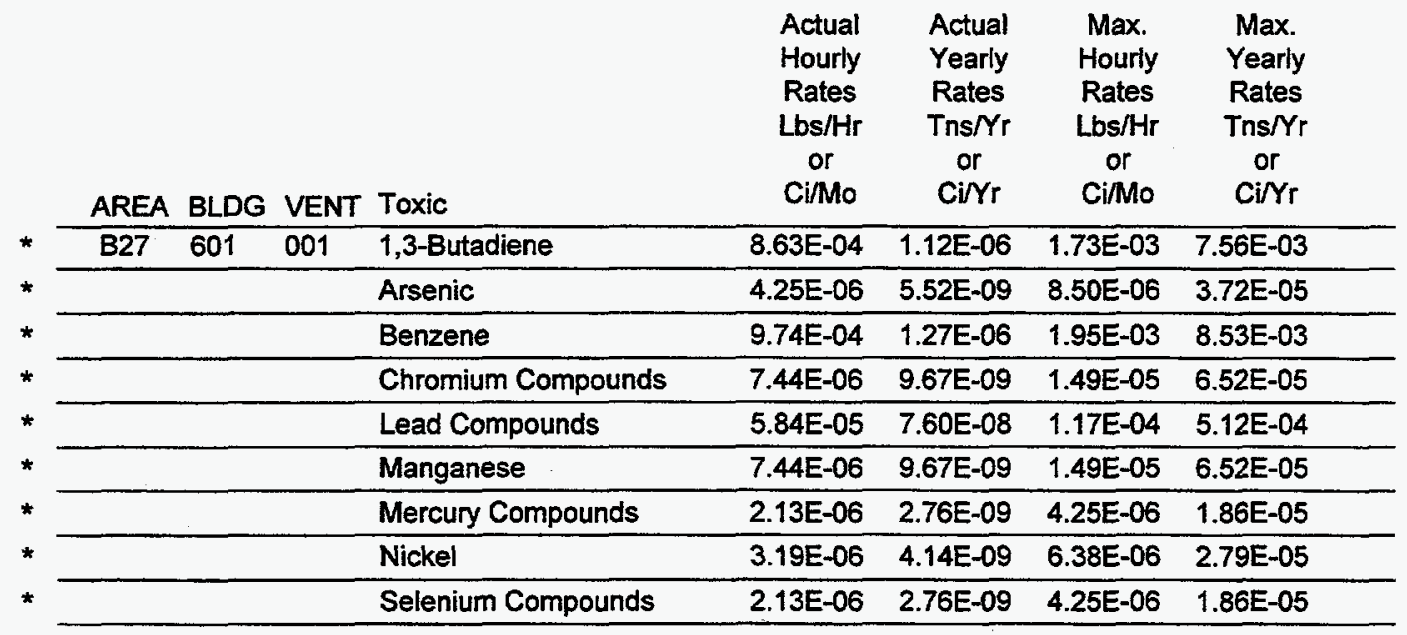




\begin{tabular}{|c|c|c|c|c|c|c|c|}
\hline AREA & BLDG & VENT & Toxic & $\begin{array}{l}\text { Actual } \\
\text { Hourly } \\
\text { Rates } \\
\text { Lbs/Hr } \\
\text { or } \\
\text { Ci/Mo }\end{array}$ & $\begin{array}{c}\text { Actual } \\
\text { Yearly } \\
\text { Rates } \\
\text { Tns } / Y r \\
\text { or } \\
\text { Ci } /{ }_{r}\end{array}$ & $\begin{array}{l}\text { Max. } \\
\text { Hourly } \\
\text { Rates } \\
\text { Lbs/Hr } \\
\text { or } \\
\text { Ci/Mo }\end{array}$ & $\begin{array}{c}\text { Max. } \\
\text { Yearly } \\
\text { Rates } \\
\text { Tns } / Y r \\
\text { or } \\
\text { Ci/Yr }\end{array}$ \\
\hline \multirow[t]{41}{*}{ CFA } & 1603 & 001 & 1,3-Butadiene & 3.59E-03 & 4.66E-05 & $3.59 \mathrm{E}-03$ & $9.69 \mathrm{E}-03$ \\
\hline & & & Arsenic & 1.77E-05 & 2.30E-07 & $1.77 E-05$ & 4.77E-05 \\
\hline & & & Benzene & 4.05E-03 & $5.26 \mathrm{E}-05$ & 4.05E-03 & 1.09E-02 \\
\hline & & & Chromium Compounds & 3.09E-05 & 4.02E-07 & 3.09E-05 & $8.35 E-05$ \\
\hline & & & Lead Compounds & 2.43E-04 & $3.16 E-06$ & 2.43E-04 & $6.56 \mathrm{E}-04$ \\
\hline & & & Manganese & 3.09E-05 & $4.02 E-07$ & 3.09E-05 & $8.35 \mathrm{E}-05$ \\
\hline & & & Mercury Compounds & 8.84E-06 & $1.15 \mathrm{E}-07$ & $8.84 E-06$ & $2.39 \mathrm{E}-05$ \\
\hline & & & Nickel & 1.33E-05 & 1.72E-07 & 1.33E-05 & $3.58 \mathrm{E}-05$ \\
\hline & & & Selenium Compounds & 8.84E-06 & $1.15 \mathrm{E}-07$ & $8.84 E-06$ & $2.39 \mathrm{E}-05$ \\
\hline & 604 & 001 & 1,3-Butadiene & $6.90 \mathrm{E}-04$ & $1.04 E-05$ & $3.45 E-03$ & $1.51 \mathrm{E}-02$ \\
\hline & & & Arsenic & 3.40E-06 & 5.10E-08 & 1.70E-05 & 7.45E-05 \\
\hline & & & Benzene & 7.79E-04 & 1.17E-05 & $3.89 E-03$ & $1.71 E-02$ \\
\hline & & & Chromium Compounds & 5.95E-06 & 8.93E-08 & $2.98 \mathrm{E}-05$ & $1.30 \mathrm{E}-04$ \\
\hline & & & Lead Compounds & 4.68E-05 & 7.01E-07 & $2.34 \mathrm{E}-04$ & $1.02 E-03$ \\
\hline & & & Manganese & 5.95E-06 & 8.93E-08 & $2.98 \mathrm{E}-05$ & $1.30 \mathrm{E}-04$ \\
\hline & & & Mercury Compounds & $1.70 \mathrm{E}-06$ & 2.55E-08 & 8.50E-06 & $3.72 E-05$ \\
\hline & & & Nickel & $2.55 \mathrm{E}-06$ & $3.83 E-08$ & $1.28 E-05$ & $5.58 \mathrm{E}-0.5$ \\
\hline & & & Selenium Compounds & $1.70 E-06$ & 2.55E-08 & 8.50E-06 & 3.72E-05 \\
\hline & 607 & 004 & Lead Compounds & & & & \\
\hline & 608 & 001 & Antimony & $1.31 \mathrm{E}-06$ & 7.33E-06 & 1.23E-05 & $5.40 E-05$ \\
\hline & & & Arsenic & 5.88E-07 & 3.28E-06 & 5.52E-06 & 2.42E-05 \\
\hline & & & Cadmium & 4.51E-07 & $2.52 E-06$ & $4.23 E-06$ & $1.85 \mathrm{E}-05$ \\
\hline & & & Chromium Compounds & $1.10 \mathrm{E}-06$ & $6.13 E-06$ & $1.03 E-05$ & $4.51 E-05$ \\
\hline & & & Formaldehyde & 1.89E-04 & $1.05 \mathrm{E}-03$ & $1.77 \mathrm{E}-03$ & $7.76 \mathrm{E}-03$ \\
\hline & & & Hexane (n-Hexane) & 4.19E-05 & 2.34E-04 & 3.93E-04 & $1.72 \mathrm{E}-03$ \\
\hline & & & Lead Compounds & 2.37E-06 & $1.32 E-05$ & 2.23E-05 & $9.75 E-05$ \\
\hline & & & Manganese & $1.06 \mathrm{E}-06$ & 5.91E-06 & 9.94E-06 & $4.35 E-05$ \\
\hline & & & Mercury Compounds & $1.18 E-07$ & $6.56 \mathrm{E}-07$ & $1.10 \mathrm{E}-06$ & $4.84 E-06$ \\
\hline & & & Nickel & $1.20 E-04$ & $6.68 \mathrm{E}-04$ & $1.12 \mathrm{E}-03$ & $4.92 E-03$ \\
\hline & & & Selenium Compounds & $1.18 E-07$ & $6.56 \mathrm{E}-07$ & 1.10E-06 & 4.84E-06 \\
\hline & 609 & 001 & 1,3-Butadiene & 1.95E-03 & $1.55 E-05$ & $5.18 E-03$ & 1.40E-02 \\
\hline & & & Arsenic & $9.61 E-06$ & $7.65 E-08$ & 2.55E-05 & $6.88 \mathrm{E}-05$ \\
\hline & & & Benzene & $2.20 \mathrm{E}-03$ & 1.75E-05 & $5.84 E-03$ & $1.58 \mathrm{E}-02$ \\
\hline & & & Chromium Compounds & $1.68 E-05$ & 1.34E-07 & $4.46 E-05$ & 1.20E-04 \\
\hline & & & Lead Compounds & 1.32E-04 & $1.05 \mathrm{E}-06$ & $3.51 E-04$ & 9.47E-04 \\
\hline & & & Manganese & 1.68E-05 & 1.34E-07 & 4.46E-05 & 1.20E-04 \\
\hline & & & Mercury Compounds & 4.80E-06 & 3.83E-08 & $1.28 \mathrm{E}-05$ & $3.44 \mathrm{E}-05$ \\
\hline & & & Nickel & $7.20 \mathrm{E}-06$ & 5.74E-08 & 1.91E-05 & $5.16 \mathrm{E}-05$ \\
\hline & & & Selenium Compounds & $4.80 E-06$ & 3.83E-08 & $1.28 E-05$ & $3.44 E-05$ \\
\hline & & 005 & Antimony & 2.24E-06 & 7.32E-06 & 1.73E-05 & $1.44 \mathrm{E}-05$ \\
\hline & & & Arsenic & $1.00 \mathrm{E}-06$ & $3.28 E-06$ & 7.74E-06 & $6.45 E-06$ \\
\hline
\end{tabular}

- Not Significant Source 


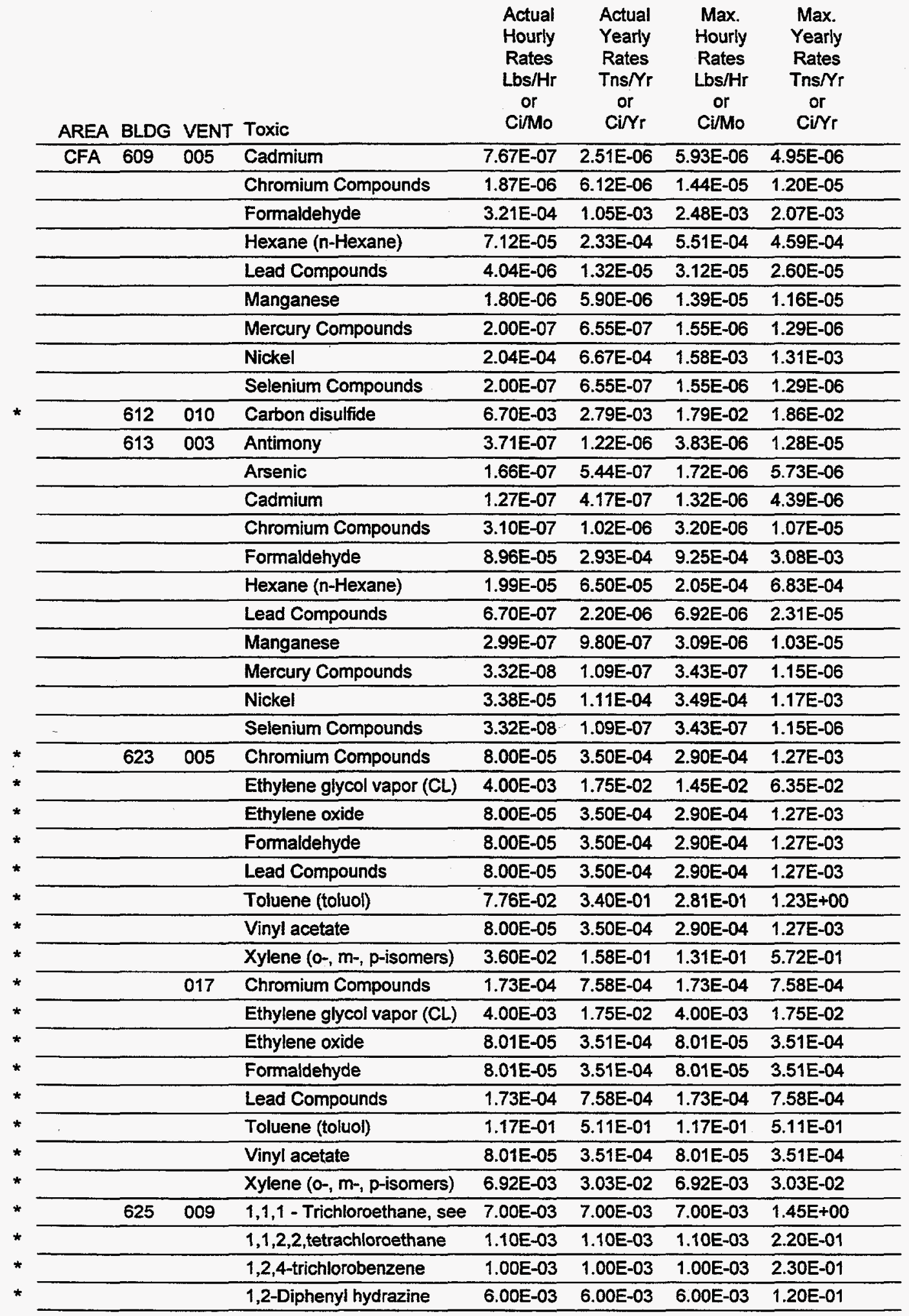

- Not Significant Source 


\begin{tabular}{|c|c|c|c|c|c|c|c|}
\hline AREA & BLDG & VENT & Toxic & $\begin{array}{l}\text { Actual } \\
\text { Hourly } \\
\text { Rates } \\
\text { Lbs/Hr } \\
\text { or } \\
\text { Ci/Mo }\end{array}$ & $\begin{array}{c}\text { Actual } \\
\text { Yearly } \\
\text { Rates } \\
\text { Tns } / Y r \\
\text { or } \\
\text { Ci } / Y r\end{array}$ & $\begin{array}{c}\text { Max. } \\
\text { Hourly } \\
\text { Rates } \\
\text { Lbs/Hr } \\
\text { or } \\
\text { Ci/Mo }\end{array}$ & $\begin{array}{c}\text { Max. } \\
\text { Yearly } \\
\text { Rates } \\
\text { Tns } / Y r \\
\text { or } \\
\text { Ciryr }\end{array}$ \\
\hline \multirow[t]{41}{*}{ CFA } & 625 & 009 & 1,4-Dichlorobenzene & $8.00 E-04$ & $8.00 \mathrm{E}-04$ & $8.00 E-04$ & $1.70 \mathrm{E}-01$ \\
\hline & & & 2,2,4-Trimethylpentane & $3.05 E+00$ & $3.05 E+00$ & $3.05 E+00$ & $6.10 \mathrm{E}+00$ \\
\hline & & & 2,4,6 - Trichlorophenol & 1.10E-01 & 1.10E-01 & $1.10 \mathrm{E}-01$ & $2.20 \mathrm{E}-01$ \\
\hline & & & 2,4-dinitrotoluene & 2.00E-03 & 2.00E-03 & $2.00 E-03$ & 4.00E-03 \\
\hline & & & 2-Butanone, see Methyl eth & $1.80 \mathrm{E}-02$ & $1.80 \mathrm{E}-02$ & $1.80 E-02$ & $3.60 \mathrm{E}-02$ \\
\hline & & & 4-nitrophenol & 1.00E-03 & $1.00 E-03$ & $1.00 E-03$ & 2.00E-03 \\
\hline & & & Aniline & 2.20E-02 & 2.20E-02 & $2.20 E-02$ & 4.40E-02 \\
\hline & & & Benzene & 2.00E-03 & 2.00E-03 & $2.00 \mathrm{E}-03$ & $4.00 \mathrm{E}-03$ \\
\hline & & & Bromoform & $1.00 \mathrm{E}-03$ & 1.00E-03 & $1.00 \mathrm{E}-03$ & 2.00E-03 \\
\hline & & & Cadmium & $6.20 \mathrm{E}-03$ & $6.20 E-03$ & $6.20 \mathrm{E}-03$ & 2.44E-02 \\
\hline & & & chlorobenzene (monochlor & $1.00 \mathrm{E}-03$ & $1.00 E-03$ & $1.00 E-03$ & 2.00E-03 \\
\hline & & & Chloroform & $1.00 \mathrm{E}-03$ & $1.00 \mathrm{E}-03$ & $1.00 \mathrm{E}-03$ & 2.00E-03 \\
\hline & & & Chromium Compounds & $1.00 \mathrm{E}-03$ & $1.00 \mathrm{E}-03$ & $1.00 \mathrm{E}-03$ & 2.00E-03 \\
\hline & & & Ethyl benzene & 2.00E-01 & 2.00E-01 & $2.00 \mathrm{E}-01$ & $4.00 \mathrm{E}-01$ \\
\hline & & & Hexane (n-Hexane) & $3.70 E+00$ & $3.70 \mathrm{E}+00$ & $3.70 \mathrm{E}+00$ & $7.00 E+00$ \\
\hline & & & Hydrochloric acid & $1.80 E+01$ & $1.80 E+01$ & $1.80 \mathrm{E}+01$ & $3.60 E+01$ \\
\hline & & & Lead Compounds & 2.26E-01 & 2.26E-01 & $2.26 E-01$ & $4.52 E-01$ \\
\hline & & & m-Xylene a,a-diamine (CL) & 2.20E-02 & $2.20 \mathrm{E}-02$ & $2.20 \mathrm{E}-02$ & $4.40 \mathrm{E}-02$ \\
\hline & & & Nickel & $1.62 \mathrm{E}-01$ & $1.62 E-01$ & $1.62 \mathrm{E}-01$ & $3.24 E-01$ \\
\hline & & & o-xylenes & $2.20 \mathrm{E}-02$ & $2.20 E-02$ & $2.20 \mathrm{E}-02$ & $4.40 \mathrm{E}-02$ \\
\hline & & & p-Cresol & $2.00 \mathrm{E}-03$ & 2.00E-03 & $2.00 \mathrm{E}-03$ & $4.00 E-03$ \\
\hline & & & p-xylenes & 2.00E-02 & $2.00 E-02$ & 2.00E-02 & $4.00 \mathrm{E}-02$ \\
\hline & & & Pentachloronitrobenzene & $4.00 \mathrm{E}-02$ & $4.00 E-02$ & 4.00E-02 & 8.00E-02 \\
\hline & & & Phenol & 1.10E-01 & $1.10 E-01$ & $1.10 \mathrm{E}-01$ & 2.20E-01 \\
\hline & & & Selenium Compounds & $5.00 \mathrm{E}-03$ & $5.00 E-03$ & 5.00E-03 & $1.00 \mathrm{E}-02$ \\
\hline & & & Toluene (toluol) & $1.00 \mathrm{E}-03$ & $1.00 E-03$ & $1.00 E-03$ & $2.00 \mathrm{E}-03$ \\
\hline & & & Trichloroethylene & $1.00 \mathrm{E}-03$ & $1.00 \mathrm{E}-03$ & $1.00 \mathrm{E}-03$ & $2.00 \mathrm{E}-03$ \\
\hline & 633 & 091 & 1,3-Butadiene & $0.00 E+00$ & $0.00 E+00$ & 1.97E-03 & 5.31E-03 \\
\hline & & & Arsenic & $0.00 \mathrm{E}+00$ & $0.00 E+00$ & 9.69E-06 & $2.62 \mathrm{E}-05$ \\
\hline & & & Benzene & $0.00 E+00$ & $0.00 E+00$ & 2.22E-03 & 5.99E-03 \\
\hline & & & Chromium Compounds & $0.00 \mathrm{E}+00$ & $0.00 E+00$ & $1.70 \mathrm{E}-05$ & $4.58 E-05$ \\
\hline & & & Lead Compounds & $0.00 E+00$ & $0.00 E+00$ & 1.33E-04 & $3.60 E-04$ \\
\hline & & & Manganese & $0.00 E+00$ & $0.00 E+00$ & $1.70 \mathrm{E}-05$ & 4.58E-05 \\
\hline & & & Mercury Compounds & $0.00 E+00$ & $0.00 E+00$ & 4.85E-06 & 1.31E-05 \\
\hline & & & Nickel & $0.00 E+00$ & $0.00 E+00$ & 7.27E-06 & $1.96 E-05$ \\
\hline & & & Selenium Compounds & $0.00 \mathrm{E}+00$ & $0.00 E+00$ & 4.85E-06 & 1.31E-05 \\
\hline & 650 & 007 & Antimony & $1.60 \mathrm{E}-06$ & 5.23E-06 & 3.34E-05 & $1.09 E-04$ \\
\hline & & & Arsenic & 7.15E-07 & 2.34E-06 & $1.50 \mathrm{E}-05$ & 4.90E-05 \\
\hline & & & Cadmium & 5.48E-07 & 1.79E-06 & 1.15E-05 & $3.76 \mathrm{E}-05$ \\
\hline & & & Chromium Compounds & 1.33E-06 & 4.37E-06 & $2.79 E-05$ & 9.15E-05 \\
\hline & & & Formaldehyde & 2.29E-04 & $7.50 E-04$ & 4.80E-03 & 1.57E-02 \\
\hline
\end{tabular}

\footnotetext{
* Not Significant Source
} 


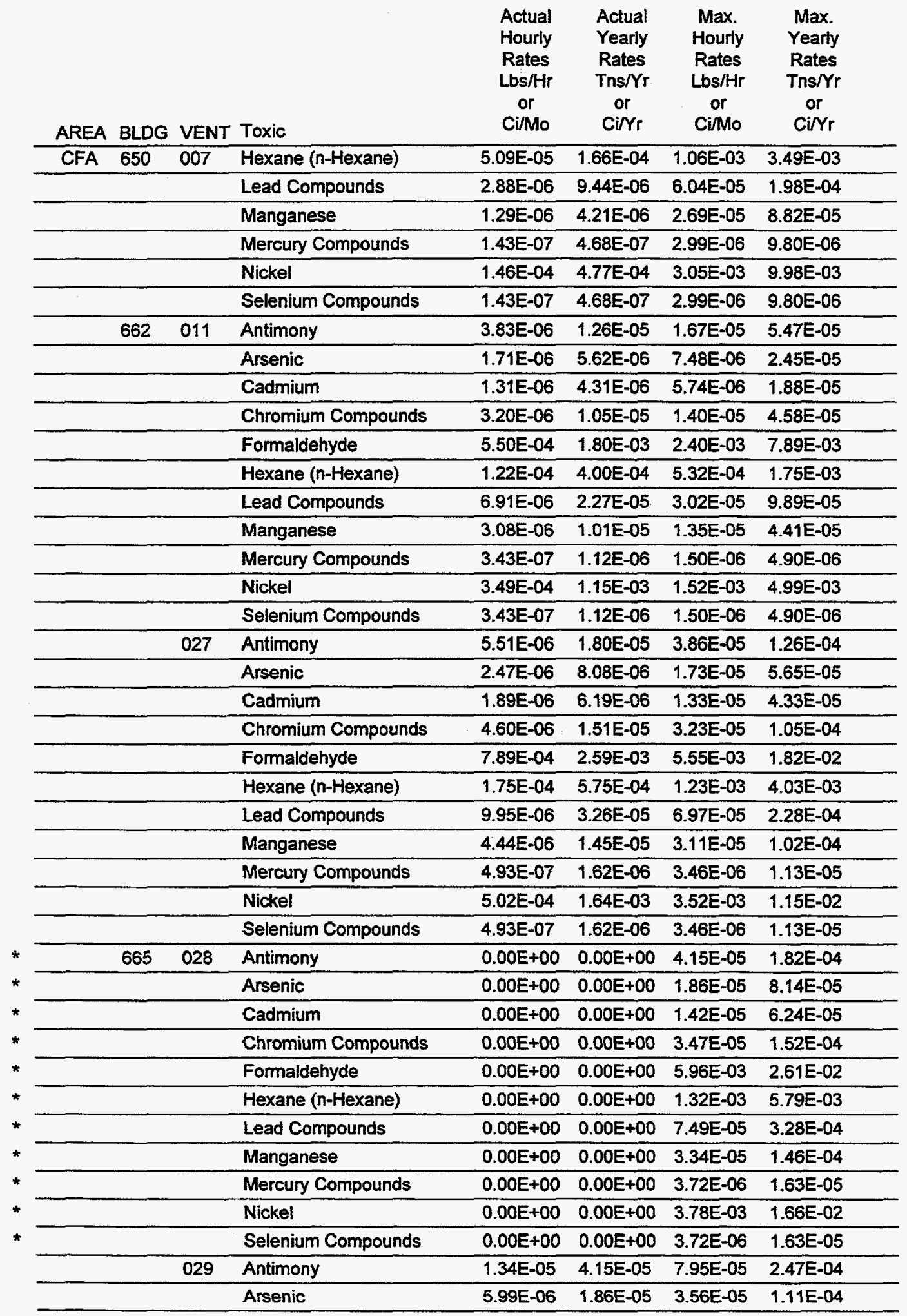

* Not Significant Source 


\begin{tabular}{|c|c|c|c|c|c|c|c|}
\hline AREA & BLDG & VENT & Toxic & $\begin{array}{c}\text { Actual } \\
\text { Hourly } \\
\text { Rates } \\
\text { Lbs/Hr } \\
\text { or } \\
\text { Ci/Mo }\end{array}$ & $\begin{array}{c}\text { Actual } \\
\text { Yearly } \\
\text { Rates } \\
\text { Tns/Yr } \\
\text { or } \\
\text { Ci } / \mathrm{r}\end{array}$ & $\begin{array}{c}\text { Max. } \\
\text { Hourly } \\
\text { Rates } \\
\text { Lbs/Hr } \\
\text { or } \\
\text { Ci/Mo }\end{array}$ & $\begin{array}{c}\text { Max. } \\
\text { Yearly } \\
\text { Rates } \\
\text { Tns } / Y r \\
\text { or } \\
\text { cirrr }\end{array}$ \\
\hline \multirow[t]{41}{*}{ CFA } & 665 & 029 & Cadmium & 4.59E-06 & 1.43E-05 & 2.73E-05 & 8.49E-05 \\
\hline & & & Chromium Compounds & 1.12E-05 & 3.47E-05 & 6.65E-05 & 2.07E-04 \\
\hline & & & Formaldehyde & 1.13E-03 & $3.51 E-03$ & 6.72E-03 & 2.09E-02 \\
\hline & & & Hexane (n-Hexane) & 2.51E-04 & 7.79E-04 & 1.49E-03 & 4.63E-03 \\
\hline & & & Lead Compounds & 2.41E-05 & $7.50 \mathrm{E}-05$ & $1.44 E-04$ & $4.46 E-04$ \\
\hline & & & Manganese & $1.08 \mathrm{E}-05$ & 3.35E-05 & $6.41 E-05$ & 1.99E-04 \\
\hline & & & Mercury Compounds & 1.20E-06 & $3.72 \mathrm{E}-06$ & 7.12E-06 & 2.21E-05 \\
\hline & & & Nickel & $1.22 \mathrm{E}-03$ & $3.79 \mathrm{E}-03$ & $7.25 \mathrm{E}-03$ & $2.25 \mathrm{E}-02$ \\
\hline & & & Selenium Compounds & 1.20E-06 & $3.72 E-06$ & $7.12 E-06$ & 2.21E-05 \\
\hline & & 030 & Antimony & $0.00 E+00$ & $0.00 E+00$ & $4.15 E-05$ & $1.82 \mathrm{E}-04$ \\
\hline & & & Arsenic & $0.00 \mathrm{E}+00$ & $0.00 \mathrm{E}+00$ & 1.86E-05 & 8.14E-05 \\
\hline & & & Cadmium & $0.00 E+00$ & $0.00 E+00$ & $1.42 E-05$ & $6.24 \mathrm{E}-05$ \\
\hline & & & Chromium Compounds & $0.00 E+00$ & $0.00 E+00$ & 3.47E-05 & 1.52E-04 \\
\hline & & & Formaldehyde & $0.00 E+00$ & $0.00 E+00$ & $5.96 E-03$ & $2.61 E-02$ \\
\hline & & & Hexane (n-Hexane) & $0.00 E+00$ & $0.00 E+00$ & 1.32E-03 & 5.79E-03 \\
\hline & & & Lead Compounds & $0.00 E+00$ & $0.00 E+00$ & 7.49E-05 & $3.28 \mathrm{E}-04$ \\
\hline & & & Manganese & $0.00 E+00$ & $0.00 E+00$ & $3.34 E-05$ & $1.46 \mathrm{E}-04$ \\
\hline & & & Mercury Compounds & $0.00 E+00$ & $0.00 E+00$ & 3.72E-06 & $1.63 \mathrm{E}-05$ \\
\hline & & & Nickel & $0.00 \mathrm{E}+00$ & $0.00 \mathrm{E}+00$ & $3.78 E-03$ & $1.66 \mathrm{E}-02$ \\
\hline & & & Selenium Compounds & $0.00 \mathrm{E}+00$ & $0.00 E+00$ & 3.72E-06 & 1.63E-05 \\
\hline & & 050 & Toluene (toluol) & 7.77E-02 & 6.06E-02 & $1.17 \mathrm{E}-01$ & $1.21 E-01$ \\
\hline & 668 & 006 & 1,3-Butadiene & $3.88 \mathrm{E}-03$ & $1.01 \mathrm{E}-04$ & $7.76 \mathrm{E}-03$ & $1.05 \mathrm{E}-02$ \\
\hline & & & Arsenic & $1.91 E-05$ & 4.97E-07 & 3.83E-05 & 5.16E-05 \\
\hline & & & Benzene & 4.38E-03 & $1.14 \mathrm{E}-04$ & 8.76E-03 & $1.18 E-02$ \\
\hline & & & Chromium Compounds & 3.35E-05 & 8.70E-07 & $6.69 \mathrm{E}-05$ & 9.04E-05 \\
\hline & & & Lead Compounds & 2.63E-04 & 6.84E-06 & $5.26 \mathrm{E}-04$ & 7.10E-04 \\
\hline & & & Manganese & 3.35E-05 & $8.70 \mathrm{E}-07$ & $6.69 \mathrm{E}-05$ & $9.04 \mathrm{E}-05$ \\
\hline & & & Mercury Compounds & $9.56 \mathrm{E}-06$ & 2.49E-07 & 1.91E-05 & $2.58 E-05$ \\
\hline & & & Nickel & 1.43E-05 & 3.73E-07 & 2.87E-05 & 3.87E-05 \\
\hline & & & Selenium Compounds & $9.56 \mathrm{E}-06$ & 2.49E-07 & $1.91 E-05$ & 2.58E-05 \\
\hline & & 023 & Antimony & $1.88 \mathrm{E}-06$ & 6.17E-06 & $3.68 \mathrm{E}-06$ & $1.20 \mathrm{E}-05$ \\
\hline & & & Arsenic & 8.41E-07 & $2.76 E-06$ & 1.65E-06 & 5.39E-06 \\
\hline & & & Cadmium & $6.45 E-07$ & 2.12E-06 & $1.26 \mathrm{E}-06$ & 4.13E-06 \\
\hline & & & Chromium Compounds & 1.57E-06 & $5.15 \mathrm{E}-06$ & 3.07E-06 & $1.01 E-05$ \\
\hline & & & Formaldehyde & 4.52E-04 & $1.48 E-03$ & 8.86E-04 & 2.90E-03 \\
\hline & & & Hexane (n-Hexane) & $1.00 E-04$ & $3.28 E-04$ & $1.97 E-04$ & $6.44 \mathrm{E}-04$ \\
\hline & & & Lead Compounds & 3.39E-06 & $1.11 \mathrm{E}-05$ & $6.64 E-06$ & 2.17E-05 \\
\hline & & & Manganese & $1.51 E-06$ & 4.97E-06 & 2.96E-06 & $9.71 E-06$ \\
\hline & & & Mercury Compounds & $1.68 E-07$ & 5.52E-07 & $3.29 E-07$ & 1.08E-06 \\
\hline & & & Nickel & $1.71 E-04$ & $5.62 \mathrm{E}-04$ & 3.35E-04 & $1.10 \mathrm{E}-03$ \\
\hline & & & Selenium Compounds & $1.68 E-07$ & 5.52E-07 & $3.29 E-07$ & 1.08E-06 \\
\hline
\end{tabular}

- Not Significant Source 


\begin{tabular}{|c|c|c|c|c|c|c|c|}
\hline AREA & BLDG & VENT & Toxic & $\begin{array}{c}\text { Actual } \\
\text { Hourly } \\
\text { Rates } \\
\text { Lbs/Hr } \\
\text { or } \\
\text { Ci/Mo }\end{array}$ & $\begin{array}{c}\text { Actual } \\
\text { Yearly } \\
\text { Rates } \\
\text { Tns } / Y r \\
\text { or } \\
\text { Ci } / Y r\end{array}$ & $\begin{array}{c}\text { Max. } \\
\text { Hourly } \\
\text { Rates } \\
\text { Lbs/Hr } \\
\text { or } \\
\text { Ci/Mo }\end{array}$ & $\begin{array}{c}\text { Max. } \\
\text { Yearly } \\
\text { Rates } \\
\text { Tns } / \mathrm{Yr}_{\mathrm{r}} \\
\text { or } \\
\mathrm{Ci} / \mathrm{Yr}\end{array}$ \\
\hline \multirow[t]{41}{*}{ CFA } & 671 & 007 & Antimony & $1.28 \mathrm{E}-05$ & 2.10E-05 & 4.38E-05 & 1.43E-04 \\
\hline & & & Arsenic & 5.75E-06 & 9.40E-06 & 1.96E-05 & $6.42 E-05$ \\
\hline & & & Cadmium & 4.41E-06 & 7.21E-06 & $1.50 E-05$ & 4.93E-05 \\
\hline & & & Chromium Compounds & 1.07E-05 & 1.76E-05 & $3.66 \mathrm{E}-05$ & $1.20 \mathrm{E}-04$ \\
\hline & & & Formaldehyde & $1.84 \mathrm{E}-03$ & 3.02E-03 & $6.28 \mathrm{E}-03$ & $2.06 E-02$ \\
\hline & & & Hexane (n-Hexane) & $4.08 E-04$ & $6.69 E-04$ & 1.39E-03 & 4.57E-03 \\
\hline & & & Lead Compounds & 2.32E-05 & 3.79E-05 & 7.91E-05 & $2.59 E-04$ \\
\hline & & & Manganese & $1.04 \mathrm{E}-05$ & 1.69E-05 & 3.53E-05 & $1.16 E-04$ \\
\hline & & & Mercury Compounds & 1.15E-06 & $1.88 E-06$ & 3.92E-06 & $1.28 \mathrm{E}-05$ \\
\hline & & & Nickel & 1.17E-03 & 1.91E-03 & $3.99 E-03$ & 1.31E-02 \\
\hline & & & Selenium Compounds & 1.15E-06 & 1.88E-06 & $3.92 E-06$ & $1.28 \mathrm{E}-05$ \\
\hline & & 008 & Antimony & $1.28 \mathrm{E}-05$ & 2.10E-05 & 4.38E-05 & 1.43E-04 \\
\hline & & & Arsenic & 5.75E-06 & $9.40 E-06$ & 1.96E-05 & $6.42 E-05$ \\
\hline & & & Cadmium & 4.41E-06 & 7.21E-06 & 1.50E-05 & 4.93E-05 \\
\hline & & & Chromium Compounds & 1.07E-05 & 1.76E-05 & $3.66 E-05$ & $1.20 E=04$ \\
\hline & & & Formaldehyde & $1.84 E-03$ & 3.02E-03 & $6.28 E-03$ & $2.06 E-02$ \\
\hline & & & Hexane (n-Hexane) & 4.08E-04 & $6.69 E-04$ & 1.39E-03 & 4.57E-03 \\
\hline & & & Lead Compounds & 2.32E-05 & 3.79E-05 & 7.91E-05 & 2.59E-04 \\
\hline & & & Manganese & $1.04 \mathrm{E}-05$ & 1.69E-05 & 3.53E-05 & 1.16E-04 \\
\hline & & & Mercury Compounds & $1.15 \mathrm{E}-06$ & $1.88 \mathrm{E}-06$ & $3.92 E-06$ & $1.28 E-05$ \\
\hline & & & Nickel & 1.17E-03 & $1.91 E-03$ & 3.99E-03 & $1.31 \mathrm{E}-02$ \\
\hline & & & Selenium Compounds & 1.15E-06 & 1.88E-06 & $3.92 E-06$ & $1.28 \mathrm{E}-05$ \\
\hline & 688 & 002 & Chromium Compounds & $9.28 \mathrm{E}-07$ & 2.41E-07 & 1.86E-06 & 4.82E-07 \\
\hline & & & Trichloroethylene & 2.04E-04 & 5.29E-05 & 4.07E-04 & $1.06 \mathrm{E}-04$ \\
\hline & & 043 & Antimony & $5.03 E-06$ & 1.56E-05 & 9.33E-05 & $2.90 E-04$ \\
\hline & & & Arsenic & 2.25E-06 & 7.00E-06 & 4.18E-05 & $1.30 \mathrm{E}-04$ \\
\hline & & & Cadmium & 1.73E-06 & 5.37E-06 & $3.20 \mathrm{E}-05$ & 9.95E-05 \\
\hline & & & Chromium Compounds & $4.20 E-06$ & 1.31E-05 & $7.80 E-05$ & 2.42E-04 \\
\hline & & & Formaldehyde & 4.25E-04 & 1.32E-03 & $7.89 E-03$ & 2.45E-02 \\
\hline & & & Hexane (n-Hexane) & 9.43E-05 & 2.93E-04 & $1.75 \mathrm{E}-03$ & 5.43E-03 \\
\hline & & & Lead Compounds & 9.08E-06 & 2.82E-05 & $1.69 \mathrm{E}-04$ & 5.23E-04 \\
\hline & & & Manganese & 4.05E-06 & 1.26E-05 & $7.52 \mathrm{E}-05$ & 2.34E-04 \\
\hline & & & Mercury Compounds & $4.50 \mathrm{E}-07$ & 1.40E-06 & $8.36 E-06$ & 2.60E-05 \\
\hline & & & Nickel & $4.59 E-04$ & 1.43E-03 & 8.51E-03 & $2.64 \mathrm{E}-02$ \\
\hline & & & Selenium Compounds & 4.50E-07 & 1.40E-06 & 8.36E-06 & $2.60 \mathrm{E}-05$ \\
\hline & & 044 & Antimony & 5.03E-06 & 1.56E-05 & 4.03E-05 & $1.26 \mathrm{E}-04$ \\
\hline & & & Arsenic & 2.25E-06 & 7.00E-06 & 1.81E-05 & 5.62E-05 \\
\hline & & & Cadmium & $1.73 E-06$ & 5.37E-06 & 1.38E-05 & 4.31E-05 \\
\hline & & & Chromium Compounds & 4.20E-06 & 1.31E-05 & 3.37E-05 & $1.05 E-04$ \\
\hline & & & Formaldehyde & 7.21E-04 & 2.25E-03 & 5.80E-03 & $1.80 \mathrm{E}-02$ \\
\hline & & & Hexane (n-Hexane) & $1.60 \mathrm{E}-04$ & 4.98E-04 & $1.29 E-03$ & $4.00 E-03$ \\
\hline
\end{tabular}

* Not Significant Source 


\begin{tabular}{|c|c|c|c|c|c|c|c|}
\hline AREA & BLDG & VENT & Toxic & $\begin{array}{c}\text { Actual } \\
\text { Hourly } \\
\text { Rates } \\
\text { Los/Hr } \\
\text { or } \\
\text { Ci/Mo }\end{array}$ & $\begin{array}{c}\text { Actual } \\
\text { Yearly } \\
\text { Rates } \\
\text { Tns/Yr } \\
\text { or } \\
\text { Ci/Yr }\end{array}$ & $\begin{array}{l}\text { Max. } \\
\text { Hourly } \\
\text { Rates } \\
\text { Lbs/Hr } \\
\text { or } \\
\text { Ci/Mo }\end{array}$ & $\begin{array}{c}\text { Max. } \\
\text { Yearly } \\
\text { Rates } \\
\text { Tns } / Y r \\
\text { or } \\
\text { Cir } / Y r\end{array}$ \\
\hline \multirow[t]{17}{*}{ CFA } & 688 & 044 & Lead Compounds & 9.08E-06 & 2.82E-05 & $7.28 \mathrm{E}-05$ & 2.27E-04 \\
\hline & & & Manganese & 4.05E-06 & $1.26 \mathrm{E}-05$ & 3.25E-05 & $1.01 \mathrm{E}-04$ \\
\hline & & & Mercury Compounds & 4.50E-07 & 1.40E-06 & 3.61E-06 & $1.12 \mathrm{E}-05$ \\
\hline & & & Nickel & 4.59E-04 & 1.43E-03 & $3.68 \mathrm{E}-03$ & $1.15 \mathrm{E}-02$ \\
\hline & & & Selenium Compounds & $4.50 \mathrm{E}-07$ & $1.40 \mathrm{E}-06$ & 3.61E-06 & 1.12E-05 \\
\hline & & 047 & 1,3-Butadiene & 2.59E-03 & 1.55E-05 & 5.18E-03 & 2.27E-02 \\
\hline & & & Arsenic & 1.28E-05 & 7.65E-08 & 2.55E-05 & 1.12E-04 \\
\hline & & & Benzene & 2.92E-03 & 1.75E-05 & 5.84E-03 & $2.56 \mathrm{E}-02$ \\
\hline & & & Chromium Compounds & 2.23E-05 & $1.34 E-07$ & 4.46E-05 & 1.95E-04 \\
\hline & & & Lead Compounds & $1.75 \mathrm{E}-04$ & $1.05 E-06$ & $3.51 E-04$ & $1.54 E-03$ \\
\hline & & & Manganese & $2.23 E-05$ & $1.34 \mathrm{E}-07$ & 4.46E-05 & $1.95 E-04$ \\
\hline & & & Mercury Compounds & $6.38 \mathrm{E}-06$ & 3.83E-08 & $1.28 \mathrm{E}-05$ & 5.58E-05 \\
\hline & & & Nickel & 9.56E-06 & $5.74 E-08$ & $1.91 \mathrm{E}-05$ & 8.38E-05 \\
\hline & & & Selenium Compounds & 6.38E-06 & $3.83 E-08$ & $1.28 \mathrm{E}-05$ & 5.58E-05 \\
\hline & 689 & 034 & Formaldehyde & $2.59 E-04$ & 1.35E-04 & $2.59 E-04$ & $2.70 \mathrm{E}-04$ \\
\hline & & & Hydrochloric acid & 8.69E-04 & $4.52 \mathrm{E}-04$ & 8.69E-04 & 9.03E-04 \\
\hline & & & Methanol, see Methyl alcoh & 1.01E-04 & 5.24E-05 & $1.01 \mathrm{E}-04$ & $1.05 E-04$ \\
\hline
\end{tabular}

* Not Significant Source 
AREA BLDG VENT Toxic

$\begin{array}{cccc}\text { Actual } & \text { Actual } & \text { Max. } & \text { Max. } \\ \text { Hourly } & \text { Yearly } & \text { Hourly } & \text { Yearly } \\ \text { Rates } & \text { Rates } & \text { Rates } & \text { Rates } \\ \text { Lbs/Hr } & \text { Tns } / Y r & \text { Lbs } / \mathrm{Hr} & \text { Tns } / Y r \\ \text { or } & \text { or } & \text { or } & \text { or } \\ \text { CiMo } & \text { Ci } / Y r & \text { CiMo } & \text { Ci } / \text { r }\end{array}$

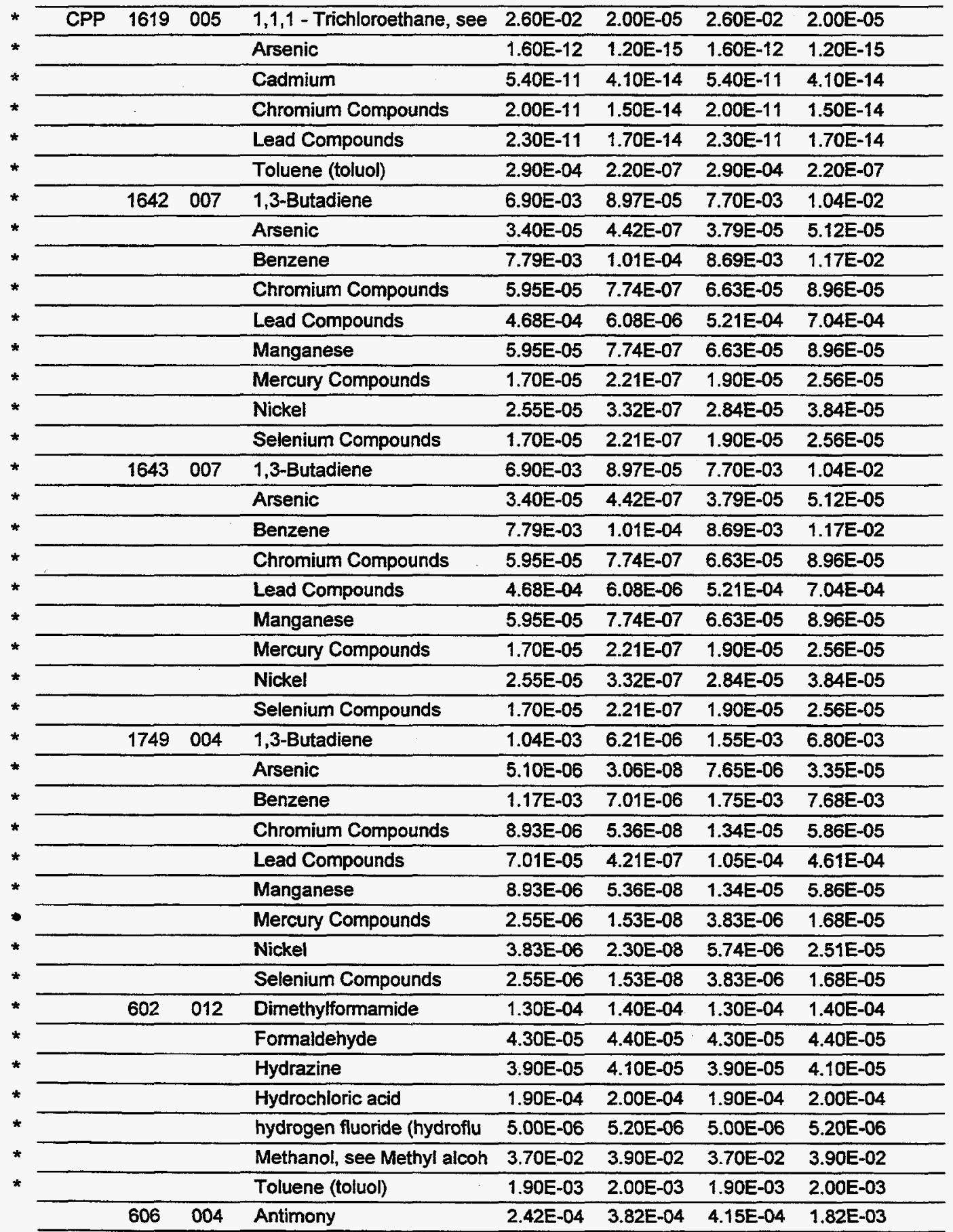

- Not Significant Source 
AREA BLDG VENT Toxic

$\begin{array}{cccc}\text { Actual } & \text { Actual } & \text { Max. } & \text { Max. } \\ \text { Hourly } & \text { Yearly } & \text { Hourly } & \text { Yearly } \\ \text { Rates } & \text { Rates } & \text { Rates } & \text { Rates } \\ \text { Lbs/Hr } & \text { Tns } / Y r & \text { Lbs/Hr } & \text { Tns } / Y r \\ \text { or } & \text { or } & \text { or } & \text { or } \\ \text { Ci/Mo } & \text { Ci } / Y r & \text { CiMo } & \text { Ci } / \text { Yr }\end{array}$

\begin{tabular}{|c|c|c|c|c|c|c|c|}
\hline CPP & 606 & 004 & Arsenic & $1.08 E-04$ & 1.71E-04 & $1.86 \mathrm{E}-04$ & $8.14 E-04$ \\
\hline & & & Cadmium & 8.31E-05 & $1.31 \mathrm{E}-04$ & 1.42E-04 & $6.24 \mathrm{E}-04$ \\
\hline & & & Chromium Compounds & 2.02E-04 & $3.19 \mathrm{E}-04$ & 3.47E-04 & 1.52E-03 \\
\hline & & & Formaldehyde & $2.05 \mathrm{E}-02$ & $3.23 E-02$ & 3.51E-02 & $1.54 \mathrm{E}-01$ \\
\hline & & & Hexane (n-Hexane) & $4.54 E-03$ & 7.16E-03 & 7.78E-03 & 3.41E-02 \\
\hline & & & Lead Compounds & 4.37E-04 & $6.90 \mathrm{E}-04$ & $7.49 E-04$ & $3.28 \mathrm{E}-03$ \\
\hline & & & Manganese & 1.95E-04 & 3.08E-04 & 3.34E-04 & 1.46E-03 \\
\hline & & & Mercury Compounds & 2.17E-05 & $3.42 \mathrm{E}-05$ & 3.72E-05 & 1.63E-04 \\
\hline & & & Nickel & 2.21E-02 & $3.48 E-02$ & $3.78 E-02$ & 1.66E-01 \\
\hline & & & Selenium Compounds & 2.17E-05 & $3.42 E-05$ & $3.72 E-05$ & 1.63E-04 \\
\hline & & 005 & Antimony & 1.79E-04 & $1.80 E-04$ & 4.63E-04 & 2.03E-03 \\
\hline & & & Arsenic & 8.00E-05 & 8.07E-05 & 2.07E-04 & $9.09 E-04$ \\
\hline & & & Cadmium & 6.13E-05 & $6.18 \mathrm{E}-05$ & 1.59E-04 & 6.97E-04 \\
\hline & & & Chromium Compounds & 1.49E-04 & 1.51E-04 & 3.87E-04 & $1.70 E-03$ \\
\hline & & & Formaldehyde & $1.51 \mathrm{E}-02$ & $1.52 \mathrm{E}-02$ & $3.92 E-02$ & 1.71E-01 \\
\hline & & & Hexane (n-Hexane) & $3.35 E-03$ & $3.38 \mathrm{E}-03$ & 8.68E-03 & $3.80 E-02$ \\
\hline & & & Lead Compounds & 3.23E-04 & 3.25E-04 & 8.37E-04 & 3.66E-03 \\
\hline & & & Manganese & $1.44 \mathrm{E}-04$ & $1.45 \mathrm{E}-04$ & 3.73E-04 & $1.64 \mathrm{E}-03$ \\
\hline & & & Mercury Compounds & 1.60E-05 & 1.61E-05 & $4.15 \mathrm{E}-05$ & $1.82 \mathrm{E}-04$ \\
\hline & & & Nickel & 1.63E-02 & $1.64 \mathrm{E}-02$ & 4.22E-02 & $1.85 \mathrm{E}-01$ \\
\hline & & & Selenium Compounds & 1.60 E-05 & 1.61E-05 & 4.15E-05 & 1.82E-04 \\
\hline & & 019 & Antimony & $1.05 E-04$ & 8.47E-05 & 4.63E-04 & 2.03E-03 \\
\hline & & & Arsenic & 4.70E-05 & $3.79 E-05$ & 2.07E-04 & $9.09 E-04$ \\
\hline & & & Cadmium & $3.60 \mathrm{E}-05$ & 2.91E-05 & 1.59E-04 & 6.97E-04 \\
\hline & & & Chromium Compounds & 8.77E-05 & 7.08E-05 & 3.87E-04 & $1.70 \mathrm{E}-03$ \\
\hline & & & Formaldehyde & $8.86 E-03$ & 7.16E-03 & $3.92 E-02$ & 1.71E-01 \\
\hline & & & Hexane (n-Hexane) & 1.97E-03 & $1.59 \mathrm{E}-03$ & 8.68E-03 & $3.80 \mathrm{E}-02$ \\
\hline & & & Lead Compounds & 1.89E-04 & $1.53 \mathrm{E}-04$ & 8.37E-04 & $3.66 \mathrm{E}-03$ \\
\hline & & & Manganese & 8.45E-0.5 & $6.83 E-05$ & 3.73E-04 & 1.64E-03 \\
\hline & & & Mercury Compounds & 9.39E-06 & 7.59E-06 & 4.15E-05 & 1.82E-04 \\
\hline & & & Nickel & $9.56 \mathrm{E}-03$ & 7.72E-03 & 4.22E-02 & $1.85 E-01$ \\
\hline & & & Selenium Compounds & 9.39E-06 & 7.59E-06 & 4.15E-05 & $1.82 E-04$ \\
\hline & 614 & 002 & 1,3-Butadiene & 4.83E-03 & 7.57E-05 & $5.56 \mathrm{E}-03$ & $7.50 E-03$ \\
\hline & & & Arsenic & $2.38 E-05$ & $3.73 \mathrm{E}-07$ & 2.74E-05 & $3.69 \mathrm{E}-05$ \\
\hline & & & Benzene & 5.45E-03 & 8.55E-05 & 6.27E-03 & 8.47E-03 \\
\hline & & & Chromium Compounds & 4.17E-05 & 6.53E-07 & $4.79 E-05$ & 6.47E-05 \\
\hline & & & Lead Compounds & 3.27E-04 & 5.13E-06 & 3.76E-04 & $5.08 \mathrm{E}-04$ \\
\hline & & & Manganese & 4.17E-05 & $6.53 E-07$ & 4.79E-05 & 6.47E-05 \\
\hline & & & Mercury Compounds & 1.19E-05 & 1.87E-07 & 1.37E-05 & 1.85E-05 \\
\hline & & & Nickel & 1.79E-05 & $2.80 E-07$ & 2.05E-05 & 2.77E-05 \\
\hline & & & Selenium Compounds & 1.19E-05 & $1.87 E-07$ & 1.37E-05 & 1.85E-05 \\
\hline
\end{tabular}

- Not Significant Source 
AREA BLDG VENT Toxic

$\begin{array}{cccc}\text { Actual } & \text { Actual } & \text { Max. } & \text { Max. } \\ \text { Hourly } & \text { Yearly } & \text { Hourly } & \text { Yearly } \\ \text { Rates } & \text { Rates } & \text { Rates } & \text { Rates } \\ \text { Lbs/Hr } & \text { Tns } / Y r & \text { Lbs/Hr } & \text { Tns } / Y r \\ \text { or } & \text { or } & \text { or } & \text { or } \\ \text { Ci/Mo } & \text { Ci/Yr } & \text { Ci/Mo } & \text { Ci/Yr }\end{array}$

\begin{tabular}{|c|c|c|c|c|c|c|c|c|}
\hline * & CPP & 616 & 004 & 1,3-Butadiene & 5.18E-03 & 8.08E-05 & $7.45 E-03$ & $1.01 \mathrm{E}-02$ \\
\hline * & & & & Arsenic & 2.55E-05 & 3.98E-07 & 3.67E-05 & 4.96E-05 \\
\hline * & & & & Benzene & 5.84E-03 & 9.11E-05 & 8.41E-03 & 1.14E-02 \\
\hline * & & & & Chromium Compounds & 4.46E-05 & $6.96 \mathrm{E}-07$ & 6.43E-05 & 8.68E-05 \\
\hline * & & & & Lead Compounds & $3.51 E-04$ & 5.47E-06 & $5.05 E-04$ & 6.82E-04 \\
\hline * & & & & Manganese & 4.46E-05 & $6.96 \mathrm{E}-07$ & 6.43E-05 & 8.68E-05 \\
\hline * & & & & Mercury Compounds & $1.28 \mathrm{E}-05$ & $1.99 \mathrm{E}-07$ & $1.84 E-05$ & $2.48 E-05$ \\
\hline * & & & & Nickel & 1.91E-05 & 2.98E-07 & 2.75E-05 & 3.72E-05 \\
\hline * & & & & Selenium Compounds & $1.28 \mathrm{E}-05$ & $1.99 \mathrm{E}-07$ & 1.84E-05 & 2.48E-05 \\
\hline * & & 637 & 010 & Cadmium & 2.20E-06 & 2.30E-06 & 2.20E-06 & 2.30E-06 \\
\hline * & & & & Hydrochloric acid & 2.20E-05 & 2.30E-05 & 2.20E-05 & 2.30E-05 \\
\hline * & & & & Mercury Compounds & $1.60 \mathrm{E}-06$ & 1.70E-06 & 1.60E-06 & $1.70 E-06$ \\
\hline * & & & & Methanol, see Methyl alcoh & 6.70E-03 & 7.00E-03 & $6.70 E-03$ & 7.00E-03 \\
\hline * & & & 064 & Hexane (n-Hexane) & $1.60 \mathrm{E}-03$ & 1.70E-03 & $1.60 \mathrm{E}-03$ & $1.00 E+01$ \\
\hline * & & 644 & 002 & 1,3-Butadiene & 4.80E-02 & 2.49E-03 & $9.59 \mathrm{E}-02$ & 9.59E-03 \\
\hline * & & & & Arsenic & $1.88 \mathrm{E}-05$ & $9.78 \mathrm{E}-07$ & $3.76 E-05$ & 3.76E-06 \\
\hline * & & & & Benzene & 5.41E-02 & 2.81E-03 & $1.08 E-01$ & 1.08E-02 \\
\hline * & & & & Chromium Compounds & $3.29 E-05$ & 1.71E-06 & $6.58 \mathrm{E}-05$ & $6.58 \mathrm{E}-06$ \\
\hline * & & & & Lead Compounds & 2.59E-04 & $1.34 E-05$ & 5.17E-04 & 5.17E-05 \\
\hline * & & & & Manganese & $3.29 E-05$ & $1.71 E-06$ & $6.58 \mathrm{E}-05$ & $6.58 \mathrm{E}-06$ \\
\hline * & & & & Mercury Compounds & $9.40 E-06$ & $4.89 \mathrm{E}-07$ & 1.88E-05 & $1.88 \mathrm{E}-06$ \\
\hline * & & & & Nickel & 1.41E-05 & 7.33E-07 & 2.82E-05 & 2.82E-06 \\
\hline * & & & & Selenium Compounds & $9.40 E-06$ & 4.89E-07 & 1.88E-05 & $1.88 E-06$ \\
\hline * & & 655 & 023 & Methyl chloride & 1.20E-02 & $1.30 \mathrm{E}-02$ & 1.20E-02 & $1.30 \mathrm{E}-02$ \\
\hline * & & 659 & 006 & 1,3-Butadiene & 1.73E-02 & $1.55 E-04$ & $3.86 E-01$ & $3.86 E-02$ \\
\hline * & & & & Arsenic & 8.50E-05 & $7.65 \mathrm{E}-07$ & 1.90E-03 & $1.90 E-04$ \\
\hline * & & & & Benzene & 1.95E-02 & 1.75E-04 & 4.36E-01 & 4.36E-02 \\
\hline * & & & & Chromium Compounds & 1.49E-04 & 1.34E-06 & 3.33E-03 & 3.33E-04 \\
\hline * & & & & Lead Compounds & 1.17E-03 & 1.05E-05 & 2.62E-02 & 2.62E-03 \\
\hline * & & & & Manganese & 1.49E-04 & 1.34E-06 & 3.33E-03 & 3.33E-04 \\
\hline * & & & & Mercury Compounds & 4.25E-05 & 3.83E-07 & 9.51E-04 & 9.51E-05 \\
\hline * & & & & Nickel & 6.37E-05 & 5.74E-07 & 1.43E-03 & 1.43E-04 \\
\hline * & & & & Selenium Compounds & 4.25E-05 & 3.83E-07 & 9.51E-04 & 9.51E-05 \\
\hline * & & & 008 & 1,3-Butadiene & $4.80 \mathrm{E}-02$ & 4.32E-04 & $1.07 E+00$ & 1.07E-01 \\
\hline * & & & & Arsenic & $1.88 \mathrm{E}-05$ & $1.69 \mathrm{E}-07$ & 4.21E-04 & 4.21E-05 \\
\hline * & & & & Benzene & 5.41E-02 & 4.87E-04 & $1.21 E+00$ & 1.21E-01 \\
\hline * & & & & Chromium Compounds & $3.29 \mathrm{E}-05$ & 2.96E-07 & 7.36E-04 & 7.36E-05 \\
\hline * & & & & Lead Compounds & $2.59 E-04$ & 2.33E-06 & 5.79E-03 & 5.79E-04 \\
\hline * & & & & Manganese & 3.29E-05 & 2.96E-07 & 7.36E-04 & 7.36E-05 \\
\hline * & & & & Mercury Compounds & $9.40 E-06$ & 8.46E-08 & $2.10 E-04$ & 2.10E-05 \\
\hline * & & & & Nickel & 1.41E-05 & 1.27E-07 & 3.16E-04 & 3.16E-05 \\
\hline
\end{tabular}

* Not Significant Source 


\begin{tabular}{|c|c|c|c|c|c|c|c|}
\hline AREA & BLDG & VENT & Toxic & $\begin{array}{l}\text { Actual } \\
\text { Hourly } \\
\text { Rates } \\
\text { Lbs/Hir } \\
\text { or } \\
\text { Ci/Mo }\end{array}$ & $\begin{array}{c}\text { Actual } \\
\text { Yearly } \\
\text { Rates } \\
\text { Tns } / \mathrm{Yr} \\
\text { or } \\
\text { Ci/Yr }\end{array}$ & $\begin{array}{c}\text { Max. } \\
\text { Hourly } \\
\text { Rates } \\
\text { Lbs/Hr } \\
\text { or } \\
\text { Ci/Mo }\end{array}$ & $\begin{array}{l}\text { Max. } \\
\text { Yearly } \\
\text { Rates } \\
\text { Tns/Yr } \\
\text { or } \\
\text { Ci/Yr }\end{array}$ \\
\hline \multirow[t]{41}{*}{ CPP } & 659 & 008 & Selenium Compounds & $9.40 E-06$ & $8.46 E-08$ & $2.10 E-04$ & 2.10E-05 \\
\hline & & 033 & Diethanolamine & 2.60E-02 & $4.90 \mathrm{E}-02$ & $2.60 E-02$ & $1.20 \mathrm{E}-01$ \\
\hline & 662 & 003 & Manganese & $2.60 E-05$ & $2.70 E-05$ & $2.60 \mathrm{E}-05$ & $2.70 \mathrm{E}-05$ \\
\hline & 663 & 048 & Ethyl benzene & 2.10E-02 & $2.10 E-02$ & 2.10E-02 & $2.10 \mathrm{E}-02$ \\
\hline & & & Toluene (toluol) & 2.40E-02 & $2.50 \mathrm{E}-02$ & $2.40 E-02$ & $2.50 \mathrm{E}-02$ \\
\hline & 684 & 001 & Hydrochloric acid & $3.20 \mathrm{E}-06$ & $1.20 \mathrm{E}-05$ & 3.20E-06 & 1.20E-05 \\
\hline & & & hydrogen fluoride (hydroflu & 5.30E-06 & 2.00E-05 & 5.30E-06 & $2.00 \mathrm{E}-05$ \\
\hline & & & Methanol, see Methyl alcoh & $7.00 \mathrm{E}-05$ & $2.60 \mathrm{E}-04$ & 7.00E-05 & 2.60E-04 \\
\hline & 687 & 026 & 1,3-Butadiene & $4.80 E-02$ & 2.49E-03 & 9.59E-02 & 9.59E-03 \\
\hline & & & Arsenic & $1.88 \mathrm{E}-05$ & 9.78E-07 & 3.76E-05 & 3.76E-06 \\
\hline & & & Benzene & 5.41E-02 & 2.81E-03 & 1.08E-01 & $1.08 \mathrm{E}-02$ \\
\hline & & & Chromium Compounds & $3.29 E-05$ & 1.71E-06 & 6.58E-05 & $6.58 \mathrm{E}-06$ \\
\hline & & & Lead Compounds & 2.59E-04 & 1.34E-05 & 5.17E-04 & 5.17E-05 \\
\hline & & & Manganese & 3.29E-05 & 1.71E-06 & 6.58E-05 & $6.58 \mathrm{E}-06$ \\
\hline & & & Mercury Compounds & 9.40E-06 & 4.89E-07 & 1.88E-05 & 1.88E-06 \\
\hline & & & Nickel & 1.41E-05 & 7.33E-07 & 2.82E-05 & $2.82 E-06$ \\
\hline & & & Selenium Compounds & 9.40E-06 & 4.89E-07 & 1.88E-05 & 1.88E-06 \\
\hline & & 049 & 1,3-Butadiene & $5.18 \mathrm{E}-04$ & $3.36 E-06$ & $1.04 E-03$ & $2.80 \mathrm{E}-03$ \\
\hline & & & Arsenic & 2.55E-06 & $1.66 E-08$ & 5.10E-06 & 1.38E-05 \\
\hline & & & Benzene & 5.84E-04 & $3.80 E-06$ & 1.17E-03 & 3.15E-03 \\
\hline & & & Chromium Compounds & 4.46E-06 & $2.90 E-08$ & 8.93E-06 & 2.41E-05 \\
\hline & & & Lead Compounds & 3.51E-05 & $2.28 E-07$ & 7.01E-05 & 1.89E-04 \\
\hline & & & Manganese & 4.46E-06 & $2.90 E-08$ & 8.93E-06 & 2.41E-05 \\
\hline & & & Mercury Compounds & $1.28 \mathrm{E}-06$ & $8.29 E-09$ & 2.55E-06 & 6.89E-06 \\
\hline & & & Nickel & 1.91E-06 & $1.24 E-08$ & 3.83E-06 & 1.03E-05 \\
\hline & & & Selenium Compounds & $1.28 \mathrm{E}-06$ & $8.29 E-09$ & 2.55E-06 & 6.89E-06 \\
\hline & 698 & 004 & Chromium Compounds & 9.00E-06 & $9.30 \mathrm{E}-06$ & 9.00E-06 & 9.30E-06 \\
\hline & & & Manganese & $2.40 \mathrm{E}-05$ & $2.50 E-05$ & $2.40 E-05$ & 2.50E-05 \\
\hline & & & Nickel & 5.60E-06 & $5.80 E-06$ & 5.60E-06 & 5.80E-06 \\
\hline & & 006 & Chromium Compounds & $9.00 \mathrm{E}-06$ & $9.30 \mathrm{E}-06$ & 9.00E-06 & $9.30 \mathrm{E}-06$ \\
\hline & & & Manganese & $2.40 E-05$ & $2.50 E-05$ & 2.40E-05 & 2.50E-05 \\
\hline & & & Nickel & 5.60E-06 & $5.80 E-06$ & 5.60E-06 & $5.80 E-06$ \\
\hline & 708 & 001 & 1,2,4-trichlorobenzene & $1.20 \mathrm{E}-01$ & $1.00 \mathrm{E}-01$ & $1.20 \mathrm{E}-01$ & $1.00 \mathrm{E}-01$ \\
\hline & & & Cadmium & $3.00 \mathrm{E}-12$ & $8.00 \mathrm{E}-12$ & $3.00 \mathrm{E}-12$ & $8.00 E-12$ \\
\hline & & & Chromium Compounds & $5.00 E-13$ & $1.50 \mathrm{E}-13$ & $5.00 \mathrm{E}-13$ & $1.50 \mathrm{E}-13$ \\
\hline & & & Formaldehyde & 4.20E-05 & 4.00E-05 & $4.20 \mathrm{E}-05$ & 4.00E-05 \\
\hline & & & hydrogen fluoride (hydroflu & $1.00 \mathrm{E}-02$ & 4.50E-03 & 1.00E-02 & 4.50E-03 \\
\hline & & & Lead Compounds & & & & $1.00 \mathrm{E}-02$ \\
\hline & & & Lead Compounds & $7.00 \mathrm{E}-16$ & $3.00 \mathrm{E}-15$ & $7.00 \mathrm{E}-16$ & $1.00 \mathrm{E}-01$ \\
\hline & & & Methanol, see Methyl alcoh & $2.70 \mathrm{E}-02$ & $2.50 \mathrm{E}-02$ & 2.70E-02 & $2.37 E+00$ \\
\hline & & & Nickel & $2.00 \mathrm{E}-16$ & $3.00 \mathrm{E}-15$ & $2.00 \mathrm{E}-16$ & $3.00 \mathrm{E}-15$ \\
\hline
\end{tabular}

* Not Significant Source 
AREA BLDG VENT Toxic

$\begin{array}{cccc}\text { Actual } & \text { Actual } & \text { Max. } & \text { Max. } \\ \text { Hourly } & \text { Yearly } & \text { Hourly } & \text { Yearly } \\ \text { Rates } & \text { Rates } & \text { Rates } & \text { Rates } \\ \text { Lbs/Hr } & \text { Tns } / Y r & \text { Lbs/Hr } & \text { Tns } / Y r \\ \text { or } & \text { or } & \text { or } & \text { or } \\ \text { Ci/Mo } & \text { Ci } / Y r & \text { Ci/Mo } & \text { Ci/Yr }\end{array}$

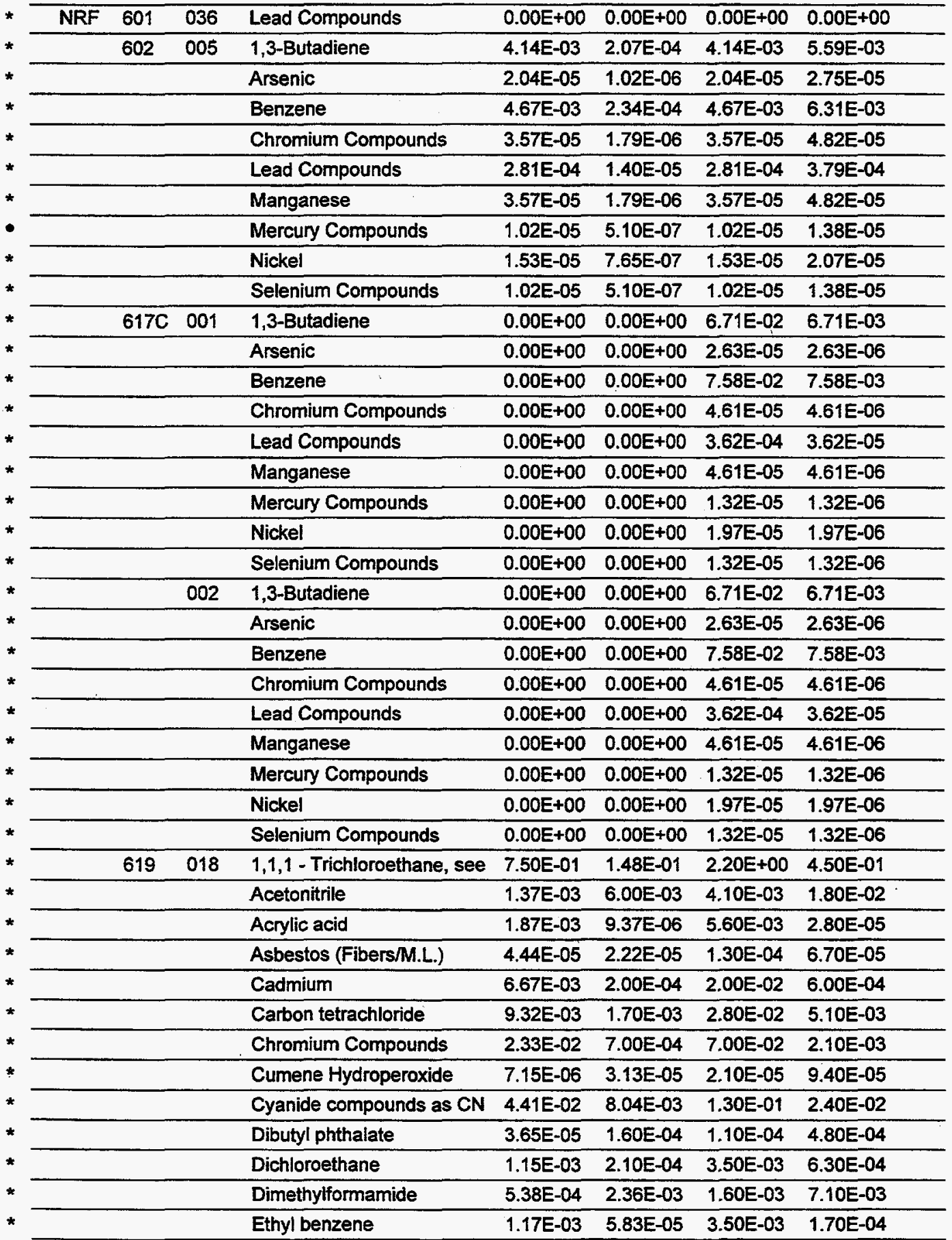

- Not Significant Source 


\begin{tabular}{|c|c|c|c|c|c|c|c|}
\hline AREA & BLDG & VENT & Toxic & $\begin{array}{c}\text { Actual } \\
\text { Hourly } \\
\text { Rates } \\
\text { Lbs/Hr } \\
\text { or } \\
\text { Ci/Mo }\end{array}$ & $\begin{array}{c}\text { Actual } \\
\text { Yearly } \\
\text { Rates } \\
\text { Tns } / Y r \\
\text { or } \\
\text { Ci/Yr }\end{array}$ & $\begin{array}{c}\text { Max. } \\
\text { Hourly } \\
\text { Rates } \\
\text { Lbs/Hr } \\
\text { or } \\
\text { Ci/Mo }\end{array}$ & $\begin{array}{c}\text { Max. } \\
\text { Yearly } \\
\text { Rates } \\
\text { Tns } / Y r \\
\text { or } \\
\text { Ci/Yr }\end{array}$ \\
\hline \multirow[t]{41}{*}{ NRF } & 619 & 018 & Ethylene glycol vapor (CL) & 3.05E-03 & 1.33E-02 & $9.10 \mathrm{E}-03$ & 4.00E-02 \\
\hline & & & Formaldehyde & $1.14 E-03$ & $6.22 \mathrm{E}-04$ & $3.40 \mathrm{E}-03$ & $1.90 \mathrm{E}-03$ \\
\hline & & & glycol ethers & $1.82 E-02$ & 7.96E-02 & 5.45E-02 & $2.40 E-01$ \\
\hline & & & Hexane (n-Hexane) & 9.94E-03 & 4.35E-02 & $3.00 E-02$ & 1.30E-01 \\
\hline & & & Hydrochloric acid & 5.01E-03 & 2.74E-03 & $1.50 \mathrm{E}-02$ & 8.20E-03 \\
\hline & & & hydrogen fluoride (hydroflu & $1.00 E-03$ & 5.01E-05 & 3.00E-03 & $1.50 \mathrm{E}-04$ \\
\hline & & & Lead Compounds & 1.89E-03 & 1.03E-03 & 5.70E-03 & 3.10E-03 \\
\hline & & & Methanol, see Methyl alcoh & $2.38 E-03$ & $1.04 \mathrm{E}-02$ & $7.10 \mathrm{E}-03$ & $3.10 \mathrm{E}-02$ \\
\hline & & & Nickel & $6.25 E-02$ & 3.13E-04 & $1.90 \mathrm{E}-01$ & $9.40 E-04$ \\
\hline & & & tetrachloroethylene (perchl & 2.70E-03 & 3.53E-04 & 2.70E-03 & 3.53E-04 \\
\hline & & & Toluene (toluol) & 2.81E-03 & $1.23 E-02$ & 8.40E-03 & $3.70 \mathrm{E}-02$ \\
\hline & & & Trichloroethylene & 2.33E-03 & $1.02 E-02$ & 7.00E-03 & $3.10 E-02$ \\
\hline & & & Vinyl acetate & $1.12 E-02$ & $5.60 \mathrm{E}-04$ & $3.40 \mathrm{E}-02$ & $1.70 E-03$ \\
\hline & 620 & 012 & Antimony & $9.22 E-04$ & $6.34 \mathrm{E}-04$ & $2.59 E-03$ & 1.14E-02 \\
\hline & & & Arsenic & 4.13E-04 & 2.84E-04 & 1.16E-03 & $5.09 \mathrm{E}-03$ \\
\hline & & & Cadmium & $3.16 E-04$ & $2.18 E-04$ & $8.90 E-04$ & $3.90 E-03$ \\
\hline & & & Chromium Compounds & 7.71E-04 & $5.30 E-04$ & 2.17E-03 & $9.49 \mathrm{E}-03$ \\
\hline & & & Formaldehyde & 2.18E-02 & $1.50 \mathrm{E}-02$ & $6.14 \mathrm{E}-02$ & $2.69 \mathrm{E}-01$ \\
\hline & & & Hexane (n-Hexane) & 4.84E-03 & 3.33E-03 & $1.36 \mathrm{E}-02$ & 5.96E-02 \\
\hline & & & Lead Compounds & $1.66 \mathrm{E}-03$ & 1.14E-03 & $4.68 \mathrm{E}-03$ & 2.05E-02 \\
\hline & & & Manganese & 7.43E-04 & 5.11E-04 & 2.09E-03 & $9.15 \mathrm{E}-03$ \\
\hline & & & Mercury Compounds & 8.26E-05 & $5.68 E-05$ & 2.32E- 04 & $1.02 E-03$ \\
\hline & & & Nickel & 8.41E-02 & $5.78 \mathrm{E}-02$ & 2.36E-01 & $1.04 E+00$ \\
\hline & & & Selenium Compounds & 8.26E-05 & 5.68E-05 & 2.32E-04 & $1.02 E-03$ \\
\hline & & 013 & Antimony & $9.22 E-04$ & $6.34 E-04$ & 2.59E-03 & $1.14 E-02$ \\
\hline & & & Arsenic & 4.13E-04 & 2.84E-04 & $1.16 \mathrm{E}-03$ & $5.09 E-03$ \\
\hline & & & Cadmium & $3.16 \mathrm{E}-04$ & $2.18 \mathrm{E}-04$ & 8.90E-04 & $3.90 E-03$ \\
\hline & & & Chromium Compounds & 7.71E-04 & $5.30 \mathrm{E}-04$ & 2.17E-03 & $9.49 \mathrm{E}-03$ \\
\hline & & & Formaldehyde & 2.18E-02 & $1.50 \mathrm{E}-02$ & $6.14 \mathrm{E}-02$ & 2.69E-01 \\
\hline & & & Hexane (n-Hexane) & 4.84E-03 & 3.33E-03 & 1.36E-02 & $5.96 \mathrm{E}-02$ \\
\hline & & & Lead Compounds & 1.66E-03 & $1.14 \mathrm{E}-03$ & 4.68E-03 & 2.05E-02 \\
\hline & & & Manganese & $7.43 E-04$ & 5.11E-04 & $2.09 E-03$ & $9.15 \mathrm{E}-03$ \\
\hline & & & Mercury Compounds & 8.26E-05 & 5.68E-05 & 2.32E-04 & $1.02 E-03$ \\
\hline & & & Nickel & 8.41E-02 & 5.78E-02 & 2.36E-01 & $1.04 \mathrm{E}+00$ \\
\hline & & & Selenium Compounds & 8.26E-05 & 5.68E-05 & 2.32E-04 & $1.02 E-03$ \\
\hline & & 014 & Antimony & $9.22 E-04$ & $6.34 \mathrm{E}-04$ & 2.59E-03 & $1.14 \mathrm{E}-02$ \\
\hline & & & Arsenic & 4.13E-04 & 2.84E-04 & $1.16 E-03$ & 5.09E-03 \\
\hline & & & Cadmium & $3.16 E-04$ & $2.18 \mathrm{E}-04$ & $8.90 E-04$ & $3.90 \mathrm{E}-03$ \\
\hline & & & Chromium Compounds & 7.71E-04 & 5.30E-04 & 2.17E-03 & 9.49E-03 \\
\hline & & & Formaldehyde & $2.18 E-02$ & $1.50 \mathrm{E}-02$ & $6.14 E-02$ & $2.69 E-01$ \\
\hline & & & Hexane (n-Hexane) & 4.84E-03 & 3.33E-03 & $1.36 \mathrm{E}-02$ & 5.96E-02 \\
\hline
\end{tabular}

* Not Significant Source 


\begin{tabular}{|c|c|c|c|c|c|c|c|}
\hline AREA & BLDG & VENT & Toxic & $\begin{array}{c}\text { Actual } \\
\text { Hourly } \\
\text { Rates } \\
\text { Lbs/Hr } \\
\text { or } \\
\text { Ci/Mo }\end{array}$ & $\begin{array}{c}\text { Actual } \\
\text { Yearly } \\
\text { Rates } \\
\text { Tns } / Y r \\
\text { or } \\
\text { Ci } / Y r\end{array}$ & $\begin{array}{c}\text { Max. } \\
\text { Hourly } \\
\text { Rates } \\
\text { Lbs/Hr } \\
\text { or } \\
\text { Ci/Mo }\end{array}$ & $\begin{array}{c}\text { Max. } \\
\text { Yearly } \\
\text { Rates } \\
\text { Tns } / Y_{r} \\
\text { or } \\
\text { Ci/Yr }\end{array}$ \\
\hline \multirow[t]{41}{*}{ NRF 6} & 620 & 014 & Lead Compounds & 1.66E-03 & 1.14E-03 & 4.68E-03 & $2.05 E-02$ \\
\hline & & & Manganese & 7.43E-04 & 5.11E-04 & 2.09E-03 & $9.15 E-03$ \\
\hline & & & Mercury Compounds & 8.26E-05 & 5.68E-05 & 2.32E-04 & $1.02 E-03$ \\
\hline & & & Nickel & 8.41E-02 & 5.78E-02 & $2.36 \mathrm{E}-01$ & $1.04 E+00$ \\
\hline & & & Selenium Compounds & $8.26 E-05$ & 5.68E-05 & 2.32E-04 & 1.02E-03 \\
\hline & 622 & 001 & 1,3-Butadiene & 4.14E-03 & 3.31E-05 & 4.14E-03 & $5.59 E-03$ \\
\hline & & & Arsenic & 2.04E-05 & 1.63E-07 & $2.04 E-05$ & 2.75E-05 \\
\hline & & & Benzene & 4.67E-03 & 3.74E-05 & 4.67E-03 & $6.31 E-03$ \\
\hline & & & Chromium Compounds & 3.57E-05 & 2.86E-07 & 3.57E-05 & 4.82E-05 \\
\hline & & & Lead Compounds & 2.81E-04 & 2.24E-06 & 2.81E-04 & 3.79E-04 \\
\hline & & & Manganese & 3.57E-05 & 2.86E-07 & 3.57E-05 & 4.82E-05 \\
\hline & & & Mercury Compounds & $1.02 E-05$ & 8.16E-08 & $1.02 E-05$ & $1.38 \mathrm{E}-05$ \\
\hline & & & Nickel & $1.53 \mathrm{E}-05$ & 1.22E-07 & $1.53 E-05$ & 2.07E-05 \\
\hline & & & Selenium Compounds & $1.02 E-05$ & $8.16 E-08$ & $1.02 E-05$ & $1.38 \mathrm{E}-05$ \\
\hline & $633 A$ & 038 & 1,3-Butadiene & $3.68 \mathrm{E}-02$ & 2.22E-03 & 4.09E-02 & $4.09 E-03$ \\
\hline & & & Arsenic & $1.44 \mathrm{E}-05$ & 8.70E-07 & $1.60 E-05$ & 1.60E-06 \\
\hline & & & Benzene & 4.16E-02 & 2.51E-03 & $4.61 \mathrm{E}-02$ & 4.61E-03 \\
\hline & & & Chromium Compounds & 2.53E-05 & 1.52E-06 & 2.80E-05 & 2.80E-06 \\
\hline & & & Lead Compounds & $1.99 \mathrm{E}-04$ & 1.20 E-05 & 2.20E-04 & $2.20 E-05$ \\
\hline & & & Manganese & 2.53E-05 & 1.52E-06 & 2.80E-05 & 2.80E-06 \\
\hline & & & Mercury Compounds & $7.22 \mathrm{E}-06$ & 4.35E-07 & 8.01E-06 & 8.01E-07 \\
\hline & & & Nickel & $1.08 E-05$ & $6.53 E-07$ & 1.20E-05 & 1.20E-06 \\
\hline & & & Selenium Compounds & 7.22E-06 & 4.35E-07 & 8.01E-06 & 8.01E-07 \\
\hline & 635 & 006 & 1,3-Butadiene & 2.66E-03 & $6.90 E-05$ & 4.31E-03 & 5.82E-03 \\
\hline & & & Arsenic & 1.31E-05 & $3.40 E-07$ & 2.13E-05 & 2.87E-05 \\
\hline & & & Benzene & $3.00 E-03$ & 7.79E-05 & 4.87E-03 & $6.57 E-03$ \\
\hline & & & Chromium Compounds & 2.29E-05 & 5.95E-07 & $3.72 E-05$ & 5.02E-05 \\
\hline & & . & Lead Compounds & $1.80 \mathrm{E}-04$ & 4.68E-06 & 2.92E-04 & $3.94 E-04$ \\
\hline & & & Manganese & 2.29E-05 & 5.95E-07 & $3.72 E-05$ & $5.02 E-05$ \\
\hline & & & Mercury Compounds & $6.54 \mathrm{E}-06$ & $1.70 E-07$ & 1.06E-05 & 1.43E-05 \\
\hline & & & Nickel & 9.82E-06 & $2.55 E-07$ & 1.59E-05 & 2.15E-05 \\
\hline & & & Selenium Compounds & $6.54 E-06$ & $1.70 \mathrm{E}-07$ & 1.06E-05 & 1.43E-05 \\
\hline & & 007 & 1,3-Butadiene & $2.66 \mathrm{E}-03$ & $6.90 E-05$ & 4.31E-03 & $5.82 E-03$ \\
\hline & & & Arsenic & 1.31E-05 & $3.40 E-07$ & 2.13E-05 & 2.87E-05 \\
\hline & & & Benzene & $3.00 E-03$ & $7.79 E-05$ & 4.87E-03 & 6.57E-03 \\
\hline & & & Chromium Compounds & $2.29 \mathrm{E}-05$ & 5.95E-07 & $3.72 \mathrm{E}-05$ & 5.02E-05 \\
\hline & & & Lead Compounds & 1.80E-04 & 4.68E-06 & 2.92E-04 & $3.94 E-04$ \\
\hline & & & Manganese & $2.29 E-05$ & 5.95E-07 & $3.72 \mathrm{E}-05$ & 5.02E-05 \\
\hline & & & Mercury Compounds & $6.54 E-06$ & 1.70E-07 & 1.06E-05 & 1.43E-05 \\
\hline & & & Nickel & 9.82E-06 & 2.55E-07 & $1.59 E-05$ & 2.15E-05 \\
\hline & & & Selenium Compounds & $6.54 \mathrm{E}-06$ & 1.70E-07 & $1.06 E-05$ & 1.43E-05 \\
\hline
\end{tabular}

- Not Significant Source 


\begin{tabular}{|c|c|c|c|c|c|c|c|}
\hline AREA & BLDG & VENT & Toxic & $\begin{array}{l}\text { Actual } \\
\text { Hourly } \\
\text { Rates } \\
\text { Lbs/Hr } \\
\text { or } \\
\text { Ci/Mo }\end{array}$ & $\begin{array}{c}\text { Actual } \\
\text { Yearly } \\
\text { Rates } \\
\text { Tns } / \mathrm{Yr} \\
\text { or } \\
\mathrm{Ci} / \mathrm{Yr}_{\mathrm{r}}\end{array}$ & $\begin{array}{l}\text { Max. } \\
\text { Hourly } \\
\text { Rates } \\
\text { Lbs/Hr } \\
\text { or } \\
\text { Ci/Mo }\end{array}$ & $\begin{array}{c}\text { Max. } \\
\text { Yearly } \\
\text { Rates } \\
\text { Tns } / Y r \\
\text { or } \\
\text { Ci/Yr }\end{array}$ \\
\hline \multirow[t]{36}{*}{ NRF } & 686 & 016 & 1,3-Butadiene & 6.71E-02 & $2.08 E-03$ & 8.63E-02 & 8.63E-03 \\
\hline & & & Arsenic & 2.63E-05 & 8.14E-07 & $3.38 E-05$ & 3.38E-06 \\
\hline & & & Benzene & 7.58E-02 & 2.34E-03 & $9.74 E-02$ & 9.74E-03 \\
\hline & & & Chromium Compounds & 4.61E-05 & 1.42E-06 & 5.92E-05 & 5.92E-06 \\
\hline & & & Lead Compounds & $3.62 E-04$ & $1.12 E-05$ & $4.65 \mathrm{E}-04$ & $4.65 E-05$ \\
\hline & & & Manganese & 4.61E-05 & 1.42E-06 & 5.92E-05 & 5.92E-06 \\
\hline & & & Mercury Compounds & $1.32 E-05$ & 4.07E-07 & $1.69 \mathrm{E}-05$ & 1.69E-06 \\
\hline & & & Nickel & 1.97E-05 & 6.11E-07 & $2.54 E-05$ & 2.54E-06 \\
\hline & & & Selenium Compounds & 1.32E-05 & 4.07E-07 & 1.69E-05 & 1.69E-06 \\
\hline & & 017 & 1,3-Butadiene & 6.71E-02 & 2.08E-03 & $8.63 E-02$ & 8.63E-03 \\
\hline & & & Arsenic & 2.63E-05 & 8.14E-07 & $3.38 E-05$ & $3.38 \mathrm{E}-06$ \\
\hline & & & Benzene & 7.58E-02 & 2.34E-03 & $9.74 \mathrm{E}-02$ & 9.74E-03 \\
\hline & & & Chromium Compounds & 4.61E-05 & 1.42E-06 & $5.92 \mathrm{E}-05$ & 5.92E-06 \\
\hline & & & Lead Compounds & 3.62E-04 & 1.12E-05 & 4.65E-04 & 4.65E-05 \\
\hline & & & Manganese & 4.61E-05 & 1.42E-06 & $5.92 \mathrm{E}-05$ & 5.92E-06 \\
\hline & & & Mercury Compounds & $1.32 \mathrm{E}-05$ & 4.07E-07 & 1.69E-05 & 1.69E-06 \\
\hline & & & Nickel & 1.97E-05 & $6.11 E-07$ & $2.54 \mathrm{E}-05$ & 2.54E-06 \\
\hline & & & Selenium Compounds & $1.32 E-05$ & 4.07E-07 & 1.69E-05 & 1.69E-06 \\
\hline & & 018 & 1,3-Butadiene & 6.71E-02 & $2.08 E-03$ & 8.63E-02 & 8.63E-03 \\
\hline & & & Arsenic & 2.63E-05 & 8.14E-07 & $3.38 \mathrm{E}-05$ & 3.38E-06 \\
\hline & & & Benzene & $7.58 \mathrm{E}-02$ & 2.34E-03 & $9.74 \mathrm{E}-02$ & $9.74 \mathrm{E}-03$ \\
\hline & & & Chromium Compounds & 4.61E-05 & 1.42E-06 & 5.92E-05 & 5.92E-06 \\
\hline & & & Lead Compounds & 3.62E-04 & 1.12E-05 & 4.65E-04 & 4.65E-05 \\
\hline & & & Manganese & 4.61E-05 & 1.42E-06 & $5.92 \mathrm{E}-05$ & 5.92E-06 \\
\hline & & & Mercury Compounds & $1.32 \mathrm{E}-05$ & 4.07E-07 & $1.69 \mathrm{E}-05$ & 1.69E-06 \\
\hline & & & Nickel & $1.97 \mathrm{E}-05$ & $6.11 \mathrm{E}-07$ & $2.54 \mathrm{E}-05$ & 2.54E-06 \\
\hline & & & Selenium Compounds & 1.32E-05 & 4.07E-07 & $1.69 \mathrm{E}-05$ & $1.69 \mathrm{E}-06$ \\
\hline & & 019 & 1,3-Butadiene & 6.71E-02 & $2.08 E-03$ & 8.63E-02 & 8.63E-03 \\
\hline & & & Arsenic & 2.63E-05 & 8.14E-07 & $3.38 \mathrm{E}-05$ & 3.38E-06 \\
\hline & & & Benzene & $7.58 \mathrm{E}-02$ & $2.34 E-03$ & 9.74E-02 & 9.74E-03 \\
\hline & & & Chromium Compounds & 4.61E-05 & $1.42 E-06$ & 5.92E-05 & 5.92E-06 \\
\hline & & & Lead Compounds & 3.62E-04 & 1.12E-05 & 4.65E-04 & 4.65E-05 \\
\hline & & & Manganese & 4.61E-05 & 1.42E-06 & 5.92E-05 & 5.92E-06 \\
\hline & & & Mercury Compounds & 1.32E-05 & 4.07E-07 & $1.69 \mathrm{E}-05$ & 1.69E-06 \\
\hline & & & Nickel & $1.97 E-05$ & $6.11 E-07$ & 2.54E-05 & 2.54E-06 \\
\hline & & & Selenium Compounds & 1.32E-05 & 4.07E-07 & 1.69E-05 & 1.69E-06 \\
\hline
\end{tabular}


AREA BLDG VENT Toxic

$\begin{array}{cccc}\text { Actual } & \text { Actual } & \text { Max. } & \text { Max. } \\ \text { Hourly } & \text { Yearly } & \text { Hourly } & \text { Yearly } \\ \text { Rates } & \text { Rates } & \text { Rates } & \text { Rates } \\ \text { Lbs/Hr } & \text { Tns } / Y r & \text { Lbs/Hr } & \text { Tns } / \text { r } \\ \text { or } & \text { or } & \text { or } & \text { or } \\ \text { CiMo } & \text { Ci } / Y r & \text { CiMo } & \text { Ci/Yr }\end{array}$

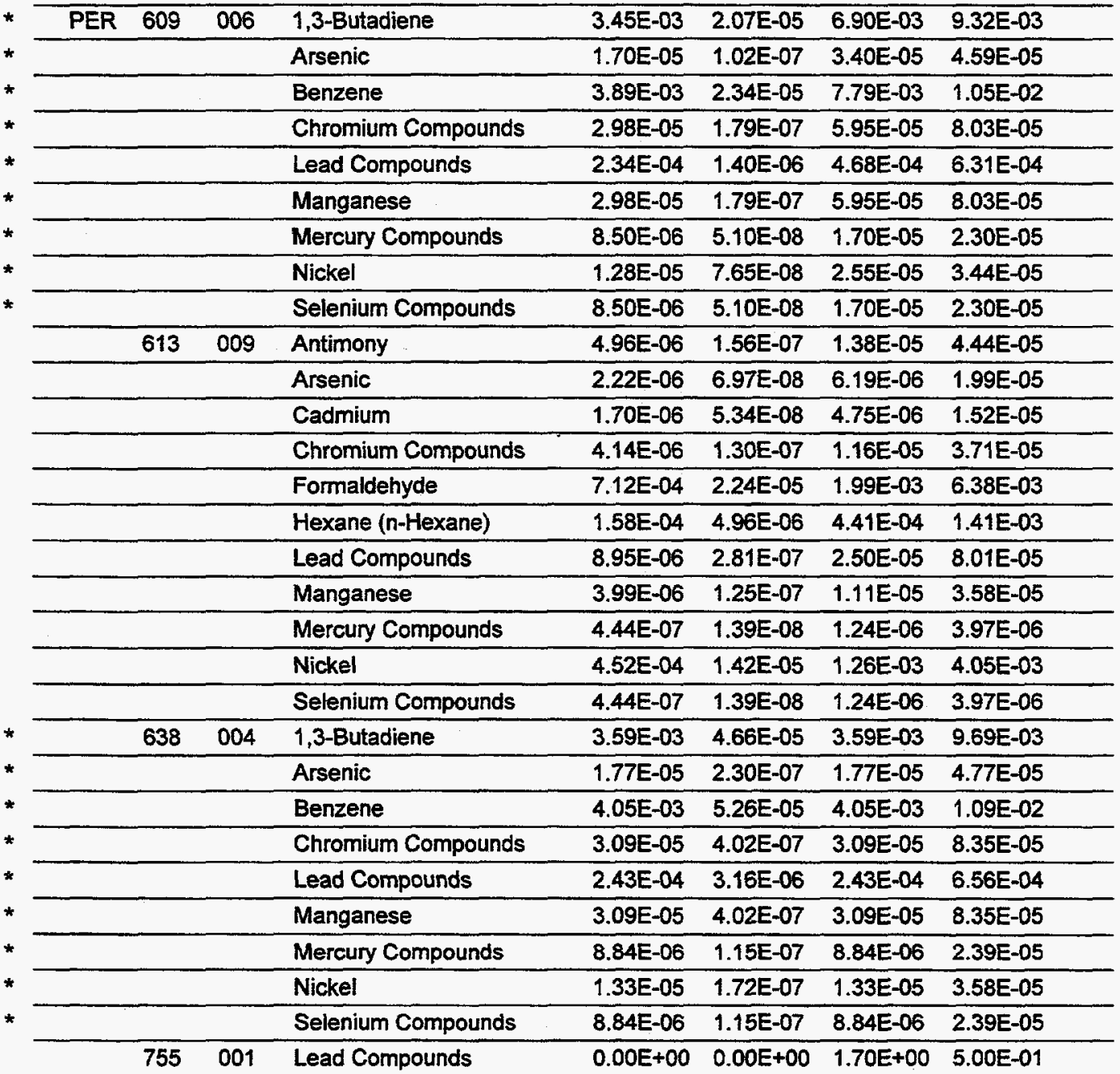

* Not Significant Source 


\begin{tabular}{|c|c|c|c|c|c|c|c|}
\hline AREA & BLDG & VENT & Toxic & $\begin{array}{c}\text { Actual } \\
\text { Hourly } \\
\text { Rates } \\
\text { Lbs/Hr } \\
\text { or } \\
\text { Ci/Mo }\end{array}$ & $\begin{array}{c}\text { Actual } \\
\text { Yearly } \\
\text { Rates } \\
\text { Tns } / \text { r } \\
\text { or } \\
\text { Ci/Yr }\end{array}$ & $\begin{array}{c}\text { Max. } \\
\text { Hourly } \\
\text { Rates } \\
\text { Lbs/Hr } \\
\text { or } \\
\text { Ci/Mo }\end{array}$ & $\begin{array}{c}\text { Max. } \\
\text { Yearly } \\
\text { Rates } \\
\text { Tns } / Y r \\
\text { or } \\
\text { Ci } / Y r\end{array}$ \\
\hline \multirow[t]{41}{*}{ TAN } & 603 & 022 & Antimony & $7.68 E-04$ & 8.90E-05 & $7.68 \mathrm{E}-04$ & $4.90 E-04$ \\
\hline & & & Arsenic & $3.44 E-04$ & $3.98 E-05$ & 3.44E-04 & 2.19E-04 \\
\hline & & & Cadmium & 2.64E-04 & 3.05E-05 & 2.64E-04 & $1.68 E-04$ \\
\hline & & & Chromium Compounds & 6.42E-04 & $7.44 \mathrm{E}-05$ & $6.42 \mathrm{E}-04$ & 4.09E-04 \\
\hline & & & Formaldehyde & $6.49 E-02$ & 7.52E-03 & $6.49 E-02$ & 4.14E-02 \\
\hline & & & Hexane ( $n$-Hexane) & $1.44 E-02$ & 1.67E-03 & $1.44 E-02$ & $9.18 E-03$ \\
\hline & & & Lead Compounds & $1.39 E-03$ & 1.61E-04 & $1.39 E-03$ & 8.84E-04 \\
\hline & & & Manganese & $6.19 \mathrm{E}-04$ & 7.17E-05 & $6.19 \mathrm{E}-04$ & $3.95 E-04$ \\
\hline & & & Mercury Compounds & $6.88 E-05$ & 7.97E-06 & $6.88 E-05$ & 4.38E-05 \\
\hline & & & Nickel & 7.01E-02 & 8.11E-03 & 7.01E-02 & 4.46E-02 \\
\hline & & & Selenium Compounds & $6.88 E-05$ & 7.97E-06 & $6.88 E-05$ & 4.38E-05 \\
\hline & & 027 & Antimony & $9.08 E-05$ & 5.83E-05 & $1.58 \mathrm{E}-04$ & $6.94 E-04$ \\
\hline & & & Arsenic & 4.07E-05 & 2.61E-05 & $7.10 \mathrm{E}-05$ & 3.11E-04 \\
\hline & & & Cadmium & 3.12E-05 & $2.00 \mathrm{E}-05$ & 5.44E-05 & 2.38E-04 \\
\hline & & & Chromium Compounds & 7.59E-05 & 4.87E-05 & $1.32 E-04$ & $5.80 \mathrm{E}-04$ \\
\hline & & & Formaldehyde & 1.30E-02 & $8.38 E-03$ & 2.28E-02 & 9.97E-02 \\
\hline & & & Hexane (n-Hexane) & 2.89E-03 & $1.86 \mathrm{E}-03$ & $5.05 E-03$ & 2.21E-02 \\
\hline & & & Lead Compounds & 1.64E-04 & $1.05 \mathrm{E}-04$ & 2.86E-04 & $1.25 \mathrm{E}-03$ \\
\hline & & & Manganese & 7.32E-05 & 4.70E-05 & $1.28 \mathrm{E}-04$ & 5.59E-04 \\
\hline & & & Mercury Compounds & 8.13E-06 & 5.22E-06 & 1.42E-05 & 6.22E-05 \\
\hline & & & Nickel & $8.28 E-03$ & 5.32E-03 & $1.44 \mathrm{E}-02$ & $6.33 E-02$ \\
\hline & & & Selenium Compounds & 8.13E-06 & 5.22E-06 & 1.42E-05 & $6.22 \mathrm{E}-05$ \\
\hline & & 028 & Antimony & $9.08 E-05$ & 5.06E-05 & 1.61E-04 & 7.04E-04 \\
\hline & & & Arsenic & 4.07E-05 & 2.26E-05 & 7.20E-05 & 3.15E-04 \\
\hline & & & Cadmium & 3.12E-05 & $1.74 \mathrm{E}-05$ & 5.52E-05 & 2.42E-04 \\
\hline & & & Chromium Compounds & 7.59E-05 & 4.23E-05 & 1.34E-04 & 5.89E-04 \\
\hline & & & Formaldehyde & 1.30E-02 & 7.26E-03 & 2.31E-02 & 1.01E-01 \\
\hline & & & Hexane (n-Hexane) & 2.89E-03 & 1.61E-03 & $5.12 E-03$ & $2.24 \mathrm{E}-02$ \\
\hline & & & Lead Compounds & $1.64 E-04$ & $9.13 E-05$ & 2.90E-04 & 1.27E-03 \\
\hline & & & Manganese & 7.32E-05 & 4.07E-05 & 1.30E-04 & 5.68E-04 \\
\hline & & & Mercury Compounds & 8.13E-06 & 4.53E-06 & 1.44E-05 & 6.31E-05 \\
\hline & & & Nickel & 8.28E-03 & 4.61E-03 & 1.47E-02 & $6.42 E-02$ \\
\hline & & & Selenium Compounds & 8.13E-06 & 4.53E-06 & 1.44E-05 & 6.31E-05 \\
\hline & 641 & 034 & Antimony & 5.15E-06 & & 5.19E-05 & 2.27E-04 \\
\hline & & & Arsenic & 2.31E-06 & & $2.32 E-05$ & $1.02 E-04$ \\
\hline & & & Cadmium & 1.77E-06 & & 1.78E-05 & 7.80E-05 \\
\hline & & & Chromium Compounds & 4.31E-06 & & 4.33E-05 & $1.90 \mathrm{E}-04$ \\
\hline & & & Formaldehyde & $7.40 E-04$ & & $7.45 E-03$ & 3.26E-02 \\
\hline & & & Hexane (n-Hexane) & 1.64E-04 & & 1.65E-03 & 7.24E-03 \\
\hline & & & Lead Compounds & 9.30E-06 & & 9.37E-05 & 4.10E-04 \\
\hline & & & Manganese & 4.15E-06 & & $4.18 E-05$ & 1.83E-04 \\
\hline
\end{tabular}

* Not Significant Source 


\begin{tabular}{|c|c|c|c|c|c|c|c|}
\hline AREA & BLDG & VENT & Toxic & $\begin{array}{l}\text { Actual } \\
\text { Hourly } \\
\text { Rates } \\
\text { Lbs/Hr } \\
\text { or } \\
\mathrm{Ci} / \mathrm{Mo}\end{array}$ & $\begin{array}{c}\text { Actual } \\
\text { Yearly } \\
\text { Rates } \\
\text { Tns } / Y r \\
\text { or } \\
\mathrm{Ci} /{ }^{\prime} \mathrm{r}\end{array}$ & $\begin{array}{l}\text { Max. } \\
\text { Hourly } \\
\text { Rates } \\
\text { Lbs/Hr } \\
\text { or } \\
\text { Ci/Mo }\end{array}$ & $\begin{array}{c}\text { Max. } \\
\text { Yearly } \\
\text { Rates } \\
\text { Tns/Yr } \\
\text { or } \\
\text { Ci/Yr }\end{array}$ \\
\hline \multirow[t]{41}{*}{ TAN } & 641 & 034 & Mercury Compounds & $4.61 E-07$ & & 4.64E-06 & 2.03E-05 \\
\hline & & & Nickel & $4.70 \mathrm{E}-04$ & & 4.73E-03 & 2.07E-02 \\
\hline & & 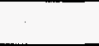 & Selenium Compounds & 4.61E-07 & & 4.64E-06 & 2.03E-05 \\
\hline & & 035 & Antimony & 5.15E-06 & & 5.19E-05 & 2.27E-04 \\
\hline & & & Arsenic & 2.31E-06 & & 2.32E-05 & 1.02E-04 \\
\hline & & & Cadmium & $1.77 \mathrm{E}-06$ & & $1.78 E-05$ & $7.80 \mathrm{E}-05$ \\
\hline & & & Chromium Compounds & 4.31E-06 & & 4.33E-05 & $1.90 \mathrm{E}-04$ \\
\hline & & & Formaidehyde & 7.40E-04 & & 7.45E-03 & $3.26 E-02$ \\
\hline & & & Hexane (n-Hexane) & $1.64 \mathrm{E}-04$ & & 1.65E-03 & 7.24E-03 \\
\hline & & & Lead Compounds & 9.30E-06 & & 9.37E-05 & 4.10E-04 \\
\hline & & & Manganese & 4.15E-06 & & 4.18E-05 & $1.83 E-04$ \\
\hline & & & Mercury Compounds & 4.61E-07 & & 4.64E-06 & 2.03E-05 \\
\hline & & & Nickel & $4.70 E-04$ & & 4.73E-03 & 2.07E-02 \\
\hline & & & Selenium Compounds & $4.61 E-07$ & & 4.64E-06 & 2.03E-05 \\
\hline & 675 & 035 & Antimony & 3.09E-05 & 1.28E-05 & 1.93E-04 & 8.45E-04 \\
\hline & & & Arsenic & $1.38 \mathrm{E}-05$ & 5.72E-06 & 8.64E-05 & 3.79E-04 \\
\hline & & & Cadmium & $1.06 E-05$ & 4.39E-06 & 6.63E-05 & $2.90 \mathrm{E}-04$ \\
\hline & & & Chromium Compounds & $2.58 \mathrm{E}-05$ & 1.07E-05 & 1.61E-04 & 7.07E-04 \\
\hline & & & Formaldehyde & 2.61E-03 & $1.08 E-03$ & 1.63E-02 & 7.15E-02 \\
\hline & & & Hexane (n-Hexane) & $5.79 \mathrm{E}-04$ & 2.40E-04 & 3.62E-03 & $1.58 E-02$ \\
\hline & & & Lead Compounds & $5.58 \mathrm{E}-05$ & 2.31E-05 & $3.49 \mathrm{E}-04$ & 1.53E-03 \\
\hline & & & Manganese & $2.49 \mathrm{E}-05$ & 1.03E-05 & $1.56 \mathrm{E}-04$ & 6.81E-04 \\
\hline & & & Mercury Compounds & 2.77E-06 & 1.14E-06 & 1.73E-05 & 7.57E-05 \\
\hline & & & Nickel & $2.82 \mathrm{E}-03$ & 1.17E-03 & $1.76 E-02$ & 7.71E-02 \\
\hline & & & Selenium Compounds & 2.77E-06 & 1.14E-06 & $1.73 E-05$ & 7.57E-05 \\
\hline & & 037 & Antimony & $1.07 \mathrm{E}-04$ & 8.01E-06 & 1.93E-04 & $8.45 E-04$ \\
\hline & & & Arsenic & 4.81E-05 & 3.58E-06 & 8.64E-05 & 3.79E-04 \\
\hline & & & Cadmium & $3.69 E-05$ & 2.75E-06 & 6.63E-05 & 2.90E-04 \\
\hline & & & Chromium Compounds & $8.98 E-05$ & 6.69E-06 & 1.61E-04 & 7.07E-04 \\
\hline & & & Formaldehyde & $9.08 \mathrm{E}-03$ & 6.77E-04 & $1.63 E-02$ & $7.15 \mathrm{E}-02$ \\
\hline & & & Hexane (n-Hexane) & 2.01E-03 & 1.50E-04 & 3.62E-03 & $1.58 E-02$ \\
\hline & & & Lead Compounds & $1.94 \mathrm{E}-04$ & 1.45E-05 & 3.49E-04 & $1.53 E-03$ \\
\hline & & & Manganese & $8.66 E-05$ & $6.45 \mathrm{E}-06$ & 1.56E-04 & $6.81 E-04$ \\
\hline & & & Mercury Compounds & $9.62 \mathrm{E}-06$ & 7.17E-07 & 1.73E-05 & 7.57E-05 \\
\hline & & & Nickel & $9.79 E-03$ & 7.30E-04 & $1.76 E-02$ & 7.71E-02 \\
\hline & & & Selenium Compounds & $9.62 \mathrm{E}-06$ & 7.17E-07 & 1.73E-05 & 7.57E-05 \\
\hline & 679 & 067 & Antimony & $7.08 \mathrm{E}-05$ & $1.43 E-04$ & 1.93E-04 & $8.45 \mathrm{E}-04$ \\
\hline & & & Arsenic & 3.17E-05 & 6.41E-05 & 8.64E-05 & $3.79 E-04$ \\
\hline & & & Cadmium & 2.43E-05 & 4.91E-05 & 6.63E-05 & $2.90 E-04$ \\
\hline & & & Chromium Compounds & 5.91E-05 & $1.20 \mathrm{E}-04$ & 1.61E-04 & 7.07E-04 \\
\hline & & & Formaldehyde & $5.98 E-03$ & 1.21E-02 & 1.63E-02 & $7.15 E-02$ \\
\hline
\end{tabular}

* Not Significant Source 


\begin{tabular}{|c|c|c|c|c|c|c|c|}
\hline AREA & BLDG & VENT & Toxic & $\begin{array}{c}\text { Actual } \\
\text { Hourly } \\
\text { Rates } \\
\text { Lbs/Hr } \\
\text { or } \\
\text { Ci/Mo }\end{array}$ & $\begin{array}{c}\text { Actual } \\
\text { Yearly } \\
\text { Rates } \\
\text { Tns } / Y r \\
\text { or } \\
\text { Ci } / Y r\end{array}$ & $\begin{array}{c}\text { Max. } \\
\text { Hourly } \\
\text { Rates } \\
\text { Lbs/Hr } \\
\text { or } \\
\text { Cimo }\end{array}$ & $\begin{array}{c}\text { Max. } \\
\text { Yearly } \\
\text { Rates } \\
\text { Tns } / Y r \\
\text { or } \\
\text { Ci/Yr }\end{array}$ \\
\hline \multirow[t]{17}{*}{ TAN } & 679 & 067 & Hexane (n-Hexane) & 1.33E-03 & $2.68 \mathrm{E}-03$ & 3.62E-03 & 1.58E-02 \\
\hline & & & Lead Compounds & $1.28 E-04$ & $2.58 \mathrm{E}-04$ & $3.49 E-04$ & $1.53 \mathrm{E}-03$ \\
\hline & & & Manganese & 5.70E-05 & $1.15 E-04$ & $1.56 \mathrm{E}-04$ & $6.81 E-04$ \\
\hline & & & Mercury Compounds & $6.34 \mathrm{E}-06$ & $1.28 \mathrm{E}-05$ & $1.73 E-05$ & 7.57E-05 \\
\hline & & & Nickel & $6.45 E-03$ & $1.30 \mathrm{E}-02$ & $1.76 E-02$ & 7.71E-02 \\
\hline & & & Selenium Compounds & 6.34E-06 & 1.28E-05 & 1.73E-05 & 7.57E-05 \\
\hline & & 068 & Antimony & 4.75E-05 & 9.91E-05 & $1.93 E-04$ & 8.45E-04 \\
\hline & & & Arsenic & 2.13E-05 & 4.44E-05 & 8.64E-05 & $3.79 E-04$ \\
\hline & & & Cadmium & $1.63 \mathrm{E}-05$ & $3.40 \mathrm{E}-05$ & $6.63 E-05$ & $2.90 E-04$ \\
\hline & & & Chromium Compounds & 3.97E-05 & 8.29E-05 & 1.61E-04 & 7.07E-04 \\
\hline & & & Formaldehyde & 4.01E-03 & 8.38E-03 & 1.63E-02 & 7.15E-02 \\
\hline & & & Hexane (n-Hexane) & 8.90E-04 & 1.86E-03 & 3.62E-03 & $1.58 \mathrm{E}-02$ \\
\hline & & & Lead Compounds & 8.57E-05 & $1.79 \mathrm{E}-04$ & 3.49E-04 & 1.53E-03 \\
\hline & & & Manganese & 3.83E-05 & $7.99 \mathrm{E}-05$ & $1.56 E-04$ & 6.81E-04 \\
\hline & & & Mercury Compounds & 4.25E-06 & 8.88E-06 & $1.73 E-05$ & 7.57E-05 \\
\hline & & & Nickel & 4.33E-03 & $9.04 \mathrm{E}-03$ & $1.76 \mathrm{E}-02$ & 7.71E-02 \\
\hline & & & Selenium Compounds & 4.25E-06 & 8.88E-06 & $1.73 E-05$ & 7.57E-05 \\
\hline
\end{tabular}


AREA BLDG VENT Toxic

$\begin{array}{cccc}\text { Actual } & \text { Actual } & \text { Max. } & \text { Max. } \\ \text { Hourly } & \text { Yearly } & \text { Hourly } & \text { Yearly } \\ \text { Rates } & \text { Rates } & \text { Rates } & \text { Rates } \\ \text { Lbs/Hr } & \text { Tns } / Y r & \text { Lbs/Hr } & \text { Tns } / Y r \\ \text { or } & \text { or } & \text { or } & \text { or } \\ \text { Ci/Mo } & \mathrm{Ci} / Y r & \mathrm{Ci} / \mathrm{Mo} & \mathrm{Ci} / \mathrm{Yr}\end{array}$

\begin{tabular}{|c|c|c|c|c|c|c|c|}
\hline TRA & 604 & 035 & Dichloromethane (Methylen & $2.00 E+00$ & $2.00 E+00$ & $2.00 E+00$ & $5.40 E+00$ \\
\hline * & 619 & 008 & 1,3-Butadiene & 3.45E-03 & 8.97E-05 & 3.45E-03 & 3.11E-03 \\
\hline * & & & Arsenic & $1.70 \mathrm{E}-05$ & 4.42E-07 & 1.70E-05 & 1.53E-05 \\
\hline * & & & Benzene & $3.89 E-03$ & 1.01E-04 & $3.89 E-03$ & 3.51E-03 \\
\hline * & & & Chromium Compounds & $2.98 \mathrm{E}-05$ & 7.74E-07 & $2.98 \mathrm{E}-05$ & $2.68 \mathrm{E}-05$ \\
\hline * & & & Lead Compounds & 2.34E-04 & $6.08 E-06$ & 2.34E-04 & 2.10E-04 \\
\hline * & & & Manganese & $2.98 \mathrm{E}-05$ & 7.74E-07 & $2.98 \mathrm{E}-05$ & 2.68E-05 \\
\hline * & & & Mercury Compounds & 8.50E-06 & 2.21E-07 & 8.50E-06 & 7.65E-06 \\
\hline * & & & Nickel & $1.28 \mathrm{E}-05$ & 3.32E-07 & $1.28 \mathrm{E}-05$ & $1.15 \mathrm{E}-05$ \\
\hline * & & & Selenium Compounds & 8.50E-06 & 2.21E-07 & 8.50E-06 & 7.65E-06 \\
\hline * & & 009 & 1,3-Butadiene & 3.45E-03 & 8.97E-05 & 3.45E-03 & $3.11 E-03$ \\
\hline * & & & Arsenic & $1.70 \mathrm{E}-05$ & 4.42E-07 & $1.70 \mathrm{E}-05$ & $1.53 E-0.5$ \\
\hline * & & & Benzene & 3.89E-03 & 1.01E-04 & $3.89 E-03$ & 3.51E-03 \\
\hline * & & & Chromium Compounds & $2.98 \mathrm{E}-05$ & 7.74E-07 & 2.98E-05 & 2.68E-05 \\
\hline * & & & Lead Compounds & $2.34 E-04$ & $6.08 \mathrm{E}-06$ & 2.34E-04 & $2.10 E-04$ \\
\hline * & & & Manganese & $2.98 \mathrm{E}-05$ & 7.74E-07 & 2.98E-05 & 2.68E-05 \\
\hline * & & & Mercury Compounds & 8.50E-06 & 2.21E-07 & 8.50E-06 & 7.65E-06 \\
\hline * & & & Nickel & $1.28 \mathrm{E}-05$ & 3.32E-07 & $1.28 \mathrm{E}-05$ & 1.15E-05 \\
\hline * & & & Selenium Compounds & 8.50E-06 & 2.21E-07 & 8.50E-06 & 7.65E-06 \\
\hline * & 633 & 003 & 1,3-Butadiene & 3.45E-03 & 8.97E-05 & $3.45 E-03$ & 3.11E-03 \\
\hline * & & & Arsenic & $1.70 \mathrm{E}-05$ & 4.42E-07 & 1.70E-05 & 1.53E-05 \\
\hline * & & & Benzene & 3.89E-03 & $1.01 E-04$ & 3.89E-03 & 3.51E-03 \\
\hline * & & & Chromium Compounds & 2.98E-05 & 7.74E-07 & 2.98E-05 & 2.68E-05 \\
\hline * & & & Lead Compounds & 2.34E-04 & $6.08 \mathrm{E}-06$ & $2.34 \mathrm{E}-04$ & 2.10E-04 \\
\hline * & & & Manganese & 2.98E-05 & 7.74E-07 & 2.98E-05 & 2.68E-05 \\
\hline * & & & Mercury Compounds & 8.50E-06 & 2.21E-07 & 8.50E-06 & 7.65E-06 \\
\hline * & & & Nickel & $1.28 \mathrm{E}-05$ & 3.32E-07 & $1.28 \mathrm{E}-05$ & 1.15E-05 \\
\hline * & & & Selenium Compounds & 8.50E-06 & 2.21E-07 & 8.50E-06 & 7.65E-06 \\
\hline * & & 004 & 1,3-Butadiene & $3.45 \mathrm{E}-03$ & $8.97 E-05$ & 3.45E-03 & 3.11E-03 \\
\hline * & & & Arsenic & 1.70E-05 & 4.42E-07 & 1.70E-05 & $1.53 E-05$ \\
\hline * & & & Benzene & $3.89 \mathrm{E}-03$ & $1.01 \mathrm{E}-04$ & 3.89E-03 & 3.51E-03 \\
\hline * & & & Chromium Compounds & $2.98 \mathrm{E}-05$ & $7.74 \mathrm{E}-07$ & $2.98 \mathrm{E}-05$ & $2.68 \mathrm{E}-05$ \\
\hline * & & & Lead Compounds & 2.34E-04 & 6.08E-06 & 2.34E-04 & 2.10E-04 \\
\hline * & & & Manganese & $2.98 E-05$ & $7.74 \mathrm{E}-07$ & 2.98E-05 & 2.68E-05 \\
\hline * & & & Mercury Compounds & 8.50E-06 & 2.21E-07 & 8.50E-06 & $7.65 E-06$ \\
\hline * & & & Nickel & $1.28 \mathrm{E}-05$ & 3.32E-07 & 1.28E-05 & 1.15E-05 \\
\hline * & & & Selenium Compounds & 8.50E-06 & 2.21E-07 & 8.50E-06 & 7.65E-06 \\
\hline * & 661 & 008 & Arsenic & 5.00E-02 & $5.00 \mathrm{E}-02$ & 5.00E-02 & 2.20E-01 \\
\hline * & & & Carbon tetrachloride & $1.70 \mathrm{E}+00$ & $1.80 E+00$ & $1.70 E+00$ & $7.40 E+00$ \\
\hline * & & & Chloroform & $6.60 \mathrm{E}+00$ & $6.90 \mathrm{E}+00$ & $6.60 E+00$ & $2.90 \mathrm{E}+01$ \\
\hline * & & & Dichloromethane (Methylen & $6.60 E+00$ & $6.90 \mathrm{E}+00$ & $6.60 E+00$ & $2.90 \mathrm{E}+01$ \\
\hline
\end{tabular}

- Not Significant Source 


\begin{tabular}{|c|c|c|c|c|c|c|c|}
\hline AREA & BLDG & VENT & Toxic & $\begin{array}{c}\text { Actual } \\
\text { Hourly } \\
\text { Rates } \\
\text { Lbs/Hr } \\
\text { or } \\
\text { Ci/Mo }\end{array}$ & $\begin{array}{c}\text { Actual } \\
\text { Yearly } \\
\text { Rates } \\
\text { Tns } / Y r \\
\text { or } \\
\text { Ci/Yr }\end{array}$ & $\begin{array}{l}\text { Max. } \\
\text { Hourly } \\
\text { Rates } \\
\text { Lbs/Hr } \\
\text { or } \\
\text { Ci/Mo }\end{array}$ & $\begin{array}{c}\text { Max. } \\
\text { Yearly } \\
\text { Rates } \\
\text { Tns } / Y r \\
\text { or } \\
\text { CirYr }\end{array}$ \\
\hline \multirow[t]{37}{*}{ TRA } & 661 & 008 & Dimethylphthalate & 9.90E-01 & 9.90E-01 & 9.90E-01 & $4.40 \mathrm{E}+00$ \\
\hline & & & Hexane (n-Hexane) & $2.60 E+00$ & $2.60 E+00$ & $2.60 E+00$ & $1.15 E+01$ \\
\hline & & & Hydrochloric acid & $6.70 \mathrm{E}+00$ & $6.70 \mathrm{E}+00$ & $6.70 \mathrm{E}+00$ & $3.80 E+01$ \\
\hline & & & Methanol, see Methyl alcoh & $1.10 \mathrm{E}+01$ & $1.10 E+01$ & $1.10 E+01$ & $4.90 E+01$ \\
\hline & & & Naphthalene & $2.20 \mathrm{E}-01$ & $2.20 \mathrm{E}-01$ & $2.20 E-01$ & $9.70 E-01$ \\
\hline & & & Phenol & $2.20 \mathrm{E}-02$ & $2.20 \mathrm{E}-02$ & $2.20 \mathrm{E}-02$ & $9.70 E-02$ \\
\hline & & & Phosphorus & 1.10E-01 & $1.10 \mathrm{E}-01$ & $1.10 \mathrm{E}-01$ & 5.00E-01 \\
\hline & & & Selenium Compounds & $3.00 \mathrm{E}-02$ & $3.00 \mathrm{E}-02$ & $3.00 \mathrm{E}-02$ & $1.20 \mathrm{E}-01$ \\
\hline & & & Toluene (toluol) & $1.80 E+00$ & $1.80 \mathrm{E}+00$ & $1.80 E+00$ & $7.90 E+00$ \\
\hline & & & Trichloroethylene & $3.10 E-01$ & 3.10E-01 & $3.10 \mathrm{E}-01$ & $1.30 E+00$ \\
\hline & 670 & 046 & 1,3-Butadiene & $4.60 E-02$ & $1.01 \mathrm{E}-01$ & 5.75E-02 & 2.52E-01 \\
\hline & & & Arsenic & $1.80 E-05$ & 3.95E-05 & $2.26 \mathrm{E}-05$ & $9.88 E-05$ \\
\hline & & & Benzene & $5.20 \mathrm{E}-02$ & $1.14 E-01$ & 6.49E-02 & 2.84E-01 \\
\hline & & & Chromium Compounds & $3.16 E-05$ & $6.91 E-05$ & $3.95 \mathrm{E}-05$ & $1.73 E-04$ \\
\hline & & & Lead Compounds & $2.48 E-04$ & 5.43E-04 & $3.10 \mathrm{E}-04$ & $1.36 \mathrm{E}-03$ \\
\hline & & & Manganese & $3.16 E-05$ & 6.91E-05 & 3.95E-05 & $1.73 E-04$ \\
\hline & & & Mercury Compounds & $9.02 E-06$ & 1.97E-05 & $1.13 E-05$ & 4.94E-05 \\
\hline & & & Nickel & 1.35E-05 & 2.96E-05 & 1.69E-05 & 7.41E-05 \\
\hline & & & Selenium Compounds & $9.02 E-06$ & 1.97E-05 & $1.13 \mathrm{E}-05$ & 4.94E-05 \\
\hline & & 053 & 1,3-Butadiene & $4.60 \mathrm{E}-02$ & 9.99E-02 & $5.75 \mathrm{E}-02$ & 2.52E-01 \\
\hline & & & Arsenic & 1.80E-05 & 3.92E-05 & $2.26 \mathrm{E}-05$ & 9.88E-05 \\
\hline & & & Benzene & $5.20 \mathrm{E}-02$ & $1.13 E-01$ & 6.49E-02 & 2.84E-01 \\
\hline & & & Chromium Compounds & $3.16 E-05$ & $6.85 E-05$ & 3.95E-05 & 1.73E-04 \\
\hline & & & Lead Compounds & $2.48 E-04$ & $5.38 \mathrm{E}-04$ & $3.10 \mathrm{E}-04$ & $1.36 \mathrm{E}-03$ \\
\hline & & & Manganese & $3.16 E-05$ & $6.85 E-05$ & $3.95 \mathrm{E}-05$ & $1.73 E-04$ \\
\hline & & & Mercury Compounds & 9.02E-06 & 1.96E-05 & 1.13E-05 & 4.94E-05 \\
\hline & & & Nickel & 1.35E-05 & 2.94E-05 & 1.69E-05 & 7.41E-05 \\
\hline & & & Selenium Compounds & 9.02E-06 & $1.96 \mathrm{E}-05$ & $1.13 E-05$ & 4.94E-05 \\
\hline & 674 & 007 & 1,3-Butadiene & $1.86 \mathrm{E}-02$ & $2.43 E-04$ & 3.73E-02 & $1.52 E-02$ \\
\hline & & & Arsenic & $9.18 \mathrm{E}-05$ & $1.20 E-06$ & $1.84 E-04$ & 7.50E-05 \\
\hline & & & Benzene & $2.10 E-02$ & $2.75 E-04$ & $4.21 E-02$ & $1.72 E-02$ \\
\hline & & & Chromium Compounds & $1.61 \mathrm{E}-04$ & $2.10 \mathrm{E}-06$ & $3.22 E-04$ & 1.31E-04 \\
\hline & & & Lead Compounds & $1.26 E-03$ & $1.65 \mathrm{E}-05$ & $2.53 E-03$ & 1.03E-03 \\
\hline & & & Manganese & 1.61E-04 & 2.10E-06 & 3.22E-04 & 1.31E-04 \\
\hline & & & Mercury Compounds & 4.59E-05 & 5.99E-07 & 9.19E-05 & $3.75 E-05$ \\
\hline & & & Nickel & $6.88 \mathrm{E}-05$ & 8.99E-07 & $1.38 \mathrm{E}-04$ & $5.62 \mathrm{E}-05$ \\
\hline & & & Selenium Compounds & 4.59E-05 & 5.99E-07 & $9.19 E-05$ & $3.75 E-05$ \\
\hline
\end{tabular}

* Not Significant Source 

Appendix C

Supporting Data for the

1994 Air Emission Inventory for the INEL 
C-2 


\section{Appendix C}

\section{Supporting Data for the 1994 Air Emission Inventory for the INEL}

This appendix presents the data collected for the current update of the Air Emission Inventory System and describes each report form in detail. All the forms list the area, building, and stack number. The following presents the information as titled on each form.

\section{C.1 AIR EMISSION INVENTORY PROCESS PARAMETERS}

This form contains the operating schedule for the process associated with the stack emissions. Some of the operating schedule parameters may not correspond exactly with the INEL's Title V Operation Permit Application. This will be corrected for the 1995 Inventory.

Column 1. Hr/Day - the number of hours in a day the equipment or process operates.

Column 2. Days/Week - the number of days in a week the equipment or process operates.

Column 3. Weeks/Year - the number of weeks in a year the equipment or process operates.

Column 4. Status - status of source (active, inactive, D\&D).

\section{C.2 AIR EMISSION INVENTORY STACK PARAMETERS}

This form lists of all the stack parameters currently recorded for each stack. Some of the stack parameters may not correspond exactly with the INEL's Title V Operation Permit Application. This will be corrected for the 1995 Inventory.

Column 1. Exit Temp $\left({ }^{\circ} \mathrm{F}\right)$ - the exit temperature of the emissions from the vent in degrees Fahrenheit.

Column 2. Temp Type - the character field for the temperature which describes it as either ambient or room temperature.

Column 3. Flow Rate - the flow rate of the emissions from the stack in cubic feet per minute.

Column 4. Velocity - the velocity of the emissions from the stack in feet per minute.

Column 5. Hgt grnd - the height of the stack from the ground in feet. 
Column 6. Elev - the elevation of the stack from sea level in feet.

Column 7. Dia or Length - the diameter of a round stack or the length of a stack for rectangular stacks in inches.

Column 8. Width - the width of a stack for rectangular stacks in inches.

Column 9. UTM Northing - the universal transverse mercator (UTM) northing coordinate in meters.

Column 10. UTM Easting - the UTM easting coordinate in meters.

\section{C.3 AIR EMISSION INVENTORY FUEL BURNING EQUIPMENT PART I} site.

This form lists information about the fuel burning equipment currently emitting emissions at the

Column 1. E - The type of fuel burning equipment: B - Boiler, F - Furnace, H - Heater, L - Large Engine, P - Propane Burner, or S -Small Engine.

Column 2. Primary Normal per Hour - the normal hourly fuel through put for the primary fuel type for this piece of equipment in gallons per hour.

Column 3. Primary Normal per Year - the normal yearly fuel through put for the primary fuel type for this piece of equipment in gallons per year.

Column 4. Primary Max per Hour - the maximum hourly fuel through put for the primary fuel type for this piece of equipment in gallons per hour.

Column 5. Primary Fuel - the primary fuel type burned in this equipment. See the list of fuel types in Table C-1.

Column 6. Second Normal per Hour - the normal hourly fuel through put for the secondary fuel type for this piece of equipment in gallons per hour.

Column 7. Second Normal per Year - the normal yearly fuel through put for the secondary fuel type for this piece of equipment in gallons per year.

Column 8. Second Max per Hour - the maximum hourly fuel through put for the secondary fuel type for this piece of equipment in gallons per hour.

Column 9. Secondary Fuel - the secondary fuel type burned in this equipment. 
Table C-1. Fuel types and grades for primary and secondary fuels.

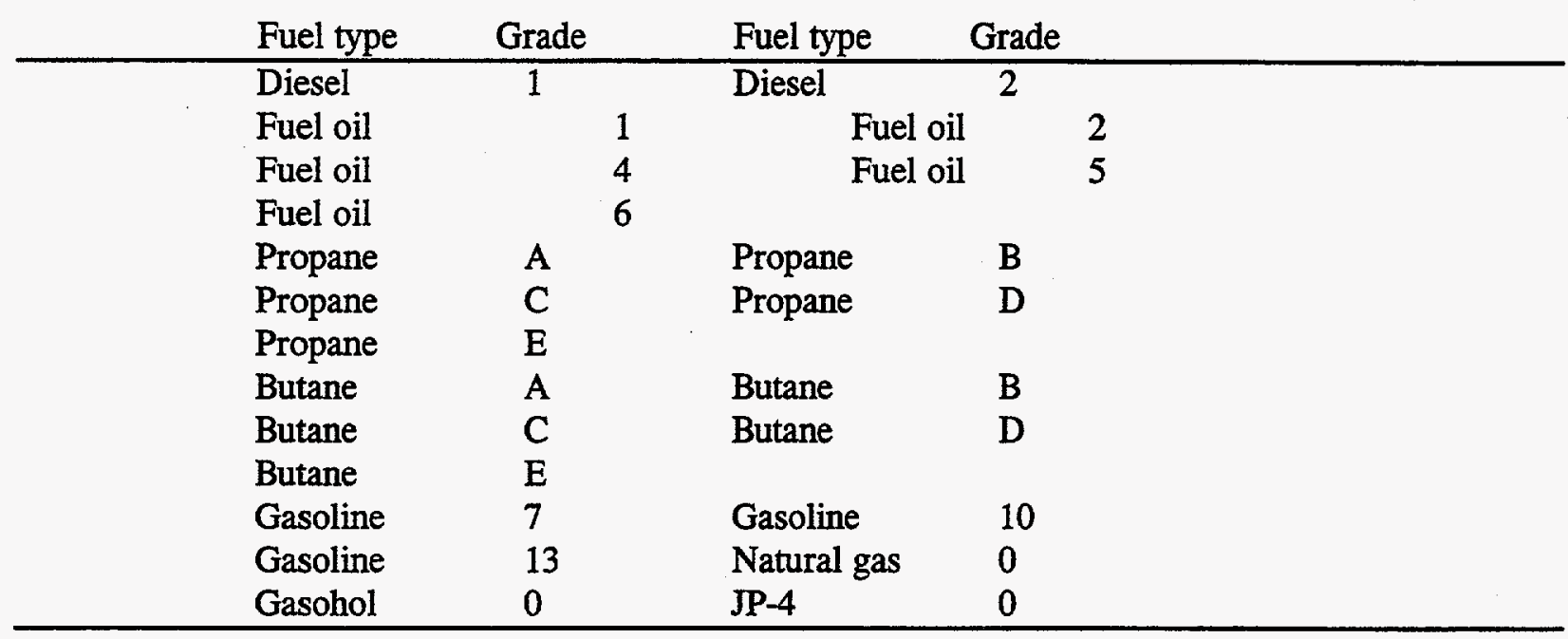

\section{C.4 AIR EMISSION INVENTORY FUEL BURNING EQUIPMENT PART II}

This form is part two of the information about fuel burning equipment.

Column 1. E - The type of fuel burning equipment: B - Boiler, F - Furnace, H - Heater, L - Large Engine, P - Propane Burner, or S -Small Engine.

Column 2. Rated Heat - the rated heat value for a boiler.

Column 3. Class - the class of boiler, furnace or heater.

Column 4. Engine Horse Power - the horsepower for engines.

Column 5. Maximum Hours - The maximum number of hours that the engine can operate.

\section{C.5 AIR EMISSION INVENTORY ORGANIC STORAGE TANKS - PART I}

This form contains information about the organic storage tanks.

Column 1. Annual Thru Put - the annual material through put for the tank in gallons per year.

Column 2. Ave. \% Full - the average percent full of the tank.

Column 3. Fill Rate - the fill rate for the tank during refilling process in gallons per minute.

Column 4. Vapor Space Height - the vapor space height of the tank in feet.

Column 5. Capacity - the capacity of the tank in gallons. 
Column 6. Tank Dia - the tank diameter in feet.

Column 7. Tank Length - the length of the tank in feet.

Column 8. Tank Type - the type of tank. (fixed roof, floating roof, variable vapor space, or pressure tank)

Column 9. Material Stored - the material stored in the tank.

Column 10. Tank Location - the location of the tank, either inside or outside of a building.

\section{C.6 AIR EMISSION INVENTORY ORGANIC STORAGE TANKS - PART II}

This form contains information about the organic storage tanks.

Column 1. Air Flow Rate - the air flow rate through the tank in cubic feet per minute.

Column 2. $\quad \mathrm{J}-(\mathrm{Y} / \mathrm{N})$ is there an inert gas jacket around the tank.

Column 3. Vapor Recovery Method - the vapor recovery method used for the tank.

Column 4. \% Recover Eff - the efficiency of the recovery method stated above.

Column 5. Tank Location - the location of the tank, either under ground or above ground.

Column 6. Orient - the orientation of the tank, horizontal or vertical.

Column 7. Roof Color - the color of the roof.

Column 8. Roof Cond - the condition of the paint on the roof.

Column 9. Shell Color - the color of the shell. See Table C-2 for a preferred list of colors.

Column 10. Shell Cond - the condition of the paint on the shell.

\section{C.7 AIR EMISSION INVENTORY INORGANIC STORAGE TANKS - PART I}

This form contains information about the inorganic storage tanks.

Column 1. Annual Thru Put - the annual material through put for the tank in gallons per year.

Column 2. Ave. \% Full - the average percent full of the tank.

Column 3. Fill Rate - the fill rate for the tank during refilling process in gallons per minute. 
Column 4. Vapor Space Height - the vapor space height of the tank in feet.

Column 5. Capacity - the capacity of the tank in gallons.

Column 6. Tank Dia - the tank diameter in feet.

Column 7. Tank Length - the length of the tank in feet.

Column 8. Tank Type - the type of tank. (fixed roof, floating roof, variable vapor space, or pressure tank)

Column 9. Material Stored - the material stored in the tank.

Column 10. Tank Location - the location of the tank, either inside or outside of a building.

Table C-2. Preferred conditions and colors for tanks.

\section{Preferred Colors:}

White

Light grey

Grey

Preferred Conditions: Good
Shiny silver

Medium grey

Aluminum, specular

Poor
Flat silver

Silver, dull

Aluminum, diffuse

\section{C.8 AIR EMISSION INVENTORY INORGANIC STORAGE TANKS - PART II}

This form contains information about the inorganic storage tanks.

Column 1. Air Flow Rate - the air flow rate through the tank in cubic feet per minute.

Column 2. $\quad J-(Y / N)$ is there an inert gas jacket around the tank.

Column 3. Vapor Recovery Method - the vapor recovery method used for the tank.

Column 4. \% Recover Eff - the efficiency of the recovery method stated above.

Column 5. Tank Location - the location of the tank, either under ground or above ground.

Column 6. Orient - the orientation of the tank, horizontal or vertical.

Column 7. Roof Color - the color of the roof.

Column 8. Roof Cond - the condition of the paint on the roof.

Column 9. Shell Color - the color of the shell. 
Column 10. Shell Cond - the condition of the paint on the shell. See Table 2 for a preferred list of colors.

\section{C.9 AIR EMISSION INVENTORY PROCESS CONTROL EQUIPMENT}

This form lists the emissions control equipment for a source. This list may not correspond exactly with the control equipment which is being claimed for the INEL's Title V Air Operating Permit Application. This will be corrected in the 1995 Inventory. 


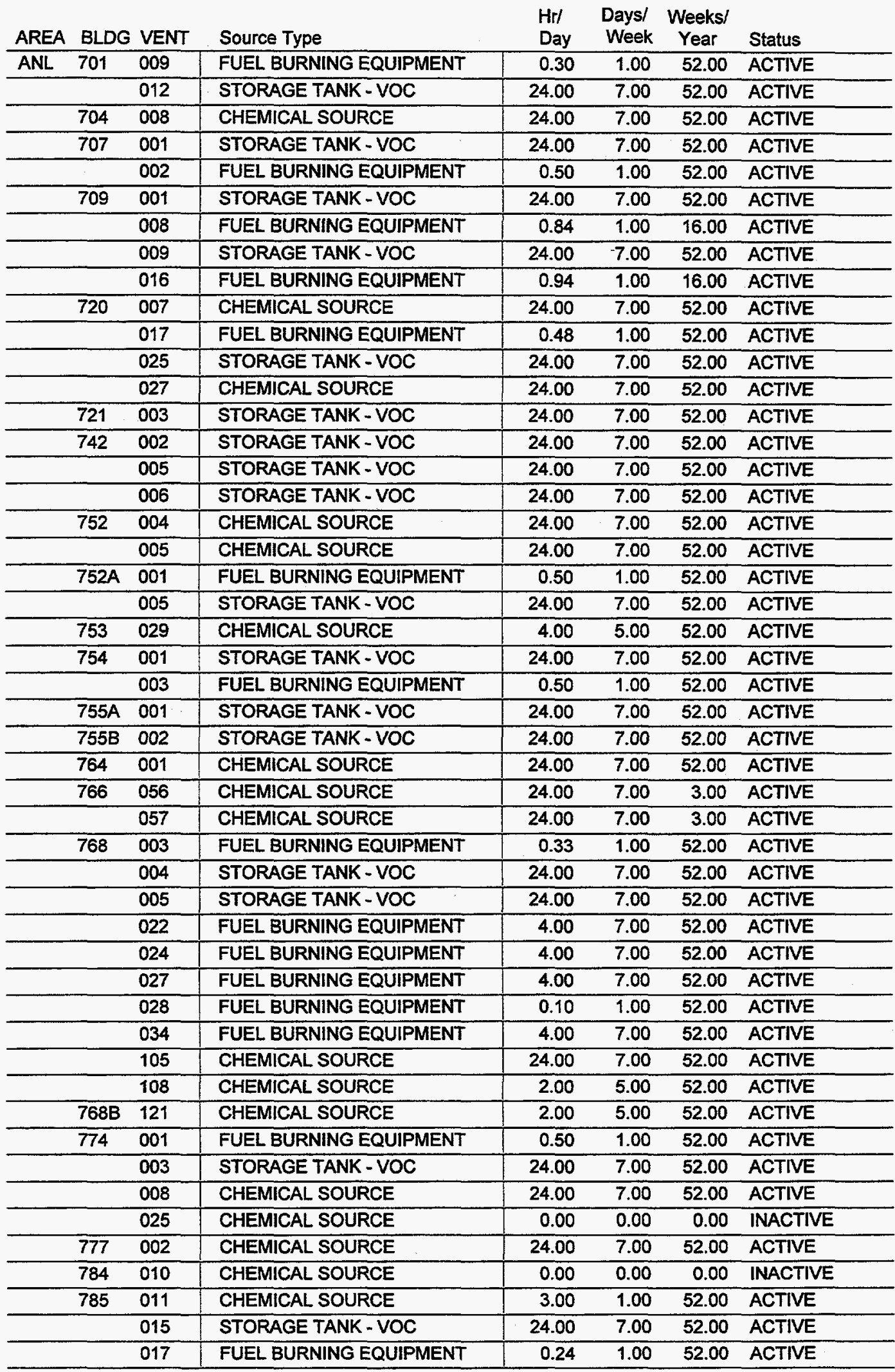




\begin{tabular}{|c|c|c|c|c|c|c|c|}
\hline AREA & BLDG & VENT & Source Type & $\begin{array}{l}\text { HrI } \\
\text { Day }\end{array}$ & $\begin{array}{l}\text { Days/ } \\
\text { Week }\end{array}$ & $\begin{array}{c}\text { Weeks/ } \\
\text { Year }\end{array}$ & Status \\
\hline \multirow[t]{4}{*}{ ANL } & 785 & 018 & CHEMICAL SOURCE & 24.00 & 7.00 & 52.00 & ACTIVE \\
\hline & 787 & 001 & CHEMICAL SOURCE & 24.00 & 7.00 & 52.00 & ACTIVE \\
\hline & 793 & 001 & CHEMICAL SOURCE & 8.00 & 5.00 & 20.00 & ACTIVE \\
\hline & & 012 & STORAGE TANK - VOC & 8.00 & 5.00 & 5.00 & ACTIVE \\
\hline & & 014 & STORAGE TANK - VOC & 8.00 & 3.00 & 2.00 & ACTIVE \\
\hline & $793 \mathrm{~A}$ & 025 & STORAGE TANK - VOC & 24.00 & 7.00 & 52.00 & ACTIVE \\
\hline & & 027 & STORAGE TANK - VOC & 24.00 & 7.00 & 52.00 & ACTIVE \\
\hline & & 029 & STORAGE TANK - VOC & 24.00 & 7.00 & 52.00 & ACTIVE \\
\hline & & 031 & STORAGE TANK - VOC & 24.00 & 7.00 & 52.00 & ACTIVE \\
\hline & & 033 & STORAGE TANK - VOC & 24.00 & 7.00 & 52.00 & ACTIVE \\
\hline & & 035 & STORAGE TANK - VOC & 24.00 & 7.00 & 52.00 & ACTIVE \\
\hline & 798 & 017 & CHEMICAL SOURCE & 0.30 & 7.00 & 52.00 & ACTIVE \\
\hline & 799 & 003 & CHEMICAL SOURCE & 0.00 & 0.00 & 0.00 & INACTIVE \\
\hline & & 010 & CHEMICAL SOURCE & 0.00 & 0.00 & 0.00 & INACTIVE \\
\hline
\end{tabular}




\begin{tabular}{|c|c|c|c|c|c|c|c|}
\hline AREA & BLDG & VENT & Source Type & $\begin{array}{l}\mathrm{Hr} / \\
\text { Day }\end{array}$ & $\begin{array}{l}\text { Days/ } \\
\text { Week }\end{array}$ & $\begin{array}{c}\text { Weeks' } \\
\text { Year }\end{array}$ & Status \\
\hline $\mathrm{B08}$ & 601 & 001 & STORAGE TANK - VOC & 24.00 & 7.00 & 52.00 & ACTIVE \\
\hline & & 003 & FUEL BURNING EQUIPMENT & 1.00 & 1.00 & 26.00 & ACTIVE \\
\hline
\end{tabular}




\begin{tabular}{|c|c|c|c|c|c|c|c|}
\hline AREA & BLDG & VENT & Source Type & $\begin{array}{l}\mathrm{Hrl} \\
\text { Day }\end{array}$ & $\begin{array}{l}\text { Days/ } \\
\text { Week } \\
\end{array}$ & $\begin{array}{c}\text { Weeks' } \\
\text { Year }\end{array}$ & Status \\
\hline \multirow[t]{5}{*}{ B16 } & 601 & 008 & STORAGE TANK - VOC & 24.00 & 7.00 & 52.00 & ACTIVE \\
\hline & 703 & 001 & STORAGE TANK - VOC & 24.00 & 7.00 & 52.00 & ACTIVE \\
\hline & 704 & 001 & STORAGE TANK - VOC & 24.00 & 7.00 & 52.00 & ACTIVE \\
\hline & & 002 & STORAGE TANK - VOC & 24.00 & 7.00 & 52.00 & ACTIVE \\
\hline & 708 & 001 & CHEMICAL SOURCE & 24.00 & 7.00 & 52.00 & ACTIVE \\
\hline
\end{tabular}




\begin{tabular}{|c|c|c|c|c|c|c|c|}
\hline AREA & BLDG & VENT & Source Type & $\begin{array}{l}\mathrm{Hrl} \\
\text { Day }\end{array}$ & $\begin{array}{l}\text { Days/ } \\
\text { Week }\end{array}$ & $\begin{array}{c}\text { Weeks/ } \\
\text { Year }\end{array}$ & Status \\
\hline 821 & 608 & 008 & CHEMICAL SOURCE & 12.00 & 7.00 & 52.00 & ACTIVE \\
\hline & & 012 & CHEMICAL SOURCE & 24.00 & 7.00 & 52.00 & ACTIVE \\
\hline
\end{tabular}




\begin{tabular}{lll|l|cccc} 
AREA & BLDG VENT & Source Type & \multicolumn{2}{c}{$\begin{array}{c}\text { Hrl } \\
\text { Day }\end{array}$} & $\begin{array}{c}\text { Days/ } \\
\text { Week }\end{array}$ & $\begin{array}{c}\text { Weeks/ } \\
\text { Year }\end{array}$ & Status \\
\hline B23 & 602 & 002 & STORAGE TANK - VOC & 1.00 & 1.00 & 26.00 & ACTIVE \\
\hline
\end{tabular}




\begin{tabular}{|c|c|c|c|c|c|c|c|}
\hline AREA & BLDG & VENT & Source Type & $\begin{array}{l}\text { Hrl } \\
\text { Day }\end{array}$ & $\begin{array}{l}\text { Days/ } \\
\text { Week }\end{array}$ & $\begin{array}{c}\text { Weeks' } \\
\text { Year }\end{array}$ & Status \\
\hline $\mathrm{B} 27$ & 601 & 001 & FUEL BURNING EQUIPMENT & 0.50 & 1.00 & 52.00 & ACTIVE \\
\hline & & 003 & STORAGE TANK - VOC & 24.00 & 7.00 & 52.00 & ACTIVE \\
\hline
\end{tabular}




\begin{tabular}{|c|c|c|c|c|c|c|c|}
\hline AREA & BLDG & VENT & Source Type & $\begin{array}{l}\mathrm{Hr} \text { l } \\
\text { Day }\end{array}$ & $\begin{array}{l}\text { Days/ } \\
\text { Week }\end{array}$ & $\begin{array}{c}\text { Weeks/ } \\
\text { Year }\end{array}$ & Status \\
\hline \multirow[t]{2}{*}{ CFA } & 100 & 001 & CHEMICAL SOURCE & 6.00 & 5.00 & 52.00 & ACTIVE \\
\hline & 101 & 001 & CHEMICAL SOURCE & 24.00 & 7.00 & 52.00 & ACTIVE \\
\hline & 102 & 001 & CHEMICAL SOURCE & 24.00 & 7.00 & 52.00 & ACTIVE \\
\hline & 103 & 001 & CHEMICAL SOURCE & 24.00 & 7.00 & 52.00 & ACTIVE \\
\hline & 104 & 001 & & 6.00 & 5.00 & 52.00 & ACTIVE \\
\hline & 105 & 001 & & 24.00 & 2.30 & 52.00 & ACTIVE \\
\hline \multirow{4}{*}{\multicolumn{2}{|c|}{1603}} & 001 & FUEL BURNING EQUIPMENT & 0.50 & 1.00 & 52.00 & ACTIVE \\
\hline & & 002 & FUEL BURNING EQUIPMENT & 0.50 & 1.00 & 52.00 & ACTIVE \\
\hline & & 003 & STORAGE TANK - VOC & 24.00 & 7.00 & 52.00 & ACTIVE \\
\hline & & 004 & STORAGE TANK - VOC & 24.00 & 7.00 & 52.00 & ACTIVE \\
\hline & 1701 & 001 & STORAGE TANK - VOC & 24.00 & 7.00 & 52.00 & ACTIVE \\
\hline & 1702 & 001 & STORAGE TANK - VOC & 24.00 & 7.00 & 52.00 & ACTIVE \\
\hline & 1703 & 001 & STORAGE TANK - VOC & 24.00 & 7.00 & 52.00 & ACTIVE \\
\hline & 1708 & 001 & STORAGE TANK - VOC & 24.00 & 7.00 & 52.00 & ACTIVE \\
\hline \multirow{7}{*}{\multicolumn{2}{|c|}{1709}} & 001 & STORAGE TANK - VOC & & & & \\
\hline & & 002 & STORAGE TANK - VOC & & & & \\
\hline & & 003 & STORAGE TANK - VOC & & & & \\
\hline & & 004 & STORAGE TANK - VOC & & & & \\
\hline & & 005 & STORAGE TANK - VOC & & & & \\
\hline & & 006 & STORAGE TANK - VOC & & & & \\
\hline & & 007 & STORAGE TANK - VOC & & & & \\
\hline & 602 & 016 & CHEMICAL SOURCE & 24.00 & 7.00 & 52.00 & ACTIVE \\
\hline & 604 & 001 & FUEL BURNING EQUIPMENT & 0.50 & 1.00 & 12.00 & ACTIVE \\
\hline & 607 & 004 & FUEL BURNING EQUIPMENT & 24.00 & 7.00 & 39.00 & ACTIVE \\
\hline \multirow{2}{*}{\multicolumn{2}{|c|}{608}} & 001 & FUEL BURNING EQUIPMENT & 24.00 & 7.00 & 39.00 & ACTIVE \\
\hline & & 005 & STORAGE TANK - VOC & 8.00 & 5.00 & 52.00 & \\
\hline \multirow{4}{*}{\multicolumn{2}{|c|}{609}} & 001 & FUEL BURNING EQUIPMENT & 0.50 & 1.00 & 12.00 & ACTIVE \\
\hline & & 002 & STORAGE TANK - VOC & 24.00 & 7.00 & 52.00 & ACTIVE \\
\hline & & 005 & FUEL BURNING EQUIPMENT & 24.00 & 7.00 & 36.00 & ACTIVE \\
\hline & & 017 & CHEMICAL SOURCE & 24.00 & 7.00 & 52.00 & ACTIVE \\
\hline \multirow{2}{*}{\multicolumn{2}{|c|}{$\ldots$}} & 019 & & & & & \\
\hline & & 020 & & 8.00 & 5.00 & 52.00 & \\
\hline \multirow{4}{*}{\multicolumn{2}{|c|}{612}} & 007 & CHEMICAL SOURCE & 2.00 & 1.00 & 52.00 & ACTIVE \\
\hline & & 008 & CHEMICAL SOURCE & 8.00 & 1.50 & 52.00 & ACTIVE \\
\hline & & 010 & CHEMICAL SOURCE & 8.00 & 2.00 & 52.00 & ACTIVE \\
\hline & & 012 & CHEMICAL SOURCE & 8.00 & 5.00 & 52.00 & ACTIVE \\
\hline & 613 & 003 & FUEL BURNING EQUIPMENT & 24.00 & 7.00 & 39.00 & ACTIVE \\
\hline \multirow{8}{*}{\multicolumn{2}{|c|}{617}} & 010 & CHEMICAL SOURCE & 0.00 & 0.00 & 0.00 & INACTIVE \\
\hline & & 011 & CHEMICAL SOURCE & 0.00 & 0.00 & 0.00 & INACTIVE \\
\hline & & 024 & FUEL BURNING EQUIPMENT & 0.00 & 0.00 & 0.00 & INACTIVE \\
\hline & & 026 & CHEMICAL SOURCE & 0.00 & 0.00 & 0.00 & INACTIVE \\
\hline & & 030 & CHEMICAL SOURCE & 0.00 & 0.00 & 0.00 & INACTIVE \\
\hline & & 031 & CHEMICAL SOURCE & 0.00 & 0.00 & 0.00 & INACTIVE \\
\hline & & 033 & CHEMICAL SOURCE & 0.00 & 0.00 & 0.00 & INACTIVE \\
\hline & & 034 & CHEMICAL SOURCE & 0.00 & 0.00 & 0.00 & INACTIVE \\
\hline \multirow{4}{*}{\multicolumn{2}{|c|}{622}} & 009 & CHEMICAL SOURCE & 8.00 & 5.00 & 52.00 & ACTIVE \\
\hline & & 015 & CHEMICAL SOURCE & 8.00 & 5.00 & 52.00 & ACTIVE \\
\hline & & 019 & CHEMICAL SOURCE & 8.00 & 5.00 & 52.00 & ACTIVE \\
\hline & & 020 & CHEMICAL SOURCE & 8.00 & 5.00 & 52.00 & ACTIVE \\
\hline
\end{tabular}




\begin{tabular}{|c|c|c|c|c|c|c|c|}
\hline AREA & BLDG & VENT & Source Type & $\begin{array}{l}\mathrm{Hrl} \\
\text { Day }\end{array}$ & $\begin{array}{l}\text { Days/ } \\
\text { Week }\end{array}$ & $\begin{array}{c}\text { Weeks' } \\
\text { Year }\end{array}$ & Status \\
\hline CFA & 622 & 021 & CHEMICAL SOURCE & 8.00 & 5.00 & 52.00 & ACTIVE \\
\hline \multirow{3}{*}{\multicolumn{2}{|c|}{623}} & 005 & CHEMICAL SOURCE & 4.00 & 5.00 & 52.00 & ACTIVE \\
\hline & & 007 & CHEMICAL SOURCE & 3.00 & 5.00 & 52.00 & ACTIVE \\
\hline & & 017 & CHEMICAL SOURCE & 4.00 & 5.00 & 52.00 & ACTIVE \\
\hline \multirow{2}{*}{\multicolumn{2}{|c|}{625}} & 009 & CHEMICAL SOURCE & 8.00 & 5.00 & 52.00 & ACTIVE \\
\hline & & 010 & CHEMICAL SOURCE & 8.00 & 5.00 & 52.00 & ACTIVE \\
\hline \multirow{2}{*}{\multicolumn{2}{|c|}{633}} & 067 & CHEMICAL SOURCE & 0.50 & 1.50 & 52.00 & ACTIVE \\
\hline & & 091 & FUEL BURNING EQUIPMENT & 0.00 & 0.00 & 0.00 & INACTIVE \\
\hline & 640 & 029 & & & & & \\
\hline & 650 & 007 & FUEL BURNING EQUIPMENT & 24.00 & 7.00 & 39.00 & ACTIVE \\
\hline \multirow{2}{*}{\multicolumn{2}{|c|}{662}} & 011 & FUEL BURNING EQUIPMENT & 24.00 & 7.00 & 39.00 & ACTIVE \\
\hline & & 027 & FUEL BURNING EQUIPMENT & 24.00 & 7.00 & 39.00 & ACTIVE \\
\hline \multirow{2}{*}{\multicolumn{2}{|c|}{664}} & 034 & FUEL BURNING EQUIPMENT & 4.00 & 5.00 & 52.00 & ACTIVE \\
\hline & & 035 & FUEL BURNING EQUIPMENT & 4.00 & 5.00 & 52.00 & ACTIVE \\
\hline \multirow{4}{*}{\multicolumn{2}{|c|}{665}} & 028 & FUEL BURNING EQUIPMENT & 0.00 & 0.00 & 0.00 & INACTIVE \\
\hline & & 029 & FUEL BURNING EQUIPMENT & 24.00 & 7.00 & 39.00 & ACTIVE \\
\hline & & 030 & FUEL BURNING EQUIPMENT & 0.00 & 0.00 & 0.00 & INACTIVE \\
\hline & & 050 & CHEMICAL SOURCE & 6.00 & 5.00 & 52.00 & ACTIVE \\
\hline \multirow{2}{*}{\multicolumn{2}{|c|}{668}} & 006 & FUEL BURNING EQUIPMENT & 0.50 & 1.00 & 52.00 & ACTIVE \\
\hline & & 023 & FUEL BURNING EQUIPMENT & 24.00 & 7.00 & 39.00 & ACTIVE \\
\hline \multirow{2}{*}{\multicolumn{2}{|c|}{671}} & 007 & FUEL BURNING EQUIPMENT & 24.00 & 7.00 & 39.00 & ACTIVE \\
\hline & & 008 & FUEL BURNING EQUIPMENT & 24.00 & 7.00 & 39.00 & ACTIVE \\
\hline & 674 & 044 & CHEMICAL SOURCE & 1.50 & 1.00 & 52.00 & ACTIVE \\
\hline & 675 & 002 & FUEL BURNING EQUIPMENT & 0.50 & 1.00 & 12.00 & ACTIVE \\
\hline & 679 & 007 & FUEL BURNING EQUIPMENT & 0.50 & 1.00 & 52.00 & ACTIVE \\
\hline & 684 & 002 & STORAGE TANK - VOC & 0.00 & 0.00 & 0.00 & INACTIVE \\
\hline \multirow{5}{*}{\multicolumn{2}{|c|}{688}} & 002 & CHEMICAL SOURCE & 2.00 & 5.00 & 52.00 & ACTIVE \\
\hline & & 003 & STORAGE TANK - VOC & 24.00 & 7.00 & 52.00 & ACTIVE \\
\hline & & 043 & FUEL BURNING EQUIPMENT & 24.00 & 7.00 & 37.00 & ACTIVE \\
\hline & & 044 & FUEL BURNING EQUIPMENT & 24.00 & 7.00 & 37.00 & ACTIVE \\
\hline & & 047 & FUEL BURNING EQUIPMENT & 0.50 & 1.00 & 12.00 & ACTIVE \\
\hline & 689 & 034 & CHEMICAL SOURCE & 4.00 & 5.00 & 52.00 & ACTIVE \\
\hline & 690 & 001 & CHEMICAL SOURCE & 8.00 & 5.00 & 52.00 & ACTIVE \\
\hline & & 002 & CHEMICAL SOURCE & 8.00 & 5.00 & 52.00 & AVTIVE \\
\hline & & 003 & CHEMICAL SOURCE & 8.00 & 5.00 & 52.00 & ACTIVE \\
\hline & & 004 & CHEMICAL SOURCE & 8.00 & 5.00 & 52.00 & ACTIVE \\
\hline & & 005 & CHEMICAL SOURCE & 8.00 & 5.00 & 52.00 & ACTIVE \\
\hline & & 006 & CHEMICAL SOURCE & 8.00 & 5.00 & 52.00 & ACTIVE \\
\hline & & 007 & CHEMICAL SOURCE & 8.00 & 5.00 & 52.00 & ACTIVE \\
\hline & & 008 & CHEMICAL SOURCE & 8.00 & 5.00 & 52.00 & ACTIVE \\
\hline & & 009 & CHEMICAL SOURCE & 8.00 & 5.00 & 52.00 & ACTIVE \\
\hline & & 010 & CHEMICAL SOURCE & 8.00 & 5.00 & 52.00 & ACTIVE \\
\hline & & 015 & CHEMICAL SOURCE & 8.00 & 5.00 & 52.00 & ACTIVE \\
\hline & & 042 & CHEMICAL SOURCE & 0.00 & 0.00 & 0.00 & ACTIVE \\
\hline & & 045 & CHEMICAL SOURCE & 8.00 & 5.00 & 52.00 & ACTIVE \\
\hline & & 047 & CHEMICAL SOURCE & 8.00 & 5.00 & 52.00 & ACTIVE \\
\hline & & 048 & CHEMICAL SOURCE & 0.00 & 0.00 & 0.00 & ACTIVE \\
\hline & & 049 & CHEMICAL SOURCE & 8.00 & 5.00 & 52.00 & ACTIVE \\
\hline & & 059 & CHEMICAL SOURCE & 0.00 & 0.00 & 0.00 & ACTIVE \\
\hline
\end{tabular}




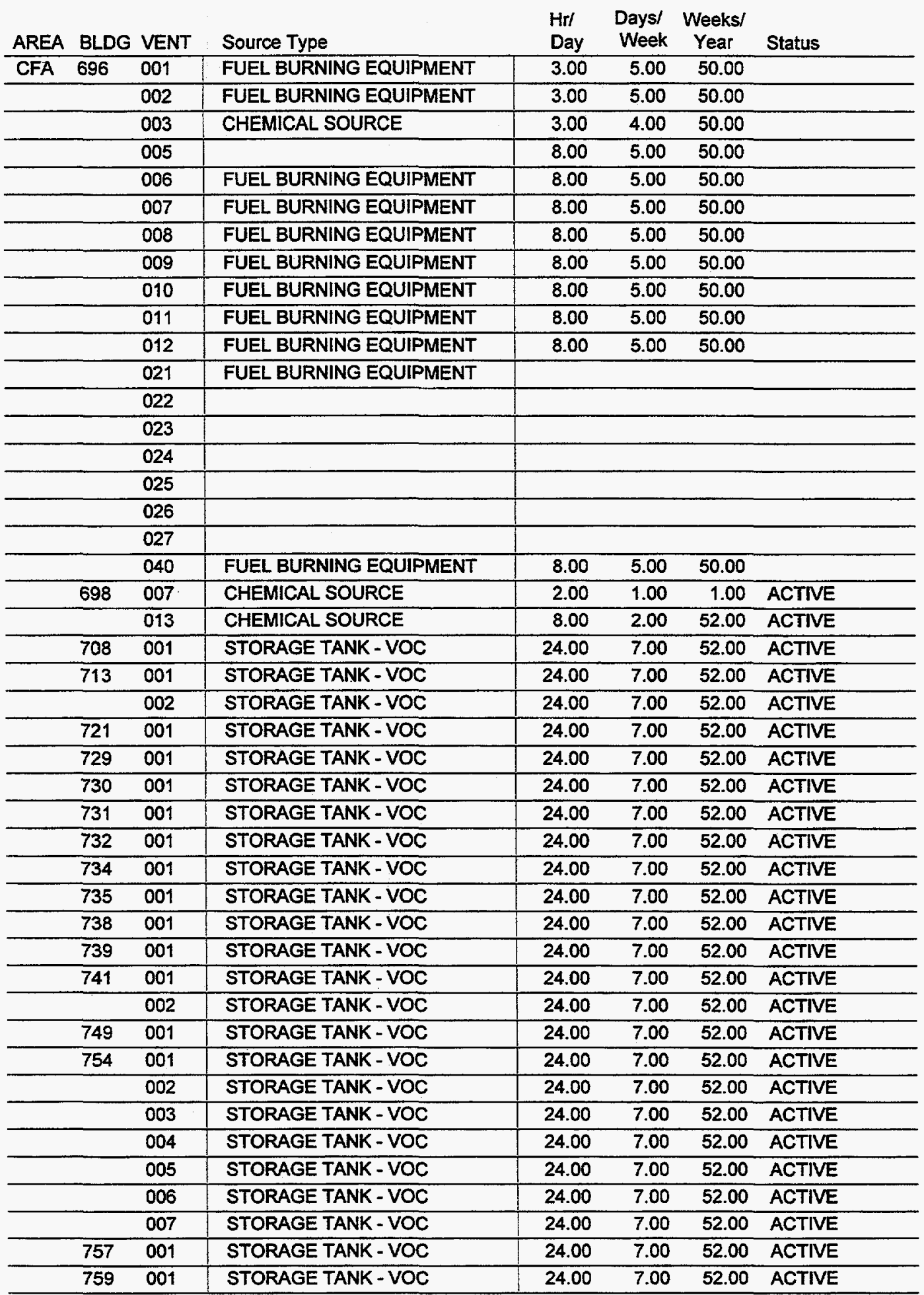




\begin{tabular}{|c|c|c|c|c|c|c|c|}
\hline AREA & BLDG & VENT & Source Type & $\begin{array}{l}\text { Hrl } \\
\text { Day }\end{array}$ & $\begin{array}{l}\text { Days/ } \\
\text { Week }\end{array}$ & $\begin{array}{c}\text { Weeks/ } \\
\text { Year }\end{array}$ & Status \\
\hline \multirow[t]{2}{*}{$\mathrm{CPP}$} & 012 & 001 & INORGANIC STORAGE TANK & 24.00 & 7.00 & 52.00 & ACTIVE \\
\hline & 015 & 001 & CHEMICAL SOURCE & & & & \\
\hline & 025 & 001 & CHEMICAL SOURCE & 24.00 & 7.00 & 52.00 & ACTIVE \\
\hline & 1608 & 001 & CHEMICAL SOURCE & 24.00 & 7.00 & 52.00 & ACTIVE \\
\hline & 1611 & 001 & CHEMICAL SOURCE & 24.00 & 7.00 & 26.00 & ACTIVE \\
\hline & 1612 & 001 & CHEMICAL SOURCE & 24.00 & 7.00 & 26.00 & ACTIVE \\
\hline & 1617 & 001 & CHEMICAL SOURCE & 24.00 & 7.00 & 52.00 & ACTIVE \\
\hline \multirow{2}{*}{\multicolumn{2}{|c|}{1619}} & 001 & CHEMICAL SOURCE & 24.00 & 7.00 & 52.00 & ACTIVE \\
\hline & & 005 & CHEMICAL SOURCE & 0.00 & 0.00 & 0.00 & ACTIVE \\
\hline \multirow{2}{*}{\multicolumn{2}{|c|}{1642}} & 003 & STORAGE TANK - VOC & 24.00 & 7.00 & 52.00 & ACTIVE \\
\hline & & 007 & FUEL BURNING EQUIPMENT & 7.40 & 7.00 & 52.00 & ACTIVE \\
\hline \multirow{2}{*}{\multicolumn{2}{|c|}{1643}} & 003 & STORAGE TANK - VOC & 24.00 & 7.00 & 52.00 & ACTIVE \\
\hline & & 007 & FUEL BURNING EQUIPMENT & 7.40 & 7.00 & 52.00 & ACTIVE \\
\hline & 1646 & 001 & CHEMICAL SOURCE & 24.00 & 7.00 & 52.00 & ACTIVE \\
\hline \multirow{2}{*}{\multicolumn{2}{|c|}{1749}} & 002 & STORAGE TANK - VOC & 24.00 & 7.00 & 52.00 & INACTIVE \\
\hline & & 004 & FUEL BURNING EQUIPMENT & 24.00 & 7.00 & 52.00 & ACTIVE \\
\hline \multirow{3}{*}{\multicolumn{2}{|c|}{601}} & 009 & INORGANIC STORAGE TANK & 24.00 & 7.00 & 52.00 & ACTIVE \\
\hline & & 014 & CHEMICAL SOURCE & 24.00 & 7.00 & 52.00 & ACTIVE \\
\hline & & 024 & STORAGE TANK - VOC & 24.00 & 7.00 & 52.00 & ACTIVE \\
\hline \multirow{3}{*}{\multicolumn{2}{|c|}{602}} & 012 & CHEMICAL SOURCE & 8.00 & 5.00 & 52.00 & ACTIVE \\
\hline & & 014 & CHEMICAL SOURCE & 8.00 & 5.00 & 52.00 & ACTIVE \\
\hline & & 031 & CHEMICAL SOURCE & 8.00 & 5.00 & 52.00 & ACTIVE \\
\hline \multirow{3}{*}{\multicolumn{2}{|c|}{603}} & 001 & CHEMICAL SOURCE & 24.00 & 7.00 & 52.00 & ACTIVE \\
\hline & & 008 & FUEL BURNING EQUIPMENT & 14.80 & 7.00 & 52.00 & ACTIVE \\
\hline & & 019 & CHEMICAL SOURCE & & & & \\
\hline & 604 & 011 & INORGANIC STORAGE TANK & 24.00 & 7.00 & 52.00 & ACTIVE \\
\hline \multirow{5}{*}{\multicolumn{2}{|c|}{606}} & 004 & FUEL BURNING EQUIPMENT & 24.00 & 7.00 & 52.00 & ACTIVE \\
\hline & & 005 & FUEL BURNING EQUIPMENT & 24.00 & 7.00 & 52.00 & ACTIVE \\
\hline & & 013 & CHEMICAL SOURCE & 24.00 & 7.00 & 52.00 & ACTIVE \\
\hline & & 019 & FUEL BURNING EQUIPMENT & 24.00 & 7.00 & 52.00 & ACTIVE \\
\hline & & 038 & CHEMICAL SOURCE & 2.50 & 1.00 & 16.00 & ACTIVE \\
\hline \multirow{2}{*}{\multicolumn{2}{|c|}{614}} & 001 & STORAGE TANK - VOC & 24.00 & 7.00 & 52.00 & ACTIVE \\
\hline & & 002 & FUEL BURNING EQUIPMENT & 7.40 & 7.00 & 52.00 & ACTIVE \\
\hline \multirow{2}{*}{\multicolumn{2}{|c|}{616}} & 004 & FUEL BURNING EQUIPMENT & 7.40 & 7.00 & 52.00 & ACTIVE \\
\hline & & 007 & STORAGE TANK - VOC & 24.00 & 7.00 & 52.00 & ACTIVE \\
\hline & 620 & NA & CHEMICAL SOURCE & & & & \\
\hline & 621 & 003 & CHEMICAL SOURCE & 1.00 & 1.00 & 33.00 & ACTIVE \\
\hline \multirow{5}{*}{\multicolumn{2}{|c|}{627}} & 007 & CHEMICAL SOURCE & 24.00 & 7.00 & 52.00 & ACTIVE \\
\hline & & 008 & CHEMICAL SOURCE & 24.00 & 7.00 & 52.00 & ACTIVE \\
\hline & & 010 & CHEMICAL SOURCE & 24.00 & 7.00 & 52.00 & ACTIVE \\
\hline & & 013 & CHEMICAL SOURCE & 24.00 & 7.00 & 52.00 & ACTIVE \\
\hline & & 016 & CHEMICAL SOURCE & 24.00 & 7.00 & 52.00 & ACTIVE \\
\hline \multirow{2}{*}{\multicolumn{2}{|c|}{630}} & 011 & CHEMICAL SOURCE & 0.00 & 0.00 & 0.00 & ACTIVE \\
\hline & & 012 & CHEMICAL SOURCE & 0.00 & 0.00 & 0.00 & ACTIVE \\
\hline \multirow{5}{*}{\multicolumn{2}{|c|}{637}} & 010 & CHEMICAL SOURCE & 16.00 & 5.00 & 52.00 & ACTIVE \\
\hline & & 021 & CHEMICAL SOURCE & 16.00 & 5.00 & 52.00 & ACTIVE \\
\hline & & 032 & CHEMICAL SOURCE & 8.00 & 5.00 & 24.00 & ACTIVE \\
\hline & & 035 & CHEMICAL SOURCE & 24.00 & 7.00 & 52.00 & ACTIVE \\
\hline & & 036 & CHEMICAL SOURCE & 24.00 & 7.00 & 52.00 & ACTIVE \\
\hline
\end{tabular}




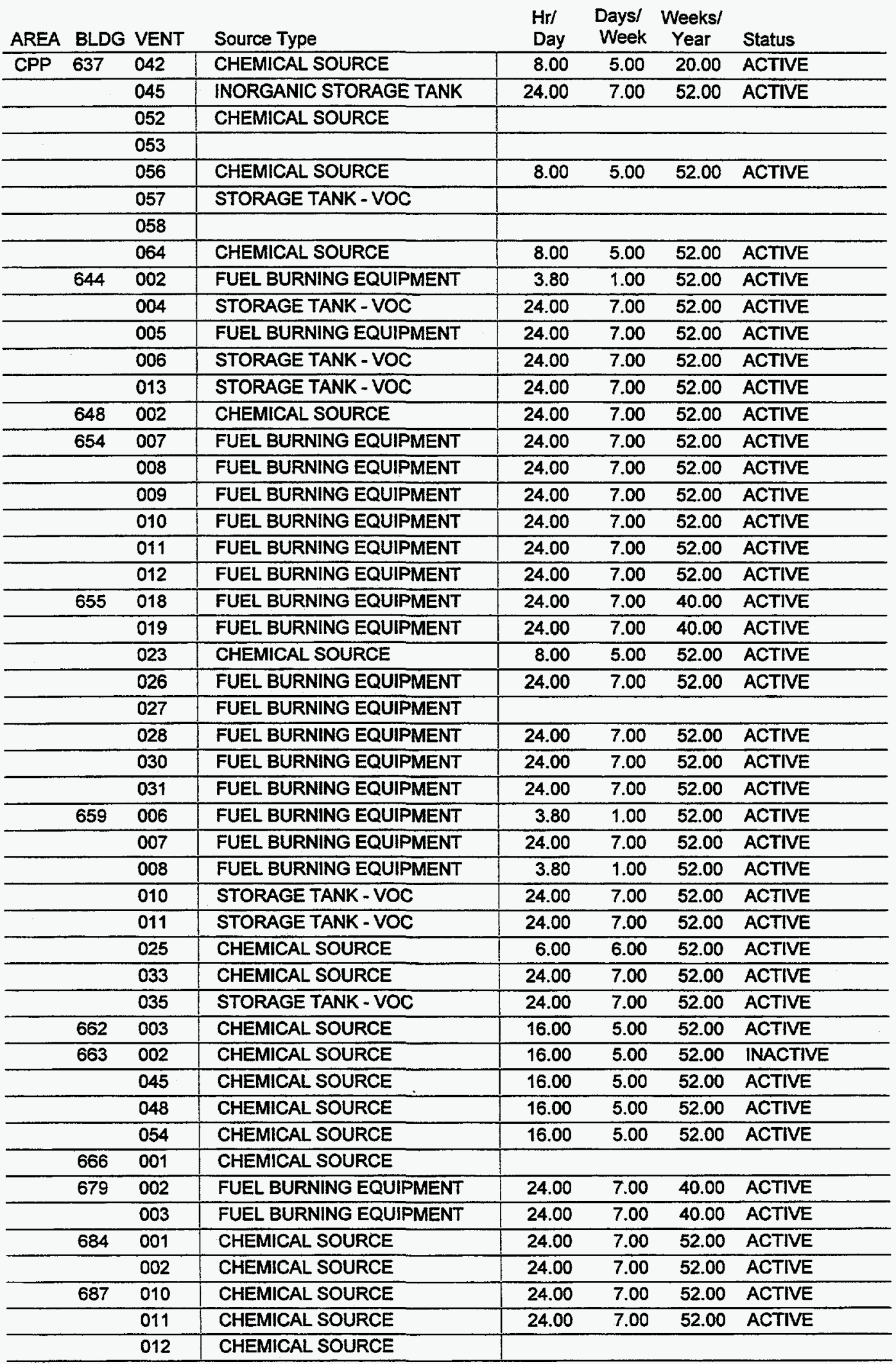




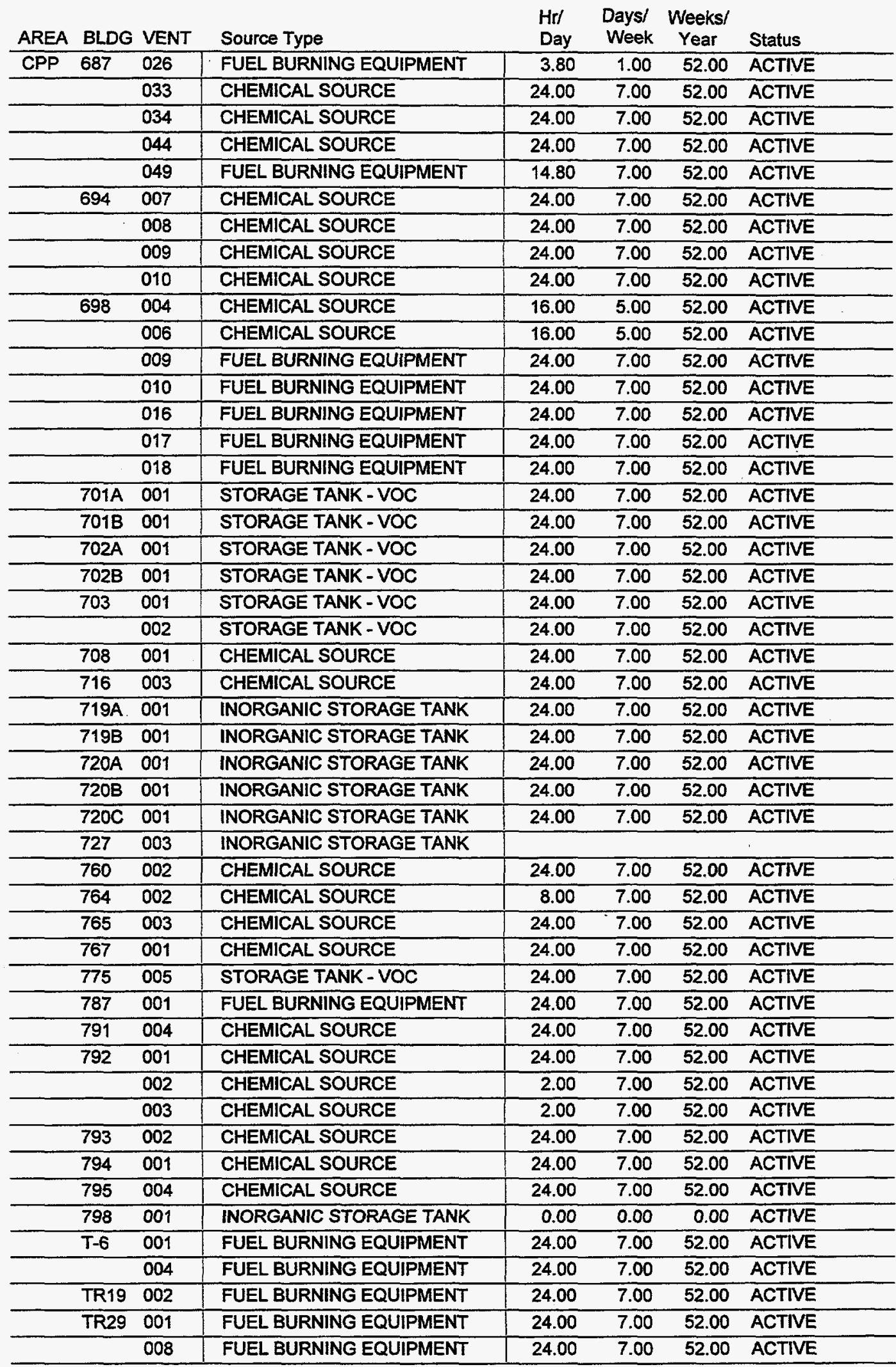


Hrl Days/ Weeks/

AREA BLDG VENT Source Type

Day Week Year Status

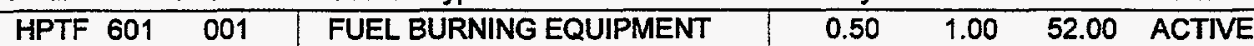




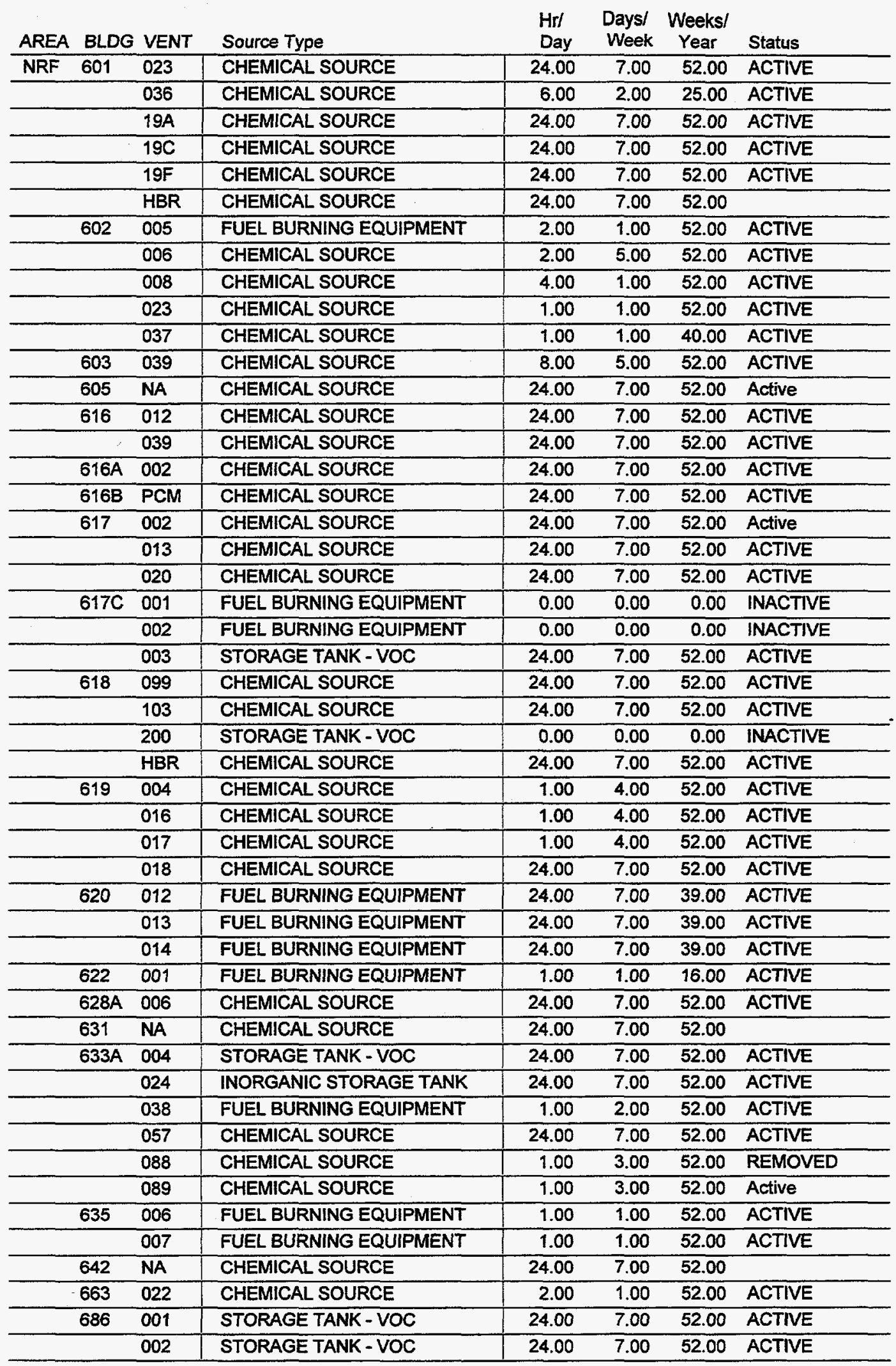




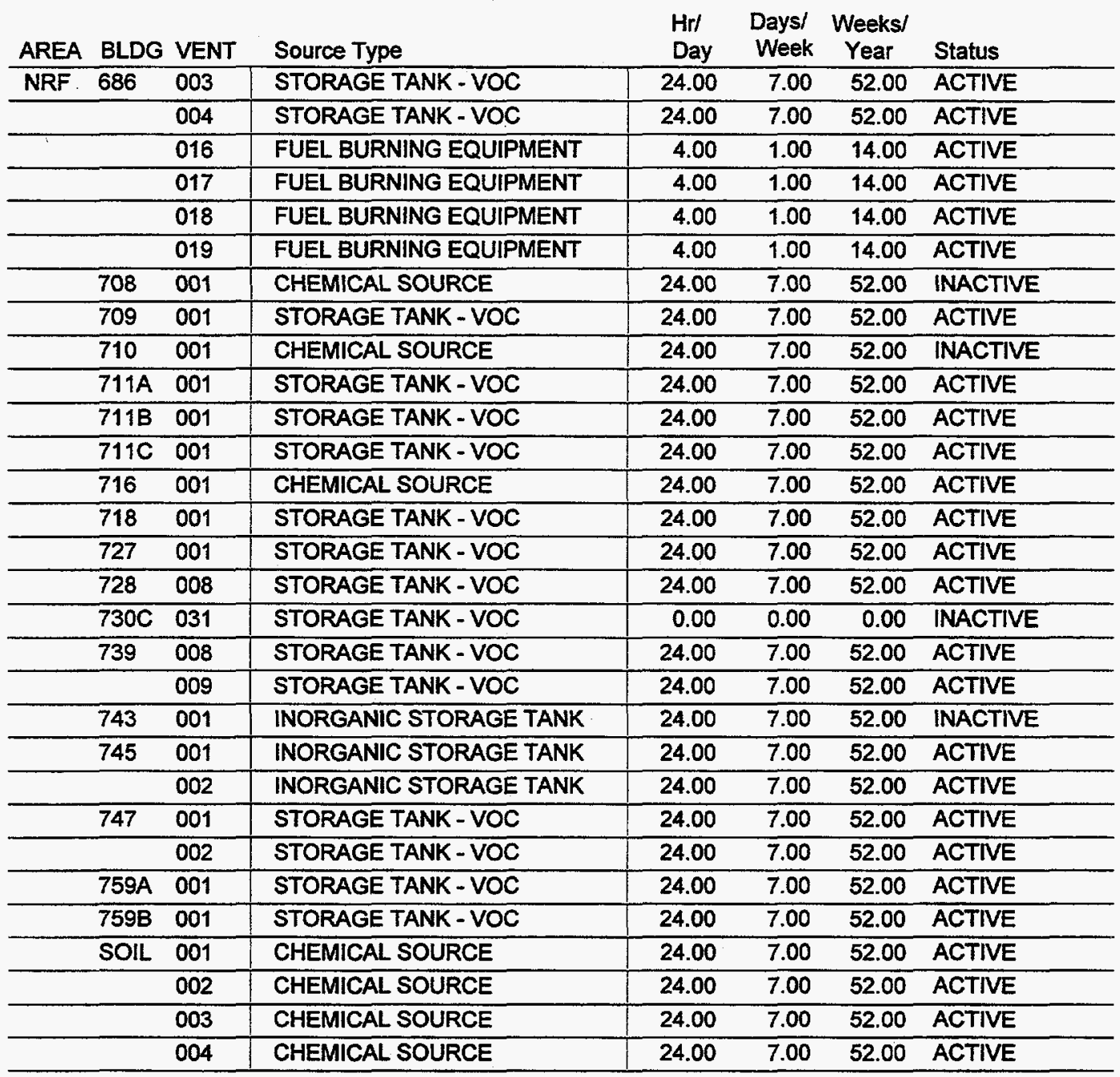




\begin{tabular}{|c|c|c|c|c|c|c|c|}
\hline AREA & BLDG & VENT & Source Type & $\begin{array}{l}\mathrm{Hrl} \\
\text { Day }\end{array}$ & $\begin{array}{l}\text { Days/ } \\
\text { Week }\end{array}$ & $\begin{array}{c}\text { Weeks/ } \\
\text { Year }\end{array}$ & Status \\
\hline \multirow[t]{3}{*}{ PER } & 601 & 010 & FUEL BURNING EQUIPMENT & 24.00 & 7.00 & 41.00 & ACTIVE \\
\hline & $601 \mathrm{~A}$ & 010 & FUEL BURNING EQUIPMENT & 24.00 & 7.00 & 41.00 & ACTIVE \\
\hline & \multirow[t]{2}{*}{609} & 006 & FUEL BURNING EQUIPMENT & 7.00 & 7.00 & 52.00 & ACTIVE \\
\hline & & 010 & STORAGE TANK - VOC & 24.00 & 7.00 & 52.00 & ACTIVE \\
\hline & 612 & 006 & FUEL BURNING EQUIPMENT & 24.00 & 7.00 & 41.00 & ACTIVE \\
\hline & 613 & 009 & FUEL BURNING EQUIPMENT & 24.00 & 7.00 & 38.00 & ACTIVE \\
\hline \multirow{3}{*}{\multicolumn{2}{|c|}{620}} & 001 & INORGANIC STORAGE TANK & 24.00 & 7.00 & 52.00 & ACTIVE \\
\hline & & 023 & FUEL BURNING EQUIPMENT & 24.00 & 7.00 & 39.00 & ACTIVE \\
\hline & & 041 & CHEMICAL SOURCE & & & & \\
\hline & 624 & 005 & INORGANIC STORAGE TANK & 24.00 & 7.00 & 52.00 & ACTIVE \\
\hline \multirow{4}{*}{\multicolumn{2}{|c|}{625}} & 001 & FUEL BURNING EQUIPMENT & 0.00 & 0.00 & 0.00 & INACTIVE \\
\hline & & 002 & STORAGE TANK - VOC & 0.00 & 0.00 & 0.00 & INACTIVE \\
\hline & & 004 & STORAGE TANK - VOC & 0.00 & 0.00 & 0.00 & INACTIVE \\
\hline & & 005 & & & & & \\
\hline \multirow{2}{*}{\multicolumn{2}{|c|}{632}} & 007 & FUEL BURNING EQUIPMENT & 24.00 & 7.00 & 41.00 & ACTIVE \\
\hline & & 008 & FUEL BURNING EQUIPMENT & 24.00 & 7.00 & 41.00 & ACTIVE \\
\hline \multirow{2}{*}{\multicolumn{2}{|c|}{638}} & 004 & FUEL BURNING EQUIPMENT & 2.00 & 4.00 & 52.00 & ACTIVE \\
\hline & & 005 & STORAGE TANK - VOC & 24.00 & 7.00 & 52.00 & ACTIVE \\
\hline & 705 & 001 & STORAGE TANK - VOC & 24.00 & 7.00 & 52.00 & ACTIVE \\
\hline & 711 & 001 & STORAGE TANK - VOC & 24.00 & 7.00 & 52.00 & ACTIVE \\
\hline & 716 & 001 & STORAGE TANK - VOC & 24.00 & 7.00 & 52.00 & ACTIVE \\
\hline & 722 & 001 & STORAGE TANK - VOC & & & & \\
\hline & 737 & 001 & STORAGE TANK - VOC & & & & \\
\hline & 740 & 001 & STORAGE TANK - VOC & 24.00 & 7.00 & 52.00 & ACTIVE \\
\hline & 742 & 001 & STORAGE TANK - VOC & 24.00 & 7.00 & 52.00 & ACTIVE \\
\hline & 743 & 001 & STORAGE TANK - VOC & 24.00 & 7.00 & 52.00 & ACTIVE \\
\hline & 752 & 001 & STORAGE TANK - VOC & 24.00 & 7.00 & 52.00 & ACTIVE \\
\hline & 755 & 001 & CHEMICAL SOURCE & 24.00 & 7.00 & 34.00 & ACTIVE \\
\hline & 756 & 001 & - & & & & \\
\hline & 765 & 001 & CHEMICAL SOURCE & 2.00 & 7.00 & 52.00 & ACTIVE \\
\hline
\end{tabular}




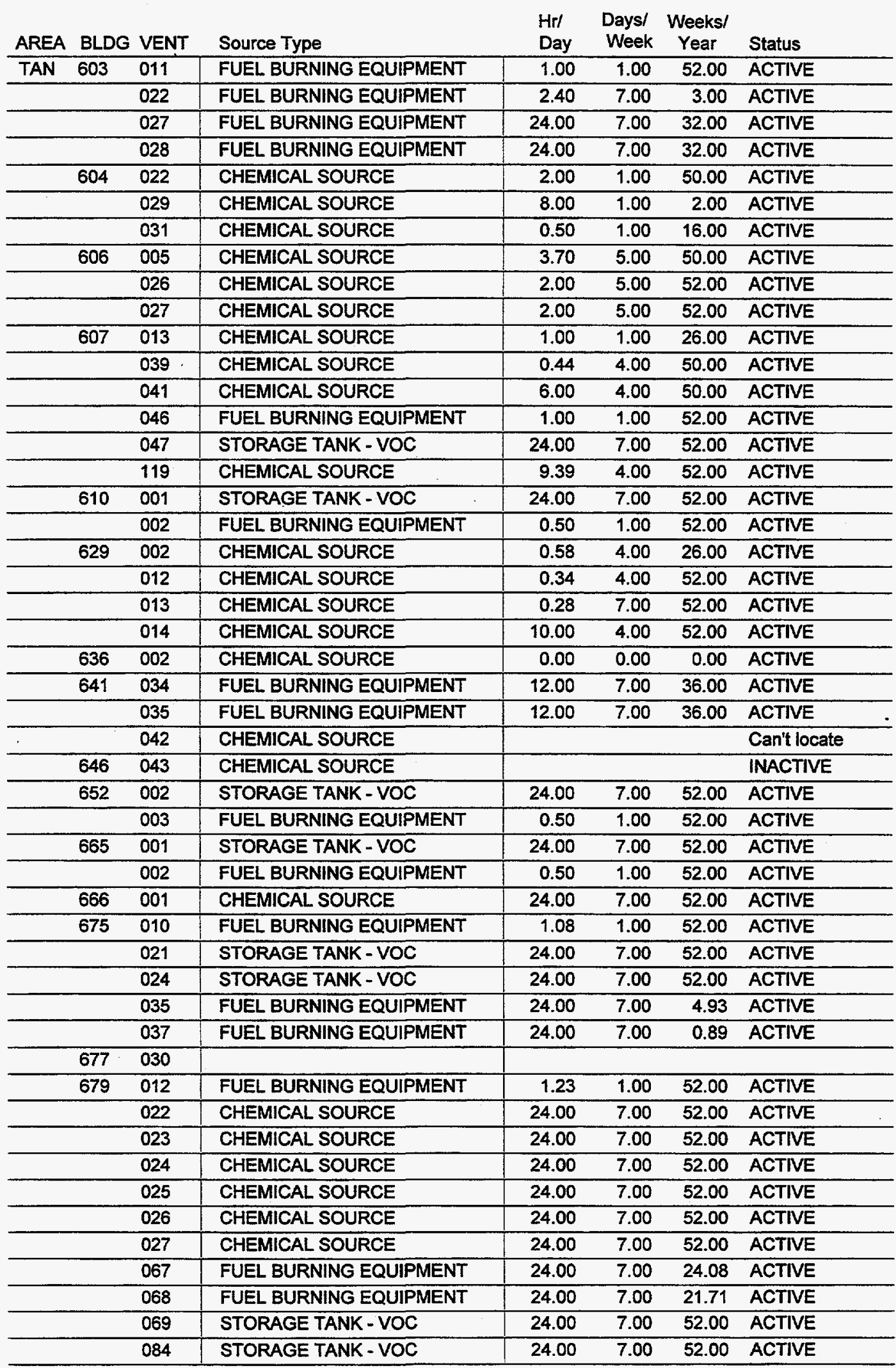




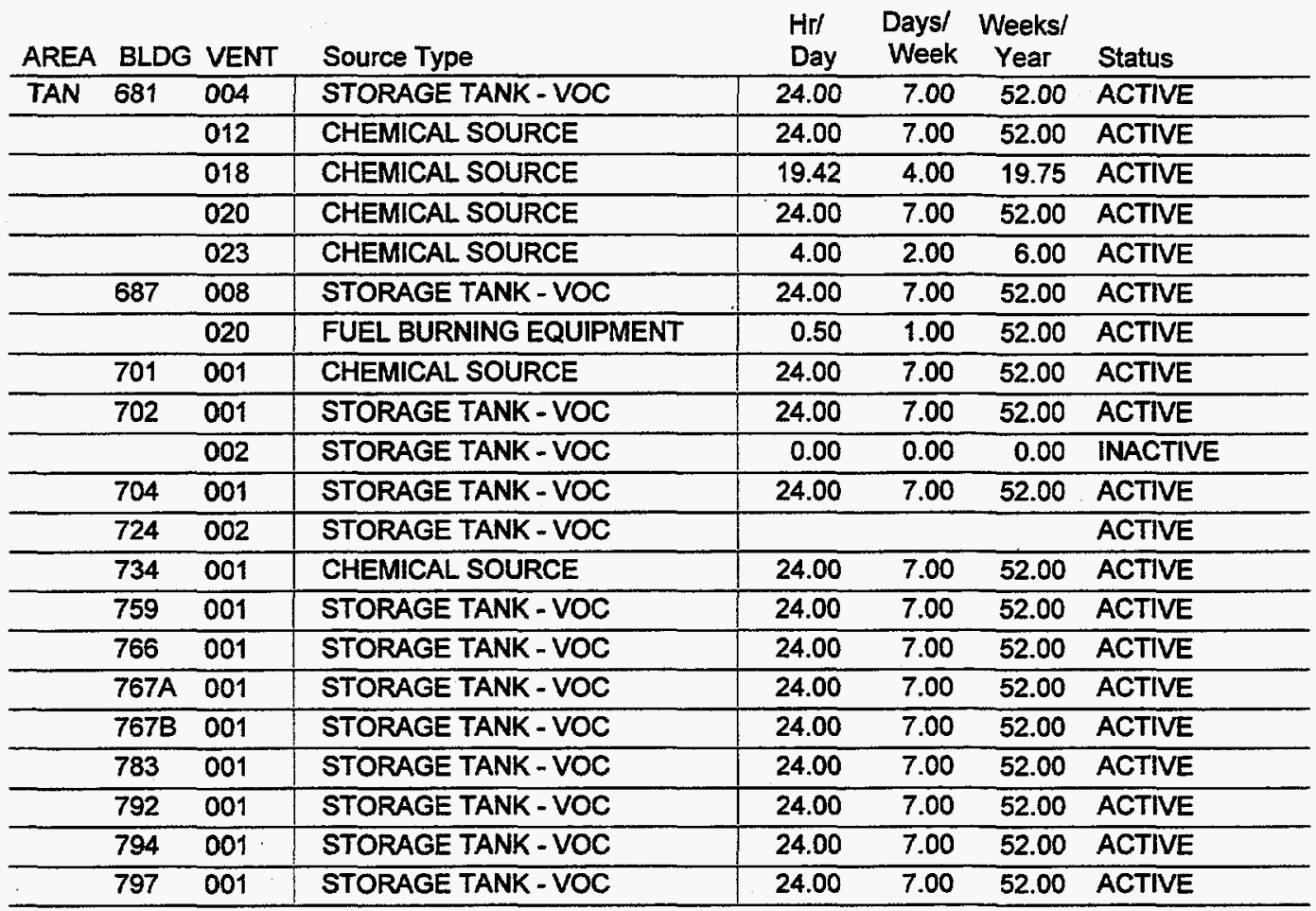




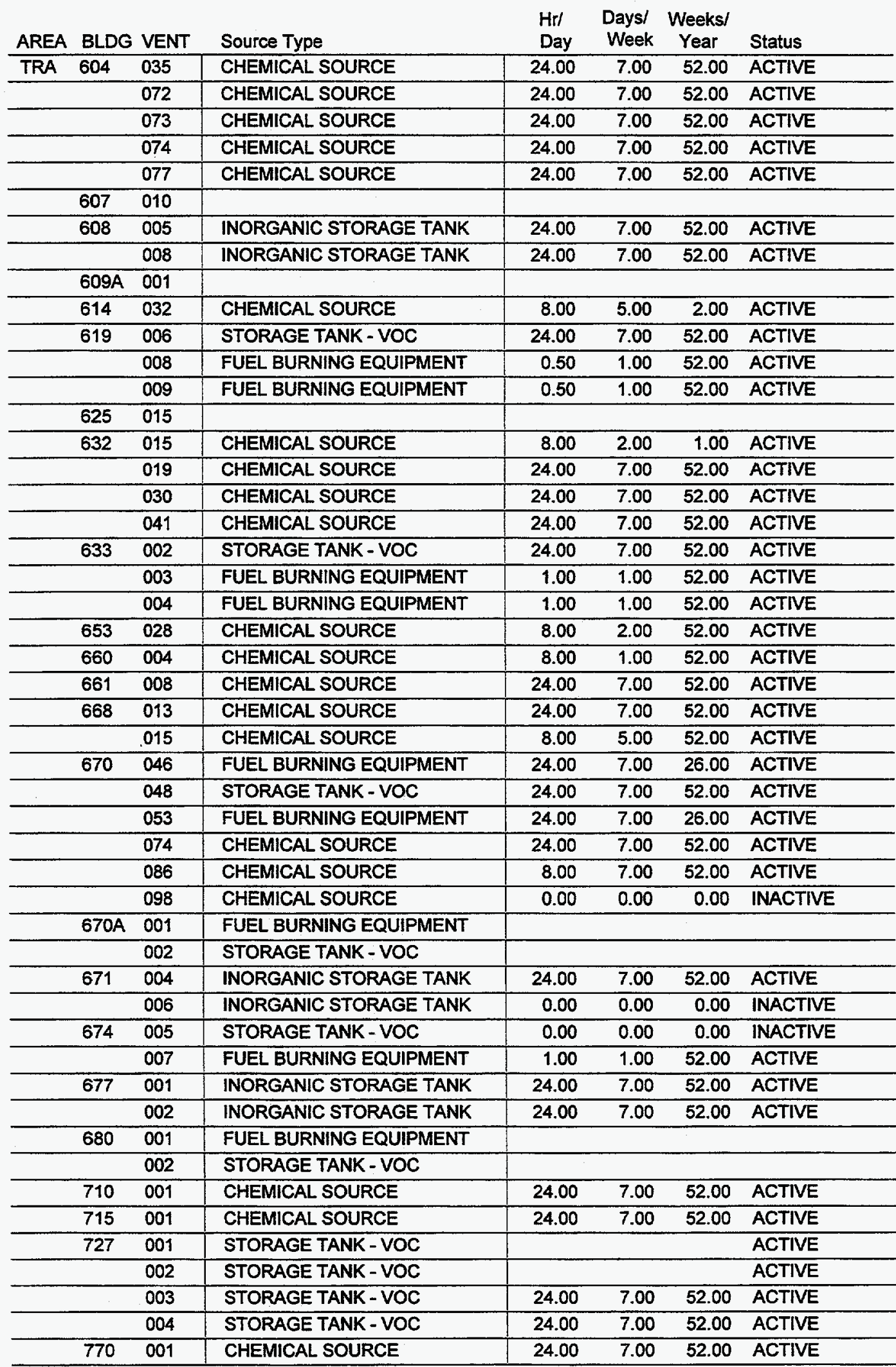




\begin{tabular}{|c|c|c|c|c|c|c|c|}
\hline AREA & BLDG & VENT & Source Type & $\begin{array}{l}\mathrm{Hrl} \\
\text { Day }\end{array}$ & $\begin{array}{l}\text { Days/ } \\
\text { Week }\end{array}$ & $\begin{array}{c}\text { Weeks/ } \\
\text { Year }\end{array}$ & Status \\
\hline TRA & 771 & 001 & CHEMICAL SOURCE & 24.00 & 7.00 & 52.00 & ACTIVE \\
\hline & 775 & 001 & STORAGE TANK - VOC & 24.00 & 7.00 & 52.00 & ACTIVE \\
\hline & 776 & 001 & & & & & \\
\hline & $777 \mathrm{~B}$ & 001 & STORAGE TANK - VOC & & & & \\
\hline & $777 \mathrm{C}$ & 001 & STORAGE TANK - VOC & & & & \\
\hline
\end{tabular}




\begin{tabular}{|c|c|c|c|c|c|c|c|}
\hline AREA & BLDG & VENT & Source Type & $\begin{array}{l}\mathrm{Hr} / \\
\text { Day }\end{array}$ & $\begin{array}{l}\text { Days/ } \\
\text { Week }\end{array}$ & $\begin{array}{c}\text { Weeks/ } \\
\text { Year }\end{array}$ & Status \\
\hline \multirow[t]{3}{*}{ WMF } & 601 & 009 & CHEMICAL SOURCE & 24.00 & 7.00 & 52.00 & ACTIVE \\
\hline & 603 & 005 & FUEL BURNING EQUIPMENT & 1.00 & 1.00 & 52.00 & ACTIVE \\
\hline & \multirow[t]{2}{*}{610} & 003 & FUEL BURNING EQUIPMENT & 1.00 & 1.00 & 52.00 & ACTIVE \\
\hline & & 004 & FUEL BURNING EQUIPMENT & 1.00 & 2.00 & 30.00 & ACTIVE \\
\hline & \multirow[t]{2}{*}{612} & 001 & FUEL BURNING EQUIPMENT & 1.00 & 1.00 & 52.00 & ACTIVE \\
\hline & & 004 & FUEL BURNING EQUIPMENT & 1.00 & 2.00 & 30.00 & ACTIVE \\
\hline & 615 & 001 & CHEMICAL SOURCE & 0.00 & 0.00 & 0.00 & INACTIVE \\
\hline & 628 & 001 & INORGANIC STORAGE TANK & & & & \\
\hline & 629 & 001 & & & & & \\
\hline \multirow{2}{*}{\multicolumn{2}{|c|}{637}} & 001 & FUEL BURNING EQUIPMENT & & & & \\
\hline & & 002 & FUEL BURNING EQUIPMENT & & & & \\
\hline \multirow{2}{*}{\multicolumn{2}{|c|}{639}} & 001 & FUEL BURNING EQUIPMENT & 1.00 & 1.00 & 52.00 & ACTIVE \\
\hline & & 002 & STORAGE TANK - VOC & 24.00 & 7.00 & 52.00 & ACTIVE \\
\hline & 640 & 001 & CHEMICAL SOURCE & 0.00 & 0.00 & 0.00 & INACTIVE \\
\hline & 656 & 001 & & & & & \\
\hline & 700 & 005 & & & & & \\
\hline \multirow{2}{*}{\multicolumn{2}{|c|}{711}} & 001 & FUEL BURNING EQUIPMENT & 1.00 & 1.00 & 52.00 & ACTIVE \\
\hline & & 004 & FUEL BURNING EQUIPMENT & 1.00 & 1.00 & 52.00 & ACTIVE \\
\hline
\end{tabular}




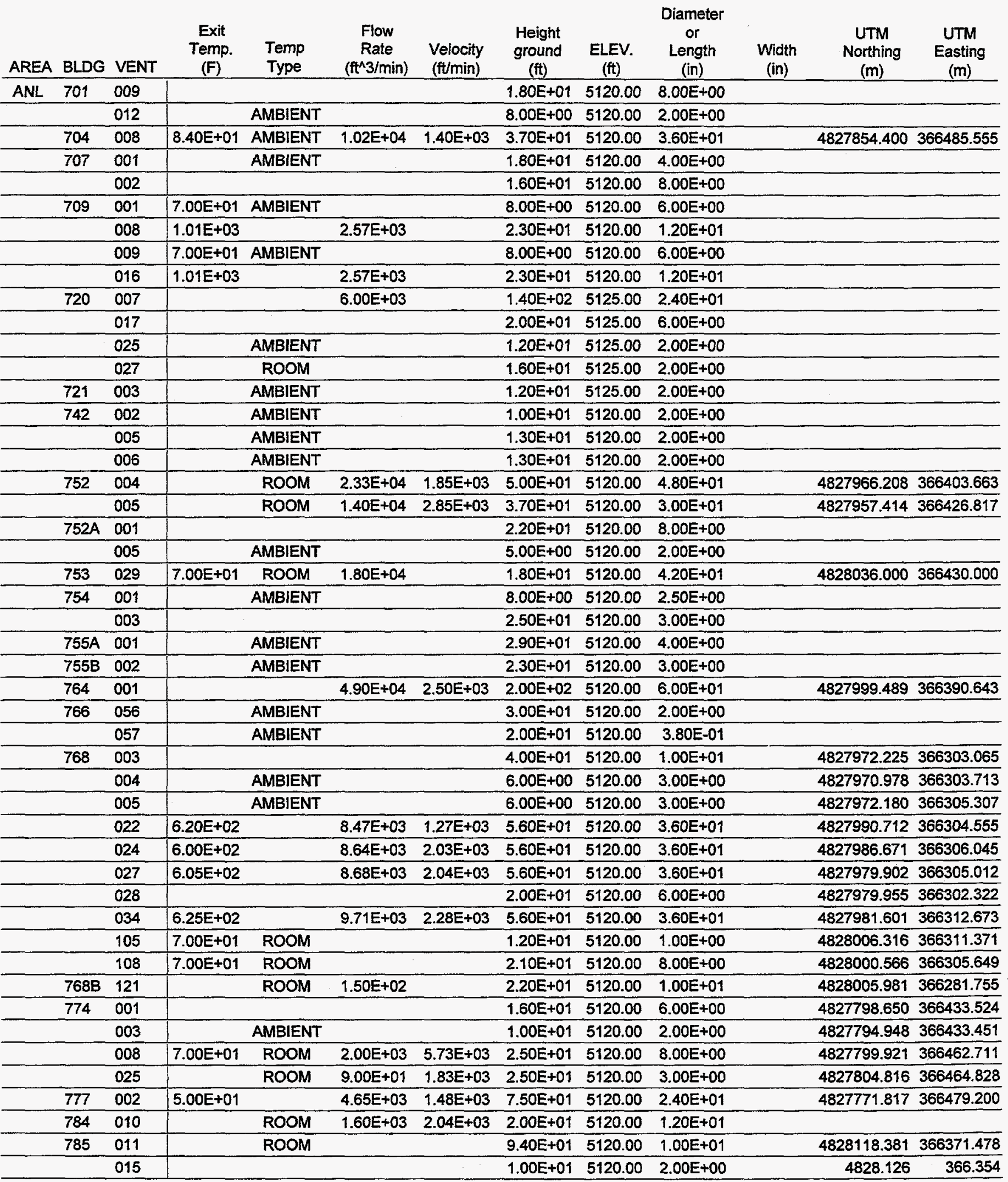




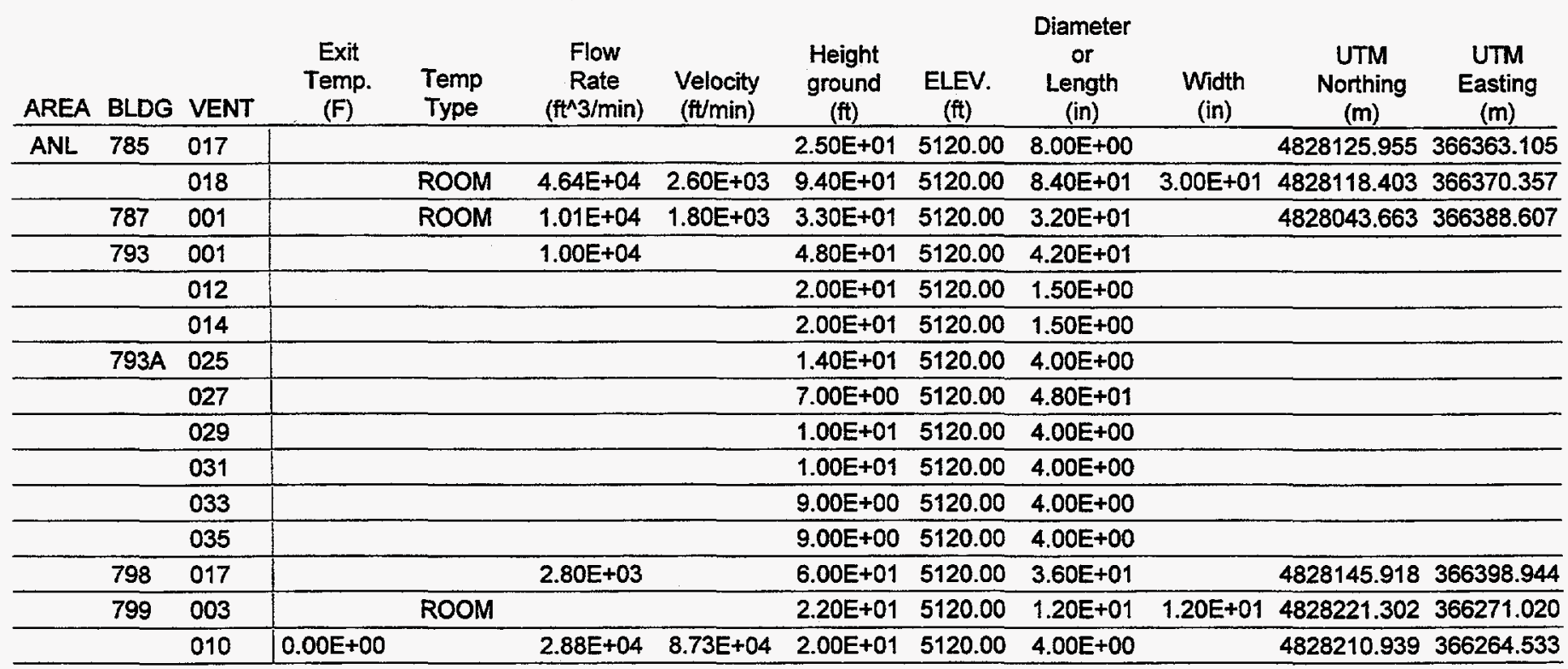




\begin{tabular}{|c|c|c|c|c|c|c|c|c|c|c|c|c|}
\hline AREA & BLDG & VENT & $\begin{array}{l}\text { Exit } \\
\text { Temp. } \\
\text { (F) }\end{array}$ & $\begin{array}{l}\text { Temp } \\
\text { Type }\end{array}$ & $\begin{array}{c}\text { Flow } \\
\text { Rate } \\
\text { (f^ } 1 / \mathrm{min})\end{array}$ & $\begin{array}{l}\text { Velocity } \\
\text { (tt/min) }\end{array}$ & $\begin{array}{l}\text { Height } \\
\text { ground } \\
\text { (ft) }\end{array}$ & $\begin{array}{c}\text { ELEV. } \\
(\mathrm{ft})\end{array}$ & $\begin{array}{l}\text { Diameter } \\
\text { or } \\
\text { Length } \\
\text { (in) }\end{array}$ & $\begin{array}{l}\text { Width } \\
\text { (in) }\end{array}$ & $\begin{array}{l}\text { UTM } \\
\text { Northing } \\
\text { (m) }\end{array}$ & $\begin{array}{l}\text { UTM } \\
\text { Easting } \\
\text { (m) }\end{array}$ \\
\hline B08 & 601 & 001 & & & & & & 4785.00 & $1.20 \mathrm{E}+01$ & $1.20 \mathrm{E}+01$ & 4849379.702 & 358919.062 \\
\hline & & 003 & & & & & $8.00 \mathrm{E}+00$ & 4785.00 & $4.00 \mathrm{E}+00$ & & 4849039.207 & 358748.815 \\
\hline
\end{tabular}




\begin{tabular}{|c|c|c|c|c|c|c|c|c|c|c|c|c|}
\hline AREA & BLDG & VENT & $\begin{array}{l}\text { Exit } \\
\text { Temp. } \\
(F)\end{array}$ & $\begin{array}{l}\text { Temp } \\
\text { Type }\end{array}$ & $\begin{array}{c}\text { Flow } \\
\text { Rate } \\
\text { (f^^3/min) }\end{array}$ & $\begin{array}{l}\text { Velocity } \\
\text { (ft/min) }\end{array}$ & $\begin{array}{l}\text { Height } \\
\text { ground } \\
\text { (fi) }\end{array}$ & $\begin{array}{c}\text { ELEV. } \\
(\mathrm{ft})\end{array}$ & $\begin{array}{c}\text { Diameter } \\
\text { or } \\
\text { Length } \\
\text { (in) }\end{array}$ & $\begin{array}{l}\text { Width } \\
\text { (in) }\end{array}$ & $\begin{array}{l}\text { UTM } \\
\text { Northing } \\
\text { (m) }\end{array}$ & $\begin{array}{c}\text { UTM } \\
\text { Easting } \\
(\mathrm{m}) \\
\end{array}$ \\
\hline \multirow{3}{*}{ B16 } & 703 & 001 & & AMBIENT & & & $1.50 \mathrm{E}+01$ & 4904.00 & $3.00 \mathrm{E}+00$ & & 4828810.330 & 343635.903 \\
\hline & \multirow[t]{2}{*}{704} & 001 & & AMBIENT & & & $1.30 E+01$ & 4850.00 & $2.25 \mathrm{E}+00$ & & 4834326.000 & 345760.000 \\
\hline & & 002 & & AMBIENT & & & $1.30 \mathrm{E}+01$ & 4850.00 & $2.25 E+00$ & & 4834326.000 & 345760.000 \\
\hline
\end{tabular}




\begin{tabular}{|c|c|c|c|c|c|c|c|c|c|c|c|c|}
\hline AREA & BLDG & VENT & $\begin{array}{c}\text { Exit } \\
\text { Temp. } \\
\text { (F) }\end{array}$ & $\begin{array}{l}\text { Temp } \\
\text { Type }\end{array}$ & $\begin{array}{c}\text { Flow } \\
\text { Rate } \\
\left(\mathrm{tt}^{\wedge} 3 / \mathrm{min}\right)\end{array}$ & $\begin{array}{l}\text { Velocity } \\
\text { (ft/min) }\end{array}$ & $\begin{array}{c}\text { Height } \\
\text { ground } \\
\text { (ft) }\end{array}$ & $\begin{array}{c}\text { ELEV. } \\
\text { (tt) }\end{array}$ & $\begin{array}{c}\text { Diameter } \\
\text { or } \\
\text { Length } \\
\text { (in) } \\
\end{array}$ & $\begin{array}{l}\text { Width } \\
\text { (in) }\end{array}$ & $\begin{array}{l}\text { UTM } \\
\text { Northing } \\
\text { (m) }\end{array}$ & $\begin{array}{l}\text { UTM } \\
\text { Easting } \\
(\mathrm{m})\end{array}$ \\
\hline $\mathrm{B} 21$ & 608 & 008 & & AMBIENT & $1.20 E+03$ & $7.10 \mathrm{E}+02$ & $2.07 E+01$ & 4974.00 & $8.75 \mathrm{E}+00$ & & 4822745.696 & 341245.663 \\
\hline & & 012 & & ROOM & 5.70E+03 & $5.70 \mathrm{E}+02$ & $1.65 \mathrm{E}+01$ & 4973.00 & $2.40 \mathrm{E}+01$ & $6.00 \mathrm{E}+01$ & 4822819.840 & 341338.312 \\
\hline
\end{tabular}




\begin{tabular}{|c|c|c|c|c|c|c|c|c|c|c|c|c|}
\hline AREA & BLDG & VENT & $\begin{array}{c}\text { Exit } \\
\text { Temp. } \\
(F) \\
\end{array}$ & $\begin{array}{l}\text { Temp } \\
\text { Type }\end{array}$ & $\begin{array}{c}\text { Flow } \\
\text { Rate } \\
\left(\mathrm{ft}^{\wedge} 3 / \mathrm{min}\right)\end{array}$ & $\begin{array}{l}\text { Velocity } \\
\text { (ft/min) }\end{array}$ & $\begin{array}{l}\text { Height } \\
\text { ground } \\
\text { (ft) }\end{array}$ & $\begin{array}{c}\text { ELEV. } \\
(\mathrm{ft})\end{array}$ & $\begin{array}{c}\text { Diameter } \\
\text { or } \\
\text { Length } \\
\text { (in) }\end{array}$ & $\begin{array}{l}\text { Width } \\
\text { (in) }\end{array}$ & $\begin{array}{c}\text { UTM } \\
\text { Northing } \\
(\mathrm{m})\end{array}$ & $\begin{array}{c}\text { UTM } \\
\text { Easting } \\
(\mathrm{m})\end{array}$ \\
\hline B23 & 602 & 002 & & & & & $5.00 \mathrm{E}+00$ & 5130.00 & $1.20 \mathrm{E}+01$ & $1.20 \mathrm{E}+01$ & & \\
\hline
\end{tabular}




\begin{tabular}{|c|c|c|c|c|c|c|c|c|c|c|c|c|}
\hline AREA & BLDG & VENT & $\begin{array}{c}\text { Exit } \\
\text { Temp. } \\
\text { (F) }\end{array}$ & $\begin{array}{l}\text { Temp } \\
\text { Type }\end{array}$ & $\begin{array}{c}\text { Flow } \\
\text { Rate } \\
\text { (ft^ } 3 / \mathrm{min})\end{array}$ & $\begin{array}{c}\text { Velocity } \\
\text { (ft/min) }\end{array}$ & $\begin{array}{c}\text { Height } \\
\text { ground } \\
\text { (ft) }\end{array}$ & $\begin{array}{c}\text { ELEV. } \\
\text { (ft) }\end{array}$ & $\begin{array}{c}\text { Diameter } \\
\text { or } \\
\text { Length } \\
\text { (in) }\end{array}$ & $\begin{array}{l}\text { Width } \\
\text { (in) }\end{array}$ & $\begin{array}{c}\text { UTM } \\
\text { Northing } \\
\text { (m) }\end{array}$ & $\begin{array}{c}\text { UTM } \\
\text { Easting } \\
\text { (m) }\end{array}$ \\
\hline B27 & 601 & 001 & & & & & $8.00 \mathrm{E}+00$ & 4940.00 & $3.00 E \div 00$ & & 4819503.676 & 346619.721 \\
\hline & & 003 & & AMBIENT & & & $6.00 \mathrm{E}+00$ & 4940.00 & $1.20 \mathrm{E}+01$ & $1.20 \mathrm{E}+01$ & 4819299.688 & 346620.253 \\
\hline
\end{tabular}




\begin{tabular}{|c|c|c|c|c|c|c|c|c|c|c|c|c|}
\hline AREA & BLDG & VENT & $\begin{array}{l}\text { Exit } \\
\text { Temp. } \\
\text { (F) }\end{array}$ & $\begin{array}{l}\text { Temp } \\
\text { Type }\end{array}$ & $\begin{array}{c}\text { Flow } \\
\text { Rate } \\
\left(\mathrm{t}^{\wedge} 3 / \mathrm{min}\right)\end{array}$ & $\begin{array}{l}\text { Velocity } \\
\text { (ft/min) }\end{array}$ & $\begin{array}{l}\text { Height } \\
\text { ground } \\
\text { (ft) }\end{array}$ & $\begin{array}{l}\text { ELEV. } \\
(\mathrm{ft})\end{array}$ & $\begin{array}{l}\text { Diameter } \\
\text { or } \\
\text { Length } \\
\text { (in) }\end{array}$ & $\begin{array}{l}\text { Width } \\
\text { (in) }\end{array}$ & $\begin{array}{l}\text { UTM } \\
\text { Northing } \\
\text { (m) }\end{array}$ & $\begin{array}{l}\text { UTM } \\
\text { Easting } \\
(\mathrm{m})\end{array}$ \\
\hline \multirow[t]{8}{*}{ CFA } & 100 & 001 & & AMBIENT & & & & 4936.00 & & & 4822259.115 & 342363.552 \\
\hline & 101 & 001 & & AMBIENT & & & & 4936.00 & & & 4822119.242 & 343143.552 \\
\hline & 102 & 001 & & AMBIENT & & & & 4936.00 & & & 4822291.256 & 343108.380 \\
\hline & 103 & 001 & & AMBIENT & & & & 4936.00 & & & 4822654.587 & 342218.219 \\
\hline & 104 & 001 & & AMBIENT & & & & 4936.00 & & & & \\
\hline & 105 & 001 & & AMBIENT & & & & 4936.00 & & & & \\
\hline & 1603 & 001 & $8.35 \mathrm{E}+02$ & & $8.05 E+02$ & & $1.05 \mathrm{E}+01$ & 4936.00 & $5.00 \mathrm{E}+00$ & & & \\
\hline & & 002 & $8.35 E+02$ & & $8.05 E+02$ & & $1.05 E+01$ & 4936.00 & $5.00 \mathrm{E}+00$ & & & \\
\hline & & 003 & & ROOM & & & $1.25 \mathrm{E}+01$ & 4936.00 & $2.00 E+00$ & & & \\
\hline & & 004 & & ROOM & & & $1.25 E+01$ & 4936.00 & $2.00 \mathrm{E}+00$ & & & \\
\hline & 1701 & 001 & & & & & & & & & & \\
\hline & 1702 & 001 & & & & & & & & & & \\
\hline & 1703 & 001 & & & & & & & & & & \\
\hline & 1708 & 001 & & & & & & & & & & \\
\hline \multirow{7}{*}{\multicolumn{2}{|c|}{1709}} & 001 & & & & & & & & & & \\
\hline & & 002 & & & & & & & & & & \\
\hline & & 003 & & & & & & & & & & \\
\hline & & 004 & & & & & & & & & & \\
\hline & & 005 & & & & & & & & & & \\
\hline & & 006 & & & & & & & & & & \\
\hline & & 007 & & & & & & & & & & \\
\hline & 602 & 016 & & ROOM & & & $8.00 \mathrm{E}+00$ & 4936.00 & $6.00 E+00$ & $4.00 \mathrm{E}+00$ & 4821498.787 & 342760.120 \\
\hline & 604 & 001 & & & & & $2.00 \mathrm{E}+00$ & 15.00 & $4.00 E+00$ & & 4821139.572 & 342883.581 \\
\hline & 607 & 004 & $2.50 \mathrm{E}+02$ & & $1.80 E+02$ & $1.08 \mathrm{E}+03$ & $1.50 E+01$ & 4936.00 & $4.00 \mathrm{E}+00$ & $6.00 E+00$ & 4821496.128 & 342944.306 \\
\hline \multirow{2}{*}{\multicolumn{2}{|c|}{608}} & 001 & $5.50 \mathrm{E}+02$ & & $1.13 E+02$ & $1.44 E+02$ & $3.45 \mathrm{E}+01$ & 4930.00 & $1.20 \mathrm{E}+01$ & & 4820908.391 & 342513.039 \\
\hline & & 005 & $7.00 E+01$ & ROOM & $.2 .74 \mathrm{E}+03$ & & $4.20 \mathrm{E}+01$ & & $1.40 \mathrm{E}+01$ & & & \\
\hline \multirow{6}{*}{\multicolumn{2}{|c|}{609}} & 001 & $9.50 \mathrm{E}+02$ & & & & $1.40 E+01$ & 4936.00 & $4.00 \mathrm{E}+00$ & & 4820917.314 & 342527.399 \\
\hline & & 002 & & ROOM & & & $9.50 E+00$ & 4936.00 & $7.50 \mathrm{E}-01$ & & 4820916.729 & 342526.037 \\
\hline & & 005 & $3.96 \mathrm{E}+02$ & & 8.27E+02 & $1.52 E+03$ & $2.70 E+01$ & 4936.00 & $1.00 \mathrm{E}+01$ & & 4820907.933 & 342532.569 \\
\hline & & 017 & & ROOM & & & $2.30 E+01$ & 4930.00 & $1.20 \mathrm{E}+01$ & & 4820920.833 & 342584.169 \\
\hline & & 019 & & & & & $4.20 E+01$ & & $1.20 \mathrm{E}+01$ & & & \\
\hline & & 020 & $7.00 \mathrm{E}+01$ & rOOM & $8.00 E+02$ & & $4.20 E+01$ & & $1.00 \mathrm{E}+01$ & & & \\
\hline \multirow{4}{*}{\multicolumn{2}{|c|}{612}} & 007 & & & & & $1.90 \mathrm{E}+01$ & 4930.00 & $4.00 \mathrm{E}+00$ & & 4821245.769 & 342907.804 \\
\hline & & 008 & & ROOM & $1.25 E+03$ & $2.29 E+03$ & $2.70 E+01$ & 4930.00 & $1.00 \mathrm{E}+01$ & & 4821242.342 & 342904.789 \\
\hline & & 010 & & ROOM & $1.25 \mathrm{E}+03$ & $2.29 E+03$ & 2.70E+01 & 4936.00 & $1.00 E+01$ & & 4821239.052 & 342905.885 \\
\hline & & 012 & & ROOM & $1.25 E+03$ & $2.29 \mathrm{E}+03$ & $2.70 E+01$ & 4936.00 & $1.00 \mathrm{E}+01$ & & 4821235.900 & 342906.845 \\
\hline & 613 & 003 & $2.60 \mathrm{E}+02$ & & $1.13 E+02$ & $2.07 E+02$ & $1.70 \mathrm{E}+01$ & 4936.00 & $1.00 E+01$ & & 4821418.815 & 342895.635 \\
\hline \multirow{8}{*}{\multicolumn{2}{|c|}{617}} & 010 & & & & & 2.15E+01 & 4936.00 & 4.80E+01 & $3.60 \mathrm{E}+01$ & 4821783.705 & 343561.434 \\
\hline & & 011 & & & & & $2.15 E+01$ & 4936.00 & $4.80 E+01$ & $3.60 E+01$ & 4821784.996 & 343558.994 \\
\hline & & 024 & 4.30E+02 & & $1.16 E+03$ & & $2.30 E+01$ & 4936.00 & $2.40 \mathrm{E}+01$ & & 4821785.843 & 343549.133 \\
\hline & & 026 & & & & & $2.10 \mathrm{E}+01$ & 4936.00 & $1.20 \mathrm{E}+01$ & & 4821782.251 & 343544.333 \\
\hline & & 030 & & & & & & 4936.00 & $2.00 \mathrm{E}+00$ & & 4821979.004 & 343474.123 \\
\hline & & 031 & & & & & & 4936.00 & $2.00 \mathrm{E}+00$ & & 4821981.244 & 343476.513 \\
\hline & & 033 & & ROOM & & & $2.10 E \div 01$ & 4936.00 & $1.00 \mathrm{E}+01$ & $1.80 \mathrm{E}+01$ & 4821767.574 & 343538.377 \\
\hline & & 034 & & ROOM & & & $2.10 \mathrm{E}+01$ & 4936.00 & $1.00 \mathrm{E}+01$ & $1.80 \mathrm{E}+01$ & 4821765.739 & 343537.660 \\
\hline \multirow{3}{*}{\multicolumn{2}{|c|}{622}} & 009 & & ROOM & $0.00 \mathrm{E}+00$ & & $1.20 \mathrm{E}+01$ & 4936.00 & $1.20 \mathrm{E}+01$ & $1.20 \mathrm{E}+01$ & 4820879.434 & 342827.035 \\
\hline & & 015 & & ROOM & $2.00 E+03$ & $2.00 E+03$ & $1.20 \mathrm{E}+01$ & 4936.00 & $1.20 \mathrm{E}+01$ & $1.20 \mathrm{E}+01$ & 4820871.722 & 342826.854 \\
\hline & & 019 & & & $0.00 E+00$ & & $4.00 \mathrm{E}+00$ & 4936.00 & $1.20 E+01$ & & 4820866.001 & 342833.908 \\
\hline
\end{tabular}




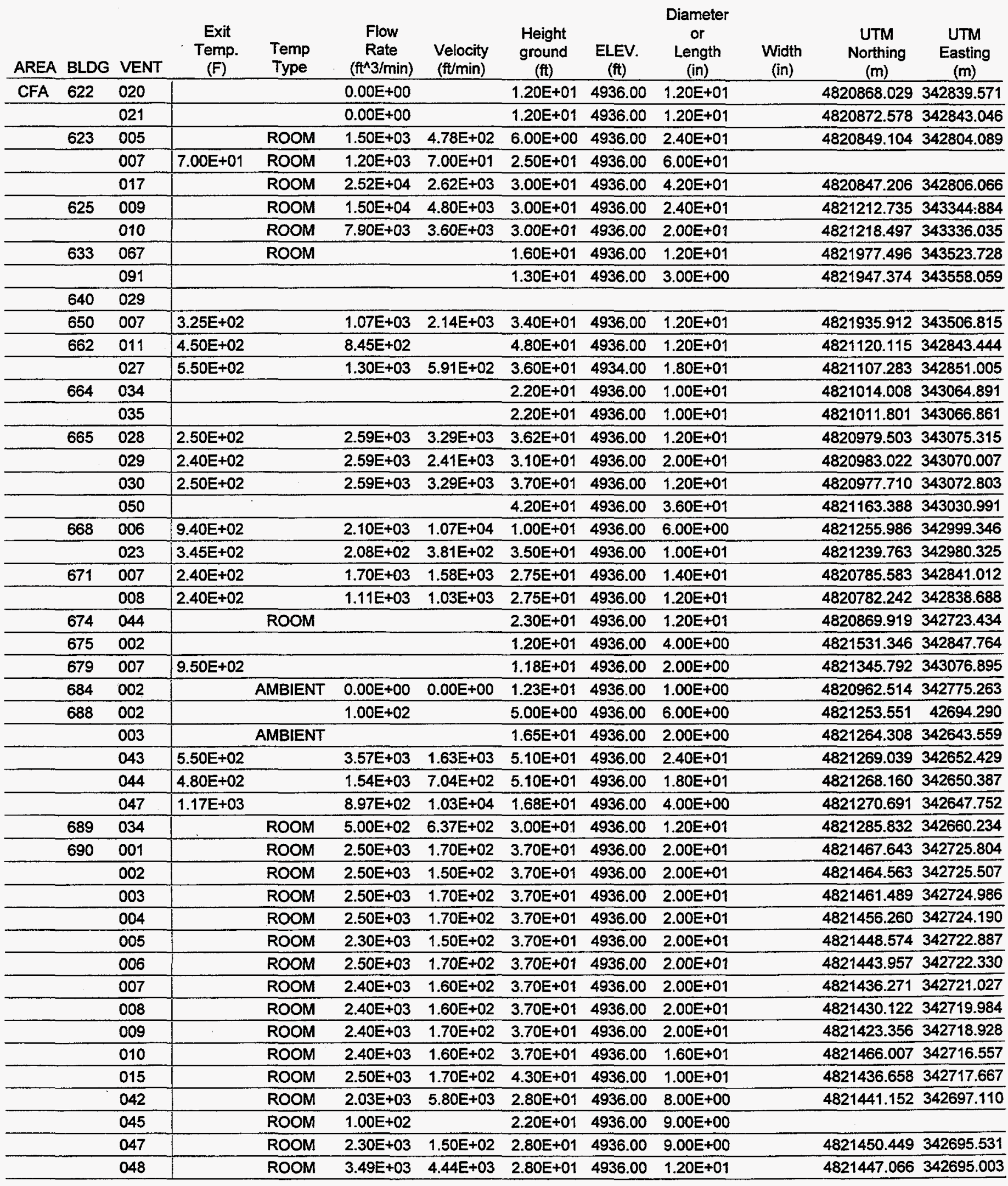




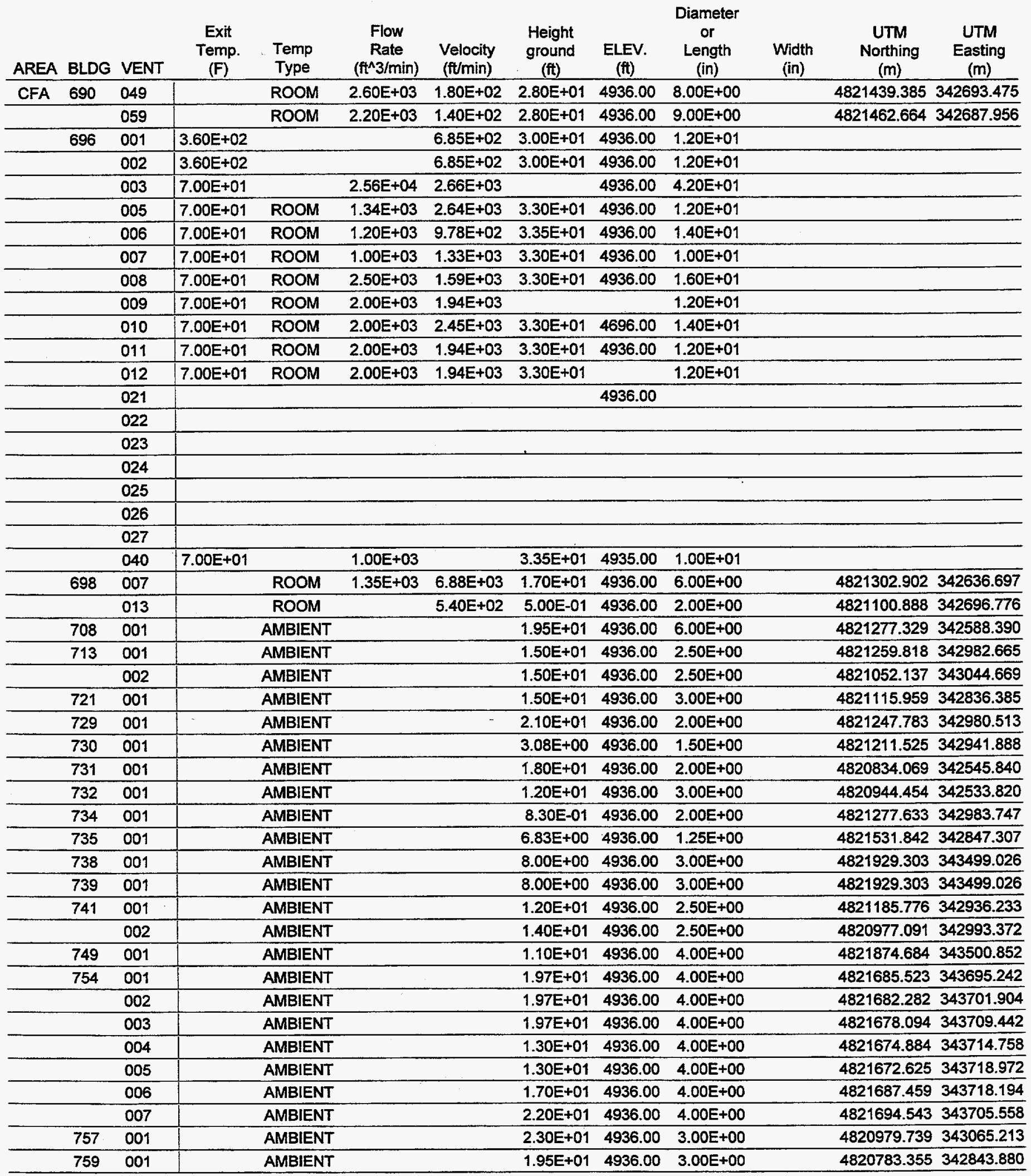




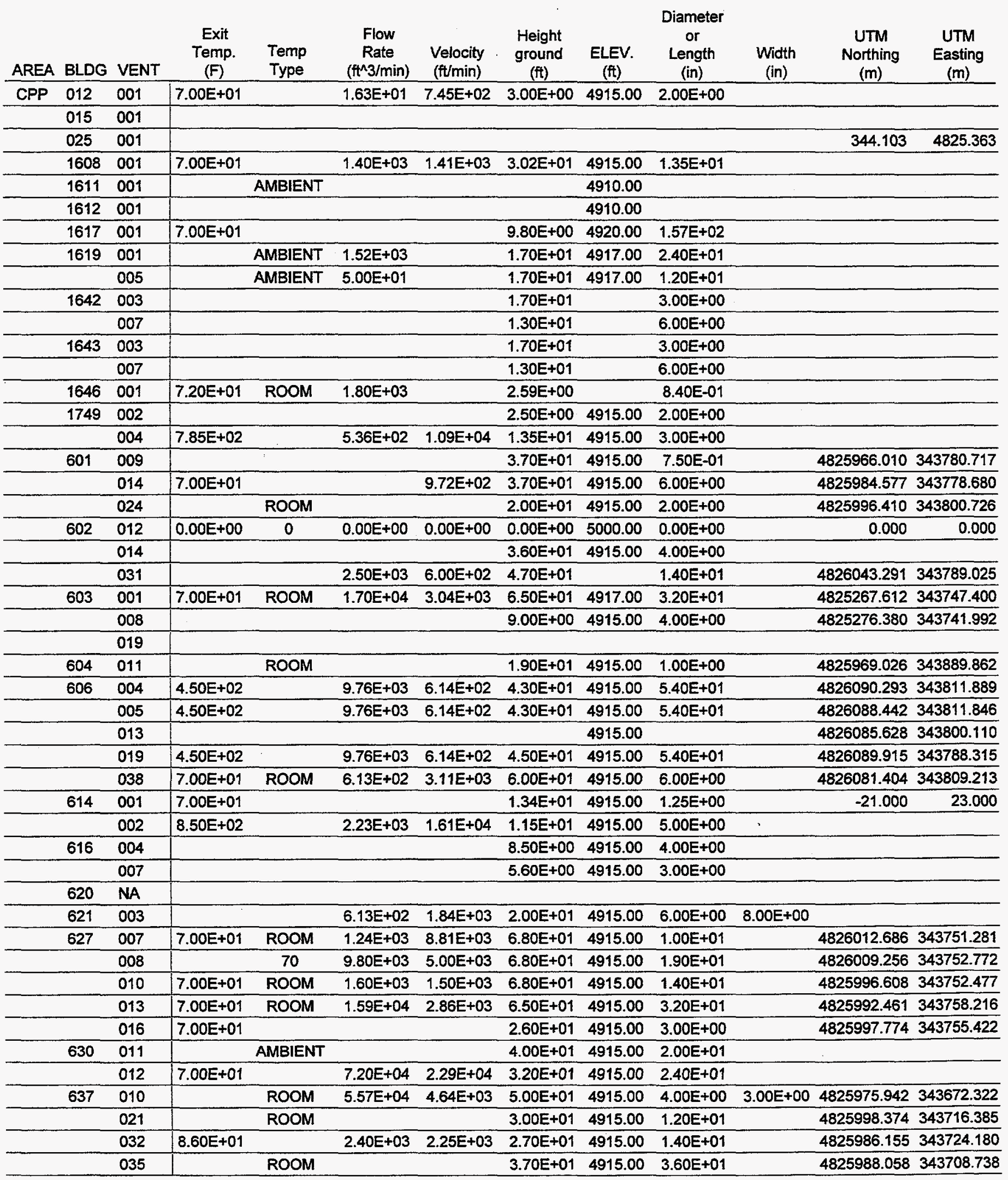




\begin{tabular}{|c|c|c|c|c|c|c|c|c|c|c|c|c|}
\hline AREA & BLDG & VENT & $\begin{array}{l}\text { Exit } \\
\text { Temp. } \\
\text { (F) }\end{array}$ & $\begin{array}{l}\text { Temp } \\
\text { Type }\end{array}$ & 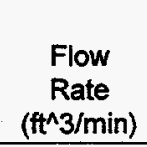 & $\begin{array}{l}\text { Velocity } \\
\text { (ft/min) }\end{array}$ & $\begin{array}{l}\text { Height } \\
\text { ground } \\
\text { (ft) }\end{array}$ & $\begin{array}{c}\text { ELEV. } \\
\text { (ft) }\end{array}$ & $\begin{array}{c}\text { Diameter } \\
\text { or } \\
\text { Length } \\
\text { (in) }\end{array}$ & $\begin{array}{l}\text { Width } \\
\text { (in) }\end{array}$ & $\begin{array}{l}\text { UTM } \\
\text { Northing } \\
\text { (m) }\end{array}$ & $\begin{array}{l}\text { UTM } \\
\text { Easting } \\
(\mathrm{m})\end{array}$ \\
\hline \multirow[t]{48}{*}{ CPP } & 637 & 036 & $1.80 E+02$ & & $4.30 \mathrm{E}+01$ & $1.23 E+02$ & $2.70 E+01$ & 4915.00 & $8.00 E+00$ & & 4825984.957 & 343709.339 \\
\hline & & 042 & $7.50 E+01$ & & $1.94 \mathrm{E}+03$ & $2.47 E+03$ & $3.00 E+01$ & 4915.00 & $1.20 E+01$ & & 4825980.403 & 343706.091 \\
\hline & & 045 & $6.00 E+01$ & & & & $8.00 E+00$ & 4915.00 & $3.00 E+00$ & & 4825991.613 & 343701.864 \\
\hline & & 052 & & & & & & & & & & \\
\hline & & 053 & & & & & & & & & & \\
\hline & & 056 & & & & & & & & & & \\
\hline & & 057 & & & & & & & & & & \\
\hline & & 058 & & & & & & & & & & \\
\hline & & 064 & & & & & & & & & & \\
\hline & 644 & 002 & $6.75 \mathrm{E}+02$ & & & & $2.45 E+01$ & 4915.00 & $1.50 E+01$ & & 4826097.188 & 343754.371 \\
\hline & & 004 & & & & & $5.17 \mathrm{E}+00$ & 4915.00 & $5.00 \mathrm{E}-01$ & & 4826088.398 & 343760.675 \\
\hline & & 005 & & & & & $1.03 E+01$ & 4915.00 & $1.50 \mathrm{E}+00$ & & 4826088.477 & 343757.310 \\
\hline & & 006 & & & & & $1.60 \mathrm{E}+01$ & 4915.00 & $1.00 \mathrm{E}+00$ & & 4826097.109 & 343757.735 \\
\hline & & 013 & & & & & $9.00 E+00$ & & $3.00 E+00$ & & & \\
\hline & 648 & 002 & & & & & $7.00 E+00$ & 4920.00 & $2.00 E+00$ & & & \\
\hline & 654 & 007 & & & & & 2.10E+01 & 4915.00 & $6.00 E+00$ & & & \\
\hline & & 008 & & & & & $2.10 E+01$ & 4915.00 & $6.00 \mathrm{E}+00$ & & & \\
\hline & & 009 & & & & & 2.10E+01 & 4915.00 & $6.00 \mathrm{E}+00$ & & & \\
\hline & & 010 & & & & & $2.10 \mathrm{E}+01$ & 4915.00 & $6.00 \mathrm{E}+00$ & & & \\
\hline & & 011 & & & & & 2.10E+01 & 4915.00 & $6.00 \mathrm{E}+00$ & & & \\
\hline & & 012 & & & & & $2.10 E+01$ & 4915.00 & $6.00 E+00$ & & & \\
\hline & 655 & 018 & & & $8.55 E+02$ & $7.79 \mathrm{E}+03$ & $2.00 E+01$ & 4915.00 & $4.50 E+00$ & & & \\
\hline & & 019 & & & $2.65 \mathrm{E}+03$ & $1.03 E+03$ & $1.80 \mathrm{E}+01$ & 4915.00 & $5.00 E+00$ & & & \\
\hline & & 023 & & & & & $0.00 E+00$ & & & & & \\
\hline & & 026 & & & $1.48 \mathrm{E}+03$ & $9.87 E+02$ & $1.90 \mathrm{E}+01$ & 4915.00 & $9.00 E+00$ & & & \\
\hline & & 027 & & & & & & & & & & \\
\hline & & 028 & & & $2.10 \mathrm{E}+03$ & $1.03 E+03$ & $1.80 \mathrm{E}+01$ & 4915.00 & $9.00 E+00$ & & & \\
\hline & & 030 & & & $2.10 \mathrm{E}+03$ & $1.03 E+03$ & $1.90 E+01$ & 4915.00 & $9.00 E+00$ & & & \\
\hline & & 031 & & & $2.65 E+03$ & $1.03 E+03$ & $1.90 \mathrm{E}+01$ & 4915.00 & $9.00 E+00$ & & & \\
\hline & 659 & 006 & $8.50 \mathrm{E}+02$ & & $1.21 E+04$ & $8.60 E+03$ & 2.35E+01 & 4915.00 & $1.60 E+01$ & & 4825975.953 & 344056.553 \\
\hline & & 007 & $1.35 E \div 03$ & & & & $9.00 E+00$ & 4915.00 & $1.50 E+00$ & & 4825970.714 & 344056.207 \\
\hline & & 008 & $7.60 E+02$ & & $9.60 \mathrm{E}+03$ & $6.90 \mathrm{E}+03$ & $2.00 E+01$ & 4915.00 & $1.60 E+01$ & & 4825961.438 & 344056.889 \\
\hline & & 010 & & & & & $6.50 \mathrm{E}+00$ & 4915.00 & $2.00 E+00$ & & 4825971.765 & 344064.086 \\
\hline & & 011 & & & & & $6.50 E+00$ & 4915.00 & $2.00 E+00$ & & 4825953.867 & 344063.895 \\
\hline & & 025 & & ROOM & $5.00 \mathrm{E}+01$ & $1.02 E+03$ & $3.40 E+01$ & 4915.00 & $3.00 \mathrm{E}+00$ & & 4825981.558 & 344054.439 \\
\hline & & 033 & & & & & $7.10 E+01$ & 4915.00 & $7.20 \mathrm{E}+01$ & & 4826010.412 & 344008.203 \\
\hline & & 035 & & & & & $3.50 E+00$ & 4915.00 & $1.50 E+00$ & & 4825972.611 & 344054.231 \\
\hline & 662 & 003 & $7.00 \mathrm{E}+01$ & & $1.14 E+03$ & $5.80 E+03$ & $1.40 \mathrm{E}+01$ & 4915.00 & $6.00 \mathrm{E}+00$ & & & \\
\hline & 663 & 002 & 7.00E+01 & & $1.38 \mathrm{E}+04$ & $3.04 E+02$ & $3.90 E+01$ & 4915.00 & $3.60 \mathrm{E}+01$ & $4.80 \mathrm{E}+01$ & 4825874.108 & 343870.148 \\
\hline & & 045 & 7.00E+01 & & $2.90 E+04$ & 4.10E+O3 & $4.05 E+01$ & 4915.00 & $3.60 \mathrm{E}+01$ & & 4825868.452 & 343914.230 \\
\hline & & 048 & $7.00 \mathrm{E}+01$ & & $6.91 E+03$ & $2.23 E+03$ & $4.70 E+01$ & 4915.00 & $2.40 \mathrm{E}+01$ & & 4825876.971 & 343932.832 \\
\hline & & 054 & $7.00 \mathrm{E}+01$ & & $2.00 \mathrm{E}+03$ & $2.55 E+03$ & 1.25E+01 & 4915.00 & $1.20 \mathrm{E}+01$ & & 4825880.201 & 343913.381 \\
\hline & 666 & 001 & & & & & & & & & & \\
\hline & 679 & 002 & & & $1.20 \mathrm{E}+03$ & $6.87 E+02$ & $1.70 E+01$ & 4915.00 & $5.00 \mathrm{E}+00$ & & & \\
\hline & & 003 & & & $1.20 E+03$ & $6.87 E+02$ & $1.70 E+01$ & 4915.00 & $5.00 \mathrm{E}+00$ & & & \\
\hline & 684 & 001 & & ROOM & $1.60 E+04$ & $3.73 E+03$ & $5.00 E+01$ & 4915.00 & $2.80 E+01$ & & 4825853.159 & 343802.104 \\
\hline & & 002 & & ROOM & $4.68 E+03$ & $2.65 E+03$ & $4.00 E+01$ & 4915.00 & $1.80 \mathrm{E}+01$ & & 4825857.587 & 343797.494 \\
\hline & 687 & 010 & & AMBIENT & $5.00 E+02$ & $3.44 E+03$ & $6.00 E+01$ & 4917.00 & $5.00 \mathrm{E}+00$ & & 4825452.931 & 344089.512 \\
\hline
\end{tabular}




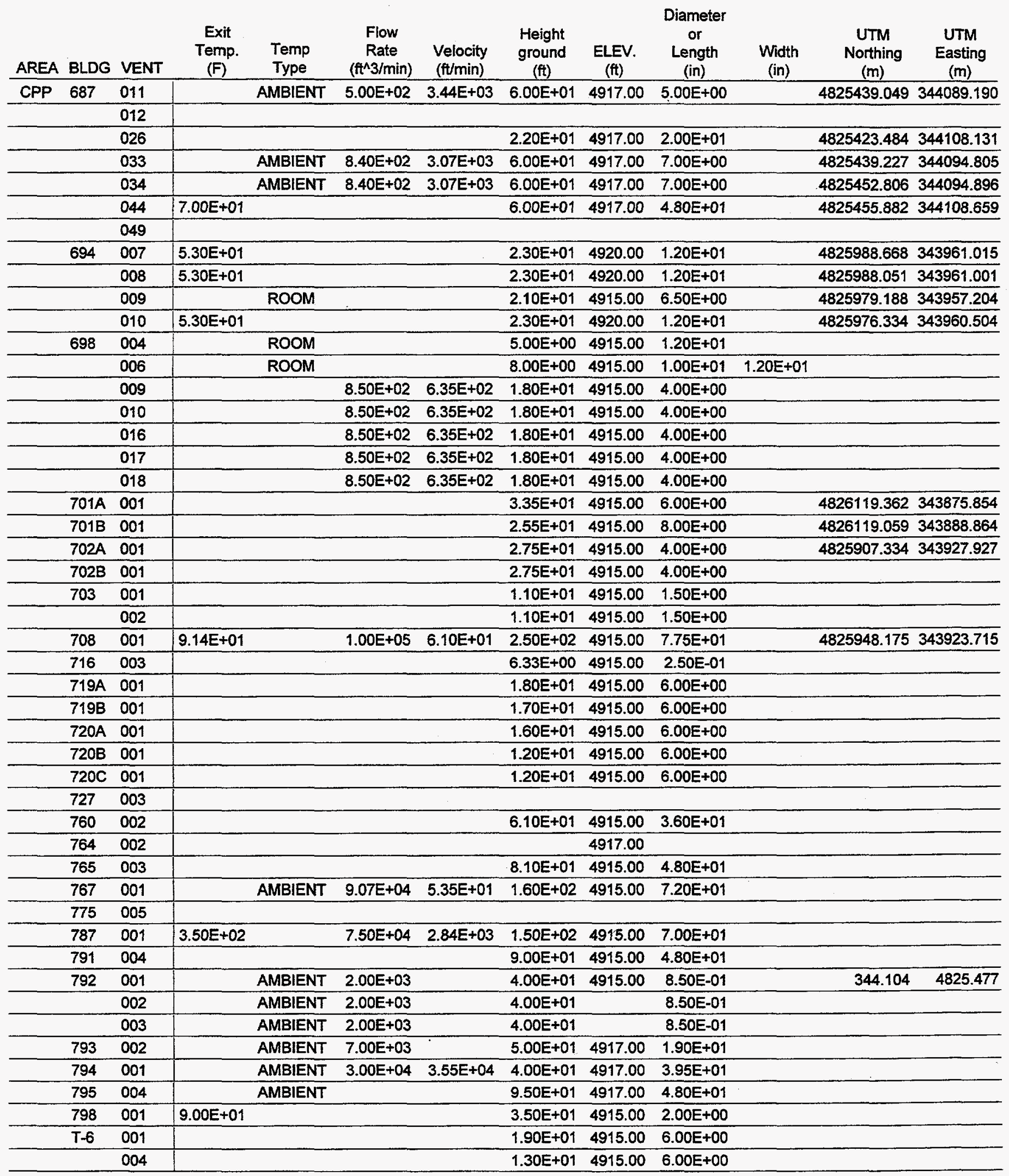




\begin{tabular}{|c|c|c|c|c|c|c|c|c|c|c|c|c|}
\hline AREA & BLDG & VENT & $\begin{array}{l}\text { Exit } \\
\text { Temp. } \\
\text { (F) }\end{array}$ & $\begin{array}{l}\text { Temp } \\
\text { Type }\end{array}$ & $\begin{array}{c}\text { Flow } \\
\text { Rate } \\
\text { (ft^3/min) }\end{array}$ & $\begin{array}{l}\text { Velocity } \\
\text { (ft/min) }\end{array}$ & $\begin{array}{l}\text { Height } \\
\text { ground } \\
\text { (ft) }\end{array}$ & $\begin{array}{c}\text { ELEV. } \\
\text { (ft) }\end{array}$ & $\begin{array}{c}\text { Diameter } \\
\text { or } \\
\text { Length } \\
\text { (in) }\end{array}$ & $\begin{array}{l}\text { Width } \\
\text { (in) }\end{array}$ & $\begin{array}{c}\text { UTM } \\
\text { Northing } \\
(m)\end{array}$ & $\begin{array}{c}\text { UTM } \\
\text { Easting } \\
(m)\end{array}$ \\
\hline CPP & TR19 & 002 & & & $6.00 E+02$ & $6.88 \mathrm{E}+03$ & $1.05 E+01$ & 4915.00 & $4.00 \mathrm{E}+00$ & & & \\
\hline & TR29 & 001 & & & & & $1.00 E+01$ & 4920.00 & $4.00 \mathrm{E}+00$ & & & \\
\hline & & 008 & & & & & $1.00 \mathrm{E}+01$ & 4920.00 & $4.00 \mathrm{E}+00$ & & & \\
\hline
\end{tabular}


Exit

Temp. (F)
Flow

Rate (f^3/min)
Diameter Height
ground Velocity Type 001

UTM Northing (m)
UTM Easting (m) 


\begin{tabular}{|c|c|c|c|c|c|c|c|c|c|c|c|c|}
\hline AREA & BLDG & VENT & $\begin{array}{c}\text { Exit } \\
\text { Temp. } \\
(F)\end{array}$ & $\begin{array}{l}\text { Temp } \\
\text { Type }\end{array}$ & $\begin{array}{c}\text { Flow } \\
\text { Rate } \\
\left(\mathrm{ft}^{\wedge} 3 / \mathrm{min}\right) \\
\end{array}$ & $\begin{array}{l}\text { Velocity } \\
\text { (ft/min) }\end{array}$ & $\begin{array}{c}\text { Height } \\
\text { ground } \\
\text { (ft) }\end{array}$ & $\begin{array}{c}\text { ELEV. } \\
\text { (ft) }\end{array}$ & $\begin{array}{c}\text { Diameter } \\
\text { or } \\
\text { Length } \\
\text { (in) } \\
\end{array}$ & $\begin{array}{l}\text { Width } \\
\text { (in) }\end{array}$ & $\begin{array}{c}\text { UTM } \\
\text { Northing } \\
\text { (m) }\end{array}$ & $\begin{array}{c}\text { UTM } \\
\text { Easting } \\
\text { (m) }\end{array}$ \\
\hline \multirow[t]{36}{*}{ NRF } & 601 & 023 & $6.80 \mathrm{E}+01$ & ROOM & $3.03 E+03$ & $1.71 E+03$ & $5.30 E+01$ & 4850.00 & $1.50 \mathrm{E}+00$ & & & \\
\hline & & 036 & $6.80 \mathrm{E}+01$ & ROOM & $1.00 \mathrm{E}+02$ & $1.15 E+03$ & $3.60 E+01$ & 4850.00 & $4.00 \mathrm{E}+00$ & & & \\
\hline & & $19 A$ & $6.80 \mathrm{E}+01$ & ROOM & $2.80 E+03$ & $7.00 \mathrm{E}+02$ & $1.48 E+02$ & 4850.00 & $2.30 \mathrm{E}+00$ & $2.80 E+01$ & & \\
\hline & & $19 \mathrm{C}$ & $6.80 \mathrm{E}+01$ & ROOM & $6.04 E+03$ & $1.51 \mathrm{E}+03$ & $1.48 E+02$ & 4850.00 & $2.40 E+01$ & $2.40 \mathrm{E}+01$ & & \\
\hline & 602 & 005 & $7.35 \mathrm{E}+02$ & & $1.90 \mathrm{E}+03$ & & $1.80 \mathrm{E}+01$ & 4850.00 & $3.30 \mathrm{E}-01$ & & & \\
\hline & & 006 & $6.80 \mathrm{E}+01$ & ROOM & & & $2.30 E+01$ & 4850.00 & $2.00 \mathrm{E}+01$ & & & \\
\hline & & 008 & $6.80 E+01$ & ROOM & & & $1.70 E+01$ & 4850.00 & $2.40 E+01$ & $2.40 E+01$ & & \\
\hline & & 023 & $6.80 \mathrm{E}+01$ & ROOM & & & $2.20 E+01$ & 4850.00 & $1.20 \mathrm{E}+01$ & & & \\
\hline & & 037 & $1.50 \mathrm{E}+02$ & & $2.00 \mathrm{E}+02$ & $4.00 \mathrm{E}+03$ & $5.00 E+00$ & 4850.00 & $3.00 E+00$ & & & \\
\hline & & 039 & $6.80 \mathrm{E}+01$ & ROOM & $8.40 \mathrm{E}+02$ & & $3.00 E+01$ & 4850.00 & $8.00 \mathrm{E}+00$ & & & \\
\hline & $616 \mathrm{~A}$ & 002 & $6.80 \mathrm{E}+01$ & ROOM & $6.00 \mathrm{E}+03$ & & $5.60 \mathrm{E}+01$ & 4850.00 & $2.76 \mathrm{E}+01$ & $1.80 \mathrm{E}+01$ & & \\
\hline & $616 \mathrm{~B}$ & $\mathrm{PCM}$ & $6.80 \mathrm{E}+01$ & ROOM & $3.20 E+04$ & $1.75 \mathrm{E}+03$ & $2.60 E+01$ & 4850.00 & & $4.20 \mathrm{E}+02$ & & \\
\hline & 617 & 002 & $6.80 \mathrm{E}+01$ & ROOM & $2.91 \mathrm{E}+04$ & & $5.10 E+01$ & 4850.00 & $2.40 \mathrm{E}+01$ & & & \\
\hline & & 013 & $6.80 E+01$ & ROOM & $1.00 \mathrm{E}+03$ & & $4.50 E+01$ & 4850.00 & $8.40 \mathrm{E}+00$ & $6.00 \mathrm{E}+01$ & & \\
\hline & & 020 & $6.80 \mathrm{E}+01$ & ROOM & $1.00 E+03$ & $6.22 \mathrm{E}+02$ & $4.50 E+01$ & 4850.00 & $8.40 E+00$ & & & \\
\hline & $617 \mathrm{C}$ & 001 & & & & & $4.50 E+01$ & 4850.00 & $1.80 \mathrm{E}+01$ & & & \\
\hline & & 002 & & & & & $4.50 E+01$ & 4850.00 & $1.80 E+01$ & & & \\
\hline & & 003 & $6.80 \mathrm{E}+01$ & ROOM & & & $3.60 E+01$ & 4850.00 & $1.08 \mathrm{E}+02$ & & & \\
\hline & 618 & 099 & $6.80 \mathrm{E}+01$ & ROOM & $4.90 \mathrm{E}+04$ & $2.50 \mathrm{E}+03$ & $1.02 E+02$ & 4850.00 & $6.00 \mathrm{E}+01$ & & & \\
\hline & & 103 & $6.80 \mathrm{E}+01$ & ROOM & $2.58 E+04$ & $2.05 E+03$ & $5.90 E+01$ & 4850.00 & $4.80 E+01$ & & & \\
\hline & & 013 & $7.00 \mathrm{E}+02$ & & $3.00 \mathrm{E}+04$ & 4.30E+03 & $3.00 E+01$ & 4850.00 & $4.20 \mathrm{E}+01$ & & & \\
\hline & & 014 & $7.00 \mathrm{E}+02$ & & $3.00 \mathrm{E}+04$ & $4.30 \mathrm{E}+03$ & $3.00 E+01$ & 4850.00 & $4.20 \mathrm{E}+01$ & & & \\
\hline & 622 & 001 & & & & & $1.40 E+01$ & 4850.00 & $4.00 \mathrm{E}+00$ & & & \\
\hline & $628 A$ & 006 & $6.80 \mathrm{E}+01$ & ROOM & $6.00 E+01$ & & $2.20 \mathrm{E}+01$ & 4850.00 & $8.40 \mathrm{E}+00$ & & & \\
\hline & 631 & NA & $6.80 \mathrm{E}+01$ & Fugitive & & & & & & & & \\
\hline & $633 A$ & 004 & & AMBIENT & $1.74 \mathrm{E}-01$ & $8.00 E+00$ & $1.80 E+01$ & 4850.00 & $2.00 \mathrm{E}+00$ & & & \\
\hline & & 024 & & AMBIENT & $3.67 E+02$ & $8.00 \mathrm{E}+00$ & $6.70 \mathrm{E}-01$ & 4850.00 & $2.00 \mathrm{E}+00$ & & & \\
\hline & & 038 & & & & & $9.00 \mathrm{E}+01$ & 4850.00 & $1.20 \mathrm{E}+01$ & & & \\
\hline & & 057 & $6.80 \mathrm{E}+01$ & ROOM & $2.65 E+04$ & & $8.60 E+01$ & 4850.00 & $7.20 \mathrm{E}+01$ & & & \\
\hline & & 088 & $4.00 \mathrm{E}+02$ & & $2.10 E+00$ & $7.50 \mathrm{E}+01$ & $3.00 E+00$ & 4850.00 & $3.00 \mathrm{E}+00$ & & & \\
\hline & & 089 & $4.00 \mathrm{E}+02$ & & $8.75 E+02$ & $4.92 \mathrm{E}+02$ & $1.00 \mathrm{E}+01$ & 4850.00 & $1.60 \mathrm{E}+01$ & $1.60 \mathrm{E}+01$ & & \\
\hline & 635 & 006 & & & & & $1.00 E+01$ & 4850.00 & $1.00 \mathrm{E}+01$ & & & \\
\hline & & 007 & & & & & $1.00 \mathrm{E}+01$ & 4850.00 & $1.00 \mathrm{E}+01$ & & & \\
\hline & 642 & NA & $6.80 \mathrm{E}+01$ & Fugitive & & & & & & & & \\
\hline & 663 & 022 & $6.80 \mathrm{E}+01$ & ROOM & $3.20 \mathrm{E}+02$ & & $8.00 E+00$ & 4850.00 & $1.20 \mathrm{E}+01$ & $1.20 \mathrm{E}+01$ & & \\
\hline & 686 & 001 & $6.80 \mathrm{E}+01$ & ROOM & & & $1.10 E+01$ & 4850.00 & $3.00 \mathrm{E}+00$ & & & \\
\hline
\end{tabular}




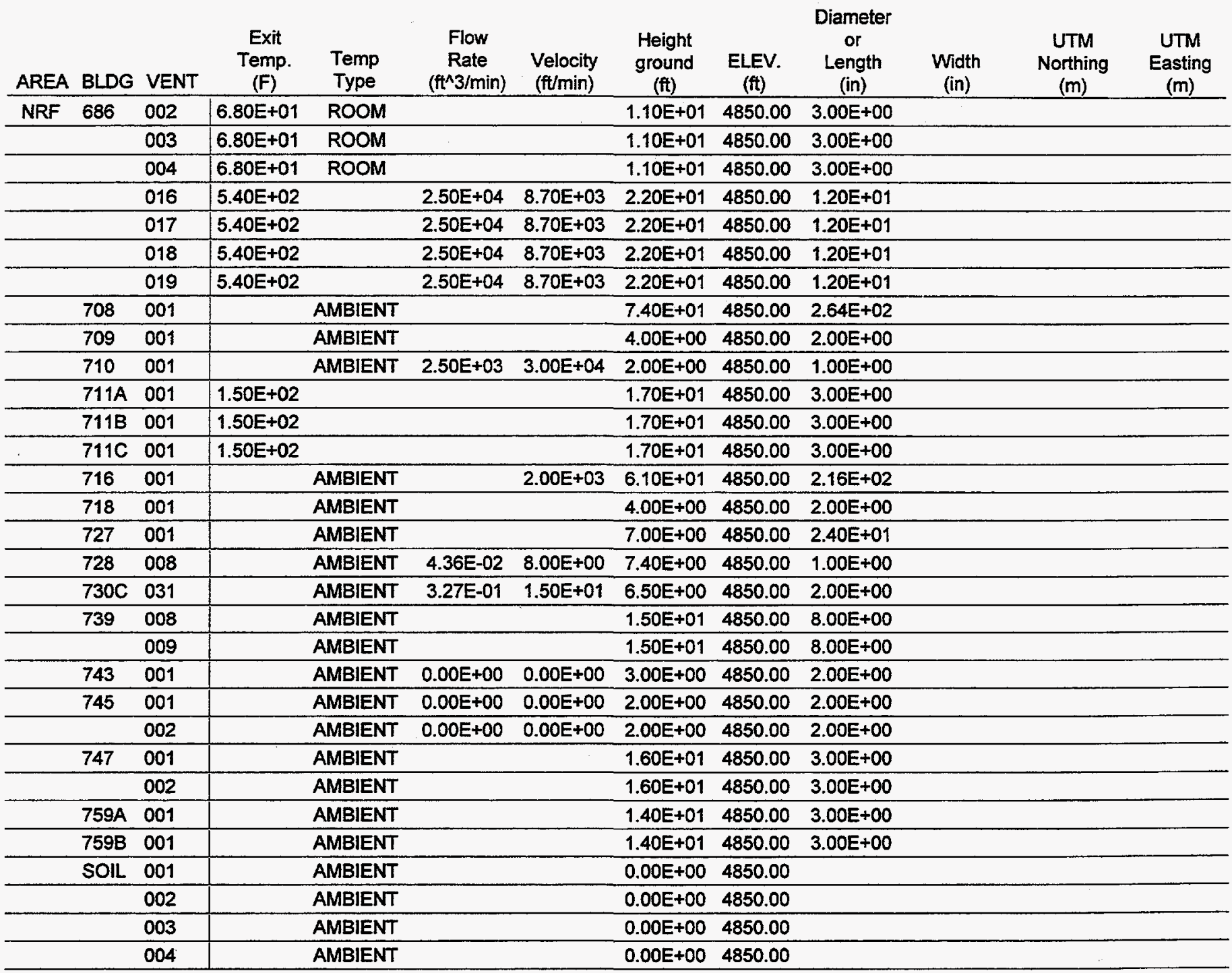




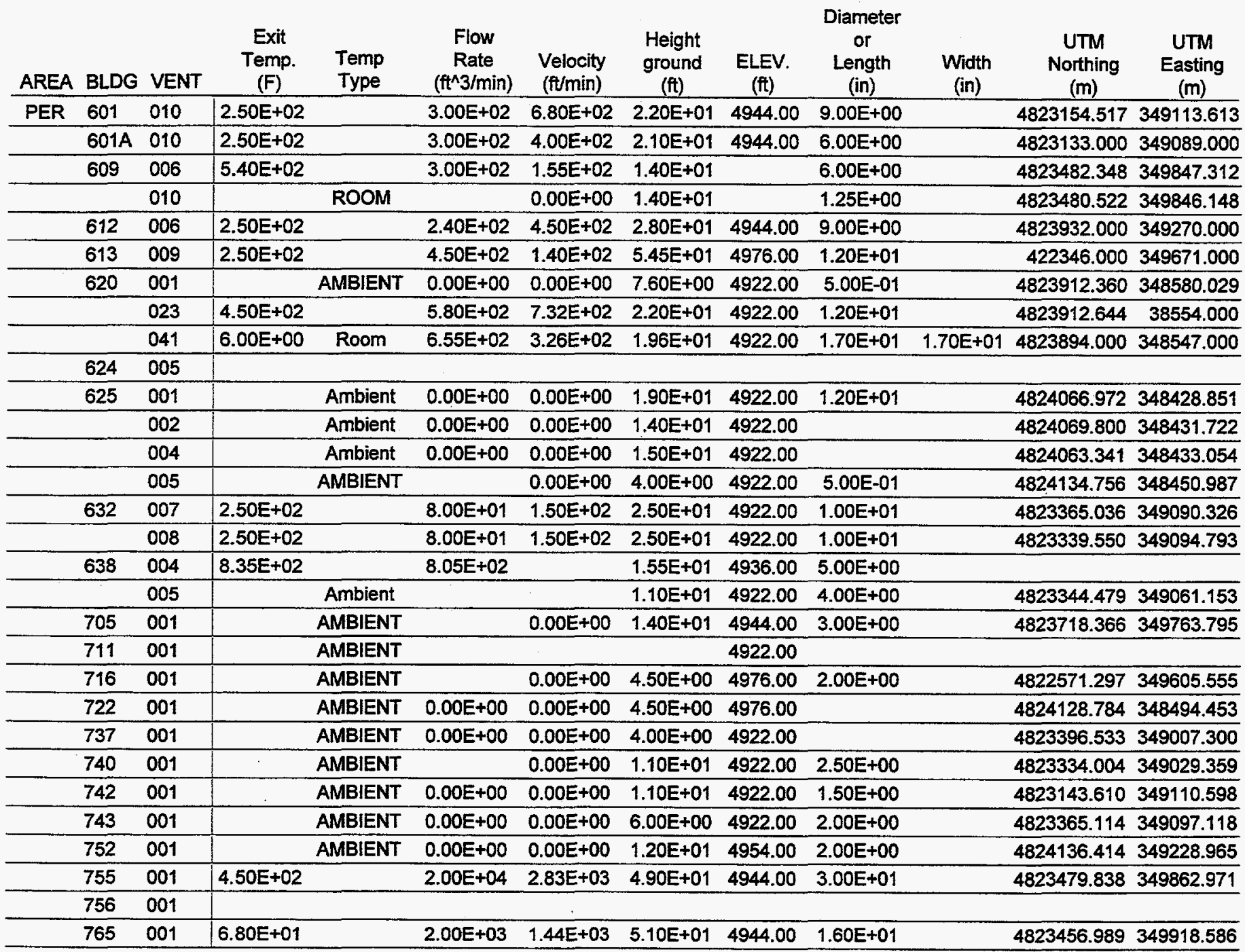




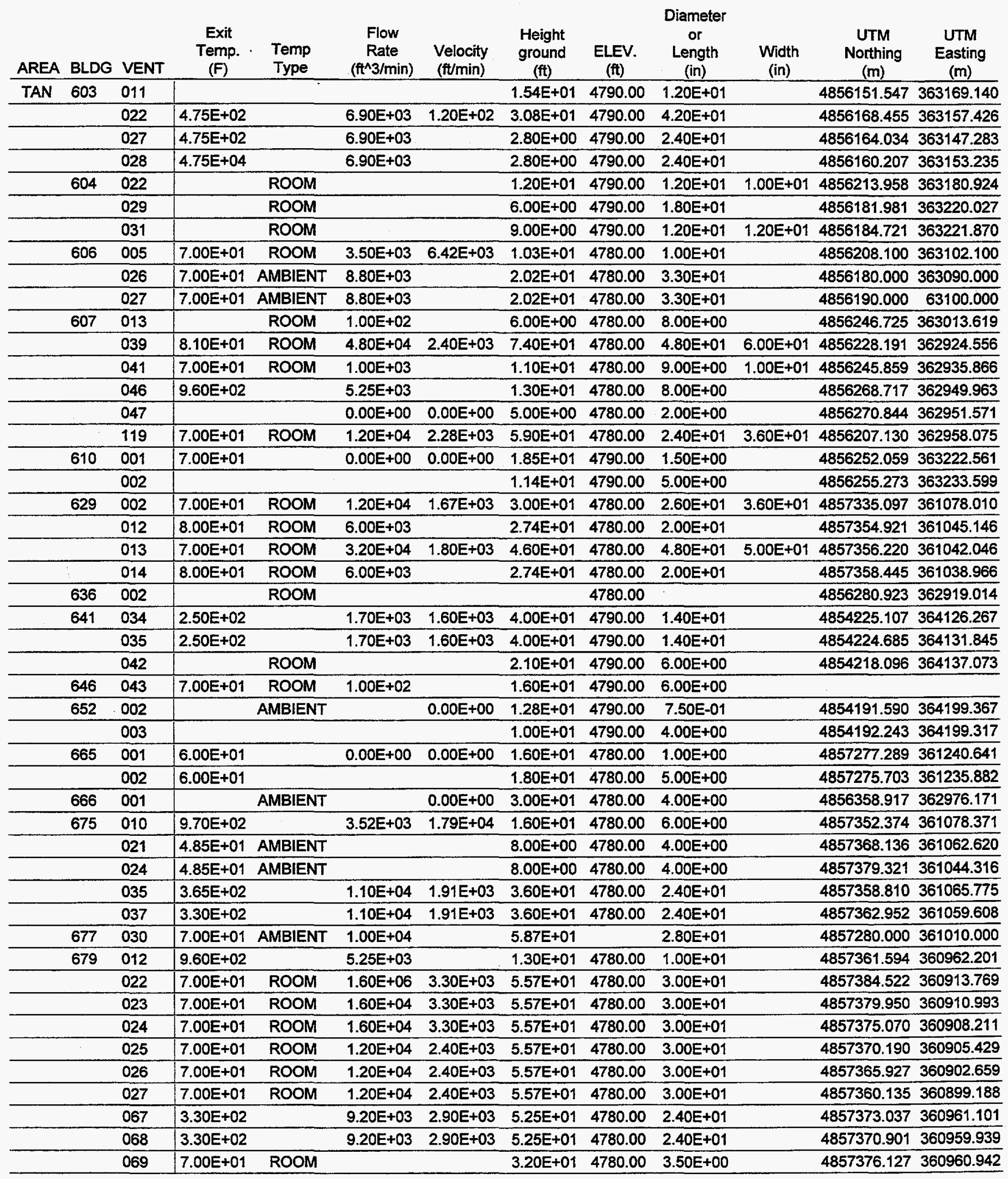




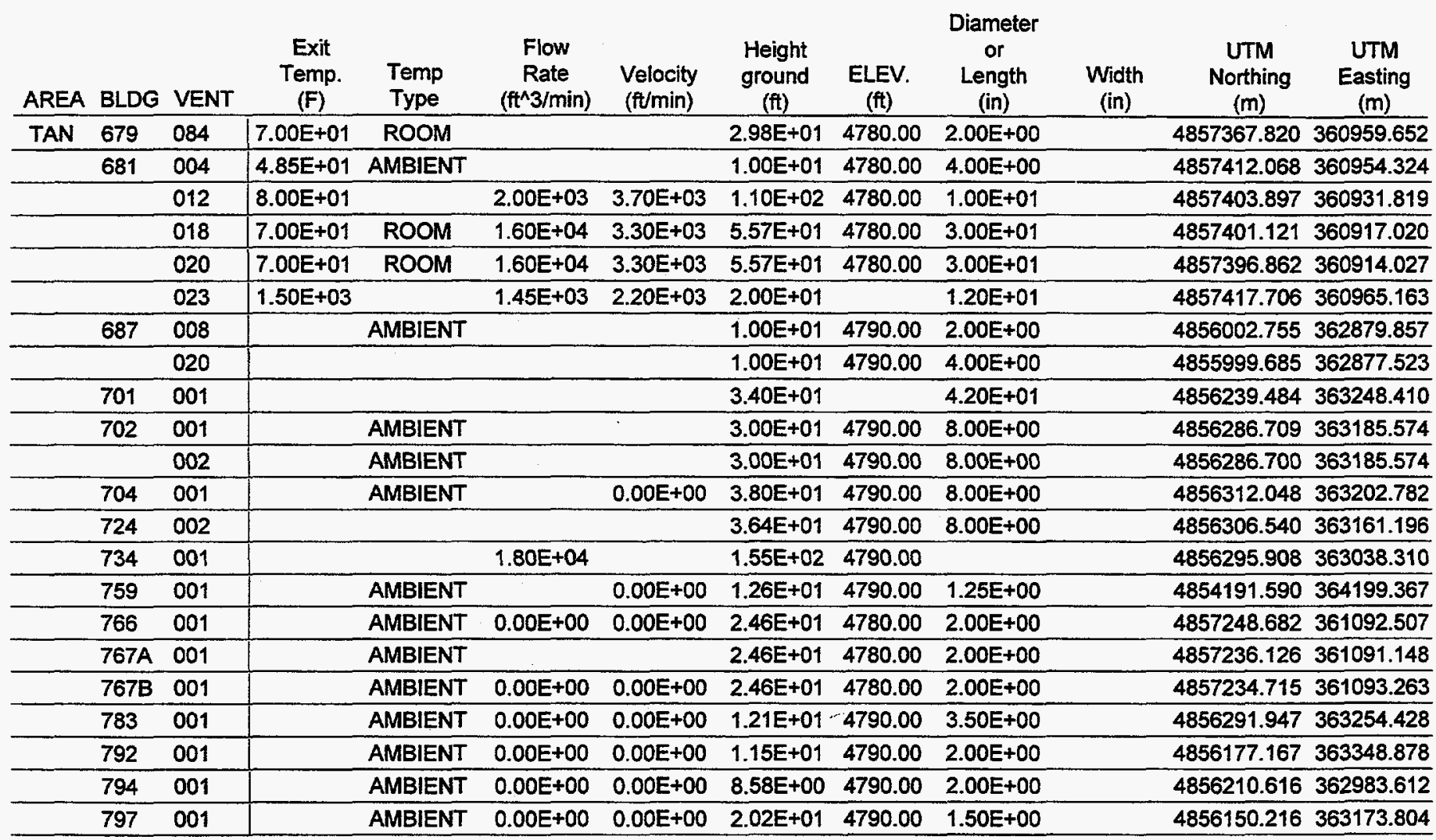




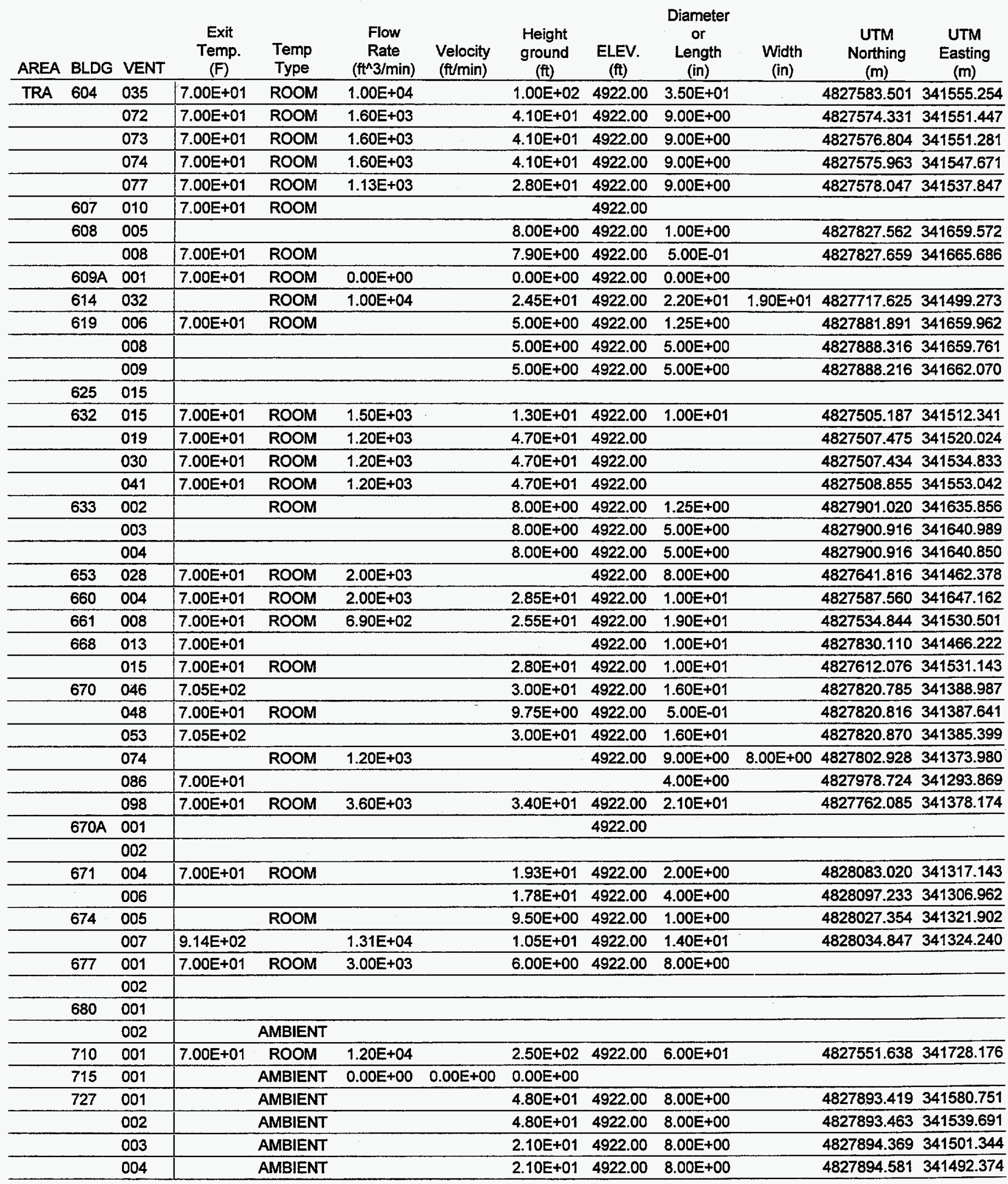




\begin{tabular}{|c|c|c|c|c|c|c|c|c|c|c|c|c|}
\hline AREA & BLDG & VENT & $\begin{array}{l}\text { Exit } \\
\text { Temp. } \\
(\mathrm{F}) \\
\end{array}$ & $\begin{array}{l}\text { Temp } \\
\text { Type }\end{array}$ & $\begin{array}{c}\text { Flow } \\
\text { Rate } \\
\left(\mathrm{f}^{\wedge} 3 / \mathrm{min}\right) \\
\end{array}$ & $\begin{array}{l}\text { Velocity } \\
\text { (ft/min) }\end{array}$ & $\begin{array}{c}\text { Height } \\
\text { ground } \\
\text { (ft) }\end{array}$ & $\begin{array}{c}\text { ELEV. . } \\
\text { (ft) }\end{array}$ & $\begin{array}{c}\text { Diameter } \\
\text { or } \\
\text { Length } \\
\text { (in) }\end{array}$ & $\begin{array}{l}\text { Width } \\
\text { (in) }\end{array}$ & $\begin{array}{c}\text { UTM } \\
\text { Northing } \\
\text { (m) }\end{array}$ & $\begin{array}{c}\text { UTM } \\
\text { Easting } \\
\text { (m) }\end{array}$ \\
\hline \multirow[t]{6}{*}{ TRA } & 770 & 001 & $7.00 \mathrm{E}+01$ & ROOM & $4.50 E+04$ & & $2.50 E+02$ & 4922.00 & $6.00 E+01$ & & 4827896.455 & 341269.613 \\
\hline & 771 & 001 & & & & & $2.00 \mathrm{E}+01$ & 4922.00 & & & 4828118.629 & 341325.734 \\
\hline & 775 & 001 & & AMBIENT & & & 2.10E+01 & 4922.00 & $8.00 E+00$ & & 4827894.157 & 341510.314 \\
\hline & 776 & 001 & & AMBIENT & & & $1.20 \mathrm{E}+02$ & 4922.00 & $2.00 E+00$ & & 4827820.748 & 41390.550 \\
\hline & $777 \mathrm{~B}$ & 001 & & & & & & & & & & \\
\hline & $777 \mathrm{C}$ & 001 & & AMBIENT & & & & 4922.00 & & & & \\
\hline
\end{tabular}




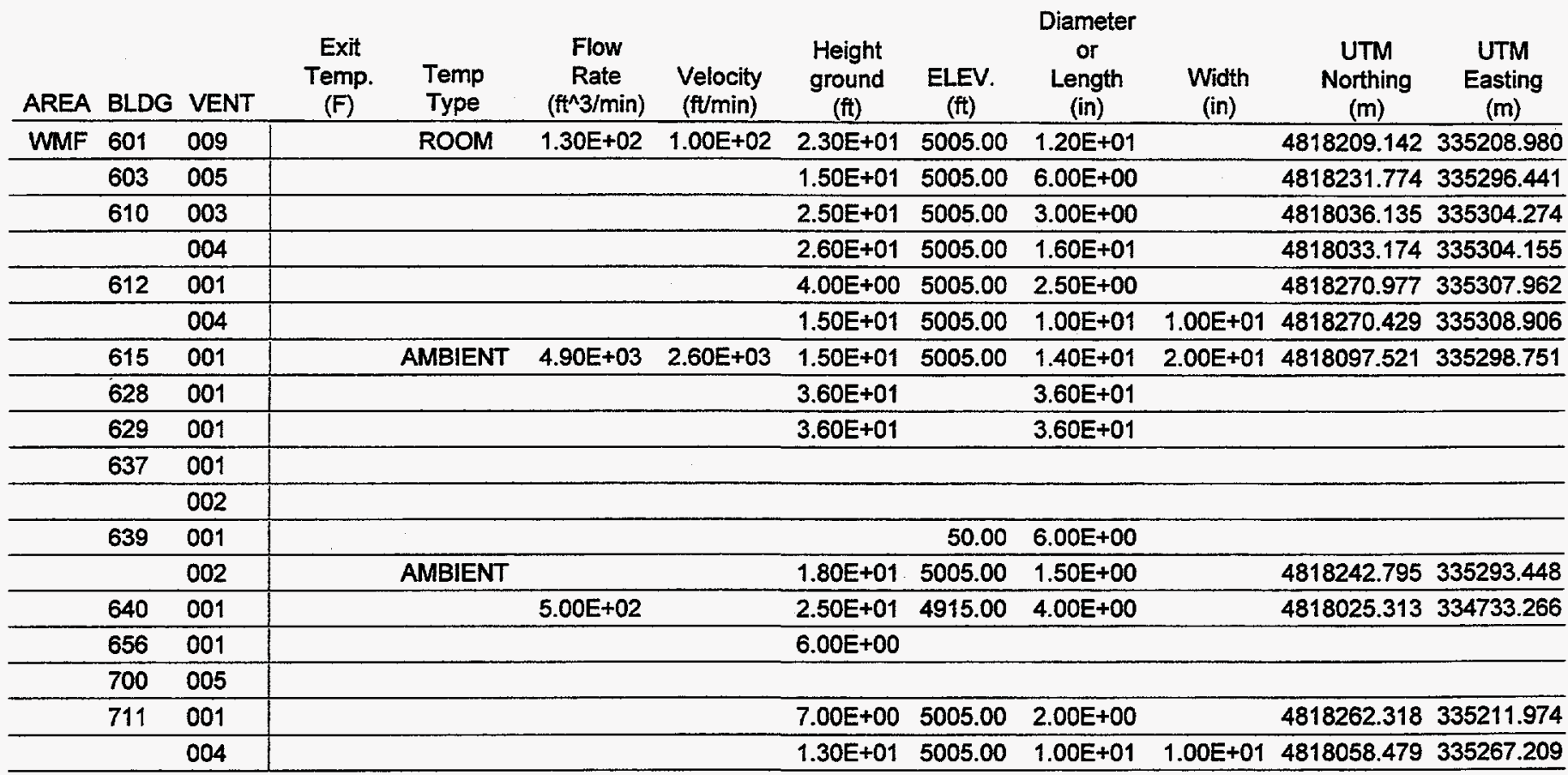


PART ।

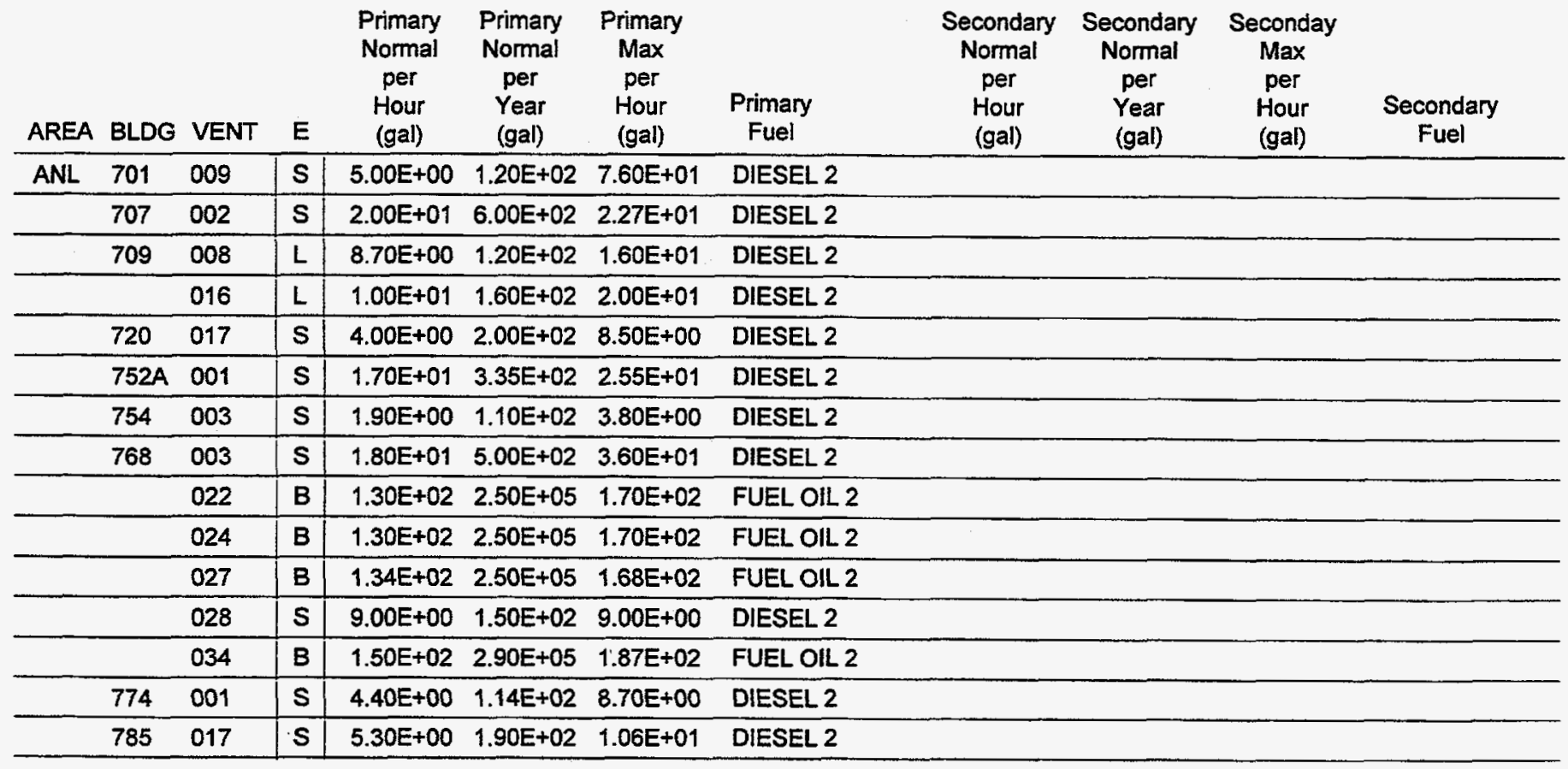


Update Survey for AIR EMISSION INVENTORY FUEL BURNING EQUIPMENT -1994

PART I

\begin{tabular}{|c|c|c|c|c|c|c|c|c|c|c|c|}
\hline AREA & BLDG & VENT & $E$ & $\begin{array}{c}\text { Primary } \\
\text { Normal } \\
\text { per } \\
\text { Hour } \\
\text { (gal) }\end{array}$ & $\begin{array}{c}\text { Primary } \\
\text { Normal } \\
\text { per } \\
\text { Year } \\
\text { (gal) }\end{array}$ & $\begin{array}{l}\text { Primary } \\
\text { Max } \\
\text { per } \\
\text { Hour } \\
\text { (gal) }\end{array}$ & $\begin{array}{l}\text { Primary } \\
\text { Fuel }\end{array}$ & $\begin{array}{c}\text { Secondary } \\
\text { Normal } \\
\text { per } \\
\text { Hour } \\
\text { (gal) }\end{array}$ & $\begin{array}{c}\text { Secondary } \\
\text { Normal } \\
\text { per } \\
\text { Year } \\
\text { (gal) }\end{array}$ & $\begin{array}{c}\text { Seconday } \\
\text { Max } \\
\text { per } \\
\text { Hour } \\
\text { (gal) }\end{array}$ & $\begin{array}{c}\text { Secondary } \\
\text { Fuel }\end{array}$ \\
\hline B08 & 601 & 003 & 5 & $2.50 \mathrm{E}+00$ & $6.50 E+01$ & $5.00 \mathrm{E}+00$ & DIESEL 2 & & & & \\
\hline
\end{tabular}


PART I

\begin{tabular}{|c|c|c|c|c|c|c|c|c|c|c|c|}
\hline AREA & BLDG & VENT & $E$ & $\begin{array}{c}\text { Primary } \\
\text { Normal } \\
\text { per } \\
\text { Hour } \\
\text { (gal) }\end{array}$ & $\begin{array}{c}\text { Primary } \\
\text { Normal } \\
\text { per } \\
\text { Year } \\
\text { (gal) }\end{array}$ & $\begin{array}{c}\text { Primary } \\
\text { Max } \\
\text { per } \\
\text { Hour } \\
\text { (gal) }\end{array}$ & $\begin{array}{l}\text { Primary } \\
\text { Fuel }\end{array}$ & $\begin{array}{c}\text { Secondary } \\
\text { Normal } \\
\text { per } \\
\text { Hour } \\
\text { (gal) }\end{array}$ & $\begin{array}{l}\text { Secondary } \\
\text { Normal } \\
\text { per } \\
\text { Year } \\
\text { (gal) }\end{array}$ & $\begin{array}{c}\text { Seconday } \\
\text { Max } \\
\text { per } \\
\text { Hour } \\
\text { (gal) }\end{array}$ & $\begin{array}{c}\text { Secondary } \\
\text { Fuel }\end{array}$ \\
\hline B27 & 601 & 001 & 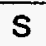 & $2.50 E+00$ & $6.50 \mathrm{E}+00$ & $5.00 E+00$ & DIESEL 2 & & & & \\
\hline
\end{tabular}



PART I

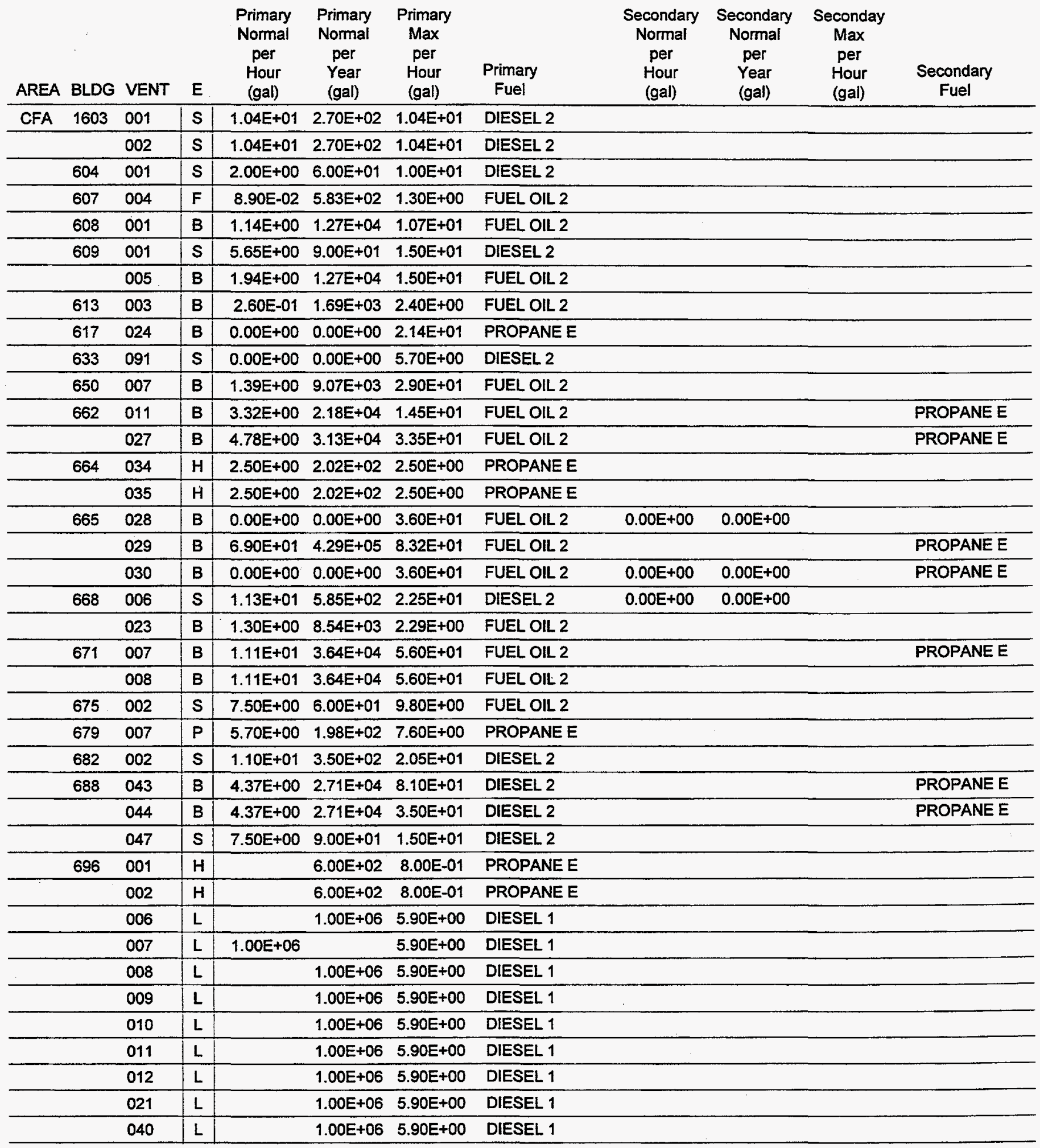


PART I

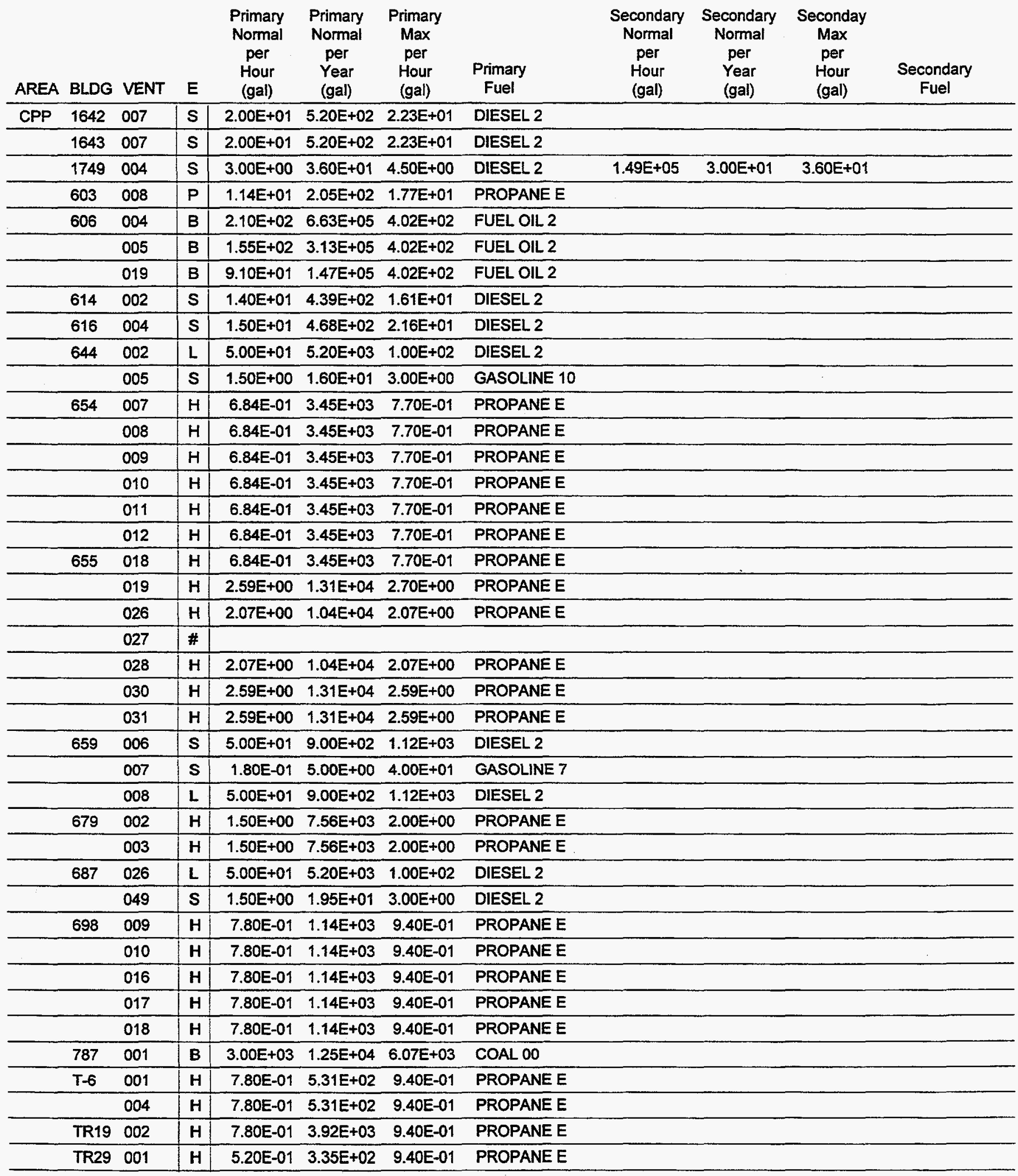


Update Survey for AIR EMISSION INVENTORY FUEL BURNING EQUIPMENT -1994

Page: 6

PART I

\begin{tabular}{|c|c|c|c|c|c|c|c|c|c|c|c|}
\hline AREA & BLDG & VENT & $E$ & $\begin{array}{c}\text { Primary } \\
\text { Normal } \\
\text { per } \\
\text { Hour } \\
\text { (gai) }\end{array}$ & $\begin{array}{c}\text { Primary } \\
\text { Normal } \\
\text { per } \\
\text { Year } \\
\text { (gal) }\end{array}$ & $\begin{array}{c}\text { Primary } \\
\text { Max } \\
\text { per } \\
\text { Hour } \\
\text { (gal) }\end{array}$ & $\begin{array}{l}\text { Primary } \\
\text { Fuel }\end{array}$ & $\begin{array}{c}\text { Secondary } \\
\text { Normal } \\
\text { per } \\
\text { Hour } \\
\text { (gal) }\end{array}$ & $\begin{array}{c}\text { Secondary } \\
\text { Normal } \\
\text { per } \\
\text { Year } \\
\text { (gal) }\end{array}$ & $\begin{array}{c}\text { Seconday } \\
\text { Max } \\
\text { per } \\
\text { Hour } \\
\text { (gal) }\end{array}$ & $\begin{array}{c}\text { Secondary } \\
\text { Fuel }\end{array}$ \\
\hline CPP & TR29 & 008 & $\mathrm{H}$ & 5.20E-01 & $3.35 E+02$ & $9.40 \mathrm{E}-01$ & PROPANE E & & & & \\
\hline
\end{tabular}


PART I

\begin{tabular}{|c|c|c|c|c|c|c|c|c|c|c|c|}
\hline AREA & BLDG & VENT & $E$ & $\begin{array}{c}\text { Primary } \\
\text { Normal } \\
\text { per } \\
\text { Hour } \\
\text { (gal) }\end{array}$ & $\begin{array}{c}\text { Primary } \\
\text { Normal } \\
\text { per } \\
\text { Year } \\
\text { (gal) }\end{array}$ & $\begin{array}{c}\text { Primary } \\
\text { Max } \\
\text { per } \\
\text { Hour } \\
\text { (gal) }\end{array}$ & $\begin{array}{c}\text { Primary } \\
\text { Fuel }\end{array}$ & $\begin{array}{l}\text { Secondary } \\
\text { Normal } \\
\text { per } \\
\text { Hour } \\
\text { (gal) }\end{array}$ & $\begin{array}{c}\text { Secondary } \\
\text { Normal } \\
\text { per } \\
\text { Year } \\
\text { (gal) }\end{array}$ & $\begin{array}{c}\text { Seconday } \\
\text { Max } \\
\text { per } \\
\text { Hour } \\
\text { (gal) }\end{array}$ & $\begin{array}{c}\text { Secondary } \\
\text { Fuel }\end{array}$ \\
\hline HPTF & 601 & 001 & $P$ & $3.50 E+01$ & $1.50 E+02$ & & PROPANE E & & & & \\
\hline
\end{tabular}


PART I

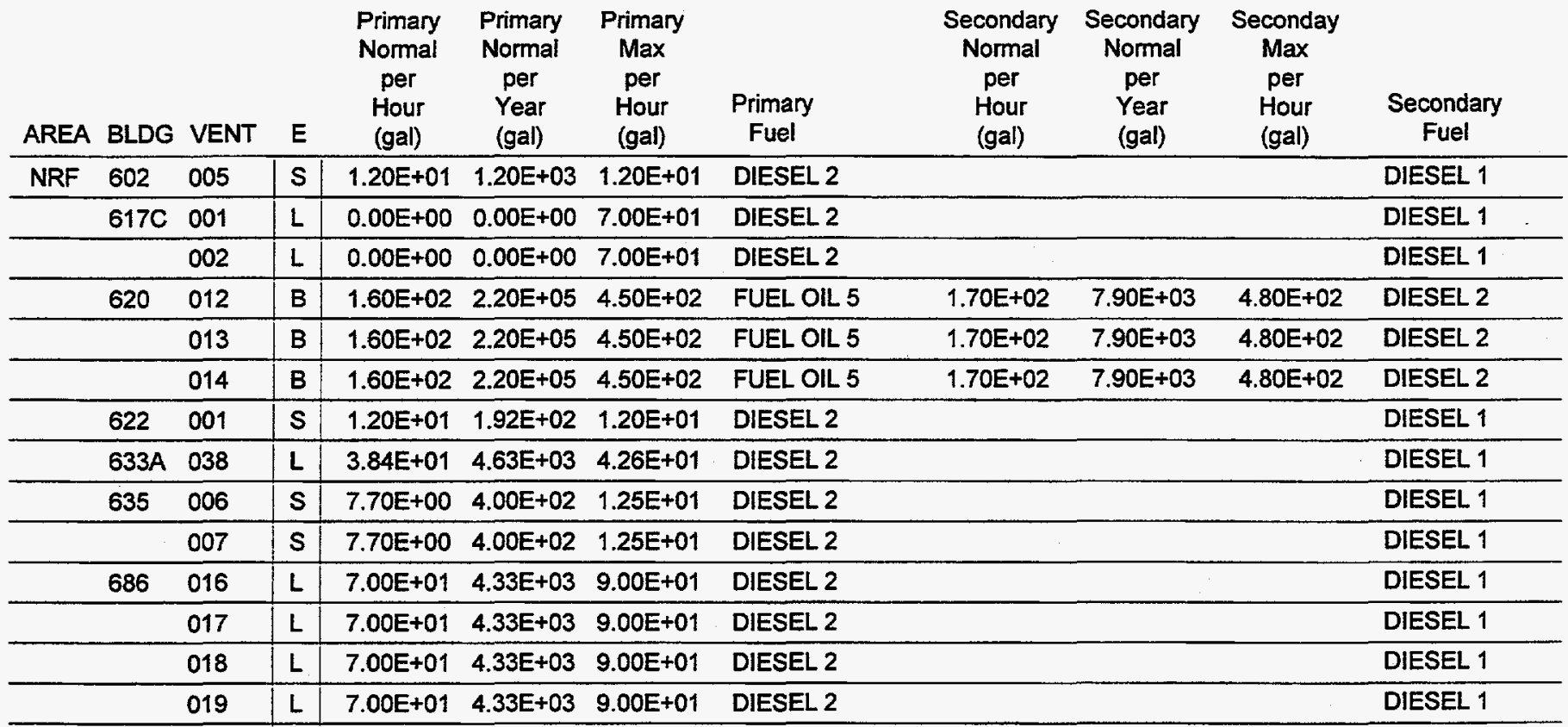


PART I

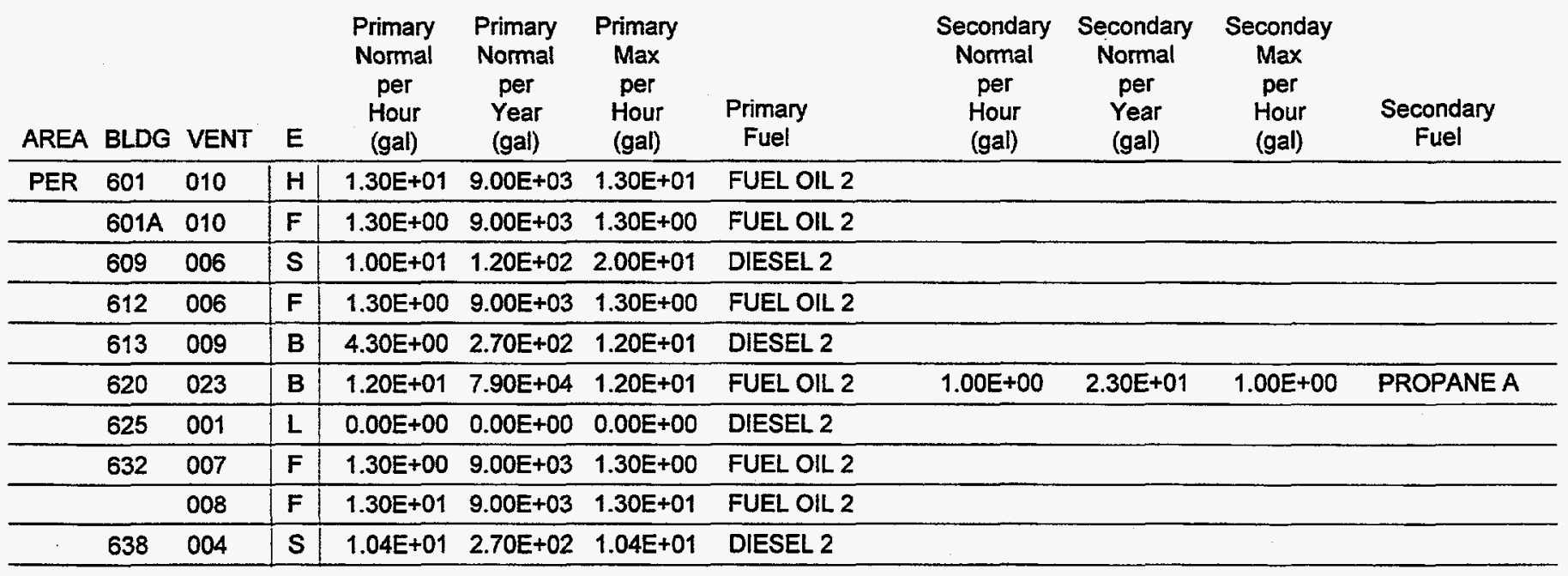




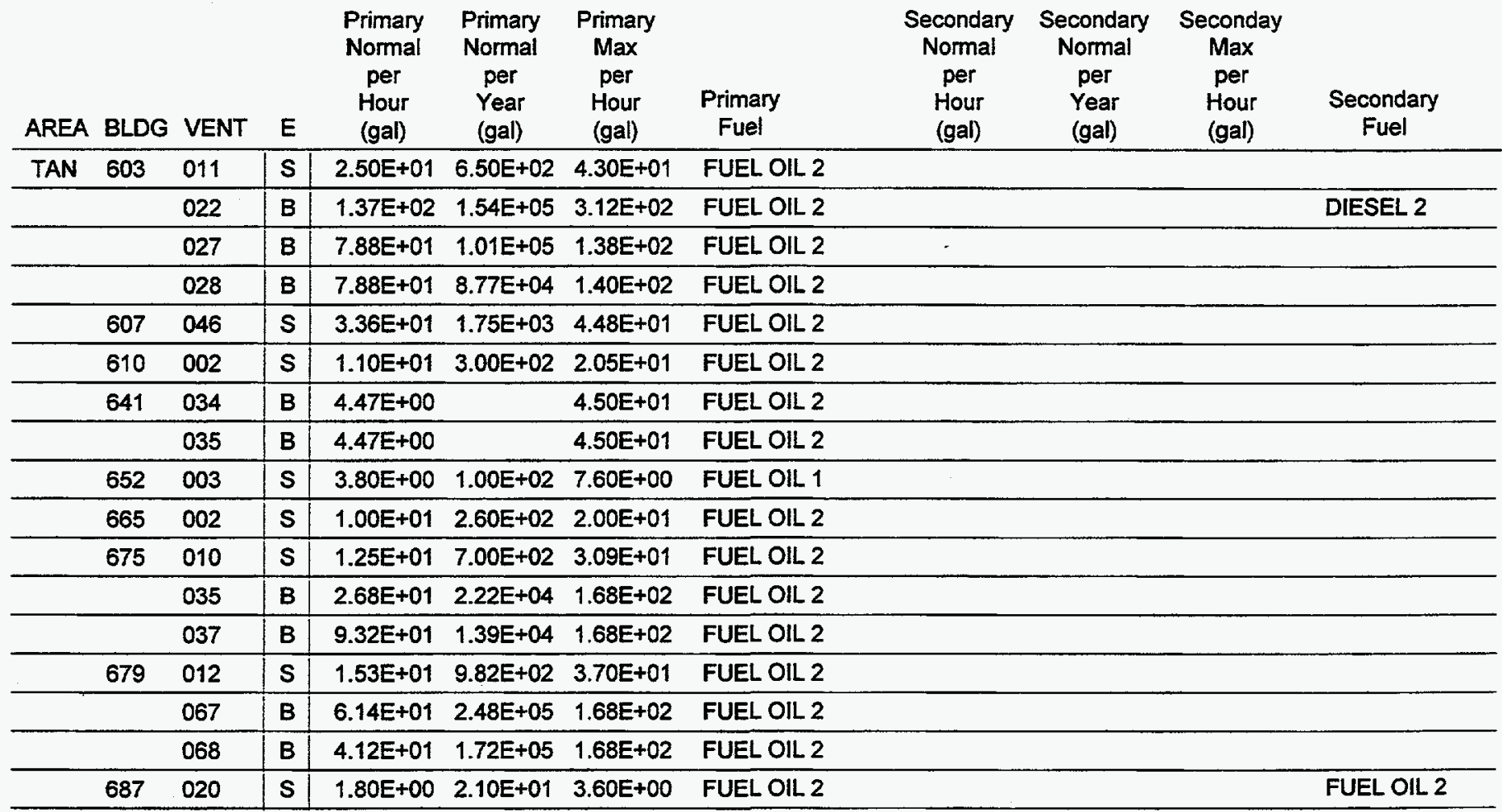


Update Survey for AIR EMISSION INVENTORY FUEL BURNING EQUIPMENT -1994

PART I

\begin{tabular}{|c|c|c|c|c|c|c|c|c|c|c|c|}
\hline AREA & BLDG & VENT & E & $\begin{array}{c}\text { Primary } \\
\text { Normal } \\
\text { per } \\
\text { Hour } \\
\text { (gal) }\end{array}$ & $\begin{array}{c}\text { Primary } \\
\text { Normal } \\
\text { per } \\
\text { Year } \\
\text { (gal) }\end{array}$ & $\begin{array}{c}\text { Primary } \\
\text { Max } \\
\text { per } \\
\text { Hour } \\
\text { (gal) }\end{array}$ & $\begin{array}{c}\text { Primary } \\
\text { Fuel }\end{array}$ & $\begin{array}{c}\text { Secondary } \\
\text { Normal } \\
\text { per } \\
\text { Hour } \\
\text { (gal) }\end{array}$ & $\begin{array}{c}\text { Secondary } \\
\text { Normal } \\
\text { per } \\
\text { Year } \\
\text { (gal) }\end{array}$ & $\begin{array}{c}\text { Seconday } \\
\text { Max } \\
\text { per } \\
\text { Hour } \\
\text { (gal) }\end{array}$ & $\begin{array}{c}\text { Secondary } \\
\text { Fuel }\end{array}$ \\
\hline \multirow[t]{3}{*}{ TRA } & 619 & 008 & $s$ & $1.00 E+01$ & $5.20 \mathrm{E}+02$ & $1.00 \mathrm{E}+01$ & DIESEL 1 & & & & \\
\hline & & 009 & $S$ & $1.00 E+01$ & $5.20 \mathrm{E}+02$ & $1.00 \mathrm{E}+01$ & DIESEL 1 & & & & \\
\hline & 633 & 003 & $\mathbf{S}$ & $1.00 \mathrm{E}+01$ & $5.20 \mathrm{E}+02$ & $1.00 \mathrm{E}+01$ & DIESEL 1 & & & & \\
\hline & \multirow[t]{2}{*}{670} & 046 & $L$ & $4.80 \mathrm{E}+01$ & $2.10 \mathrm{E}+05$ & $6.00 \mathrm{E}+01$ & DIESEL 2 & & & & \\
\hline & & 053 & $\mathbf{L}$ & $4.80 \mathrm{E}+01$ & $2.08 E \div 05$ & $6.00 \mathrm{E}+01$ & DIESEL 2 & & & & \\
\hline & $670 A$ & 001 & $S$ & & & & DIESEL 2 & & & & \\
\hline 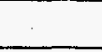 & 674 & 007 & $S$ & $5.40 \mathrm{E}+01$ & $1.41 E+03$ & $1.08 E+02$ & DIESEL 2 & & & & \\
\hline & 680 & 001 & $\mathbf{S}$ & $1.00 E+00$ & $6.00 \mathrm{E}+00$ & & DIESEL 1 & & & & \\
\hline
\end{tabular}


PART I

\begin{tabular}{|c|c|c|c|c|c|c|c|c|c|c|c|}
\hline AREA & BLDG & VENT & $E$ & $\begin{array}{l}\text { Primary } \\
\text { Normal } \\
\text { per } \\
\text { Hour } \\
\text { (gal) }\end{array}$ & $\begin{array}{c}\text { Primary } \\
\text { Normal } \\
\text { per } \\
\text { Year } \\
\text { (gal) }\end{array}$ & $\begin{array}{l}\text { Primary } \\
\text { Max } \\
\text { per } \\
\text { Hour } \\
\text { (gal) }\end{array}$ & $\begin{array}{c}\text { Primary } \\
\text { Fuel }\end{array}$ & $\begin{array}{l}\text { Secondary } \\
\text { Normal } \\
\text { per } \\
\text { Hour } \\
\text { (gal) }\end{array}$ & $\begin{array}{c}\text { Secondary } \\
\text { Normal } \\
\text { per } \\
\text { Year } \\
\text { (gal) }\end{array}$ & $\begin{array}{c}\text { Seconday } \\
\text { Max } \\
\text { per } \\
\text { Hour } \\
\text { (gal) }\end{array}$ & $\begin{array}{l}\text { Secondary } \\
\text { Fuel }\end{array}$ \\
\hline \multirow[t]{2}{*}{ WMF } & 603 & 005 & $\mathbf{P}$ & $2.00 E+00$ & $2.00 E+02$ & $2.70 E+00$ & PROPANE E & & & & \\
\hline & \multirow[t]{2}{*}{610} & 003 & $P$ & $4.00 E+00$ & $2.00 E+02$ & $4.00 E+00$ & PROPANE E & & & & \\
\hline & & 004 & $\mathbf{P}$ & $4.00 E+00$ & $2.40 E+03$ & $4.00 E+00$ & PROPANE E & & & & \\
\hline & 612 & 004 & $\mathbf{P}$ & $3.50 E+01$ & $2.00 E+04$ & $3.50 E+01$ & PROPANE E & & & & \\
\hline & \multirow[t]{2}{*}{637} & 001 & B & & & & PROPANE A & & & & \\
\hline & & 002 & $\mathrm{H}$ & & & & & & & & \\
\hline & 639 & 001 & $\mathbf{S}$ & & & & & & & & \\
\hline & 711 & 001 & $\mathbf{P}$ & $1.00 \mathrm{E}+00$ & $2.00 \mathrm{E}+02$ & $1.30 \mathrm{E}+00$ & PROPANE E & & & & \\
\hline
\end{tabular}


PART II

\begin{tabular}{|c|c|c|c|c|c|c|c|}
\hline $\begin{array}{l}\text { AREA } \\
\text { ANL } \\
\end{array}$ & $\begin{array}{l}\text { BLDG } \\
701 \\
\end{array}$ & $\begin{array}{l}\text { VENT } \\
009 \\
\end{array}$ & $\begin{array}{l}E \\
S\end{array}$ & $\begin{array}{l}\text { Rated } \\
\text { Heat }\end{array}$ & CLASS & $\begin{array}{l}\text { Horse } \\
\text { Power } \\
143.0\end{array}$ & $\begin{array}{c}\text { Maximum Hours } \\
5400\end{array}$ \\
\hline & 707 & 002 & $S$ & & & 460.0 & 1800 \\
\hline \multirow{2}{*}{\multicolumn{2}{|c|}{709}} & 008 & $L$ & & & & 8760 \\
\hline & & 016 & $L$ & & & & 8760 \\
\hline & 720 & 017 & $\mathbf{S}$ & & & 173.0 & 5400 \\
\hline & $752 \mathrm{~A}$ & 001 & $S$ & & & 390.0 & 2700 \\
\hline & 754 & 003 & $S$ & & & 77.0 & 8760 \\
\hline & 768 & 003 & $s$ & & & 741.0 & 200 \\
\hline & & 022 & B & 22.5 & INDUSTRIAL & & 8760 \\
\hline & & 024 & B & 24.0 & INDUSTRIAL & & 8760 \\
\hline & & 027 & B & 24.0 & INDUSTRIAL & & 8760 \\
\hline & & 028 & $S$ & & & 173.0 & 5400 \\
\hline & & 034 & B & 25.0 & INDUSTRIAL & & 8760 \\
\hline & 774 & 001 & $S$ & & & 166.0 & 5400 \\
\hline & 785 & 017 & $\mathbf{S}$ & & & 290.0 & 2700 \\
\hline
\end{tabular}


PART II

\begin{tabular}{lllllll} 
AREA & BLDG & VENT & E & $\begin{array}{l}\text { Rated } \\
\text { Heat }\end{array}$ & CLASS & \multicolumn{2}{c}{$\begin{array}{c}\text { Horse } \\
\text { Power }\end{array}$} & $\begin{array}{c}\text { Maximum Hours } \\
\text { B08 }\end{array} \quad 601$ & 003 & $\mathrm{~S}$ & & 60.0 & 8760 \\
\hline
\end{tabular}




\begin{tabular}{lllllll} 
AREA & BLDG & VENT & E & $\begin{array}{l}\text { Rated } \\
\text { Heat }\end{array}$ & CLASS & Horse \\
B27 & 601 & 001 & $\mathrm{~S}$ & & $\begin{array}{c}\text { Power } \\
\text { Maximum Hours }\end{array}$ \\
\hline
\end{tabular}




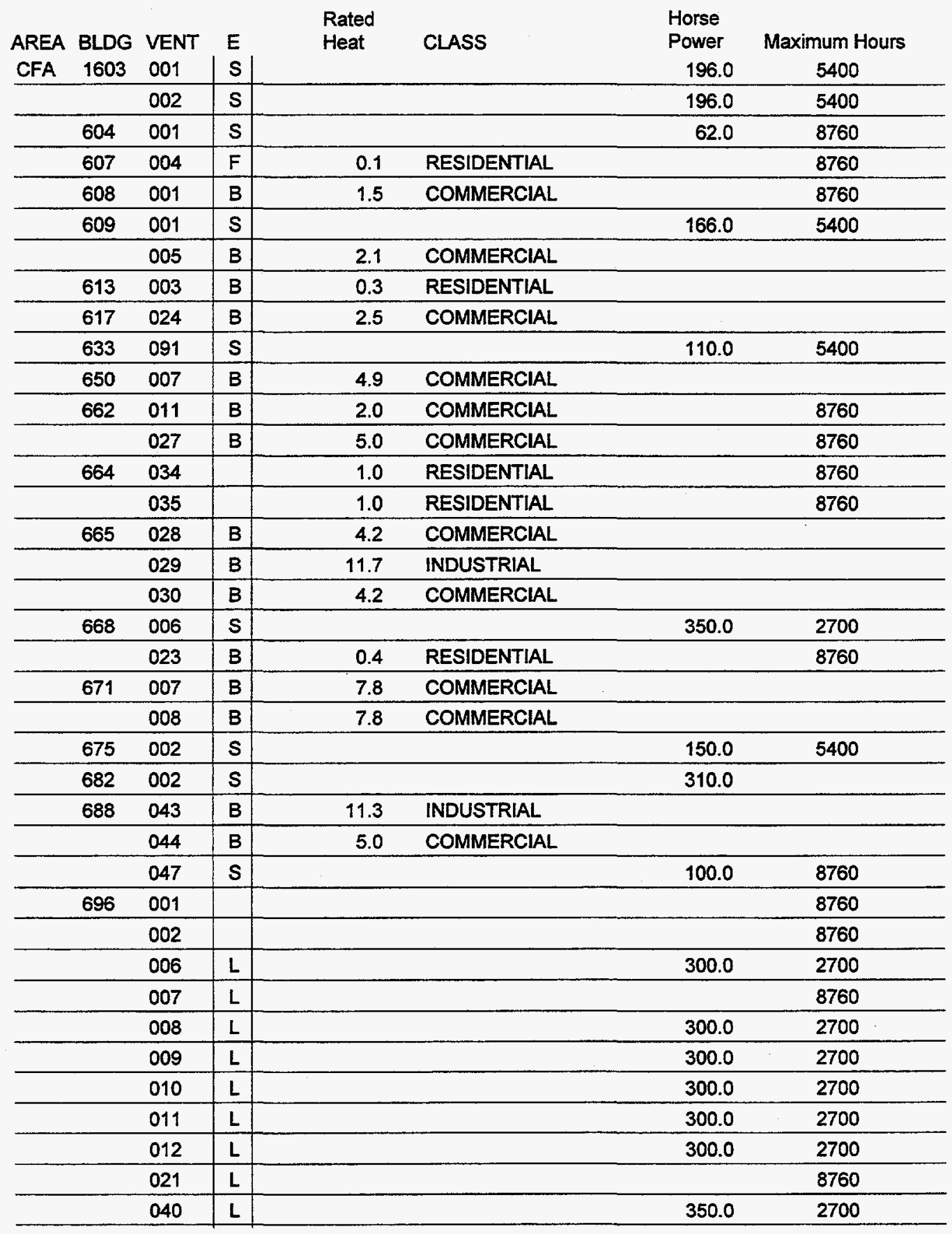




\begin{tabular}{|c|c|c|c|c|c|c|c|}
\hline $\begin{array}{l}\text { AREA } \\
\text { CPP } \\
\end{array}$ & $\begin{array}{c}\text { BLDG } \\
1642 \\
\end{array}$ & $\begin{array}{l}\text { VENT } \\
007 \\
\end{array}$ & $\begin{array}{l}E \\
S\end{array}$ & $\begin{array}{l}\text { Rated } \\
\text { Heat }\end{array}$ & CLASS & $\begin{array}{c}\text { Horse } \\
\text { Power } \\
370.0 \\
\end{array}$ & $\begin{array}{c}\text { Maximum Hours } \\
2700 \\
\end{array}$ \\
\hline & 1643 & 007 & $\mathrm{~s}$ & & & 370.0 & 2700 \\
\hline & 1749 & 004 & $\mathrm{~s}$ & & & 50.0 & 8760 \\
\hline \multirow{3}{*}{\multicolumn{2}{|c|}{606}} & 004 & B & 53906.0 & INDUSTRIAL & & 8760 \\
\hline & & 005 & $\mathrm{~B}$ & 53906.0 & INDUSTRIAL & & 8760 \\
\hline & & 019 & $\mathrm{~B}$ & & INDUSTRIAL & & 8760 \\
\hline & 614 & 002 & $\mathrm{~s}$ & & & 300.0 & 2700 \\
\hline & 616 & 004 & $\mathrm{~s}$ & & & 360.0 & 2700 \\
\hline \multirow{2}{*}{\multicolumn{2}{|c|}{644}} & 002 & $L$ & & & 2000.0 & 200 \\
\hline & & 005 & $s$ & & & 14.0 & 8760 \\
\hline \multirow{6}{*}{\multicolumn{2}{|c|}{654}} & 007 & & & & & 8760 \\
\hline & & 008 & & & & & 8760 \\
\hline & & 009 & & & & & 8760 \\
\hline & & 010 & & & & & 8760 \\
\hline & & 011 & & & & & 8760 \\
\hline & & 012 & & & & & 8760 \\
\hline \multirow{6}{*}{\multicolumn{2}{|c|}{655}} & 018 & & & & & 8760 \\
\hline & & 019 & & & & & 8760 \\
\hline & & 026 & & & & & 8760 \\
\hline & & 028 & & & & & 8760 \\
\hline & & 030 & & & & & 8760 \\
\hline & & 031 & & & & & 8760 \\
\hline \multirow{3}{*}{\multicolumn{2}{|c|}{659}} & 006 & $s$ & & & 1740.0 & 200 \\
\hline & & 007 & $\mathrm{~s}$ & & & 8.0 & 8760 \\
\hline & & 008 & $\mathrm{~L}$ & & & 1616.0 & 200 \\
\hline \multirow{2}{*}{\multicolumn{2}{|c|}{679}} & 002 & & & & & 8760 \\
\hline & & 003 & & & & & 8760 \\
\hline \multirow{2}{*}{\multicolumn{2}{|c|}{687}} & 026 & $\mathbf{L}$ & & & 2535.0 & 200 \\
\hline & & 049 & $\mathrm{~s}$ & & & 14.0 & 5400 \\
\hline \multirow{5}{*}{\multicolumn{2}{|c|}{698}} & 009 & & & & & 8760 \\
\hline & & 010 & & & & & 8760 \\
\hline & & 016 & & & & & 8760 \\
\hline & & 017 & & & & & 8760 \\
\hline & & 018 & & & & & 8760 \\
\hline & 787 & 001 & B & & INDUSTRIAL & & 8760 \\
\hline \multirow{2}{*}{\multicolumn{2}{|c|}{$T-6$}} & 001 & & & & & 8760 \\
\hline & & 004 & & & & & 8760 \\
\hline & TR19 & 002 & & & & & 8760 \\
\hline \multirow{2}{*}{\multicolumn{2}{|c|}{ TR29 }} & 001 & & & & & 8760 \\
\hline & & 008 & & & & & 8760 \\
\hline
\end{tabular}


PART II

\begin{tabular}{|c|c|c|c|c|c|c|c|}
\hline $\begin{array}{l}\text { AREA } \\
\text { NRF }\end{array}$ & $\begin{array}{l}\text { BLDG } \\
602\end{array}$ & $\begin{array}{l}\text { VENT } \\
005\end{array}$ & $\begin{array}{l}E \\
S \mid\end{array}$ & $\begin{array}{l}\text { Rated } \\
\text { Heat }\end{array}$ & CLASS & $\begin{array}{l}\text { Horse } \\
\text { Power } \\
300.0\end{array}$ & $\begin{array}{c}\text { Maximum Hours } \\
2700\end{array}$ \\
\hline \multirow{2}{*}{\multicolumn{2}{|c|}{$617 \mathrm{C}$}} & 001 & $\mathbf{L}$ & & & 1400.0 & 200 \\
\hline & & 002 & $\mathrm{~L}$ & & & 1400:0 & 200 \\
\hline \multirow{3}{*}{\multicolumn{2}{|c|}{620}} & 012 & B & 48.0 & INDUSTRIAL & & 8760 \\
\hline & & 013 & B & 48.0 & INDUSTRIAL & & 8760 \\
\hline & & 014 & $\mathrm{~B}$ & 48.0 & INDUSTRIAL & & 8760 \\
\hline & 622 & 001 & $S$ & & & 400.0 & 2700 \\
\hline & $633 \mathrm{~A}$ & 038 & $L$ & & & 716.0 & 200 \\
\hline \multirow{2}{*}{\multicolumn{2}{|c|}{635}} & 006 & $\mathbf{s}$ & & & 220.0 & 2700 \\
\hline & & 007 & $\mathbf{s}$ & & & 220.0 & 2700 \\
\hline & 686 & 016 & $L$ & & & 1410.0 & 200 \\
\hline & & 017 & $L$ & & & 1410.0 & 200 \\
\hline & & 018 & $L$ & & & 1410.0 & 200 \\
\hline & & 019 & $L$ & & & 1410.0 & 200 \\
\hline
\end{tabular}


PART II

\begin{tabular}{|c|c|c|c|c|c|c|c|}
\hline $\begin{array}{l}\text { AREA } \\
\text { PER }\end{array}$ & $\begin{array}{l}\text { BLDG } \\
601\end{array}$ & $\begin{array}{l}\text { VENT } \\
010\end{array}$ & $E$ & $\begin{array}{l}\text { Rated } \\
\text { Heat } \\
0.4\end{array}$ & $\begin{array}{l}\text { CLASS } \\
\text { RESIDENTIAL }\end{array}$ & $\begin{array}{l}\text { Horse } \\
\text { Power }\end{array}$ & $\begin{array}{c}\text { Maximum Hours } \\
6923\end{array}$ \\
\hline & $601 \mathrm{~A}$ & 010 & $F$ & 0.2 & RESIDENTIAL & & 6923 \\
\hline & 609 & 006 & $\mathbf{s}$ & & & 335.0 & 2700 \\
\hline & 612 & 006 & $\mathbf{F}$ & 0.6 & COMMERCIAL & & 6923 \\
\hline & 613 & 009 & $\mathbf{B}$ & 1.7 & COMMERCIAL & & 6417 \\
\hline & 620 & 023 & B & 1.6 & COMMERCIAL & & 6580 \\
\hline & 625 & 001 & $\mathbf{L}$ & & & 760.0 & 200 \\
\hline \multirow{2}{*}{\multicolumn{2}{|c|}{632}} & 007 & $\mathbf{F}$ & 0.3 & RESIDENTIAL & & 6923 \\
\hline & & 008 & $\mathbf{F}$ & 0.3 & RESIDENTIAL & & 6923 \\
\hline & 638 & 004 & $\mathbf{s}$ & & & 196.0 & 5400 \\
\hline
\end{tabular}


PART II

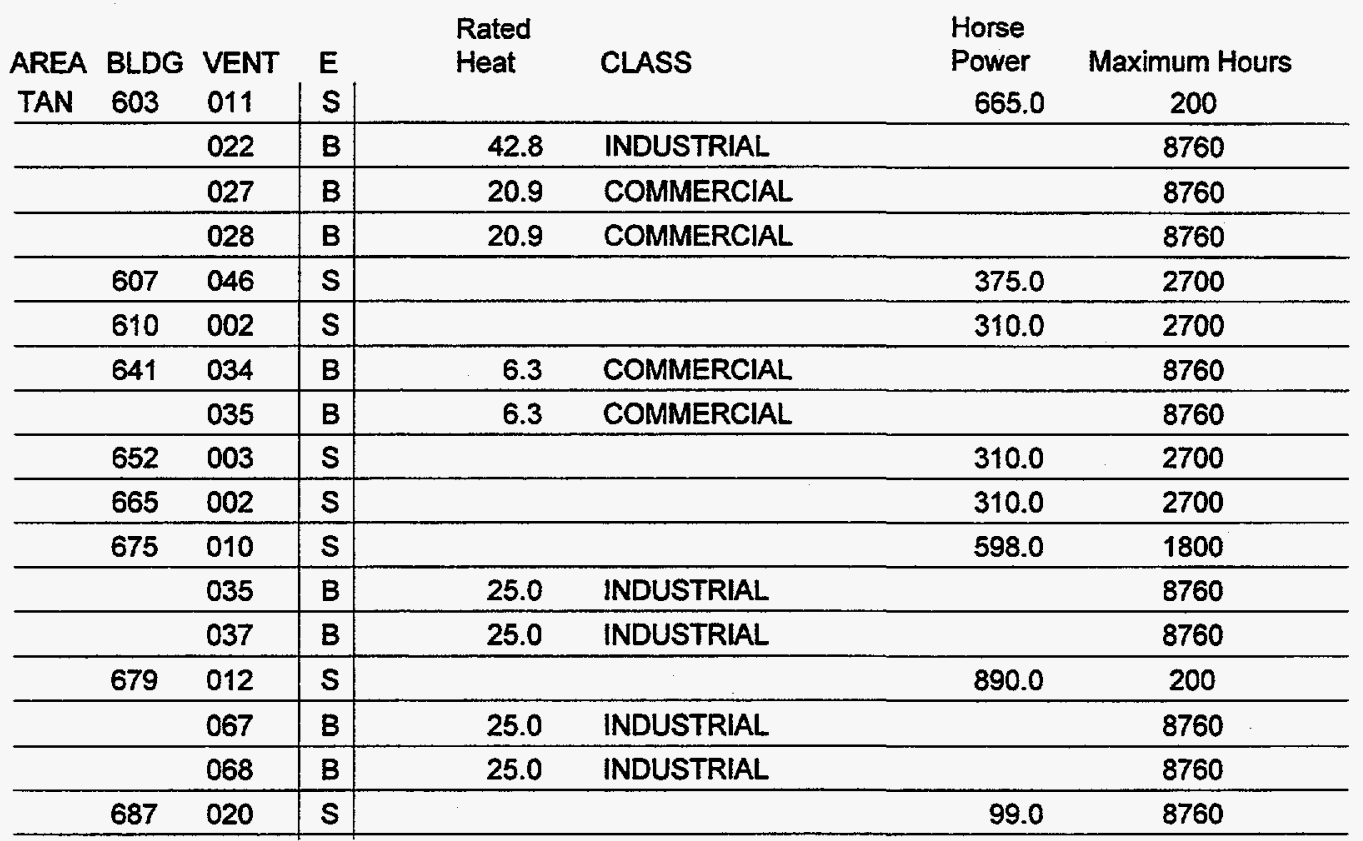


PART II

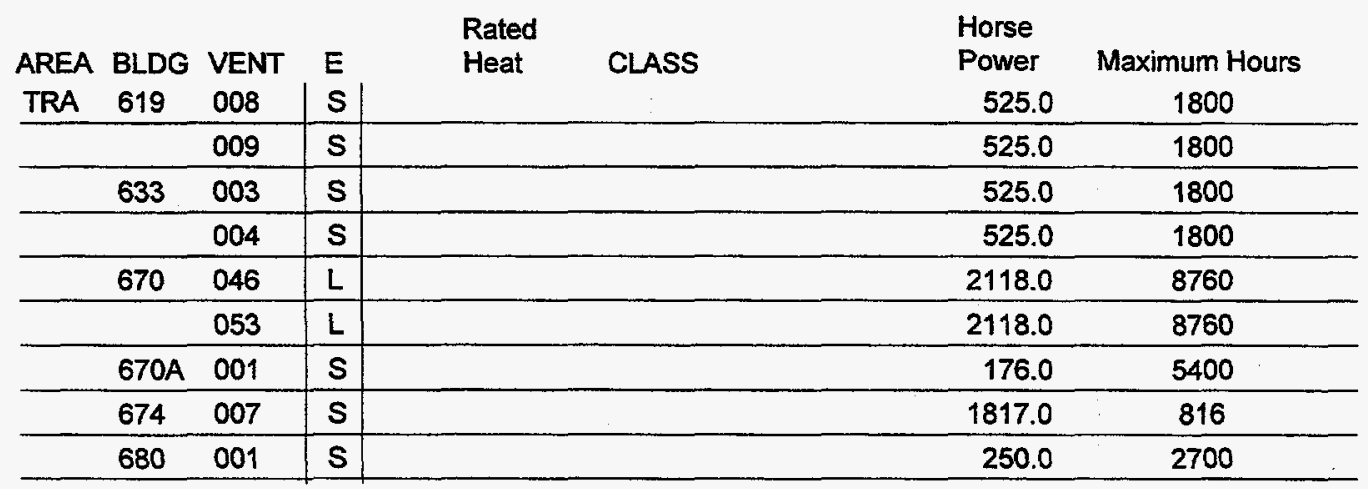



PART II

\begin{tabular}{|c|c|c|c|c|c|c|c|}
\hline $\begin{array}{l}\text { AREA } \\
\text { WMF }\end{array}$ & $\begin{array}{l}\text { BLDG } \\
637\end{array}$ & $\begin{array}{l}\text { VENT } \\
001\end{array}$ & $\begin{array}{l}E \\
B\end{array}$ & $\begin{array}{l}\text { Rated } \\
\text { Heat }\end{array}$ & CLASS & $\begin{array}{l}\text { Horse } \\
\text { Power }\end{array}$ & $\begin{array}{c}\text { Maximum Hours } \\
8760\end{array}$ \\
\hline & & 002 & & 1.2 & RESIDENTIAL & & 8760 \\
\hline & 639 & 001 & S & & & 217.0 & 2700 \\
\hline
\end{tabular}


PART I

\begin{tabular}{|c|c|c|c|c|c|c|c|c|c|c|c|c|}
\hline AREA & BLDG & VENT & $\begin{array}{l}\text { Annual } \\
\text { Thru Put } \\
\text { (gal/yr) }\end{array}$ & $\begin{array}{c}\text { Ave. } \\
\% \\
\text { Full }\end{array}$ & $\begin{array}{l}\text { Fill } \\
\text { Rate } \\
\text { (gall } \\
\text { min) }\end{array}$ & $\begin{array}{l}\text { Vapor } \\
\text { Space } \\
\text { Height } \\
\text { (ft) }\end{array}$ & $\begin{array}{c}\text { Capacity } \\
\text { (gal) }\end{array}$ & $\begin{array}{l}\text { Tank } \\
\text { Dia. } \\
\text { (ft) }\end{array}$ & $\begin{array}{l}\text { Tank } \\
\text { Length } \\
\text { (ft) }\end{array}$ & Tank Type & Material Stored & Tank Location \\
\hline & 707 & 001 & $6.0 \mathrm{E}+02$ & 0.8 & 20 & 5.0E-01 & $2.8 E+023$ & $3.0 E+00$ & $6.0 E+00$ & FIXED ROOF & DIESEL \#2 & INSIDE BUILDING \\
\hline & 709 & 001 & $1.2 E+03$ & 0.9 & 100 & $.6 \mathrm{E}+00$ & $1.1 \mathrm{E}+034$ & $4.0 E+00$ & $1.3 E+01$ & FIXED ROOF & DIESEL \#2 & INSIDE BUILDING \\
\hline & & 009 & $1.2 \mathrm{E}+03$ & 0.9 & 100 & $.6 E+00$ & 1.1E+034 & $4.0 E+00$ & $1.3 E+01$ & FIXED ROOF & DIESEL \#2 & INSIDE BUILDING \\
\hline & 721 & 003 & $1.2 E+03$ & 0.5 & & $.8 E+00$ & $5.0 E+023$ & $3.5 E+00$ & $7.0 E+00$ & FIXED ROOF & DIESEL \#2 & OUTSIDE BUILDING \\
\hline & 742 & 002 & $4.3 E+03$ & 0.5 & 100 & $.0 E+00$ & $4.0 E+036$ & $6.0 E+00$ & $1.8 \mathrm{E}+01$ & FIXED ROOF & GASOLINE & OUTSIDE BUILDING \\
\hline & & 005 & $3.9 E+03$ & 0.5 & 100 & $.0 E+00$ & $2.3 E+026$ & $6.3 E+00$ & $1.3 E+01$ & FIXED ROOF & DIESEL \#2 & OUTSIDE BUILDING \\
\hline & & 006 & $1.5 \mathrm{E}+04$ & 0.5 & 100 & $.0 \mathrm{E}+00$ & $2.3 E+026$ & $6.3 E+00$ & 1.3E+01 & FIXED ROOF & GASOLINE & OUTSIDE BUILDING \\
\hline & $752 A$ & 005 & $3.4 \mathrm{E}+02$ & 0.5 & 100 & $.8 \mathrm{E}+00$ & $5.0 \mathrm{E}+023$ & $3.5 E+00$ & $7.0 E+00$ & FIXED ROOF & DIESEL \#2 & OUTSIDE BUILDING \\
\hline & 768 & 004 & $2.0 \mathrm{E}+03$ & 0.9 & 100 & 5.8E-01: & $3.0 \mathrm{E}+035$ & $5.3 E+00$ & 1.6E+01 & FIXED ROOF & DIESEL \#2 & OUTSIDE BUILDING \\
\hline & & 005 & $1.0 \mathrm{E}+06$ & 0.9 & 100 & $.0 E+00$ & $1.0 \mathrm{E}+041$ & $1.0 E+01$ & 1.7E+01 & FIXED ROOF & DIESEL \#2 & OUTSIDE BUILDING \\
\hline & 774 & 003 & $2.0 E+02$ & 0.9 & 100 & 5.3E-01 & $1.0 \mathrm{E}+035$ & $5.3 E+00$ & $9.0 E+00$ & FIXED ROOF & DIESEL \#2 & OUTSIDE BUILDING \\
\hline & 785 & 015 & $1.9 E+04$ & 0.5 & & $.5 \mathrm{E}+00$ & $5.0 \mathrm{E}+023$ & $3.8 E+00$ & $5.8 \mathrm{E}+00$ & FIXED ROOF & Diesel \#2 & INSIDE BUILDING \\
\hline & 793 & 012 & $0.0 E+00$ & 0.0 & 200 & $.0 E+00$ & $3.0 \mathrm{E}+023$ & $3.7 E+00$ & $5.2 E+00$ & PRESSURE & RADIOACTIVE ETHAN & INSIDE BUILDING \\
\hline & & 014 & $0.0 E+00$ & 0.0 & 200 & $.0 \mathrm{E}+00$ & $3.0 \mathrm{E}+023$ & $3.7 E+00$ & $5.2 E+00$ & PRESSURE & ETHANOL & INSIDE BUILDING \\
\hline & $793 \mathrm{~A}$ & 025 & $0.0 E+\infty 0$ & 0.2 & 200 & 8.0E-01 & $6.0 E+031$ & 1.0E+01 & $1.2 E+01$ & PRESSURE & ETHANOL & OUTSIDE BUILDING \\
\hline & & 027 & $0.0 E+00$ & 0.5 & 200 & $.9 E+00$ & $5.0 \mathrm{E}+023$ & $3.8 E+00$ & $5.8 \mathrm{E}+00$ & PRESSURE & ETHANOL & OUTSIDE BUILDING \\
\hline & & 029 & $0.0 E+00$ & 0.8 & 200 & 2.0E-01 & $6.0 \mathrm{E}+031$ & $1.0 E+01$ & $1.2 E+01$ & PRESSURE & ETHANOL & OUTSIDE BUILDING \\
\hline & & 031 & $0.0 \mathrm{E}+00$ & 0.8 & 200 & $.4 \mathrm{E}+00$ & $7.5 E+025$ & $5.5 \mathrm{E}+00$ & $6.2 E+00$ & PRESSURE & ETHANOL & OUTSIDE BUILDING \\
\hline
\end{tabular}




\section{PART I}

Fill Vapor

Annual Ave. Rate Space Tank Tank

Thru Put \% (gal/ Height Capacity Dia. Length

AREA BLDG VENT (gal/yr) Full $\mathrm{min}$ ) (ft) $\quad$ (gal) $\quad$ (ft) $\quad$ (ft) Tank Type Material Stored

\begin{tabular}{lll|lllllllll}
\hline B08 & 601 & 001 & $6.5 E+01$ & 0.8 & 200 & $3.4 E-01$ & $6.0 E+01$ & $2.0 E+00$ & $2.0 E+00$ & FIXED ROOF DIESEL \#2 & INSIDE BUILDING \\
\hline
\end{tabular} 


\section{PART I}

\begin{tabular}{|c|c|c|c|c|c|c|c|c|c|c|c|c|}
\hline AREA & BLDG & VENT & $\begin{array}{c}\text { Annual } \\
\text { Thru Put } \\
\text { (gal/yr) }\end{array}$ & $\begin{array}{c}\text { Ave. } \\
\% \\
\text { Full }\end{array}$ & $\begin{array}{c}\text { Fill } \\
\text { Rate } \\
\text { (gal/ } \\
\text { min) } \\
\end{array}$ & $\begin{array}{c}\text { Vapor } \\
\text { Space } \\
\text { Height } \\
\text { (ft) }\end{array}$ & $\begin{array}{c}\text { Capacity } \\
\text { (gal) }\end{array}$ & $\begin{array}{l}\text { Tank } \\
\text { Dia. } \\
\text { (ft) }\end{array}$ & $\begin{array}{c}\text { Tank } \\
\text { Length } \\
\text { (ft) }\end{array}$ & Tank Type & Material Stored & Tank Location \\
\hline \multirow[t]{4}{*}{ B16 } & 601 & 008 & $5.5 \mathrm{E}+02$ & 0.9 & 100 & 5.8E-01 & $1.0 E+03$ & $5.3 E+00$ & $6.0 \mathrm{E}+00$ & FIXED ROOF & DIESEL \#2 & OUTSIDE BUILDING \\
\hline & 703 & 001 & $1.1 \mathrm{E}+03$ & 0.8 & 100 & 8.8E-01 & $5.0 E+02$ & $1.2 E+01$ & $4.4 E+00$ & FIXED ROOF & GAS/DIESEL MIX & OUTSIDE BUILDING \\
\hline & 704 & 001 & $7.1 E+04$ & 0.5 & 100 & 4.0E-01 & $1.5 E+04$ & $1.1 E+01$ & $2.9 E+01$ & FIXED ROOF & gasoline & OUTSIDE BUILDING \\
\hline & & 002 & $1.7 E+04$ & 0.5 & 100 & 4.0E-01 & $1.5 E+04$ & $1.1 E+01$ & $2.9 E+02$ & FIXED ROOF & diesel & OUTSIDE BUILDING \\
\hline
\end{tabular}


PART I

Fill Vapor

Annual Ave. Rate Space Tank Tank

Thru Put \% (gall Height Capacity Dia. Length

AREA BLDG VENT (gal/yr) Full $\mathrm{min}$ ) (ft) $(\mathrm{gal}) \quad$ (ft) $\quad$ (ft) Tank Type Material Stored

\begin{tabular}{|lll|lllllllll}
\hline B23 & 602 & 002 & $6.5 E+01$ & 0.8 & 200 & $3.4 E-01$ & $6.0 E+01$ & $2.0 E+00$ & $2.1 E+00$ & FIXED ROOF DIESEL \#2 & INSIDE BUILDING
\end{tabular} 


\section{PART I}

\begin{tabular}{|c|c|c|c|c|c|c|c|c|c|c|c|c|}
\hline AREA & BLDG & VENT & $\begin{array}{c}\text { Annual } \\
\text { Thru Put } \\
\text { (gal/yr) }\end{array}$ & $\begin{array}{c}\text { Ave. } \\
\% \\
\text { Full }\end{array}$ & $\begin{array}{c}\text { Fill } \\
\text { Rate } \\
\text { (gall } \\
\text { min) }\end{array}$ & $\begin{array}{c}\text { Vapor } \\
\text { Space } \\
\text { Height } \\
\text { (ft) }\end{array}$ & $\begin{array}{c}\text { Capacity } \\
\text { (gal) }\end{array}$ & $\begin{array}{l}\text { Tank } \\
\text { Dia. } \\
\text { (ft) }\end{array}$ & $\begin{array}{c}\text { Tank } \\
\text { Length } \\
\text { (ft) }\end{array}$ & Tank Type & Material Stored & Tank Location \\
\hline B27 & 601 & 003 & $6.5 E+01$ & 0.8 & 200 & 3.4E-01 & $6.0 \mathrm{E}+01$ & $2.0 E+00$ & $2.0 \mathrm{E}+00$ & FIXED ROOF & DIESEL \#2 & INSIDE BUILDING \\
\hline
\end{tabular}




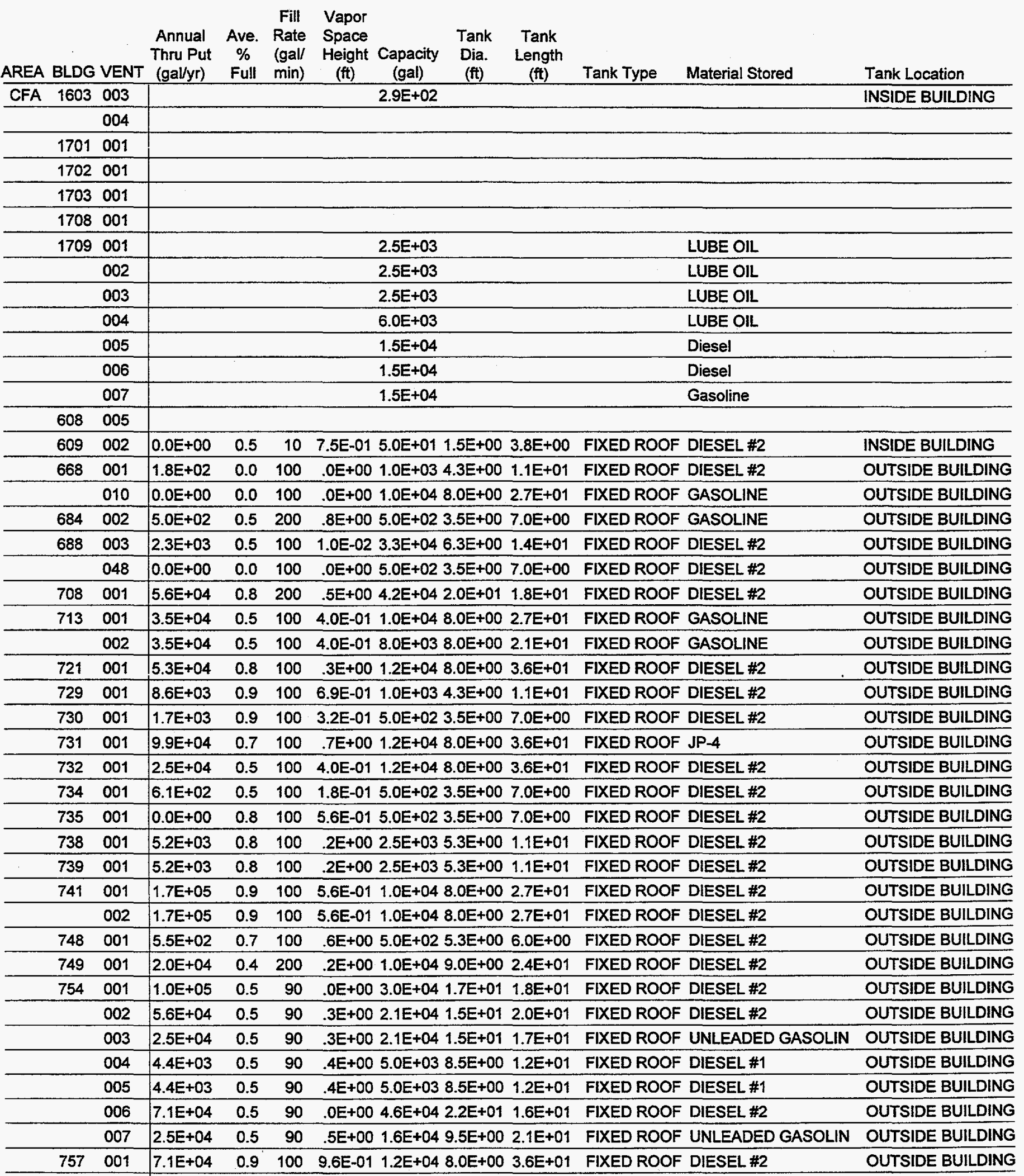




\section{PART 1}

Fill Vapor

Annual Ave. Rate Space: Tank Tank

Thru Put \% (gal/ Height Capacity Dia. Length

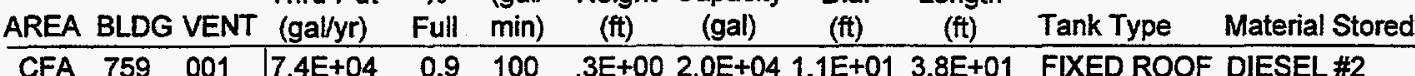




\begin{tabular}{|c|c|c|c|c|c|c|c|c|c|c|c|c|}
\hline AREA & BLDG & VENT & $\begin{array}{c}\text { Annual } \\
\text { Thru Put } \\
\text { (gal/yr) }\end{array}$ & $\begin{array}{c}\text { Ave. } \\
\% \\
\text { Full }\end{array}$ & $\begin{array}{c}\text { Fill } \\
\text { Rate } \\
\text { (gal/ } \\
\text { min) } \\
\end{array}$ & $\begin{array}{c}\text { Vapor } \\
\text { Space } \\
\text { Height } \\
\text { (f) }\end{array}$ & $\begin{array}{c}\text { Capacity } \\
\text { (gal) }\end{array}$ & $\begin{array}{c}\text { Tank } \\
\text { Dia. } \\
\text { (ft) }\end{array}$ & $\begin{array}{l}\text { Tank } \\
\text { Length } \\
\text { (ft) }\end{array}$ & Tank Type & Material Stored & Tank Location \\
\hline & 1643 & 003 & $2.6 E+02$ & 0.8 & 100 & $.0 E+00$ & $5.0 E+02$ & $4.0 E+00$ & $6.0 \mathrm{E}+00$ & FIXED ROOF & DIESEL \#2 & INSIDE BUILDING \\
\hline & 1749 & 002 & $0.0 E+00$ & 0.4 & 200 & $.5 E+00$ & $1.5 E+02$ & $2.0 \mathrm{E}+00$ & $5.0 \mathrm{E}+00$ & FIXED ROOF & DIESEL \#2 & INSIDE BUILDING \\
\hline & 601 & 024 & & & & & & & & & & \\
\hline & 616 & 007 & $2.2 E+02$ & 0.4 & 200 & 8.5E-01 & $8.5 E+01$ & $1.9 E+00$ & $4.0 \mathrm{E}+00$ & FIXED ROOF & DIESEL \#2 & INSIDE BUILDING \\
\hline & 637 & 057 & & & & & & & & & & \\
\hline & 644 & 004 & $1.6 E+01$ & 0.8 & 200 & $1.0 \mathrm{E}-01$ & $5.4 E+00$ & $6.5 E-01$ & $2.2 \mathrm{E}+00$ & FIXED ROOF & GASOLINE & INSIDE BUILDING \\
\hline & & 006 & $5.2 E+03$ & 0.8 & 10 & $.0 \mathrm{E}+00$ & $5.0 E+01$ & $1.7 E+00$ & $3.1 \mathrm{E}+00$ & FIXED ROOF & DIESEL \#2 & INSIDE BUILDING \\
\hline & & 013 & $2.5 E+03$ & 0.5 & 200 & $.0 E+00$ & $3.0 E+03$ & $3.0 E+00$ & $1.5 E+01$ & FIXED ROOF & DIESEL \#2 & OUTSIDE BUILDING \\
\hline & $701 \mathrm{~A}$ & 001 & $1.1 \mathrm{E}+06$ & 0.8 & 200 & $.3 E+00$ & $2.4 E+05$ & $3.5 E+01$ & 3.3E+01 & FIXED ROOF & DIESEL \#2 & OUTSIDE BUILDING \\
\hline & $701 \mathrm{~B}$ & 001 & $0.0 E+00$ & 0.8 & 200 & $.4 E+00$ & $5.0 E+04$ & $2.0 E+01$ & 2.2E+01 & FIXED ROOF & DIESEL \#2 & OUTSIDE BUILDING \\
\hline & $702 \mathrm{~A}$ & 001 & $0.0 E+00$ & 0.8 & 200 & $.2 E+00$ & $2.0 E+04$ & $1.2 \mathrm{E}+01$ & $2.4 \mathrm{E}+01$ & FIXED ROOF & KEROSENE & OUTSIDE BUILDING \\
\hline & $702 B$ & 001 & $0.0 E+00$ & 0.8 & 200 & $.2 E+00$ & 2.0E+04 & $1.2 E+01$ & $2.4 \mathrm{E}+01$ & FIXED ROOF & KEROSENE & OUTSIDE BUILDING \\
\hline & 703 & 001 & $2.6 E+03$ & 0.7 & 100 & $.4 \mathrm{E}+00$ & $1.0 E+03$ & $4.0 \mathrm{E}+00$ & $1.2 \mathrm{E}+01$ & FIXED ROOF & DIESEL \#2 & OUTSIDE BUILDING \\
\hline & & 002 & $6.3 E+03$ & 0.3 & 100 & $.6 \mathrm{E}+00$ & $2.0 E+03$ & $5.0 E+00$ & $1.4 E+01$ & FIXED ROOF & UNLEADED GAS & OUTSIDE BUILDING \\
\hline & 775 & 005 & $1.6 \mathrm{E}+03$ & 0.5 & 200 & & $1.5 E+03$ & $5.3 E+00$ & $9.0 \mathrm{E}+00$ & FIXED ROOF & DIESEL \#2 & OUTSIDE BUILDING \\
\hline
\end{tabular}


PART I

\begin{tabular}{|c|c|c|c|c|c|c|c|c|c|c|c|c|}
\hline AREA & BLDG & VENT & $\begin{array}{c}\text { Annual } \\
\text { Thru Put } \\
\text { (gallyr) }\end{array}$ & $\begin{array}{c}\text { Ave. } \\
\% \\
\text { Full }\end{array}$ & $\begin{array}{c}\text { Fill } \\
\text { Rate } \\
\text { (gal/ } \\
\text { min) } \\
\end{array}$ & $\begin{array}{l}\text { Vapor } \\
\text { Space } \\
\text { Height } \\
\text { (ft) }\end{array}$ & $\begin{array}{c}\text { Capacity } \\
\text { (gal) }\end{array}$ & $\begin{array}{l}\text { Tank } \\
\text { Dia. } \\
\text { (ft) }\end{array}$ & $\begin{array}{c}\text { Tank } \\
\text { Length } \\
\text { (fi) }\end{array}$ & Tank Type & Material Stored & Tank Location \\
\hline & 618 & 200 & $0.0 \mathrm{E}+00$ & 0.0 & 100 & $.0 \mathrm{E}+00$ & $1.5 \mathrm{E}+03$ & $4.0 \mathrm{E}+00$ & $9.5 \mathrm{E}+00$ & FIXED ROOF & DIESEL \#2 & OUTSIDE BUILDING \\
\hline & $633 A$ & 004 & $4.6 \mathrm{E}+03$ & 0.9 & 200 & 5.0E-01 & $6.4 \mathrm{E}+038$ & 8.0E+00 & $1.6 \mathrm{E}+01$ & FIXED ROOF & DIESEL \#2 & OUTSIDE BUILDING \\
\hline & 686 & 001 & $4.3 E+03$ & 0.9 & 200 & 3.2E-01 & $2.2 \mathrm{E}+02$ & $4.0 E+00$ & $2.3 \mathrm{E}+00$ & FIXED ROOF & DIESEL \#2 & INSIDE BUILDING \\
\hline & & 003 & $4.3 E+03$ & 0.9 & 200 & 3.2E-01 & $2.2 E+02$ & $4.0 \mathrm{E}+00$ & $2.3 \mathrm{E}+00$ & FIXED ROOF & DIESEL \#2 & INSIDE BUILDING \\
\hline & & 004 & $4.3 E+03$ & 0.9 & 200 & 3.2E-01 & $2.2 E+02$ & $4.0 E+00$ & $2.3 \mathrm{E}+00$ & FIXED ROOF & DIESEL \#2. & INSIDE BUILDING \\
\hline & 709 & 001 & $0.0 \mathrm{E}+00$ & 0.7 & 200 & $.5 \mathrm{E}+00$ & $3.0 E+03$ & $5.0 \mathrm{E}+00$ & $1.8 \mathrm{E}+01$ & FIXED ROOF & DIESEL \#2 & OUTSIDE BUILDING \\
\hline & $711 \mathrm{~A}$ & 001 & $1.8 \mathrm{E}+05$ & 0.8 & 200 & $.0 E+00$ & $2.5 E+04$ & 1.7E+01 & $1.6 \mathrm{E}+01$ & FIXED ROOF & FUEL OIL \#5 & OUTSIDE BUILDING \\
\hline & $711 \mathrm{~B}$ & 001 & $1.8 E+0.5$ & 0.8 & 200 & $.0 E+00$ & $2.5 E+04$ & $1.7 \mathrm{E}+01$ & $1.6 \mathrm{E}+01$ & FIXED ROOF & FUEL OIL \#5 & OUTSIDE BUILDING \\
\hline & 728 & 008 & $8.0 \mathrm{E}+02$ & 0.8 & 200 & 8.4E-01 & $2.8 \mathrm{E}+02$ & $3.5 \mathrm{E}+00$ & $4.0 \mathrm{E}+00$ & FIXED ROOF & DIESEL \#2 & OUTSIDE BUILDING \\
\hline & $730 \mathrm{C}$ & 031 & $0.0 \mathrm{E}+00$ & 0.0 & 200 & $.0 E+00$ & $1.0 E+048$ & 8. $5 \mathrm{E}+00$ & $2.5 \mathrm{E}+01$ & FIXED ROOF & DIESEL \#2 & OUTSIDE BUILDING \\
\hline & 739 & 008 & $0.0 \mathrm{E}+00$ & 0.9 & 200 & 5.0E-01 & $1.2 E+04$ & $1.0 \mathrm{E}+01$ & $2.0 \mathrm{E}+01$ & FIXED ROOF & DIESEL \#2 & OUTSIDE BUILDING \\
\hline & & 009 & $0.0 \mathrm{E}+00$ & 0.9 & 200 & 5.0E-01 & $1.2 \mathrm{E}+04$ & $1.0 \mathrm{E}+01$ & $2.0 \mathrm{E}+01$ & FIXED ROOF & DIESEL \#2 & OUTSIDE BUILDING \\
\hline & 747 & 001 & $0.0 \mathrm{E}+00$ & 0.5 & 200 & $.5 \mathrm{E}+00$ & $1.0 \mathrm{E}+04$ & $1.0 \mathrm{E}+01$ & $1.5 E+01$ & FIXED ROOF & FUEL OIL \#5 & OUTSIDE BUILDING \\
\hline & & 002 & $0.0 E \div 00$ & 0.5 & 200 & $.5 \mathrm{E}+00$ & $1.0 E+04$ & $1.0 \mathrm{E}+01$ & $1.5 E+01$ & FIXED ROOF & FUEL OIL \#5 & OUTSIDE BUILDING \\
\hline & $759 A$ & 001 & $8.7 E+03$ & 0.8 & 200 & 4.0E-01 & $2.5 E+04$ & $1.0 \mathrm{E}+01$ & 4.0E+01 & FIXED ROOF & DIESEL \#2 & OUTSIDE BUILDING \\
\hline & $759 \mathrm{~B}$ & 001 & $8.7 E+03$ & 0.8 & 200 & 4.0E-01 & $2.5 E+04$ & 1.0E+01 & $4.0 E+01$ & FIXED ROOF & DIESEL \#2 & OUTSIDE BUILDING \\
\hline
\end{tabular}


PART I

\begin{tabular}{|c|c|c|c|c|c|c|c|c|c|c|c|c|}
\hline AREA & BLDG & VENT & $\begin{array}{l}\text { Annual } \\
\text { Thru Put } \\
\text { (gal/yr) }\end{array}$ & $\begin{array}{c}\text { Ave. } \\
\% \\
\text { Full }\end{array}$ & $\begin{array}{l}\text { Fill } \\
\text { Rate } \\
\text { (gal/ } \\
\text { min) } \\
\end{array}$ & $\begin{array}{c}\text { Vapor } \\
\text { Space } \\
\text { Height } \\
\text { (ft) } \\
\end{array}$ & $\begin{array}{c}\text { Capacity } \\
\text { (gal) }\end{array}$ & $\begin{array}{c}\text { Tank } \\
\text { Dia. } \\
\text { (ft) } \\
\end{array}$ & $\begin{array}{c}\text { Tank } \\
\text { Length } \\
\text { (ft) }\end{array}$ & Tank Type & Material Stored & Tank Location \\
\hline \multirow{2}{*}{\multicolumn{2}{|c|}{625}} & 002 & & & & & & & & & & \\
\hline & & 004 & & & & & & & & & & \\
\hline & 626 & 005 & $6.8 \mathrm{E}+01$ & 0.8 & 2 & 2.5E-01 & $1.1 \mathrm{E}+02$ & 2.0E+00 & $6.0 E+00$ & FIXED ROOF & DIESEL \#2 & INSIDE BUILDING \\
\hline & 705 & 001 & $5.5 E+02$ & 0.8 & 200 & $.2 E+\infty$ & 4.0E+03 & $8.0 E+00$ & $1.3 E+01$ & FIXED ROOF & MIXED \#1 \& \#2 DIESE & OUTSIDE BUILDING \\
\hline & 711 & 001 & $3.0 E+02$ & 0.8 & 100 & 3.2E-01 & $3.0 \mathrm{E}+02$ & $3.2 E+00$ & $5.2 \mathrm{E}+00$ & FIXED ROOF & DIESEL \#2 & OUTSIDE BUILDING \\
\hline & 716 & 001 & $3.5 E+03$ & 0.9 & 100 & $.9 \mathrm{E}+00$ & $4.0 E+03$ & $5.0 \mathrm{E}+00$ & 2.0E+01 & FIXED ROOF & DIESEL \#2 & OUTSIDE BUILDING \\
\hline & 722 & 001 & & & & & & & & & & \\
\hline & 737 & 001 & & & & & $2.5 E+03$ & & & & & \\
\hline & 752 & 001 & $5.8 \mathrm{E}+02$ & 0.9 & 100 & $.9 E+00$ & $2.5 E+03$ & $5.0 \mathrm{E}+00$ & $1.4 E+01$ & FIXED ROOF & DIESEL \#2 & OUTSIDE BUILDING \\
\hline
\end{tabular}


PART I

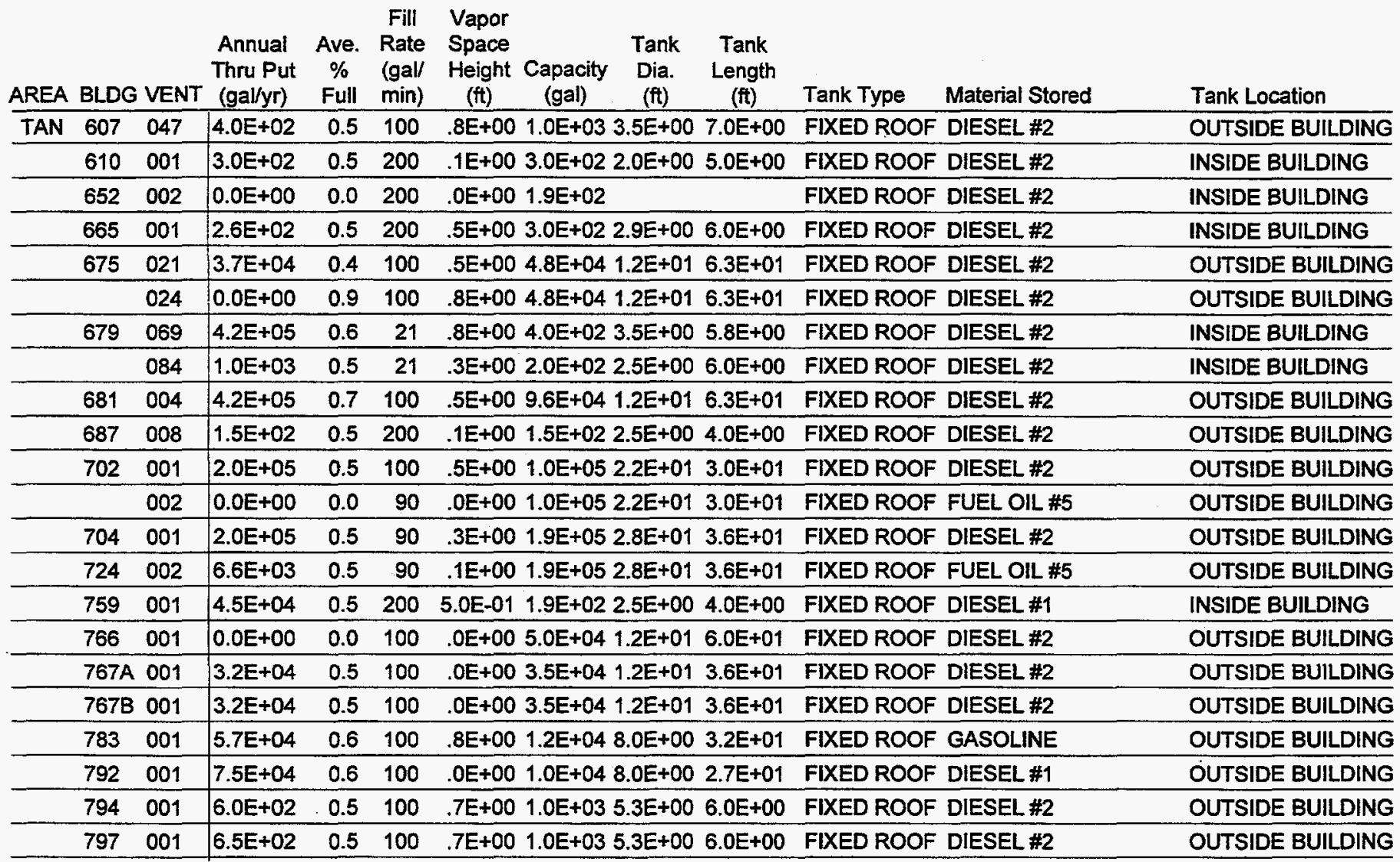


PART I

\begin{tabular}{|c|c|c|c|c|c|c|c|c|c|c|c|}
\hline AREA & BLDG & VENT & $\begin{array}{c}\text { Annual } \\
\text { Thru Put } \\
\text { (gal/yr) }\end{array}$ & $\begin{array}{c}\text { Ave. } \\
\% \\
\text { Full }\end{array}$ & $\begin{array}{c}\text { Fill } \\
\text { Rate } \\
\text { (gal/ } \\
\text { min) } \\
\end{array}$ & $\begin{array}{c}\text { Vapor } \\
\text { Space } \\
\text { Height } \\
\text { (fi) }\end{array}$ & $\begin{array}{c}\text { Capacity } \\
\text { (gal) }\end{array}$ & $\begin{array}{c}\text { Tank } \\
\text { Dia. } \\
(\mathrm{ft}) \\
\end{array}$ & $\begin{array}{c}\text { Tank } \\
\text { Length } \\
\text { (ft) }\end{array}$ & Material Stored & Tank Location \\
\hline & 633 & 002 & $7.8 \mathrm{E}+02$ & 0.8 & 200 & 9.4E-01 & $6.6 E+02$ & $3.8 E+00$ & $8.0 \mathrm{E}+00$ & FIXED ROOF DIESEL \#2 & INSIDE BUILDING \\
\hline & 670 & 048 & $9.6 E+01$ & 1.0 & 2 & $5.0 \mathrm{E}-01$ & $1.0 \mathrm{E}+01$ & 8.3E-01 & $2.0 \mathrm{E}+00$ & FIXED ROOF DIESEL \#2 & INSIDE BUILDING \\
\hline & 670A & 002 & & & & & & & & FIXED ROOF DIESEL \#2 & \\
\hline & 680 & 002 & & & & & $3.0 E+02$ & & & FIXED ROOF DIESEL \#2 & \\
\hline & 727 & 001 & $0.0 E+00$ & 0.0 & 200 & $.0 \mathrm{E}+00$ & $2.2 E+05$ & $3.0 \mathrm{E}+01$ & 4.2E+01 & FIXED ROOF DIESEL \#2 & OUTSIDE BUILDING \\
\hline & & 002 & $0.0 \mathrm{E}+00$ & 0.0 & 200 & $.0 E+00$ & $2.2 E+05$ & 3.0E+01 & $4.2 \mathrm{E}+01$ & FIXED ROOF DIESEL \#2 & OUTSIDE BUILDING \\
\hline & & 003 & $1.3 E+05$ & 0.8 & 150 & $.0 E+00$ & $3.0 \mathrm{E}+04$ & $1.6 E+01$ & 2.1E+01 & FIXED ROOF DIESEL \#2 & OUTSIDE BUILDING \\
\hline & & 004 & $1.3 E+05$ & 0.8 & 150 & $.0 E+00$ & $9.2 E+0.4$ & $2.0 E+01$ & $2.1 E+01$ & FIXED ROOF DIESEL \#2 & OUTSIDE BUILDING \\
\hline
\end{tabular}




\section{PART I}

\begin{tabular}{|c|c|c|c|c|c|c|c|c|c|c|c|c|}
\hline AREA & BLDC & VENT & $\begin{array}{l}\text { Annual } \\
\text { Thru Put } \\
\text { (gal/yr) }\end{array}$ & $\begin{array}{c}\text { Ave. } \\
\% \\
\text { Full }\end{array}$ & $\begin{array}{c}\text { Fill } \\
\text { Rate } \\
\text { (gal/ } \\
\text { min) }\end{array}$ & $\begin{array}{c}\text { Vapor } \\
\text { Space } \\
\text { Height } \\
\text { (ft) }\end{array}$ & $\begin{array}{c}\text { Capacity } \\
\text { (gal) }\end{array}$ & $\begin{array}{l}\text { Tank } \\
\text { Dia. } \\
\text { (ft) }\end{array}$ & $\begin{array}{c}\text { Tank } \\
\text { Length } \\
\text { (ft) }\end{array}$ & Tank Type & Material Stored & Tank Location \\
\hline WMF & 639 & 002 & $5.6 E+02$ & 0.6 & 200 & $.0 E+00$ & $2.5 E+02$ & $3.0 E+00$ & $5.0 \mathrm{E}+00$ & FIXED ROOF & DIESEL \#2 & INSIDE BUILDING \\
\hline
\end{tabular}


PART II

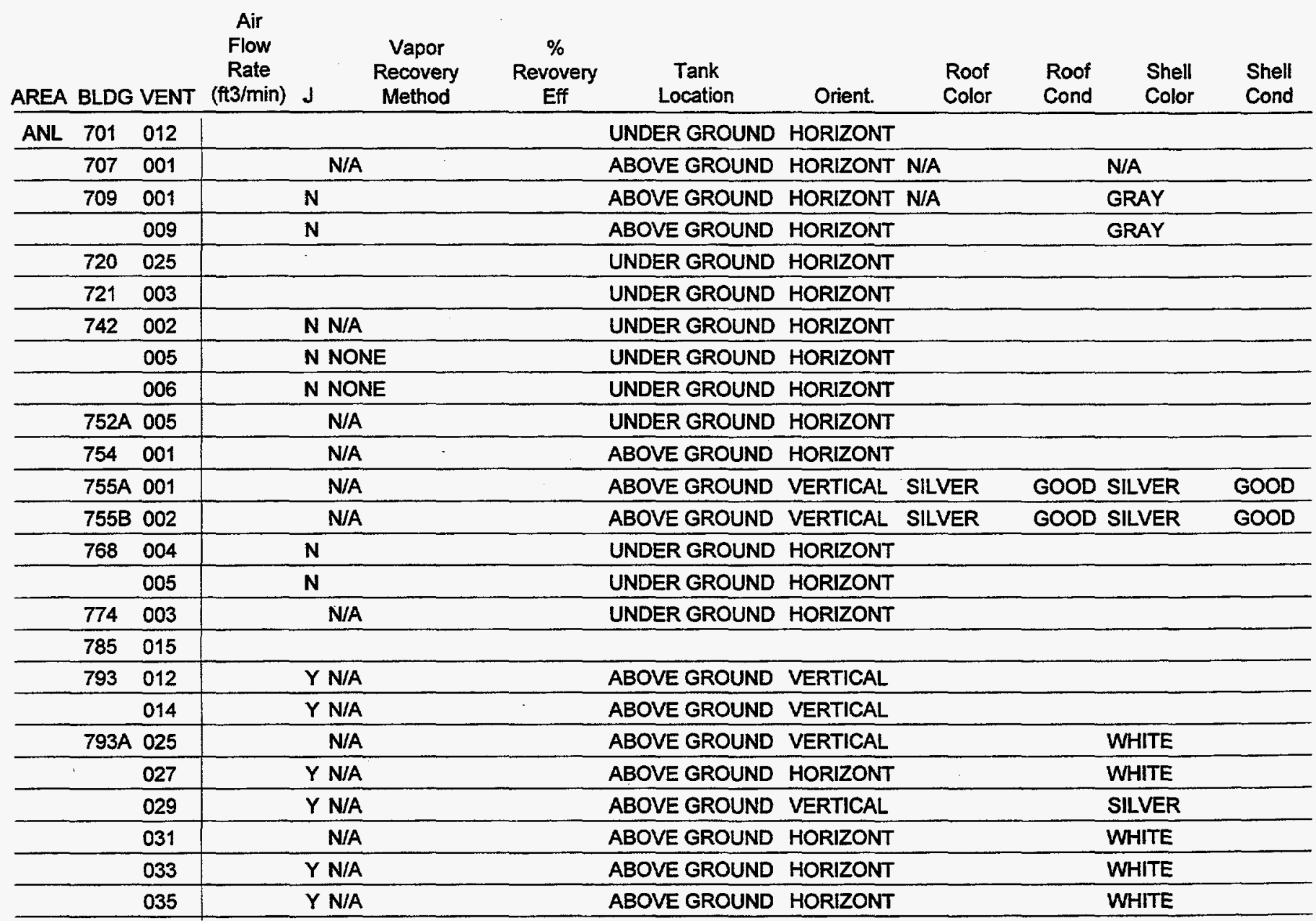


PART II

\begin{tabular}{|c|c|c|c|c|c|c|c|c|c|c|c|c|}
\hline REA & BLDG & VENT & $\begin{array}{c}\text { Air } \\
\text { Flow } \\
\text { Rate } \\
\text { (ft3/min) }\end{array}$ & $\mathrm{J}$ & $\begin{array}{l}\text { Vapor } \\
\text { Recovery } \\
\text { Method }\end{array}$ & $\begin{array}{c}\% \\
\text { Revovery } \\
\text { Eff }\end{array}$ & $\begin{array}{c}\text { Tank } \\
\text { Location }\end{array}$ & Orient. & $\begin{array}{l}\text { Roof } \\
\text { Color }\end{array}$ & $\begin{array}{l}\text { Roof } \\
\text { Cond }\end{array}$ & $\begin{array}{l}\text { Shell } \\
\text { Color }\end{array}$ & $\begin{array}{l}\text { Shell } \\
\text { Cond }\end{array}$ \\
\hline
\end{tabular}


PART II

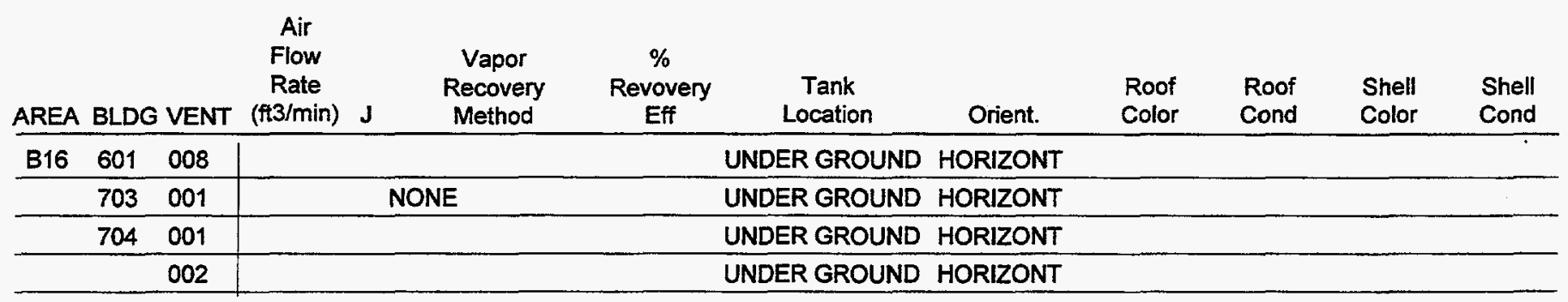




\begin{tabular}{|c|c|c|c|c|c|c|c|c|c|c|c|c|}
\hline AREA & BLDC & 6 VENT & $\begin{array}{c}\text { Air } \\
\text { Flow } \\
\text { Rate } \\
\text { (ft3/min) }\end{array}$ & $J$ & $\begin{array}{l}\text { Vapor } \\
\text { Recovery } \\
\text { Method }\end{array}$ & $\begin{array}{c}\%_{<} \\
\text {Revovery } \\
\text { Eff }\end{array}$ & $\begin{array}{c}\text { Tank } \\
\text { Location }\end{array}$ & Orient. & $\begin{array}{l}\text { Roof } \\
\text { Color }\end{array}$ & $\begin{array}{l}\text { Roof } \\
\text { Cond } \\
\end{array}$ & $\begin{array}{l}\text { Shell } \\
\text { Color }\end{array}$ & $\begin{array}{l}\text { Shell } \\
\text { Cond }\end{array}$ \\
\hline
\end{tabular}


PART II

\begin{tabular}{|c|c|c|c|c|c|c|c|c|c|c|c|c|}
\hline AREA & BLDG & VENT & $\begin{array}{c}\text { Air } \\
\text { Flow } \\
\text { Rate } \\
\text { (ft3/min) } \\
\end{array}$ & $J$ & $\begin{array}{c}\text { Vapor } \\
\text { Recovery } \\
\text { Method }\end{array}$ & $\begin{array}{c}\% \\
\text { Revovery } \\
\text { Eff }\end{array}$ & $\begin{array}{c}\text { Tank } \\
\text { Location }\end{array}$ & Orient. & $\begin{array}{l}\text { Roof } \\
\text { Color }\end{array}$ & $\begin{array}{l}\text { Roof } \\
\text { Cond } \\
\end{array}$ & $\begin{array}{l}\text { Shell } \\
\text { Color } \\
\end{array}$ & $\begin{array}{l}\text { Shell } \\
\text { Cond }\end{array}$ \\
\hline
\end{tabular}


PART II

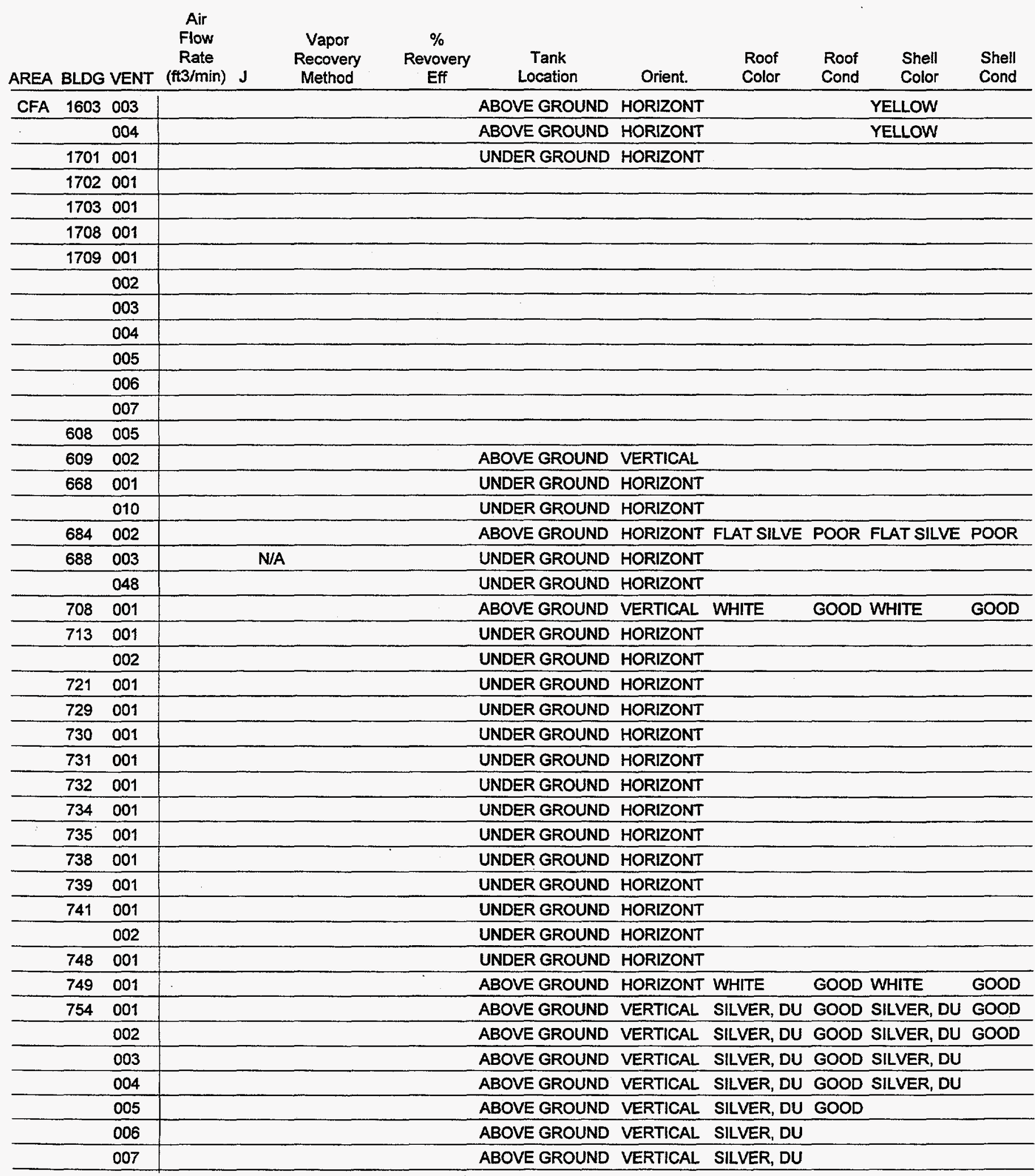


PART II

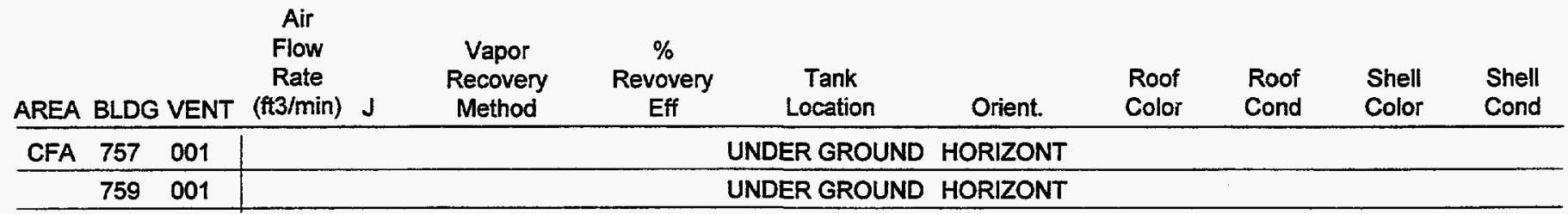


PART II

\begin{tabular}{|c|c|c|c|c|c|c|c|c|c|c|c|c|}
\hline AREA & BLDG & VENT & $\begin{array}{c}\text { Air } \\
\text { Flow } \\
\text { Rate } \\
\text { (ft3/min) }\end{array}$ & $\mathrm{J}$ & $\begin{array}{l}\text { Vapor } \\
\text { Recovery } \\
\text { Method }\end{array}$ & $\begin{array}{c}\% \\
\text { Revovery } \\
\text { Eff }\end{array}$ & $\begin{array}{c}\text { Tank } \\
\text { Location }\end{array}$ & Orient. & $\begin{array}{l}\text { Roof } \\
\text { Color }\end{array}$ & $\begin{array}{l}\text { Roof } \\
\text { Cond }\end{array}$ & $\begin{array}{l}\text { Shell } \\
\text { Color }\end{array}$ & $\begin{array}{l}\text { Shell } \\
\text { Cond }\end{array}$ \\
\hline & 1643 & 003 & & & & & ABOVE GROUND & HORIZONT & & & & \\
\hline & 1749 & 002 & & & & & UNDER GROUND & HORIZONT & RED & GOOD & RED & GOOD \\
\hline & 616 & 007 & & & & & ABOVE GROUND & HORIZONT & DULL RED & \multicolumn{3}{|c|}{ DULL RED } \\
\hline & 637 & 057 & & & & & & & & & & \\
\hline & 644 & 004 & & N/A & & & ABOVE GROUND & HORIZONT & SILVER, DU & \multicolumn{3}{|c|}{ SILVER, DU } \\
\hline & & 006 & & & & & ABOVE GROUND & VERTICAL & BLUE & GOOD & & GOOD \\
\hline & & 013 & & & & & ABOVE GROUND & HORIZONT & SILVER & GOOD & SILVER & GOOD \\
\hline & $701 \mathrm{~A}$ & 001 & $1.4 E+05$ & & & & ABOVE GROUND & VERTICAL & SHINY SILV & GOOD & SILVER, DU & GOOD \\
\hline & 701B & 001 & & $\mathbf{N}$ & & & ABOVE GROUND & VERTICAL & SHINY SILV & TIN & SILVER, DU & TIN \\
\hline & $702 \mathrm{~A}$ & 001 & $7.5 \mathrm{E}+03$ & & & & ABOVE GROUND & VERTICAL & FLAT SILVE & BAD & FLAT SILVE & $B A D$ \\
\hline & $702 \mathrm{~B}$ & 001 & $1.4 E+03$ & & & & ABOVE GROUND & VERTICAL & FLAT SILVE & BAD & FLAT SILVE & BAD \\
\hline & 703 & 001 & $2.6 E+03$ & & & & UNDER GROUND & HORIZONT & & & & \\
\hline & & 002 & $3.5 \mathrm{E}+04$ & & & & UNDER GROUND & HORIZONT & & & & \\
\hline & 775 & 005 & & & & & ABOVE GROUND & HORIZONT & GRAY & GOOD & GRAY & GOOD \\
\hline
\end{tabular}


PART II

\begin{tabular}{|c|c|c|c|c|c|c|c|c|c|c|c|}
\hline AREA & BLDG & VENT & $\begin{array}{c}\text { Air } \\
\text { Flow } \\
\text { Rate } \\
\text { (ft3/min) }\end{array}$ & $J$ & $\begin{array}{c}\text { Vapor } \\
\text { Recovery } \\
\text { Method }\end{array}$ & $\begin{array}{c}\% \\
\text { Revovery } \\
\text { Eff }\end{array}$ & $\begin{array}{c}\text { Tank } \\
\text { Location }\end{array}$ & Orient. & $\begin{array}{l}\text { Roof } \\
\text { Color }\end{array}$ & $\begin{array}{l}\text { Roof } \\
\text { Cond }\end{array}$ & $\begin{array}{l}\text { Shell } \\
\text { Cond }\end{array}$ \\
\hline & 618 & 200 & & $\mathbf{N}$ & & & UNDER GROUND & HORIZONT & & & \\
\hline & $633 A$ & 004 & & $\mathbf{N}$ & & & ABOVE GROUND & HORIZONT & GRAY & POOR GRAY & GOOD \\
\hline & & 003 & & $N$ & & & ABOVE GROUND & VERTICAL & & & \\
\hline & & 004 & & $\mathbf{N}$ & & & ABOVE GROUND & VERTICAL & & & \\
\hline & 709 & 001 & & $\mathrm{~N}$ & & & ABOVE GROUND & HORIZONT & SILVER & GOOD SILVER & GOOD \\
\hline & $711 \mathrm{~A}$ & 001 & & $\mathbf{N}$ & & & ABOVE GROUND & VERTICAL & SILVER & GOOD SILVER & GOOD \\
\hline & $711 \mathrm{~B}$ & 001 & & $\mathbf{N}$ & & & ABOVE GROUND & VERTICAL & SILVER & GOOD SILVER & GOOD \\
\hline & 728 & 008 & & $\mathbf{N}$ & & & ABOVE GROUND & HORIZONT & LIGHT GRE & GOOD LIGHT GRE & GOOD \\
\hline & $730 \mathrm{C}$ & 031 & & $\mathbf{N}$ & & & ABOVE GROUND & HORIZONT & BLACK & GOOD BLACK & GOOD \\
\hline & 739 & 008 & & $\mathbf{N}$ & & & ABOVE GROUND & HORIZONT & SILVER & GOOD SILVER & GOOD \\
\hline & & 009 & & $\mathbf{N}$ & & & ABOVE GROUND & HORIZONT & SILVER & GOOD SILVER & GOOD \\
\hline & 747 & 001 & & $\mathbf{N}$ & & & ABOVE GROUND & VERTICAL & SILVER & GOOD SILVER & GOOD \\
\hline & & 002 & & $N$ & & & ABOVE GROUND & VERTICAL & SILVER & GOOD SILVER & GOOD \\
\hline & $759 A$ & 001 & & $\mathbf{N}$ & & & ABOVE GROUND & HORIZONT & BLACK & GOOD BLACK & GOOD \\
\hline & $759 \mathrm{~B}$ & 001 & & $\mathbf{N}$ & & & ABOVE GROUND & HORIZONT & BLACK & GOOD BLACK & GOOD \\
\hline
\end{tabular}


PART II

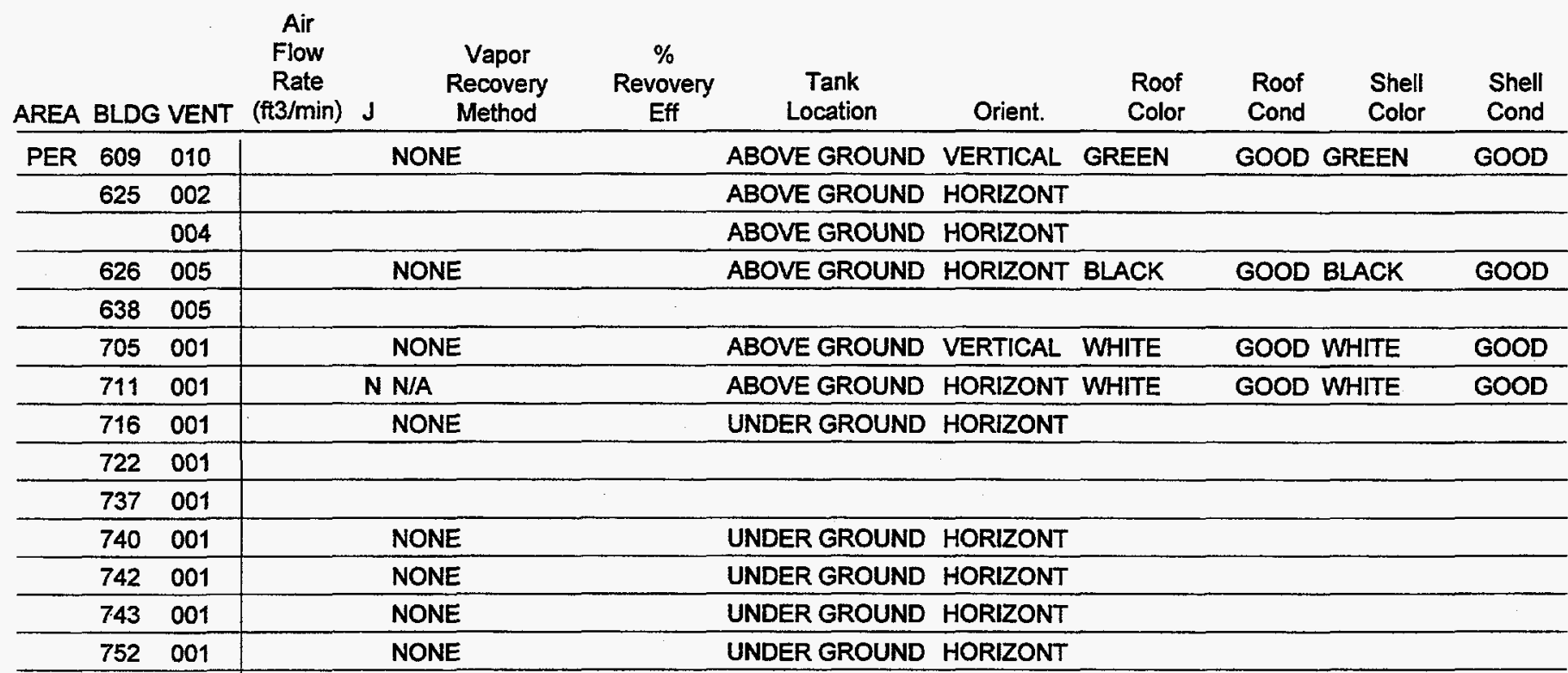


PART II

\begin{tabular}{|c|c|c|c|c|c|c|c|c|c|c|c|}
\hline AREA & BLDG & VENT & $\begin{array}{c}\text { Air } \\
\text { Flow } \\
\text { Rate } \\
\text { (ft3/min) } \\
\end{array}$ & $\begin{array}{l}\text { Vapor } \\
\text { Recovery } \\
\text { Method }\end{array}$ & $\begin{array}{c}\% \\
\text { Revovery } \\
\text { Eff }\end{array}$ & $\begin{array}{c}\text { Tank } \\
\text { Location }\end{array}$ & Orient. & $\begin{array}{l}\text { Roof } \\
\text { Color }\end{array}$ & $\begin{array}{l}\text { Roof } \\
\text { Cond }\end{array}$ & $\begin{array}{l}\text { Shell } \\
\text { Color }\end{array}$ & $\begin{array}{l}\text { Shell } \\
\text { Cond }\end{array}$ \\
\hline & 610 & 001 & & NONE & & ABOVE GROUND & HORIZONT & & & YELLOW & \\
\hline & 652 & 002 & & & & ABOVE GROUND & HORIZONT & & & & \\
\hline & & 024 & & N/A & & UNDER GROUND & HORIZONT & & & & \\
\hline & 679 & 069 & & N N/A & & ABOVE GROUND & HORIZONT & & & WHITE & GOOD \\
\hline & & 084 & & & & ABOVE GROUND & HORIZONT & & & WHITE & GOOD \\
\hline & 681 & 004 & & N/A & & UNDER GROUND & HORIZONT & & & & \\
\hline & 687 & 008 & & NONE & & ABOVE GROUND & HORIZONT & & & & \\
\hline & 724 & 002 & & N/A & & ABOVE GROUND & VERTICAL & WHITE & GOOD & LIGHT GRE & GOOD \\
\hline & 759 & 001 & & & & ABOVE GROUND & HORIZONT & LT. BLUE & FAIR & LT. BLUE & POOR \\
\hline & 766 & 001 & & NONE & & UNDER GROUND & HORIZONT & & & & \\
\hline & $767 \mathrm{~A}$ & 001 & & NONE & & UNDER GROUND & HORIZONT & & & & \\
\hline & 767B & 001 & & NONE & & UNDER GROUND & HORIZONT & & & & \\
\hline & 783 & 001 & & & & UNDER GROUND & HORIZONT & & & & \\
\hline & 792 & 001 & & & & UNDER GROUND & HORIZONT & & & & \\
\hline & 794 & 001 & & $\mathbf{N}$ & & UNDER GROUND & HORIZONT & & & & \\
\hline & 797 & 001 & & $\mathbf{N}$ & & UNDER GROUND & HORIZONT & & & & \\
\hline
\end{tabular}


PART II

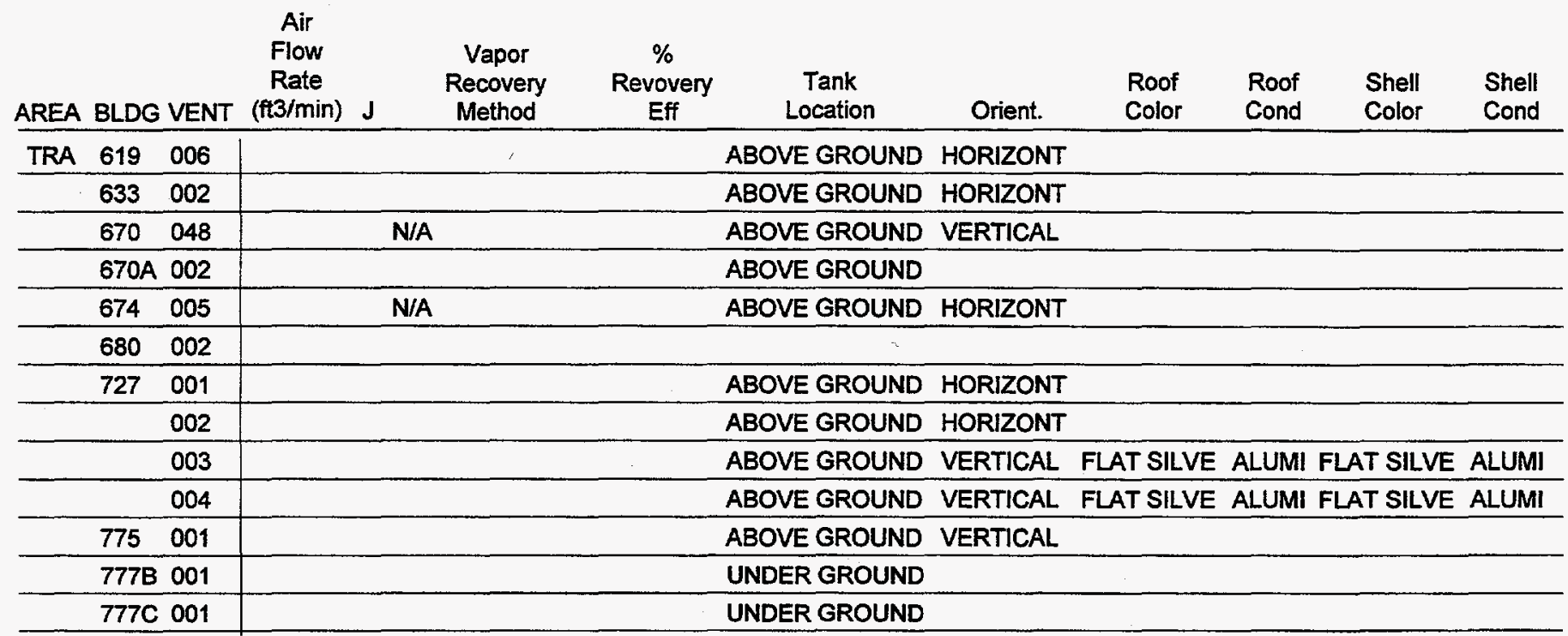


PART II

\begin{tabular}{|c|c|c|c|c|c|c|c|c|c|c|c|c|}
\hline AREA & BLDC & S VENT & $\begin{array}{c}\text { Air } \\
\text { Flow } \\
\text { Rate } \\
\text { (ft3/min) } \\
\end{array}$ & $\mathrm{J}$ & $\begin{array}{c}\text { Vapor } \\
\text { Recovery } \\
\text { Method }\end{array}$ & $\begin{array}{c}\% \\
\text { Revovery } \\
\text { Eff }\end{array}$ & $\begin{array}{c}\text { Tank } \\
\text { Location }\end{array}$ & Orient. & $\begin{array}{l}\text { Roof } \\
\text { Color } \\
\end{array}$ & $\begin{array}{l}\text { Roof } \\
\text { Cond }\end{array}$ & $\begin{array}{l}\text { Shell } \\
\text { Color }\end{array}$ & $\begin{array}{l}\text { Shell } \\
\text { Cond }\end{array}$ \\
\hline
\end{tabular}




\begin{tabular}{|c|c|c|c|c|c|c|c|c|c|c|c|c|}
\hline AREA & BLDG & VENT & $\begin{array}{l}\text { Annual } \\
\text { Thru Put } \\
\text { (gal/yr) }\end{array}$ & $\begin{array}{c}\text { Ave. } \\
\% \\
\text { Full }\end{array}$ & $\begin{array}{c}\text { Fill } \\
\text { Rate } \\
\text { (gall } \\
\text { min) }\end{array}$ & $\begin{array}{c}\text { Vapor } \\
\text { Space } \\
\text { Height } \\
\text { (ft) }\end{array}$ & $\begin{array}{c}\text { Capacity } \\
\text { (gal) }\end{array}$ & $\begin{array}{l}\text { Tank } \\
\text { Dia. } \\
\text { (ft) }\end{array}$ & $\begin{array}{c}\text { Tank } \\
\text { Length } \\
\text { (ft) }\end{array}$ & Tank Type & Material Stored & Tank Locatio \\
\hline & 601 & 009 & $6.3 E+02$ & 0.5 & & $.5 E+00$ & $3.1 E+02$ & $3.0 E+00$ & $6.0 E+00$ & FIXED ROOF & AMMONIUM HYDROXI & INSIDE BUILDING \\
\hline & 604 & 011 & & & & & & & & & & \\
\hline & 637 & 045 & & 0.2 & & $.8 E+00$ & $2.0 E+03$ & $5.0 \mathrm{E}+00$ & $1.0 E+01$ & FIXED ROOF & ZIRCONIUM DISSOLU & OUTSIDE BUILDIN \\
\hline & $719 \mathrm{~B}$ & 001 & & 0.9 & & $.1 E+00$ & $1.8 E+04$ & $1.0 \mathrm{E}+01$ & $3.3 E+01$ & FIXED ROOF & NITRIC ACID & OUTSIDE BUILDIN \\
\hline & $720 \mathrm{~A}$ & 001 & $4.8 \mathrm{E}+04$ & 0.9 & & $.4 \mathrm{E}+00$ & $1.6 E+04$ & 1.7E+01 & $3.8 \mathrm{E}+01$ & FIXED ROOF & ALUMINUM NITRATE & OUTSIDE BUILDIN \\
\hline & $720 \mathrm{~B}$ & 001 & 4.8E+04 & 1.0 & & 2.7E-01 & $6.2 E+03$ & $1.0 E+01$ & $1.2 E+01$ & FIXED ROOF & ALUMINUM NITRATE & OUTSIDE BUILDIN \\
\hline & $720 \mathrm{C}$ & 001 & $4.8 \mathrm{E}+04$ & 1.0 & & 2.7E-01 & $6.2 E+03$ & 1.1E+01 & 1.2E+01 & FIXED ROOF & ALUMINUM NITRATE & OUTSIDE BUILDIN \\
\hline & 727 & 003 & & & & & & & & & & \\
\hline
\end{tabular}




\section{PART I}

\begin{tabular}{|c|c|c|c|c|c|c|c|c|c|c|c|c|}
\hline AREA & BLDG & VENT & $\begin{array}{l}\text { Annual } \\
\text { Thru Put } \\
\text { (gal/yr) }\end{array}$ & $\begin{array}{c}\text { Ave. } \\
\% \\
\text { Full }\end{array}$ & $\begin{array}{c}\text { Fill } \\
\text { Rate } \\
\text { (gall } \\
\text { min) }\end{array}$ & $\begin{array}{c}\text { Vapor } \\
\text { Space } \\
\text { Height } \\
\text { (ft) }\end{array}$ & $\begin{array}{c}\text { Capacity } \\
\text { (gal) }\end{array}$ & $\begin{array}{l}\text { Tank } \\
\text { Dia. } \\
\text { (ft) }\end{array}$ & $\begin{array}{l}\text { Tank } \\
\text { Length } \\
\text { (ft) }\end{array}$ & Tank Type & Material Stored & Tank Locatio \\
\hline \multirow{3}{*}{ NRF } & 743 & 001 & $7.8 E+02$ & 0.0 & & $.7 E+00$ & $8.0 \mathrm{E}+03$ & $8.0 \mathrm{E}+00$ & $2.2 \mathrm{E}+01$ & FIXED ROOF & SULFURIC ACID & OUTSIDE BUILDIN \\
\hline & 745 & 001 & $2.4 E+03$ & 0.5 & & $.0 \mathrm{E}+\infty 0$ & $6.8 \mathrm{E}+037$ & $7.5 E+00$ & $2.4 E+01$ & FIXED ROOF & SULFURIC ACID & OUTSIDE BUILDIN \\
\hline & & 002 & $3.6 E+03$ & 0.5 & & $.0 E+\infty 0$ & $6.8 \mathrm{E}+037$ & $7.5 \mathrm{E}+00$ & $2.4 E+01$ & FIXED ROOF & SODIUM HYDROXIDE & OUTSIDE BUILDIN \\
\hline
\end{tabular}




\section{PART I}

Fill Vapor

Annual Ave. Rate Space

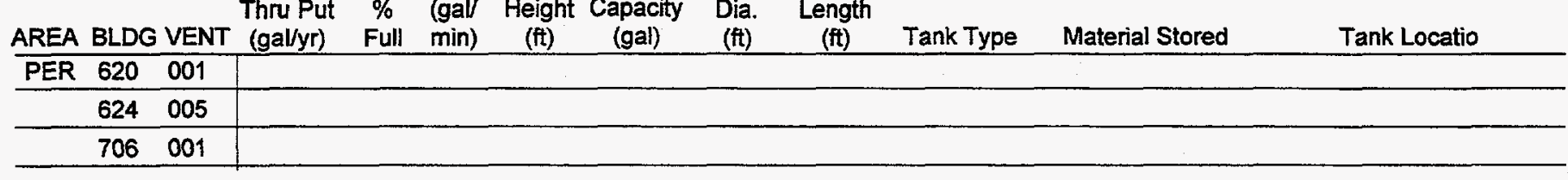


PART I

Fill Vapor

Annual Ave. Rate Space Tank Tank

Thru Put \% (gal/ Height Capacity Dia. Length

\begin{tabular}{|c|c|c|c|c|c|c|c|c|c|c|c|c|}
\hline AREA & $B L D C$ & 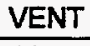 & (gal/yr) & Full & $\min )$ & (ft) & (gal) & (f) & (ft) & Tank Type & Material Stored & Tank Locatio \\
\hline TRA & 671 & 004 & $2.8 \mathrm{E}+04$ & 0.8 & & $.4 \mathrm{E}+00$ & $1.5 \mathrm{E}$ & $5.4 \mathrm{E}+00$ & $9.4 \mathrm{E}+00$ & FIXED ROOF & SULFURIC ACID & INSIDE BUILDING \\
\hline \multirow{2}{*}{\multicolumn{2}{|c|}{677}} & 001 & $3.3 E+04$ & 0.5 & & $.0 \mathrm{E}+00$ & $9.0 \mathrm{E}+03$ & $1.2 E+01$ & $1.3 E+01$ & FIXED ROOF & SULFURIC ACID & INSIDE BUILDING \\
\hline & & 002 & $2.0 E+04$ & 0.5 & & $.0 \mathrm{E}+00$ & $9.0 \mathrm{E}+03$ & 1.2E+01 & $1.3 \mathrm{E}+01$ & FIXED ROOF & SODIUM HYDROXIDE & INSIDE BUILDING \\
\hline
\end{tabular}




\begin{tabular}{|c|c|c|c|c|c|c|c|c|c|c|c|c|}
\hline AREA & BLDG & VENT & $\begin{array}{c}\text { Air } \\
\text { Flow } \\
\text { Rate } \\
\text { (ft3/min) }\end{array}$ & $\mathrm{J}$ & $\begin{array}{l}\text { Vapor } \\
\text { Recovery } \\
\text { Method }\end{array}$ & $\begin{array}{c}\% \\
\text { Revovery } \\
\text { Eff }\end{array}$ & $\begin{array}{c}\text { Tank } \\
\text { Location } \\
\end{array}$ & Orient. & $\begin{array}{l}\text { Roof } \\
\text { Color }\end{array}$ & $\begin{array}{l}\text { Roof } \\
\text { Cond }\end{array}$ & $\begin{array}{l}\text { Shell } \\
\text { Color }\end{array}$ & $\begin{array}{l}\text { Shell } \\
\text { Cond } \\
\end{array}$ \\
\hline & 601 & 009 & & & N/A & & ABOVE GROUND & HORIZONT & SILVER & & SILVER & \\
\hline & 604 & 011 & & & & & & & & & & \\
\hline & $719 B$ & 001 & & & N/A & & ABOVE GROUND & HORIZONT & SILVER, DU & BAD & SILVER, DU & BAD \\
\hline & $720 \mathrm{~A}$ & 001 & & & N/A & & ABOVE GROUND & VERTICAL & SILVER & GOOD & SILVER & GOOD \\
\hline & $720 B$ & 001 & & & N/A & & ABOVE GROUND & VERTICAL & SILVER & GOOD & SILVER & GOOD \\
\hline & $720 \mathrm{C}$ & 001 & & & N/A & & ABOVE GROUND & VERTICAL & SILVER & GOOD & SILVER & GOOD \\
\hline & 727 & 003 & & & & & & & & & & \\
\hline
\end{tabular}


PART II

\begin{tabular}{|c|c|c|c|c|c|c|c|c|c|c|c|c|}
\hline AREA & BLDG & VENT & $\begin{array}{c}\text { Air } \\
\text { Flow } \\
\text { Rate } \\
\text { (ft3/min) }\end{array}$ & $\mathrm{J}$ & $\begin{array}{l}\text { Vapor } \\
\text { Recovery } \\
\text { Method }\end{array}$ & $\begin{array}{c}\% \\
\text { Revovery } \\
\text { Eff }\end{array}$ & $\begin{array}{c}\text { Tank } \\
\text { Location }\end{array}$ & Orient. & $\begin{array}{l}\text { Roof } \\
\text { Color }\end{array}$ & $\begin{array}{l}\text { Roof } \\
\text { Cond }\end{array}$ & $\begin{array}{l}\text { Shell } \\
\text { Color }\end{array}$ & $\begin{array}{l}\text { Shell } \\
\text { Cond }\end{array}$ \\
\hline & 743 & 001 & & & N/A & & ABOVE GROUND & HORIZONT & GREY & GOOD & GREY & GOOD \\
\hline & 745 & 001 & & & NONE & & ABOVE GROUND & HORIZONT & GREY & POOR & GREY & POOR \\
\hline
\end{tabular}




\begin{tabular}{|c|c|c|c|c|c|c|c|c|c|c|c|c|}
\hline AREA & BLDG & VENT & $\begin{array}{c}\text { Air } \\
\text { Flow } \\
\text { Rate } \\
\text { (ft3/min) }\end{array}$ & $J$ & $\begin{array}{l}\text { Vapor } \\
\text { Recovery } \\
\text { Method }\end{array}$ & $\begin{array}{c}\% \\
\text { Revovery } \\
\text { Eff }\end{array}$ & $\begin{array}{c}\text { Tank } \\
\text { Location }\end{array}$ & Orient. & $\begin{array}{l}\text { Roof } \\
\text { Color } \\
\end{array}$ & $\begin{array}{l}\text { Roof } \\
\text { Cond } \\
\end{array}$ & $\begin{array}{l}\text { Shell } \\
\text { Color }\end{array}$ & $\begin{array}{l}\text { Shell } \\
\text { Cond }\end{array}$ \\
\hline & 624 & 005 & & & & & & & & & & \\
\hline & 706 & 001 & & & & & & & & & & \\
\hline
\end{tabular}


PART II

\begin{tabular}{|c|c|c|c|c|c|c|c|c|c|c|c|c|}
\hline AREA & BLDC & VENT & $\begin{array}{c}\text { Air } \\
\text { Flow } \\
\text { Rate } \\
\text { (ft3/min) }\end{array}$ & J & $\begin{array}{l}\text { Vapor } \\
\text { Recovery } \\
\text { Method }\end{array}$ & $\begin{array}{c}\% \\
\text { Revovery } \\
\text { Eff }\end{array}$ & $\begin{array}{c}\text { Tank } \\
\text { Location }\end{array}$ & Orient. & $\begin{array}{l}\text { Roof } \\
\text { Color }\end{array}$ & $\begin{array}{l}\text { Roof } \\
\text { Cond }\end{array}$ & $\begin{array}{l}\text { Shell } \\
\text { Color } \\
\end{array}$ & $\begin{array}{l}\text { Shell } \\
\text { Cond }\end{array}$ \\
\hline \multirow{3}{*}{ TRA } & & 008 & & & & & ABOVE GROUND & VERTICAL & & & & \\
\hline & 671 & 004 & & N/A & & & ABOVE GROUND & HORIZONT & & & & \\
\hline & & 002 & & N N/A & & & ABOVE GROUND & VERTICAL & & & & \\
\hline
\end{tabular}


$\%$

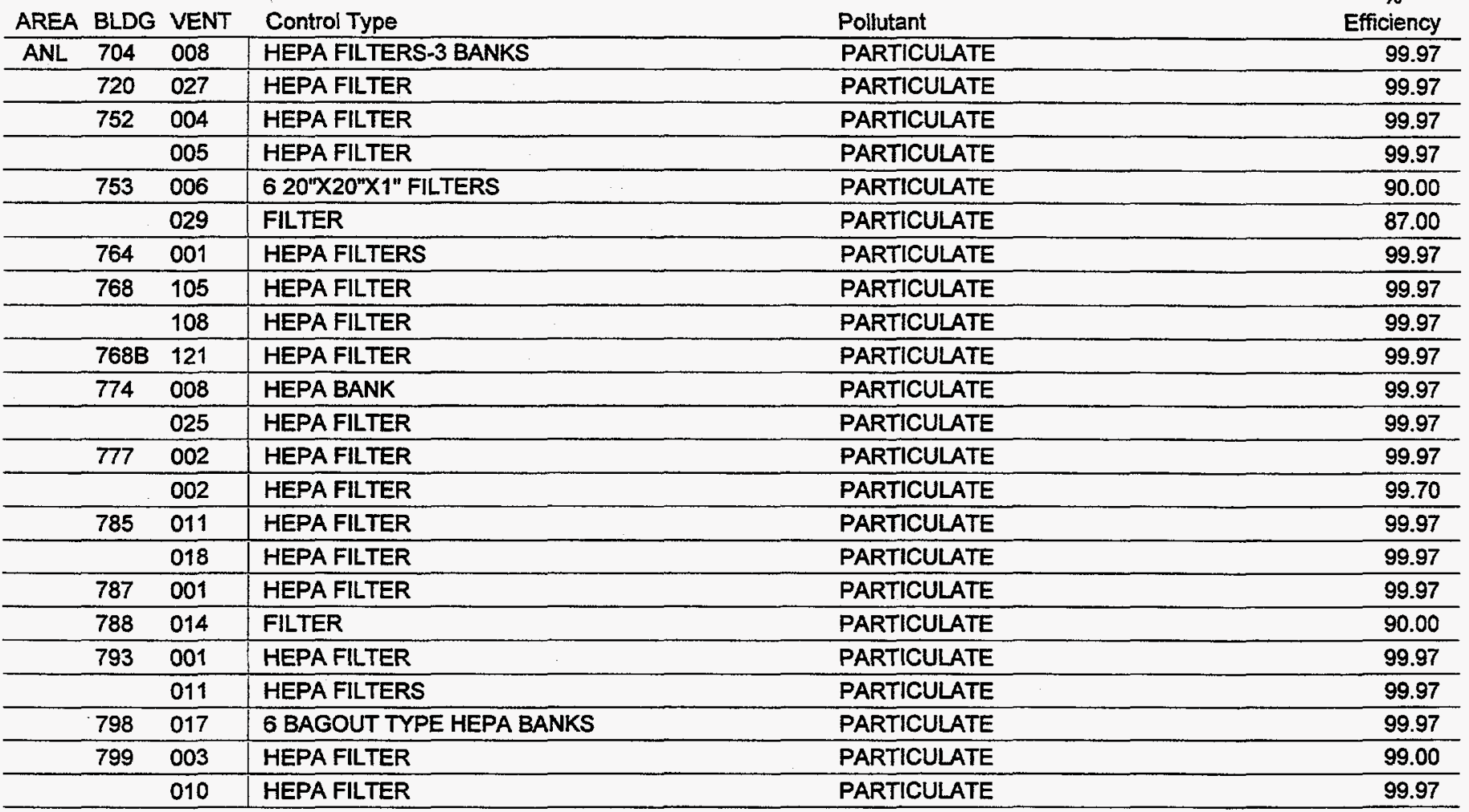




\begin{tabular}{ccc|lll}
\hline CFA & 623 & 005 & BINKS TYPE FILTER & PARTICULATE & 90.00 \\
\hline & 017 & BINKS TYPE FILTER & PARTICULATE & 90.00 \\
\hline 625 & 010 & HEPA FILTERS & PARTICULATE & 99.97 \\
\hline 633 & 067 & HEPA FILTER & PARTICULATE & 99.97 \\
\hline
\end{tabular}




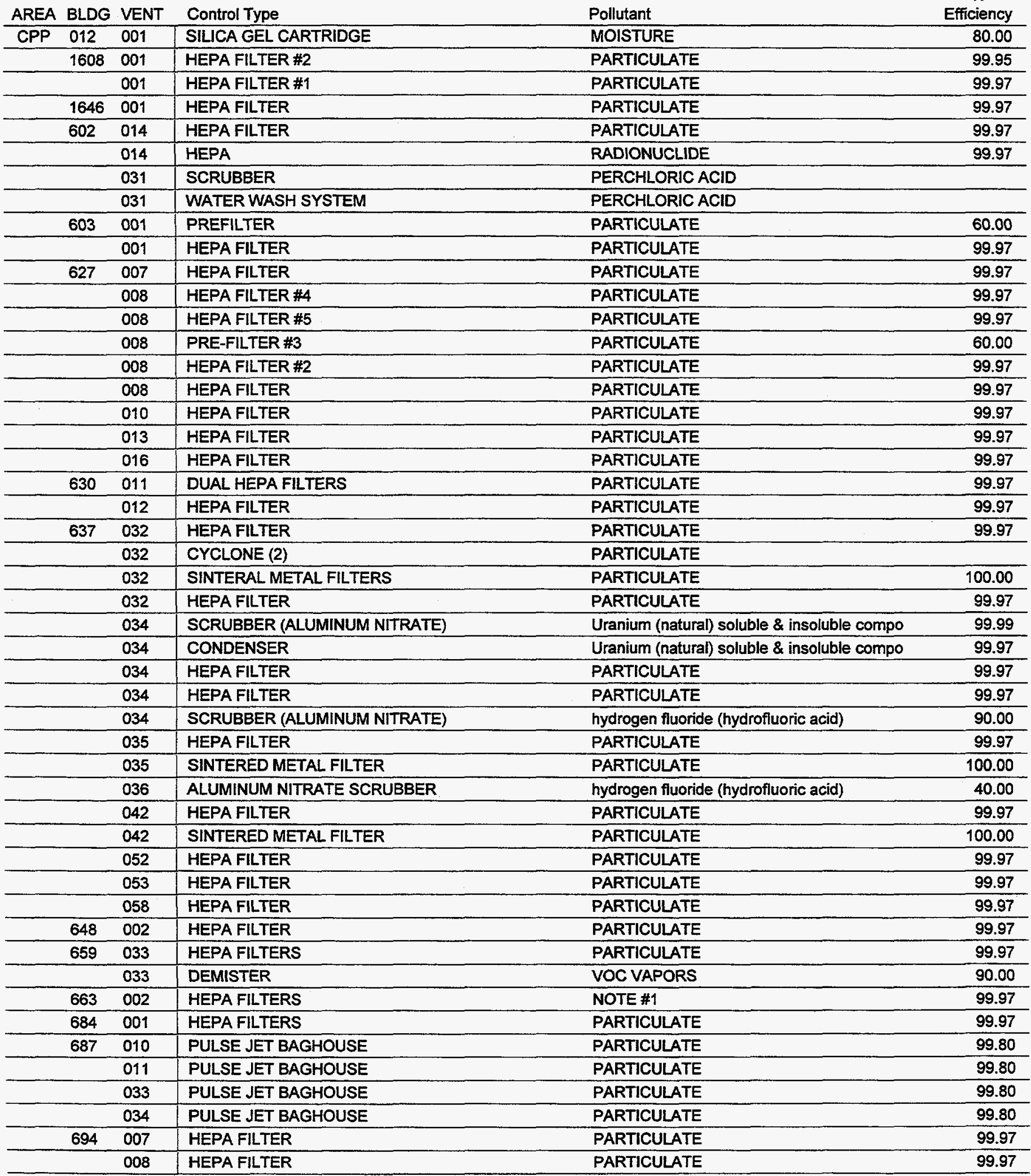




\begin{tabular}{|c|c|c|c|c|c|}
\hline AREA & BLDG & VENT & Control Type & Pollutant & Efficiency \\
\hline \multirow[t]{2}{*}{ CPP } & 694 & 009 & HEPA FILTER & PARTICULATE & 99.97 \\
\hline & & 010 & HEPA FILTER & PARTICULATE & 99.97 \\
\hline & 708 & 001 & HEPA FILTER & PARTICULATE & 99.97 \\
\hline & & 001 & HEPA FILTER (FROM SOG) & PARTICULATE & 99.97 \\
\hline & & 001 & SUPERHEATER/FIBERGLASS PACKED PREFILTER & PARTICULATE & 90.00 \\
\hline & & 001 & FINAL HEPA FILTER (NOG, DOG, CPM,L CELL. & PARTICULATE & 99.97 \\
\hline & & 001 & HEPA FILTER (FROM WCF-POG-633) & PARTICULATE & 99.97 \\
\hline & & 001 & HEPA FILTER (FROM 604, CPM, DOG) & PARTICULATE & 99.97 \\
\hline & & 001 & HEPA FILTER (FROM 604, V06) & PARTICULATE & 99.97 \\
\hline & & 001 & DEMISTER (FROM 604, VOG) & ACIDS, LIQUIDS & \\
\hline & & 001 & FIBERGLASS PACKED PREFILTER & PARTICULATE & 90.00 \\
\hline & & 001 & HEPA FILTER (FROM 601, E-DOG) & PARTICULATE & 99.97 \\
\hline & & 001 & DEMISTER (FROM 604, E-DOG) & ACIDS, LIQUIDS & \\
\hline & & 001 & HEPA FILTER (FROM 604,633,SOG) & PARTICULATE & 99.97 \\
\hline & & 001 & HEPA FILTER (FROM 601, E-DOG) & PARTICULATE & 99.95 \\
\hline & & 001 & DEEP BED FIBERGLASS PREFILTER & PARTICULATE & 90.00 \\
\hline & 727 & 002 & CAUSTIC SCRUBBER & hydrogen fluoride (hydrofluoric acid) & 99.00 \\
\hline & 765 & 003 & HEPA FILTER & PARTICULATE & 99.97 \\
\hline & & 003 & OFF GAS FILTER & PARTICULATE & \\
\hline & & 003 & HEPA FILTER & PARTICULATE & 99.97 \\
\hline & & 003 & OFF GAS PREFILTER & PARTICULATE & \\
\hline & 787 & 001 & REVERSE AIR CLEANING BAGHOUSE & PARTICULATE & 99.80 \\
\hline & 791 & 004 & OFF GAS PREFILTER & PARTICULATE & \\
\hline & & 004 & OFF GAS HEPA & PARTICULATE & 99.97 \\
\hline & & 004 & OFF GAS HEPA & PARTICULATE & 99.95 \\
\hline & & 005 & OFF GAS PREFILTER & PARTICULATE & \\
\hline & & 005 & OFF GAS HEPA & PARTICULATE & 99.95 \\
\hline & & 005 & HEPA FILTER & PARTICULATE & 99.97 \\
\hline & & 005 & OFF GAS HEPA FILTER & PARTICULATE & 99.97 \\
\hline & & 005 & HEPA FILTER & PARTICULATE & 99.97 \\
\hline & & 006 & HEPA FILTER & PARTICULATE & 99.97 \\
\hline & & 006 & OFF GAS PREFILTER & PARTICULATE & \\
\hline & & 006 & OFF GAS HEPA & PARTICULATE & 99.95 \\
\hline & & 006 & HEPA FILTER & PARTICULATE & 99.97 \\
\hline & & 006 & OFF GAS HEPA & PARTICULATE & 99.97 \\
\hline & 792 & 001 & PULSE JET DUST COLLECTOR & PARTICULATE & 99.80 \\
\hline & & 002 & CYCLONE & PARTICULATE & 99.00 \\
\hline & & 002 & BAG FILTER & PARTICULATE & 99.50 \\
\hline & & 003 & BAG FILTER & PARTICULATE & 99.50 \\
\hline & & 003 & CYCLONE & PARTICULATE & 99.00 \\
\hline & 793 & 002 & PULSE JET DUST COLLECTOR & PARTICULATE & 99.80 \\
\hline & 794 & 001 & FABRIC FILTER DUST COLLECTOR & PARTICULATE & 99.80 \\
\hline & & 001 & FABRIC FILTER DUST COLLECTOR & PARTICULATE & 99.80 \\
\hline
\end{tabular}




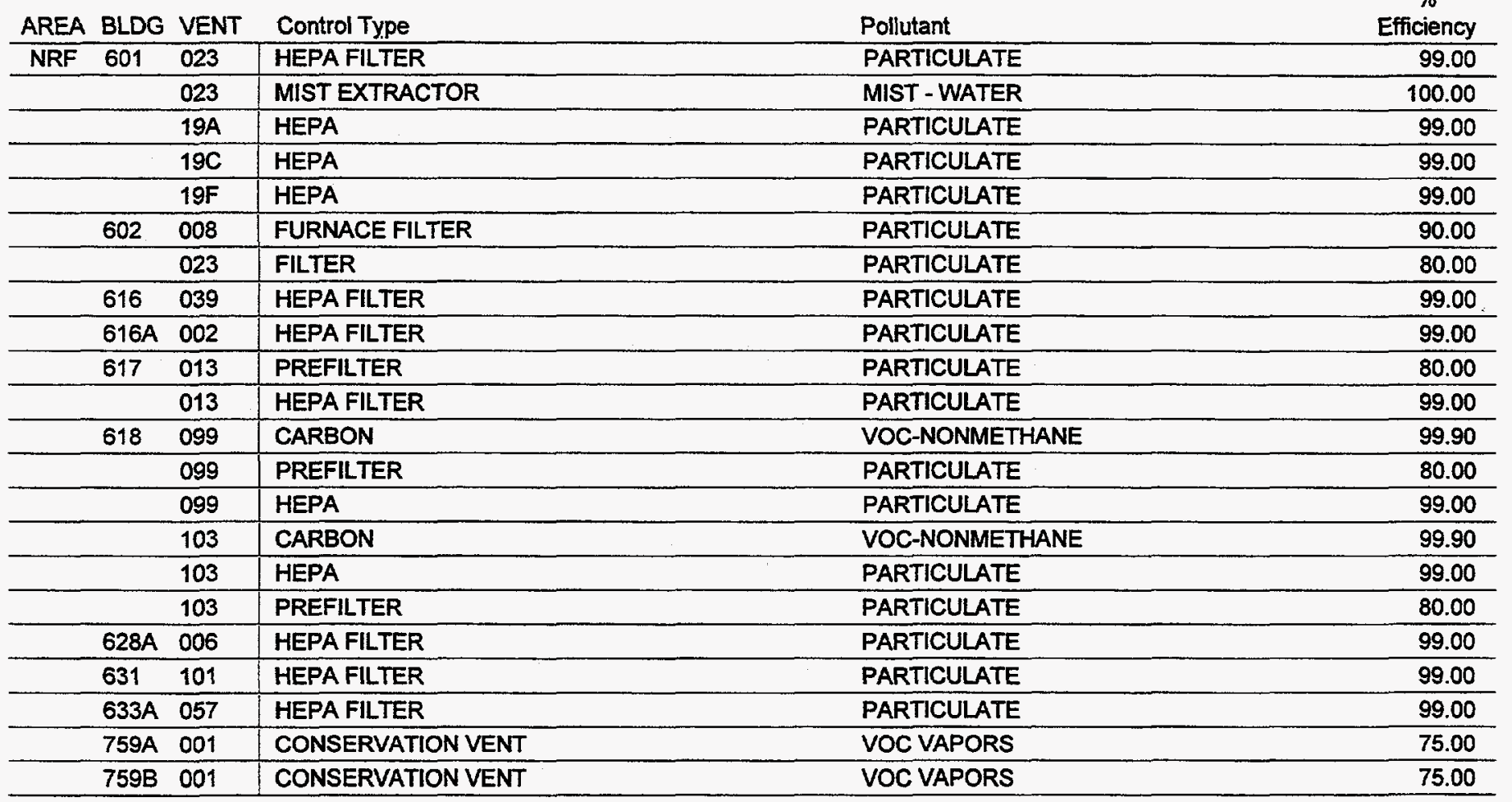


AREA BLDG VENT Control Type

Pollutant

$\%$

\begin{tabular}{ccc|lll}
\hline PER & 620 & 016 & HEPA FILTER & PARTICULATE & 99.97 \\
\hline & 041 & HEPA FILTER & PARTICULATE & 99.97 \\
\hline 622 & 003 & HEPA FILTER \#1 & PARTICULATE & 99.97 \\
\hline 755 & 001 & HEPA FILTER & PARTICULATE & 99.97 \\
\hline & 001 & BAGHOUSE & PARTICULATE & 90.00 \\
\hline 756 & 001 & HEPA FILTER & PARTICULATE & 99.97 \\
\hline 765 & 001 & HEPA FILTER & PARTICULATE & 99.97 \\
\hline
\end{tabular}




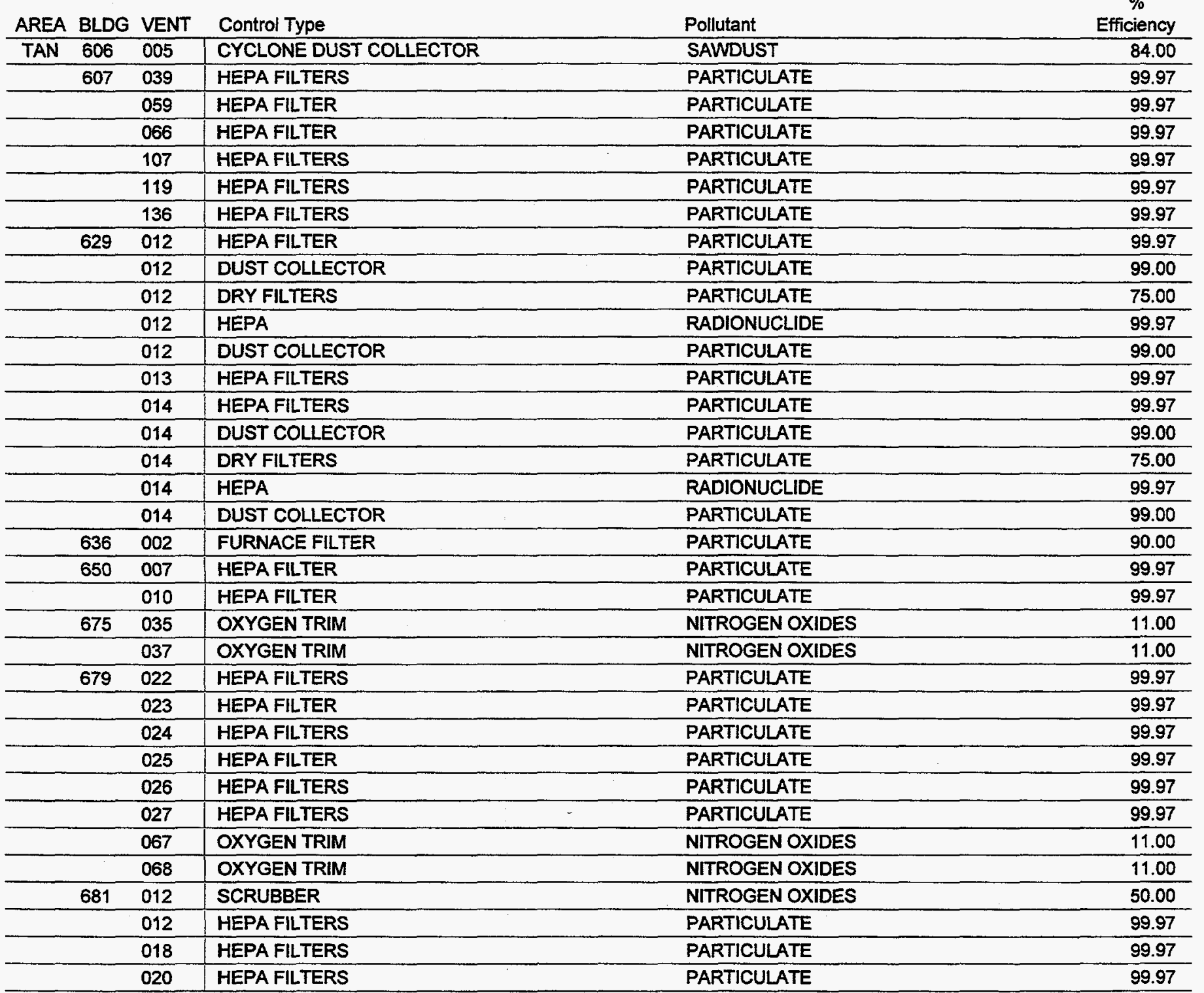




\begin{tabular}{|c|c|c|c|c|c|}
\hline AREA & BLDG & VENT & Control Type & Pollutant & $\begin{array}{c}\% \\
\text { Efficiency }\end{array}$ \\
\hline TRA & 604 & 035 & HEPA FILTER & PARTICULATE & 99.97 \\
\hline & 632 & 019 & HEPA FILTER & PARTICULATE & 99.97 \\
\hline & & 019 & PREFILTER & PARTICULATE & 60.00 \\
\hline & & 019 & AGX ABSORBER & lodine $(\mathrm{CL})$ & \\
\hline & & 030 & HEPA FILTER & PARTICULATE & 99.97 \\
\hline & & 030 & PREFILTER & PARTICULATE & 60.00 \\
\hline & & 030 & AGX ABSORBER & lodine (CL) & \\
\hline & & 041 & CHARCOAL FILTER & lodine $(\mathrm{CL})$ & \\
\hline & & 041 & HEPA FILTER \#2 & PARTICULATE & 99.97 \\
\hline & & 041 & HEPA FILTER \#1 & PARTICULATE & 99.97 \\
\hline & & 041 & PREFILTER & PARTICULATE & 60.00 \\
\hline & 660 & 004 & HEPA FILTER & PARTICULATE & 99.97 \\
\hline & \multirow[t]{2}{*}{661} & 008 & HEPA FILTER & PARTICULATE & 99.97 \\
\hline & & 008 & PRE-FILTER & PARTICULATE & \\
\hline & \multirow[t]{4}{*}{670} & 074 & HEPA FILTER & PARTICULATE & 99.97 \\
\hline & & 086 & HEPA & PARTICULATE & 99.97 \\
\hline & & 086 & FURNACE FILTER & PARTICULATE & 80.00 \\
\hline & & 098 & HEPA FILTER & PARTICULATE & 99.97 \\
\hline
\end{tabular}




\begin{tabular}{rc|c|c}
\hline WMF & 601 & 009 & HEPA FILTER \\
\hline 615 & 001 & HEPA FILTER \\
\hline 640 & 001 & HEPA FILTER \\
\hline 700 & 002 & HEPA FILTER
\end{tabular}

